\author{
UNIVERSIDADE DE SÃO PAULO \\ FACULDADE DE FILOSOFIA, LETRAS E CIÊNCIAS HUMANAS \\ DEPARTAMENTO DE HISTÓRIA
}

\begin{abstract}
ANGELA FILENO DA SILVA
Vozes de Lagos: brasileiros em tempos do império britânico
\end{abstract}

Versão corrigida

São Paulo

2016 


\author{
UNIVERSIDADE DE SÃO PAULO \\ FACULDADE DE FILOSOFIA, LETRAS E CIÊNCIAS HUMANAS \\ DEPARTAMENTO DE HISTÓRIA
}

\title{
Vozes de Lagos: brasileiros em tempos do império britânico
}

Costa da Mina, 1840-1900

\author{
Angela Fileno da Silva \\ angelafileno@terra.com.br \\ angelafilenos@gmail.com
}

Tese apresentada ao Departamento de História da Faculdade de Filosofia, Letras e Ciências Humanas da Universidade de São Paulo para obtenção do título de Doutor em História.

Área de Concentração: História Social

Orientadora: Profa. Dra. Leila Maria Gonçalves Leite Hernandez

Versão corrigida

São Paulo

2016 
Autorizo a reprodução e divulgação total ou parcial deste trabalho, por qualquer meio convencional ou eletrônico, para fins de estudo e pesquisa, desde que citada a fonte.

Catalogação na Publicação

Serviço de Biblioteca e Documentação

Faculdade de Filosofia, Letras e Ciências Humanas da Universidade de São Paulo

Silva, Angela Fileno da Silva

Sv Vozen de Lagos: bramileiroa en tempoa do imperio

Leila Maria Gonçalves Leite Hernandez Hernandez. Säo Paulo, 2016 .

$329 \mathrm{f}$.

Tese (Doutorado) - Faculdade de Filonofia, Letran e Ciencian Humanas da Univeraidade de Säo Paulo. Departamento de Hiat6ria. Área de concentraçäo: Hiet6ria Social.

1. Branileiron em Lagos. 2. Colonizaçĩo britAnica. 3. Exploradorea britsnicos. 4. Jornaie de Lagoe. 5. Blue Booka. I. Hernandez, Leila Maria Gonçalvea Leite Hernandez, orient. II. Título. 


\section{Vozes de Lagos: brasileiros em tempos do império britânico}

Costa da Mina, 1840-1900

Tese apresentada ao Departamento de História da Faculdade de Filosofia, Letras e Ciências Humanas da Universidade de São Paulo, aprovada pela Banca Examinadora constituída pelos seguintes professores:

Profa. Dra. Leila Maria Gonçalves Leite Hernandez

DH - FFLCH/USP

Orientadora

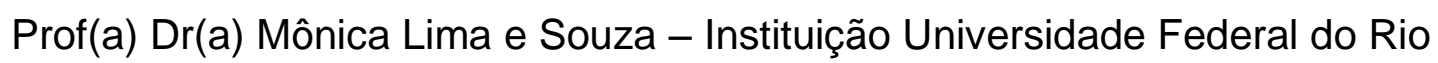
de Janeiro/ CFCH

Prof(a) Dr. Acácio Sidinei Almeida Santos - Instituição Universidade Federal do $\mathrm{ABC} / \mathrm{RI}$

Prof(a) Dr. Alexandre Almeida Marcussi - Instituição Universidade Federal de Minas Gerais/FAFICH

$\operatorname{Prof}(a) \operatorname{Dr}(a)$ Marina de Mello e Souza - Instituição Faculdade de Filosofia, Letras e Ciências Humanas/DH

São Paulo, 25 de abril de 2016. 
Para minha avó Maria Gonçalves Fileno, que nunca assinou seu próprio nome, mas ensinou aos filhos e netos o valor do conhecimento. 
Chegar ao final desta tese me permitiu muitas constatações. A primeira e a mais importante delas é a de que uma pesquisa, por mais solitária que seja em alguns momentos, é sempre resultado da solidariedade, colaboração e incentivo de muitas outras pessoas. Não foram poucas as palavras e gestos de estímulo que recebi em momentos de angústia. Nas dificuldades de compreensão, sempre tive um amigo ou professor (ou os dois juntos) que me indicasse uma pista capaz de esclarecer questões aparentemente insolúveis. $E$ em situações em que precisei de ajuda para encontrar documentos e livros, a vida me apresentou novos amigos e tornou amigos distantes, mais próximos. Por isto, agradecer em palavras tudo o que recebi ao longo destes quatro anos e meio de doutoramento é pouco diante de tudo o que me foi oferecido por estas pessoas.

À professora Leila Maria Gonçalves Leite Hernandez, agradeço a orientação cuidadosa e perspicaz. Por estar sempre disponível para uma conversa, pelas minuciosas leituras e por acreditar que meus limites à compreensão estavam além do que eu própria imaginava. Leila, suas demonstrações de carinho e sua serenidade diante das turbulências da vida influenciaram minha maneira de enxergar o mundo. Obrigada por contribuir para a minha formação intelectual e, sobretudo, humana.

À professora Marina de Mello e Souza, pela arguição criteriosa e precisa durante o exame de qualificação. Por ter participado das minhas primeiras descobertas sobre o tema dos retornos para a Costa da Mina, quando ainda era sua orientanda de mestrado, e por me deixar livre para escolher meus próprios caminhos dentro da academia, obrigada.

Ao professor Acácio Almeida dos Santos, por sua participação generosa durante o exame de qualificação. Suas indicações de leitura foram fundamentais em relação aos rumos que esta tese tomou. Por se mostrar um 
leitor atento e por acreditar nas possibilidades de análise em um momento em que esta pesquisa apresentava tão poucos resultados concretos, obrigada.

Agradeço à pesquisadora Alcione Amós, uma daquelas amizades que a vida me ofereceu. Por sua generosidade em me ceder os Blue Books relativos à Nigéria e pelas conversas acerca de como encaminhava seus próprios estudos, obrigada.

À professora Mônica Lima e Souza, por compartilhar seus livros raros, por nossas conversas via email e pelas palavras de incentivo quando ainda elaborava meu projeto de pesquisa. Enfim, por seu entusiasmo contagiante, obrigada.

À Alice Bonasio, Tom Atkinson, Adriana Peitil e Rogério Costa, amigos distantes que se mostraram próximos em razão de seu apoio a esta pesquisa. Alice e Tom, obrigada por fotografar e enviar para mim os últimos exemplares das Government Gazettes que não tive tempo de consultar quando, em 2011, estive em Londres. Adriana e Rogério, obrigada por enviar para o Brasil livros que só poderiam ser entregues em Nova York.

Aos amigos de doutoramento Juliana Ribeiro da Silva Bevilacqua, Rosana Gonçalves, Helena Wakim Moreno, Elaine Ribeiro e Alexandre Almeida Marcussi, pelas apuradas discussões propostas pelas disciplinas oferecidas pelas professoras Leila Hernandes e Maria Cristina Cortez Wissenbach, por compartilharem bibliografias e pelas conversas a respeito de como desenvolviam suas próprias pesquisas, obrigada. Um agradecimento especial à Juliana Bevilacqua, Rosana Gonçalves e Helena Wakin, pelo apoio emocional e por nossas conversas sempre bem humoradas. A fase de escritura da tese passou, nossa amizade não.

Agradeço aos colegas Guilherme Gamito e Daniel Néry pela elaboração dos mapas apresentados, a ajuda de vocês nos momentos finais de formatação dessa pesquisa foi realmente imprescindível. Aos amigos de décadas, Ana Cláudia Mendes Souza, Denise Scótolo, Dolores Freixa, Flávia Ulian, Juliana Pedreschi Rodrigues e Raul Arriagada, por compartilharem impressões, leituras e, sobretudo, por se fazerem sempre presentes, obrigada. 
À Capes, pela bolsa de doutorado indispensável à realização desta tese, em especial ao financiamento da viagem de pesquisa que me permitiu 0 acesso aos documentos guardados no National Archives e na British Library, em Londres.

Finalmente, guardo um agradecimento especial à minha família. O último ano de doutorado foi marcado pela dor de perdas difíceis de superar. Tenho absoluta certeza de que sem o esteio de pessoas tão incríveis não teria seguido em frente e terminado esta pesquisa. Aos meus pais, João e Dulce, agradeço o amor incondicional. Foi esse sentimento que me deu a tranquilidade de saber que minhas escolhas sempre seriam apoiadas e, mais ainda, incentivadas por vocês. Pai, por me ensinar a sonhar, obrigada. Mãe, por ser a minha primeira professora e por me indicar o caminho à conquista dos meus sonhos, obrigada. Ao meu marido, Rogério, companheiro de uma vida, por ser minha razão nos momentos de desespero, minha esperança nas horas de descrença e por simplesmente me amar com todos os meus defeitos, obrigada. À minha filha, Isabela, menina de sete anos que nasceu em meio a um mestrado e cresceu vendo a mãe agarrada à tese. Saiba que todas as lágrimas que você derramou em razão das minhas ausências eu chorei em dobro, mas em silêncio. Por ser a minha menina, meu coração, minha felicidade, enfim, por ser você....mil vezes obrigada! 
"O fio da vida (...), mesmo que está podre não parte. Puxando-lhe, emendandoIhe, sempre a gente encontra um princípio num sítio qualquer mesmo que esse princípio é o fim doutro princípio."

Luandino Vieira 
A ideia de que os brasileiros estabelecidos em Lagos elaboraram identidades cambiantes que se reformularam em resposta aos contextos apresentados ao longo do período de 1840 a 1900, constituiu o foco central desta tese. Neste sentido, proponho compreender os contextos em que os brasileiros de Lagos tiveram de ressignificar e atualizar os signos responsáveis por conferir identificação aos integrantes de seu grupo. Para isto, selecionei um conjunto de documentos formado por três tipos de fontes. Com o propósito de entender como os brasileiros eram representados por missionários anglicanos e metodistas, exploradores, oficiais da marinha e cônsules britânicos analisei as narrativas de viagem, relatórios enviados ao Foreign Office e artigos publicados em revistas mantidas por associações científicas da época. $O$ segundo grupo de documentos corresponde a três jornais publicados em Lagos entre os anos de 1881 e 1900, a saber: The Lagos Observer, The Lagos Weekly Record e o periódico oficial do governo colonial britânico, The Government Gazette. A leitura destas fontes revelou aspectos importantes acerca da participação dos brasileiros na sociedade lagosiana da segunda metade do século XIX. O terceiro compêndio de fontes é formado por relatórios anuais elaborados pela administração colonial da cidade e reunidos sob a denominação de Blue Books. Este conjunto de registros trata dos mais diferentes assuntos relacionados ao governo britânico operado na cidade e constitui importante fonte para análise acerca da maneira como os brasileiros eram representados pelo governo colonial. A partir destes três conjuntos de documentos tornou-se possível perceber as formas como os signos de pertencimento que definiam as identidades dos brasileiros foram elaborados a partir do contato, das trocas e das disputas entre os demais componentes sociais existentes na cidade de Lagos oitocentista.

Palavras-chave: 1. Brasileiros em Lagos; 2. Nigéria; 3. Colonização britânica; 4. Jornais de Lagos; 5 . África ocidental. 
The Brazilians established in Lagos developed shifting identities which were reshaped in response to the presented contexts throughout the period 1840 to 1900 , was the central focus of this thesis. In this regard, I propose to understand the contexts in which the Brazilian from Lagos had to reframe and update the responsible signs for checking identification to the members of their group. For this, I selected a set of documents composed of three types of sources. In order to understand how Brazilians were represented by Anglican and Methodist missionaries, explorers, officers of the Navy and British consuls, I analyzed the travel narratives, reports to the Foreign Office and articles published in magazines kept by scientific associations at the time. The second group of documents corresponds to three newspapers published in Lagos between the years 1881 and 1900, namely: The Lagos Observer, The Lagos Weekly Record and the official journal of the British colonial government, The Government Gazette. Reading these sources revealed important aspects concerning the Brazilian participation in Lagos society in the second half of the nineteenth century. The third compendium of sources consists of annual reports by the colonial administration of the city and gathered under the name of Blue Books. This set of records focus on the most different topics related to the British government based in the city and is an important source of analysis about the way the Brazilians were represented by the colonial government. From these three sets of documents it was possible to see the ways in which the belonging signs which defined the identity of Brazilians were prepared from the contact, exchanges and disputes between the other social components existing in the Lagos of the nineteenth century.

Keywords: 1. Brazilians in Lagos; 2.Nigeria; 3. British colonization; 4. Lagos newspapers; 5. Western Africa. 
Capítulo 1 - Traficantes, "trained Negroes" e "Brazilian emigrants"

1.1. Traficantes ou brasileiros? As representações britânicas do século XIX..... 34

1.2. Pertencimento étnico e possibilidades interpretativas 74

Capítulo 2 - Lagos, um porto negreiro. 85

2.1. A abertura de Lagos para o comércio atlântico de escravos 87

2.1.1. Os conflitos no interior e o fornecimento de escravos para Lagos 99

2.2. O olhar de Duncan sobre a Costa da Mina 103

2.3. As partidas de Salvador para a Costa da Mina.

2.4. O tráfico e as ações britânicas na Costa da Mina.

Capítulo 3 - A conquista do "ninho de pirataria e pilhagem" 129

3.1. A instauração do protetorado britânico em Lagos. 130

3.2. O Parlamento britânico e o combate ao tráfico 148

3.3. O retorno de Akitoye à Lagos 152

3.4. Lagos: Protetorado da Grã-Bretanha (1851-1861)...... 162 


\section{Capítulo 5 - Os jornais e as representações dos brasileiros}

5.1. Os anúncios de estabelecimentos e negócios brasileiros

Apêndice 1: Importações para Lagos.

Apêndice 2: Mercadorias fornecidas pelo Brasil. 304

Apêndice 3: Exportações de Lagos.

Apêndice 4: Brasileiros com licença para comercializar bebidas destiladas em Lagos. 
Mapa 1: Expedições britânicas entre 1830 e 1854. 36

Mapa 2: Lagos e portos vizinhos (c. 1800) 46

Mapa 3: Cidade de Lagos, rede de lagoas, estuários e canais do entorno 155

Mapa 4: Domínios de Kosoko durante o exílio em Epe 165

Mapa 5: Estradas de ferro britânicas, 1912 219

Mapa 6: Cidade de Lagos, c. 1886 273

\section{LISTA DE FIGURAS}

Figura 1: Oficina de impressão do Governo Colonial Britânico em Lagos 67

Figura 2: Estação de Axo, Estrada de Ferro Lagos - Abeokuta............ 218

Figura 3: Anúncio de venda de batatas pelo Senhor S.C. Soares......... 225

Figura 4: Ponte Carter, 6 de novembro de 1929............................. 232

Figura 5: Anúncio da aspirina Teplitzer, vendida por E.F. Gomes......... 236

Figura 6: Anúncio de mudança de endereço do barbeiro M.B. Moreira. 238

Figura 7: Anúncio do Restaurante Da Rocha..................................... 239

Figura 8: Comunicado de montagem de apresentação feita pela The Brazilian Dramatic Company........................................................ 251

Figura 9: Igreja Católica de Lagos, a Holy Cross................................ 257

Figura 10: Sede do governo colonial britânico, a Government House 263

Figura 11: Vista da marina de Lagos, com destaque para a Igreja católica Holy Cross.

279 
Tabela 1: Principais portos de tráfico da Costa da Mina entre 1791 e 1865. 96

Tabela 2: Obás e escravos embarcados em Lagos 133

Tabela 3: Volume de importações para Lagos..... 195

Tabela 4: Produtos importados por Lagos e fornecidos pelo Brasil (1870). 197

Tabela 5: Volume de exportações de Lagos..................................... 200

Tabela 6: Comerciantes brasileiros que ocupavam armazéns em Lagos... 204

Tabela 7: Relatório de população, casamentos, nascimentos e mortes 1866

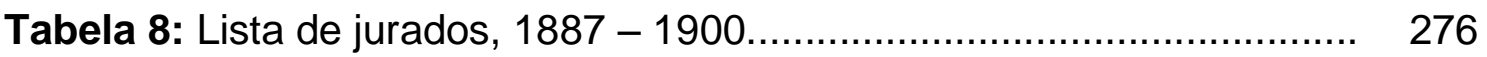

Apêndice 1: Importações para Lagos ............................................. 302

Apêndice 2: Mercadorias fornecidas pelo Brasil ................................ 304

Apêndice 3: Exportações de Lagos .............................................. 317

Apêndice 4: Brasileiros com licença para comercializar bebidas

destiladas em Lagos .......................................................... 319 
APEBa Arquivo Público do Estado da Bahia

APROL Additional Papers Relating to the Occupation of Lagos, Parliament Papers, 1862, LXI, 339

CFP Correspondence with Foreign Powers, Parliament Papers, 1862, LXI, 339

CMS Church Missionary Society

co Colonial Office

GG Government Gazettes

LO Lagos Observer

PROL Papers Relating to the Occupation of Lagos, Parliament Papers, 1862, LXI, 339

RGS Royal Geographical Society

SMA Société des Missions Africaines 
Os 'repatriados' (...) representam e representarão entre os seus concidadãos menos desenvolvidos da região iorubá um núcleo admirável de difusão do progresso e da civilização que adquiriram de forma cruel. ${ }^{1}$

Em junho de 1887, a Rainha Vitória comemorou seus cinquenta anos de reinado. Como parte dos arranjos em torno das cerimônias que marcaram essa data, comitês responsáveis pela organização das celebrações do jubileu de ouro, divulgaram o programa das atividades festivas nos periódicos de Lagos. Parte das comemorações do dia 22 de junho incluía uma procissão - chamada pelo jornal The Lagos Observer, de "Brazilian Caretas" - um banquete e uma queima de fogos de artifício. ${ }^{2}$ Os festejos em honra à rainha ocorreram nos dias $21,22,23,24,28$ de junho e 7 de julho. Antes que o ciclo de cerimônias oficiais se iniciasse, um grupo de brasileiros entregou uma mensagem ao então governador da colônia de Lagos, Cornelius Alfred Moloney. A missiva assinada por dezenove membros da comunidade brasileira da cidade felicitava a monarca pelo seu jubileu e lhe fazia "votos de longo e pacífico reinado". 3 resposta a essa manifestação pública de apreço à Coroa britânica foi emitida pelo próprio governador Moloney que, referindo-se aos participantes da procissão como "the returnees Brazilians", elogiou seus integrantes como "um núcleo admirável de difusão do progresso e da civilização". ${ }^{4}$

Estabelecidos na Costa da Mina, referência historicamente construída sobre o território compreendido entre o forte de São Jorge da Mina e o delta do

\footnotetext{
${ }^{1}$ Lagos Government (Jubilee) Gazette, Monday, 11 de julho de 1887. National Archives/UK. CO 150/2. Um excerto deste documento também está publicado em: VERGER, Pierre. Fluxo e Refluxo do tráfico de escravos entre o Golfo de Benin e a Bahia de todos os Santos: dos séculos XVII a XIX. São Paulo: Corrupio, 1987, p.621.

${ }^{2} \mathrm{O}$ programa destas comemorações pode ser lido no periódico The Lagos Observer, 18 de junho de 1887, Vol. V1, N ${ }^{\circ}$. World Newspaper Archive, African Newspapers, 1800 - 1922.

${ }^{3}$ The Lagos Observer, 18 de junho de 1887, Vol. V1, No8. World Newspaper Archive, African Newspapers, $1800-1922$.

${ }^{4}$ Lagos Government (Jubilee) Gazette, Monday, 11 de julho de 1887. National Archives/UK. CO 150/2. Nessa edição especial do periódico estão também publicadas as cartas de agradecimento, assinadas por Moloney e endereçadas aos Members of the Yoruba Society, ao Senior Jubilee Commitee e à Women's Jubilee Society.
} 
rio Níger, a presença de brasileiros na região é percebida pelas produções especializadas no tema como anterior aos séculos XVIII e XIX. ${ }^{5}$ A partir do final do século XVII, a existência de brasileiros nesta área estava associada ao comércio escravista realizado com o Brasil, em específico, com a Bahia. De acordo com Verger, o termo "Costa da Mina" começou a ser empregado, ainda no século $\mathrm{XV}$, para se referir à região onde estava o forte português de São Jorge da Mina, fundado em 1482. O local cresceu em importância a partir do século XVII, quando se tornou atracadouro de comerciantes baianos. Nesse momento, a designação passou a se referir à porção da costa que compreendia os seguintes pontos: Grande Popo, Ajudá, Jaquim, Apá e Onim, este último porto tornou-se conhecido, décadas mais tarde, como Lagos. Dessa forma, o trecho litorâneo que, de início, designava apenas as imediações do forte de São Jorge, passou então a incluir a "Costa a leste da Mina". Nesta tese optei por empregar a designação Costa da Mina, em lugar da denominação geográfica Golfo do Benim, por entender que o termo carrega as nuanças de sua formulação ligada ao comércio atlântico negreiro. ${ }^{6}$

Como veremos ao longo deste estudo, embora diversos negreiros baianos estivessem estabelecidos na Costa da Mina desde o século XVII, foi somente a partir da década de 1840 que os relatos produzidos por oficiais da marinha inglesa, missionários anglicanos e metodistas, exploradores e membros da administração colonial britânica voltaram a registrar a presença de brasileiros na região. Os primeiros escritos elaborados ainda a partir de meados dos anos de 1840 tratavam de uma população composta, quase que em exclusivo, por traficantes. Estes indivíduos ligados ao comércio atlântico de escravizados teriam constituído, durante os séculos XVIII e início do XIX, verdadeiras fortunas. Morando em imóveis cujo padrão arquitetônico em muito

\footnotetext{
${ }^{5}$ A respeito deste assunto cito aqui algumas das produções mais importantes: LAW, Robin. The evolution of the brazilian community in Ouidah in MANN, Kristin; BAY, Edna (eds.) Rethinking the African Diaspora: the making of a Black Atlantic World in the Bight of Benin and Brazil. Portland: Frank Cass Publishers, 2001; LAW, Robin. Ouidah: The Social History of a West African slaving 'port', 1727-1892. Ohio: Ohio University Press/ Oxford: James Currey, 2004; SOUMONNI, Elisée. Daomé e o mundo atlântico. Centro de Estudos AfroAsiáticos/Universidade Cândido Mendes, 2001; VERGER, Pierre. Fluxo e Refluxo do tráfico de escravos entre o Golfo do Benim e a Bahia de Todos os Santos. São Paulo: Corrupio.1987 e SILVA, Alberto da Costa e. Francisco Félix de Souza, mercador de escravos. $2^{\underline{a}}$ ed. Rio de Janeiro: Nova Fronteira/Ed. UERJ, 2004.

${ }^{6}$ Cf. VERGER, Pierre.Op.cit.1987.pp.12, 19 e 20.
} 
se aproximava das residências baianas oitocentistas, os brasileiros-traficantes são considerados pelas produções especializadas os responsáveis por estabelecer as condições de atração necessárias para a instalação de uma segunda leva populacional que começou a desembarcar na Costa da Mina no século XIX, em maior número a partir de $1835 .^{7}$

Somados aos traficantes-brasileiros, este segundo grupo era formado por libertos e seus descendentes que partiram de Salvador, principalmente depois da Revolta dos malês (em 1835) e, em menor quantidade, do Recife e do Rio de Janeiro. Além destes dois conjuntos de indivíduos, havia ainda os retornados vindos de Cuba, cuja proximidade comercial com os negreiros baianos estava associada ao tráfico, que continuou a ser praticado em direção à ilha do Caribe até $1867 .{ }^{8} \mathrm{Em}$ meados da década de 1830, o grande volume de retornos de libertos para a Costa da Mina conferiu uma nova configuração humana à região. Uma vez estabelecidos em Lagos, a presença dos brasileiros na cidade foi heterogênea tanto no tempo como no espaço. Este é o ponto a partir do qual esta pesquisa se desenvolve. Ao reconhecer que os signos de pertencimento à comunidade brasileira lagosiana se constituíram a partir dos diálogos com egbas, ijexás, ondos e em resposta à atuação colonial britânica na cidade, esta pesquisa propõe o entendimento dos contextos em que as identidades brasileiras foram ressignificadas e atualizadas, a fim de continuarem a fazer sentido para aqueles que as exerciam. Em outras palavras, o objetivo central desta tese é compreender as conjunturas em que os brasileiros formularam e redefiniram seus signos de pertencimento - ou nos

\footnotetext{
7 Refiro-me, em especial, às seguintes publicações: CASTILLO, Lisa Earl. Mapping the nineteeth-century Brazilian returnee movement: Demographics, life stories and the question of slavery. Atlantic Studies, 13:1, 2016, pp.25-52; GURÁN, Milton. De africanos no Brasil a "brasileiros" na África: os agudas do Golfo do Benim in CHAVES, Rita; SECCO, Carmen; MACÊDO, Tania (orgs.) Brasil/África: como se o mar fosse mentira. São Paulo: UNESP; Luanda/Angola: Chá de Caxinde, 2006; GURAN, Milton. Agudás: os "brasileiros" do Benim. Rio de Janeiro: Nova Fronteira, 2000; GURAN, Milton. Da bricolagem da memória à construção da própria imagem entre os agudás do Benim. Afro-Ásia, $\mathrm{N}^{\circ} 28,2002$, pp.45-76; GURAN, Milton; REIS, João José. Urbain-Karim Elisio da Silva, um agudá descendente de negro male. AfroÁsia, $N^{\circ}$ 28, 2002, pp.77-96; LAW, Robin; MANN, Kristin. West Africa in the Atlantic Community: the case of the Slave Coast. In Willian and Mary Quarterly, 56, 2, 1999.pp.307334; TURNER, J.M. Escravos Brasileiros no Daomé. Afro-Ásia, 1970, pp.5-23.

${ }^{8} \mathrm{O}$ entendimento de que o retorno de libertos do Brasil em direção à costa ocidental africana ocorreu em contextos muito próximos às voltas a partir de Cuba e Estados Unidos, reaparece, entre outros, em: PARIS, Melanie. Repatriated Africans from Cuba and Brazil in nineteenth century Lagos. Ohio: thesis of master of arts/The Ohio State University, 1998 e OTERO, Solimar. Afro-Cuban Diasporas in the Atlantic World. Rochester: University of Rochester Press, 2010.
} 
termos da antropóloga Manuela Carneiro da Cunha, seus "sinais diacríticos" constituindo o que convencionei chamar de identidades cambiantes. ${ }^{9}$ Considero que a escolha pela adjetivação do substantivo "identidades", tornando as identidades cambiantes, me permite salientar um elemento central à percepção do que significava ser brasileiro entre 1840 e 1900. Para esta pesquisa importava compreender como as identidades brasileiras estavam sempre a se reinventar em resposta a processos históricos específicos. Além deste aspecto, entendo que estes processos de invenção e de reinvenção ocorreram a partir da sobreposição de signos de pertencimento que foram, ao longo do tempo, sendo acrescentados a um conjunto de outros signos sem que os anteriores fossem apagados. Neste sentido, caberia aqui perguntar quais seriam, afinal, os signos de pertencimento associados a estas identidades dos brasileiros que viveram em Lagos durante os últimos sessenta anos do século XIX?

Desde os anos de 1940 análises produzidas por antropólogos, linguistas, etnólogos e historiadores se interessam por responder a esta questão. ${ }^{10}$ Para muitos destes pesquisadores, os brasileiros que no oitocentos se estabeleceram na Costa da Mina e, em específico na cidade de Lagos, exprimiam por meio da língua, da cultura, da arquitetura, da religião e do trabalho os emblemas de um pertencimento comum. Alguns destes emblemas ganhavam maior visibilidade em momentos em que a identidade brasileira era exercida pública e coletivamente. É o caso das reuniões promovidas por associações lagosianas que realizavam encontros em que se entoavam canções em língua portuguesa. Ou quando os programas de comemorações em torno dos cinquenta e sessenta anos do reinado da rainha Victoria respectivamente, os jubileus de ouro e de diamante - contaram com a participação brasileira em desfiles pelas ruas da cidade. Ou ainda, quando em

\footnotetext{
${ }^{9}$ As sociedades egbas, ijexás e ondos são citadas por Cunha como as que mantinham relações mais estreitas com os brasileiros de Lagos. Cf. CUNHA, Manuela Carneiro da. Negros, estrangeiros. Os escravos libertos e sua volta à África. $2^{\mathrm{a}}$ ed. revisada e ampliada. São Paulo: Companhia das Letras, 2012, p.162.

${ }^{10}$ Embora reconheça a existência de uma ampla bibliografia dedicada ao tema do retorno de livres e libertos para a Costa da Mina, refiro-me aqui aos que considero os principais pesquisadores que se debruçaram sobre o assunto: Lourenço Dow Turner, J.F. Almeida Prado, Pierre Verger, Gilberto Freyre, Yêda Pessoa de Castro, José Honório Rodrigues, Julio Santana Braga, Marianno e Manuela Carneiro da Cunha, Jerry Michael Turner, Milton Guran, Alberto da Costa e Silva, Mônica Lima e Souza, Alcione Amós, Robin Law e Elisée Soumonni.
} 
dias de rito eclesiástico a população brasileira tomava a rua da missão católica - a Catholic Mission Street - para chegar até a igreja da Société des Missions Africaines (SMA) em Lagos: a Holy Cross. Podemos ainda considerar que a presença do cristianismo sobredeterminou a influência dos islamizados que chegaram até a cidade a partir da Revolta dos malês. Tema que, por si, mereceria outro trabalho de pesquisa.

No que se refere às formas de expressão, se somavam a signos de pertencimento menos episódicos, em geral associados à sua longa permanência na cidade. A existência de um bairro brasileiro, o Brazilian Quarter, cujos imóveis lembravam em muitos aspectos os casarões erguidos na Bahia do século XIX, constitui uma das marcas materiais deixadas na cidade por esta população. No entanto, como bem demonstrou Marianno Carneiro da Cunha, embora as fachadas destas grandes casas fossem baianas, seus usos eram também africanos. ${ }^{11}$ Ao abrigar famílias extensas, um ponto comercial localizado à frente do imóvel e, no caso de grandes comerciantes, ao associarem a função de moradia à de estocagem de artigos que seriam negociados no mercado atlântico, estas casas foram construídas para cumprir múltiplas funções. Pedreiros, carpinteiros e mestre de obras vindos do Brasil assumiram a tarefa de erguer os sobrados brasileiros-baianos na cidade. Ao longo do século XIX, alguns outros ramos profissionais se tornaram emblemas do pertencimento a esta comunidade. Barbeiros, sapateiros, alfaiates, açougueiros e, em maior número, comerciantes varejistas e atacadistas eram as principais ocupações em que predominavam seus integrantes. Como detentores de técnicas aprendidas do outro lado do Atlântico, no Brasil, alguns destes profissionais se tornaram valorizados pela administração colonial britânica, que via nestes indivíduos um ponto de partida à "civilização" de sua recém-conquistada colônia.

A ideia de que os brasileiros de Lagos constituíram identidades plurais, que comportavam diferentes adjetivações e cujos signos de pertencimento se reformularam e atualizaram seus sentidos para continuarem existindo, encaminhou esta pesquisa para um recorte temporal estabelecido por três

\footnotetext{
${ }^{11}$ CUNHA, Marianno Carneiro da. Da senzala ao sobrado, arquitetura brasileira na Nigéria e na República Popular do Benim. São Paulo: Nobel/Edusp, 1985.
} 
balizas cronológicas. A primeira se refere à década de 1840 , período em que podemos constatar um aumento no número de registros deixados por britânicos que estiveram na Costa da Mina. Estes escritos são formados por narrativas de viagem produzidas por exploradores e oficiais da marinha antitráfico enviados pela Grã-Bretanha para convencer o então rei do Daomé, Guezo, a abandonar o comércio atlântico de indivíduos escravizados. Neste momento, o serviço diplomático britânico, o Foreign Office, mobilizava apoio político e recursos financeiros governamentais com o propósito de retomar algumas das fortificações inglesas que, desde o início do século XIX, estavam desocupadas. O esvaziamento destes fortes teve início em 1807, quando a lei de Abolição do Comércio de Escravos, a Abolition of the Slave Trade Act, foi aprovada no Parlamento britânico. Em Ajudá, o forte William, na atual Acra, o forte James, e na Costa do Cabo Corso, o Cape Coast Castle, eram considerados pontos estratégicos de vigilância e repressão ao tráfico escravista praticado neste trecho da costa. Em vista disto, em 1845 o Foreign Office criou o Consulado dos Golfos do Benim e de Biafra, com sede na ilha de Fernando Pó. ${ }^{12}$

O estabelecimento de um posto consular na Costa da Mina deu maior sustentação às incursões britânicas em direção à capital do reino do Daomé, Abomé, e por localidades situadas às margens do rio Níger. A maior parte destas expedições era cotizada entre companhias comerciais particulares, associações científicas e de pesquisa e pela Coroa da Grã-Bretanha. Uma das incumbências daqueles que lideravam estas viagens era a produção de descrições capazes de informar, com riqueza de detalhes, as etapas da viagem e as possibilidades de ganho, caso os recursos naturais encontrados ao longo dos percursos fossem explorados. De maneira geral, as narrativas escritas entre 1845 e 1850 tratam de um processo de aproximação de enviados britânicos em relação às chefias locais. Esta aproximação ocorria em função da assinatura de tratados pelo fim do tráfico atlântico de escravos e pela supressão dos ritos que envolviam sacrifícios humanos. No entanto, a partir da década de 1850, registros deixados por funcionários do consulado britânico,

\footnotetext{
${ }^{12}$ LAW, Robin. Ouidah: The Social History of a West African slaving 'port', 1727-1892. Ohio: Ohio University Press/ Oxford: James Currey, 2004, p.160-163 e 218.
} 
por oficiais da armada da rainha Victória e por religiosos da CMS tornaram-se cada vez mais enfáticos quanto à dominação territorial de trechos da Costa da Mina. Este aspecto em específico estaria relacionado ao segundo marco temporal definido para esta pesquisa.

Em dezembro de 1851, a cidade de Lagos foi bombardeada pelo esquadrão antitráfico estacionado à frente do igá (ou palácio real), onde residia o então obá Kosoko. A ação das forças da Grã-Bretanha é considerada um ponto de viragem na política britânica que, até aquele momento, se limitava a propor a assinatura de tratados em que as chefias locais se comprometiam com a supressão do tráfico. Sob 0 argumento de que estes acordos não alcançaram os resultados esperados, a Grã-Bretanha dava uma guinada em relação à forma como estes documentos passaram a ser apresentados. Depois da demonstração da força bélica britânica na cidade de Lagos, outros doze tratados foram firmados com chefias de localidades na Costa da Mina. Com exceção do Daomé, todas as demais cidades atenderam de pronto ao chamado que visava acabar com o comércio escravista. ${ }^{13}$ Nas décadas que se seguiram a 1850, a escalada colonizadora que tornou Lagos protetorado da Grã-Bretanha se espalhou por outras porções litorâneas da Costa da Mina, alcançou a cidade egba de Abeokuta e, mais ao sudeste, penetrou pelo curso do rio Níger em direção ao interior.

Os processos que intensificaram a violência promovida pelo governo colonial lagosiano sobre cidades situadas em território ljebu e Oió, constituem o terceiro e último marco temporal desta tese. Embora os primeiros movimentos referentes à atuação britânica em territórios afastados da costa tenham se iniciado ainda na década de 1840, foi a partir dos anos de 1880 e 1890 que a penetração colonial da Grã-Bretanha chegou até áreas mais distantes do litoral e ganhou contornos melhor definidos. Sob a designação de "expedições pacificadoras" o então governador de Lagos, Gilbert Carter, levou a cabo um conjunto de ações que tinham o propósito de estabelecer a regularidade da produção e do escoamento das "safras comerciais" de amendoim, algodão e

${ }^{13}$ Como veremos no segundo capítulo, em 1852, o rei daomeano Guezo firmou um acordo junto aos oficiais enviados pela Coroa britânica. Todavia, o Foreign Office considerou os termos aceitos por Guezo insatisfatórios, o que inviabilizou sua aplicação neste primeiro momento. 
dendê, encaminhadas até o porto lagosiano. ${ }^{14}$ As medidas "pacificadoras" encabeçadas por Carter trouxeram uma série de mudanças nas dinâmicas comerciais estabelecidas entre grandes companhias europeias instaladas em Lagos e intermediários locais.

A abertura dos caminhos à penetração destas firmas exportadoras fez decrescer a importância das intermediações comerciais promovidas, principalmente, por saros e brasileiros. $\mathrm{O}$ assunto é abordado por autores importantes como Jean Kopytoff, Toyin Falola e Kristin Mann. ${ }^{15}$ No entanto, estes pesquisadores não têm a população brasileira como ponto central de suas interpretações. Com exceção das obras de Manuela Carneiro da Cunha e Alcione Amós, são raros os estudos que se debruçam a entender o lugar dos brasileiros nos anos de 1880 e 1890 em Lagos. Neste sentido, a terceira baliza cronológica que orienta esta tese está associada à compreensão da forma como os brasileiros, cujas atividades comerciais estavam atreladas ao comércio atlântico, redefiniram sua atuação na cidade face ao novo cenário político e econômico que se esboçava nas duas décadas finais do século XIX.

Seguindo as pistas deixadas por pesquisadores que se dedicaram à compreensão das dinâmicas sociais, econômicas e políticas que envolveram a população brasileira existente em Lagos no período entre 1840 e 1900, reuni um corpus documental constituído por três tipos de fontes. O primeiro conjunto de documentos é composto por escritos deixados por oficiais da marinha britânica, cônsules e vice-cônsules dos Golfos do Benim e de Biafra, narrativas de missionários anglicanos e metodistas, artigos publicados em periódicos da Church Missionary Society (CMS) e, também, por relatórios e correspondências trocadas entre funcionários britânicos empregados na administração colonial lagosiana. Este compêndio de fontes é formado por documentos impressos e

${ }^{14}$ O termo "safras comerciais" e os produtos destinados à exportação foram indicados por Martin H.Y.Kaniki em: A economia colonial: as antigas zonas britânicas in BOAHEN, Albert Adu (ed.). História Geral da África, VII: África sob dominação colonial, 1880-1935. Brasília: UNESCO, 2010. p.448.

${ }^{15}$ Entre os estudos publicados por estes autores, ressalto: KOPYTOFF, Jean Herskovits. $A$ Preface to Modern Nigeria. The "Sierra Leonians" in Yoruba, 1830-1890. Wisconsin: The University of Wisconsin Press, 1965; FALOLA, Toyin; HEATON, Matthew M. A History of Nigeria. Cambridge: Cambridge University Press, 2008 e MANN, Kristin. Slavery and the Birth of an African City: Lagos, 1760 - 1900. Indiana: Indiana University Press, 2007. 
publicados, disponíveis para consulta no Instituto de Estudos Brasileiros (IEB) e na biblioteca da Faculdade de Filosofia, Letras e Ciências Humanas (FFLCH), ambos pertencentes à Universidade de São Paulo. Além destes locais de pesquisa, alguns dos relatos consultados passaram por um processo de digitalização e estão disponíveis para consulta no site: www.archive.org. A maioria das publicações oferecidas por este portal se encontra em boas condições de leitura, o que permite que sejam visualizadas na íntegra.

O segundo grupo de fontes é formado por um conjunto de três títulos de periódicos publicados em Lagos entre os anos de 1881 e 1906: o The Lagos Observer (1883 - 1888); o The Lagos Weekly Record (1891 - 1906) e a The Government Gazette (1881 - 1900). Os dois primeiros jornais se encontram digitalizados, seu acesso é feito pela base de dados World Newspaper Archive, seção African Collection. ${ }^{16}$ O último título, The Government Gazette, é um jornal oficial publicado pelo governo colonial britânico e impresso em Lagos. Embora seja uma importante fonte de informações acerca da maneira como a colonização britânica se constituiu na cidade, este terceiro periódico ainda não foi digitalizado. Seus exemplares estão guardados no National Archives, em Londres, e são parte da coleção Colonial Office.

O terceiro compêndio de documentos é constituído por relatórios anuais elaborados pela administração colonial de Lagos, denominados Blue Books. Esta tese trabalha com um conjunto de fontes classificados como Nigeria, 1862 - 1945. A extensa coleção dos Blue Books referente a Lagos e a outras colônias da Grã-Bretanha no continente africano está digitalizada e pode ser consultada através de uma assinatura de acesso ao site: www.britishonlinearchives.co.uk. ${ }^{17}$ Os dados reunidos nestas fontes seguiam

${ }^{16}$ O World Newspaper Archive, seção African Collection, oferece ainda outros títulos de periódicos africanos. Estes jornais não foram selecionados em razão do recorte temporal estabelecido por esta tese. Na esperança de estudos futuros em língua portuguesa, relaciono a seguir os nomes dos periódicos disponíveis nesta base de dados e seus respectivos períodos de publicação: The Lagos Standard (1907 - 1920), Nigerian Chronicle (1908-1915); Nigerian Pioneer (1914-1922) e Times of Nigeria (1914-1920).

17 O site British Online Archives reúne coleções de Blue Books relativas aos seguintes territórios que estiveram sob controle da Grã-Bretanha: Serra Leoa 1824-1843; Costa do Ouro 1846-1939; Basutolândia (Lesoto) 1926-1946; Cabo da Boa Esperança 1821-1909; Gambia 1828-1945; Kenia 1901-1946; Niassalândia 1904-1938; Rodésia do Norte 1924-1948; Rodésia do Sul 1904-1953; Tanganica 1921-1948; Uganda 1901-1945 e Zanzibar 1913-1947. Agradeço 
um padrão de sistematização que serviu a todas as colônias britânicas dispersas pelo planeta. De maneira geral, o Colonial Office enviava aos territórios pertencentes à Grã-Bretanha uma série de tabelas e quadros informativos impressos que deveriam ser preenchidos manualmente pelos respectivos departamentos locais. Estes departamentos eram responsáveis por coligir, selecionar, organizar e remeter novamente ao Colonial Office o maior volume das informações solicitadas. Registros de gastos com estabelecimentos de saúde; documentos referentes ao número de presidiários; tabelas de custos e de despesas públicas; nomeações, férias e mudanças de cargos no funcionalismo colonial; orçamento e contagem de alunos inscritos nas missões religiosas de ensino; quantidade e valores dos artigos importados e exportados são alguns exemplos do conteúdo encontrado nestas fontes.

Ao tomar como esteio a ideia de que os signos de pertencimento que definiam as identidades dos brasileiros de Lagos foram construídos a partir do contato, das trocas e das disputas entre os demais componentes sociais existentes na Lagos oitocentista, dividi esta tese em cinco capítulos. O primeiro deles, Traficantes, "trained Negroes" e "Brazilian emigrants", analisa como as narrativas escritas a partir de 1845 produziram diferentes formas de representação da população brasileira estabelecida na Costa da Mina. Estas variações na maneira como os brasileiros eram registrados em relatos de viagem e em artigos apresentados às sociedades científicas da época carregam consigo as preocupações de seus autores em relação ao domínio, colonização, ocupação e exploração de áreas de interesse da Grã-Bretanha. Ainda neste mesmo capítulo, há uma discussão em torno da questão das identidades étnicas como categorias formuladas por outros grupos. Neste sentido, retomo alguns dos principais autores do campo da antropologia, a fim de compreender em que medida as variações do sentido de ser brasileiro poderiam ser denominadas como identidades cambiantes. Embora esta tese não tenha pretensões antropológicas, apoio parte das interpretações apresentadas em estudos realizados por estes pesquisadores.

imensamente a generosidade da pesquisadora Alcione Amós por ter cedido seus documentos relativos à coleção intitulada Nigéria. 
No segundo capítulo, Lagos, um porto negreiro, trato dos processos históricos que transformaram a cidade no principal atracadouro escravista da Costa da Mina. Ao analisar um conjunto de interações de longa duração estabelecidas entre os habitantes de Lagos e de cidades como Iseri, Benim, Oió e ljebu procurei expor algumas das dinâmicas de poder que estiveram relacionadas ao fornecimento de cativos aos negreiros estabelecidos no porto lagosiano. A atuação de traficantes brasileiros como João de Oliveira, Domingos José Martins, Marcos Borges Ferras, entre outros citados ao longo deste capítulo, se mostrou fundamental para a abertura e consolidação do comércio atlântico de indivíduos escravizados. A intensificação das atividades operadas por negreiros ao longo da primeira metade do século XIX fez crescer as preocupações do Foreign Office acerca da eficácia de suas ações no combate ao tráfico. Em meados da década de 1840, a reocupação de fortes, que desde 1807 haviam sido desocupados, constitui um dos marcos na reformulação da política britânica em prol da extinção do comércio negreiro pelo Atlântico. Sob estes aspectos, o objetivo deste capítulo é discutir o papel desempenhado pelos brasileiros-traficantes em meio ao recrudescimento das ações da Grã-Bretanha para colocar termo ao tráfico. No entanto, nos anos de 1840 a população brasileira instalada em Lagos não era composta apenas por mercadores de escravos. Muitos africanos e descendentes, libertos e livres, que haviam se estabelecido na cidade em maior número a partir de 1835 , não estavam diretamente ligados a este comércio. Neste sentido, é também objetivo desta parte da pesquisa mostrar os contextos com os quais estes indivíduos se depararam ao se estabelecerem na cidade.

O terceiro capítulo, A conquista do "ninho de pirataria e pilhagem", discute o lugar dos negreiros brasileiros em meio às disputas em torno do mando de Lagos entre Akitoye e Kosoko. Ao longo dos anos de 1840, Kosoko empreendeu uma série de ações políticas e ataques contra o obá Akitoye e seu principal apoiador, o Eletu Odibo. Estas ofensivas foram, em parte, sustentadas por alguns brasileiros-traficantes conhecidos a partir da historiografia pelos nomes de Marcos Borges Ferras, Lima e Nobre. De outro modo, tais produções também se referem à Domingos José Martins como um dos brasileiros que 
apoiou Akitoye se colocando contra Kosoko. ${ }^{18}$ Estas disputas pela posição de obá se tornaram ainda mais complexas quando o Foreign Office intensificou as ações antitráfico operadas pelo Esquadrão Africano ancorado na região. Além disto, este era um momento em que os posicionamentos acerca do combate ao tráfico não eram percebidos de maneira uniforme e consensual entre os cidadãos britânicos. Desta forma, parte deste capítulo é dedicada ao entendimento dos debates liderados pelo ex-parlamentar Thomas Fowell Buxton acerca da eficiência da atuação britânica contra os negreiros estabelecidos na região. O modo como as ideias de Buxton influenciaram a atuação política do Foreign Office na tomada de Lagos e na extensão da influência britânica por territórios vizinhos, são também assuntos tratados por este capítulo.

O quarto capítulo, A colonização britânica em Lagos (de 1861 a 1900), apresenta a tomada do porto lagosiano pelas forças da Grã-Bretanha, em 1861, como parte de um processo de escalada da violência colonizadora sobre a região. O propósito desta parte da tese é apresentar como os brasileiros que viviam na cidade, no período entre 1861 e 1900, tiveram de reinventar seu lugar econômico, social e cultural em resposta aos diferentes contextos impostos em função da instalação colonial britânica. Em um primeiro momento, - Colonial Office incentivava a exploração comercial do óleo ou azeite de dendê e do algodão, sem que para isto fosse necessária a interiorização da presença colonial em áreas produtoras, em geral, afastadas do litoral. A forma como os brasileiros atuaram no comércio atlântico atacadista e no varejo de bens importados é um dos assuntos deste capítulo. No entanto, a posição comercial ocupada pelos negociantes brasileiros de Lagos experimentou mudanças a partir da década de 1880. A "pacificação" dos envolvidos na Guerra de Ekitiparapo e as medidas que se seguiram às violentas intervenções executadas pelo governo de Lagos provocaram novas alterações nas dinâmicas comerciais da região. Neste sentido, esta parte da pesquisa também

\footnotetext{
${ }^{18} \mathrm{Em}$ especial, nas seguintes publicações: SILVA, Alberto da Costa e. Um rio chamado Atlântico: a África no Brasil e o Brasil na África. Rio de Janeiro: Nova Fronteira/EdUERJ, 2003, p.128; SMITH, Robert Sydney. The Lagos Consulate, 1851-1861. London: Macmillan Press/Univesity of Lagos Press, 1978, p.30-31 e MANN, K., Op.cit., 2007,p.48.
} 
propõe o entendimento dos processos pelos quais os comerciantes brasileiros reformularam suas formas de atuação frente à nova situação.

No quinto capítulo, Os jornais e as representações dos brasileiros (1880 a 1900), se concentram as análises da participação dos brasileiros em diferentes esferas da vida colonial lagosiana. A primeira delas se refere aos anúncios de estabelecimentos comerciais pertencentes a esta população. As chamadas dos comerciantes brasileiros eram publicadas nos periódicos The Lagos Observer e The Lagos Weekly Record. Em seguida, trato das formas de exposição pública e coletiva de alguns dos signos de pertencimento à comunidade existente na cidade. A intenção é discutir os modos de elaboração dos componentes de uma identidade cambiante, que se reconfigurava em resposta às limitações políticas, econômicas e sociais instituídas pelo governo colonial. $\mathrm{Na}$ tentativa de compreender as alternativas de subsistência formuladas neste contexto, recorri aos registros do funcionalismo público, publicados em relatórios anuais coligidos pelos Blue Books. Ao final, este capítulo ainda expõe algumas reflexões acerca da participação intelectual de um dos membros de maior visibilidade da comunidade brasileira existente em Lagos na última década do século XIX: Moisés da Rocha. Com o propósito de demonstrar que, dentro da comunidade brasileira, as opiniões acerca do governo colonial britânico não eram uniformes em relação a todos os assuntos tratados, procedi a análise dos textos assinados pelo brasileiro e publicados pelo jornal The Lagos Weekly Record.

Resta ainda mencionar que esta pesquisa trabalha essencialmente com documentos redigidos em inglês. Por este motivo, em momentos em que cito excertos de textos originais optei por traduzi-los livremente, a fim de permitir um melhor entendimento. Também escolhi manter designações de nomes, sociedades e lugares em língua portuguesa quando estas já existiam. Por último, em alguns momentos no segundo capítulo desta tese, adotei a denominação de Lagos mesmo quando me referia a acontecimentos anteriores à chegada dos comerciantes europeus e à designação de seu território como tal. Consciente do anacronismo desta denominação, fiz uso do nome pelo qual a ilha se tornou mais conhecida por entender que esta escolha facilitaria a 
compreensão do leitor. No entanto, sublinho que, antes de se tornar Lagos, o mesmo lugar foi conhecido como Oko, Eko e Onim. 


\section{Traficantes, "trained Negroes" e "Brazilian emigrants"}

Todo reino, toda província, deveria ter seu próprio autor. ${ }^{19}$

Este capítulo inicial tem como objetivo analisar as diferentes formas de representação da população brasileira estabelecida na Costa da Mina ao longo do século XIX. Para isto, selecionei cinco autores que relataram suas experiências em Lagos ou em cidades vizinhas a este porto. Todos estes documentos foram escritos originalmente em língua inglesa e publicados entre as décadas de 1840 e 1880. A maior parte das fontes escolhidas foi produzida por indivíduos ligados ao serviço diplomático da Grã-Bretanha, o Foreign Office. A exceção dentro deste conjunto é o relato de viagem do afro-jamaicano Robert Campbell, integrante do Niger Valley Exploring Party, uma organização nascida nos Estados Unidos fundamentada na ideia do retorno de africanos e descendentes como resposta a uma sociedade norte-americana que oferecia poucas alternativas de vida à população negra liberta. Campbell esteve nas cidades de Lagos e Abeokuta entre o final de 1859 e início de 1860. Sua obra foi publicada em 1861 e se refere às suas experiências vividas nesta viagem. ${ }^{20}$

\footnotetext{
19 "Every kingdom, every province, should have its own monographer." A frase do século XVIII foi atribuída ao naturalista britânico, Gilbert White, e está impressa na folha de rosto dos dois volumes do livro: BURTON, R.F. A mission to Gelele, king of Dahome. $2^{\mathrm{a}} \mathrm{ed}$. vol. I e II London: Tinsley Brothers, 1864.

${ }^{20}$ Refiro-me aos seguintes relatos de viagem, aqui ordenados de acordo com a data de publicação: DUNCAN, John. Travels in Western Africa, in 1845 \& 1846. A journey from Whydah, through the kingdom of Dahomey, to Adofoodia, in the interior, vol. I e II. London: Richard Bentley, 1847; FORBES, Frederick E. Dahomey and the dahomans: the journals of two missions to the king of Dahomey, and residence at this capital, in the years 1849 and 1850. vol.I e II London: Longman, 1851; CAMPBELL, Robert. A Pilgrimage to my motherland, an account of a journey among the egbas and yorubas of Central Africa, in 1859-1860. New York: Thomas Hamilton, 1861; BURTON, Richard Francis. Wanderings in West Africa: from Liverpool to Fernando Pó. vol.I, London: Tinsley Brothers, 1863A; BURTON, Richard Francis. Abeokuta and the Camaroons Mountains: an exploration. vol.I, London: Tinsley Brothers, 1863B; BURTON, Richard Francis. A mission to Gelele, king of Dahome. 2 $2^{\mathrm{a}}$ ed. vol. I e II London: Tinsley Brothers, 1864 e MOLONEY, Cornelius Alfred, Correspondence Affair on the West Coast of Africa. In The Journal of the Manchester Geographical Society. vol.V, Manchester: The Manchester Geographical Society, 1889.
} 
A leitura do compêndio de documentos selecionado revelou que as formas de representação dos brasileiros que viviam nas cidades de Ajudá, Badagri, Abeokutá, Porto Novo e Lagos expressavam significativas diferenças, a partir das quais seria possível depreender preocupações em relação ao tráfico, à lucratividade de Lagos enquanto colônia britânica ou à possibilidade de extensão das lavouras comerciais de óleo de palma, algodão, amendoim e borracha por territórios mais afastados do litoral. Em apoio à atuação mais incisiva da armada antitráfico da rainha Victoria, por exemplo, o oficial naval Frederick Forbes identificou quais eram os negreiros brasileiros atuando na região, ao final década de 1840. Nos escritos deixados por Forbes, e também naqueles produzidos pelo vice-cônsul John Duncan, os donos das embarcações negreiras foram nomeados como traficantes e tiveram seus nomes arrolados em publicações amplamente lidas na Inglaterra oitocentista. ${ }^{21}$ Em um momento de intensificação das pressões pela supressão definitiva do tráfico, e a despeito de todos os esforços britânicos em torno da questão, Forbes e Duncan denunciavam aqueles que consideravam serem os responsáveis pela continuidade das operações no comércio ilegal de escravos: os negreiros brasileiros.

Esta mesma preocupação não se verifica no relato produzido nos anos de 1860, pelo então cônsul das baías do Benim e de Biafra, Richard Francis Burton. Em seus escritos, os traficantes eram uma parcela da população ainda existente na Costa da Mina, embora seus integrantes estivessem naquele momento empobrecidos. Como testemunhos do sucesso das ações britânicas no combate ao tráfico, Burton listou os nomes daqueles negreiros que, no passado, haviam constituído verdadeiras fortunas. Além disto, seus registros demonstravam uma preocupação em expor outro grupo de brasileiros que vivia na região: os "Brazilian emigrants". No momento em que Burton escreveu seus relatos de viagem, o Parlamento inglês e as firmas comerciais de Manchester, Liverpool e Londres discutiam as possibilidades de ampliação do cultivo do algodão e de produção do óleo de palma na recém-estabelecida colônia de

\footnotetext{
${ }^{21}$ A questão da popularização das publicações impressas em jornais, revistas e livros é tratada por: CURTIN, Philip D. The Image of Africa. British Ideas and Action, 1780 - 1850. Vol.2, Wisconsin: University of Wisconsin Press, 1973, pp.325 e 338.
} 
Lagos. ${ }^{22}$ Sobre esses assuntos, o cônsul defendia o aproveitamento da mão de obra dos libertos, cuja passagem pela escravidão no Brasil havia Ihes conferido o "aprendizado" necessário à atuação nas lavouras comerciais lagosianas.

Embora de maneiras e em momentos históricos diferentes, Robert Campbell (1859-1860) e o governador de Lagos, Cornelius Alfred Moloney (1886-1891), também descreveram a atuação das "pessoas do Brasil e de Cuba" como parte de um conjunto de ações que promoveriam a "civilização" de Lagos. ${ }^{23}$ À semelhança de Burton, os dois relatos consideravam a experiência da escravatura nas Américas como uma etapa de "treinamento" a ser aproveitada nas lavouras orientadas ao mercado exportador. No caso do registro produzido por Campbell, é possível perceber uma argumentação mais preocupada na defesa da criação de uma colônia agrícola em Abeokuta, do que na descrição dos brasileiros que viviam na cidade. Quase três décadas depois, o artigo publicado por Moloney ampliava de maneira significativa a atenção conferida à participação dos brasileiros no crescimento econômico de Lagos. Ao final da década de 1880 , as possibilidades de ocupação agrícola e de aumento dos ganhos comerciais justificavam a conquista britânica no interior da região nomeada como protetorado da Grã-Bretanha. Assim sendo, os brasileiros eram representados como uma população que poderia transferir seu conhecimento agrícola aos demais moradores da colônia de Lagos. ${ }^{24}$

Mas afinal, quais foram os contextos que transformaram as formas de representação dos brasileiros de traficantes para trabalhadores agrícolas absorvidos pelas lavouras comerciais de produtos destinados ao mercado exportador? Poderíamos considerar estes indivíduos como mais um grupo étnico entre os diversos outros existentes em Lagos neste período? Em busca de respostas a estas questões encaminhei minha análise em direção à discussão do sentido que as identidades étnicas assumem enquanto categorias

\footnotetext{
${ }^{22}$ Cf. MANN, Kristin. Slavery and the Birth of an African City: Lagos, 1760 - 1900. Indiana: Indiana University Press, 2007, p.89; SMITH, Robert Sydney. The Lagos Consulate, 18511861. London: Macmillan Press/Univesity of Lagos Press, 1978, cap.4 e GALLAGHER, J. Fowell Buxton and the New African Policy, 1838-1842, Cambridge Historical Journal, vol.10, No. 1, 1950, p.46.

${ }^{23}$ Cf. CUNHA, Manuela Carneiro da. Negros, estrangeiros. Os escravos libertos e sua volta à África. $2^{2}$ ed. revisada e ampliada. São Paulo: Companhia das Letras, 2012, p.166.

${ }^{24}$ MOLONEY, Cornelius Alfred . Op.cit.,1889,p.276.
} 
explicativas formuladas, em grande medida, por outros grupos. Ao tomar como ponto de partida a interpretação de Manuela Carneiro da Cunha, de que as identidades brasileiras só podem ser compreendidas se vinculadas a determinados momentos históricos e articuladas aos demais componentes que compõem um universo societário mais amplo, propus, ao final deste capítulo, o entendimento de que os brasileiros formularam identidades cambiantes, em contato com os diversos interlocutores sociais que lhes foram apresentados ao longo de todo o século XIX.

\subsection{Traficantes ou brasileiros? As representações britânicas do século XIX}

Os negros meio educados retornam com orgulho para o seu país, sábios como macacos que viram o mundo... ${ }^{25}$

Em meados de 1844, o então explorador escocês John Duncan deixou o território britânico e embarcou no vapor Prometheus com o propósito de chegar até a costa ocidental da África. Esta não era a primeira viagem de Duncan à região. Poucos anos antes, ele havia servido como mestre de armas na Expedição de 1841/42, pelo rio Níger. Esta se tornou famosa por ser a primeira expedição oficial inglesa a penetrar por uma das principais vias de acesso ao interior do continente. Constituída a partir dos esforços do governo britânico, da participação de associações científicas e comerciais e da Church Missionary Society (CMS), os viajantes de 1841/42 tinham quatro objetivos. O primeiro deles estava relacionado ao papel que a African Civilization Society assumiu nesta expedição. A equipe científica fornecida pela associação deveria recolher o maior número de informações acerca das condições políticas e comerciais dos territórios percorridos. O segundo dizia respeito à assinatura de tratados de supressão do comércio de escravos junto às autoridades locais. Esta era uma

\footnotetext{
25 "The half-educated blacks returns in pride to his country, a savant as a monkey that has seen the world..." [minha tradução] FORBES, Frederick E. Op.cit., vol.I, 1851, p.118.
} 
demanda de grupos humanitários e da CMS, cuja pressão no Parlamento inglês era significativa naquele momento. Em terceiro lugar estava o propósito de estabelecer um ou mais postos de comércio ao longo do Níger, como uma resposta à "violenta e vocal oposição" de Robert Jamieson. O comerciante era proprietário dos vapores Quorra e Ethiope e, como tal, se opunha à penetração oficial da Grã-Bretanha sob o argumento de que, desde 1835, sua companhia realizava incursões comerciais pelo mesmo rio. $^{26}$ Como último objetivo, a expedição tinha a intenção de instalar uma fazenda modelo na conjunção dos rios Níger e Benué, na cidade de Lokoja, plano que ficaria a cargo da Agricultural Association, cujas ações se mostraram ineficientes no decorrer da década de $1840 .{ }^{27}$

A respeito das viagens anteriores à Expedição de 1841/42, o historiador Philip Curtin explica que estas primeiras incursões tinham propósitos estritamente comerciais e, em função disto, eram realizadas e pagas por empresas britânicas com interesse em "abrir" esta importante via de acesso ao interior. Entre 1832 e 1833, MacGregor Laird liderou um grupo que foi financiado pela African Inland Commercial Company. Por volta de 1834, esta companhia foi dissolvida e suas embarcações vendidas. Um destes navios, o Quorra, foi comprado por Robert Jamieson que, em 1835, contratou os serviços do capitão John Beecroft. Este se tornou responsável pelas incursões britânicas realizadas pelo Quorra. Em 1840, com um novo vapor, o Ethiope, a companhia de Jamieson tornou-se a primeira a navegar com maior regularidade pelo Níger. A obra de Curtin permite um melhor entendimento acerca do trajeto percorrido por expedições que palmilharam territórios compreendidos entre a Gâmbia e o estuário do rio Níger, realizadas entre os anos de 1830 e 1855. Um mapa apresentado pelo autor assinala as viagens lideradas por Macgregor Laird entre 1832 e 1833; por John Beecroft nos anos de 1835,1840 e 1845 e por William Balfour Baikie, em $1854 .^{28}$

\footnotetext{
${ }^{26}$ CURTIN, Philip D. Op.cit. 1973, pp.296-298.

${ }^{27} \mathrm{Ibid}$, p.303. M'Bokolo também analisa a escalada comercial britânica pelo Níger e, ao mencionar a Expedição de 1841/42, comenta que o empreendimento de Lokoja fracassou em seu objetivo de instalar e manter lavouras na cidade. M'BOKOLO, Elikia. África Negra. História e Civilizações. Tomo II. Do século XIX aos nossos dias. 2ª edição. Lisboa: Colibri, 2011, p.143.

${ }^{28}$ É possível que Curtin tenha se baseado na carta geográfica elaborada por William Winwood Reade, em seu livro The African Sketch-Book, para produzir o mapa ao qual me refiro. A obra
} 


\section{Mapa 1: Expedições britânicas entre 1830 e 1854}

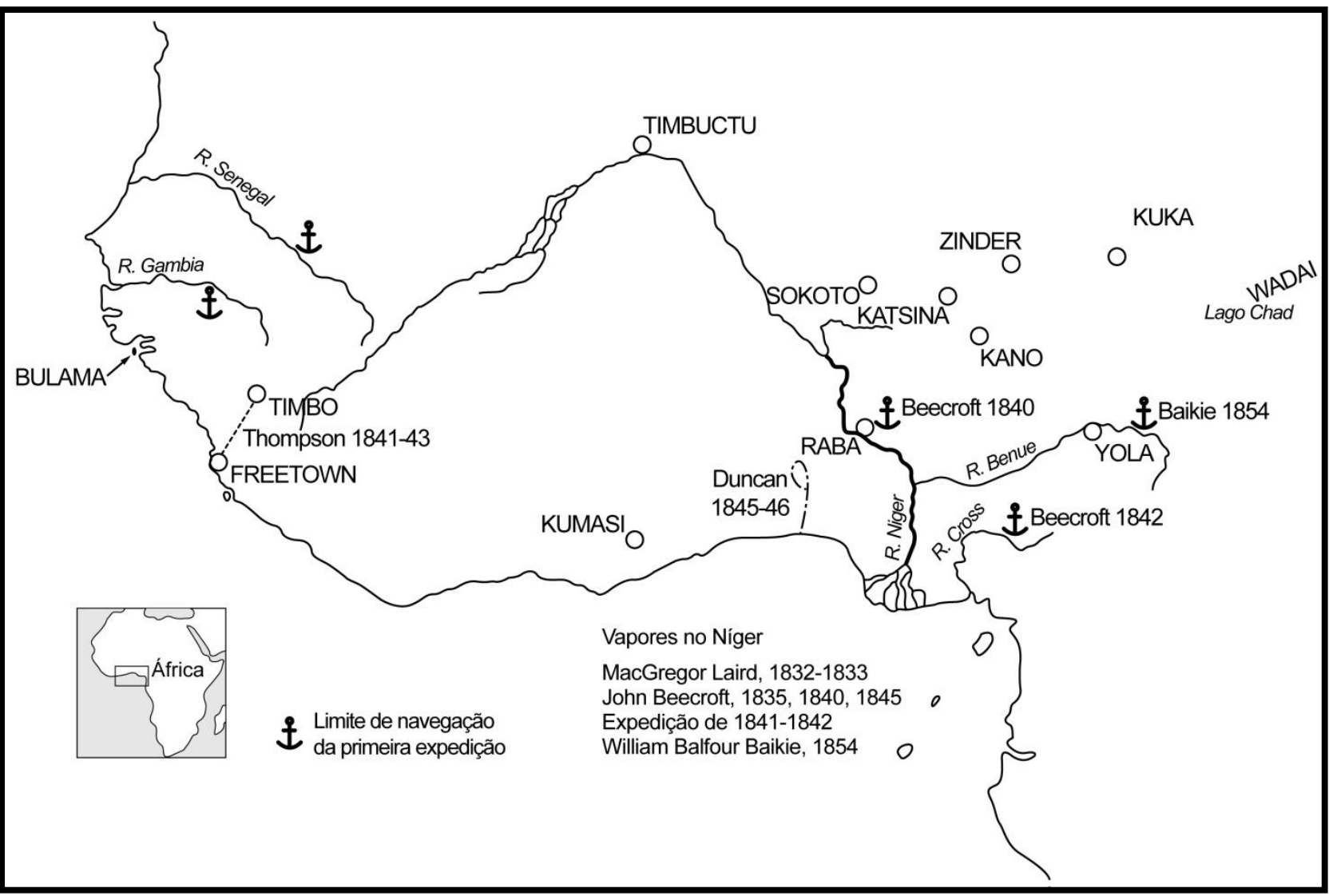

Fonte: Mapa adaptado de CURTIN, Philip D. The Image of Africa. British Ideas and Action, 1780 - 1850. Vol.2, Wisconsin: University of Wisconsin Press, 1973, p.309 e READE, William Winwood. The African Sketch-Book. vol. I, London: Smith, Elder \& Co, 1873, p.407.

Quando John Duncan participou da Expedição de 1841/42 a firma de Robert Jamieson já havia percorrido um extenso trecho do curso do rio Níger. Neste sentido, a despeito desta viagem não ter sido a primeira e o índice de mortalidade entre europeus ser elevado, o percurso completado por Duncan alcançou alguns êxitos. ${ }^{29} \mathrm{O}$ principal deles foi o de promover a ampliação dos interesses científicos, comerciais e humanitários dos europeus pelo continente africano, em especial, pelas localidades banhadas pelas bacias dos rios Níger e Benué.

de Reade foi publicada em 1873. Esta representação cartográfica recebeu o título de The Pioneers of Discovery in Africa. Nela foram apontadas as incursões da Grã-Bretanha principalmente ao longo do curso dos rios Niger, Nilo, Congo e Zambeze. As referências às obras mencionadas são, respectivamente: CURTIN, Philip D. Op.cit., 1973,p.309 e READE, William Winwood. The African Sketch-Book. vol. I, London: Smith, Elder \& Co, 1873, p.407.

29 De acordo com Curtin, cerca de 48 europeus morreram logo nos primeiros dois meses de viagem. Entre os 159 membros restantes da expedição, 55 (quase um terço) faleceram antes que a missão pudesse retornar para a Grã-Bretanha. CURTIN, Philip D. Op.cit., 1973, p.303. 
O aumento das atenções dispensadas a esta porção da Costa da Mina ocorreu em um contexto de retomada dos fortes britânicos que estavam desocupados desde os primeiros anos do século XIX. O abandono das fortificações decorria da supressão do comércio escravista pela Grã-Bretanha. Em 1807, as campanhas parlamentares contra o comércio atlântico de escravos tornaram ilegal o tráfico praticado por britânicos por meio da lei de Abolição do Comércio de Escravos (Abolition of the Slave Trade Act). Ao final da primeira década do século XIX, os fortes ingleses até então empregados como pontos de apoio ao comércio de cativos realizado por britânicos foram progressivamente desocupados. Em razão disto, os registros elaborados por estes estabelecimentos deixaram de ser produzidos. ${ }^{30}$ Vinte e seis anos mais tarde, no ano de 1833, a abolição da escravidão em todas as possessões coloniais da Grã-Bretanha (a Slavery Abolition Act) foi aprovada.

A proibição de exploração da mão de obra cativa deu maior vigor às ações do esquadrão antitráfico instalado na Costa da Mina. Como consequências da nova legislação houve a intensificação das atividades de combate ao comércio negreiro e a retomada das fortificações existentes na região. Em Ajudá, por exemplo, o forte William que não contava com uma guarnição militar desde 1812, voltou a receber oficiais a partir de 1849. E na Costa do Cabo, o forte britânico denominado Cape Coast Castle, que serviu como ponto de estocagem de cativos até o início do século XIX, foi reativado e transformado em sede da administração britânica na Costa do Ouro nos anos de $1840 .^{31}$

Em um contexto em que o Foreign Office, adotava um conjunto de ações para retomar pontos estratégicos da Costa da Mina, John Duncan empreendeu sua segunda expedição ao interior da África ocidental. Financiado pela Royal Geographical Society, cuja sede estava em Londres, e sustentado politicamente pelo Foreign Office, Duncan partiu de Ajudá no final do ano de 1845 e seguiu em direção a Abomé, capital do reino do Daomé. A partir deste

\footnotetext{
${ }^{30}$ Os historiadores Law e Mann analisam a escassez das fontes deixadas pelos britânicos entre o final da década de 1810 e início dos anos de 1840, em: LAW, Robin. Ouidah: The Social History of a West African slaving 'port', 1727-1892. Ohio: Ohio University Press/ Oxford: James Currey, 2004, cap.6 e MANN, Kristin. Slavery and the Birth of an African City: Lagos, 1760 - 1900. Indiana: Indiana University Press, 2007, p.39.

${ }^{31}$ Cf. LAW, Robin. Op.cit., 2004, p.7 e 218.
} 
ponto, a expedição pretendia chegar às "Montanhas do Congo" que, naquele momento, os viajantes europeus erroneamente acreditavam se estenderem pelo interior do continente a partir da Senegâmbia, seguindo na direção leste. De acordo com Bassett e Porter, ao longo dos séculos XVIII e XIX esta suposta cadeia de montanhas foi descrita por comerciantes e exploradores como uma barreira natural que impedia a penetração de europeus por regiões afastadas da costa. Embora as "Montanhas do Congo" só existissem nos mapas oitocentistas, o desafio de atravessá-las ou de percorrê-las em toda sua extensão - o que era considerado ainda mais difícil - era um feito almejado por diversos exploradores, inclusive por John Duncan. ${ }^{32}$

A viagem de 1844/45 realizada por Duncan não foi a primeira expedição britânica à capital daomeana. Antes do explorador escocês, Thomas Dickson já havia percorrido os caminhos que ligavam Ajudá até Abomé. Entre 1825/27, Dickson que era membro de uma missão liderada pelo comandante Hugh Clapperton, partiu do porto de Ajudá e seguiu em direção ao norte até alcançar, 23 dias depois, Abomé. As correspondências enviadas por Dickson para Clapperton dão conta da sua chegada à capital daomeana. Acompanhado pelo conhecido traficante brasileiro, Francisco Félix de Souza o chachá de Ajudá, Dickson foi recebido por Guezo. Na ocasião, o oficial britânico ofereceu a Guezo um conjunto de bens fornecidos por Félix de Souza. Após passar algum tempo em Abomé, Dickson seguiu em direção à cidade borgu de Nikki. Depois disto a comunicação enviada pelo oficial cessa, o que nos permite presumir seu falecimento. $^{33}$

\footnotetext{
${ }^{32}$ BASSETT, Thomas J; PORTER, Phillip W. "From the Best Authorities": The Mountains of Kong in the Cartography of West Africa. The Journal of Africa History, vol.32, n.3, 1991, pp.367413. Neste artigo Bassett e Porter analisam as representações cartográficas das "Montanhas do Congo" como um recurso à compreensão do contexto histórico destas produções. Além deste aspecto, os autores discutem a questão da "autoridade dos mapas" como realizações científicas capazes de perpetuar por cerca de um século a ideia de uma cadeia imaginária de montanhas. Ainda de acordo com os autores, o viajante Mungo Park e o cartógrafo James Rennell são considerados responsáveis pela divulgação da existência das "Montanhas do Congo".

${ }^{33}$ Cf. LOCKHART, Jamie Bruce; LOVEJOY, Paul E. (ed.). Hugh Clapperton into the Interior of Africa. Records of the Second Expedition 1825 - 1927. Leiden: Brill, 2005, Apendix II e LAW, Robin. Further Light on John Duncan's Account of the 'Fellatah Country', History in Africa, vol.28, 2001, p.130. Sobre a elaboração de representações cartográficas dos territórios percorridos por estes viajantes e como Hugh Clapperton produzia seus mapas a partir da coleta de informações entre as populações locais, sugiro: DRIVER, Felix. The World and Africa: Rediscovering African Geographies. Royal Geographical Society, 2011.p.6.
} 
Vinte anos mais tarde, em 1845, antes de iniciar sua longa jornada pelo interior da África ocidental, John Duncan se deteve por algum tempo no porto de Ajudá. Durante este período sua comitiva reuniu suprimentos e presentes que deveriam ser entregues à Guezo e às chefias locais das cidades pelas quais passariam. Para tanto, também recebeu o apoio de Francisco Félix de Souza. Embora Félix de Souza estivesse acamado pelo reumatismo e, em 1845, possivelmente já contasse com mais de oitenta anos, o negreiro acolheu a comitiva britânica e forneceu suprimentos e artigos disponíveis em suas lojas, sem cobrar por nenhuma mercadoria. Também graças à influência do chachá, - explorador conseguiu permissão para visitar Abomé, onde esperava encontrar com Guezo. ${ }^{34}$

Durante o percurso da expedição até a capital daomeana, o explorador escocês identificou "muitos lugares bem cultivados por pessoas retornadas do Brasil". Estas lavouras estavam há seis ou sete milhas de Ajudá. Percebidas como uma "inesperada e gratificante" surpresa durante a viagem, as pequenas plantações contavam com residências onde era possível realizar paradas para descanso ou refeição. Afirmando que aquelas eram as pessoas mais "industriosas" que havia encontrado até o momento, Duncan expunha sua posição em relação aos efeitos da escravidão. Para o viajante que se tornaria mais tarde vice-cônsul de Ajudá, os indivíduos retornados do Brasil provavam que "para este país [o Daomé] a escravidão teria efeitos bons e ruins". Aos olhos de Duncan, a passagem pelo cativeiro no Brasil permitiu que a parcela brasileira da população demonstrasse "algum sinal de civilização", perspectiva que reapareceria nos registros produzidos por Richard Burton, Robert Campbell e Alfred Moloney em décadas posteriores. ${ }^{35}$

Embora os libertos vindos do Brasil tenham recebido alguma atenção em seu relato, eles não eram o foco das preocupações de Duncan nesta viagem. A visita à capital do Daomé tinha duas intenções bastante específicas. A primeira

\footnotetext{
${ }^{34}$ Para Costa e Silva, quando Francisco Félix de Souza faleceu - em 8 de maio de 1849 - sua idade estava entre 81 e 94 anos. SILVA, Alberto da Costa e. Francisco Félix de Souza, mercador de escravos. Rio de Janeiro: Nova Fronteira/ed. UERJ, 2004, p.165.

${ }^{35}$ DUNCAN, John. Op.cit., 1847, vol.1, p.185, 186 e 141, respectivamente. A menção do Daomé como um país é relativamente comum entre os documentos selecionados para análise neste capítulo. Entre os britânicos, o termo "país" era aplicado a territórios onde era possível identificar organizações políticas, militares e econômicas semelhantes às existentes na Europa.
} 
delas consistia em persuadir o rei daomeano, Guezo, a abandonar a prática de sacrifícios humanos. Enquanto a segunda estava em convencê-lo a suspender o tráfico atlântico de escravos. Duncan chegou à capital do reino justamente no momento em que aconteciam as cerimônias anuais que incluíam os ditos sacrifícios. Todavia, seus argumentos não foram suficientes para dissuadir Guezo em relação às práticas de decapitação, degola e de ingestão do sangue de suas vítimas. Em seu encontro com o rei do Daomé, o explorador se colocou contra o tráfico, acenando em direção à possibilidade de assinatura de um tratado entre o Daomé e a Grã-Bretanha, proposta que foi prontamente rechaçada por Guezo. ${ }^{36}$

No início de 1846, a comitiva britânica retornou à cidade costeira de Ajudá. Embora a primeira viagem empreendida por John Duncan não tenha alcançado sucesso em relação às suas intenções iniciais, é possível considerála um marco na retomada das ações oficiais da Grã-Bretanha na Costa da Mina. A missão liderada por Duncan foi descrita pelo explorador em duas ocasiões. A primeira em um artigo publicado pelo Journal of the Royal Geographical Society, no ano de 1846. Portanto, logo após seu retorno ao litoral da Costa da Mina. E a segunda no ano seguinte, em 1847, quando Duncan lançou um extenso livro, em dois volumes, em que descrevia suas experiências ao longo desta jornada. ${ }^{37}$

Em outubro de 1849, cerca de quatro anos depois da primeira expedição de 1844/45, o oficial do esquadrão antitráfico, Frederick E. Forbes, acompanhou a segunda viagem apoiada pelo Foreign Office até Abomé. Alguns meses antes, neste mesmo ano, a Grã-Bretanha havia criado o Consulado dos Golfos do Benim e de Biafra, cuja sede estava localizada na ilha de Fernando Pó. O primeiro cônsul nomeado para este posto foi John Beecroft. Como ex-governador em exercício da possessão britânica de Fernando Pó (entre 1830 e 1833) e antigo capitão da firma de Robert Jamieson

\footnotetext{
${ }^{36}$ Ibid, cap.XII. Entre as páginas 249 e 252, Duncan descreve em detalhes a execução de quatro prisioneiros em poder de Guezo.

${ }^{37}$ A referência ao artigo apresentado na Royal Geographical Society é: DUNCAN, John. Notice of a Journey from Whydah on the West Coast of Africa to Adofoodiah in the Interior, Journal of the Royal Geographical Society, 16, 1846, pp.154-162. Law analisa os locais visitados por esta expedição em: LAW, Robin. Further Light on John Duncan's Account of the 'Fellatah Country', History in Africa, vol.28, 2001, pp.129-138.
} 
(de 1834 a 1849), Beecroft foi escolhido para comandar as operações britânicas realizadas em direção às porções mais ao interior do continente. Com o cônsul Beecroft instalado em Fernando Pó, coube a John Duncan assumir o vice-consulado estabelecido em Ajudá. No ano 1849, o recémnomeado vice-cônsul liderou sua segunda viagem exploratória até a capital do Daomé. $^{38}$ No entanto, em razão de seu falecimento prematuro, os registros referentes a esta expedição nunca foram publicados. ${ }^{39} \mathrm{Na}$ ocasião, Forbes ocupava o posto de tenente no esquadrão de combate ao tráfico e, antes de ser alocado na Costa da Mina, já havia servido nas Índias Ocidentais e na China. Segundo o próprio oficial, sua ampla experiência na armada da rainha Victoria constituiu o elemento decisivo para que fosse escolhido para integrar a missão de 1849. Esta viagem oficial até Abomé foi descrita por Forbes e ganhou uma primeira edição, também em dois volumes, no ano de 1851.40

Quando a comitiva formada por funcionários e soldados da Coroa britânica desembarcou em Ajudá, Francisco Félix de Souza já havia falecido. Uma série de ritos funerários em honra ao antigo chachá movimentava a cidade. Parte das cerimônias incluíam sacrifícios humanos que foram descritos com pesar pelo oficial naval. Segundo Forbes, embora a morte de Félix de Souza tivesse ocorrido no mês de maio, cinco meses depois "a cidade ainda estava em estado de ebulição". Cerca de trezentas amazonas, enviadas por Guezo até a costa, dançavam e acendiam tochas diariamente na praça

\footnotetext{
${ }^{38}$ A trajetória de John Beecroft como oficial britânico, agente comercial e cônsul das baías do Benim e de Biafra é analisada no artigo: DIKE, K.O. John Beecroft, $1790-1854$. Her Britannic Majesty's Consul to the Bights of Benin and Biafra, 1849 - 1854. Journal of the Historical Society of Nigeria, vol. 1, n. 1, December, 1956, pp.5-14.

${ }^{39}$ Duncan faleceu no dia 29 de outubro de 1849. Frederick Forbes narrou as circunstâncias e causas do falecimento do vice-cônsul de Ajudá em seu relato: FORBES, Frederick E. Dahomey and the dahomans: the journals of two missions to the king of Dahomey, and residence at this capital, in the years 1849 and 1850. vol.I London: Longman, 1851, p.93.

${ }^{40}$ Em uma publicação anterior à "Dahomey and the dahomans..." Forbes avalia as operações do "Esquadrão Africano": FORBES, Frederick E. Six months' service in the African Blockade, from April to October, 1848, in command of H.M.S. Bonetta. London: Richard Bentley, 1849. Além desta publicação e da obra referente à expedição de 1849 à capital do Daomé, Forbes também registrou sua experiência na China, entre 1842 a 1847, período em que pôde verificar "as últimas hostilidades" decorrentes da Guerra do Ópio na região: FORBES, Frederick. Five Years in China from 1842 to 1847. With an account of the occupation of the islands of Labuan and Borneo by Her Majesty's Forces. London: Richard Bentley, 1848. É possível ler uma análise acerca de como as representações do oficial naval sobre o Daomé se transformaram em função de um discurso em prol da escalada da violência no combate ao tráfico em: GEBARA, Alexsander. Uma análise dos textos de Frederick Forbes nas décadas de 18401850. O esquadrão africano e o final do tráfico escravo na África ocidental. História, Histórias. Brasília, vol.1, n.1, 2013.
} 
principal de Ajudá, grupos tocavam pelas ruas, galinhas da Guiné, patos, cabras, pombos e porcos eram conduzidos até os locais de sacrifício. Desta forma, os ritos funerários se estendiam por toda noite e eram regados pela cachaça baiana fartamente distribuída à população. ${ }^{41}$

Depois de receber permissão para seguir até Abomé, a expedição deixou a tumultuada Ajudá. Em apenas quatro dias a comitiva chegou aos portões da capital do reino do Daomé, onde permaneceu até ser conduzida ao interior da cidade e levada à presença de Guezo e de seus cabeceiras. Nesta rápida recepção, Guezo, por meio de seu porta-voz, solicitou notícias do missionário Thomas Birch Freeman que seis anos antes, em 1843, estivera naquela mesma sala. Após trocarem informações acerca do religioso e de alguns enviados britânicos desaparecidos, o rei daomeano deixou o recinto sem que Duncan pudesse anunciar os motivos de sua visita. Poucos dias depois, o vice-cônsul adoeceu gravemente e a comitiva foi obrigada a retornar à costa. ${ }^{42}$

Cerca de sete meses mais tarde, em maio de 1850, o oficial naval regressou à Abomé. Desta vez estava acompanhado pelo cônsul dos Golfos do Benim e de Biafra, John Beecroft. Nesta nova viagem à capital do Daomé Beecroft manteve as mesmas incumbências da expedição liderada por Duncan: convencer Guezo a abandonar o tráfico e a prática de sacrifícios humanos. Contudo, uma solicitação mais imediata predominou durante as discussões: a suspensão do ataque das forças daomeanas à cidade de Abeokuta. Conforme Forbes, ao argumentar que Abeokuta era aliada da Coroa britânica e que diversos missionários viviam e atuavam neste porto, Beecroft procurou convencer Guezo a recuar de sua decisão. No entanto, o rei respondeu ao cônsul que não desistiria de seu intento e, neste caso, era "melhor aconselhar os missionários a deixarem a cidade". ${ }^{43}$ Diante da firmeza da réplica de Guezo, Beecroft se contentou em resgatar um liberto de Serra Leoa que havia sido reescravizado.

\footnotetext{
${ }^{41}$ FORBES, Frederick E. Op.cit., vol.I,1851, p.49.

${ }^{42}$ FORBES, Frederick E. Op.cit., vol.I, 1851. O capítulo Abomey, its court and its people narra o encontro da comitiva britânica com Guezo e seus cabeceiras.

${ }^{43}$ lbid, vol.II, p. 190.
} 
Após uma breve busca, o cônsul foi informado de que o saro procurado, de nome John M'Carthy, vivia no compound de um dos cabeceiras do rei. Depois de advertir o cabeceira com a ameaça de levar a questão até a rainha Victória e ao rei Guezo, M'Carthy, sua esposa e filha, foram liberados para integrarem a missão em seu retorno à costa. De acordo com o relato de Forbes, a expedição voltou para Ajudá acrescida por quatro novos passageiros: os três primeiros, eram o sarô John M'Carthy, sua mulher e filha. A quarta integrante era uma criança oferecida, pelo próprio Guezo, à rainha Victoria. A menina foi citada pelo oficial como "resgatada" de um destino trágico: ser escrava do rei daomeano e, possivelmente, servir em sacrifício.

O episódio narrado pelo oficial da marinha antitráfico nos permite elaborar algumas suposições acerca do gesto desempenhado por Guezo. O envio de uma de suas cativas como presente a ser entregue à monarca da Grã-Bretanha, pode ser interpretado como parte de uma complexa e disputada negociação diplomática entre os dois governos. Neste sentido, é possível que na ação do rei do Daomé estivesse implícito um desafio à autoridade inglesa, naquele momento empenhada em extinguir o tráfico atlântico. Como que desdenhando dos argumentos em defesa do término do comércio atlântico de escravos, Guezo enviava um "excelente espécime frenológico" à rainha branca. Uma atitude que pode ser entendida como uma demonstração de força e de firmeza em relação à manutenção das práticas condenadas pelo governo britânico. ${ }^{44}$

A oferta de Guezo é narrada por Forbes como um "resgate". Assim, para completar este ato era necessário estendê-lo também ao resgate da alma. Desta forma, a menina de cerca de oito anos de idade foi batizada com o nome de Sarah Forbes Bonetta. E, a partir deste momento, passou a carregar no sobrenome os signos da atuação britânica contra o tráfico: o nome do oficial responsável por sua transferência para a Inglaterra (Forbes) e o da embarcação por ele capitaneada (Bonetta). Conforme indica em seu relato, Forbes mantinha grandes expectativas em relação à jovem:

\footnotetext{
${ }^{44}$ FORBES, Frederick E. Op.cit., vol.II,1851, p.192-195. O episódio em que Forbes registra o resgate de Sarah Forbes Bonetta está na p.206.
} 
Para a idade dela, que estimamos ser de oito anos, ela é um gênio perfeito, ela agora fala bem inglês e tem um grande talento para música. (...) Ela está muito à frente de qualquer criança branca de sua idade, sua aptidão para o aprendizado, sua capacidade mental e ternura, a tornam uma excelente espécime de sua raça, a partir do qual se pode verificar a capacidade intelectual do negro. ${ }^{45}$

Além da descrição das capacidades intelectuais de Sarah Bonetta, Forbes estampou a página de abertura do segundo volume de seu relato "Dahomey and the dahomans..." - com uma gravura da criança recémresgatada. Esta imagem se tornou a primeira de um conjunto de outras imagens e fotografias tomadas em diferentes momentos da vida de Bonetta. Os retratos de Bonetta estamparam diversos periódicos londrinos no século XIX. Como era comum à época, as fotografias de Sarah Bonetta eram posadas e, em geral, tiradas em estúdios. Posteriormente, no século $\mathrm{XXI}$, estes registros integraram exposições realizadas no Reino Unido. ${ }^{46}$ Depois de desembarcar em Londres e de ser colocada sob a proteção da rainha Victoria, que a tornou sua afilhada, Sarah Forbes Bonetta parece ter cumprido as expectativas de Frederick Forbes em relação ao seu desempenho intelectual.

Alguns anos mais tarde a afilhada da rainha Victoria viajou novamente pelo Atlântico, desta vez em direção a Serra Leoa. Depois de estabelecida em Freetown, Sarah Bonetta frequentou a escola feminina mantida pela CMS, a Fourah Bay College. Em 1862, quando tinha por volta de dezenove anos, Bonetta se casou com um rico comerciante saro, J.P. Davies. Fotografada em várias ocasiões, a imagem da afilhada da rainha Victoria espelhava as ações britânicas no combate ao tráfico e à escravidão. Ao lado do missionário saro Samuel Ajayi Crowther, primeiro bispo africano nomeado pela igreja anglicana,

\footnotetext{
${ }^{45}$ Ibid, vol.II, 1851, p.208.

${ }^{46}$ Imagens de Sarah Forbes Bonetta integraram a exposição "Black Victorians: Black People in British Art, 1800 - 1900", realizada no ano de 2005, na Manchester City Art Gallery. A mostra fotográfica exibia fotografias de negros "domesticados" pelo universo Victoriano. No ano seguinte, esta mesma exposição foi transferida ao Birmingham Museum and Gallery. Em 2010, uma mostra acerca do trabalho do fotógrafo Camille Silvy, no National Portrait Gallery, em Londres, também incluiu imagens tomadas de Sarah F. Bonetta. Cf. WEST, Shearer. Black Victorians: Black People in British Arte, 1800 - 1900. Victorian Literature and Culture, Cambridge University Press, vol.35, March 2007, pp.329 - 334.
} 
Sarah Bonetta era a personificação do bom desempenho da Grã-Bretanha na implantação da política antitráfico levada a cabo na Costa da Mina.

No ano de 1850, quando Sarah foi resgatada por Frederick Forbes, a armada antitráfico considerava os portos de Ajudá e Lagos os principais pontos de embarque de escravos. Nas duas ocasiões em que Forbes representou 0 governo britânico junto à Guezo, em 1849 e 1850, suas expedições partiram de Ajudá em direção à Abomé. Apesar destas viagens não passarem por Lagos, os registros deixados pelo oficial naval guardavam considerações acerca deste porto. De acordo com o próprio autor, sua atuação na repressão ao comércio de cativos havia the fornecido informações suficientes para reputar à cidade de Lagos a posição de "um dos maiores entrepostos de escravos na África". Esta situação estava ligada à localização geográfica de seu porto, cujas atividades atavam Lagos "a todos os países da Guiné". ${ }^{47}$

Como podemos observar na representação cartográfica a seguir, uma rede de lagoas e canais colocava em contato os portos negreiros de Jaquim, Porto Novo, Apa e Badagri. O acesso por água a estes embarcadouros exigia a passagem por Lagos, o que tornava a ilha um ponto de interesse estratégico para as atividades britânicas de combate ao tráfico. Soma-se a este aspecto o fato de a cidade estar situada próximo à embocadura do rio Ogun, principal via de acesso à Abeokuta. Esta abrigava, desde 1843, um estabelecimento missionário da CMS. A instalação dos anglicanos Samuel Crowther e do reverendo Henry Townsend em Abeokuta ampliou as discussões do Foreign Office a respeito da possibilidade de uma intervenção em Lagos. ${ }^{48}$

\footnotetext{
${ }^{47}$ FORBES, Frederick E. Op.cit, vol.1, 1851, p.9.

${ }^{48}$ Embora o ano de 1843 assinale a fundação da missão de Abeokuta, Townsend e Crowther só chegaram à cidade dos egbas em 1846. Entre os autores que tratam das ações evangelizadoras promovidas pela Church Missionary Society (a CMS) temos: ISICHEI, Elizabeth. History of Christianity in Africa from Antiquity to the Present. London: Society for Promoting Christian Knowledge, 1995, cap. 6. West Africa to c. 1900; GEBARA, Alexsander. A África de Richard Francis Burton: antropologia, política e livre comércio. São Paulo: Alameda, 2010, p.70 e MANN, Kristin. Op.cit., 2007, p.92.
} 


\section{Mapa 2: Lagos e portos vizinhos (c. 1800)}

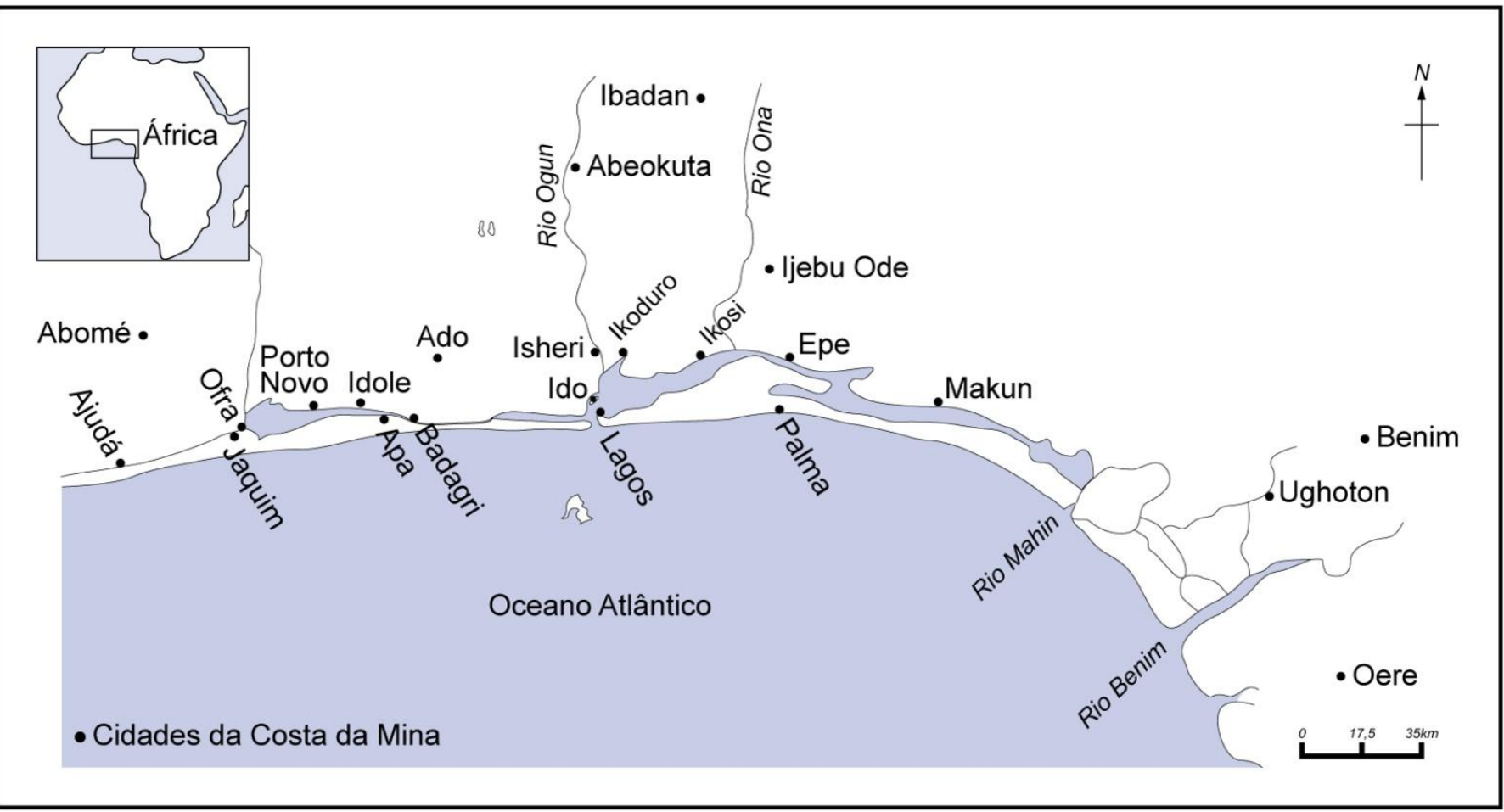

Fonte: Mapa adaptado de LAW, Robin. Trade and Politics behind the Slave Coast: The Lagoon Traffic and the Rise of Lagos, 1500 - 1800. The Journal of African History, vol.24, n.3,1983, p.327.

Espraiando-se por diversos embarcadouros da Costa da Mina, o tráfico atlântico de escravos era visto pelas autoridades governamentais britânicas como uma questão cujo combate exigia a mobilização de considerável esforço político e vultosos recursos humanos e financeiros. Desde 1833, quando as campanhas contra a escravidão saíram vitoriosas do Parlamento - por meio da Slavery Abolition Act, que tornou a escravidão na Grã-Bretanha e nas colônias britânicas ilegal - as ações da Inglaterra no combate a esta prática assumiram contornos melhor definidos e sintetizados no progressivo recrudescimento das pressões diplomática e naval sobre os pontos de comercialização de escravos. Todavia, dezesseis anos depois, em 1849, o tráfico e a escravidão ainda persistiam no continente africano e nas Américas, a despeito de todas as ações britânicas em prol do contrário. ${ }^{49}$

49 No caso do tráfico em direção ao Brasil, parlamentares como Clemente Pereira consideravam a questão um assunto de soberania nacional. Sob o argumento de que a manutenção do comércio escravista era um problema que deveria ser solucionado pelo Poder Legislativo brasileiro, deputados ampliavam o prazo para a extinção da atividade, beneficiando 
Negreiros brasileiros como Domingos José Martins, Don José de Almeida, Don José dos Santos (conhecido também como José Francisco dos Santos ou Alfaiate), Izidoro, Antonio e Ignacio de Souza - os três últimos, filhos do famoso chachá Francisco Félix de Souza - estão arrolados nos registros de Frederick Forbes. As citações aos traficantes brasileiros são encontradas ao longo de todo o relato deixado pelo oficial naval. Em um trecho de sua obra, Forbes descreve a propriedade de Don José dos Santos (o Alfaiate) como um local que servia para guardar cativos e óleo de palma. Além de plantar palmeiras produtoras do fruto próprio para a fabricação do dendê, Santos também recebia carregamentos vindos do interior. As cabaças contendo óleo de palma eram descarregadas e negociadas no terreiro da casa do traficante. Apesar de diversificarem seus empreendimentos, atuando também no comércio de dendê, os grandes traficantes ainda mantinham parte de seus negócios no mercado atlântico de escravos. Aos olhos de Forbes, este aspecto tornava a perseguição ao comércio escravista uma tarefa ainda mais complexa, visto que as mesmas embarcações que transportavam para o Brasil, principalmente, óleo de palma, panos da costa e noz de cola, poderiam também carregar em seus porões cativos que seriam negociados tão logo desembarcassem nos portos do litoral brasileiro. ${ }^{50}$

Para escapar dos bloqueios promovidos pelo esquadrão antitráfico era preciso disfarçar os tumbeiros como se fossem embarcações destinadas ao transporte de mercadorias lícitas. O sucesso do disfarce dependia, ainda de acordo com Forbes, das habilidades específicas do negreiro que se arriscava em tal empreitada. José de Almeida, por exemplo, é descrito como o mais rico traficante de Ajudá, cujas atividades no porto de Popo (o relato não especifica se seria Popo Grande ou Pequeno) estariam sob seu monopólio. Almeida era um ex-escravo "astuto e notoriamente inteligente". Sua perspicácia estava relacionada à "educação" recebida no Brasil ainda durante os anos de cativeiro.

toda a cadeia de indivíduos ligada ao mercado atlântico negreiro. O historiador Jaime Rodrigues analisa as discussões em torno da supressão do tráfico, ocorridas na Câmara dos Deputados, em sua obra: RODRIGUES, Jaime. O infame comércio. Propostas e experiências no final do tráfico de africanos para o Brasil (1800-1850). Campinas: Ed. da Unicamp, 2000, pp.95-106. Os embates sobre o tema ocorridos no Parlamento britânico na década de 1830 são tratados por Mann, em: MANN, Kristin. Op.cit., 2007,cap.3.

${ }^{50}$ Cf. FORBES, Frederick E. Op.cit, vol.1, 1851, p.114. 
A passagem por terras brasileiras teria conferido ao liberto as habilidades necessárias para que ele obtivesse sucesso comercial em sua volta à Costa da Mina. No entanto, este sucesso estava diretamente vinculado ao tráfico. Assim, atuando como negreiro, Forbes julgava que Almeida "tirava proveito de sua educação e, em seu retorno, traía seu próprio povo." ${ }^{51}$

Corrompidos por outros mercadores de escravos já instalados na região, libertos como José de Almeida empregavam no tráfico atlântico a "educação" acumulada durante os anos de cativeiro no Brasil. Neste excerto em específico, o vocábulo "educação" assumia também um sentido negativo, pois estava associado ao tráfico escravista. Segundo Forbes, sem a orientação dos britânicos ou de missionários católicos e protestantes, diversos outros exescravos se tornariam negreiros. E estes indivíduos não eram uma parcela da população a ser desperdiçada. De acordo com o oficial, aqueles que haviam passado pela escravidão nas Américas poderiam introduzir os padrões civilizatórios europeus na Costa da Mina. Se, em países escravistas como o Brasil, os melhores jovens fossem selecionados para receber "educação profissional como clérigos, doutores, agricultores e artesãos, ao retornarem aos seus países poderiam logo ajudar na civilização e incentivar o desprezo pelo sacrifício e pela escravidão". Do contrário, sem o auxílio da Grã-Bretanha e das instituições religiosas europeias, estes indivíduos tornavam-se apenas "negros meio educados", em inglês "half-educated blacks". E, nesta condição, os libertos voltariam para a África "orgulhosos" e "sábios", comportando-se como "macacos que viram o mundo" e, uma vez estabelecidos na Costa da Mina, não tardariam a se tornar negreiros. ${ }^{52}$

Dez anos depois da viagem empreendida por Forbes, em 1849, as referências aos brasileiros que moravam na região se modificaram em alguns aspectos. No ano de 1859, o afro-jamaicano Robert Campbell integrou, juntamente com o Dr. Martin R. Delany, uma expedição organizada pelo Niger Valley Exploring Party. A viagem foi financiada por associações ligadas aos interesses da indústria têxtil de Manchester e por filantropos norte-americanos e britânicos. De acordo com Blackett, a organização da missão passou por

\footnotetext{
${ }^{51}$ lbid, vol.1, p.151.

52 Ibid, vol.1, p.151 e 118.
} 
diversos problemas para arrecadar recursos suficientes para a realização de uma expedição com um maior número de integrantes. Por isto, antes de seguir em direção à Costa da Mina, Robert Campbell partiu para a Grã-Bretanha. Após desembarcar em Londres, o jamaicano iniciou uma campanha para angariar os fundos necessários à execução do projeto junto às associações britânicas, pois "estavam todos [os membros do Niger Valley Exploring Party] cansados de mendigar aqui [nos Estados Unidos]". Na Inglaterra, Campbell foi apresentado a Gerald Ralston, ministro da Libéria alocado em Londres; ao Dr. Thomas Hodgkin, filantropo e vice-presidente da Pennsylvania State Colonization Society e a Thomas Clegg, industrial de Manchester envolvido na promoção do cultivo do algodão na África. ${ }^{53}$

Depois desta passagem pela Inglaterra, Robert Campbell embarcou em direção à Costa da Mina, onde planejava encontrar com seu companheiro de viagem, Martin Robison Delany. Segundo Gilroy, ao longo da vida Delany atuou como "jornalista, editor, médico, cientista, juiz, soldado, inventor, fiscal da alfândega, orador, político e romancista". Na década de 1850, logo após ingressar no curso de medicina em Harvard, foi forçado a abandonar os estudos em razão da pressão dos alunos contra a presença de um estudante negro na universidade. Somado a isto, uma extenuante e infrutífera batalha na justiça pelo direito à herança de sua esposa colaborou para que Delany deixasse de lado sua vida acadêmica na pequena cidade de Cambridge e voltasse à Filadélfia. Uma vez fora do ambiente universitário, Robert Delany publicou uma série de escritos em que discutia a questão racial norteamericana. Fazendo uso de seus conhecimentos acerca da frenologia, ele elaborou textos que contra-argumentavam os discursos formulados pela etnologia racista. Além disto, suas publicações estendiam para outros países as análises de situações de discriminação e violência racial vividas pela população negra dos Estados Unidos. Ainda de acordo com Gilroy, Delany considerava que as diferenças experimentadas pelos negros diasporizados seriam "meramente acidentais". Estas distinções escamoteavam uma unidade latente que aguardava a ação do pan-africanismo militante para ganhar forma.

\footnotetext{
${ }^{53}$ Cf. BLACKETT, Richard. Martin R. Delany and Robert Campbell: Black Americans in Search of an African Colony. The Journal of Negro History, vol.62, No. 1, jan. 1977, p.12-14.
} 
Sobre este aspecto, a resposta de Delany à opressão estava na constituição de um "estado-nação supra-étnico forte e completamente sintético". ${ }^{54}$

No ano de 1859, a expedição liderada por Robert Campbell e Martin Delany apostava no estabelecimento deste "estado-nação" de dimensões continentais. O objetivo desta viagem era firmar um acordo com o então alake de Abeokuta, Okukenu, a fim de que libertos vindos da América do Norte pudessem se fixar em seu território. Esta missão foi concebida no contexto do retorno de libertos de diversas partes das Américas para a região denominada geograficamente como Golfo do Benim, movimento que se tornou conhecido como "back to Africa". ${ }^{55} \mathrm{Em}$ um momento em que a supressão da escravidão não significava um rompimento efetivo com condições de existência pregressas, a travessia do Atlântico era vista como opção por uma nova vida.

Campbell e Delany escreveram, cada um, narrativas em que registraram as experiências vividas ao longo da expedição até Abeokuta. ${ }^{56}$ Os escritos de Delany revelam uma perspectiva que aliava os esforços comerciais e civilizatórios empregados pelo capital britânico, às habilidades intelectuais dos libertos norte-americanos e à força física dos africanos encontrados na cidade dos egbas. A posição adotada por Delany não diferia de maneira significativa dos registros deixados por Campbell. Afinal, ao sustentar junto aos industriais e filantropos que haviam arcado com os custos daquela expedição, a ideia de que o sucesso na criação de um estabelecimento agrícola, produtor de algodão, estaria associado à instalação de libertos vindos dos Estados Unidos

\footnotetext{
${ }^{54}$ GILROY, Paul. O Atlântico Negro, modernidade e dupla consciência. Trad. Cid Knipel Moreira. Rio de Janeiro: Editora 34/UCAM/Centro de Estudos Afro-Asiáticos, 2002, pp.65-82.

${ }^{55}$ Entre os pesquisadores que estudam a travessia em direção à África ocidental de livres e libertos, provenientes tanto do Brasil, quanto dos Estados Unidos e Caribe estão: GILROY, Paul. Op.cit., 2002 e SOUZA, Mônica Lima e. Entre margens: o retorno à África de libertos no Brasil, 1830-1870. tese de doutorado. UFF/RJ, 2008. pp.114/115. V.Y.Mudimbe dedica um capítulo de sua obra, "A invenção da África", para discutir as questões acerca do movimento "back to Africa" levantadas por E.W.Blyden, no século XIX: MUDIMBE, V.Y. A Invenção da África. Gnose, Filosofia e a Ordem do Conhecimento. Ramada/Luanda: Edições Pedago/Edições Mulemba, 2013, cap.IV O legado e as questões de E.W.Blyden.

${ }^{56}$ A narrativa de viagem de Martin Delany foi publicada, no ano de 1861 , originalmente com o título de: Official Report of the Niger Valley Exploring Party. New York/London: Thomas Hamilton/Webb, MMillington \& Co, 1861. Em 1969, a obra ganhou uma nova edição e título, sendo reimpressa como: DELANY, Martin. Search for a Place: Black Separatism and Africa, 1860. Ann Arbor: University of Michigan Press, 1969. Esta tese trabalha com a segunda edição do relato de Delany. A obra de Campbell foi publicada no mesmo ano e pela mesma casa editorial: CAMPBELL, Robert. A Pilgrimage to my motherland, an account of a journey among the egbas and yorubas of Central Africa, in 1859-1860. New York: Thomas Hamilton, 1861.
} 
na região, Campbell colocava em evidência a preexistência de brasileiros que se mostravam

\begin{abstract}
Industriosos, empreendedores e, um aqui e outro ali, carregavam consigo algum conhecimento útil em artes que foram, sem dúvida, a forma pela qual realizaram um trabalho gigantesco que, agora alcançou o seu máximo, e precisa ser continuado de um modo ainda mais elevado por indivíduos mais civilizados e da mesma raça, os quais por uma série de razões estão melhor adaptados a uma realização bem sucedida. ${ }^{57}$
\end{abstract}

Ao apresentar os brasileiros como "industriosos", "empreendedores" e donos de conhecimentos "úteis" não especificados em seu registro, Robert Campbell acenava para outra forma de representação destes indivíduos que viviam em Lagos e Abeokuta. Nos escritos publicados por Campbell, os retornados do Brasil não eram traficantes, mas agricultores. Neste sentido, reconhecendo as contribuições dos brasileiros à "civilização" desta porção da Costa da Mina, Campbell prevenia acerca dos limites ao "trabalho gigantesco" realizado por estas pessoas. Para solucionar este problema e dar continuidade às ações iniciadas pelos brasileiros seria necessário estabelecer uma nova população, composta por "indivíduos mais civilizados e da mesma raça". Os indivíduos referidos por Campbell seriam libertos provenientes dos Estados Unidos. Percebidos como mão de obra superior à dos brasileiros, estes novos trabalhadores não apenas impulsionariam a participação comercial de Abeokuta e Lagos no mercado internacional, como também trariam novo fôlego às ações de cristianização promovidas pelos missionários presbiterianos e batistas que, no futuro, poderiam se estabelecer nas cidades localizadas mais ao interior. ${ }^{58}$

A associação entre proselitismo cristão e dominação territorial, proposta por Campbell e Delany, chamou a atenção da Igreja anglicana e das

\footnotetext{
${ }^{57}$ CAMPBELL, Robert. Op.cit., 1861, p.73.

58 Segundo Isichei, desde 1846, existia em Calabar uma missão fundada pela United Presbyterian, cujos integrantes eram cristãos negros e brancos provenientes da Jamaica. Além disto, a partir de 1843, negros vindos dos Estados Unidos e brancos americanos atuavam em ações promovidas pela igreja batista. Na década de 1840 , os batistas mantinham atividades na Costa do Ouro, Fernando Pó, Camarões e Congo. ISICHEI, Elizabeth. History of Christianity in Africa from Antiquity to the Present. London: Society for Promoting Christian Knowledge, 1995,pp.166-167.
} 
autoridades ligadas ao Foreign Office em relação aos interesses da Niger Valley Exploring Party na região. Meses depois do acordo com o alake Okukenu ser firmado, o reverendo Henry Townshend e o cônsul britânico Henry Grant Foote questionaram a validade do documento. ${ }^{59}$ No início de 1860 , os dois enviados da Niger Valley Exploring Party embarcam novamente para a Grã-Bretanha e, em seguida, retornam aos Estados Unidos. Segundo Blackett, mesmo depois da proposta da fundação da colônia de Abeokuta ser deixada de lado, Robert Campbell retornou à Lagos. ${ }^{60}$ Dois anos mais tarde, em março de 1862, o jamaicano, sua esposa e seus quatro filhos desembarcaram no porto lagosiano e fixaram residência na cidade. A trajetória de Campbell foi marcada por sua participação na vida pública e política local. Em 1863, ele fundou o jornal The Anglo-African que, apesar de uma curta duração (de junho de 1863 a dezembro de 1865), marcou o início da imprensa não oficial em Lagos. Sua atuação em associações científicas e literárias, em especial na The Lagos Mutual Improvement Society e na Lagos Scientific Society, tornou Campbell um dos líderes intelectuais de seu tempo. ${ }^{61}$

Embora o projeto aventado pelo Niger Valley Exploring Party não tenha se concretizado, a menção de Campbell acerca da presença de brasileiros como integrantes de uma etapa inicial no processo de "civilização" que, naquele momento, havia "alcançado o seu máximo" é uma das primeiras referências que descola a representação dos brasileiros do tráfico atlântico de escravos. Ainda que, em 1850, a supressão definitiva do comércio escravista para o Brasil tivesse como consequência a significativa redução no número de traficantes, a atividade continuou a ser praticada, em menor volume, em direção a Cuba. E, até 1867, ano em que o tráfico para Cuba também foi

\footnotetext{
59 O debate referente à validade do acordo firmado entre Okukenu e os enviados do Niger Valley Exploring Party ganha novos contornos se analisado à luz das discussões que antecederam as ações em torno da assinatura do tratado de cessão de Lagos, em agosto de 1861. Voltarei a este ponto no quarto capítulo desta tese.

${ }^{60}$ BLACKETT, Richard J.M. Return to the Motherland: Robert Campbell, a Jamaican in Early Colonial Lagos. Phylon, vol.40, No.4, 1979, pp. 375-386.

${ }^{61}$ Sobre a participação de Robert Campbell na formação da imprensa em Lagos, indico: SAWADA, Nozomi. The educated elite and associational life in early Lagos newspapers: in search of unity for the progress of society. Tese de doutorado, Birmingham/UK: Centre of West African Studies School of History and Cultures College of Arts and Law / University of Birmingham, 2011, p.32.
} 
extinto, ainda havia negreiros brasileiros neste negócio. ${ }^{62}$ No entanto, não foram negreiros os brasileiros escolhidos para compor o relatório de Campbell acerca das possibilidades de criação de um estabelecimento agrícola em Abeokuta. Os brasileiros de Campbell eram "industriosos" e "empreendedores" e, embora suas competências se assemelhassem à "inteligência" dos traficantes arrolados por Forbes, pois resultavam da passagem pela escravidão no Brasil, eles pareciam tomar parte do esforço liderado pelos britânicos para "civilizar" aquela porção da Costa da Mina.

A incorporação dos brasileiros como parte do discurso em torno da "civilização" da África está presente também em outros registros de viagem produzidos no século XIX. Ao final de 1861, quase dois anos depois do término da expedição de Campbell e Delany, Richard Francis Burton assumiu o consulado das baías do Benim e de Biafra, com sede na ilha de Fernando Pó. Meses antes, em agosto de 1861, o então obá de Lagos, Docemo, assinou um tratado de cessão da cidade, tornando-a efetivamente colônia da Grã-Bretanha. Neste contexto, o novo cônsul britânico realizou, às suas próprias expensas, uma série de viagens pela África ocidental. Entre 1863 e 1864, a expedição orientada ao encontro com o rei daomeano Glele foi a única oficialmente designada pelo governo da Grã-Bretanha. ${ }^{63}$ A viagem se estendeu de dezembro de 1863 a fevereiro de 1864 e teve como um de seus resultados concretos a publicação, no ano de 1864, de um relato em que Burton deixou registradas suas experiências exploratórias pela região. Neste documento, Lagos foi descrita como uma cidade "pestilenta", cuja população europeia somava setenta pessoas, dentre as quais nove haviam falecido nos últimos trinta dias. Sua insalubridade decorria das péssimas condições do ar e das águas que circundavam o território lagosiano. Em vista disto, Burton afirmava "nenhum homem estará seguro se permanecer em Lagos por uma semana."64

Quando o cônsul britânico publicou suas impressões acerca da "arenosa Lagos", a cidade já era colônia da Grã-Bretanha há mais de dois anos. As

\footnotetext{
${ }^{62}$ Cf. LAW, Robin. A Comunidade brasileira de Uidá e os últimos anos do tráfico atlântico de escravos, 1850-66. Revista Afro-Ásia, 27, 2002, pp. $41-77$.

${ }^{63}$ Cf. GEBARA, Alexsander. Op.cit., 2010, p.51.

${ }^{64}$ BURTON, Richard Francis. A mission to Gelele, king of Dahome. $2^{\mathrm{a}}$ ed. vol.I, London: Tinsley Brothers, 1864, pp.27-28.
} 
ações que a tornaram mais uma das possessões britânicas na África aconteceram em um momento de valorização da principal matéria-prima exportada em seu atracadouro: o óleo de palma, conhecido no Brasil como óleo ou azeite de dendê (termos doravante empregados como sinônimos). Conforme explica Mann, a intensificação da atividade industrial na Europa demandava grandes quantidades deste produto. Velas, sabão, ração para 0 gado e glicerina que, com o tempo passou a ter também uso medicinal, eram alguns dos artigos industrializados que tinham grandes porções de dendê em sua composição. ${ }^{65}$

Além disto, o óleo e a noz de palma não eram as únicas matérias-primas exportadas pelo porto de Lagos. Ao longo da primeira metade da década de 1860, o algodão se tornou um bem escasso no mercado internacional. A Guerra Civil norte-americana, que se estendeu de 1861 a 1865, praticamente cortou o fornecimento desta mercadoria para as indústrias têxteis britânicas. Em resposta à insuficiência da oferta, a Grã-Bretanha passou a estimular o plantio do algodão em seus domínios coloniais. Como o solo e o clima de Lagos não eram favoráveis ao cultivo do produto, foram abertas lavouras em porções do território mais ao interior, nas cidades de Abeokuta e lbadan. Esta progressiva interiorização da agricultura comercial orientada para atender aos interesses britânicos teve início nos anos de 1860. Nas décadas seguintes, estas lavouras se ampliaram para porções cada vez mais distantes do litoral, seguindo as bacias dos rios Ogun, Oni e, mais ao sul, do rio Niger.

Nas plantações de dendê e algodão, a produção estava condicionada à demanda europeia. E, neste sentido, as casas comerciais exportadoras estabelecidas em Lagos pressionavam intermediários e, indiretamente, agricultores para obter um volume cada vez maior destas matérias-primas. Contudo, a intensificação da produção tinha limite. Para Richard Burton, estas limitações estavam na mão de obra. Afinal, "o negro, em seu estado selvagem, faz com que suas esposas trabalhem, ele não, ou melhor, ele não pode trabalhar, exceto quando obrigado (...) ou por necessidade" ${ }^{66}$ A solução para a escassez de trabalhadores nas lavouras comerciais de algodão e de dendê

\footnotetext{
${ }^{65}$ MANN, Kristin. Op.cit., 2007, pp.118-120.

${ }^{66}$ BURTON, Richard Francis. Op.cit. vol II, 1864, p.204.
} 
estava no aprendizado fora da África. Sustentando uma dimensão positiva da escravidão, o cônsul dos Golfos do Benim e de Biafra expunha argumentos que, nos dias atuais, poderiam soar como contraditórios a todas as ações britânicas empenhadas em extinguir o tráfico atlântico. No entanto, para Burton, o repúdio ao tráfico e ao cativeiro não necessariamente significava o desmerecimento completo da experiência da escravidão. E, neste aspecto, os "Brazilian emigrants" expunham a função didática do sistema escravista, uma vez que

o envio do negro da África [para as Américas] é como mandar um garoto para escola; essa é a única chance de progresso do aprendizado de que há mais na vida do que tocar tambor e dançar, falar e cantar, beber e matar. ${ }^{67}$

Como os outros escritos do século XIX analisados, o discurso civilizacional presente neste relato estava respaldado em referenciais europeus. Assim, a passagem pela escravidão era considerada pelo cônsul uma experiência, em determinados aspectos, benéfica. Neste excerto em específico, Richard Burton afirmava que o tempo vivido sob o regime escravista se converteria no aprendizado de novos ofícios e na incorporação de padrões comportamentais mais "civilizados". Nestes termos, a proximidade com o universo do homem branco, proporcionada pela vida na escravidão, "educaria" o africano para o trabalho na lavoura.

Ao mostrar conhecer profundamente os escritos deixados pelos já mencionados John Duncan e Frederick Forbes, assim como expondo seu domínio sobre as realizações da CMS, da Wesleyan Missionary Society e da Société des Missions Africaines (SMA), Burton construiu uma narrativa que, por meio da acumulação de informações, da observação e da descrição minuciosa dos acontecimentos, buscou documentar a geografia, a flora, a fauna e as populações encontradas. Não por acaso a epígrafe escolhida por Burton para figurar na página de rosto de sua obra - A mission to Gelele, king of Dahome foi atribuída ao naturalista britânico, Gilbert White. Segundo White, "Todo reino, toda província, deveria ter seu próprio autor". Neste sentido, os dados

${ }^{67}$ Ibid, vol II, p. 204. 
fornecidos por estes autores constituiriam um repertório de informações, imagens e mapas que ajudariam a guiar as ações britânicas sobre os territórios de seu interesse na Costa da Mina. ${ }^{68}$

Assumindo o papel de viajante erudito, Burton examinou fragmentos de realidades, cotejou documentos e relatos anteriores ao seu estabelecimento na Costa da Mina, editou e atualizou percepções a partir de suas experiências concretas. De acordo com Said, em seus escritos Burton representava a si mesmo como o "personagem principal", em torno do qual sua narrativa se desenvolvia. Esta posição o tornava um "comentarista autorizado" a registrar e analisar suas experiências como viajante, uma vez que resultavam da combinação entre empiria e erudição. ${ }^{69} \mathrm{~A}$ ideia de que os escritos produzidos por viajantes europeus - fossem eles cientistas, religiosos ou funcionários enviados por suas metrópoles - produziram saberes sobre territórios e populações que, até o século XIX, permaneciam desconhecidas e os processos que aliaram estes conhecimentos às ambições econômicas e políticas imperiais foi discutida por Mary Louise Pratt, obra que abordarei no segundo e quinto capítulos desta pesquisa. ${ }^{70}$

Voltando à narrativa produzida por Burton a partir de sua viagem oficial até Abomé, quando o cônsul da baía de Biafra registrou esta expedição, as relações de tráfico entre a Bahia e o Daomé haviam diminuído de maneira significativa. Os negreiros brasileiros encontrados em Ajudá viviam numa situação bastante diferente daquela descrita por viajantes das décadas de 1840 e 1850. Alguns já haviam falecido e muitos perderam verdadeiras fortunas em razão das apreensões realizadas pelo esquadrão antitráfico da rainha Victória. Numa narrativa sintonizada com sua época e com a ideia de sistematização e ordenação da realidade observada, o cônsul britânico teve o cuidado de listar os nomes dos principais brasileiros que ainda viviam a comercializar escravos nas cidades de Ajudá, Porto Novo, Badagri e Aguê. E, indo além, ordenou os

\footnotetext{
${ }^{68}$ A epígrafe atribuída a Gilbert White se encontra reproduzida em: BURTON, R.F. A mission to Gelele, king of Dahome. $2^{\mathrm{a}}$ ed. vol. I e II London: Tinsley Brothers, 1864.

69 SAID, Edward W. Orientalismo: o Oriente como invenção do Ocidente. São Paulo: Companhia das Letras, 2007, pp.269-270.

${ }^{70}$ PRATT, Mary Louise. Os olhos do império: relatos de viagem e transculturação. Trad. Jézio Hernani Bonfim Gutierre, Bauru: EDUSC, 1999.
} 
indivíduos arrolados segundo a posição, possivelmente econômica, destes nas sociedades em que viviam:

A seguir a lista de portugueses, brasileiros, mulatos e africanos civilizados ainda restantes no mercado. Cinco portugueses, a saber:

1. Antonio Vieira da Silva, estabelecido em Ajudá, Popo Grande e Ague.

2. Francisco de Souza Maciel.

3. Ignacio de Souza Magallaes; Ajudá, Porto Novo e Badagri.

4. Jacinto Joaquim Rodriguez; Ajudá e Porto Novo.

5. J. Suares Pereira; Ajudá e Ague. ${ }^{71}$

Entre as cinco pessoas relacionadas por Burton como portuguesas encontrei apenas algumas referências historiográficas à Jacinto Joaquim Rodriguez. De acordo com Costa e Silva, o comerciante nasceu na llha da Madeira e, por volta do ano de 1844, teria se instalado na Costa da Mina. ${ }^{72}$ Embora os estudos que tratam da sua atuação como negreiro não deixem explícito, é possível que as pressões britânicas em torno da supressão do tráfico atlântico tenham-no levado a estabelecer seus negócios em mais de um porto. Como tantos outros negreiros de sua época, Rodriguez procurava burlar o esquadrão antitráfico atuando em diferentes embarcadouros. Instalado em Ajudá e em Porto Novo, ele lançava mão dos artifícios disponíveis para se safar do bloqueio naval empreendido pelo esquadrão da Grã-Bretanha estacionado no Golfo do Benim. Além deste aspecto ligado à forma como administrava suas atividades comerciais, Costa e Silva destaca a questão da sua procedência. De acordo com o historiador, Jacinto Rodriguez não era brasileiro, mas um madeirense com negócios na Costa da Mina. Este elemento, em especial, revela uma característica da identidade brasileira relacionada a esta primeira geração de brasileiros-traficantes: a variedade de origem. De fato, a historiografia mostra que muitos negociantes considerados brasileiros eram, na verdade, provenientes de Cuba, Ilha da Madeira ou Portugal. ${ }^{73}$ Dentro deste mesmo grupo existiam ainda africanos cuja inserção

\footnotetext{
${ }^{71}$ BURTON, R. F. Op.cit. vol I, 1864, p.74.

72 SILVA, Alberto da Costa e.Um rio chamado Atlântico: a África no Brasil e o Brasil na África. Rio de Janeiro: Nova Fronteira/EdUERJ, 2003, p.157.

${ }^{73}$ Sobre os retornos a partir de Cuba, sugiro em específico as seguintes obras: SARRACINO, Rodolfo. Los que volvieron a África. Havana: Editorial de Ciencias Sociales, 1988; SARRACINO, Rodolfo. Cuba-Brasil: os que voltaram à África. Estudos Afro-Asiáticos, n.20,
} 
no comércio atlântico (escravista ou de produtos lícitos) acontecia por meio da associação com grandes negreiros.

A incorporação de indivíduos em razão de sua atuação no comércio atlântico negreiro levou alguns destes mercadores a serem classificados a posteriori como brasileiros, a despeito de seu nascimento e de nunca terem sido escravos no Brasil. A presença do traficante cubano Juan José Zangronis (também grafado Zangronie, Sangron, Sangronio e Zangromys) em Ajudá exemplifica como a atração exercida por negreiros como Francisco Félix de Souza podia cooptar pessoas de origens diversas à comunidade brasileira que se formava ao seu redor. Este é também o caso das famílias Adjovi, Houénou, Codjia, Gnahoui e Hodonou. De acordo com Law, os fundadores destes grupos eram africanos que nunca foram escravos no Brasil. Ao invés disto, eram parceiros comerciais de Félix de Souza e, como tais, forneciam cativos ao chachá de Ajudá. ${ }^{74}$

Embora muitas das produções historiográficas recentes reconheçam que a constituição da identidade brasileira contou com o acréscimo de pessoas cujos interesses comerciais eram o fio condutor que atava seus membros, no momento em que Burton publicou seu relato, em 1864, tal perspectiva ainda não havia se constituído. Para o cônsul britânico, a existência de "portugueses, brasileiros, mulatos e africanos civilizados" deveria ser registrada com precisão. Deste modo, a breve lista contendo apenas cinco nomes de portugueses foi seguida por outra quase três vezes maior, com quatorze negreiros arrolados sob a designação de brasileiros:

1. Francisco Antonio Monteiro

2. F. J. Medeiros, no momento em Ague (alguns dizem que é um português nascido nos Estados Unidos).

3. Francisco Olympio Silva, em Porto Seguro.

junho, 1991, pp.85-100 e, em tempos mais recentes, OTERO, Solimar. Afro-Cuban diasporas in the Atlantic world. Rochester: University of Rochester Press, 2010.

${ }^{74}$ A respeito da trajetória de Juan José Zangronis ver: LAW, Robin. "The evolution of the brazilian Community in Ouidah" in MANN, Kristin; BAY, Edna (eds.) Rethinking the African Diaspora: the making of a Black Atlantic World in the Bight of Benin and Brazil.Portland: Frank Cass Publishers, 2001, p.26; SILVA, Alberto da Costa e. Francisco Felix de Souza, mercador de escravos. 2 $2^{\mathrm{a}}$ ed. Rio de Janeiro: Nova Fronteira/EdUERJ, 2004, p.121 e LAW, Robin; MANN, Kristin. Op.cit, 1999, p.326. No que se refere a incorporação das famílias Adjovi, Houénou, Codjia, Gnahoui e Hodonou ao chamado grupo de brasileiros de Ajudá, sugiro: LAW, Robin. Ouidah: The Social History of a West African slaving 'port', 1727-1892. Ohio: Ohio University Press/ Oxford: James Currey, 2004, pp.175-177. 
4. Marco Borges Ferras.

5. João Pinheiro de Souza, comumente conhecido por Taparica.

6. Gulielme Martins do Nascimento.

7. Marcelino dos Martins Silva.

8. Ricardo Augusto Amadie: fala ingles e francês.

9. João Victor Angelo.

10. José Francisco dos Santo, comumente conhecido por Alfaiate;

11. Angelo Custodio das Chagas.

12. João Antonio Dias.

13. Francisco Giorge.

14. Domingo Rafael Martinez, filho de J. Domingo Martinez. ${ }^{75}$

Neste segundo rol apresentado por Richard Burton fui capaz de localizar, em meio às produções historiográficas consultadas por esta pesquisa, os nomes de apenas seis brasileiros. Um deles é F.J. de Medeiros cujo nome completo, de acordo com Costa e Silva, era Francisco José de Medeiros. Segundo Burton, o local de nascimento deste traficante seria incerto, entendimento que se repete também em Costa e Silva. Conforme as pesquisas realizadas por este autor, Francisco Medeiros teria nascido na Ilha da Madeira ou nos Estados Unidos. Por volta de 1850, já em idade adulta, Medeiros migrou para Ajudá, onde se casou com a filha caçula de Francisco Félix de Souza. Deste relacionamento nasceu Julio de Medeiros, mercador de armas de fogo que na década de 1890 abasteceu as forças de Béhanzin, no Daomé, contra os soldados franceses comandados pelo coronel Dodds, cujas incursões militares visavam a conquista do território daomeano. ${ }^{76}$

Além do negreiro Francisco José de Medeiros, também Francisco Olympio da Silva é mencionado por Costa e Silva como um dos fundadores da cidade de Lomé, atual capital do Togo. Na década de 1960, seu neto Sylvanus Olympio, foi um dos líderes do movimento pela independência do Togo e primeiro presidente do país. ${ }^{77}$ A participação destacada de integrantes das famílias Medeiros e Olympio em disputas políticas ligadas à escalada

\footnotetext{
${ }^{75}$ BURTON, R. F. Op.cit. vol I, 1864, pp.74/75.

${ }^{76}$ SILVA, Alberto da Costa e. Um rio chamado Atlântico: a África no Brasil e o Brasil na África. Rio de Janeiro: UFRJ, 2003,pp.140-141. Ainda de acordo com Costa e Silva, o fornecimento de armas de fogo por Julio de Medeiros não impediu a derrota de Béhanzin. Em 1894, depois de sua captura pelas forças francesas, Béhanzin embarcou para o exílio na Martinica.

$77 \mathrm{Em}$ artigo que analisa as trajetórias de alguns dos africanos que voltaram para Ajudá e Benim, Lisa E. Castillo lembra que Sylvanus Olympio era bisneto do liberto nagô Antonio Pereira dos Santos, cujo passaporte teria sido expedido em 24 de maio de 1836. CASTILLO, Lisa Earl. Mapping the nineteeth-century Brazilian returnee movement: Demographics, life stories and the question of slavery. Atlantic Studies, 13:1, 2016, p. 29.
} 
colonizadora e às lutas independentistas parece não ter se repetido entre os descendentes de Marcos Borges Ferras, João Pinheiro de Souza e José Francisco dos Santos, este último também conhecido por Alfaiate. As pesquisas historiográficas produzidas sobre estes negreiros informam acerca de suas intensas atividades comerciais. Borges Ferras, cuja atuação será tratada com maior profundidade no terceiro capítulo, era um rico traficante de escravos habituado a atravessar o Atlântico a bordo de sua goeleta Relâmpago. A respeito do mercador João Pinheiro de Souza, mais um genro do chachá Félix de Souza, sabemos apenas que atendia pela alcunha de Taparica e, como seus companheiros de tráfico, embarcou enquanto pôde escravos em tumbeiros que atravessavam o Atlântico. Tal escassez de informações não se repetiu em relação a José Francisco dos Santos, também conhecido como Zé Alfaiate. Desde o final da década de 1840 este traficante havia diversificado seus negócios, incluindo entre suas atividades o comércio de azeite de dendê. ${ }^{78}$

As relações tecidas entre Francisco dos Santos e comerciantes estabelecidos em Salvador chegam até nossos dias por meio de cartas trocadas entre ele e seus correspondentes. Conforme explica Verger, na introdução à edição brasileira de sua obra Fluxo e Refluxo, um conjunto de 112 cartas comerciais enviadas pelo Alfaiate aos seus parceiros baianos se tornou o ponto de partida de sua extensa pesquisa de doutoramento acerca do trânsito de mercadorias, pessoas e ideias de um lado a outro do Atlântico. ${ }^{79}$ Casado com uma das filhas do chachá, chamada Francisca de Souza, cujo nome africano era Sikè Daho, Santos conseguiu acumular riquezas a partir de suas operações como negreiro. ${ }^{80}$ Esta condição Ihe permitiu acrescentar à sua atuação no tráfico o comércio de bens lícitos. Como mencionei há algumas páginas atrás, em 12 de março de 1849, Zé Alfaiate (alcunha que o tornou

\footnotetext{
${ }^{78}$ A respeito das pesquisas que tratam de Marcos Borges Ferras, veja: VERGER, Pierre. Fluxo e Refluxo do tráfico de escravos entre o Golfo de Benin e a Bahia de todos os Santos: dos séculos XVII a XIX. São Paulo: Corrupio, 1987, pp.436-438. A trajetória do negreiro João Pinheiro de Souza é analisada em: SILVA, Alberto da Costa e. Francisco Félix de Souza, mercador de escravos. Rio de Janeiro: Nova Fronteira/ed.UERJ, 2004, p.122.

${ }_{79}$ VERGER, Pierre. Op.cit., 1987, p.7. Uma parte deste compêndio de cartas encontrado por Verger foi publicado em: VERGER, Pierre. Influence du Brésil au Golfe du Benin, in Mémoire de I'IFAN, n.27, Dakar, 1957. Agradeço imensamente ao colega Gilson Brandão de Oliveira por me oferecer uma cópia deste material, trazida do Centro de Estudos Afro-Orientais, pertencente à Universidade Federal da Bahia (CEAO/UFBA).

${ }^{80}$ Cf. SILVA, Alberto da Costa e. Op.cit.,2004,pp.112,120,144, 156 e 159.
} 
famoso) foi visitado por Frederick Forbes. Neste encontro o oficial da armada britânica registrou sua admiração pela imensa plantação de dendezeiros e por um pátio repleto de cabaças cheias de azeite encontradas na propriedade de Santos. Em um momento em que os riscos relacionados ao comércio atlântico de escravos cresciam em função das pressões do esquadrão britânico antitráfico, Alfaiate diversificava suas atividades, apostando também na venda do dendê no mercado internacional. ${ }^{81}$

O último nome inventariado por Burton como pertencente a um brasileiro é o de Domingo Rafael Martinez, filho do famoso traficante Domingos José Martins (ou Martinez). Citado por Burton como um indivíduo de cerca de vinte anos, capaz de se comunicar em inglês e francês, Rafael Martins parece ser o integrante mais jovem do grupo listado pelo cônsul britânico. Consegui reunir poucas informações acerca das atividades desempenhadas por este brasileiro. Aparentemente, Rafael Martins herdou uma parte significativa da fortuna e dos negócios de seu pai. Em testamento escrito por Domingos Martins no ano de 1845 - dezenove anos antes de sua morte em janeiro de 1864 -, o negreiro deu conta de seus bens, libertou escravos e distribuiu propriedades entre filhos, irmãos e parentes que viviam na Bahia. Este registro foi reproduzido na íntegra por Verger em sua obra Fluxo e Refluxo. No documento, Domingos Martins assinalava que, a despeito de nunca ter se casado, havia constituído uma prole formada por seis filhos gerados a partir da "cópula carnal com algumas mulheres". Rafael era um deles, e junto com suas irmãs Maria, Leocadia, Adelaide, Angelina e Marcolina foram reconhecidos por seu pai "como se nascidos fossem de legítimo matrimônio". Além das propriedades deixadas por Domingos Martins na Bahia, seu único filho do sexo masculino herdou sua posição e negócios em Ajudá e em Porto Novo. Este aspecto se mostrou determinante à inclusão de Rafael Martins na lista dos quatorze brasileiros apresentada por Richard Burton. ${ }^{82}$

\footnotetext{
${ }^{81}$ FORBES, Frederick E. Op.cit, vol.1, 1851, p.114.

${ }^{82}$ AEB, sec. judic., maço 7181, N 41, 1864 Apud VERGER, Pierre. Op.cit., 1987, pp.481-483. O décimo item do testamento de Domingos José Martins indicava os bens que seriam herdados por seu filho, Rafael Martins: "Deixo em legado a meu Filho Rafael a minha Rossa da Bahia, sita aos Barris, com casa nobre de morar, com toda a mobília que n'ella se acha ao tempo de meu falecimento e com oito escravos, para que tudo desfructe; e morrendo solteiro ou sem descendentes, passará este legado à Sta. Casa da Misericórdia da mesma cidade da Bahia, exceptuados somente os Escravos, que em tal caso ficarão imediatamente livres."
} 
Até este ponto a relação de nomes recolhidos por Burton estava restrita aos homens, cujas atividades comerciais os atavam ao tráfico atlântico de indivíduos escravizados. Todavia, este não era um campo vedado às mulheres. Como o cônsul britânico fez questão de citar, havia ao menos quatro brasileiras engajadas no tráfico, eram elas:

1. Maria Elena do Carmo

2. Benvinde Teresa de Jesus.

3. Leopoldina Teresa de Jesus.

4. Maria da Piedade do Nascimento. ${ }^{83}$

As menções à participação comercial feminina não são muito comuns na literatura de viagem britânica produzida sobre a Costa da Mina ao longo do século XIX. São raros os escritos deixados por oficiais, exploradores e funcionários ingleses que se referem às contribuições das mulheres em um circuito comercial mais amplo, o qual incluía o comércio atlântico. Todavia, mesmo que numericamente reduzidas, algumas mulheres tiveram participação relevante nas trocas comerciais ligadas ao envio de escravos para as Américas. É o caso de Madame Tinubu, esposa do obá de Lagos, Adele, e grande comerciante de escravos, dendê, algodão e marfim. ${ }^{84} \mathrm{Com}$ negócios estabelecidos em Lagos, Badagri e Abeokuta, Tinubu constituiu uma extensa rede de dependentes e parceiros comerciais que lhe acrescentaram prestígio e ganhos econômicos responsáveis por torná-la uma das poucas mulheres traficantes-comerciantes cuja trajetória se tornou objeto de estudo de pesquisadores. $^{85}$

Por ser africana, Tinubu não apareceu entre as quatro brasileiras listadas por Burton. No entanto, sua capacidade de se adequar ao momento em que a pressão britânica levou traficantes a diversificarem seus negócios, seu posicionamento político em meio às disputas entre Akitoye e Kosoko e sua

\footnotetext{
${ }^{83}$ BURTON, R. F. Op.cit. vol I, 1864, p.75.

${ }^{84}$ De acordo com Mann, depois da morte do obá Adele, Madame Tinubu se casou pela segunda vez com um escravo de nome Yesufu Bada. Este segundo marido de Tinubu atuava nas forças lagosianas. MANN, Kristin. Op.cit., 2007, p.375, n.82.

${ }^{85}$ Entre os estudos que tratam da vida de Tinubu, destaco: ISICHEI, Elizabeth. A History of Nigeria. Essex: Longman, 1984, pp.191-192; KOPYTOFF, Jean Herskovits. A Preface to Modern Nigeria. The "Sierra Leonians" in Yoruba, 1830-1890. Wisconsin: The University of Wisconsin Press, 1965, pp.99-104; MANN, Kristin. Op.cit., 2007, pp.57,59,72,99, 132, 141-142; SMITH, Robert Sydney. Op.cit.1978, p.74 e VERGER, Pierre. Op.cit., 1987, pp.576,578,579 e 583.
} 
resistência à colonização britânica imposta a Lagos a partir do ano de 1861, são indicativos de uma participação feminina muito mais ampla do que os registros de viajantes descreveram e a produção historiográfica atual tem se mostrado capaz de analisar. Neste sentido, o reconhecimento da escassez de estudos sobre este tema pode significar um posterior alargamento das interpretações acerca dos contatos comerciais, culturais e políticos proporcionados pela circulação atlântica. Embora esta pesquisa não tenha fôlego suficiente para abarcar, em específico, a participação das brasileiras que, em Lagos, integraram os processos de constituição identitária de seu grupo, fica aqui assinalada a expectativa de estudos futuros.

Depois da lista das mulheres brasileiras ligadas ao tráfico, a última parte da relação elaborada por Richard Burton compreendia "alguns brasileiros de menor importância associados às casas já citadas." Em seguida, como que explicando a posição inferior atribuída a este último grupo, o cônsul britânico acrescentou

Os dez a seguir são africanos ou libertos brasileiros [Brazil liberated], na sua maioria nagôs (egbas) ou homens de Ajudá. Nenhum deles é importante, há outros poucos cujos nomes não merecem menção.

1. João Antonio de Rego.

2. Elisbão Lino.

3. Thobias Barreto Brandão.

4. Joaquim das Neves.

5. Damião de Oliveira, que é considerado o melhor pedreiro de Ajudá.

6. Antonio d'Almeida.

7. José de Fonçeca Muniz, filho de J.C. Muniz.

8. Pedro Pinto da Silveira. Este é o conhecido traficante Pedro Cogio, de Popo Pequeno. Ele possui um filho que reside em Ajudá e administra os negócios de José Alfaiate. Seu nome é,

9. Domingo Francisco da Silveira.

10. Pedro Fellis d'Almeida. ${ }^{86}$

Ao adotar uma narrativa sintonizada com sua época, Richard Burton colocava africanos e libertos vindos do Brasil nunca categoria de menor importância e, como complemento, ainda mencionava a existência de outros brasileiros que sequer mereciam citação. A despeito da explicação introdutória elaborada pelo cônsul britânico, a lista apresentada em seu relato não era

${ }^{86}$ BURTON, R. F. Op.cit. vol I, 1864, p.74/75. 
pequena. Composta por dez nomes de brasileiros com negócios estabelecidos na Costa da Mina, a relação de Burton incluiu ao menos três negreiros cujas trajetórias são tratadas pela historiografia empregada nesta pesquisa. $O$ primeiro deles é Antonio de Almeida, escravo liberto do pernambucano Manoel Joaquim de Almeida. Conforme nos informa Pierre Verger, Antonio morou na Bahia durante os anos em que serviu como escravo. Na década de 1840, depois de viver alguns anos em liberdade, Antonio conseguiu amealhar recursos suficientes para que ele e seu filho Bernardino cruzassem o Atlântico em direção à Costa da Mina. Primeiro fixaram residência em Aguê, cidade costeira localizada entre Popo Grande e Popo Pequeno (ou Anexô) e, anos mais tarde, se instalaram em Ajudá. ${ }^{87}$

Parte da história de vida de Antonio de Almeida foi descrita em seu testamento registrado em 1864 e aberto vinte e seis anos mais tarde, na ocasião de seu falecimento em 1890. Ao declarar possuir uma numerosa descendência, constituída por treze filhos legitimados "como si de legal matrimônio os houvesse", Antonio colocava em evidência a composição de uma família formada a partir de relacionamentos tecidos tanto na Bahia como na Costa da Mina. Alguns dos filhos do liberto viviam em Salvador. Era o caso de Paulino, filho de Filiciana, também mãe de Bernardino, filho primogênito de Almeida que acompanhou a transferência de seu pai para a Costa da Mina e foi nomeado em testamento como herdeiro universal de seus bens e seu sucessor. Além destes dois filhos do sexo masculino citados em testamento, Almeida tinha outros onze descendentes, todos do sexo feminino. Com exceção de Paulino e Bernardino, todos os demais descendentes de Antonio d'Almeida tinham mães escravas que, aparentemente, eram libertadas à medida que acrescentavam filhos à sua extensa prole. ${ }^{88}$

A riqueza das informações fornecidas pela carta testamental deixada por d'Almeida não se repete com os outros negreiros arrolados por Burton. $O$ segundo traficante mencionado pela historiografia selecionada por esta

\footnotetext{
${ }^{87}$ VERGER, Pierre. Os Libertos: sete caminhos na liberdade de escravos da Bahia no século XIX. São Paulo: Corrupio, 1992, pp. 121-124. Sobre o traficante Manoel Joaquim de Almeida, antigo senhor de Antonio de Almeida, sugiro: VERGER, Pierre. Op.cit., 1987, pp.457-458.

${ }^{88}$ VERGER, Pierre. Os Libertos: sete caminhos na liberdade de escravos da Bahia no século XIX. São Paulo: Corrupio, 1992, pp. 121- 124.
} 
pesquisa é Pedro Pinto da Silveira, também conhecido como Pedro Codio (ou Codjo, Codjio, Kojio ou Kodjo) da Silveira. A imprecisão dos dados referentes a este comerciante de escravos se apresenta já na indefinição de parte de seu sobrenome. Além disto, segundo Costa e Silva, Silveira não era natural do Brasil, mas da cidade de Popo Pequeno. Inscrito no comércio com o Novo Mundo, Silveira teria cruzado por diversas vezes o Atlântico em direção à Bahia. ${ }^{89}$ Se é possível apurar pouquíssimos dados acerca da história de vida de Pedro da Silveira, menos ainda se sabe a respeito do terceiro negociante brasileiro incluído na lista elaborada pelo cônsul britânico: Pedro Fellis d'Almeida. É também Costa e Silva quem esclarece ser Pedro d'Almeida um grande comerciante de dendê, cujos negócios teriam se iniciado sob a proteção do chachá Francisco Félix de Souza. Como tantos outros brasileiros que se estabeleceram em Ajudá ou em portos vizinhos, d'Almeida deve ter encontrado em Félix de Souza o apoio necessário para iniciar seus empreendimentos comerciais na Costa da Mina. ${ }^{90}$

A lista dos brasileiros residentes ou com negócios em Ajudá e localidades vizinhas a este porto é fornecida ao leitor como nota de rodapé. Neste caso, a intenção de Richard Burton não era denunciar os traficantes existentes na Costa da Mina. Em 1864, esta não era a principal preocupação de seu consulado. Ao construir uma argumentação que considerava o comércio atlântico de escravos uma questão praticamente resolvida, Burton mencionava que um dos maiores negreiros da região, Domingos José Martins, havia perdido o interesse no tráfico. E esta não era uma condição exclusiva deste grande traficante. Afinal, "há doze anos havia em Ajudá duzentos espanhóis e portugueses [traficantes], incluindo brasileiros e mulatos". Em 1863, quando Burton esteve em Ajudá, a situação havia se alterado. De acordo com o cônsul, os poucos negreiros que ainda mantinham negócios no tráfico estavam arrolados nesta nota e, tal como Domingos Martins, haviam progressivamente migrado suas atividades para o comércio de algodão e de óleo de palma. ${ }^{91}$

\footnotetext{
${ }^{89}$ SILVA, Alberto da Costa e. Op.cit.,2004, p.117.

90 Ibid, p.146.

${ }^{91}$ BURTON, R. F. Op.cit. vol I, 1864, p.74/75.
} 
Embora este seja o relato em que o autor dedicou maior atenção à presença de brasileiros no porto daomeano e nas cidades costeiras próximas, A mission to Gelele, king of Dahome não foi a única obra de Richard Burton. No ano anterior, o cônsul do Benin e Biafra publicou dois livros que narravam suas experiências em viagens não oficiais que passaram por Abeokuta, Freetown, Lagos e por outras cidades menores. Segundo Gebara, Burton partiu de Liverpool em 24 de agosto de 1861. Após cerca de um mês de viagem, ele desembarcou na ilha de Fernando Pó, sede administrativa de seu consulado. ${ }^{92}$ Esta viagem marítima, assim como as paradas realizadas na costa africana até o destino final, foram descritas no livro Wanderings in West Africa. Durante uma parada de três dias em Freetown, capital de Serra Leoa, o autor entrou em contato com alguns saros, brasileiros e cubanos - os dois últimos denominados, "the Brazilian or the Cuban emancipado" - que viviam na cidade. Neste primeiro momento, o cônsul recém-chegado à costa ocidental da África se decepcionou com a forma como viviam estes indivíduos. De acordo com o as informações por ele apuradas, saros e brasileiros que moravam livremente na costa haviam

retornado ao seu paganismo natural, e se tornado traficantes de escravos, despudoradamente se colocando sob a proteção dos nativos, renegando a bandeira que os havia salvado de uma longa vida de servidão. ${ }^{93}$

Esta situação só não era pior em razão do esforço de alguns poucos missionários que atuavam em Serra Leoa. Ocupados com a imensa tarefa de converter, educar e civilizar seu rebanho, religiosos da CMS e da Wesleyan Missionary Society se empenhavam em divulgar suas realizações em pequenos periódicos impressos em oficinas locais. Estes jornais eram editados - além de serem também escritos, impressos e administrados - por missionários como o reverendo anglicano Jones, editor do African Herald, cujo título do periódico mudaria, mais tarde, para African Weekly Times. Além deste jornal, Burton também cita o Sierra Leone Watchman, editado pela igreja

\footnotetext{
${ }^{92}$ GEBARA, Alexsander Lemos de Almeida. Op.cit., 2010, p.46-47.

${ }^{93}$ BURTON, Richard Francis. Wanderings in West Africa: from Liverpool to Fernando Pó. vol.I, London: Tinsley Brothers, 1863A, p.239.
} 
metodista e considerado pelo cônsul uma publicação representativa da "juventude de Serra Leoa". ${ }^{94}$ De acordo com Sawada, as igrejas anglicana, wesleyana e batista desempenharam um papel importante no desenvolvimento da imprensa em toda a Costa da Mina. Em Lagos, por exemplo, a CMS dispunha de tipografia própria e de um ponto de comercialização e de distribuição de suas publicações, localizado na esquina das ruas Broad com Odunlami. Esta instituição religiosa foi também responsável pelo primeiro jornal redigido em iorubá, o Iwe Irohin Fun Awon ara Egba ati Yoruba. Quando começou a ser produzido, em 1859, este jornal tinha periodicidade quinzenal e era escrito apenas em iorubá. A partir de 1860 o periódico ganhou um suplemento em inglês e, no ano de 1866 , tornou-se uma publicação bilíngue. ${ }^{95}$

\section{Figura 1: Oficina de impressão do Governo Colonial Britânico em Lagos} $(\text { sem data })^{96}$

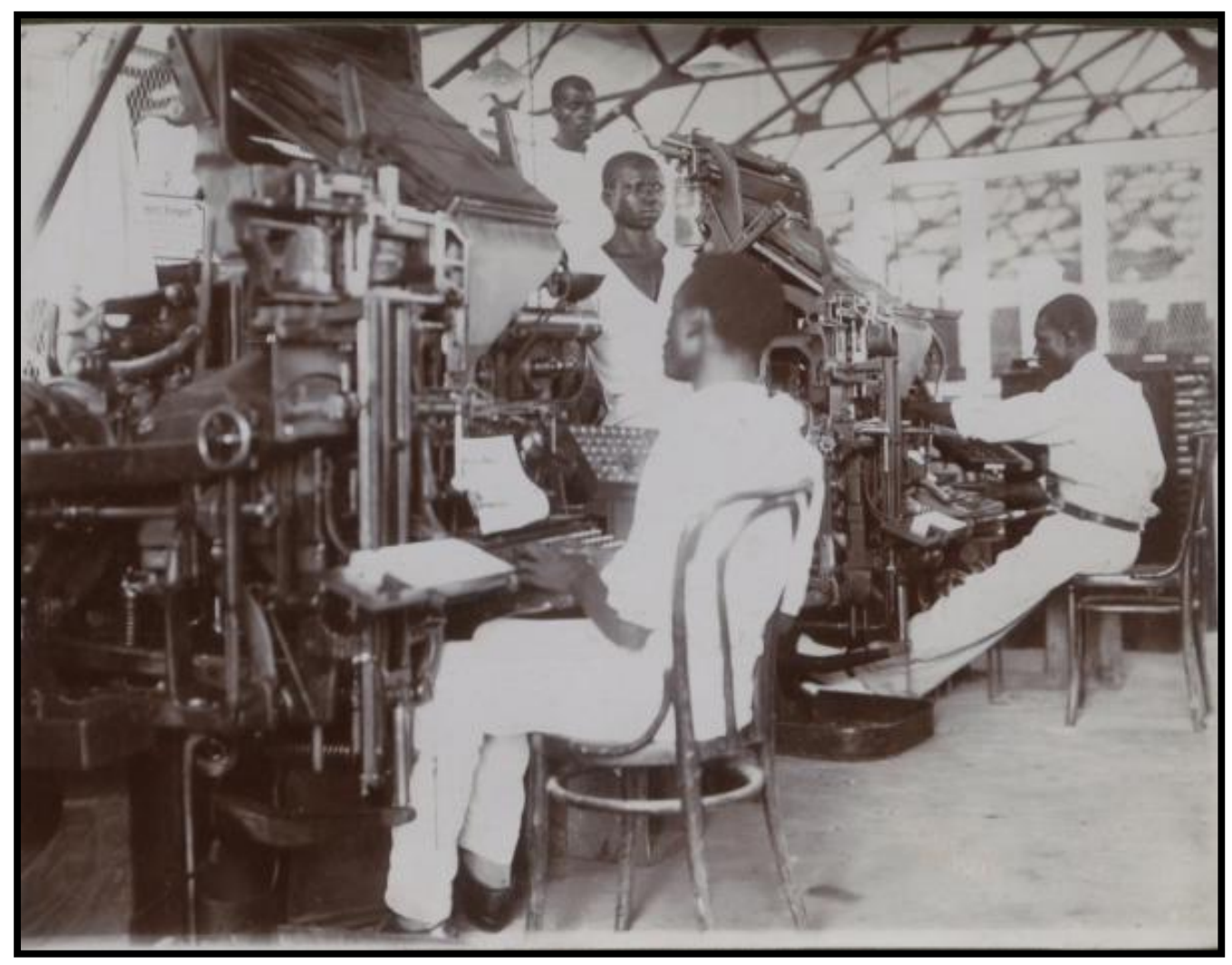

Fonte: National Archives. Nigeria, CO 1069.71.138.

\footnotetext{
94 Ibid, vol.I, p.241.

${ }^{95}$ Cf.SAWADA, Nozomi. The Educated Elite and Associational Life in Early Lagos Newspapers: in search of unity for the progress of Society. Tese de doutorado. Centre of West African Studies. University of Birmingham, 2011,pp.13 e 22.

${ }^{96}$ Esta imagem integra uma coleção do National Archives composta por 905 fotos. Embora não exista indicação da data em que esta fotografia foi tomada, muitas outras imagens que compõem a coleção foram tiradas na década de 1920.
} 
É possível que o número de jornais impressos em oficinas estabelecidas na Costa da Mina tenha despertado a curiosidade de Richard Burton. Com um ímpeto pela catalogação o cônsul britânico elaborou, em uma longa nota de rodapé, uma lista dos jornais publicados em Serra Leoa, Libéria, Costa do Ouro e Abeokuta. Ao mapear a produção impressa na região que compreendia o consulado dos Golfos do Benim e de Biafra, Burton indicava os territórios onde era possível verificar a influência europeia no campo da cultura escrita.

Em 2 de outubro de 1861, Richard Burton seguiu em direção a Lagos. A partir desta cidade ele iniciou sua primeira expedição não oficial em território africano. Os registros desta viagem foram publicados dois anos depois, sob o título Abeokuta and the Camaroons Mountains: an exploration. ${ }^{97}$ No prefácio, Burton explicou as razões que o teriam levado a escrever mais este livro. Conforme o cônsul britânico, outras obras a respeito da região montanhosa dos Camarões já haviam sido feitas. No entanto, nenhuma delas foi produzida por um viajante que de fato estivera neste território. Por esta razão, justificou o autor, o livro teria maior importância, afinal não era uma coletânea de relatos de terceiros. Nesta e em outras narrativas deixadas por Burton, a viagem adquiria a característica de peregrinação. Segundo Said, estes escritos seriam uma espécie de "novo e viçoso repositório de experiências" em oposição ao "mofo dos arquivos" produzidos por registros burocráticos ou epístolas comerciais. ${ }^{98}$ Este aspecto coloca Burton como um viajante erudito, cuja observação proporcionada por um relativo distanciamento the permitia descrever e analisar fragmentos de realidade previamente selecionados para integrar seus relatos. Em sua minuciosa narrativa acerca dos percalços rumo às montanhas de Camarões, Burton descreveu suas experiências em meio aos missionários da CMS e da igreja wesleyana em Abeokuta. ${ }^{99}$

Ao tratar da disputa entre Akitoye e Kosoko pelo mando de Lagos, o autor reforçou o papel dos missionários Thomas Freeman, Henry Townshend e Samuel Crowther nas discussões acerca da tomada da cidade. Em um capítulo

\footnotetext{
${ }^{97}$ BURTON, Richard Francis. Abeokuta and the Camaroons Mountains: an exploration. vol.I, London: Tinsley Brothers, 1863B. Todas as três obras citadas de Burton foram publicada em dois volumes.

${ }_{98}^{98}$ SAID, Edward W. Op.cit., 2007, p.235.

${ }^{99}$ BURTON, Richard Francis.Op.cit,vol.I, 1863B, p.75.
} 
dedicado exclusivamente a este episódio, o cônsul mencionou a participação do traficante brasileiro Domingos Martins, no bloqueio dos caminhos que levavam até o interior. Em 1846, graças a uma suspensão momentânea dos conflitos, depois de dezessete longos meses de contendas, Townshend e Crowther deixaram Badagri e seguiram até Abeokuta, cidade onde desde 1843 existia uma missão anglicana. Dois anos depois, em 1848, o reverendo Townshend atendeu ao chamado de seus superiores e retornou à GrãBretanha. O relato de Burton não explica com exatidão quais foram os motivos que levaram o missionário a deixar a congregação de Abeokuta. No entanto, o autor foi categórico ao afirmar que, quando Townshend retornou para uma segunda temporada na cidade, em 1851, constatou que a maior parte dos convertidos de Abeokuta havia voltado às práticas fetichistas. ${ }^{100} \mathrm{O}$ episódio citado por Burton conferia sustentação a um conjunto de argumentos que defendia a presença de missionários, oficiais e funcionários da administração britânica em cidades como Badagri, Lagos e Abeokuta. Entretanto, mais do que se fazer presente nestes territórios era necessário torná-los lucrativos. E, neste sentido, a produção de óleo de palma e o cultivo do algodão eram consideradas as alternativas mais viáveis.

No ano de 1890, o então governador de Lagos, Cornelius Alfred Moloney, submeteu um artigo à Royal Geographical Society (RGS). Desde 1878, Alfred Moloney ocupava cargos executivos na administração colonial lagosiana. Entre 1878 e 1880, atuou como governador em exercício de Lagos. Em 1886, ano em que a Grã-Bretanha separou a administração lagosiana da Costa do Ouro, Moloney foi nomeado governador de Lagos, posição em que permaneceu até 1891. Desta forma, quando seu artigo foi apresentado à RGS, em 1890, Moloney acumulava cerca de doze anos de experiência na cidade.

O texto produzido pelo governador de Lagos foi considerado por ele mesmo um conjunto de apontamentos acerca da vegetação, fauna marinha e geologia da região que compreendia a ilha e seus arredores. Este aspecto em específico permitia entrever os interesses comerciais britânicos por territórios cada vez mais afastados do litoral da Costa da Mina. Além disto, como uma

${ }^{100}$ Ibid, vol.I, p.241. 
referência a todo um conhecimento constituído antes de seu estabelecimento no governo lagosiano, Moloney listou outros indivíduos cujas expedições passaram pela região. Entre aqueles que integravam esta lista estavam 0 cônsul Richard Francis Burton, o explorador escocês Mungo Park e o missionário batista Thomas Jefferson Bowen. ${ }^{101}$

O texto que veio a público em 1890 não foi o único produzido por Alfred Moloney. Um ano antes de sua publicação ser impressa pela Royal Geographical Society, o governador de Lagos escreveu um longo artigo acerca das possibilidades agrícolas e econômicas da cidade e das localidades consideradas sob a "influência de Lagos." Publicado em 1889 pela revista da Sociedade de Geografia de Manchester - a The Journal of the Manchester Geographical Society - da qual Moloney era membro, o documento refletia a respeito do plantio, colheita e beneficiamento do algodão plantado em Lagos e nas cidades iorubás de Abeokuta e Ibadan, situadas numa porção mais afastada do litoral. Em acréscimo, o documento apresentava as possibilidades de ganho àqueles que investissem na implantação da lavoura de algodão nos arredores da cidade. Mostrando conhecer os interesses de seus interlocutores, o governador iniciou suas considerações expondo a importância econômica de Lagos na Costa da Mina. ${ }^{102}$

A colônia era um dos destinos das "manufaturas excedentes" produzidas em Manchester. E, em sentido inverso, era de seu porto que partiam embarcações carregadas de matérias-primas. A partir destas considerações iniciais, Moloney concebeu que a "promoção de um desenvolvimento permanente e amplo do seu próprio país [de Lagos] e, como consequência, dos interesses britânicos" estava na "repatriação do negro vindo do Novo Mundo". Apresentando tabelas que comparavam a qualidade e os preços do algodão colhidos nos Estados Unidos e na colônia portuguesa de Angola, o governador demonstrava domínio sobre o tema do comércio internacional desta mercadoria. De acordo com sua argumentação, as lavouras norte-americanas,

\footnotetext{
${ }^{101}$ MOLONEY, Alfred. Notes on Yoruba and the Colony and Protectorate of Lagos, West Africa. Proceedings of the Royal Geographical Society and Monthly Record of Geography, vol.12, No. 10, October, 1890, pp. 596-614.

${ }_{102}$ MOLONEY, Cornelius Alfred. Correspondence Affair on the West Coast of Africa. In The Journal of the Manchester Geographical Society. vol.V, Manchester: The Manchester Geographical Society, 1889, pp.256 e 255, respectivamente.
} 
angolanas e as plantations de cana de açúcar no Brasil, eram movidas pelo trabalho africano. Sendo assim, Moloney questionava: "por que negros daqui [de Lagos] ou repatriados dos Estados Unidos ou do Brasil não poderiam trabalhar em seu próprio país?"103

Em busca da resposta a esta questão, o governador iniciou uma extensa análise acerca das condições técnicas da produção do algodão, assim como da disponibilidade de mão de obra para o trabalho nesta lavoura. Para Alfred Moloney, a adaptação e o aperfeiçoamento do algodão a ser plantado em Lagos seriam resolvidos por meio dos trabalhos realizados na recém-instalada Estação Botânica, situada na porção continental da colônia, em Ebute Metta, inaugurada no ano de $1887 .{ }^{104}$ Conforme o próprio governador sustentava, as principais finalidades do local eram: cultivar árvores e plantas endêmicas de valor comercial; treinar trabalhadores (entre eles brasileiros) para o plantio orientado à exportação e ambientar novas espécies de plantas para a lavoura comercial. O segundo propósito em específico estava relacionado à falta de lavradores, cujo trabalho agrícola e de beneficiamento do algodão produziria safras a serem comercializadas no mercado internacional. Em outro longo artigo a respeito dos planos de instalação da Estação, Moloney especificava cargos, funções e salários dos funcionários públicos que atuariam no lugar, previa a distribuição gratuita de alguns tipos de sementes e propunha o treinamento agrícola de órfãos que viviam em instituições de caridade. ${ }^{105}$

Um dos problemas que reduzia a qualidade e, como consequência, o valor dos bens produzidos em Lagos era a adulteração das mercadorias e de seus pesos e medidas. Segundo Moloney, o acréscimo de óleos mais baratos

\footnotetext{
103 Ibid, p. 257.

${ }^{104}$ Moloney faz referência ao trabalho realizado na Estação Botânica de Lagos em seu artigo apresentado no ano de 1890 à Royal Geographical Society: MOLONEY, Alfred. Op.cit.,1890, p.614. Também Cunha trata da criação deste equipamento do governo britânico em: CUNHA, Manuela Carneiro da. Op.cit., 2012, p.175.

105 O plano de instalação da Estação Botânica de Lagos foi publicado no Lagos Observer em: The Lagos Observer, 21 e 28 de janeiro de 1888, World Newspaper Archive, African Newspapers, $1883-1888$. A proposta de treinamento de órfãos estava ligada a uma legislação promulgada em 1877: a Alien Children Registration Ordinance. Esta legislação estabelecia que as crianças que ingressassem em Lagos teriam 48 horas para que seus responsáveis registrassem sua chegada. Do contrário seriam consideradas vítimas de tráfico interno e encaminhadas a uma instituição de caridade. Este assunto é tratado por Mann em: MANN, Kristin. Op.cit., 2007, pp.179, 183-184, 208 e 218. A leitura de exemplares das Government Gazettes revelou listagens de crianças, cujos nomes, idades e responsáveis aparecem registrados.
} 
ao óleo de dendê, a mistura de sementes ao algodão colhido, a mescla de cascas à noz de palma e a adulteração de pesos e medidas, tiveram como resultado duas regulamentações: a Ordinance to Prevent the Adulteration of Produce (promulgada em fevereiro de 1889), que proibia agricultores e comerciantes de recorrerem aos artifícios citados para aumentar o volume de seus produtos; e a Weights and Measures Ordinance (em vigor desde agosto de 1889), cujos artigos padronizavam pesos e medidas. ${ }^{106}$ Contudo, os problemas assinalados pelo governador persistiam. Era preciso acrescentar à força de trabalho lagosiana "o esforço, inteligência e caráter" dos repatriados. E, justificando esta posição, Moloney argumentava que o trabalho da população negra havia tornado o Brasil um grande exportador de "café, açúcar, algodão, tabaco, mandioca entre outras commodities comerciais". Sendo assim, o retorno de "negros treinados" para Lagos traria amplas vantagens econômicas, na medida em que estes indivíduos fossem encaminhados às lavouras comerciais já abertas. ${ }^{107}$

O artigo de Alfred Moloney foi apresentado e publicado cerca de um ano depois da abolição da escravidão no Brasil. Neste contexto, o governador anunciava ser "bastante conhecido o desejo de muitos deles [dos libertos] de seguir os passos de seus companheiros que retornaram à África ocidental." ${ }^{108}$ Para tanto, sugeria que as associações de alforria existentes no Brasil, cuja função consistia em promover a compra da liberdade, amparassem africanos e seus descendentes que desejassem voltar ao seu "país de origem". Neste trecho, o documento resumia a função destas organizações como se fossem destinadas apenas a conceder empréstimos para compra da liberdade. No entanto as juntas de alforria, como eram popularmente conhecidas em terras brasileiras, poderiam cumprir funções muito mais amplas. Se associadas às irmandades religiosas, por exemplo, os valores angariados também serviam para o pagamento de enterros, socorro dos membros desvalidos ou promoção

\footnotetext{
${ }^{106}$ A lei que visava evitar a adulteração dos produtos exportados para o mercado internacional e a que fixava os pesos e medidas dos produtos podem ser lidas integralmente em: SPEED, Edwin Arney. Ordinances and orders and rules thereunder in force in the Colony of Lagos. On April $30^{\text {th }}, 1901$ with an appendix containing the letters patent constituting the colony, and the instructions accompanying them; various acts of Parliament; orders of the Queen in Council; treaties, and proclamation. Vol. II, London: Stevens and Sons,1902. pp.553 - 557 e pp.600 612, respectivamente.

${ }_{107}$ MOLONEY, Alfred. Op.cit. 1889, p.268.

108 Ibid, p. 267.
} 
de festas e celebrações. Sobre este aspecto, ao constituir um discurso em prol da transferência de libertos do Brasil para Lagos, Moloney enfatizava os elementos considerados pertinentes à sua argumentação, deixando de lado as outras funções assumidas por estas organizações. ${ }^{109}$

Em favor da travessia atlântica o governador também propunha a criação de uma linha regular de vapores, cujas atividades incrementariam as viagens de libertos para Lagos, assim como o comércio entre o porto lagosiano e as cidades costeiras do Brasil. Como evidência das possibilidades de ganho com a ampliação dos negócios atlânticos, Moloney apresentou um balanço das exportações e importações realizadas entre Brasil e Lagos, durante o período de 1882 e 1887. Em um momento de crescimento da demanda por mão de obra para atuar nas lavouras exportadoras, o britânico defendia a volta de libertos como necessária ao "estabelecimento de centros de civilização e para a disseminação das habilidades que eles haviam aprendido no hemisfério ocidental". ${ }^{110} \mathrm{E}$, a respeito deste aspecto, reforçava que

os emancipados do Brasil e os negros nos Estados Unidos da América podem, e irão, representar poderosos contingentes. A prosperidade comercial que eles proporcionaram ao Brasil e aos Estados Unidos pode se estender à África. ${ }^{111}$

Seguindo os argumentos expostos por Alfred Moloney, libertos norteamericanos e brasileiros estariam não apenas equiparados uns aos outros, como aptos a constituir a "prosperidade comercial" de Lagos. Afinal, como os dados apresentados no artigo sugeriam, a expansão comercial em direção a territórios mais afastados da costa esbarrava no déficit de mão de obra nas lavouras de dendê e de algodão. Embora, desde a década de 1860, Lagos fosse percebida, nas palavras de Lady Glover, esposa do administrador

\footnotetext{
109 Antonia Aparecida Quintão produziu um importante estudo acerca das irmandades de homens pretos e pardos existentes em Pernambuco e no Rio de Janeiro, no século XVIII, cuja referência é: QUINTÃO, Antonia Aparecida. Lá vem meu parente: as irmandades de pretos e pardos no Rio de Janeiro e em Pernambuco (Século XVIII). São Paulo: Annablume/Fapesp, 2002. Sobre o funcionamento das irmandades, a forma como estas sociedades leigas constituíam seus bens e as comemorações praticadas por estes grupos, veja também: SOUZA, Marina de Mello e. Reis Negros no Brasil escravista: história da festa de coroação do Rei Congo. Belo Horinzo: Ed. UFMG, 2002.

${ }_{110}$ MOLONEY, Alfred. Op.cit. 1889, p.268.

111 Ibid, pp.274-275.
} 
britânico John Hawley Glover, como a "Liverpool da África ocidental", a manutenção desta posição exigia que seus armazéns estivessem repletos de bens valorizados pelo mercado exportador. ${ }^{112}$ Dendê e seus subprodutos, algodão, amendoim, borracha e marfim eram as principais mercadorias comercializadas no porto lagosiano nas duas últimas décadas do século XIX. Para solucionar o problema da insuficiência de trabalhadores atuando nas lavouras comerciais, Moloney propunha a transferência de libertos das Américas para as plantações localizadas mais ao interior. À sua maneira, o governador também considerava a experiência da escravidão uma etapa capaz de conferir aos libertos as habilidades necessárias ao trabalho nas lavouras cultivadas na colônia e protetorado de Lagos.

\subsection{Pertencimento étnico e possibilidades interpretativas}

De resto, o que significa nomear-se a si próprio? (...) O nome que atribuo a mim próprio corresponde precisamente a um pseudônimo, e o nome que geralmente reconheço como sendo 'o meu' foi-me atribuído ou transmitido por terceiros. ${ }^{113}$

As diferentes formas de representação dos brasileiros inscritas nos registros produzidos por Duncan, Forbes, Campbell, Burton e Moloney constituem indicativos das relações de poder subsumidas na construção dos rótulos de pertencimento a este grupo. Parafraseando Bazin, não se é brasileiro sem ter sido designado como tal. ${ }^{114} \mathrm{~A}$ atribuição de um nome a um conjunto de indivíduos considerados unidos por traços de semelhança, decorre da necessidade de enunciação daquele que produz o registro. E, sob este

\footnotetext{
112 GLOVER, Lady. Life of Sir John Hawley Glover. London: Smith, Elder and Co. 1897, p.91, 100. John Hawley Glover foi administrador e, depois, governador de Lagos por quase dez anos, de 1863 a 1872. Sua esposa, conhecida como Lady Glover, publicou em 1897, uma obra que trata da carreira pública do marido.

${ }_{113}$ BAZIN, Jean. Cada qual com o seu bambara in AMSELLE, Jean-Loup; M'BOKOLO, Elikia (coord.) Pelos meandros da etnia. Etnias, tribalismo e estado em África. Luanda/Ramada: Edições Mulemba/Edições Pedago, 2014, p.120.

114 Jean Bazin examina as formas como os bambaras foram representados pelos europeus em diferentes momentos históricos. A proposta do autor é refletir a respeito da questão dos rótulos étnicos como construções historicamente localizadas. Sobre este aspecto Bazin afirmava: "Não se 'é' bambara sem ter sido designado enquanto tal: designado por quem, em que contexto, quando?" BAZIN, Jean. Cada qual com o seu bambara in AMSELLE, Jean-Loup; M'BOKOLO, Elikia (coord.) Op.cit, 2014.
} 
aspecto, as formas de enunciação aplicadas a um determinado grupo engendram relações de poder assimétricas, nem sempre evidentes. A urdidura de discursos pautados na valorização de determinados grupos, em detrimento de outros, pode encerrar os indivíduos dentro de categorias arranjadas por meio de critérios de superioridade e de inferioridade étnicas. Estas clivagens elaboradas, via de regra, pelo colonizador se apresentam na estrutura de discursos que, muitas vezes, reproduzem rótulos étnicos que perpetuam a assimetria e obliteram as vozes daqueles circunscritos por estas construções.

Neste sentido, os indivíduos mencionados nos relatos aqui apresentados não são brasileiros até o momento em que um conjunto de circunstâncias e interesses britânicos os nomeia como tais. Dito de outra forma, tais indivíduos se tornaram brasileiros em resposta às condições específicas dos contextos em que estavam inscritos. ${ }^{115}$ Antes disto, eram traficantes. E, como Forbes, Duncan e Burton fizeram questão de mencionar, possuíam nomes. Francisco Félix de Souza, Domingos José Martins, José de Almeida e José dos Santos, são exemplos de alguns deles. Em um contexto em que o foco das preocupações do Foreign Office estava na extinção definitiva do tráfico atlântico de escravos, os indivíduos identificados por John Duncan e Frederick Forbes eram negreiros, e não brasileiros. Nestes relatos de viagem os brasileiros foram nomeados como traficantes porque era este o grupo que os enviados britânicos procuravam combater. Denunciando quais eram os principais envolvidos neste negócio, Forbes arrolou os nomes dos negreiros cujas embarcações transportavam pelo Atlântico, juntamente com os bens lícitos, escravos.

Além dos registros produzidos pelo oficial naval Frederick Forbes, também o cônsul Richard Francis Burton teve o cuidado de listar os nomes dos negreiros brasileiros estabelecidos nas cidades costeiras de Ajudá, Porto Novo, Badagri e Aguê. No entanto, nestes escritos os comerciantes de escravos não representavam mais uma ameaça à supressão do tráfico atlântico. Ao contrário, em meados da década de 1860, os negreiros encontrados por Burton

${ }^{115}$ Em seu estudo sobre os bambaras, Bazin resume a ideia da incorporação do rótulo étnico na afirmação: "mais do que serem bambaras, os indivíduos tornam-se bambaras". BAZIN, Jean. Cada qual com o seu bambara in AMSELLE, Jean-Loup; M'BOKOLO, Elikia (coord.) Op.cit. 2014,p.103. 
eram o testemunho vivo de que a atuação da Grã-Bretanha no combate à atividade havia alcançado seu intento. A constatação de que a maioria dos negócios destes indivíduos se encontrava, naquele momento, na bancarrota constituiu a principal evidência de que as ações ligadas ao comércio atlântico de escravos estavam com seus dias contados. Em contrapartida, aqueles que ainda desfrutavam de alguma prosperidade haviam convertido seus negócios ao comércio de mercadorias lícitas. Muitos destes ex-traficantes estavam associados aos libertos vindos da Bahia que, a partir de 1835, desembarcavam em maior número em cidades situadas no litoral da Costa da Mina, em razão da Revolta dos malês. ${ }^{116}$

A Revolta ocorrida no ano de 1835 , eclodiu em Salvador e teve como consequência direta a travessia de libertos africanos e de seus descendentes. A maioria das viagens se realizou da Bahia para a região denominada geograficamente como Golfo do Benim. Em um momento em que Lagos passava por um processo de diversificação de sua população, a partir do acréscimo de libertos aos antigos negreiros, estes indivíduos começaram a ser chamados de brasileiros. E, como tais, eram considerados parte de um conjunto de pessoas que, a despeito de sua imensa heterogeneidade, guardavam traços cujas semelhanças conferiam um pertencimento comum. ${ }^{117}$

\footnotetext{
${ }^{116}$ Os locais onde desembarcaram aqueles que retornavam são analisados pela historiadora Monica Lima de Souza. Em sua pesquisa ela apresenta e interpreta uma importante fonte relativa à travessia atlântica de um grupo de libertos que solicitava auxílio ao encarregado dos negócios britânicos no Rio de Janeiro, James Hudson. Nesta missiva os indivíduos interessados em receber a retaguarda da Grã-Bretanha declaravam como destino final o porto de Cabinda, cidade localizada ao sul do Equador. Este documento demonstra a existência de libertos que partiram de portos diferentes de Salvador e expõe a existência de destinos para além da Costa da Mina. Razões pelas quais libertos africanos, residentes no Brasil, desejam ir e fundar uma cidade em Cabinda na Costa ocidental da África in SOUZA, Mônica Lima e. Entre margens: o retorno à África de libertos no Brasil, 1830-1870. tese de doutorado. UFF/RJ, 2008. Anexol.

${ }_{117}$ Sobre os contextos que levaram a esta revolta e as leis promulgadas depois do desfecho do levante: REIS, João José. Rebelião escrava no Brasil, a história do levante dos malês (1835), edição revista e ampliada, São Paulo: Brasiliense, 2003. Outro trabalho de pesquisa, este de doutoramento, preocupado em analisar as travessias atlânticas como parte de um momento histórico mais amplo, denominado "back to Africa", pode ser consultado em: SOUZA, Mônica Lima e. Op.cit., 2008. Também a dissertação de mestrado de Luciana Brito fornece importantes contribuições em relação às legislações promulgadas após a rebelião de 1835: BRITO, Luciana. Sob o Rigor da Lei: africanos e africanas na legislação baiana (1830-1841). Campinas: Dissertação de mestrado. IFCH/UNICAMP, 2009. Esta mesma pesquisadora também publicou outros dois importantes artigos relacionados ao tema: BRITO, Luciana da Cruz. Sob o Rigor da Lei: Africanos e a Legislação Baiana no Século XIX. Sankofa. Revista de História da África e de Estudos da Diáspora Africana. n. 2, dez.2008, pp.38-57 e BRITO,
} 
Para Robert Campbell, as "pessoas do Brasil ou de Cuba" constituíam uma parcela da população cujo trabalho havia introduzido grandes avanços na "civilização" de Abeokuta. Este processo seria continuado por meio da instalação de uma segunda matriz populacional formada por libertos provenientes dos Estados Unidos, considerados "da mesma raça", todavia mais "civilizados" do que seus antecessores. ${ }^{118}$ Cerca de trinta anos depois, o governador de Lagos, Alfred Moloney, equiparava os "repatriados dos Estados Unidos" aos do Brasil. De acordo com Moloney, estes ex-escravos coincidiam essencialmente em dois aspectos. Primeiro, embora de maneiras diferentes, os dois grupos passaram pela travessia atlântica e pela escravidão no continente americano. Segundo, a experiência do trabalho compulsório havia conferido a estes indivíduos habilidades técnicas que, se associadas a um estímulo ao "repatriamento" e à tutela britânica, poderiam solucionar a questão do déficit de mão de obra nas lavouras de algodão na colônia de Lagos. Afinal, na virada do século XIX para $\circ \mathrm{XX}$, 0 governador de Lagos considerava vantajoso 0 "repatriamento" de "trained negroes" para o trabalho na produção do algodão. ${ }^{119}$

Traficantes, "educated blacks", "Brazilian emigrants" ou "trained Negroes", são múltiplas as expressões associados aos brasileiros que viveram na Costa da Mina ao longo do século XIX. ${ }^{120}$ Assim, quanto mais os significados do nome brasileiro se multiplicam nos registros produzidos no oitocentos, mais entrelaçadas parecem ser as dinâmicas que determinam seu uso. Como consequência deste processo, maior é o desconforto em estabelecer quais elementos definem esta população. Conforme examina Bazin em sua análise acerca da possibilidade de se prescindir, ou não, da etnia para explicar os bambaras, "à semelhança do que sucede com os fantasmas, não se

Luciana da Cruz. A legalidade como estratégia: africanos que questionaram a repressão das leis baianas na primeira metade do século XIX. Revista dos Pós-graduandos em História Social da Unicamp, n.16, 2009, pp.15-28. Em minha pesquisa de mestrado, procurei discutir os processos de "retorno" à Costa da Mina e os desdobramentos deste movimento em: SILVA, Angela Fileno da. "Amanhã é dia santo": circularidades atlânticas e a comunidade brasileira na Costa da Mina. São Paulo: Alameda/ Fapesp, 2014.

${ }_{118}$ CAMPBELL, Robert. Op.cit,. 1861, p.73.

${ }_{119}^{119}$ MOLONEY, Alfred. Op.cit. 1889, pp.268, 269.

120 John Duncan e Frederick Forbes nomeiam o grupo em questão como traficantes. Robert Campbell denomina-os como "educated blacks". Enquanto Richard Burton e Alfred Moloney percebem os indivíduos com os quais entraram em contato como "Brazilian emigrants" e "trained Negroes", respectivamente. 
trata de saber se ela [a etnia] existe ou não, mas quais as condições da sua aparição". Tomando este pressuposto para o caso dos brasileiros, a etnia não seria um referente a ser descartado. Ao contrário, o estudo da forma como a identidade étnica é exercida, colabora para a compreensão dos processos de urdidura destes rótulos. Se este exercício não for feito, corremos o risco de "destruir porventura os museus, mas guardar as etiquetas."121

Como forma simbólica capaz de circunscrever indivíduos diferentes sob uma comunidade imaginada comum, a noção de etnia confere coerência interpretativa a pesquisadores, mas não espelha a multiplicidade humana. Ainda de acordo com Bazin, a atribuição de um mesmo nome a indivíduos considerados pertencentes a um determinado grupo seria um indicativo de "consubstancialidade", cuja acepção contraria um dos pressupostos da humanidade: a diversidade. Ao resumirmos os indivíduos às categorias representadas na forma de grupos étnicos, negligenciamos as subjetividades que permitem aos seres humanos uma existência múltipla e variável. A impossibilidade dos integrantes de um grupo serem feitos de uma substância comum, confere um caráter relativo à questão do pertencimento étnico. Como categorias historicamente construídas, em grande medida, por outros grupos e, em particular, pelo colonizador, as etnias pressupõem vínculos que, em seu exercício, expõem "significados flutuantes". ${ }^{122}$

Segundo Amselle e M'Bokolo, as dinâmicas étnicas se encarregam de atualizar os elos entre os integrantes do grupo. De acordo com esta perspectiva, as etnias se constituem como categorias flexíveis, cujas fronteiras são permeáveis aos contatos e às trocas. Neste sentido, os indivíduos não pertenceriam a apenas uma etnia, mas a um universo de identificação a partir do qual as identidades étnicas seriam acionadas em função de contextos políticos, sociais e culturais específicos. ${ }^{123}$

\footnotetext{
${ }^{121}$ BAZIN, Jean. Cada qual com o seu bambara in AMSELLE, Jean-Loup; M'BOKOLO, Elikia (coord.) Op.cit. 2014, pp.110 e 90, respectivamente.

122 Ibid, p.89.

123 AMSELLE, Jean-Loup; M'BOKOLO, Elikia (coord.) Op.cit. 2014, p.11. Amselle também publicou um capítulo em que discute a questão da etnia como categoria colonial e seus desdobramentos nos processos de independência africana, em: AMSELLE, Jean-Loup. Etnicidade e Identidade em África in CORDELIER, Serge (coord.) Nações e nacionalismos. Lisboa: Dom Quixote, 1998.
} 
Em 2012, Manuela Carneiro da Cunha publicou a segunda edição, revista e ampliada, de sua brilhante obra Negros, estrangeiros, impressa pela primeira vez no ano de 1985, mas iniciada dez anos antes, em 1975. Esta nova versão manteve a proposta de entendimento dos processos de constituição identitária da comunidade brasileira de Lagos. Em vista disto, logo no texto de abertura da segunda edição, Cunha retomou a discussão sobre se a etnia seria uma categoria viável para explicar a população brasileira. Prevenindo o leitor de que "etnicidade não é coisa que se recomende no absoluto", a autora explicava que a etnia constitui "um poderoso mobilizador de forças, que pode fortalecer subalternos ou gerar opressões e massacres intoleráveis". No entanto, seu livro não prescindiu desta noção para analisar a construção da identidade brasileira, ocorrida em momentos históricos específicos e em permanente interação com um universo societário mais amplo. Reconhecendo que as discussões antropológicas da década de 1970 acrescentaram à noção de etnicidade a ideia de que ela é construída de maneira "situacional e contrastiva", Cunha interpretou os processos de formulação da identidade brasileira como uma resposta às dinâmicas políticas e às outras identidades que juntas formavam um sistema. Como uma categoria capaz de engendrar relações de poder assimétricas, a autora também considerou a identidade étnica brasileira como um termo em permanente disputa. Estes enfrentamentos em torno dos rótulos étnicos poderiam exacerbar diferenças, deslocar limites e definições, ou conferir poder político a alguns grupos. ${ }^{124}$

Segundo Cunha, para sustentar a existência de uma determinada identidade étnica seria necessário afirmar uma anterioridade histórica. Tal anterioridade seria "putativa" e se exprimiria por meio da cultura. Assim sendo, a anterioridade histórica de uma etnia estaria subentendida nas formas do grupo externar suas narrativas de origem, de exercer suas diferenças ou de colocar em ação os símbolos que conferem identidade ao conjunto de indivíduos. Para a autora, é por meio do exercício da cultura que os grupos étnicos tornam públicos os "sinais diacríticos" capazes de diferenciá-los. Ao selecionar as manifestações culturais consideradas condizentes com uma narrativa histórica construída, a constituição do grupo étnico ocorreria a partir

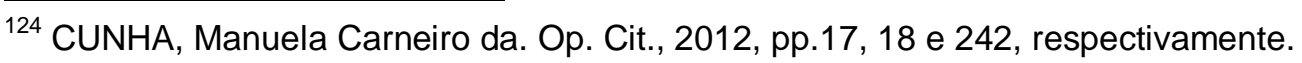


do que a antropóloga denomina como "descontinuidade de planos". Desta forma, enquanto a concepção de cultura está vinculada à atualização permanente de seus componentes e práticas, a etnicidade confere "uma ênfase na imutabilidade aparente do produto". Esta distinção entre os processos de constituição étnica e a produção cultural consiste em uma crítica à concepção reificada de cultura. ${ }^{125}$

Colocando em questão a forma como os estudos sobre etnicidade se apropriaram do termo "cultura" para compor um rol de crenças, ideias, características e traços comuns a um determinado grupo, Cunha se aproximou da noção de cultura aventada por Clifford Geertz. Para o antropólogo, o trabalho etnográfico não se resumiria ao inventário dos dados coletados em campo. Tomando como ponto de partida a proposição de Max Weber de que o ser humano estaria "amarrado a teias de significados que ele mesmo teceu", Geertz propõem que a etnografia seja entendida "como uma ciência interpretativa, à procura de significado." Dito de outro modo, a realidade se apresentaria ao etnógrafo como uma "multiplicidade de estruturas conceituais complexas" resultantes da atuação simbólica dos indivíduos. A atuação do etnólogo tornaria a "teia" simbólica urdida pelos seres humanos mais compreensível ou, nos termos do próprio autor, "descrita com densidade." 126

A descrição densa aventada por Geertz propõe que a cultura seja compreendida como um texto. A leitura da produção cultural de um grupo é o que torna possível decodificar o conjunto de sistemas simbólicos que mediam a relação do indivíduo com a realidade. Porém, mesmo nestes termos, o autor reconhece as limitações desta perspectiva. Tais limites estariam determinados pelo acesso do pesquisador às realidades locais. Ao perceber que o conhecimento sobre um grupo étnico é sempre parcial, fragmentado, fornecido pelos nascidos dentro daquela cultura e, na melhor das hipóteses, elaborado em segunda mão, Geertz define os estudos sobre a cultura como a análise do "fluxo do discurso social". Este aspecto coloca em questão a impossibilidade das interpretações determinarem os limites que separam "o modo de

\footnotetext{
${ }_{125}$ Ibid, pp. 242 e 243, respectivamente.

${ }^{126}$ GEERTZ, Clifford. A interpretação das culturas. 13a reimpressão. Rio de Janeiro: LTC, 2008, pp.4 e 7 , respectivamente.
} 
representação e o conteúdo substantivo" de uma cultura. A rigor, pois, ao compreender a análise cultural como intrinsecamente incompleta, o autor aponta para a possibilidade do entendimento da cultura a partir do contexto de sua produção. Como sistemas entrelaçados de signos interpretáveis, a elaboração da cultura é resultado de operações sociais historicamente localizadas. ${ }^{127}$

Neste debate acerca da interpretação das culturas, o casal de antropólogos sul-africanos Jean e John Comaroff, no texto Etnografia e imaginação histórica, acrescentam novas reflexões às perspectivas aventadas por Geertz. ${ }^{128}$ Ao reconhecerem que a "etnografia é historicamente contingente e culturalmente configurada", ambos pesquisadores apontam para o fato dos contextos também serem construções localizadas social e temporalmente. Nas palavras dos autores,

Os contextos tampouco estão lá, simplesmente. Também eles precisam ser analiticamente construídos à luz de nossos pressupostos acerca do mundo social. ${ }^{129}$

Este aspecto em específico coloca em evidência a ideia de que a própria interpretação da elaboração das identidades étnicas a partir do contexto de sua produção, também revela aspectos do "mundo social" daquele que produz o discurso etnográfico. Neste sentido, o discurso acerca da produção cultural de um grupo se constituiria como um mosaico de signos e práticas atados entre si em função do sentido que cada uma de suas peças faz para quem as interpreta. Tal entendimento ainda reconhece que a tessitura das análises elaboradas por antropólogos pode subsumir conflitos e disputas em torno do poder. Nesta chave, a cultura se apresentaria, ainda de acordo com o casal Comaroff, como um "conjunto de significantes-em-ação situados na história e desenrolando-se ao longo dela, significantes ao mesmo tempo materiais e

${ }^{127}$ GEERTZ, Clifford. Op.cit., 2008, pp.11-12.

${ }^{128} \mathrm{O}$ texto ao qual faço referência é a introdução do livro Ethnography and the Historical Imagination, publicado em língua inglesa no ano de 1992, e ainda sem tradução para o português. No entanto, é possível ler a introdução deste livro em língua portuguesa em: COMAROFF, J \& COMAROFF, J. Etnografia e imaginação histórica. Tradução de Iracema Dulley e Olivia Janequine In Proa - Revista de Antropologia e Arte (on-line). Ano 02, vol.01, n.02, nov. 2010. Disponível em: http://www.ifch.unicamp.br/proa/Traducoesll/comaroff.html, acesso em: 15/06/2015.

${ }^{129}$ Ibid, p.14. (Itálico colocado pelos autores) 
simbólicos, sociais e estéticos." Assim, alguns destes significados estariam entretecidos, configurando "visões de mundo relativamente explícitas". De maneira inversa, outros se mostrariam aos seus intérpretes de forma menos coerente ou de modo "indeterminado." Neste segundo grupo estariam os significados difíceis de serem decifrados por não apresentarem sentidos correspondentes no "mundo social" do pesquisador. ${ }^{130}$

De acordo com Jean e John Comaroff a chave para o exercício da antropologia estaria no que denominam como "etnografia da imaginação histórica". Para tanto, ambos propõem que os estudos acerca da produção cultural se dediquem a "explorar os processos que constituem e transformam os mundos particulares - processos que dão forma, reciprocamente, aos sujeitos e aos contextos". Dito em outros termos, o elemento fundamental da abordagem metodológica proposta pelos Comaroff estaria na compreensão dos processos de interação e de troca mútuas entre os sujeitos e seus contextos. ${ }^{131}$

A perspectiva de que a constituição da identidade étnica decorre de processos complexos que, na maioria das vezes, envolvem contradições, trocas e mudanças foi também tratada por Manuela Carneiro da Cunha. Ao analisar a maneira pela qual os brasileiros que viviam em Lagos constituíram, ao longo do século XIX, várias identidades étnicas formuladas em contato com as múltiplas realidades locais, - africanas e coloniais e, do outro lado do Atlântico, com os elementos fornecidos pelas trocas comerciais (e, também culturais e de ideias) com a Bahia - Cunha assumiu a concepção de que a produção do sentido conferido aos sistemas simbólicos ocorre sempre no âmbito de processos situacionais. Logo na introdução à primeira edição de Negros, estrangeiros, a autora reconheceu que sua obra não havia demonstrado a existência de uma identidade compartilhada entre brasileiros de Lagos e libertos africanos da Bahia. Para a antropóloga, a identidade dos brasileiros de Lagos teria se formado muito mais em resposta à expansão do Império Britânico e em diálogo com "um mosaico de grupos submetidos a um progressivo colonialismo", do que em função dos vínculos estabelecidos pelo comércio escravista mantido com o Brasil. Esta perspectiva interpretativa

\footnotetext{
${ }^{130} \mathrm{Ibid}$, p.34.

${ }^{131}$ Ibid, p.38.
} 
permeia todo o livro. No entanto ao final, a autora coloca em questão o eixo a partir do qual sua obra se desenvolveu. Ao sugerir que, talvez, a identidade étnica seja "uma condição supérflua" à constituição das histórias pessoais e coletivas dos brasileiros em Lagos, Cunha abriu caminho para outras possibilidades interpretativas relacionadas ao assunto. ${ }^{132}$

É possível que uma resposta prudente para a dúvida sobre se devemos, ou não, renunciar à noção de etnia como categoria explicativa esteja, porventura, na tentativa de compreender a constituição da etnia como um processo móvel e diversificado. Uma vez que a identidade brasileira está inscrita em contextos mais amplos de colonização, de interação e de troca com outras sociedades, a análise das várias dimensões de pertencimento ao grupo pode constituir um meio através do qual poderíamos nos aproximar da multiplicidade de sentidos associados ao ser (ou ao tornar-se) brasileiro. A exemplo do que propõe Cunha, a identidade étnica brasileira seria uma das formas simbólicas de definição do indivíduo, forma esta construída em resposta a contextos históricos específicos e em permanente atualização de sentido.

Para Amselle e M'Bokolo, mesmo reconhecendo que os grupos étnicos sejam construções antropológicas elaboradas, via de regra, pelo colonizador, em determinadas situações, estes etnônimos seriam reivindicados pelo grupo a fim de afirmar, fortalecer ou disputar o lugar político a ser ocupado por seus integrantes. ${ }^{133}$ Estes autores percebem que, em certos momentos históricos em períodos pós-independência, por exemplo - o pertencimento étnico esteve associado aos enfrentamentos em torno do controle político do aparelho do Estado. Como símbolo constituído em um momento histórico específico, a etnia de um grupo pode assumir ao longo do tempo significados múltiplos. São estas variações do sentido de ser brasileiro que interessam a esta pesquisa. Desta forma, reitero que o fio condutor deste estudo se refere à proposta de compreender os processos de identificação referentes aos brasileiros que viveram em Lagos, entre 1840 e 1900, a partir do que denomino como identidades cambiantes. Tomando como pressuposto a ideia de que os brasileiros reformularam, descartaram e incorporaram novos sentidos de

\footnotetext{
${ }_{132}$ CUNHA, Manuela Carneiro da. Op. Cit., 2012, pp. 25 e 245, respectivamente.

${ }^{133}$ AMSELLE, Jean-Loup; M'BOKOLO, Elikia (coord.) Op.cit. 2014, p.39.
} 
pertencimento ao longo do recorte temporal apresentado, procuro demonstrar os processos pelos quais estas identidades se configuraram a partir do contato, das alianças e das disputas com grupos britânicos, sarôs e egbas.

Nesta visada, ao longo das décadas de 1840 a 1860, embora o número de libertos instalados em Lagos desde 1835 fosse crescente, a maioria dos registros britânicos se referia aos brasileiros, definindo-os como traficantes. Deste modo, a identidade brasileira nascente se constituiu associada ao tráfico. Esta identidade atribuída continha valores próprios dos paradigmas culturais europeus relativos à condenação ao comércio de indivíduos escravizados. No início dos anos de 1860 a questão do tráfico com o Brasil já havia se solucionado e as rotas que ainda alimentavam os mercados negreiros existentes em Cuba estavam próximas da extinção. Em função deste novo contexto, as formas de representação das identidades dos brasileiros de Lagos também se modificaram, a fim de sustentar um discurso acerca da eficácia das ações empreendidas pelo Esquadrão Africano. Campbell, nos anos sessenta, e Moloney, no final dos anos oitenta e início da década de 1890, encontraram outras formas de representar os brasileiros, desta vez, associando-os ao trabalho agrícola. Sob estes aspectos, algumas questões permanecem: Em quais contextos a identidade étnica dos brasileiros de Lagos seria reivindicada? Quais seriam os aspectos que definiriam estes indivíduos? Como a administração colonial britânica identificou os brasileiros ao longo do tempo? Em que momentos a identidade brasileira era colocada em ação? Embora as questões aqui apresentadas não nos libertem de categorias explicativas limitadoras de uma compreensão mais ampla, talvez abram um caminho para o entendimento de como estas identidades se constituíram a partir do contato com as diversas realidades que se apresentavam ao grupo. 


\section{Lagos, um porto negreiro}

Seu valor como colônias é muito pequeno, já que o clima da África sempre impedirá os colonos europeus de se estabelecerem por si próprios na costa, exceto em uma

extensão bastante limitada. ${ }^{134}$

Neste segundo capítulo o objetivo central é entender os processos que, na primeira metade do século XIX, transformaram Lagos no principal porto de embarque de escravos da Costa da Mina. Em função disto, recorri à produção historiográfica que trabalha com narrativas orais e se dedica a explicar uma série de conflitos, cujos desdobramentos estiveram relacionados ao fornecimento de cativos para os negreiros estabelecidos no porto lagosiano. ${ }^{135}$ O propósito desta etapa introdutória foi expor um conjunto de interações de longa duração estabelecidas entre os habitantes de Lagos e de localidades como Iseri, Benim, ljebu e Oió. De acordo com a historiografia estudada, algumas destas interações estiveram ligadas às disputas em torno de pontos de tráfico na região, ao esfacelamento do poder de Oió e às sucessivas contendas entre cidades que disputavam entre si uma melhor posição em função dos novos arranjos de poder que se estabeleceram neste contexto.

\footnotetext{
134 "Their value as colonies is very small, since the climate of Africa will always prevent European settlers from establishing themselves on the coast, except to a very limited extent." Trecho do relatório da Church Missionary Intelligencer (CMI) publicado em 1872. Neste documento, sem assinatura, a Grã Bretanha é colocada como auxiliar no grande empreendimento de cristianização do continente. CMI, What the West Coast was before the extinction of the Slave Traffic - Capture of Lagos in 1851 in A Monthly Journal of Missionary Information. Vol.VIII. London: Church Missionary House, 1872, p.124.

${ }^{135}$ Refiro-me, principalmente, às seguintes obras: FALOLA, Toyin; OGUNTOMISIN, G.O. Yoruba Warlords of the 19th Century. Trenton/NJ; Asmara/Eritrea: Africa World Press, 2001; FALOLA, Toyin; HEATON, Matthew M. A History of Nigeria. Cambridge: Cambridge University Press, 2008; FALOLA, Toyin. A History of Nigeria. West Port, CT: Greenwood Press, 1999; MANN, Kristin. Slavery and the Birth of an African City: Lagos, 1760 - 1900. Indiana: Indiana University Press, 2007 e SOUMONNI, Elisée. Daomé e o mundo atlântico. Centro de Estudos Afro-Asiáticos/Universidade Cândido Mendes, 2001.
} 
Sob estas circunstâncias específicas, Lagos deixou de lado o papel secundário que desempenhou no comércio atlântico de escravos até a virada do século XVIII para o XIX, para assumir uma posição de proeminência nesta atividade. Durante cerca de cinquenta anos, de 1800 a 1850, a cidade experimentou um crescimento econômico sustentado, em grande medida, pelo tráfico. Esta situação despertou a atenção do governo britânico que, na década de 1840, passou a enviar seus oficiais navais, cônsules e vice-cônsules para ocupar os dois principais fortes ingleses da costa ocidental africana: o forte Williams, em Ajudá, e o Cape Coast Castle, que se tornou um dos postos da administração consular britânica na Costa do Ouro. Até 1807, estas e outras fortificações menores eram guarnecidas por militares e funcionários públicos ligados ao Foreign Office. Entretanto, a partir deste ano, estes atracadouros foram abandonados em razão da promulgação do Abolition of the Slave Trade Act, que determinava a supressão do comércio atlântico de escravos. A desocupação completa destes embarcadouros durou alguns anos. Afinal conforme Law, os últimos funcionários que viviam no forte Williams, por exemplo, voltaram para a Inglaterra apenas no ano de $1812 .{ }^{136}$

Trinta e quatro anos mais tarde, em 1846, esta mesma fortificação foi reocupada como sede do vice-consulado de Ajudá. A retomada de antigos pontos de atuação britânica na costa africana veio acompanhada por expedições exploratórias lideradas pelo cônsul dos Golfos do Benim e de Biafra, John Beecroft e pelo vice-cônsul de Ajudá, John Duncan. Além disso, religiosos enviados por sociedades missionárias anglicanas e metodistas respectivamente, pela Church Missionary Society (CMS) e a Wesleyan Missionary Society - começaram a fundar congregações em diversos pontos da Costa da Mina. Relatos escritos por oficiais da marinha naval, cônsules, vice-cônsules da Grã-Bretanha e religiosos que, a partir da década de 1840 se estabeleceram na região pesquisada, constituem um relevante conjunto de documentos que menciona a presença de brasileiros na cidade de Lagos. Quando combinadas à historiografia produzida acerca das circunstâncias das partidas de africanos e descendentes de Salvador para a Costa da Mina, estas

\footnotetext{
${ }^{136}$ LAW, Robin. Ouidah: The Social History of a West African slaving 'port', 1727-1892. Ohio: Ohio University Press/ Oxford: James Currey, 2004, p.160-163 e 218.
} 
fontes revelam aspectos importantes acerca da forma como a população brasileira residente em Lagos se constituiu a partir da Revolta dos malês, em 1835. Neste sentido, a ideia de que a chegada de africanos e descendentes, libertos e livres, transformou de maneira significativa a composição humana da cidade é também um dos aspectos tratados neste capítulo.

\subsection{A abertura de Lagos para o comércio atlântico de escravos}

Se você não sabe onde a chuva começou a te molhar, não vai saber onde o sol já te secou. ${ }^{137}$

Localizada na extremidade oeste da principal ilha que compõe uma rede de lagoas, estuários e canais paralelos ao litoral do atual Golfo do Benim, Lagos se constituiu inicialmente como um ponto de apoio aos pescadores que viviam e transitavam pela região. ${ }^{138}$ No século XVI, a chegada dos auoris marcou o início o povoamento na ilha. Estes habitantes vinham de Iseri, cidade situada mais ao norte, às margens do rio Ogun. Inicialmente, tal grupo teria se fixado no continente, na porção conhecida como Ebute Metta. ${ }^{139}$ Mais tarde, parte destes indivíduos fundou dois outros estabelecimentos: Oto e Ido. Em seguida, um dos primeiros povoadores, Aromire, primogênito de Olofin e neto do antepassado mítico dos iorubás, Odudua, deixou o continente, atravessou a laguna e se instalou na porção da ilha que passou a ser conhecida como Oko

\footnotetext{
137 Provérbio ibgo citado por Chinua Achebe em: ACHEBE, Chinua. A educação de uma Criança sob o Protetorado Britânico: ensaios. São Paulo: Companhia das Letras, 2012, p. 64.

${ }_{138}$ Sublinho que, antes de se tornar Lagos, o mesmo lugar foi conhecido como Oko, Eko e Onim.

${ }^{139} \mathrm{~A}$ ausência de datação quando me refiro às primeiras populações que se estabeleceram em Lagos é justificada pelo fato da maioria das informações procederem de pesquisas que se basearam em tradições locais, muitas das quais orais. A respeito desse período, consultei os seguintes autores cujas pesquisas trabalham com estas tradições: ADERIBIGBE, A.B. Early History of Lagos to About 1850 in ADERIBIGBE, A.B. (ed.) Lagos: The Development of an African City. Lagos: Longman, 1975; MANN, Kristin. Slavery and the Birth of an African City: Lagos, 1760 - 1900. Indiana: Indiana University Press, 2007, SILVA, Alberto da Costa e. A manilha e o libambo: a África e a escravidão, de 1500 a 1700. Rio de Janeiro: Nova Fronteira, 2002. Cap.9. O Benim e o delta do Níger e ANIBABA, Musliu Olaiya. A Lagosian of the 20th Century. Lagos: Tisons Limited, 2003, cap.1.
} 
(atual Lagos). A partir de tradições orais, o historiador Aderibigbe narrou o processo de saída dos dez filhos de Olofin da cidade de Iseri. O autor também analisou as implicações políticas decorrentes desse movimento ao considerar que a fundação de novos estabelecimentos ampliou a influência econômica, política e cultural de Iseri, assim como constituiu novas chefias mantidas sob o controle do Olofin. ${ }^{140}$ Segundo o pesquisador Costa e Silva, as tradições iorubanas se referem a Oko como o local onde Aromire instalou uma fazenda de pimenta. Estas tradições também explicam a origem dos chefes ilejos, os "senhores da terra" descendentes de Aromire, e por isto considerados os primeiros habitantes da ilha. Estes indivíduos eram reconhecidos pelo uso do kerevesi (ou gorro branco). ${ }^{141}$

Iniciada por Aromire, a chefia dos ilejos se manteve mesmo depois das forças do obá Orhogbua, do Benim, chegarem à ilha na segunda metade do século XVI. A partir desse momento tropas enviadas por este obá ocuparam Oko, que passou a se chamar Eko, ou "acampamento", em edo. Para Kristin Mann, uma das principais pesquisadoras contemporâneas da história de Lagos, a forma como o Benim estabeleceu seu domínio não apenas sobre a ilha, mas por toda a região anteriormente sob influência Iseri, permitiu a manutenção da posição dos ilejos. Ao constituir um conselho de governo para administrar os territórios recém-submetidos, o Benim buscou incorporar estas chefias locais. Deste modo, legitimando o status dos ilejos, o Orhogbua respondia às demandas deste grupo pela permanência dos direitos sobre a terra e de controle da pesca. ${ }^{142}$

Ainda de acordo com a autora, em algum momento antes de 1682 o obá do Benim "nomeou um vice-rei para supervisionar a comunidade [da recémestabelecida Eko] e extrair-Ihe tributo". Embora existam diversas versões

\footnotetext{
${ }^{140}$ ADERIBIGBE, A.B. Early History of Lagos to About 1850 in ADERIBIGBE, A.B. (ed.) Op.cit, 1975, cap.1. Para uma análise profunda acerca dos processos de formação de sociedades africanas a partir da perspectiva de fronteira, sugiro: KOPYTOFF, Igor.(org.) The African Frontier. The reproduction of Traditional African Societies. Bloomington: Indianapolis: Indiana University Press, 1989, parte 1, p.3-84, em especial.

${ }^{141}$ Publicações em inglês costumam grafar o título de "dono da terra", como idejo. Em situações em que a grafia de palavras pode ser encontrada de diferentes formas, tanto na documentação, quanto nas publicações historiográficas, optei por manter as designações em português, quando estas existiam.

${ }^{142}$ MANN, Kristin. Op.cit., 2007, p.28.
} 
acerca de como a nova chefia da ilha passou a ser indicada pelos edos, há um consenso entre os historiadores a respeito da posição que Eko passou a ocupar a partir deste momento. Tornando-se centro do poder dos edos na região, a ilha deixou de ser politicamente dependente de Ido. ${ }^{143}$

Costa e Silva é um dos pesquisadores que apresenta e comenta as diversas versões produzidas pelas tradições iorubanas e benins. $O$ autor previne que as narrativas "são numerosas e conflitantes", mas reconhece que as tradições marcam a ruptura do sistema político sobre o qual predominava 0 alafim. ${ }^{144}$ Em outras palavras, com a conquista de Eko (Lagos) pelo Benim os chefes locais deixaram de receber o título de alafim e passaram a ser nomeados como obás. O escolhido para ocupar o lugar de obá deveria ter sua posição confirmada pelo Benim, para o qual Eko estava obrigada a enviar periodicamente tributos. Esta mudança veio acompanhada pelo acréscimo de, ao menos, dois outros títulos à já existente chefia dos ilejos. O primeiro era o de Eletu Odibo, principal chefe dos àkárìgbèrè, cujas atribuições administrativas incluíam a escolha e instalação do obá. O segundo era o de Asogbon, chefia militar dos àbàgbón, que estava associada à ampliação da autoridade dos edos sobre o território conquistado. Além do status político, os membros dos grupos àkárìgbèrè e àbàgbón desfrutavam de uma posição privilegiada no comércio escravista. De acordo com Mann, esta condição decorria da proximidade do grupo em relação ao obá. ${ }^{145}$

Não é possível precisar com exatidão até quando Eko se manteve submetida aos edos enviando tributos ao Benim. No entanto, podemos supor que, até a segunda metade do século XVIII, o volume de bens encaminhados

\footnotetext{
${ }^{143}$ Ibid, p.27/28. Mann também possui outras importantes publicações que tratam da história de Lagos e da presença brasileira na ilha, entre elas estão: MANN, Kristin. Marriage Choices among the Educated African Elite in Lagos Colony, 1880-1915. The International Journal of African Historical Studies, Vol.14, No. 2, 1981, pp.201-228; MANN, Kristin; BAY, Edna (eds.) Rethinking the African Diaspora: the making of a Black Atlantic World in the Bight of Benin and Brazil. Portland: Frank Cass Publishers, 2001 e MANN, Kristin. Women, Landed Property, and the Accumulation of Wealth in Early Colonial Lagos. Signs, vol.16, No. 4, 1991, pp.682-706.

${ }^{144}$ SILVA, Alberto da Costa e. Op.cit., 2002, p.341. Outra publicação que trata da mudança de posição de Eko depois da conquista do Benim é ADERIBIGBE, A.B. Early History of Lagos to About 1850 in ADERIBIGBE, A.Op.cit., 1975,pp.5-9.

${ }_{145}$ MANN, Kristin. Op.cit., 2007, p.29, 63 e 71. Segundo Costa e Silva, o título de obá pode também ser escrito das seguintes maneiras: olugoron, ologun e eleko. SILVA, Alberto da Costa e. Um rio chamado Atlântico: a África no Brasil e o Brasil na África. Rio de Janeiro: UFRJ, 2003, p.119.
} 
até o Benim não era tão significativo. Durante este período, a ilha desempenhou um papel secundário no comércio atlântico de escravos. Seus habitantes tinham como função o transporte de cativos de um atracadouro a outro. Para isto utilizavam grandes canoas que eram também empregadas na pesca. A intrincada rede de lagoas e canais era cercada por manguezais, o que tornava a circulação pela região uma tarefa para conhecedores. Desta forma, os embarcadouros já estabelecidos em Porto Novo e Badagri dependiam do transporte operado pelos moradores da ilha.

A partir da década de 1760, a ascensão do obá Akinsemoyin e a chegada do negreiro João de Oliveira à ilha modificaram o papel de Lagos no comércio atlântico de escravos. Desde a década de 1720, Porto Novo e Badagri eram pontos de exportação de cativos fornecidos por Oió, enquanto Ajudá e Aladá eram portos abastecidos pelo Daomé. Quando Akinsemoyin assumiu o mando em Lagos, ele convidou alguns negreiros para estabelecer seus negócios na cidade. Entre os comerciantes de escravos levados até Lagos pelo obá estava o brasileiro João de Oliveira. ${ }^{146}$

A trajetória de Oliveira como negreiro participante das redes comerciais tecidas com a Costa da Mina e, do outro lado do Atlântico, com Salvador chega até nossos dias por meio de um processo criminal guardado no Arquivo Histórico Ultramarino e transcrito por Pierre Verger. ${ }^{147}$ No início do mês de maio de 1770, João de Oliveira retornou da Costa da Mina e desembarcou no porto de Salvador. De acordo com um requerimento em que o réu solicitou a devolução de seus bens, naquele momento sequestrados pelas autoridades alfandegárias baianas, Oliveira declarou ter residido na Costa da Mina "durante

\footnotetext{
${ }^{146}$ Cf. OJO, Olatunji. The Organization of the Atlantic Slave Trade in Yorubaland, ca. 1777 to ca. 1856. The International Journal of African Historical Studies, vol.41, n.1, 2008, p.79.

${ }^{147}$ VERGER, Pierre. Os Libertos: sete caminhos na liberdade de escravos da Bahia no século XIX. São Paulo: Corrupio, 1992. Além de Pierre Verger, outros pesquisadores também tratam da atuação de João de Oliveira na Costa da Mina, em: GURAN, Milton. Agudás, os 'brasileiros' do Benim face à colonização francesa do Daomé, p.505 in SANTOS, Maria Emília Madeira (dir.) A África e a Instalação do Sistema Colonial (c.1885 - c.1930). III Reunião Internacional de História de África. Lisboa: Centro de Estudos de História e Cartografia Antiga, 2000; LAW, Robin; MANN, Kristin. West Africa in the Atlantic Community: the case of the Slave Coast. In Willian and Mary Quarterly, 56, 2, 1999, p.317 e SILVA, Alberto da Costa e Francisco Félix de Souza, mercador de escravos. Rio de Janeiro: Nova Fronteira/ed.UERJ, pp.23,35-36 e 63.
} 
37 ou 38 anos". ${ }^{148}$ Não há um consenso acerca do tempo de permanência de João de Oliveira na região. Esta dificuldade em precisar o tempo exato de sua permanência neste território talvez estivesse relacionada ao número de viagens empreendidas ao Brasil. Neste sentido, é possível que o desembarque em solo baiano, ocorrido em 1770, não tenha sido o primeiro realizado pelo liberto. Afinal, depois de alforriado o mercador de escravos fez crescer seus negócios em Porto Novo e Onim (Lagos), atividade que exigia constantes travessias atlânticas em direção à capital baiana. No entanto, no ano de 1770, quando o negreiro mais uma vez voltou a Salvador não estava sozinho. Junto a ele quatro cabeceiras enviados por Akinsemoyin compunham a primeira embaixada, enviada a partir da cidade de Lagos, a desembarcar na Bahia. ${ }^{149}$

Esta não foi a única comitiva remetida por um obá de Lagos à Salvador. De acordo com o historiador Aderibigbe, em 1807, um embaixador e um secretário enviados por Ajan - citado como "príncipe de Onim [Lagos]" e identificado por Alberto da Costa e Silva como Osinlokun - encontraram-se com o Conde da Ponte, então governador da Província da Bahia. O envio de comitivas à capital baiana continuou ao menos nas duas décadas subsequentes, em 1820 e 1830. Nos anos de 1830, as relações entre Salvador e Lagos se estreitaram ao ponto do tenente coronel Manoel Alvarez Lima declarar, em ofício encaminhado a d. Pedro I, ocupar a função de "embaixador do rei de Onim" na Bahia. ${ }^{150}$

\footnotetext{
${ }^{148}$ Cf. Requerimento do negro João de Oliveira, no qual pede lhe sejam restituídos os escravos e bens, que injustamente lhe haviam requisitado, Arquivo Histórico Ultramarino (AHU), 8246 in VERGER, Pierre. Op.cit., 1992, p.102.

149 Os registros de Legitimação de Passaporte, guardados no Arquivo Público do Estado da Bahia (APEBa), revelam que eram recorrentes as viagens de comerciantes de escravos entre a Costa da Mina e Salvador. Cf. SILVA, Angela Fileno da. Op.cit. 2014, p.37. Pesquisas em arquivos históricos, estudos de campo realizados no Benim e na Nigéria e reinterpretação de dados coletados por outros autores permitiram que Castillo traçasse as trajetórias de alguns dos libertos que viajaram para a Costa da Mina a partir de 1835. CASTILLO, Lisa Earl. Mapping the nineteeth-century Brazilian returnee movement: Demographics, life stories and the question of slavery. Atlantic Studies, 13:1, 2016, pp.25-52.

${ }^{150}$ ADERIBIGBE, A.D. Early History of Lagos to about 1850 in ADERIBIGBE, A.B.; AJAYI, J.F.A. (ed.) Lagos: The Development of an African City. Lagos: Longman, 1975, p.13-14; SILVA, Alberto da Costa e.Um rio chamado Atlântico: a África no Brasil e o Brasil na África. Rio de Janeiro: Nova Fronteira/EdUERJ, 2003, pp.8,11-12. O envio de embaixadas africanas até Salvador foi um expediente utilizado também pelos daomeanos. Como informa Verger, entre os anos de 1750 e 1811, o Daomé encaminhou um total de quatro embaixadas com destino a Salvador e Lisboa. A primeira delas, a mando de Tegbesu, chegou no ano de 1750. Depois dessa primeira missão, Agonglô, remeteu sua comitiva, em 1795. Durante o reinado de Adandozan duas embaixadas foram conduzidas, em 1805 e 1811. Todas essas missões
} 
Embora o envio de comitivas de Lagos para a capital baiana houvesse se repetido até a década de 1830, é possível que em 1770, quando Oliveira desembarcou em Salvador na companhia dos cabeceiras de Akinsemoyin, sua ação tenha confundido as autoridades alfandegárias locais. Afinal, alguns dias depois da chegada do traficante e da comitiva que o acompanhava, Oliveira e os enviados lagosianos foram detidos por ordem do Provedor da Alfândega da capital baiana. Acusados de contrabando, os acusados tiveram seus bens sequestrados pela Polícia Provincial de Salvador durante o tempo em que duraram a investigação e apuração do processo. Depois de um mês na cadeia, Oliveira foi solto. Novamente em liberdade, o mercador de cativos encaminhou às autoridades baianas um requerimento em que pedia a restituição dos setenta e nove escravos do sexo masculino e de outras quarenta e três escravas do sexo feminino tomados no momento de sua prisão. ${ }^{151}$

O termo de prisão lavrado contra o negreiro nos informa que João de Oliveira declarava ser "natural do gentio da Costa da Mina", procedência que possivelmente se referia muito mais ao ponto de embarque para o Brasil do que efetivamente seu local de nascimento. ${ }^{152}$ Esta fonte também revelou que depois de residir por cerca de trinta e oito anos na mesma região de onde partiu como escravo, Oliveira fixou residência em Salvador, na Freguesia do

tinham como objetivo central convencer o governo português a traficar exclusivamente no porto de Ajudá, abandonando outros embarcadouros estabelecidos na Costa dos Escravos, principalmente em Lagos, Porto Novo, Badagry e Anexô. VERGER, Pierre. Fluxo e Refluxo do tráfico de escravos entre o Golfo de Benin e a Bahia de todos os Santos: dos séculos XVII a XIX. São Paulo: Corrupio, 1987, Cap.7. Embaixadas dos reis do Daomé e dos países vizinhos para a Bahia e Portugal. Para uma análise específica acerca da embaixada enviada por Tegbesu, em 1750, sugiro: LARA, Silvia Hunold. Uma embaixada africana na América portuguesa in JANCSÓ, István; KANTOR, Iris (orgs) Festa: Cultura \& Sociabilidade na América Portuguesa. Vol.I, São Paulo: Hucitec/Editora da Universidade de São Paulo/FAPESP/ Imprensa Oficial, 2001.

${ }^{151}$ Requerimento do negro João de Oliveira...AHU, 8246 in VERGER, Pierre. Op.cit.1992, pp.101-104.

${ }^{152}$ Ao analisar os processos de constituição da identidade dos escravos desembarcados no Rio de Janeiro, no século XVIII, Mariza de Carvalho Soares chama atenção para o fato da designação de nação não representar necessariamente uma etnia ou um grupo social com características comuns. Para a historiadora, a nação seria o termo que definiria um grupo de indivíduos negociados em um determinado porto. A partir do que Soares propõe, podemos supor que o local de procedência declarado por João de Oliveira estivesse associado ao porto a partir do qual ele realizou sua primeira travessia atlântica, ainda menino e como escravo. SOARES, Mariza de Carvalho. Devotos da Cor. Identidade étnica, religiosidade e escravidão no Rio de Janeiro, século XVIII. Rio de Janeiro: Civilização Brasileira, 2000. 
Pilar. ${ }^{153}$ Sua volta ao Brasil, cujo intuito declarado era de fixar moradia, foi empregada como um dos argumentos que comprovariam as boas intenções do liberto. Deste modo, no requerimento em que solicitava a restituição de seus bens, o comerciante de escravos explicava os motivos de sua viagem à Salvador. Segundo este documento, "mesmo vivendo entre os seus, favorecido pela fortuna, a estima e o respeito" em Lagos, o ex-escravo desejava "passar o resto de sua vida entre os católicos, para morrer assim com todos os sacramentos da Igreja". Tais intenções se comprovariam por meio do apoio material por ele oferecido às obras realizadas na capela-mor da Igreja de Nossa Senhora da Immaculada Conceição dos Militares, em Recife, e às "diversas esmolas em escravos com as quais socorreu algumas confrarias" na mesma cidade. Com o propósito de sustentar a idoneidade das ações de Oliveira, este requerimento narrava a trajetória do ex-escravo, capturado "ainda menor de idade" e vendido a um senhor residente na Província de Pernambuco. Anos mais tarde, depois de sua conversão à fé católica e de se mostrar fiel ao seu dono, o réu retornou à Costa da Mina ainda como escravo. ${ }^{154}$

O excerto do documento que trata da viagem de João de Oliveira para a África ocidental sugeria que, embora juridicamente a travessia atlântica não tenha alterado sua condição de escravo, na prática, ele desfrutava de um tipo de liberdade possível somente àqueles cativos capazes de conquistar a confiança do seu senhor. Assim, uma vez estabelecido na Costa da Mina, Oliveira atuou como correspondente comercial de seu proprietário, remetendoIhe cativos que seriam vendidos no Recife. Mesmo distante, o detido declarou ter se mantido fiel ao seu dono. Como prova, o ex-escravo dizia haver prestado contas e enviado, periodicamente, "grandes quantidades de escravos com o

\footnotetext{
${ }^{153}$ Cf. Termo de prizão feito ao Reo João de Oliveira preto forro de Nação Mina lançado no livro Terceiro de culpados a folha cento e secenta e oito e verso. AHU, 8249 in VERGER, Pierre. Op.cit.1992, pp.105/106. Como mencionei há pouco, não há consenso acerca dos anos de permanência de João de Oliveira na Costa da Mina. Em razão disto, mantive o número de anos registrado especificamente neste documento, ou seja: trinta e oito anos.

${ }^{154}$ Requerimento do negro João de Oliveira...AHU, 8246 in VERGER, Pierre. Op.cit.1992, p.102.
} 
objetivo de conseguir reembolsar-Ihe o valor de sua liberdade". Em razão de sua lealdade, Oliveira alcançou o status jurídico de liberto. ${ }^{155}$

Aparentemente, a liberdade era uma condição importante para um comerciante de escravos cujos negócios exigiam, de tempos em tempos, travessias atlânticas até cidades que abrigavam grandes mercados negreiros no Brasil. No entanto, não era este o sentido que o requerimento de devolução de bens encaminhado por Oliveira sublinhava. Acrescentando às demonstrações de fidelidade ao seu senhor, as suas contribuições como "o maior protetor dos portugueses" que atracavam na Costa da Mina, o comerciante expunha os argumentos que julgava necessários para reaver os setenta e nove escravos "machos" e quarenta e três "femias", que estavam em poder das autoridades provinciais. Além disto, João de Oliveira declarava ser o responsável pela abertura, às suas próprias expensas, dos embarcadouros de Porto Novo e Lagos. ${ }^{156}$

Ao se apresentar como um indivíduo capaz de honrar compromissos, de zelar pelos interesses dos comerciantes baianos junto às chefias locais africanas e de contribuir para o incremento dos negócios entre Salvador e os portos de Lagos e Porto Novo, Oliveira assumia também no Brasil os signos distintivos de uma condição social bastante específica: de liberto e de mercador de escravos com residência estabelecida na Costa da Mina, mas com negócios constituídos em ambos os lados do Atlântico. Este status, entretanto, não abreviou seus dias de encarceramento e tampouco permitiu que as intenções dos embaixadores de Akinsemoyin fossem apresentadas ao governo provincial e aos comerciantes baianos. Cerca de dois meses depois do desembarque, Oliveira e a comitiva do obá de Lagos atravessaram novamente o Atlântico.

\footnotetext{
${ }^{155}$ Como mais um indício da lealdade prestada aos seus senhores, o réu mencionou que, mesmo depois de livre, socorreu sua antiga senhora na viuvez. Requerimento do negro João de Oliveira... AHU, 8246 in VERGER, Pierre. Op.cit.1992, p.102.

${ }^{156}$ Costa e Silva lembra que não há concordância entre os pesquisadores acerca da abertura de Porto Novo por João de Oliveira, alguns estudos consideram que outro brasileiro, Eucaristus de Campos, teria antecedido as atividades comerciais do primeiro já no ano de 1752. Contudo, tanto Costa e Silva quanto Verger concordam em atribuir a Oliveira o aparelhamento do embarcadouro e organização das operações de tráfico no local. Sobre o assunto ver: SILVA, Alberto da Costa e. Op.cit. 2004, p.35. SILVA, Alberto da Costa e. A manilha e o libambo: a África e a escravidão, de 1500 a 1700. Rio de Janeiro: Nova Fronteira, 2002, p.559, VERGER, Pierre. Op.cit., 1987, p.211 e 212 e VIANNA FILHO, Luiz. O negro na Bahia. $2^{\mathrm{a}}$ ed. São Paulo: Martins, 1976, p.57, a 1ª edição desta obra é de 1946.
} 
Voltaram com o prejuízo de dez escravos falecidos durante o tempo em que permaneceram encarcerados, e decepcionados com as "circunstâncias desagradáveis que depararam ao chegarem à Bahia". ${ }^{157}$

A documentação produzida a partir do episódio da prisão de João de Oliveira nos permite entrever o papel desempenhado por um liberto que, estabelecido em portos escravistas da Costa da Mina, intermediava o comércio negreiro com negociantes de Salvador e de Recife. Vivendo nesta região desde 1732 (ou 1733, não se sabe ao certo) podemos supor que Oliveira mantivesse alguma relação com chefias locais muito antes da malfadada viagem em 1770. É possível que Akinsemoyin tenha conhecido Oliveira durante seu exílio em Apa ou em Badagri. Conforme indica Mann, Akinsemoyin foi banido por seu irmão Gabaro, terceiro obá de Lagos, provavelmente em razão de disputas em torno do reconhecimento dos ilejos como chefes da terra. Durante o período em que esteve impedido de permanecer na cidade, o futuro obá teria se aproximado de negreiros brasileiros, iniciando seus negócios com escravos. Depois da morte de Gabaro, Akinsemoyin retornou à ilha e recebeu o título de obá. ${ }^{158}$

Acompanhado por Oliveira, que há algum tempo atuava em Porto Novo, o obá recém-empossado passou a apoiar e a promover o comércio de escravos em seu porto. Em Lagos, João de Oliveira se tornou não apenas agente comercial de escravos, mas também intermediário nas negociações de cativos entre o obá e os comerciantes vindos, principalmente, da Bahia. ${ }^{159}$ As contribuições do negreiro foram produtivas, pois na primeira metade do século XIX, Lagos já era considerado o principal porto de escravos da Costa da Mina, ultrapassando Ajudá em número de cativos.

\footnotetext{
${ }^{157}$ De acordo com o Termo de Avaliação, obrigação e entrega dos bens sequestrados a João de Oliveira, dos 79 cativos apreendidos, apenas 69 foram devolvidos. Durante os dias em que ficaram sob o poder do Estado dez escravos morreram. VERGER, Pierre. Op.cit.1992, p. 104. ${ }_{158}$ De acordo com Mann, Akinsemoyin ocupou o mando de Lagos por quinze anos, de 1760 a 1775. Depois de seu falecimento ele foi sucedido por um de seus sobrinhos, Eletu Kekere, filho de Gabaro. A autora não se atém aos acontecimentos pertinentes ao curto período em que Kekere esteve no poder. Sua obra se limita a mencionar que, depois de Kekere outro sobrinho de Akinsemoyin assumiu a posição de obá: Ologun Kuture, filho de Erelu Kuti. Desfrutando de um mando mais longo, Kuture permaneceu como obá de Lagos de c.1780 a 1801/1803. MANN, Kristin. Op.cit., 2007, p.36, 44/45, respectivamente.

${ }^{159}$ Cf. ADERIBIGBE, A.B. Op.cit., 1975, p.11.
} 
Segundo Law, desde 1820 a maior parte dos negócios em Lagos estava ligada ao comércio atlântico de escravos. ${ }^{160}$ De acordo com as informações fornecidas pela base de dados The Trans-Atlantic Slave Trade Database, a partir de 1801, houve um crescimento significativo no número de cativos embarcados neste porto. ${ }^{161}$ Entre 1801 e 1810, Lagos encaminhou quase onze mil cativos às Américas. Apenas a título de comparação, neste mesmo período, os escravos vendidos por Ajudá somaram pouco mais de cinco mil. Como é possível verificar na tabela a seguir, a posição de prevalência de Lagos em relação aos demais portos da Costa da Mina se manteve até 1850, ano em que a cidade se tornou protetorado britânico.

Tabela 1: Principais portos de tráfico da Costa da Mina entre 1791 e 1865

\begin{tabular}{|c|c|c|c|c|c|}
\hline 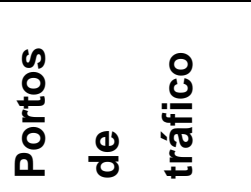 & $\frac{\pi}{\frac{\pi}{0}}$ & : & $\begin{array}{ll}\circ \\
\text { ํํㅇ } \\
\text { z }\end{array}$ & 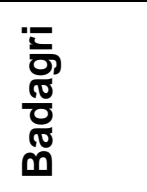 & 흥 \\
\hline 1791 a 1800 & 15.041 & 2.113 & 6.763 & 2.650 & 26.567 \\
\hline 1801 a 1810 & 5.999 & 10.955 & 2.669 & 1.321 & 20.944 \\
\hline 1811 a 1820 & 5.178 & 5.592 & 1.606 & 2.481 & 14.857 \\
\hline 1821 a 1830 & 10.834 & 13.525 & 843 & 508 & 25.710 \\
\hline 1831 a 1840 & 11.355 & 19.046 & 490 & 3.004 & 33.895 \\
\hline 1841 a 1850 & 8.258 & 24.901 & 1.673 & 354 & 35.186 \\
\hline 1851 a 1860 & 4.981 & 1.516 & - & - & 6.497 \\
\hline 1861 a 1865 & 2.787 & - & - & & 2.787 \\
\hline Total / porto & 64.433 & 77.648 & 14.044 & 10.318 & \\
\hline
\end{tabular}

Fonte: Tabela elaborada a partir das informações disponíveis em http://www.slavevoyages.org/tast/database/search.faces

${ }^{160}$ Cf.LAW, Robin.Trade and Politics behind the Slave Coast: The Lagoon Traffic and the Rise of Lagos, 1500 - 1800. The Journal of African History, vol.24, No. 3, 1983. p.347. A localização dos portos negreiros tratados nesse estudo está grafada no Mapa 2: Lagos e Portos Vizinhos (c. 1800), apresentado no primeiro capítulo desta tese.

161 A Trans-Atlantic Slave Trades Database originou-se na década de 1960, quando Herbert S. Klein e outros pesquisadores passaram a recolher e a organizar dados acerca de navios negreiros que cruzavam o Atlântico. Nas décadas seguintes outros estudiosos se somaram à iniciativa. Em 1999 o grupo lançou o primeiro fruto de seu trabalho: um CD-ROM contendo informações a respeito de 27.233 viagens feitas por tumbeiros. Os esforços dos pesquisadores se ampliaram ainda mais e, a partir de 2010, o site www.slavevoyages.org passou a fornecer um conjunto ainda maior de dados acerca do comércio atlântico de escravos. 
No entanto, antes de se transformar no principal ponto de negociação de escravos da Costa da Mina, a cidade precisou superar alguns obstáculos. No século XVIII, um dos maiores entraves à ampliação de suas atividades estava na manutenção da regularidade no abastecimento dos cativos fornecidos por ljebu Ode, cidade localizada a leste de Lagos, na margem esquerda do rio Ona. Em vista disto, até o início do século XVIII, Lagos era um porto de menor importância. Neste período, a maior parte de suas trocas se concentrava no comércio de panos e de alimentos também produzidos pelos ijebus. Desta forma, para honrar os acordos comerciais estabelecidos a crédito com os negreiros europeus, os mercadores de Lagos recorriam aos fornecedores fixados em pontos mais distantes da costa, mais especificamente, em ljebu Ode. ${ }^{162} \mathrm{~A}$ estratégia encarecia o valor final das peças humanas encaminhadas às Américas e tornava o comércio praticado na ilha menos atraente quando comparado a atracadouros vizinhos, como: Porto Novo, Badagri e Cotonu. Para estes três portos o fornecimento regular de escravos era garantido por Oió.

No entanto, esta situação começou a se modificar a partir de 1727 , quando Agaja, rei do Daomé, iniciou uma série de ataques contra Ajudá com a intenção de conquistar e incorporar este território aos seus domínios. Depois da submissão de Ajudá às forças daomeanas, Agaja tomou algumas medidas para que o controle sobre este porto se tornasse mais efetivo. Para isto, a partir de 1733, promoveu um processo de centralização e de complexificação administrativa que teve por finalidade garantir o domínio do Daomé sobre Ajudá. ${ }^{163}$ Neste contexto, Agaja estabeleceu uma guarnição militar na cidade, transformando-a em sede de seu governo e orientando uma parcela significativa da economia daomeana ao tráfico atlântico. Além desta ação,

\footnotetext{
162 O pagamento adiantado constituiu um dos elementos das relações comerciais entre comerciantes de escravos africanos, intermediários locais e negreiros europeus. Na década de 1850, com a instalação do protetorado da Grã-Bretanha em Lagos, comerciantes britânicos tomaram chefias locais como "fiadores" nas negociações com intermediários africanos. Tratarei desse assunto no quarto capítulo desta pesquisa, quando as pressões britânicas pelo controle do comércio legítimo irão exacerbar tais tensões. Cf. FALOLA, Toyin. A History of Nigeria. West Port, CT: Greenwood Press, 1999, p.46. Disponível em http://site.ebrary.com/id/5005127?ppg=59.

${ }^{163}$ Cf. LAW, Robin. Ouidah: The Social History of a West African slaving 'port', 1727-1892. Ohio: Ohio University Press/ Oxford: James Currey, 2004. cap.2.
} 
indivíduos de sua confiança também foram designados para desempenhar o papel de intermediários e propagadores das determinações das autoridades centrais nos territórios conquistados. Um deles era o ivogã, cuja função consistia em mediar os interesses do Daomé junto aos comerciantes europeus e brasileiros. Além deste, o boya, cumpria a função de chefiar os mercadores oficiais do rei, enquanto o kao garantia o domínio do território como comandante da guarnição militar estabelecida em Ajudá. ${ }^{164}$

Parte destas transformações também incluiu investidas às redes de comércio de escravos que abasteciam portos vizinhos, assim como assaltos a negreiros que negociavam em atracadouros próximos. A estratégia visava eliminar embarcadouros concorrentes e garantir que as naus atracassem exclusivamente em Ajudá. De acordo com Law, os ataques do Daomé a outros pontos de comércio escravista continuaram a ser praticados pelos sucessores de Agaja. Segundo o historiador, os chefes daomeanos - Tegbesu (1740-1774), Kpengla (1774-1789), Agonglo (1789-1797), Adandozan (1797-1818) e Guezo (1818 - 1858) - mantiveram a prática de destruição de atracadouros, saque dos estoques de escravos e prisão dos negociantes com a finalidade de afugentar tumbeiros e desestabilizar o comércio escravista nos portos vizinhos. ${ }^{165}$

A possibilidade de perder a carga de cativos negociada em outras localidades na Costa da Mina, fora de Ajudá e, o que era pior, tornar-se prisioneiro do Daomé, bastava para que muitas embarcações buscassem pontos de abastecimento de escravos distantes da atuação das tropas daomeanas. ${ }^{166}$ Indiretamente, Lagos se beneficiou das ações de Agaja (e de

164 Cf. SOUMONNI, Elisée. Daomé e o mundo atlântico. Centro de Estudos AfroAsiáticos/Universidade Cândido Mendes, 2001, p.41. Gebara também comenta a criação de cargos administrativos decorrente da expansão do reino do Daomé, em: GEBARA, Alexsander. A Africa de Richard Francis Burton: antropologia, política e livre comércio. São Paulo: Alameda, 2010, pp. 91-92.

${ }^{205}$ LAW, Robin. Op.cit., 1983, p.346 e LAW, Robin. Ouidah: the social history of a West African slaving 'port', 1727-1892. Ohio: Ohio University Press/Oxford: James Currey, 2004, p.125.

166 Podemos tomar como exemplo da atuação das forças daomeanas, o caso da prisão de Innocêncio Marques de Sant'Anna. Em setembro de 1804, o pardo Innocêncio Marques de Sant'Anna, responsável pelo carregamento da corveta Dianna, foi aprisionado pelas forças de Adandozan e levado até Abomé. Ao chegar ao centro de poder daomeano, Innocêncio encontrou seis outros marinheiros, "Vassalos de Sua Alteza Real", capturados por Adandozan, alguns deles vivendo como prisioneiros há vinte e quatro anos. Em novembro do mesmo ano, Innocêncio partiu em direção a Portugal para acompanhar a terceira embaixada do Daomé. Após servir de intérprete dos enviados daomeanos, o ex-prisioneiro de Adandozan recebeu em Lisboa documentos que orientavam o Secretário de Estado da Bahia a lhe conceder o título de Quarto Capitão do Regimento de Milícias dos Homens Pardos, colocação que the conferia 
seus sucessores) sobre esses pontos de comércio de escravos nascentes. Embora os negreiros europeus não pudessem mais completar seus carregamentos nos atracadouros mais próximos de Ajudá, os estoques de cativos continuavam sendo vendidos para além do alcance dos guerreiros daomeanos: em Lagos.

Nesta conjuntura, este porto viu aumentar o número de tumbeiros que para ali se encaminhavam em busca de peças humanas que seriam conduzidas à travessia atlântica. No entanto, o problema da regularidade no fornecimento de cativos que chegavam até o embarcadouro persistia. Esse entrave ao crescimento de Lagos como porto negreiro se manteve até pelo menos o início do século XIX. A partir da primeira década do oitocentos, disputas entre cidades iorubás e o movimento jihadista, liderado pelo imã fulani Usman Dan Fodio, se espalharam pelos territórios Haussá, Jukun, Nupe e Oió, localidades que se tornaram as principais produtoras de cativos que abasteciam os comerciantes negreiros da ilha. ${ }^{167}$ Desta forma, a ampliação dos suprimentos de escravos destinados ao mercado atlântico era garantida pelos prolongados distúrbios ocorridos ao norte, no interior do continente.

\subsubsection{Os conflitos no interior e o fornecimento de escravos \\ para Lagos}

A década de 1820 marcou o ápice dos conflitos tanto no centro de Oió, em Oió Ile, como em outras localidades que lhe eram tributárias. Entre as rivalidades de maior repercussão política e econômica deste período, destacase a revolta de llorin, encabeçada pelo líder do exército de Oió e chefe de Ilorin, Afonjá. Desde a segunda década do século XVIII, esta cidade estava

inclusive um soldo mensal. Em carta redigida em outubro de 1805 ao Secretário do governo baiano, Visconde de Anadia, Innocêncio denunciava que, como ele no passado, muitos outros indivíduos ligados ao comércio de escravos ainda continuavam prisioneiros de Adandozan. A trajetória deste prisioneiro pode ser lida em: VERGER, Pierre. Op.cit.1992, pp.13-17 e 106-113. ${ }^{167}$ Uma análise mais completa a respeito da propagação do islamismo por estas localidades e os desdobramentos da jihad depois da morte de dan Fodio, pode ser lida em: FALOLA, Toyin; HEATON, Matthew M. A History of Nigeria. Cambridge: Cambridge University Press, 2008, pp.62-73. 
submetida a Oió. Sua localização geográfica a tornava ponto de resistência contra as constantes incursões nupe sobre seu território. Em 1796, um levante liderado por Afonjá depôs o alafim Awole, forçando-o a cometer suicídio. De acordo com os historiadores Falola e Oguntomisin, o levante de Afonjá contra Awole estava relacionado a uma tentativa do próprio alafim de ocasionar a morte de Afonjá. Segundo as tradições orais pesquisadas pelos autores, quando Awole ordenou que o chefe de llorin atacasse a poderosa cidade de Onko tinha como intenção forçar o suicídio de Afonjá, pois sua derrota seria quase certa. De acordo com os costumes locais, se um líder guerreiro fosse vencido em combate este deveria provocar a própria morte. Desta forma, antecipando-se ao desfecho esperado pelo alafim, Afonjá preparou uma ofensiva contra Oió lle que colocou termo ao mando de Awole. Todavia, ao contrário do que o próprio comandante insurgente supunha, Afonjá não assumiu o mando de Oió. Em seu lugar, Oyomesi - principal chefe Oió, cujas atribuições incluíam a escolha daquele que ocuparia o mando - optou por Adebo para assumir a posição de alafim. ${ }^{168}$

Preterido a esta posição, Afonjá rompeu em definitivo com Oió. Desta maneira, llorin suspendeu o envio de tributos e deixou de contribuir com os guerreiros que garantiriam a segurança de Oió lle e do alafim. Nos vinte anos que se seguiram ao primeiro levante de Afonjá, llorin se manteve independente de Oió, mas incapaz de articular uma nova ofensiva contra o então alafim Adebo. Essa situação se alterou a partir de 1817, quando Afonjá recebeu centenas de muçulmanos iorubás e haussás que se levantaram contra o alafim de Oió e deixaram Oió lle. Atraídos pela possibilidade de apurar riquezas a partir dos confrontos empreendidos por Afonjá e pela expectativa de constituição de uma comunidade muçulmana - a jama - esses indivíduos foram essenciais no processo de esfacelamento do poder do alafim.

\footnotetext{
${ }^{168}$ Cf. FALOLA, Toyin; OGUNTOMISIN, G.O. Yoruba Warlords of the 19th Century. Trenton/NJ; Asmara/Eritrea: Africa World Press, 2001. p.161. Sobre os escravos muçulmanos que desembarcaram em Salvador, sua relação com a Revolta dos malês de 1835 e as estratégias de exercício do islão no interior da sociedade escravista baiana, temos: REIS, João José. Rebelião escrava no Brasil. A história do levante dos malês. Edição revista e ampliada. São Paulo: Companhia das Letras, 2003, em especial o Cap. 7. A "Sociedade Malê": organização e proselitismo.
} 
A jama era numa comunidade formada por muçulmanos, procedentes de Oió. Seus membros eram identificados pelo uso de dois anéis de metal, um no dedão e outro no terceiro ou quarto dedo. Em llorin, o líder da jama era Sarkin Gambari, cuja atuação foi crucial na condução das ações de apoio a Afonjá sobre os territórios de Igbomina, Ibolo, llobu e Ejigbo. ${ }^{169}$ Além dos seguidores de Gambari, llorin também recebeu os jihadistas fulanis que integravam o movimento de Usuman dan Fodio. Juntos estes dois grupos engrossaram as fileiras de llorin lançadas ao ataque do centro de poder Oió: Oió lle. Deste novo confronto, Afonjá e seus apoiadores saíram vitoriosos. ${ }^{170}$

No entanto, em 1823, apenas seis anos depois da tomada de Oió, uma nova revolta eclodiu em llorin. Desta vez o levante foi encabeçado por Salih, primeiro imã de llorin e líder fulani estabelecido na província. A aliança entre llorin e os fulanis se desfez quando Afonjá expulsou os aliados de seu território. As razões que levaram o chefe de llorin a romper com o pacto firmado com os muçulmanos fulanis chegam até nós por meio das tradições recolhidas e estudadas por Falola e Oguntomisin. Segundo esses historiadores, algumas versões se referem à recusa ou morosidade na conversão de Afonjá ao islamismo, comportamento que teria elevado as tensões entre os fulanis e o chefe de llorin. De acordo com outra publicação escrita por Falola, desta vez em parceria com Heaton, o movimento jihadista teve como princípio eliminar chefias que haviam se convertido ao islamismo, mas que permitiam que a nova religião convivesse ou se combinasse a práticas religiosas precedentes. Complementarmente, alguns estudos que se debruçam sobre o tema indicam que Salih desfrutava de grande autonomia política dentro de llorin. ${ }^{171}$ Uma vez combinadas, todas estas ações podem ter contribuído para que o líder fulani se voltasse contra Afonjá que, de acordo com o movimento reformista, permanecia infiel ao profeta Maomé. ${ }^{172}$

\footnotetext{
${ }^{169}$ FALOLA, Toyin; OGUNTOMISIN, G.O. Op.cit., 2001. p.161/162.

${ }_{170}^{170}$ FALOLA, Toyin; HEATON, Matthew M. Op.cit.,2008, pp.62-65.

171 Quando menciono os estudos sobre o tema, refiro-me especialmente às seguintes publicações: FALOLA, Toyin; HEATON, Matthew M. Op. Cit. 2008, pp.62-83 e FALOLA, Toyin; OGUNTOMISIN, G.O. Op.cit., 2001. Cap.9.

${ }_{172}$ Para uma melhor compreensão do processo de expansão do Califado de Sokoto durante a jihad iniciada por dan Fodio, sugiro a consulta aos mapas apresentados em: FALOLA, Toyin; HEATON, Matthew M. Op.cit., 2008, p.76.
} 
A revolta iniciada por Salih resultou na conquista islâmica da importante cidade de llorin. A insurreição assassinou tanto Afonjá, quanto seu opositor, Salih. A morte de Afonjá levou ao poder o comandante fulani, Abd al-Salam. Incorporando llorin ao Califado de Sokoto, al-Salam recebeu o título de emir e constituiu um eficiente exército jihadista contra as cidades iorubás, em especial, contra Oió lle. Já na década seguinte, em 1830, o Califado de Sokoto controlava a maior parte do território Jukun e Nupe. Neste momento, Oió lle também havia se submetido ao poder do exército jihadista de Usuman dan Fodio, tornando-se parte do novo emirado de llorin. ${ }^{173}$

As disputas em torno do controle de Oió também resultaram no enfraquecimento de seu poder sobre outras localidades que the deviam tributos anuais. Em 1823 o Daomé, desde o século XVIII tributário de Oió, iniciou uma insurreição em larga escala, cujos desdobramentos puseram termo à sujeição dos daomeanos ao pagamento de obrigações. Também neste momento, refugiados de Oió estabeleceram novos núcleos populacionais na região atualmente conhecida como iorubalândia. Povoados como Ibadan, ljaye e Abeokuta cresceram tornando-se, em décadas posteriores, cidades iorubás bastante poderosas. Nos anos de 1830, Ibadan e ljaye se consolidaram como cidades autônomas, cada qual com sistemas políticos próprios. De acordo com Falola e Heaton, enquanto ljaye fundou o seu mando sob o princípio da hereditariedade, Ibadan adotou um governo baseado na meritocracia militar. Desta forma, em lbadan, um comandante poderia pleitear o governo da cidade em função da sua capacidade de ampliação de uma cadeia de dependentes. Estes autores também comentam que Abeokuta se constituiu a partir de populações egba em fuga das guerras de Owu, tornando-se mais um centro de grande importância na região. ${ }^{174} \mathrm{~A}$ movimentação de refugiados e a reorganização política e militar após o esfacelamento do poder de Oió levaram a uma série de prolongadas disputas entre as cidades iorubás. Tais rivalidades

\footnotetext{
${ }^{173}$ Cf. FALOLA, Toyin; OGUNTOMISIN, G.O. Op.cit., 2001. pp.164/165. As disputas de poder em Ilorin nas duas últimas décadas do século XVIII e até os anos de 1830 também são tratados em: FALOLA, Toyin; HEATON, Matthew M. Op. Cit. 2008, p.74/75.

${ }_{174}$ Os conflitos envolvendo Owu se iniciaram em 1813, quando a cidade atacou o mercado de Apomu com o objetivo de controlar suas atividades. Ao longo dos doze anos seguintes, Owu manteve suas ofensivas contra Apomu e as cidades de Ife, ljebu e Iwo que, a partir de c.1821, formaram uma aliança para destruir Owu. Uma análise mais detalhada da sucessão de conflitos, ocorrida entre 1813 e 1825, pode ser lida em: FALOLA, Toyin; OGUNTOMISIN, G.O. Op.cit., 2001. pp.5 e 6.
} 
garantiam o fornecimento regular de escravos a Lagos, reforçando a proeminência comercial de seu porto que, a partir do século XIX, cresceu em razão do volume de comércio de peças humanas. ${ }^{175}$

Se, por um lado, no início do século XIX, a ampliação da oferta de cativos e a regularidade de seu abastecimento fortaleceram o tráfico em Lagos, atraindo um número cada vez maior de negociantes de escravos vindos da Bahia, por outro, em Salvador, aumentava a demanda por peças cativas encomendadas a este porto. Afinal, ao importar um volume crescente de escravos, os senhores se antecipavam à extinção do tráfico, acrescentando aos seus estoques de mão de obra novas aquisições recém-chegadas deste ponto de comércio escravista africano. ${ }^{176}$ Nesse contexto, a ampliação da demanda por novos escravos na Bahia, associada a já mencionada conjuntura de disputas em torno do colapso de Oió, ao movimento jihadista de Dan Fodio e aos ataques do Daomé contra as embarcações que atracavam em portos concorrentes, transformaram a economia lagosiana.

\subsection{O olhar de Duncan sobre a Costa da Mina}

Os nativos deste lugar são os mais depravados e sem princípios patifes de toda a África ou, talvez, do mundo. Se não fosse pelo senhor de Suza [Francisco Félix de Souza] e seus amigos, na verdade, ali não haveria segurança para o homem branco. $^{177}$

$\mathrm{Na}$ cidade de Lagos, desde pelo menos a segunda metade do século XVIII, parte das atividades relacionadas ao tráfico era operada por negreiros que possuíam relações econômicas e pessoais com a Bahia. Ao negociar em

\footnotetext{
${ }^{175}$ Cf. FALOLA, Toyin; HEATON, Matthew M. Op.cit., 2008, p.76.

${ }^{176}$ De acordo com o Tratado de 1826, firmado entre Brasil e Inglaterra, o tráfico atlântico seria progressivamente reduzido até 1830, ano em que seria definitivamente abolido. No entanto, correspondentes britânicos que viviam no Brasil mostraram baixas expectativas em relação ao cumprimento do compromisso. Para R. Gordon, por exemplo, o tráfico "seria exercido com dez vezes mais força durante o prazo de três anos até 1830 e depois continuaria ilicitamente, com a conivência do governo brasileiro." Gordon para Canning, $\mathrm{N}^{\circ} 2,27$ de novembro de 1826, F.O. 84/56 Apud BETHELL, Leslie. A abolição do tráfico de escravos no Brasil: a Grã-Bretanha, o Brasil e a questão do tráfico de escravos, 1807 - 1869. São Paulo: Edusp. 1976. p.75.

177 The natives of this place are the most depraved, unprincipled villains in all Africa, or perhaps in the world. Were it not for M. de Suza and his friends, indeed, there would be no safety for white men. DUNCAN, John. Op.cit.,vol. I. 1847, p.113.
} 
seu próprio nome e/ou ao intermediar trocas com lagosianos que viviam do comércio escravista, estes mercadores também ocupavam uma porção mais larga da Costa da Mina, estabelecendo pontos de tráfico não apenas em Lagos, mas se espalhando também por Aguê, Anecho, Ajudá, Cotonu, Porto Novo e Badagri. ${ }^{178}$

Era relativamente comum, entre os negreiros que concentravam maiores posses, a construção e a manutenção de mais de um imóvel ao longo da Costa da Mina. Os traficantes mais prósperos erguiam e mantinham múltiplas residências ao longo deste trecho litorâneo. Tal recurso alargava a atuação comercial destes mercadores de escravos por vários portos da região. Além disto, suas casas cumpriam diversas funções. Serviam de ponto de estocagem e comercialização de escravos e de mercadorias que seriam despachados ao Brasil. Eram locais onde ficavam guardados documentos referentes aos negócios firmados com comerciantes baianos. E como indica John Duncan, costumavam ser ocupadas por famílias numerosas, constituídas a partir de múltiplos casamentos, além de funcionarem como abrigo aos viajantes que desembarcavam nas imediações. Para Duncan, estas "elegantes casas, ricamente decoradas" eram uma prova dos lucros apurados pelos traficantes brasileiros engajados no tráfico. ${ }^{179}$

Em sua estadia no porto daomeano, Duncan visitou a casa de Isidoro de Souza, um dos filhos de Francisco Félix de Souza. Naquela ocasião o chachá de Ajudá ainda era vivo e desfrutava dos privilégios de ser amigo pessoal de Guezo. ${ }^{180}$ O imóvel de seu filho mais velho - Isidoro - foi descrito por Duncan

\footnotetext{
${ }^{178}$ Cf. LAW, Robin. Yoruba Liberated Slaves who Returned to West Africa in FALOLA, Toyin; CHILDS, Matt D. (ed.) The Yoruba Diaspora in the Atlantic World. Bloomington/Indianapolis: Indiana University Press, 2004. p.352. Os portos em que atuavam tais negreiros são listados por Cunha, em: CUNHA, Manuela Carneiro da. Negros, estrangeiros. Os escravos libertos e sua volta à África. $2^{\mathrm{a}}$ ed. revisada e ampliada. São Paulo: Companhia das Letras, 2012, p.137. A localização desses portos pode ser melhor compreendida a partir do Mapa 2: Lagos e Portos vizinhos, c.1800, apresentado no capítulo anterior.

179 DUNCAN, John. Travels in Western Africa, in 1845 \& 1846. A journey from Whydah, through the kingdom of Dahomey, to Adofoodia, in the interior, vol. I. London: Richard Bentley, 1847, p.102.

180 Segundo Costa e Silva, a tradição da família Souza não nos dá a ascendência precisa de Isidoro. É possível que ele fosse filho de mãe africana, de nome Jijibu, filha de Comalangã ou que, nascido na Bahia, tivesse sido levado por seu pai para África. No entanto, é certo que dois filhos de Francisco Félix de Souza - Isidoro e Antonio - passaram uma temporada fora de Ajudá. Com o propósito de completarem os estudos, o primeiro foi enviado para Bahia, enquanto o segundo foi estudar em Portugal. Sobre o assunto, ver SILVA, Alberto da Costa e.
} 
como situado em uma pequena ilha nas imediações de Popo. A partir desta “agradável” localização era possível ter "uma ampla visão do oceano Atlântico", o que facilitava a vigilância de Isidoro sobre as ações do esquadrão antitráfico britânico na região. O registro do explorador não oferece detalhes acerca do aspecto exterior desta residência. No entanto, seu relato fornece uma cuidadosa descrição acerca dos elementos decorativos presentes no interior do imóvel. De acordo com estes escritos, a casa de Isidoro era "lindamente decorada em estilo espanhol e ricamente mobiliada com materiais europeus". Suas paredes estavam preenchidas por gravuras sustentadas por molduras em ouro. Nestes quadros Napoleão figurava em diferentes episódios históricos: em uma de suas batalhas, em seu exílio na ilha de Santa Helena e em seu funeral na França. ${ }^{181}$

Construída segundo o padrão arquitetônico das casas baianas oitocentistas e decorada à europeia, a moradia de Isidoro era a expressão material de seu comportamento diante do ilustre enviado britânico. Descrito como um homem de "semblante ameno e agradáveis maneiras", o filho de Félix de Souza era um traficante generoso inclusive com seus escravos domésticos. Muito embora, tal generosidade não tivesse um efeito positivo entre seus cativos, que viviam uma "vida fácil e indolente". E, de acordo com Duncan, ao invés de trabalharem

...a maioria destes escravos domésticos passa todo tempo entretida com algum jogo em que os participantes permanecem deitados ou sentados, ou ainda, estendem o corpo todo na sujeira, como porcos. ${ }^{182}$

Colocando-se como um observador que não interfere nos acontecimentos presenciados, John Duncan narrou suas experiências pelos caminhos que ligavam Ajudá até a capital do reino do Daomé, Abomé. Nestes registros, as populações encontradas foram descritas a partir do emprego de adjetivos que categorizavam os indivíduos numa espécie de escala evolutiva.

Op.cit. 2004, p.24 e SILVA, Alberto da Costa e. Francisco Félix de Souza, mercador de escravos. Rio de Janeiro: Nova Fronteira/ed.UERJ, 2004, p.108.

${ }^{181}$ DUNCAN, John. Op.cit.,vol. I. 1847, p.102.

182 Ibid,vol. I, p.103. 
Nesta chave, os europeus ocupariam o topo da escala da humanidade. Como contraponto à civilização europeia, os africanos eram considerados "ladrões", "preguiçosos", "sujos", "covardes" ou "insolentes", entre outros tantos adjetivos cujos sentidos se aproximavam entre si. ${ }^{183}$ No entanto, haveria algumas nuanças entre os africanos considerados genericamente como inferiores. Para o viajante escocês, por exemplo, os fantes eram "sem exceção, entre todos os africanos que vi, os mais preguiçosos e sujos." 184

Postos nesta condição em razão de sua "incapacidade de compreensão" e por demonstrarem "grande indolência", os fantes seriam piores do que os axantes, "seus vizinhos". Esta população ocupava a mais baixa posição no discurso classificatório de Duncan. E, seu lugar se manteve mesmo nos momentos em que o explorador reconheceu algumas habilidades técnicas dos indivíduos pertencentes a esta sociedade. Neste sentido, a manufatura de tecidos e a metalurgia do ouro não constituíam provas da capacidade criativa e produtiva dos fantes. Ao contrário, os produtos do trabalho têxtil e da metalurgia revelavam indícios de um "considerável poder de imitação" e suas realizações, uma vez examinadas de perto, mostravam-se "defeituosas". 185

Além dos fantes com os quais John Duncan teve contato na Costa do Cabo, havia os habitantes da cidade litorânea de Acra. ${ }^{186}$ Neste local os religiosos wesleyanos mantinham uma missão. Em função disto o britânico pôde "observar as maneiras e os hábitos das pessoas, as quais diferiam consideravelmente daquelas da Costa do Cabo ou Annamaboe, embora não exista grande distância entre ambas localidades". Ainda que Duncan deixe interdito, seu relato permite interpretar que a distinção entre os moradores da Costa do Cabo e os de Acra era resultado da presença da Igreja wesleyana na cidade. Assumindo uma posição que se considerava distanciada das dinâmicas sociais, o viajante sublinhava a atuação missionária dos enviados wesleyanos ao destacar que "os nativos deste lugar [Acra] são mais generosos em suas

\footnotetext{
${ }_{183}$ Todos os adjetivos acima citados foram retirados do relato de viagem escrito por John Duncan.

${ }_{184}$ DUNCAN, John. Op.cit.,vol. I. 1847, p.32.

185 Ibid, vol. I, p.32.

${ }^{186}$ Conforme expliquei na introdução desta tese, quando os nomes de localidades possuírem tradução para o português, optei pelo termo em nossa língua. No caso da cidade da Costa do Cabo, o termo que aparece no documento consultado é Cape Coast.
} 
maneiras e, em muitas de suas especificidades, eles diferem totalmente dos fantes". 187

As comparações do viajante em relação às populações residentes na Costa da Mina não se limitaram aos fantes. Em um episódio em que Duncan narra os percalços de uma viagem de cabotagem empreendida entre Ajudá e Popo é também possível perceber a adjetivação como recurso discursivo à categorização das sociedades encontradas. Ao descrever o assassinato de um comerciante europeu praticado por três dos canoeiros que estavam a serviço da firma hamburguesa por ele representada, o britânico deixou explícitos seus juízos em relação à população residente em Ajudá. Para ele,

os nativos deste lugar são os mais depravados e sem princípios patifes de toda a África ou, talvez, do mundo. Se não fosse pelo senhor de Suza [Francisco Félix de Souza] e seus amigos, na verdade, ali não haveria segurança para o homem branco. ${ }^{188}$

Embora atuassem no comércio atlântico de escravos, os negreiros brasileiros de Ajudá foram descritos por Duncan como "cordiais, gentis e de boas maneiras". À primeira vista, estes comportamentos não condiziam com a brutalidade do tráfico. No entanto, o viajante logo esclarecia ao leitor a especificidade das origens de "Souza e seus amigos". Aqueles comerciantes que negociavam escravos no porto daomeano seriam portugueses e espanhóis que, embora vivessem entre "depravados" e "patifes", mantinham-se à parte desta sociedade, prezando pela conservação de práticas e hábitos "civilizados". Envoltos em um véu de civilização, estes traficantes portugueses - na verdade, baianos ou portugueses com negócios há muito tempo estabelecidos com a Bahia - tratavam seus escravos com tamanho "respeito" que nenhum dos cativos de Souza, por exemplo, "aceitou a liberdade quando esta lhe foi oferecida”. ${ }^{189}$

\footnotetext{
${ }^{187}$ DUNCAN, John. Op.cit.,vol. I. 1847, p.55.

${ }^{188}$ No texto em inglês o termo villains pode ter mais de uma tradução. A escolha por traduzi-lo como "patifes" decorre do contexto em que o vocábulo foi empregado. A partir da leitura de outras passagens deste relato é possível inferir que "M. de Suza" significa "Mister de Souza", ou seja, Francisco Félix de Souza. DUNCAN, John. Op.cit.,vol. I. 1847, p.113.[itálico meu]

${ }^{189}$ Ibid, vol. I, p.113.
} 
O relato produzido a partir das experiências de viagem de John Duncan, entre os anos de 1845 e 1846, constitui um tipo de literatura de viagem que contribuiu para a construção de um campo discursivo sobre o qual as ações colonizadoras europeias se apoiaram. A ideia de que, a partir do século XVIII, uma nova "consciência planetária" levou viajantes europeus a registrar e a publicar as experiências vividas nas Américas e na África é o eixo central da obra Os olhos do império. Relatos de viagem e transculturação, escrita por Mary Louise Pratt. Neste livro, Pratt propõe interpretar a história das representações europeias sobre o mundo não europeu. Nos termos da própria autora, promover a "descolonização" de um conhecimento que foi produzido a partir do olhar europeu, mas não necessariamente por indivíduos nascidos no Velho Continente. Para isto, Pratt elaborou uma refinada análise acerca de como a produção de saberes a respeito de territórios situados no Novo Mundo e na África constituiu noções de imperialismo que justificavam, aos próprios europeus, suas ações colonizadoras. ${ }^{190}$

Inspirada na ideia de transculturação proposta por Fernando Ortiz, Mary Pratt foi além das interpretações apresentadas por este autor ao concentrar seus estudos nas produções literárias resultantes do que denominou "zonas de contato". Segundo a autora, a partir do século XVIII, as viagens ao redor do mundo tornaram possível o registro e a publicação de relatos acerca do encontro entre colonizador e colonizado. Os diálogos decorrentes deste contato não refletiam apenas a hegemonia do colonizador. Embora Pratt reconheça que tais interações não se desenrolaram sem disputas e assimetrias, sua obra dedica atenção às dimensões interpenetráveis dos mundos postos em contato. Considerando a permeabilidade das fronteiras culturais das sociedades colocadas nas "zonas de contato", o livro sugere que os relatos de viagem sejam entendidos como repositórios de diferentes vozes: dos "colonizadores e colonizados, ou de viajantes e 'visitados'." Desta forma, como narrativas constituídas a partir das trocas interculturais, estas publicações não exprimiram somente as vozes hegemônicas do império, mas se constituíram em diálogo

\footnotetext{
190 PRATT, Mary Louise. Os olhos do império. Relatos de viagem e transculturação. Bauru: Edusc, 1999.
} 
com as representações coloniais, ainda que na maioria dos casos, a partir do léxico do colonizador. ${ }^{191}$

O amplo e diversificado conjunto de relatos com os quais Mary Pratt trabalha reflete a própria variedade do sujeito imperial. No entanto, mesmo pulverizando este sujeito - associando-o ao comércio, à burocracia e ao campo dos estudos científicos - a autora nos permite perceber que, embora os discursos sejam múltiplos, existe um esteio comum entre eles: o império. As expedições científicas constituídas a partir do século XVIII são a expressão mais concreta da amplitude do sujeito imperial. Na maior parte das vezes, as expedições oficiais britânicas que percorreram a África ocidental eram compostas por: funcionários nomeados pelo Foreign Office; oficiais a serviço do esquadrão antitráfico; religiosos integrantes da Church Missionary Society (CMS) ou da Wesleyan Missionary Society, além de geógrafos, botânicos, geólogos, entre outros interessados na "descoberta" do continente africano. Somava-se a estes integrantes, que de diferentes maneiras estavam vinculados ao império colonial britânico, um número muito superior de trabalhadores africanos. Eram eles que carregavam no próprio lombo ou em canoas - quando o leito dos rios assim permitia - equipamentos, mercadorias e alimentos. Também eram africanos os indivíduos recrutados no litoral para servirem como guias, indicando os melhores caminhos e desviando de regiões em conflito. Alguns dos guias atuavam ainda como intérpretes, negociando a passagem por territórios vedados ao ingresso de estrangeiros ou mediando as trocas com chefias que condicionavam a abertura de caminhos ao pagamento de tributos.

Em 1845, John Duncan partiu de Ajudá em direção a Abomé, cidade onde seria recebido por Guezo. Naquele momento o explorador ainda não era funcionário do Foreign Office. Sua nomeação como vice-cônsul de Ajudá aconteceria quatro anos mais tarde, em 1849. A despeito desta missão possuir incumbências específicas, determinadas pela Coroa britânica, as despesas de Duncan foram pagas em sua totalidade (e antecipadamente) pela Royal Geographical Society (RGS). A instituição foi fundada no ano de 1833 e era

${ }^{191}$ lbid, p.52/53. 
apadrinhada pelo rei William IV e, mais tarde, pela rainha Victoria. A RGS não foi a primeira associação com sede em Londres dedicada à pesquisa científica em territórios sobre os quais repousavam os interesses imperialistas da GrãBretanha. Antes dela existia, desde 1788, a Linnean Society, cujos estudos se concentravam no campo da história natural; a Palestine Association, criada em 1807; a Geological Society, fundada no ano mesmo ano de 1807; a Royal Astronomical Society, iniciada em 1823; a Zoological Society, instituída em 1826 e o Raleigh Club, também fundado em $1826 .{ }^{192}$

A RGS se constituiu desde seu início como uma organização de prestígio no cenário científico londrino. De acordo com Heffernan, no ano de sua fundação (1833) a RGS já contava com 460 associados. Este número superava organizações semelhantes existentes em Paris e Berlim, nesta mesma época. Na década de 1850, a sociedade alcançou 800 integrantes e, duas décadas depois, em 1870, cerca de 2.400. ${ }^{193}$ Parte da proeminência obtida pela associação estava ligada ao aporte de recursos recebidos diretamente da Coroa britânica e das vultosas doações oferecidas por seus membros. Frequentada por oficiais, missionários, integrantes da burocracia britânica e profissionais ligados às ciências, a RGS tornou-se, nas palavras de Johnston e William, um "espaço social polissêmico", a partir do qual eram projetadas as diferentes representações formuladas por exploradores no retorno de suas jornadas. ${ }^{194}$

Criada com os propósitos de encorajar expedições científicas por territórios de interesse da Grã-Bretanha e de disseminar o conhecimento geográfico produzido a partir destas viagens, a RGS ajudou a compor um repertório de publicações acerca do continente africano. Nos termos de Gebara, a sociedade funcionava como "um centro de coleta, acumulação e divulgação de conhecimento geográfico". Este mesmo autor também esclarece que os dados e informações gerados pelos membros desta instituição

192 Cf. HEFFERNAN, Mike. Geographical traditions: emergence and divergence in CLIFFORD, Nicholas J.; HOLLOWAY, Sarah L.; RICE, Stephen P.; VALENTINE, Gill (eds.) Key concepts in Geography. 2a ed, London: Sage, 2009.

${ }^{193} \mathrm{Cf}$. Ibid, p.8. Entre os membros da Royal Geographical Society, que produziram os relatos analisados nesta pesquisa, é comum encontrarmos, ao lado do nome do autor, a sigla FRGS, cujo significado é Fellow of The Royal Geographical Society.

${ }_{194}$ JOHNSTON, Ron; WILLIAM, Michael. A century of British Geography. London: Oxford University Press, 2003, p. 19. 
constituíam uma "produção 'científica' útil para a nação britânica". ${ }^{195}$ Como as viagens eram pagas com os recursos da instituição, os relatórios e as narrativas escritos por seus exploradores eram discutidos em reuniões cujos participantes se envolviam, por vezes, em acalorados debates. ${ }^{196}$ De acordo com Barnett, antes dos textos serem publicados pelos dois veículos de divulgação pertencentes à RGS - o Journal of the Royal Geographical Society e o Proceedings of the Royal Geographical Society - diversas questões acerca do manuscrito eram propostas e discutidas entre seus membros. ${ }^{197}$ As produções de John Duncan a respeito de suas experiências na Costa da Mina são exemplos deste processo de elaboração discursiva, cujos resultados foram impressos em função do apoio material oferecido pela RGS. As experiências vividas pelo viajante foram divulgadas em duas publicações de sua autoria: em um artigo impresso pelo Journal of the Royal Geographical Society, em 1846; e no livro Travels in Western Africa, in 1845 \& 1846, lançado no ano de $1847 .{ }^{198}$

Sobre as publicações de Duncan, as considerações tecidas por Mary Pratt auxiliam na compreensão do sentido que o retorno à Inglaterra assumia para os viajantes britânicos em geral e, para John Duncan, em específico. Ao analisar as narrativas vitorianas produzidas por exploradores que, ao longo da década de 1860, partiram em direção ao continente africano à procura da nascente do rio Nilo, a autora, sublinha que era no regresso à Europa que o explorador se consagrava. Afinal, recebendo os créditos por ter completado o feito que lhe fora proposto, o viajante também obtinha os recursos vinculados à

\footnotetext{
${ }^{195}$ GEBARA, Alexsander. Op.cit. 2010, p.124.

196 Um dos debates mais famosos em torno da produção do discurso geográfico se deu entre Richard Francis Burton e John Hanning Speke. Em 1857, Burton e Speke realizaram uma viagem que tinha como propósito encontrar a nascente do rio Nilo. A discussão entre os exploradores acerca da localização do ponto exato onde nascia o Nilo se arrastou por quase vinte anos. A controvérsia só chegou ao final quando, em 1875, H.M.Stanley circunavegou o Lago Victoria e, depois de seu retorno à Inglaterra, afirmou que, de fato, Speke estava correto em suas afirmações. Cf. BAKER, J.N.L. Sir Richard Burton and the Nile Sources. The English Historical Review, vol.59, n.233, jan.1944, pp.48-61.

197 BARNETT, Clive. Impure and Worldly Geography: the Africanist Discourse of the Royal Geographical Society, 1831 - 1873. Transactions of the Institute of British Geographers, vol.23, n.2, 1998, p.243.

${ }^{198}$ As obras publicadas por Duncan são: DUNCAN, John. Notice of a Journey from Whydah on the West Coast of Africa to Adofoodiah in the Interior, Journal of the Royal Geographical Society, 16, 1846, pp.154-162 e DUNCAN, John. Travels in Western Africa, in 1845 \& 1846. A journey from Whydah, through the kingdom of Dahomey, to Adofoodia, in the interior, vol. I e II. London: Richard Bentley, 1847.
} 
realização da missão, assim como se tornava apto a escrever, publicar e comercializar suas experiências de viagem. ${ }^{199}$

Embora a maioria das associações recompensasse financeiramente seus enviados somente quando (e se) voltassem à Inglaterra, este não era um procedimento comum entre os exploradores remetidos pela RGS. Ao contrário, a RGS costumava adiantar o pagamento de grandes somas de recursos, em espécie e em mercadorias, aos líderes de suas expedições. De acordo com Heffernan, uma das implicações decorrentes desta antecipação financeira e material era a determinação precisa, por parte da RGS, dos objetivos que deveriam ser cumpridos ao longo da viagem. ${ }^{200}$ Todavia, a antecipação de parte das recompensas financeiras não diminuía o mérito do retorno ao ponto de partida dos exploradores financiados por esta sociedade. Afinal, a volta ao continente europeu representava o cumprimento da última etapa da "aventura". Este era o momento em que a narrativa da experiência ganhava visibilidade. $A$ exposição junto aos seus pares dos percalços e hostilidades enfrentados em negociações com chefias africanas, as dificuldades materiais e logísticas vividas, assim como os desafios referentes à ameaça constante de doenças, eram relativamente comuns nos escritos produzidos por exploradores como John Duncan.

Os registros deixados pelo viajante escocês são marcados pela incorporação de suas experiências pessoais, por referências às interações com brasileiros e pela apropriação discursiva de tudo o que ele observou. Ao reivindicar autoridade sobre suas considerações, Duncan encaminhou seu discurso no sentido de demonstrar os benefícios decorrentes do contato dos africanos com a "civilização" europeia. Este aspecto explicaria o fato dele considerar os libertos brasileiros como as "pessoas mais industriosas" encontradas em seu percurso até Abomé. Afinal, embora nascidos entre os fulanis e oiós, estes libertos haviam passado pela escravidão no Brasil e, em

\footnotetext{
${ }^{199}$ PRATT, Mary Louise. Op.cit., 1999, pp.342-343.

200 HEFFERNAN, Mike. Geographical traditions: emergence and divergence in CLIFFORD, Nicholas J.; HOLLOWAY, Sarah L.; RICE, Stephen P.; VALENTINE, Gill (eds.) Op.cit., 2009, p.8.
} 
função desta experiência, eram capazes de cultivar belas e viçosas plantações. ${ }^{201}$

Além disto, suas residências constituíam outra evidência material de que os brasileiros compunham um grupo à parte em relação às sociedades africanas locais. Vivendo em casas "limpas e confortáveis", situadas "em um dos mais belos lugares que a imaginação pode conceber", estes libertos foram elogiados pela hospitalidade e apreço dedicados aos viajantes europeus que se hospedavam nestas moradias. Se desfrutavam dos recursos que a natureza Ihes oferecia era porque haviam, no passado, servido como escravos no Brasil. Este aspecto reforçava a percepção de que a "indolência" e a "desonestidade" existentes entre os demais africanos impediam a realização plena das potencialidades da natureza de seu continente. Tal como afirmou Pratt, ao analisar a literatura de viagem produzida por Mungo Park, "os obstáculos à utopia não são, é claro, europeus, mas africanos." ${ }^{202}$ Para Duncan, a presença de libertos vindos do Brasil, vivendo nas imediações de Ajudá e aptos ao trabalho na lavoura, eram indicativos de que, caso os britânicos se instalassem na Costa da Mina, seria possível "melhorar e moralizar" as sociedades locais. $^{203}$

\subsection{As partidas de Salvador para a Costa da Mina}

Eu não me lembrava muito bem da África que tinha deixado, portanto, não tinha muitas expectativas em relação ao que encontraria. Ou talvez, na época, tenha pensado isso apenas para me conformar, porque não gostei nada do que vi. ${ }^{204}$

Quando John Duncan esteve na cidade litorânea de Ajudá, visitou outros portos situados em suas imediações, e seguiu em direção ao interior percorrendo os caminhos que levavam até Abomé, o tráfico de escravos em

\footnotetext{
201 DUNCAN, John. Op.cit., 1847, vol. 1, p.185.

202 PRATT, Mary Louise. Op.cit., 1999, p.153 e 188, respectivamente.

${ }^{203}$ DUNCAN, John. Op.cit., 1847, vol. 1, p.185-186.

${ }^{204}$ Neste excerto da obra literária Um defeito de cor, a personagem principal - Kehinde confronta as memórias do tempo em que viveu na África, antes de ser capturada para ser feita cativa, com a realidade encontrada ao desembarcar em Ajudá. GONÇALVEZ, Ana Maria. Um defeito de cor. $4^{\mathrm{a}}$ ed. Rio de Janeiro: Record, 2008, p.731.
} 
direção ao Brasil estava às vésperas de ser extinto. Em 1850, apenas três anos depois do relato de Duncan ser impresso na Grã-Bretanha, o comércio escravista foi suspenso nos portos brasileiros. Contudo, mesmo depois do principal destino destes cativos - o Brasil - se fechar ao tráfico, a atividade continuou existindo até 1867 em direção à Cuba, ainda que em menor volume. Neste sentido, os registros deixados pelo viajante escocês podem ser entendidos como produções em diálogo com o contexto de reconfiguração da atuação britânica na Costa da Mina. A reocupação de fortes abandonados na primeira década do século XIX, o incentivo e o financiamento de expedições exploratórias, a intensificação da atuação do esquadrão antitráfico na região do Golfo do Benim e a adoção de uma política de assinatura de tratados com chefias locais, foram algumas das ações tomadas pelo Foreign Office na década de 1840.

Entre as medidas acima citadas, talvez a de maior peso e visibilidade fosse aquela relacionada à supressão definitiva do comércio atlântico de escravos. Nas décadas de 1830 e 1840, o debate acerca da eficácia da atuação britânica no combate ao tráfico ganhou espaço em disputas políticas e entre a opinião pública britânica, tema que será refinado no terceiro capítulo desta tese. Em diálogo com as questões de seu tempo, John Duncan apontou quais eram, onde estavam estabelecidos e como atuavam os principais negreiros que viviam em Ajudá e em portos vizinhos. No entanto, seu relato também dedicou espaço aos libertos vindos do Brasil. Explicando aos leitores que estes ex-escravos declaravam ter vivido na Bahia "seus mais felizes dias", o explorador escocês deixava entrever seu interesse por compreender os contextos que encaminharam estes indivíduos novamente até a Costa da Mina. Mesmo sem reproduzir suas interlocuções com os brasileiros libertos, os escritos de Duncan registraram o contato direto com estas pessoas. Ao perguntar a diversos retornados os motivos da partida para a África e do abandono de "tão agradável servidão", o explorador parafraseou as vozes de seus entrevistados, resumindo e organizando suas respostas. Nas palavras de John Duncan, aqueles libertos haviam atravessado o Atlântico em razão de 
uma revolta entre alguns escravos na Bahia, o que significou a ruína de muitos senhores e de diversos engenhos de cana de açúcar, em razão disto estes senhores não podiam mais sustentá-los ou mantê-los como empregados. ${ }^{205}$

É bastante possível que a revolta citada pelos interlocutores de Duncan fosse a já mencionada Revolta dos malês, ocorrida em 1835. Este aspecto em si não desperta para questões relevantes quanto à forma como a narrativa se constituiu. Entretanto pouco mais adiante, o explorador registra o que considera o motivo pelo qual aqueles ex-escravos haviam se transferido para Ajudá. De acordo com seus registros, como desdobramento da revolta ocorrida na Bahia muitos senhores de escravos haviam ruído e, impossibilitados de "sustentá-los ou mantê-los", tiveram de se desfazer de seus "empregados". Desta forma, com alguma sutileza John Duncan transfigurava a escravidão em emprego e assinalava o fato de que a subsistência da escravaria era um ônus a ser pago pelo senhor depauperado por um levante provocado pelos próprios escravos.

Em 1847, ano em que a narrativa de viagem de John Duncan foi impressa, o número de leitores na Grã-Bretanha havia se ampliado de modo relevante. Conforme indica Curtin, era comum os viajantes publicarem livros ou artigos contando experiências vividas em expedições fora da Europa. Em geral, os textos dos artigos eram editados em periódicos mantidos por sociedades religiosas ou de estudos científicos. Os relatórios produzidos pela Church Missionary Intelligencer, os artigos da Methodist Magazine e do Journal of the Royal Geographical Society são exemplos de espaços utilizados por aqueles que desejavam difundir suas realizações. Entre os leitores britânicos, a alfabetização e a melhoria do acesso à compra de livros ajudaram a popularizar as imagens associadas ao continente e às sociedades africanas visitadas por exploradores, oficiais, funcionários britânicos e missionários. ${ }^{206}$

No ano em que Duncan desembarcou no porto daomeano de Ajudá, em 1845, a Revolta dos malês ocorrida em Salvador havia completado exatos dez

\footnotetext{
${ }^{205}$ DUNCAN, John. Op.cit., 1847, vol. 1, p.201/202.

206 CURTIN, Philip D. The Image of Africa. British Ideas and Action, 1780 - 1850. Vol.2, Wisconsin: University of Wisconsin Press, 1973, p.325.
} 
anos. A insurreição de 1835 foi o primeiro levante urbano acontecido na capital baiana. O movimento liderado por africanos escravos e libertos foi rapidamente debelado pelas autoridades provinciais da Bahia. Os desdobramentos pósrevolta incluíram a intensificação do rigor policial e legislativo sobre a população africana que vivia na cidade. ${ }^{207}$ Neste contexto, a travessia atlântica de africanos e descendentes, livres e libertos, até a Costa da Mina se apresentava como uma das alternativas para uma nova vida. $O$ desembarque destes indivíduos transformou a paisagem humana de Lagos e trouxe implicações econômicas, sociais e culturais que serão objeto de análise nos demais capítulos desta pesquisa.

O aumento no volume de partidas de Salvador em direção a esta porção da costa ocidental africana esteve ligado, principalmente, à aplicação de um conjunto de ações de restrição da autonomia dos africanos libertos e de medidas que oneraram a vida na capital baiana. Conforme aponta Brito, a dura repressão que se seguiu à Revolta de 1835 era resultado de um clima de medo de que novos levantes urbanos eclodissem na Bahia. ${ }^{208} \mathrm{~A}$ deportação de trinta e quatro libertos condenados pela participação na insurreição em Salvador foi apenas uma das medidas tomadas pelas autoridades provinciais baianas. ${ }^{209}$ Os debates promovidos pela Assembleia Legislativa de Salvador versavam a respeito das formas de controle, vigilância e repressão sobre a população africana que vivia na capital. Afinal, apenas quatro meses depois da sublevação, iniciada na madrugada do dia 24 para 25 de janeiro de 1835, foi

\footnotetext{
${ }^{207}$ A principal obra acerca da Revolta dos malês continua sendo de autoria de João José Reis: Rebelião escrava no Brasil, a história do levante dos malês (1835), Edição revista e ampliada, São Paulo: Brasiliense, 2003. Alberto da Costa e Silva dialoga com a obra de Reis no texto: Sobre a rebelião de 1835, na Bahia in Um rio chamado Atlântico: a África no Brasil e o Brasil na África. Rio de Janeiro: Nova Fronteira/ UFRJ, 2003.pp.189-214.

${ }^{208}$ Em extensa pesquisa no Arquivo Público do Estado da Bahia (APEBa), Luciana Brito analisa as repercussões da Revolta dos malês a partir da legislação formulada em resposta ao clima de suspeição, vigilância e controle estabelecido em Salvador. Veja em: BRITO, Luciana da Cruz. Sob o rigor da lei: africanos e africanas na legislação baiana (1830 - 1841), Campinas: Dissertação de mestrado, IFCH/UNICAMP, 2009. E, também, em: BRITO, Luciana da Cruz. Sob o Rigor da Lei: Africanos e a Legislação Baiana no Século XIX. Sankofa. Revista de História da África e de Estudos da Diáspora Africana. $N^{\circ}$ 2, dez.2008.pp.38-57 e BRITO, Luciana da Cruz. A legalidade como estratégia: africanos que questionaram a repressão das leis baianas na primeira metade do século XIX. Revista dos Pós-graduandos em História Social da Unicamp, n.16, 2009, pp.15-28.

${ }^{209}$ Reis analisa o contexto em que foram definidas as sentenças aos condenados por participar da Revolta de 1835, em: REIS, João José. Rebelião escrava no Brasil, a história do levante dos malês (1835), Edição revista e ampliada, São Paulo: Brasiliense, 2003, p.453.
} 
promulgada uma das legislações mais severas dirigida à população africana de Salvador: a lei de número nove.

Os vinte e três artigos que compunham este novo corpo de leis foram formulados com base em depoimentos obtidos pelas autoridades policiais durante a devassa que se seguiu à revolta. Cinco destes artigos estavam diretamente associados à deportação da população africana da Bahia. Num primeiro momento, estavam sujeitos à "reexportação" os africanos forros suspeitos de promover "insurreição de escravos" e os "africanos importados como escravos depois da proibição do tráfico". Aos demais africanos livres que permanecessem na província, e se mantivessem isentos de qualquer acusação, o $4^{\circ}$ artigo avisava acerca da extensão da medida tão logo "se tenha designado um lugar para a sua reexportação". ${ }^{210}$

Apenas três meses depois da lei de número nove entrar em vigor, outro conjunto de disposições legais, dirigido aos escravos urbanos e forros que atuavam nos cantos de trabalho, foi promulgado: a lei de número quatorze. Encadeado ao clima de vigilância e controle instalado na capital da província baiana, este conjunto de leis substituía os cantos por capatazias. O propósito era garantir um maior controle sobre uma das principais organizações de trabalho de escravos e libertos em Salvador. No entanto, ao se recusarem a operar de acordo com os novos termos estabelecidos, os trabalhadores dos cantos de Salvador mostravam haver limites à interferência do Estado na organização do trabalho urbano. Nas palavras de João José Reis, passado algum tempo, "as autoridades desistiram" e as capatazias voltaram a operar como cantos. ${ }^{211}$

No entanto, o mesmo não aconteceu com a lei de número nove. Embora o governo provincial baiano não tenha seguido adiante no processo de "reexportação" sistemática de africanos libertos, o controle estabelecido sobre esta população levou muitos a atravessarem o Atlântico em sentido inverso. Mesmo sem serem deportados oficialmente, diversos africanos e seus

\footnotetext{
${ }^{210}$ APEBa. Seção Legislativa da Assembleia Provincial Legislativa da Bahia. Série: Registro de leis. Livro 1. (1835-1840). Lei número 09, de 13 de maio de 1835 Apud BRITO, Luciana da Cruz. Op.cit., 2009, p.41 e 121.

${ }^{211}$ Reis comenta os impactos da Lei No 14 e a "desobediência" africana que a tornou inaplicável em: REIS, João José. Op.cit., 2003, pp.503-508.
} 
descendentes se apresentaram à Polícia Provincial da Bahia para solicitar os documentos necessários às viagens para fora do Brasil: o passaporte e sua correspondente legitimação de passaporte. ${ }^{212}$ Para a burocracia provincial da época, a simples posse do passaporte não era garantia de autorização de embarque. Era ainda necessário que o passageiro obtivesse um documento que afiançava serem legítimas as informações fornecidas à polícia: a legitimação de passaporte. Esse último documento era expedido pela Polícia Provincial e, em geral, tinha validade máxima de oito dias.

As certidões de legitimação eram numeradas e nelas inscrevia-se o nome do passageiro, local de destino, tipo de trabalho e, em alguns casos, motivo da viagem. De acordo com Amós, a certidão de legitimação custava entre três mil e duzentos a quatro mil réis, somava-se a essa quantia mais cento e sessenta réis referentes ao selo oficial colado ao documento. Nos casos em que o viajante embarcava acompanhado - pela mulher, filhos, irmãos, pais e até mesmo por escravos - a legitimação incluía nomes e idades desses outros passageiros, estendendo a esses indivíduos a autorização de embarque. $^{213}$

Desta forma, mesmo considerando que muitos dos africanos e descendentes que conseguiram a documentação necessária à viagem não empreendessem efetivamente a travessia atlântica, os registros de legitimação de passaporte nos permitem conjeturar acerca das partidas de livres e libertos para a região da Costa da Mina. Em pesquisa de mestrado realizada junto aos registros de legitimação de passaporte, guardados no Arquivo Público do Estado da Bahia (APEBa), apurei que a maioria dos que partiam de Salvador em direção à costa ocidental africana, entre 1824 e 1860, declaravam dirigir-se para a Costa d'África, Portos d'África, Benguela e Luanda (ou Loanda). Raras foram as legitimações expedidas para Onim, nome pelo qual Lagos era também conhecida. Apenas a título de comparação, em 1835, ano de maior volume de retornos de africanos e descendentes, 334 forros solicitaram sua

\footnotetext{
${ }^{212}$ Para uma melhor compreensão dos motivos do retorno e uma interpretação que entende a volta de libertos à costa ocidental da África como saída e não como opção, temos: CUNHA, Manuela Carneiro da. Op.cit.2012, p.126. REIS, João José. 2003. p.454.

${ }^{213}$ Veja mais detalhes sobre esse tipo de documento, em: AMÓS, Alcione Meira. Os que voltaram: a história dos retornados afro-brasileiros na África Ocidental no século XIX. Belo Horizonte: Tradição Planalto, 2007, pp.25-27.
} 
legitimação de passaporte e afirmaram ter como destino final a "Costa d'África". Neste mesmo ano, 24 libertos comunicaram às autoridades provinciais partir para "Portos d'África" e 18 informaram dirigir-se para "Loanda" e "Benguela". Em contrapartida, ainda no ano de 1835, nenhum viajante registrou Onim ou Lagos como destino de desembarque. ${ }^{214}$ Ao longo dos 36 anos de documentos pesquisados, encontrei apenas dez registros de passageiros que anunciavam ser Onim o destino final de sua viagem. Todos eles tiveram seus passaportes legitimados no mesmo dia: 18 de março de 1856. Este aspecto, em especial, nos sugere que os libertos planejavam viajar em grupo. No entanto, as circunstâncias que teriam unido estas pessoas e a confirmação de sua chegada ao destino previsto ainda nos escapam. ${ }^{215}$

Entre as informações fornecidas pelos registros pesquisados é possível perceber que, com exceção de Benguela e Luanda (localidades situadas na África Central) as demais denominações - "Costa d'África" e "Portos d'África" não se referem a um ponto específico do litoral ocidental africano. A despeito da imprecisão desse conjunto de fontes, é possível que muitos dos libertos que desembarcaram na Costa da Mina, vindos da capital baiana, tenham se instalado em Lagos. Afinal, não são poucos os relatos de missionários e viajantes que se referem à presença de africanos "self-emancipated", cuja passagem pela escravidão no Brasil Ihes conferia a designação de brasileiros.

\footnotetext{
${ }^{214}$ Cf. SILVA, Angela Fileno da. "Amanhã é dia santo": circularidades atlânticas e a comunidade brasileira na Costa da Mina. São Paulo: Alameda/FAPESP, 2014, pp.135-166. Durante pesquisa de mestrado consultei os livros de registro de passaporte disponíveis no Arquivo Público do Estado da Bahia. Tais livros estão guardados no APEBa e são manuscritos não microfilmados que podem ser encontrados na Seção Colonial e Provincial, Série Polícia, com o título Registro de Passaportes. Os maços de número 5878 até 5898 são referentes ao intervalo de tempo de 1824 a 1860.

${ }^{215}$ Nestes registros de legitimação de passaporte estão em nome dos seguintes passageiros: Pompeo Monteiro, Antonio João Landislao, Maria da Cruz e Lucrecia Joaquina da Lapa. Duas mulheres viajavam em companhia de seus filhos, eram elas: Efigênia Monteiro, com suas duas filhas, Maria d'Alleluia e Maria Victoria, e Joanna Maria da Conceição, com os filhos Luiz e Maria Antonia. Em todas as inscrições os viajantes se declararam libertos. Polícia Passaportes. Seção Colonial e Provincial. Registro de Passaporte, 1842-1857, Maço 5883, APEBa. 18 de março de 1856. Como indica Castillo, a leitura exclusiva dos registros de passaporte não nos permite elaborar afirmações acerca da forma como estes africanos e descendentes, libertos e livres, viajavam. A fim de suprimir as lacunas deixadas pela historiografia, a pesquisadora ampliou seu corpus documental em direção a outras fontes e acrescentou informações recolhidas em seus estudos etnográficos realizados no Benim e na Nigéria nos anos de 2012 e 2014. CASTILLO, Lisa Earl. Op.cit., 2016, pp.25-52.
} 
Documentos deixados por religiosos católicos da Société des Missions Africaines (SMA), que em 1861 haviam fundado uma missão em Ajudá, mencionam a existência de "um bom número de escravos originários destes países [ou seja, vindos das Américas]" vivendo em Lagos. ${ }^{216} \mathrm{Em} 1862$, o missionário superior Francisco Xavier Borghero realizou sua primeira incursão por localidades vizinhas ao porto do Daomé. Uma das cidades visitadas pelo missionário foi Lagos, ocasião em que identificou a existência de católicos entre a população lagosiana. No entanto, o contato do religioso com tais católicos não levou imediatamente à fundação de uma missão na cidade. Borghero continuou sua expedição até Porto Novo, local em que pretendia obter autorização para estabelecer uma nova missão. No ano seguinte, em setembro de 1863, após sua segunda passagem por Lagos, o abade acolheu os pedidos dos brasileiros pela criação de uma igreja e uma escola eclesiástica na cidade. Assim, entre 1864 e 1868, se instituiu uma congregação que, embora não dispusesse ainda de vigário era visitada com regularidade por religiosos que viviam em Porto Novo. Apenas depois de quatro anos do funcionamento desse primeiro núcleo, uma missão foi fundada em Lagos. Nesta mesma ocasião, em 1868, o abade Pierre Bouche iniciou a construção de uma escola da SMA na cidade. ${ }^{217}$

\footnotetext{
216 Cf. BORGHERO, Francisco; MANDIROLA, Renzo; MOREL, Yves (eds.) Journal de Francesco Borghero, preimier missionaire du Dahomey, 1861-1865. Paris: Éditions Karthala, 1997, p.45. De acordo com relato escrito pelo cônsul britânico Sir Richard Francis Burton, essa primeira missão da SMA foi liderada por Borghero e acompanhada pelos seguintes religiosos: François Fernandes, um espanhol da diocese de Lugo, falecido em Ajudá (em 1863) apenas dois anos depois de seu desembarque; Louis Eddé, francês da diocese de Chartres, cuja morte ocorreu a caminho de Serra Leoa, em 1862. Mais tarde, outros religiosos chegaram àquelas imediações, dividindo-se entre os portos de Ajudá, Lagos, Porto Novo e Aguê. BURTON, R.F. A mission to Gelele, king of Dahome. $2^{\mathrm{a}}$ ed. vol.I. London: Tinsley Brothers, 1864, p.69.

${ }_{217}$ As considerações de Francisco Borghero acerca da forma como os brasileiros praticavam o catolicismo, assim como uma estimativa do número de católicos que viviam em Lagos nas duas ocasiões em que visitou a cidade podem ser lidas em: BORGHERO, Francisco; MANDIROLA, Renzo; MOREL, Yves (eds.) Journal de Francesco Borghero, preimier missionaire du Dahomey, 1861-1865. Paris: Éditions Karthala, 1997.pp.45-50. Para uma análise acerca do estabelecimento missionário em Lagos e, também, em outras localidades da Costa da Mina: CUNHA, Manuela Carneiro da. Negros, estrangeiros. Os escravos libertos e sua volta à África. $2^{\mathrm{a}}$ ed. revisada e ampliada. São Paulo: Companhia das Letras, 2012, p.167-168.
} 


\subsection{O tráfico e as ações britânicas na Costa da Mina}

Era tempo de lua cheia. Mas, naquela noite, as vozes das crianças não foram ouvidas.

O ilo da aldeia, onde elas sempre se reuniam para brincar quando havia lua, estava vazio. [...] Umófia estava como um animal assustado, de orelhas em pé, a farejar o ar silencioso e agourento, sem saber para que lado fugir. ${ }^{218}$

As narrativas de viagem escritas por religiosos católicos pertencentes à SMA são documentos que só começaram a ser elaborados a partir da década de 1860. Além destes registros, missionários metodistas pertencentes à Wesleyan Missionary Society, que desde 1842 existia em Badagri, e enviados anglicanos da CMS, cujos trabalhos em Abeokuta e em Badagri se iniciaram, respectivamente, em 1843 e 1845, produziram escritos acerca de suas experiências nas localidades em que estavam instalados. Antes disto, entre os séculos XVII e XVIII, a maior parte dos documentos escritos era elaborada por oficiais e funcionários que trabalhavam nas fortificações britânica, francesa e portuguesa, estabelecidas em Ajudá. Este conjunto de escritos é constituído por relatórios e correspondências referentes às atividades mantidas por mercadores que negociavam seus produtos e, em troca, partiam dos embarcadouros carregados de escravos. Todavia, ao final do século XVIII e início do XIX, este tipo de documentação deixou de ser produzida pela França e Grã-Bretanha. Relembro que, em 1794, a França aboliu a escravidão em seu território e estendeu esta medida a todas as suas colônias. Todavia, no ano de 1802, apenas oito anos depois da promulgação da lei que determinava a libertação dos escravos na França e em seus territórios, a escravatura foi

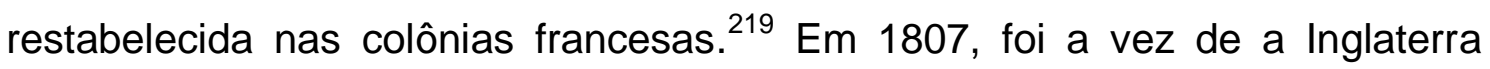
determinar o fim do comércio atlântico de escravos por meio do Abolition of the Slave Trade Act.

${ }^{218}$ Excerto em que Achebe descreve os acontecimentos que antecederam a prisão do personagem principal, Okonkwo, pelas autoridades coloniais britânicas. ACHEBE, Chinua. $O$ mundo se despedaça. São Paulo: Companhia das Letras, 2009, p.218.

${ }^{219}$ Para uma discussão aprofundada acerca da abolição francesa ocorrida em 1794 e os desdobramentos que levaram ao restabelecimento da escravatura nas colônias francesas, consultar: SOARES, Laurent Azevedo Marques de. A primeira abolição francesa da escravidão (4 de fevereiro de 1794) e o problema dos regimes de trabalho. Saeculum. Revista de História, 29: João Pessoa, jul/dez.2013, pp. 125-143. 
As alterações legislativas promovidas pelos governos francês e britânico tiveram como consequência direta o abandono dos fortes mantidos por estes dois países na Costa da Mina. Com a suspensão imediata do tráfico pela Coroa da Grã-Bretanha não havia mais justificativa para a permanência de funcionários e oficiais britânicos nestas fortificações. A progressiva desocupação destes espaços teve como consequência um lapso dos registros escritos por funcionários ingleses, durante quase toda a primeira metade do século XIX. ${ }^{220}$

A legislação britânica que determinava o fim do tráfico também regulava outras questões. Entre as ações regulamentadas pela nova lei estavam os procedimentos tomados pelas autoridades após a apreensão de navios negreiros. De acordo com as determinações legislativas, os cativos capturados pelo esquadrão britânico eram alistados nas forças armadas ou inscritos em um sistema de apprenticeship, cujo objetivo era promover o treinamento destes indivíduos para que atendessem à crescente demanda por trabalhadores aptos a executar tarefas em tipografias, estabelecimentos comerciais e na lavoura exportadora. ${ }^{221}$

É importante aqui ressaltar que o Abolition of the Slave Trade Act foi uma lei voltada ao comércio negreiro atlântico e ao destino conferido aos africanos cativos, cujas naus eram interceptadas pela armada da rainha Victoria. De fato, a extinção da escravidão foi aprovada pelo Parlamento inglês apenas no ano de 1833. Isto significava que embora o tráfico escravista fosse uma prática proibida desde o final da primeira década do século XIX, a escravidão praticada por britânicos só se tornou ilegal vinte e seis anos mais tarde. Em 1807, a saída britânica dos fortes localizados na Costa do Cabo e em Ajudá, apenas para citar dois exemplos deste tipo de estabelecimento

\footnotetext{
${ }^{220}$ Os historiadores Law e Mann analisam a suspensão dos registros franceses e britânicos neste período, em: LAW, Robin. Ouidah: The Social History of a West African slaving 'port', 1727-1892. Ohio: Ohio University Press/ Oxford: James Currey, 2004, cap.6 e MANN, Kristin. Op.cit., 2007, p.39.

${ }^{221} \mathrm{Em} \mathrm{1819,}$ uma Comissão Mista foi criada com a função de julgar os casos dos navios apreendidos pelo esquadrão antitráfico. Em geral, as comissões eram formadas por dois comissários, um britânico e outro da nacionalidade da embarcação em julgamento. Sobre o encaminhamento dos capturados até Serra Leoa e os processos de constituição da identidade dos chamados "africanos livres", sugiro: DELGADO, Érika Melek. Identidades em trânsito: o caso dos africanos livres na primeira colônia britânica da África Ocidental. Revista de Ciências Humanas, Viçosa, v.14, n.2, jul./dez., 2014, pp.356-372.
} 
situado na região, favoreceu o negócio de seres humanos que continuou a ser praticado por negreiros baianos. Afinal, com a eliminação da concorrência de negreiros britânicos, o forte de São João Baptista de Ajudá, construído com o dinheiro apurado a partir do comércio de indivíduos escravizados e mantido por negreiros baianos, e os atracadouros erguidos em Lagos, Badagri, Porto Novo, Popo Grande e Popo Pequeno (ou Anexô) ampliaram de maneira expressiva suas atividades no tráfico.

É certo que a desocupação das fortificações pertencentes à GrãBretanha, operada nas três primeiras décadas do século XIX, não promoveu a imediata transferência de todos os súditos da rainha Victória para a Inglaterra. John Beecroft é um exemplo emblemático da permanência destes indivíduos na região. Durante cinco anos, de 1829 a 1834, Beecroft ocupou na ilha de Fernando Pó diferentes postos de trabalho a serviço da Coroa inglesa. Neste momento a ilha era uma possessão espanhola e parte de seu território era utilizada como base para as operações da armada antitráfico. Em 1829, Beecroft desembarcou em Fernando Pó, a fim de assumir o cargo de superintendente de obras [superintendent of works]. No ano seguinte, se tornou governador em exercício no local, posto em que permaneceu por três anos, entre 1830 e 1833.

Em 1834, a maioria dos funcionários ingleses que vivia em Fernando Pó já havia atendido as determinações do Foreign Office e retornado à Inglaterra. Contrário à decisão do governo britânico de retirar seu contingente naval e administrativo da possessão espanhola, Beecroft continuou na ilha atuando como comerciante e explorador. Contratado pela firma inglesa de Robert Jamieson, o britânico tornou-se capitão da embarcação Quorra, um dos primeiros navios pertencente a um comerciante particular a ingressar pelo rio Níger. Tal como Beecroft, é possível que alguns poucos britânicos instalados na Costa da Mina tenham ficado na região a despeito de todas as resoluções oficiais do governo da Grã-Bretanha pelo contrário. ${ }^{222}$

\footnotetext{
${ }^{222}$ A respeito da carreira de John Beecroft, sugiro: DIKE, K.O. John Beecroft, $1790-1854$. Her Brittanic Majesty's Consul to the Bights of Benin and Biafra, $1849-1854$. Journal of the Historical Society of Nigeria, vol. 1, n. 1, December, 1956, pp.5-14. Sobre as expedições pelo
} 
A decisão pela desocupação dos fortes mantidos pela Grã-Bretanha implicou numa redução significativa no número de oficiais mantidos em terra na Costa da Mina. De acordo com o historiador Philip Curtin, nas duas primeiras décadas do século XVIII cerca de trezentos soldados da Coroa britânica viviam nestas fortificações. Esta situação se modificou a partir de 1830. Neste período menos de dez integrantes da armada da rainha Victoria moravam nos postos estabelecidos no continente. Se considerarmos os comerciantes, representantes de firmas europeias e outros indivíduos que não estavam sob o comando direto do governo inglês, este número se elevaria para próximo de duzentas pessoas. Enquanto o contingente de britânicos que viviam na costa diminuía, crescia o volume de oficiais e soldados embarcados no Esquadrão Africano empregado no combate ao comércio atlântico de escravos. Ainda segundo Curtin, ao manter os membros da armada britânica em navios estacionados próximo à costa, o comando naval acreditava salvaguardar seus súditos do clima pestilento encontrado nas cidades da Costa da Mina. ${ }^{223}$

O afastamento do contingente naval destes territórios se estendeu até os anos de 1840. A partir de 1841, o Foreign Office voltou a enviar funcionários britânicos para expedições em terra. Também neste mesmo período, o governo passou a incentivar o estabelecimento de missões da CMS e da Wesleyan Missionary Society na região. Pautado por um discurso de combate ao tráfico de escravos e interessado em garantir sua presença em áreas de influência disputadas com a França, o Foreign Office iniciou, na década de 1840, uma política de incentivo e apoio aos missionários, cientistas e oficiais que se encaminhavam para a Costa da Mina. ${ }^{224}$ Entre 1839 e 1843, o missionário metodista, filho de pai africano e de mãe britânica, nascido em Hampshire, Inglaterra, Thomas Birch Freeman, realizou duas viagens pela África ocidental:

rio Níger que antecederam a Expedição de $1841 / 42$ e eram financiadas por firmas particulares britânicas, indico: CURTIN, Philip D. Op.cit., 1973, pp.296-298.

${ }_{223}$ CURTIN, Philip D. Op.cit., 1973, p.294.

${ }^{224}$ De acordo com Mann, a longa campanha britânica contra o tráfico foi marcada, entre outras coisas, por discussões parlamentares acerca da conquista territorial da África ocidental. Mais adiante no terceiro capítulo, analisarei os debates políticos relacionados à questão da relação do discurso abolicionista com a ocupação colonial da Grã-Bretanha em Lagos. Esse tema é amplamente tratado na obra: MANN, Kristin. Op.cit., 2007, cap. 3. 
na primeira chegou até a cidade ashanti ${ }^{225}$ de Kumasi e, na segunda, percorreu o trecho compreendido entre Serra Leoa e Badagri, passando por Ajudá e, em seguida, subindo o rio Ogun chegando até Abeokutá. ${ }^{226}$

Dois anos depois, entre 1845 e 1846, John Duncan realizou sua incursão até Abomé. ${ }^{227}$ Mais tarde, no ano de 1846, depois da reocupação britânica do forte de Ajudá e da criação do consulado da Grã-Bretanha nas baías do Benim e Biafra, Duncan assumiu o cargo de vice-cônsul de Ajudá. Em 1850, neste contexto de restabelecimento das ações da Coroa inglesa na região, o vice-cônsul nomeado há apenas quatro anos tentou repetir o feito alcançado em 1845: chegar até a capital daomeana de Abomé. Como mencionei no primeiro capítulo desta tese, o oficial naval membro do esquadrão britânico antitráfico, Frederick Forbes, fazia parte da comitiva de Duncan. Nas duas ocasiões em que Duncan liderou expedições que tinham por finalidade chegar até Abomé, o grupo não passou por Lagos. No entanto, outros ingleses incluíram o porto lagosiano em sua rota.

Freeman e Forbes, por exemplo, estiveram na ilha em momentos diferentes. Ali entraram em contato com negreiros brasileiros, cujas atividades ligadas ao tráfico se espalharam por diversos embarcadouros da região. Entre estes mercadores brasileiros que atuavam em mais de um porto de escravos, podemos citar o traficante Domingos José Martins, filho de um dos participantes da Revolução Pernambucana de 1817. Martins teria desembarcado na Costa da Mina pela primeira vez por volta de 1835, e se estabeleceu em Ajudá, sob a proteção do chachá Francisco Félix de Souza. ${ }^{228}$

\footnotetext{
${ }^{225}$ A mesma palavra pode ser encontrada grafada das seguintes formas: achante, achanti, axanti, axante, ashante, asante ou asanti. Cf. SILVA, Alberto da Costa e. Op.cit. 2002, p.121, nota 24.

${ }^{226}$ Os relatos destas duas viagens estão em: FREEMAN, Thomas Birch. Journal of Various Visits to the Kingdoms of Ashanti, Aku and Dahomi in Western Africa. Cambridge: Cambridge University Press, 2010. A primeira edição é de 1844. Há também uma publicação de 1968. A atuação missionária de Freeman foi narrada na biografia: MILUM, John. Thomas Birch Freeman: Missionary Pioneer to Ashanti, Dahomey, and Egba. New York: Fleming H. Revell Company, 1893. Informações acerca da vida do religioso metodista e alguns excertos de seus escritos estão em: SILVA, Alberto da Costa e. Imagens da África: da Antiguidade ao Século XIX. São Paulo: Penguin, 2012, pp.362-364.

${ }^{227}$ Reitero que o relato da viagem de Duncan até a Abomé está publicado em: DUNCAN, John. Travels in Western Africa, in 1845 \& 1846. A journey from Whydah, through the kingdom of Dahomey, to Adofoodia, in the interior, vol. I e II. London: Richard Bentley, 1847.

${ }^{228} \mathrm{Em}$ nota Verger reproduz o testamento de Domingos José Martins. Neste documento, o traficante declara sua filiação. VERGER, P. Op.cit. 1987, p. 482, nota 82. A trajetória de Martins
} 
Três anos mais tarde, em 1838, mudou-se para Lagos, porto em que atuou como empregado de um traficante conhecido pelo curioso nome de Dos Amigos. De acordo com Ross, este negreiro teria morrido apenas oito meses depois da chegada de Martins que, aproveitando seu falecimento, assumiu os negócios do ex-patrão. Durante os seis anos em que permaneceu em Lagos, Domingos Martins constituiu fortuna a partir do comércio de escravos. ${ }^{229}$

Em 1844, o negociante partiu de Lagos em direção ao Brasil. Infelizmente, a historiografia produzida a respeito do afamado negreiro não explica os motivos que o levaram para o outro lado do Atlântico. Igualmente, os documentos consultados nesta pesquisa não nos deixam pistas capazes de justificar este retorno. Deste modo, torna-se possível apenas apontar algumas suposições. No ano de 1841, o principal oponente de Akitoye, Kosoko, retornou a Lagos. Kosoko era sobrinho de Akitoye e, em outras situações, já havia demonstrado a intenção de ocupar a posição de obá da cidade. A volta do sobrinho do obá à cidade levou algumas chefias a suspeitarem das intenções de Kosoko em relação à disputa pelo mando. Como aliado de Akitoye é possível que Domingos Martins temesse ter seus negócios interrompidos em virtude das ambições de Kosoko pelo lugar do tio. Em função disto, Martins pode ter optado por passar um tempo em Salvador, ao lado de seus filhos que há alguns anos viviam na capital baiana.

Ao longo dos dois anos em que esteve na Bahia, o traficante também cuidou de negócios que, até aquele momento, eram administrados por procuradores estabelecidos em Salvador. ${ }^{230}$ Além disto, escreveu e registrou em 10 de dezembro de 1845, no Rio de Janeiro, seu testamento. Neste documento Domingos Martins deu conta de seus bens e vontades. Declarandose filho do já falecido Domingos José Martins e de Francisca Romana Pinto,

\footnotetext{
também é narrada por ROSS, David A. The Career of Domingo Martinez in the Bight of Benin, 1833-64. The Journal of African History, Vol. 6, Nº 1, 1965, pp.79-90. Além desse artigo, duas obras publicadas por Alberto da Costa e Silva tratam deste traficante, são elas: SILVA, Alberto da Costa e. Francisco Félix de Souza, mercador de escravos. Rio de Janeiro: Nova Fronteira/EdUERJ, 2004, especialmente nas pp. 118-119, 145-146,156,157,159 e 165 e SILVA, Alberto da Costa e.Um rio chamado Atlântico: a África no Brasil e o Brasil na África. Rio de Janeiro: Nova Fronteira/EdUERJ, 2003, especificamente em pp.40-42, 63,123,125,127,131 e 134.

${ }^{229}$ ROSS, David A. Op.cit., 1965, p.79.

${ }^{230}$ Cf.VERGER, P. Op.cit. 1987, p.456.
} 
até aquele momento ainda viva, o traficante reconheceu a paternidade de sua extensa prole. Naquele ano de 1845, todos os seus seis filhos eram ainda menores. Maria, Leocádia, Adelaide, Angelina, Marcolina e Rafael viviam na Bahia sob o cuidado de dois tutores e parceiros comerciais do pai: José Bento Alves e Joaquim Pereira Marinho. Nesta mesma situação permaneceram depois que o traficante retornou à Costa da Mina, em 1846. Desta vez Martins instalou seus negócios em Porto Novo e Ajudá. De acordo com Ross, estes embarcadouros the ofereceram melhores condições à realização de seus negócios ligados ao tráfico. Uma vez estabelecido em Ajudá, o negreiro foi amparado por Guezo e, aos poucos, retomou sua proeminência no comércio de cativos. ${ }^{231}$ Para alguns pesquisadores, Domingos Martins chegou a ocupar uma posição comercial - mas não o mesmo lugar social - semelhante à de Francisco Félix de Souza, àquela altura já falecido. ${ }^{232}$

A despeito da maior parte das fontes sobre os mercadores de escravos se concentrarem nos escritos deixados pelos viajantes britânicos que estiveram na região, é possível perceber a presença de negreiros em Lagos desde, pelo menos, as três últimas décadas do século XVIII. O processo criminal aberto contra João de Oliveira é um importante indício da participação desta primeira geração de negociantes no mercado atlântico de escravos, cujas trocas comerciais eram firmadas com Salvador. Além dos documentos relativos a Oliveira, um conjunto de cartas emitidas por estes negreiros, assim como relatórios escritos pelo esquadrão inglês antitráfico, compõem um corpo documental referente às atividades dos traficantes de escravos que viviam em Lagos antes do oitocentos. ${ }^{233}$

\footnotetext{
${ }^{231}$ ROSS, David A. Op.cit., 1965, p.80.

${ }^{232}$ Segundo Costa e Silva, a partir de 1845 o rei Guezo permitiu que outros negreiros se instalassem em Ajudá. Tal mudança tornou Francisco Félix de Souza um comissionado dos embarques que, a partir de então, seriam realizados sem que o chachá desfrutasse do privilégio de primazia nas negociações. Esta mudança na forma como Félix de Souza operava seus negócios permitiu a instalação e gradual ampliação das atividades de negreiros como Domingos Martins na cidade. SILVA, Alberto da Costa e. Op.cit., 2004, p.156.

${ }^{233}$ Trechos de cartas testamentais e de correspondências comerciais escritas por negreiros podem ser lidos, em segunda mão, ao longo das obras de Verger. Em especial, nas seguintes publicações: VERGER, Pierre. Op. Cit., 1987 e VERGER, Pierre. Op.cit., 1992. Este segundo livro compreende um interessante compêndio de documentos reproduzidos integralmente. Sobre as viagens de pesquisa realizadas por Verger em companhia de Roger Bastide, no ano de 1958, recomendo: LUHNING, Angela (org.). Verger - Bastide: dimensões de uma amizade. Rio de Janeiro: Bertrand Brasil, 2002. Também um importante artigo escrito por J.F. Almeida
} 
A partir da década de 1850, quando Lagos se tornou protetorado britânico, a produção de documentos que se reportavam à presença de uma segunda geração de brasileiros na cidade aumentou significativamente. Grande parte dos registros acerca desta parcela da população era produzida por funcionários que atuavam na administração do recém-criado protetorado. ${ }^{234}$ Neste contexto, Lagos se tornou um porto essencial às ações colonizadoras inglesas, atuando como base a partir da qual saíam as incursões exploratórias britânicas por territórios mais afastados do litoral. De acordo com Law, a localização estratégica da ilha a tornava o único ponto em que as naus poderiam atracar durante todo o ano. Embarcadouros vizinhos, como Popo Grande e Aladá (ou Ardra), por exemplo, ficavam abertos apenas durante o período das cheias. Além do aspecto da navegabilidade, a cidade se encontrava entre os centros comerciais de Aladá, ljebu e Benim, localidades situadas mais ao interior, sobre as quais os britânicos guardavam interesses: econômicos, pois relacionados à expansão do mercado de óleo de dendê; morais, por estarem associados à extinção do tráfico atlântico de escravos; e religiosos, referentes ao proselitismo cristão na região. ${ }^{235} \mathrm{~A}$ forma como 0 governo da Grã-Bretanha promoveu seus interesses sobre o território lagosiano e o conjunto de argumentos que garantiu a sustentação das ações militares empreendidas em terra, são assuntos tratados no capítulo a seguir.

Prado e apresentado no IV Congresso de História Nacional, promovido pelo IHGB em 1949, permite a leitura de um conjunto de interrogatórios promovido pelo Parlamento de Londres e dirigido aos suspeitos de envolvimento com o tráfico atlântico. Estes documentos foram transcritos e estão em: PRADO, J.F. de Almeida. A Bahia e suas relações com o Daomé in $O$ Brasil e o colonialismo europeu. São Paulo: Companhia Editora Nacional, 1956. Em razão do recorte temporal desta tese, 1840 e 1900, não me aprofundarei no estudo das fontes que foram produzidas em período anterior à década de 1840 .

${ }_{234}$ Sobre a questão da sistematização da contagem populacional, sugiro: DANIEL, S. Ola. Health and Social Welfare in ADERIBIGBE, A.B. (ed.) Op.cit., 1975, p.160.

${ }^{235}$ Cf. LAW, Robin. Op.cit.,1983, p.322. No terceiro capítulo discutirei os argumentos apresentados por setores que, fundamentados em princípios econômicos e morais sistematizados pelo ex-Parlamentar Thomas Fowell Buxton, defenderam o bombardeio da marinha britânica sobre Lagos, em 1851. 


\section{A conquista do "ninho de pirataria e pilhagem"}

Como um ninho de pirataria e pilhagem, a destruição de Lagos foi um dever assumido pelas nações civilizadas, em defesa da lei das nações e dos princípios há tanto tempo estabelecidos pelas mais elevadas autoridades internacionais. ${ }^{236}$

Em 1848, quatro naus da armada da rainha Victoria patrulhavam 0 trecho da costa ocidental africana compreendido entre as cidades de Freetown (em Serra Leoa) e o porto daomeano de Ajudá. Estas embarcações compunham a armada antitráfico britânica e faziam parte do Esquadrão Africano instalado na Costa da Mina. De acordo com os registros do oficial naval Frederick Forbes, comandante de um dos navios desta frota, nos primeiros seis meses em que as naus bloquearam a região foram apreendidos onze tumbeiros que seguiriam em direção às Américas. Ainda segundo este mesmo oficial, se o combate ao tráfico fosse realizado de maneira eficiente, o lucro dos negreiros diminuiria e, dentro de pouco tempo, o comércio atlântico de escravos cessaria por completo. ${ }^{237}$

Embora Forbes estivesse correto ao prever o término das atividades negreiras pelo Atlântico, sua estimativa se mostrou um pouco otimista. Afinal, mesmo em menor escala, o tráfico com o Brasil continuou existindo por mais dois anos, até 1850. Além disto, os comerciantes que se dirigiam à Costa da Mina em busca de estoques de braços cativos mantiveram seus negócios em

\footnotetext{
236 "As a nest of piracy and plunder, the destruction of Lagos was a duty owing by civilized nations to themselves, in vindication of the law of nations, and the principles so long ago laid down by the highest international authorities." Excerto do panfleto anônimo publicado em Londres, no ano de 1852, na ocasião da instalação do protetorado em Lagos. The Destruction of Lagos. London: James Ridgway, 1852.

${ }^{237}$ FORBES, Frederick E. Dahomey and the dahomans: the joulnals of two missions to the king of Dahomey, and residence at this capital, in the years 1849 and 1850. vol.I, London: Longman, 1851 , p.VI/VII.
} 
direção a Cuba até 1867, ano em que Havana promulgou uma legislação mais rigorosa inviabilizando o negócio negreiro. ${ }^{238}$

Em 24 de dezembro de 1851, três embarcações que integravam o Esquadrão Africano venceram a barreira que dava acesso a um emaranhado de canais e de lagoas que circundavam Lagos e se posicionaram em frente ao igá onde vivia Kosoko. A manobra liderada pelo cônsul Beecroft antecedeu um intenso bombardeio sobre a cidade. Durante quatro dias as naus britânicas mantiveram o cerco que levou à fuga de Kosoko para Epe. A deposição do antigo obá, a restituição do mando de Akitoye e a submissão da cidade transformada em protetorado britânico, constituem alguns dos marcos das ações do Foreign Office na Costa da Mina. Sob este aspecto, o terceiro capítulo propõe discutir o lugar ocupado por alguns negreiros brasileiros em meio às disputas, entre Akitoye e Kosoko, pela posição de obá em Lagos. Este era um momento de intensificação da política britânica de combate ao tráfico e de ampliação do número de missões anglicanas e metodistas na região. $\mathrm{O}$ acréscimo destes novos elementos às dinâmicas políticas lagosianas e os fatores que tornaram ainda mais complexos os conflitos pelo mando na cidade são assuntos também tratados nesta parte da pesquisa.

\title{
3.1. A instauração do protetorado britânico em Lagos
}

\begin{abstract}
Quando eu estava prestes a retornar para casa algumas pobres crianças demonstraram em suas faces seu agradecimento por ensinar-Ihes o livro do homem

branco. $^{239}$
\end{abstract}

Em dezembro de 1851 a marinha real britânica bombardeou Lagos, destituiu Kosoko de sua posição de obá e o substituiu pelo seu oponente: Akitoye. $O$ ataque naval promovido pelos ingleses e a instauração do

\footnotetext{
${ }^{238}$ Cf. LAW, Robin. A Comunidade brasileira de Uidá e os últimos anos do tráfico atlântico de escravos, 1850-66. Revista Afro-Ásia, № 27, 2002, p.47.

${ }_{239}$ "When I was about to return home some of the poor children fell on their faces to thank me for teaching them the White Man's Book". PAGE, Jesse. The black bishop, Samuel A. Crowther. London: Hodder and Stoughton, 1908. p.90.
} 
protetorado na ilha são considerados, em parte, um desfecho às disputas em torno do título de obá da cidade. De acordo com Mann, na década de 1830, depois de uma breve e impopular atuação, o obá Idewu Ojulari foi pressionado pelos chefes locais a cometer suicídio. Com a morte de Idewu, e na ausência de descendentes diretos, seu irmão Kosoko apresentou, pela primeira vez, suas intenções em relação a esta posição de mando. Entretanto, neste ano de 1835, Kosoko não conseguiu o apoio do Eletu Odibo. Como vimos, uma das atribuições do Eletu Odibo consistia em escolher e instalar os obás de Lagos. Em lugar de Kosoko, este chefe convidou Adele, que naquele momento vivia em Badagri, para assumir esta posição.

Segundo Costa e Silva, Adele teria ocupado o poder de Lagos em duas ocasiões. A primeira quando sucedeu Akinsemoyin, possivelmente entre 1811 e 1821 e a segunda entre 1835 e 1837, quando ocupou o lugar deixado por Ojulari. Da primeira vez em que Adele assumiu o poder na cidade, ele empreendeu um conjunto de ações no sentido de restringir a atuação de negreiros portugueses e brasileiros. Esta escolha política abreviou seu mando e o levou à deposição por seu irmão, Osilokun (ou Elisogun). Exilado em Badagri, o obá derrotado recorreu, no ano de 1825, ao apoio dos britânicos para bombardear a cidade. Todavia, as intenções de Adele não foram levadas adiante pelas autoridades da Grã-Bretanha e Osinlokun permaneceu no poder por mais quatro anos, até a sua morte em 1829. Nesta ocasião, a despeito das tentativas de Adele, um dos filhos de Osinlokun, chamado Idewu Ojulari, assumiu o poder. ${ }^{240}$

Após o suicídio de Ojulari, Adele voltou pela segunda ocasião ao trono de Lagos. Desta vez permaneceu no mando por apenas dois anos, de 1835 a 1837. Completado este período Adele morreu, deixando o poder de Lagos novamente vazio. De acordo com Mann, Kosoko se apresentou mais uma vez à posição e foi, pela segunda ocasião, preterido pelo mesmo chefe que, em seu lugar, optou por Oluwole, um dos filhos de Adele. Além desta nova recusa, Eletu Odibo acusou uma das irmãs de Kosoko, conhecida pelo nome de Opo Olu, de praticar bruxaria, justificando assim sua expulsão da cidade. Em razão

\footnotetext{
${ }^{240}$ SILVA, Alberto da Costa e. Um rio chamado Atlântico: a África no Brasil e o Brasil na África. Rio de Janeiro: Nova Fronteira/EdUERJ, 2003, pp.124-125.
} 
destes acontecimentos Kosoko iniciou uma ofensiva contra seu oponente, mas ao final, saiu derrotado. Depois de ter sido vencido, Kosoko se exilou em Ajudá, cidade em que viveu por alguns anos. Ainda de acordo com a historiadora Kristin Mann, enquanto o futuro obá estava exilado em Ajudá, o Eletu Odibo mandou que os restos mortais da mãe de Kosoko fossem desenterrados e jogados na lagoa em frente à ilha. ${ }^{241}$

Durante o período em que permaneceu em território do Daomé, o líder lagosiano se aproximou de negreiros brasileiros e portugueses, constituindo sua própria rede de parceiros comerciais no tráfico. Conforme explicam Falola e Oguntomisin, em 1841, uma explosão de pólvora no igá (ou palácio) de Oluwole tornou o lugar do obá novamente vazio. ${ }^{242}$ Nas tradições orais estudadas por Mann, Akitoye - tio de Kosoko - assumiu a posição de obá de Lagos e, em seguida, convidou o sobrinho para retornar à cidade. O gesto foi narrado como uma tentativa de reconciliação com o exilado. Sob protestos dos demais chefes, Kosoko foi conduzido novamente até Lagos pela embarcação do famoso negreiro brasileiro Domingos José Martins, aliado comercial e político de Akitoye.

Após a sua instalação em Ereko, na porção nordeste da ilha, Kosoko recebeu de Akitoye o título de oloja. Na prática, a posição conferida ao sobrinho implicava no controle do mercado de Ereko, assim como numa autorização para que este estabelecesse seu próprio ìgá e formasse sua corte. Aparentemente, as ofertas de Akitoye não foram suficientes para conter as ações de Kosoko contra seu oponente, o Eletu Odibo. Mesmo depois de ter sido estabelecido como oloja de Ereko, Kosoko instigou uma série de ataques sobre Eletu Odibo, que se exilou em Badagri. No entanto, o principal chefe responsável pela nomeação do obá permaneceu por pouco tempo fora de Lagos. Logo após sua saída, Akitoye ordenou o retorno de seu aliado que o fez acompanhado pelas forças egbas de Badagri. ${ }^{243}$

Em represália ao retorno do chefe rival e, possivelmente, suspeitando uma resposta violenta de Akitoye contra si, Kosoko iniciou em julho de 1845

\footnotetext{
${ }^{241}$ MANN, K., Op.cit., 2007,pp.48 e 49.

242 FALOLA, Toyin; OGUNTOMISIN, G.O. Op.cit., 2001. p.142.

${ }^{243}$ MANN, K., Op.cit., 2007,p.48.
} 
uma ofensiva dirigida ao seu tio. Munido pelo apoio do Daomé e de ljebu, as forças de Kosoko queimaram a cidade, cercaram o exército de Akitoye e impediram o abastecimento de água. Esta última medida forçou os soldados a beberem água salgada, o que conferiu ao confronto o nome de İgá Omiró, traduzido como "a batalha da água salgada". Após vinte e um dias de conflito, o assassinato do Eletu Odibo e a fuga Akitoye para Abeokuta, Kosoko se tornou obá de Lagos, posição que manteve até o bombardeio britânico sobre a cidade, em $1851{ }^{244}$

Durante os seis anos em que ocupou o mando em Lagos, de 1845 a 1851, Kosoko não apenas continuou a praticar o comércio ilegal de escravos, como expandiu seus negócios ampliando o número de cativos embarcados em seu porto. Os dados fornecidos pela The Trans-Atlantic Slave Trade Database nos permitem verificar que, entre os anos de 1846 e 1850, mais de treze mil escravos atravessaram o Atlântico em direção às Américas. Este é o segundo maior número apurado a partir desta base de dados. Como é possível perceber na tabela a seguir, entre 1836 e 1840, 14.327 escravos partiram de Lagos com destino ao Novo Mundo.

Tabela 2: Obás e escravos embarcados em Lagos

\begin{tabular}{|l|l|l|}
\hline & $\begin{array}{l}\text { Número de escravos } \\
\text { embarcados }\end{array}$ & Obás de Lagos \\
\hline $\mathbf{1 8 3 6}-\mathbf{1 8 4 0}$ & 14.327 & $\begin{array}{l}\text { Adele }(1835-1837) \\
\text { Oluwole }(1837-1841)\end{array}$ \\
\hline $\mathbf{1 8 4 1}-\mathbf{1 8 4 5}$ & 11.861 & Akitoye (1841-1845) \\
\hline $\mathbf{1 8 4 6 - 1 8 5 0}$ & 13.040 & Kosoko (1845-1851) \\
\hline $\begin{array}{l}\text { Total de escravos } \\
\text { embarcados }\end{array}$ & 39.228 & \multicolumn{1}{|c}{} \\
\cline { 1 - 2 } & &
\end{tabular}

Fonte: Tabela elaborada a partir dos dados fornecidos pela base de dados The Trans-Atlantic Slave Trade Database, consultados em: http://www.slavevoyages. org/tast/database/search.faces

\footnotetext{
${ }^{244}$ Conforme as tradições pesquisadas por Mann, o Eletu Odibo foi afogado na mesma lagoa em que ele havia, anos antes, despejado os restos mortais da mãe de Kosoko. Esta ação é interpretada como uma retaliação à violação dos restos mortais da mãe de Kosoko, promovida pelo chefe aliado de Akitoye. MANN, K., Op.cit., 2007,p.49.
} 
Os números do tráfico permaneceram elevados também entre $1841 \mathrm{e}$ 1845, anos em que Akitoye ocupou o mando na cidade. Neste intervalo de tempo, 11.861 cativos foram encaminhados às Américas a partir do porto lagosiano. Este aspecto em especial nos permite compreender com maior clareza que, durante o tempo em que Akitoye se manteve como obá de Lagos, o tráfico continuava sendo uma atividade essencial à cidade. Mais adiante analisarei as transformações do discurso formulado por Akitoye acerca do comércio escravista frente aos seus interesses por retomar seu mando.

Sob o comando de Kosoko, a expansão do tráfico em Lagos se tornou possível graças ao acréscimo de novos agentes comerciais a já existente rede de traficantes brasileiros. Estes agentes eram os ibigás, grupo formado por cativos feitos escravos nos moldes da escravidão africana, cujos integrantes desfrutavam da confiança do obá. Conhecidos por cuidarem dos interesses comerciais de seus donos e de atuarem em combates, estes indivíduos eram considerados, nos termos da antropóloga Sandra Barnes, "órfãos sociais". Em um de seus artigos, Barnes discute como os elementos estrangeiros escravos, esposas ou refugiados - se tornaram agentes potenciais de mudança quando passaram por processos de incorporação à comunidade que os recebeu. No caso dos ibigás a autora lembra que, como estrangeiros - nos termos da autora, outsiders - estes indivíduos compunham uma categoria inferiorizada. Afinal, eram escravos e, em razão desta condição não possuíam vínculos de parentesco com os grupos linhageiros da sociedade em que viviam. Por este motivo, ibigás como o Oshodi Tapa "entram na nova comunidade sem uma identidade, e são incorporados pelas linhagens como membros de menor status, com menos direitos e maior número de obrigações". ${ }^{245}$ Segundo a antropóloga, este aspecto da escravidão africana, via de regra, colocava o indivíduo numa situação de alheamento social. No entanto, alguns dos ibigás que serviram à Kosoko superaram a posição de estrangeiros, constituindo riqueza, status social privilegiado e uma parentela própria.

\footnotetext{
${ }^{245}$ BARNES, Sandra T. Ritual, Power, and outside Knowledge. Journal of Religion in Africa,
} vol.20, Fasc.3, Out./1990, pp.248- 261. 
Apesar da posição alcançada por alguns dos ibigás residentes em Lagos, o historiador Paul Lovejoy previne que a compreensão acerca da posição de estrangeiros, ocupada pelos cativos que foram escravizados por outros africanos, deve ser antes de tudo, localizada dentro das dimensões de tempo e espaço. Em seus estudos, Lovejoy percebe que não raras vezes sociedades africanas construíram formas de incorporação do escravo ao grupo linhageiro de seu senhor. Complementarmente, é necessário lembrar que tais esquemas de incorporação de escravos ao clã tiveram suas nuanças. Em muitos casos, apesar de seu progressivo ingresso na família, estes indivíduos dificilmente deixavam de ter suas ações limitadas e de serem equiparados a uma "criança". Outro aspecto importante é o fato desta relação passar por profundas transformações na segunda metade do século XIX, a partir da extinção do tráfico transoceânico e da ampliação do trabalho escravo nas lavouras exportadoras africanas. Além disto, não eram muito comuns os casos de ibigás que superaram os limites impostos por uma condição de relativo alheamento social. Entre aqueles que desempenharam papéis de maior destaque e, por esta razão tiveram sua atuação analisada pela historiografia, estavam: Oshodi Tapa, Dada Antonio e Ojo Akanbi. Todos os três atuavam como agentes comerciais e administrativos de Kosoko. ${ }^{246}$

Ao negociarem escravos em nome de Kosoko e ao recolherem taxas entre mercadores vindos do além-mar e comerciantes provenientes do interior, estes cativos de confiança se tornaram homens ricos e poderosos. Ainda de acordo com Barnes, Oshodi Tapa e Dada Antonio primeiro serviram ao pai de Kosoko - Osinlokun - e depois, ao filho. Além disto, Oshodi Tapa figura entre os ibigás que alcançaram uma posição de maior destaque dentre os seguidores de Kosoko. Para Barnes, a trajetória do escravo de origem nupe, que conquistou a confiança do obá, constituiu riqueza e se tornou chefe de uma larga parentela, é um dos raros exemplos de incorporação de um estrangeiro ao grupo social ao qual foi acrescentado. Como parte deste processo, Oshodi Tapa obteve permissão para estabelecer um lugar de culto

${ }^{246}$ Cf. LOVEJOY, Paul E. A escravidão na África: uma história de suas transformações. Tradução Regina Bhering e Luiz Guilherme Chaves, Rio de Janeiro: Civilização Brasileira, 2002. p.32. Sobre a incorporação de escravos à família do senhor, sugiro: MEILLASSOUX, Claude. Antropologia da escravidão. Rio de Janeiro: Jorge Zahar Editor, 1995, Capítulo introdutório: Parentes e Estranhos. 
aos ancestrais de origem nupe, o Gunnu. Desta forma, o ibigá ampliou o poder sobre seus dependentes para além da esfera econômica e social. Tornando-se líder religioso de uma parentela formada a partir da compra de escravos, de múltiplos casamentos e de seus descendentes, Oshodi Tapa deixou seu status de escravo para se tornar um líder reconhecido entre os seguidores de Kosoko. $^{247}$

Segundo Mann, enquanto eram ibigás do obá Osinlokun (pai de Kosoko), Oshodi Tapa e Dada Antonio foram enviados ao Brasil para aprenderem a língua portuguesa e travarem relações com os comerciantes estabelecidos na Bahia. Aparentemente, estas ligações tecidas de costa a costa renderam frutos que, em décadas posteriores, foram colhidos por seu filho, Kosoko. De acordo com os dados apresentados na tabela 2 - Obás e escravos embarcados em Lagos - e a partir de um levantamento realizado por Mann, ao longo dos anos em que Kosoko esteve no poder em Lagos as receitas apuradas com o tráfico cresceram de maneira significativa quando comparadas com as de seu sucessor, Akitoye. ${ }^{248}$ Este crescimento nos lucros o levou a buscar na Bahia carpinteiros e tanoeiros dispostos a cumprir suas determinações. O objetivo do obá de Lagos era construir suas próprias embarcações para atravessar o Atlântico. Assim, caso seu intento fosse alcançado, parte dos escravos enviados ao Brasil poderia ser remetida diretamente para agentes baianos com os quais mantinha relações comerciais.

A estratégia política de Kosoko consistia em reduzir a participação dos intermediários que atuavam no comércio negreiro pelo Atlântico. Todavia, não podemos assegurar que Kosoko tenha cumprido seu propósito. O que podemos entrever a partir da análise historiográfica produzida sobre este período é, ao contrário, uma maior aproximação de Kosoko em relação aos

\footnotetext{
${ }^{247}$ BARNES, Sandra T. Op.cit.,1990,pp.248 e 261.

${ }^{248}$ Cf. MANN, K., Op.cit., 2007. A respeito dos lucros do tráfico em Lagos, consulte p.61. Neste trecho, a historiadora compila os dados sobre o tráfico apresentados pelos autores Eltis, Lovejoy e Richardson. Sistematizando tais informações numa tabela, Mann torna possível comparar a receita proveniente desta atividade desde o reinado de Ologun Kutere (1780-1802), passando por um interregno de nove anos (1802-1811), depois por Adele (1811-1821), Osinlokun (1821-1829), Idewu Ojulari (1829-1834/35), Adele novamente (1835-1837), Oluwole (1837-1841), Akitoye (1841-1845), terminando com Kosoko (1845-1851). Este levantamento não trata do segundo mando de Akitoye, de 1851 a 1853, por coincidir com o período de instalação do protetorado britânico na cidade, período em que se supunha a extinção o tráfico atlântico.
} 
correspondentes de Salvador. Neste sentido, o relacionamento de Kosoko com seus parceiros na Bahia parece ter se estendido para além dos negócios. ${ }^{249}$

Entre as quarenta e oito cartas apreendidas pela armada da rainha Victória, na ocasião da instalação do consulado de Lagos, uma delas tratava da viagem de três "filhos" do obá que partiram de Salvador. Em 28 de agosto de 1850, o capitão Désonnais, comandante da embarcação L'Industrie, enviava notícias dos "filhos" de Kosoko, cujos nomes seriam: Simplício, Lourenço e Camílio. De acordo com a missiva, todos estavam bem e logo chegariam a Lagos, embora no momento do embarque em Salvador estivessem infectados com febre amarela. Se, por um lado, a proximidade entre Kosoko e os mercadores estabelecidos na Bahia pode ter possibilitado ao obá enviar seus próprios filhos para serem educados em Salvador, por outro, é também possível que os "filhos" mencionados neste documento fossem, na verdade, escravos encomendados junto a algum correspondente baiano. A leitura dos registros de legitimação de passaporte realizada ao longo de minha pesquisa de mestrado, revelou que alguns brasileiros enriquecidos, estabelecidos na Costa da Mina, encomendavam escravos na Bahia. Embora raros, os casos de tráfico em sentido inverso estavam, em geral, associados às habilidades técnicas do cativo. ${ }^{250}$

É também difícil acreditar que o obá atribuísse os nomes portugueses Simplício, Lourenço e Camílio - aos seus descendentes. Suspeitando ser este um episódio de remessa de escravos de Salvador para Lagos, fica a hipótese

\footnotetext{
${ }^{249}$ MANN, Kristin. Op.cit., 2007. Sobre a compra de escravos carpinteiros e tanoeiros na capital baiana, veja a p.72.

${ }^{250} \mathrm{Ibid}$, p.66. Também Verger nos informa a respeito da carta remetida à Kosoko. O mesmo autor apresenta ainda um pequeno trecho de um relatório emitido pelo cônsul britânico Benjamin Campbell. Neste documento os filhos de Kosoko teriam sido levados à Bahia por insistência de negreiros brasileiros que tinham interesse na expansão do comércio em Lagos. PRO, FO 84/1031, 1/09/1857 apud VERGER, Pierre. Op.cit., 1987, pp.264/265. Como exemplo de caso de tráfico em sentido inverso temos o registro de legitimação de passaporte expedido em nome do escravo Paulo. Em 28 de agosto de 1845, o senhor Jerônimo Castro, que vivia na Costa da Mina, mandou vir de Salvador o escravo Paulo. Na ocasião, a mão de obra remetida para África foi inscrita no livro de registro de legitimação como "de África, creado remetido por Luiz Felippe Crocco a ser entregue a Jerônimo Castro, amo do mesmo africano". Também Domingos José Martins, em 13 de outubro de 1846, obteve o passaporte de cinco cativos: três homens, uma mulher e uma criança. Cf.SILVA, Angela Fileno da. Op.cit., 2014,pp.161-163. Os dois registros de legitimação citados nesta nota estão, respectivamente, em: APEBa. Polícia. Seção Colonial e Provincial. Registro de Passaporte, 1845-1847, Maço 5888, 28 de agosto de 1845 e APEBa, Polícia. Seção Colonial e Provincial. Registro de Passaporte, 1845-1847, Maço 5888,13 de outubro de 1846.
} 
de que os embarcados não eram mão de obra comum, mas indivíduos capazes de desempenhar trabalhos específicos, talvez ligados ao comércio atlântico. Episódios como este exemplificam as relações diretas do obá de Lagos com correspondentes baianos. No entanto, mesmo negociando diretamente com agentes comerciais de Salvador, Kosoko não descartou a atuação dos intermediários brasileiros que viviam em Lagos. Afinal, o tráfico operado por estes comerciantes era de interesse do obá, pois implicava no pagamento de impostos e no fornecimento de armas e munições essenciais à manutenção de seu mando. Neste sentido, um dos negreiros vinculados ao comércio de escravos em Lagos era Marcos Borges Ferras, que se tornou conhecido pela historiografia em razão de existir contra ele um extenso processo, movido pelo Governo Provincial da Bahia, por "importação" de escravos.

De acordo com os interrogatórios analisados por Verger, o negreiro brasileiro teria partido para a região da Costa da Mina pela primeira vez no ano de 1843. Depois desta viagem, é possível que Borges Ferras tenha realizado diversas outras travessias entre Lagos e Salvador. Ao menos uma destas ficou registrada entre as legitimações de passaporte que pesquisei. Em três de julho de 1846, Marcos Borges Ferras, se dirigiu até a Polícia Provincial baiana, declarou-se "cidadão brazileiro" e informou partida para a "Costa d'Affrica". ${ }^{251}$ Onze anos mais tarde, em 1857, a saída do traficante não foi tão simples. De acordo com Verger, o traficante era proprietário da goeleta Relâmpago que, em 1851, havia partido de Lagos carregada com cerca de quinhentos escravos que seriam vendidos em Salvador. Todavia, no momento em que se acercava da costa baiana, nas proximidades da ilha de Morro de São Paulo, a nau foi capturada pelo comandante Manoel Ernesto de Souza França. ${ }^{252}$

Depois de uma árdua batalha na justiça, a embarcação foi leiloada, suas mercadorias confiscadas e seus escravos declarados livres. Seis anos após a apreensão de sua goeleta, em 1857, Ferras voltou a pisar em solo baiano. Não sabemos ao certo o que teria levado o negreiro a arriscar seu retorno à província. Talvez tenha se fiado na impunidade de seus atos após algum tempo

\footnotetext{
${ }^{251}$ APEBa. Polícia Passaportes. Seção Colonial e Provincial. Registro de Passaporte, 18421857, Maço 5896, 03 de julho de 1846.

${ }^{252}$ Cf. VERGER, Pierre. Op.cit., 1987, pp.436/437.
} 
ou, como levanta Verger a partir de um excerto do relato do abade Pierre Bouche, tivesse de acertar contas com um consignatário em débito. De qualquer forma, assim que desembarcou em Salvador, o negreiro foi levado às autoridades provinciais, permanecendo detido até a conclusão do processo criminal que pesava sobre ele. ${ }^{253}$

Em janeiro de 1858, Borges Ferras foi condenado a três anos de prisão, multa de duzentos mil réis por cabeça de escravo e a obrigação de pagar sua viagem de retorno para a Costa da Mina ao final dos anos em que permaneceria detido. Após cumprir sua pena, Ferras voltou para Lagos. Neste porto o traficante continuou a remeter escravos aos seus parceiros comerciais estabelecidos do outro lado do Atlântico. Embora naquele momento, sua rede de negócios estivesse limitada aos correspondentes fixados em Cuba. Em anos anteriores, durante o período em que Kosoko se manteve como obá de Lagos (1845-1851), Ferras se tornou um dos fornecedores de fuzis e de pólvora que ampliaram o poder bélico de Kosoko. As armas e munições obtidas junto ao traficante contribuíram para o fortalecimento da recém-conquistada posição do obá, mantendo Akitoye afastado de Lagos. ${ }^{254}$

Quando Akitoye foi apeado do mando, em 1845, ele e seus seguidores penetraram pelo interior, acompanhando o curso do rio Ogun até chegarem em Abeokuta. $O$ estabelecimento de Akitoye na cidade egba lhe permitiu mobilizar aliados importantes à sua recondução ao poder em Lagos. No exílio, o obá destituído buscou apoio entre as chefias egbas, cujas relações de parentesco materno lhe garantiram abrigo. Em troca, os líderes de Abeokuta esperavam facilidades no comércio de armas e munições praticado no porto lagosiano. Passado o curto período em que permaneceu em Abeokuta, o obá deposto voltou à costa, fixando moradia num porto vizinho à Lagos: Badagri. Uma vez estabelecido neste embarcadouro, Akitoye realizou a primeira investida contra seu oponente. Menos de um ano após sua deposição, no início de março de

\footnotetext{
253 A apreensão da goeleta Relâmpago, em 1851, e o processo decorrente de seu envolvimento com o tráfico é narrado por Verger em: VERGER, Pierre. Op.cit., 1987, pp.434 438. É também o mesmo autor que, citando um trecho do diário de viagem de Pierre Bouche, levanta a hipótese de que Marcos Borges Ferras tenha "se arriscado a ir ao Brasil acertar suas contas com seu consignatário" Cf. BOUCHE, Pierre. La Côte des Esclaves et Le Dahomey. Paris, 1885, p.384 Apud VERGER, Pierre. Op.cit., 1987, p.438.

${ }^{254} \mathrm{O}$ fornecimento de armas e munição para Kosoko pode ser consultado em: VERGER, Pierre. Op.cit., 1987, p.577.
} 
1846, o antigo obá reuniu aliados egbas para um ataque à ilha. Dois anos mais tarde, em 1848, uma segunda ofensiva foi desferida por Akitoye. No entanto, a despeito do apoio das forças egbas e dos recursos fornecidos pelo negreiro brasileiro, aliado de Akitoye, Domingos José Martins, ambas tentativas de destituição de Kosoko fracassaram. ${ }^{255}$

O malogro destas incursões possivelmente levou o ex-obá a ampliar sua rede de alianças. Enquanto esteve em Abeokuta, Akitoye se mostrou favorável à instalação dos missionários que chegavam até a cidade. Os primeiros a se estabelecerem foram o saro Samuel Crowther e o inglês Henry Townshend, os dois pertencentes à Church Missionary Society (CMS). Mais tarde, após a transferência de Akitoye do interior para o porto de Badagri, o antigo obá também se aproximou dos missionários metodistas Thomas Birch Freeman e William de Graft que, desde 1842, trabalhavam na Wesleyan Missionary Society, fundada na cidade. ${ }^{256}$ A proximidade de Akitoye com os enviados religiosos permitiu que o fracasso dos ataques de 1846 e de 1848 não fosse completo. Um artigo publicado no periódico da Church Missionary Intelligencer (CMI) apoiava o retorno do obá deposto ao mando em Lagos. O texto elogiava o trabalho dos anglicanos na extinção do comércio atlântico de escravos. Neste documento, os missionários tomavam as ofensivas de Akitoye contra Kosoko como fortes indícios da oposição do antigo obá ao tráfico. ${ }^{257}$

Apesar disso, durante os quatro anos em que Akitoye ocupou o poder em Lagos (de 1841 a 1845) uma parte substancial dos recursos que sustentavam a economia da cidade vinha do tráfico atlântico. Como os dados apresentados na tabela 2 informam, neste mesmo período, quase doze mil

\footnotetext{
255 Cf.SMITH, Robert Sydney. The Lagos Consulate, 1851-1861. London: Macmillan Press/Univesity of Lagos Press, 1979, p.21. O apoio de Domingos José Martins aos ataques de Akitoye à Lagos também é mencionado em: ROSS, David. Op.cit. 1965, p.80.

${ }^{256}$ De acordo com a historiadora Elizabeth Isichei os primeiros missionários cristãos que se estabeleceram na região do Golfo do Benim eram católicos e vinham das ilhas de São Tomé e Cabo Verde. No século XIX, no entanto, as missões protestantes ganharam força com a conversão de saros. Ao ingressarem na vida religiosa, muitos destes recém-convertidos passaram a se dedicar ao proselitismo. Uma análise mais aprofundada a respeito da disseminação do cristianismo neste período pode ser lida em: ISICHEI, Elizabeth. History of Christianity in Africa from Antiquity to the Present. London: Society for Promoting Christian Knowledge, 1995. Cap.6.

${ }^{257} \mathrm{CMI}$, What the West Coast was before the extinction of the Slave Traffic - Capture of Lagos in 1851, p.125 in A Monthly Journal of Missionary Information. Vol.VIII. London: Church Missionary House, 1872.
} 
cativos embarcaram no porto lagosiano e seguiram em direção às Américas. Este número é um indicativo da posição de Akitoye em relação ao comércio escravista. No entanto, diante das autoridades britânicas e de missionários anglicanos e wesleyanos, o ex-obá formulava um discurso de oposição ao tráfico atlântico de escravos. Ademais, ao apoiar a fundação de grupos cristãos em Abeokuta e Badagri, Akitoye colocava em ação suas estratégias para se angariar o apoio britânico, a fim de recobrar o poder em Lagos. Aos olhos de religiosos e de oficiais da marinha da Grã-Bretanha, o antigo obá se mostrava a melhor opção à cidade. Afinal, enquanto Kosoko permaneceu no mando, todas as propostas de instalação de missionários em seus domínios foram repelidas. Ao recusar suspender das atividades ligadas ao tráfico, o sobrinho de Akitoye desencorajava o proselitismo cristão em seu território e amealhava opositores entre oficiais e religiosos ingleses. Neste contexto, as alianças estabelecidas por Akitoye adquiriram sentidos diferentes em função das circunstâncias em que foram forjadas e das partes envolvidas nestas aproximações. Assim, se entre religiosos e oficiais da marinha britânica Akitoye se mostrava um ferrenho opositor ao comércio escravista, não era esta a posição que assumia diante dos traficantes brasileiros com os quais mantinha estreitas relações de negócios.

No ano de 1845, a chegada de Samuel Ajayi Crowther ao porto de Badagri reforçou a imagem, junto às autoridades anglicanas, de que o obá destituído era contrário ao tráfico atlântico. Enquanto aguardava a abertura dos caminhos para Abeokuta, a fim de seguir viagem até esta cidade, o missionário ouviu as queixas de Akitoye contra Kosoko. Segundo o obá deposto, seu sobrinho havia conspirado para tornar Lagos um dos principais portos negreiros da Costa da Mina. Neste trecho, a biografia de Crowther nos fornece uma descrição de Kosoko, possivelmente elaborada a partir desta conversa com Akitoye. Segundo o religioso da CMS, o recém-estabelecido obá de Lagos era "um traficante de escravos cruel e impiedoso, responsável por muitos massacres, e que tentava obter a possessão da cidade [Badagri] e ameaçava Abeokuta". Denunciando as intenções de Kosoko para além do território de Lagos e apontando suas relações com o mercado atlântico de escravos, Akitoye atraiu o apoio de Samuel Crowther que, inicialmente, não 
percebeu as ligações que 0 antigo obá ainda mantinha com negreiros brasileiros, em especial com o já mencionado traficante Domingos José Martins. $^{258}$

Em meados dos anos de 1840, Samuel Crowther era um missionário saro da CMS. Embora ordenado há apenas dois anos (em 1843) não se pode dizer que Crowther fosse inexperiente no que se refere aos contatos estabelecidos com chefias locais. Isto porque entre 1841 e 1842, o saro integrou como intérprete a Expedição pelo rio Níger, viagem que também contou com a participação do então explorador escocês John Duncan. No ano de 1842, o religioso publicou seu relato a respeito desta jornada. Um segundo registro desta viagem foi elaborado pelo reverendo James Frederick Schon, preceptor de Crowther e também membro da Expedição de 1841/1842. Embora ambas narrativas constituam livros independentes, foram impressas e lançadas como uma única obra. A primeira parte do livro é dedicada às observações do revendo Schon acerca de sua experiência na Costa da Mina. A jornada do superior de Crowther teria se iniciado em Serra Leoa e terminado na ilha de Fernando Pó, passando pela Monróvia, Acra, Ajudá e por territórios identificados por nomes atribuídos às populações estabelecidas nestas localidades, tais como: ibo, bezzani, nufi e fulatah, para citar algumas. A segunda parte da obra foi escrita por Crowther e ocupou um número muito menor de páginas, quando comparada ao livro de Schon. Ao final de seus escritos, o jovem missionário acrescentou algumas das correspondências enviadas à Londres e dirigidas à Secretaria da CMS. Em uma destas missivas, Crowther mencionou e comentou a leitura do livro The African Slave Trade, and its Remedy, escrito por um dos líderes do movimento abolicionista britânico, Thomas Fowell Buxton, obra que analisarei mais adiante neste mesmo capítulo. ${ }^{259}$

Cerca de vinte e quatro anos mais tarde, em 1866, um segundo livro escrito por Samuel Crowther veio a público. Nesta edição, o saro que desde

\footnotetext{
${ }^{258}$ PAGE, Jesse. The black bishop, Samuel A. Crowther. London: Hodder and Stoughton, 1908. p.87.

${ }^{259}$ A obra que traz os relatos do Reverendo James F. Schon e do missionário Samuel A. Crowher é: SHON, J.F.; CROWTHER, S.A. Op.cit. 1842. A referência completa do livro escrito por Buxton é: BUXTON, Thomas Fowell. The African slave trade, and its remedy. London: John Murray, 1840.
} 
1864 era bispo da igreja anglicana, atualizava os leitores acerca das ações da CMS realizadas nos núcleos de cristianização fundados ao longo do Níger. Para Crowther, o intento almejado tanto por religiosos, como pela Coroa britânica seria alcançado por completo na medida em que outras ações fossem combinadas ao combate ao tráfico. Neste caso, a introdução do comércio e indústria lícitos e a propagação do cristianismo constituiriam os "meios mais seguros para elevar a África na escala das nações". ${ }^{260}$ Embora reconheça a importância de ambos escritos deixados pelo religioso, encontrei raras referências à Lagos nestes documentos. Em razão disto, optei por trabalhar com a biografia de Samuel Crowther, cuja autoria é de Jesse Page. ${ }^{261}$

A obra de Page reproduz excertos de correspondências trocadas entre 0 missionário e outros religiosos da CMS. Parte dos documentos apresentados compõe um conjunto de missivas escritas por Crowther e outros anglicanos, entre eles o reverendo Canon Henry Venn, o bispo James Johnson e o, também reverendo, J. Bradford Whiting. Neste sentido, tomando de empréstimo o pressuposto formulado pelo casal de antropólogos Comaroff, de que "as biografias são tudo, menos inocentes", considero este exemplar de literatura biográfica uma produção discursiva entretecida aos acontecimentos de sua época. ${ }^{262}$ O livro escrito por Page não foi o único a tratar da vida de

\footnotetext{
${ }^{260}$ Mudimbe trata da trajetória de Samuel Crowther em sua interessante análise acerca do discurso missionário, em: MUDIMBE, V.Y. A Invenção da África. Gnose, Filosofia e a Ordem do Conhecimento. Ramada/Luanda: Edições Pedago/Edições Mulemba, 2013, cap.III. O Poder do Discurso. Isichei também apresenta suas reflexões sobre o papel dos missionários saros no estabelecimento colonial na região da atual Nigéria em: ISICHEI, Elizabeth. A History of Nigeria. Essex: Longman, 1984, em especial o cap.11. Christianity. A mesma autora ainda publicou o resultado de seu imenso trabalho de pesquisa concentrado em entender a história do cristianismo no continente, cuja referência é: ISICHEI, Elizabeth. Op.cit., 1995. O capítulo seis - West Africa to c.1900 - é especialmente importante para o tema da participação missionária nas ações colonizadoras da Grã-Bretanha, no século XIX, na África ocidental.

${ }^{261}$ Refiro-me à obra: PAGE, Jesse. The black bishop, Samuel A. Crowther. London: Hodder and Stoughton, 1908. Também recorri aos relatórios publicados pela Church Missionary Intelligencer com o propósito de compreender a atuação da CMS em Lagos ao longo do período que compreende essa pesquisa. Tive acesso aos compêndios de notícias produzidos pela Church Missionary Intelligencer nos seguintes anos: 1860, 1867, 1872 e 1881. Quando trato dos documentos produzidos pelo próprio Crowther, estou me referindo às seguintes publicações: SCHON, J.F; CROWTHER, S.A. Journals of the Ver. James Frederick Schon and Mr. Samuel Crowther, who with the sanction of her Majesty's Government, accompanied the Expedition up the Niger, in 1841. In behalf of the CMS with appendices and map. London: Hatchard and Son, 1842 e CROWTHER, Samuel Adjai. A Charge Delivered on the Banks of the River Niger in West Africa. London: Seeley, Jackson \& Halliday, 1866.

${ }^{262}$ COMAROFF, J \& COMAROFF, J. Etnografia e imaginação histórica. Tradução de Iracema Dulley e Olivia Janequine IN Proa - Revista de Antropologia e Arte (on-line). Ano 02, vol.01, n.02, nov. 2010.p.32. Tomei o caso específico da literatura biográfica por ser este o tipo de
} 
Crowther. No entanto, a seleção desta produção em específico está ligada ao fato desta narrativa ter se popularizado entre leitores anglófonos fora do continente africano. ${ }^{263}$ Conforme informa a historiadora Nara Improta França, a primeira edição da obra assinada por Page foi lançada em Lagos, no ano de 1888. Apenas um ano depois, em 1889, uma segunda edição foi impressa, desta vez nos Estados Unidos, na cidade de Nova lorque. Em 1892, este mesmo livro foi editado em Londres. Ainda de acordo com França, esta biografia ganhou cinco edições em menos de quatro anos. Um número considerado significativo para o final do século XIX.264

Ademais, Jesse Page era membro da Royal Geographical Society, instituição cujas produções, na maioria das vezes, apoiavam a atuação do Foreign Office na Costa da Mina. Este aspecto em específico esclarece o fato desta narrativa estar permeada por argumentos em torno do sucesso das ações britânicas no combate ao tráfico, dos benefícios decorrentes da cristianização das populações da Costa da Mina e das transformações civilizadoras ocorridas após o bombardeio à cidade de Lagos, promovido no ano de 1851. De fato, a biografia escrita por Page nos informa que, no dia 12 de novembro de 1846, os missionários da CMS conseguiram chegar à Abeokuta. No entanto, a despeito dos esforços de Samuel Crowther para colocar um termo ao comércio de escravos na cidade, o missionário considerou os resultados insatisfatórios em razão da "interposição de um inimigo" às suas ações. $^{265}$

$O$ inimigo mencionado pelo religioso era ninguém menos do que 0 mercador de escravos, Domingos Martins, aliado de Akitoye (em Lagos) e de Guezo (em Ajudá) no tráfico. A atuação deste negreiro em prol do comércio de

produção com o qual trabalho nesta parte da pesquisa. No entanto, entendo que outras formas de escritura - narrativas de viagem, romance, novela, panfletos etc - também foram elaboradas a partir dos diálogos e dissensões de seus autores com sua época.

${ }^{263}$ Apenas como exemplo, podemos citar os seguintes textos biográficos a respeito de Samuel Crowther: CHILDE, A.F. Good out of evil, or The history of Adjai. London: Wertheim and MacIntosh, 1852; MACKENZIE, P.R. Inter-religious Encounters in Nigeria. S.A. Crowhter's Attitude to African Traditional Religion and Islam. Leicester: Leicester University Press, 1976 e WALLS, Andrew F. The Legacy of Samuel Ajayi Crowther. International Bulletin of Missionary Research, vol.16, n.4, jan.1992.

${ }^{264}$ FRANÇA, Nara Muniz Improta. Producing Intellectuals: Lagosian Books and Pamphlets between 1874 and 1922. Tese de doutorado. Sussex/UK: University of Sussex, 2013.p.45.

${ }^{265}$ PAGE, Jesse. Op.cit., 1908. p.91. 
cativos incluía o envio de presentes às chefias de Abeokuta "prometendo livrar os caminhos [que ligavam a cidade à costa] de bandidos, se lhe fosse permitido estabelecer o tráfico de escravos". Temendo que a instalação dos missionários na cidade pudesse comprometer seus negócios, Martins prevenia os chefes locais de que "se o cristianismo se tornar forte em Abeokuta, o comércio escravista sofreria". ${ }^{266}$ Aparentemente, este apelo do brasileiro não surtiu o efeito desejado. Na verdade, a pressão sobre o comércio ilegal de escravos se intensificou nos anos seguintes.

Em fevereiro de 1851, o cônsul britânico que vivia em Fernando Pó, John Beecroft, viajou até Badagri e Abeokuta. Em um contexto de intensificação das manobras da armada britânica e de retomada das ações do Foreign Office na Costa da Mina, Akitoye - naquele momento exilado em Badagri - recorreu a Beecroft com o propósito de obter apoio político e material para um ataque a Lagos capaz de depor Kosoko. Em relatório enviado ao Foreign Office, o cônsul informava que havia embarcado o obá destituído, suas duas esposas e mais três serviçais para Fernando Pó. Ao assumir um discurso de comprometimento com a extinção do tráfico, Akitoye pressionava por uma intervenção inglesa que lhe devolvesse o mando perdido. ${ }^{267}$

Diante do relato de Beecroft e da possibilidade de tornar Lagos um porto livre do comércio atlântico de escravos, Lord Palmerston, Foreign Secretary da Grã-Bretanha entre 1846 e 1851, enviou ao cônsul instruções acerca do modo como seriam conduzidas as ações diplomáticas em relação a Kosoko. Assim, em 21 de fevereiro de 1851, Palmerston determinava que o cônsul fizesse "saber que o governo britânico está resolvido a pôr um fim ao comércio de escravos africanos e tem os meios e o poder" para realizar esse intento. Com o objetivo de demonstrar a capacidade bélica da Grã-Bretanha, Beecroft foi orientado por seu superior a enumerar a atuação inglesa sobre outros territórios dentro da própria costa ocidental africana e fora deste continente, na

\footnotetext{
${ }^{266}$ Ibid, p.91.

267 Cf. DIKE, K.O. Op.cit., 1956, pp.5-14 e CURTIN, Phillip. Op.cit., 1973, pp. 296-298 e 314315.
} 
América espanhola, no Brasil e em Cuba. ${ }^{268}$ Ao final da missiva, o Foreign Secretary instruiu o cônsul a prevenir Kosoko da seguinte maneira:

Se o chefe mostrar disposições para recusar, vós devereis suplicar para lembrar-se que Lagos está perto do mar, e que sobre o mar há os navios e os canhões da Inglaterra; e também de que guarde em sua memória que não detém sua autoridade sem rivais, e que os chefes das tribos africanas não guardam sempre seus postos até o fim de suas vidas. ${ }^{269}$

A tomada de Lagos pelas forças britânicas também teve o apoio de missionários da CMS e da Wesleyan Missionary Society. Para muitos destes religiosos a erradicação do comércio de escravos só se completaria com a instalação do aparato colonial da Grã-Bretanha sobre pontos de tráfico ainda operantes, tal como era Lagos. Entre os missionários que pensavam desta maneira estava Samuel Crowther que, em março de 1851, partiu de Abeokuta, onde vivia desde 1846, para aquela que seria sua terceira viagem para a Inglaterra. Logo após sua chegada em Londres, no mês de agosto, o missionário encaminhou uma carta à própria rainha Victória. Nesta missiva o ex-cativo humildemente se colocou como servo da casa de Deus e de Vossa Majestade para, ao final, implorar à "bondosa rainha branca que tratasse com as pessoas da costa de Lagos que ainda prosperavam no tráfico de carne e sangue". 270

Em novembro deste mesmo ano, Crowther foi chamado para uma audiência no castelo de Windsor. Recebido pelo próprio príncipe Albert, o missionário da CMS descreveu sua trajetória desde a captura até o resgate pela marinha antitráfico britânica e sua posterior conversão ao cristianismo em Serra Leoa. Neste trecho da biografia de Crowther, Page mencionou que durante toda a narrativa de sua história de vida, o missionário indicou, por meio de um mapa publicado em uma edição do Blue Book, os locais pelos quais passou quando ainda era cativo e, mais tarde, em que esteve depois de ser

\footnotetext{
${ }^{268}$ SMITH, Robert Sydney. Op.cit., 1979, p.22.

269 Public Record Office, Londres (PRO), Foreign Office (FO) 84/858 Apud VERGER, Pierre. Op.cit., 1987, p.566. O despacho enviado por Palmerston acerca do tratado com Kosoko é comentado em: SMITH, Robert Sydney. Op.cit., 1979, p.19.

${ }^{270}$ PAGE, Jesse. Op.cit., 1908, p.100.
} 
libertado e de se converter ao cristianismo. Os Blue Books eram compilações de relatórios, esboços de mapas e dados estatísticos produzidos por funcionários ligados ao Colonial Office. Os compêndios de documentos sobre Lagos começaram a ser produzidos a partir de 1863, um ano após a cidade se tornar colônia da Grã-Bretanha. No ano de 1851, Crowther deve ter consultado o registro cartográfico incluído no Blue Book referente a Serra Leoa ou à Costa do Ouro, estes produzidos desde 1824 e 1846 , respectivamente. ${ }^{271}$

$\mathrm{Na}$ audiência de Samuel Crowther com o príncipe Albert os mapas impressos em um destes Blue Books serviram como apoio à narrativa do religioso. Este episódio foi considerado por Page uma demonstração da credibilidade das afirmações fornecidas por Crowther a respeito da situação do comércio negreiro naquele momento. No encontro com o príncipe, o missionário demonstrou um profundo conhecimento das dinâmicas do tráfico na Costa da Mina. Seu minucioso relato incluía uma crítica à prática do comércio escravista no porto de Lagos. Afinal, foi deste embarcadouro que partiu o navio negreiro que por muito pouco não atravessou o Atlântico e o encaminhou a uma vida de escravidão nas Américas. Depois da breve e emocionante exposição, o príncipe Albert expressou sua opinião a respeito das futuras ações da Grã-Bretanha sobre este conhecido embarcadouro negreiro. Segundo a biografia de Crowther, o príncipe teria afirmado: "Lagos deve ser demolida por todos os meios". ${ }^{272}$

No mês seguinte, em 18 de dezembro, Lord Palmerston enviou ao missionário uma carta em que agradecia as "importantes e interessantes informações relativas à Abeokuta" fornecidas durante uma reunião realizada em sua casa em agosto daquele mesmo ano. Na missiva Palmerston destacava os interesses britânicos "no bem estar da nação egba e na

\footnotetext{
${ }^{271}$ Os Blue Books relativos a Serra Leoa foram produzidos entre 1824 e 1943. A coleção referente à Costa do Ouro reúne documentos elaborados entre os anos de 1846 e 1939. Os registros sobre Lagos estão reunidos nos Blue Books da Nigéria e se referem ao período de 1863 a 1845. A extensa coleção de Blue Books produzidos pelo Colonial Office foi digitalizada e está disponível no site British Online Archives (www.britishonlinearchives.co.uk). Além dos compêndios citados é possível também encontrar Blue Books relativos às seguintes localidades: Basutolândia (Lesoto) 1926-1946; Cabo da Boa Esperança 1821-1909; Gambia 1828-1945; Kenia 1901-1946; Niassalândia 1904-1938; Rodésia do Norte 1924-1948; Rodésia do Sul 1904-1953; Tanganica 1921-1948; Uganda 1901-1945 e Zanzibar 1913-1947.

${ }^{272}$ PAGE, Jesse. Op.cit., 1908, p.105.
} 
comunidade estabelecida em Abeokuta, cidade que parece ser o centro a partir do qual as luzes do cristianismo e da civilização poderiam se espalhar sobre os países vizinhos". A correspondência era uma resposta clara à proposição de Crowther de, num prazo de seis anos, transformar o cristianismo "na religião nacional" de Lagos. ${ }^{273}$

\subsection{O Parlamento britânico e o combate ao tráfico}

É verdadeiro que os habitantes da África se encontram na mais profunda ignorância e superstição, mas há ainda entre eles sintomas redentores suficientes, embora tênues, para provar que a falha não está em sua natureza, mas em sua condição. ${ }^{274}$

Os missionários instalados em Abeokuta e Badagri não foram os únicos a pressionar a Coroa britânica por uma atuação mais incisiva da armada antitráfico em Lagos. Em décadas anteriores ao bombardeio de 1851 esta era uma questão também debatida por parlamentares em Londres. Afinal, embora o tráfico nas colônias inglesas já estivesse abolido desde 1807, movimentos contrários a essa atividade se queixavam da ineficiência das operações realizadas pelas esquadras que patrulhavam a Costa da Mina e o litoral das Américas. Nesta época, um dos líderes que alcançou maior visibilidade na luta contra o comércio escravista atlântico foi Thomas Fowell Buxton. Em 1824, Thomas Buxton sucedeu William Wilberforce na campanha parlamentar pelo término da escravidão entre os súditos britânicos, contribuindo para a propagação do movimento entre as camadas populares inglesas. ${ }^{275}$

\footnotetext{
${ }^{273}$ PAGE, Jesse. Op.cit., 1908, p.102. Nesta carta, Lord Palmerston também agradecia a visita de Samuel Crowther à sua casa, em agosto de 1851.

274 "It is true that the inhabitants of Africa are in the very depths of ignorance and superstition, but, still, there are amongst them redeeming symptoms, however slight, sufficient to prove that the fault is not in their nature, but in their condition". BUXTON, Thomas Fowell. The African slave trade, and its remedy. London: John Murray, 1840.p.457.

${ }^{275}$ William Wilberforce também é considerado uma liderança no movimento contra o tráfico de escravos. De acordo com sua biografia, Wilberforce faleceu em julho de 1833, pouco depois da Slavery Abolition Act ser aprovada. WILBERFORCE, Robert Isaac; WILBERFORCE, Samuel. The life of William Wilberforce. Philadelphia: Perkins \& Marvin, 1839.
} 
Mesmo depois da promulgação da Abolition of the Slave Trade Act (1807) e da Slavery Abolition Act (1833), Buxton continuou a atuar em favor da supressão internacional das atividades ligadas ao tráfico. De acordo com Gallagher, em 1835 o parlamentar apresentou uma resolução que equiparava o tráfico à pirataria. Nos dois anos seguintes, em 1836 e no início de 1837, ele elaborou um relatório acerca das populações africanas que viviam nas colônias britânicas. Sua carreira parlamentar foi abreviada quando perdeu as eleições, em junho de 1837. No entanto, Buxton não se retirou do debate político em torno da questão do comércio negreiro pelo Atlântico. Segundo a biografia escrita por seu filho, Charles Buxton, o ex-parlamentar se manteve atuante em sociedades britânicas que apoiavam a extinção da atividade. Entre as associações de maior destaque que tiveram Buxton entre seus membros estavam a African Civilization Society, a Church Missionary Society e o Comittee of the British and Foreign Anti-Slavery Society. No caso específico da CMS, importa aqui ressaltar que Buxton atuou como presidente desta sociedade por mais de cinquenta anos, além de ocupar o cargo de tesoureiro por outros nove anos (de $1886-1895) .{ }^{276}$

Depois de ter perdido as eleições de 1837, o ex-membro do Parlamento de Londres publicou sua obra de maior fôlego e impacto, The African Slave Trade, and its Remedy. Editado pela primeira vez em 1839, o livro de Thomas Buxton foi recebido como um manifesto contra o que ele mesmo considerou ser "a falência dos nossos esforços de supressão" do tráfico de escravos. ${ }^{277} \mathrm{Na}$ primeira versão, intitulada apenas como The African Slave Trade, o líder abolicionista apontou os principais destinos para onde se encaminhavam os cativos africanos, teceu críticas em relação à mortalidade decorrente de todo o processo de escravização e indicou quais eram as cidades africanas que tinham sua economia sustentada pelo comércio negreiro. ${ }^{278}$

\footnotetext{
${ }^{276}$ Respectivamente: GALLAGHER, J. Fowell Buxton and the New African Policy, 1838-1842, Cambridge Historical Journal, vol.10, No. 1, 1950, pp.36-58, BUXTON, Charles. Memoirs of Sir Thomas Fowell Buxton. 3a ed. London: John Murray, 1849 e RUSSEL, George W.E. Lady Victoria Buxton, a memoir with some account of her husband. London: Longmans, Green and Co., 1919, p.133.

${ }^{277}$ BUXTON, Thomas Fowell. Op.cit, 1840. pp.III-IV.

278 Os impactos da obra de Buxton foram analisados com maior profundidade pelas seguintes publicações: MANN, K. Op.cit. 2007,p.87 e GALLAGHER, J. Op.cit.,1950, p.40. Nos registros deixados pelo missionário Samuel Crowther e pelo governador de Lagos Cornelius Alfred
} 
No ano seguinte, em 1840, a obra de Buxton foi novamente impressa com quase o dobro do número de páginas da edição anterior. Em nota à segunda edição, Buxton advertia que sua intenção inicial era imprimir dois volumes em separado: The African Slave Trade, e outro, The Remedy. No entanto, sem explicar as razões que levaram à mudança de planos, o autor lançou uma segunda versão unindo as duas produções. Nesta publicação Buxton acrescentou uma cuidadosa argumentação acerca de como a GrãBretanha deveria atuar na extinção definitiva do comércio atlântico de escravos. Para o ex-parlamentar, os esforços diplomáticos e o controle naval, operados pela marinha britânica, se mostraram ineficientes em seu propósito de acabar com o mercado atlântico de escravos. Afinal, até aquele momento, o foco das preocupações dos agentes de repressão ao tráfico eram os negreiros e os donos de escravos. De acordo com Buxton, o "remédio" para a supressão definitiva desta atividade estava na África. Nesta perspectiva, o autor defendia que

a primeira coisa a ser feita seria colocar todos os impedimentos possíveis no caminho do comércio de escravos, tornando-o mais precário e menos lucrativo do que é até o momento. ${ }^{279}$

Para que esta intenção se realizasse, o esquadrão antitráfico deveria concentrar todo o seu efetivo na vigilância apenas da costa africana, sem dividir a armada em ações de controle nas Américas. Além disso, a eficiência das atividades navais britânicas seria ampliada se o número de embarcações aumentasse e fosse reforçado pelo acréscimo de vapores aos esquadrões. ${ }^{280}$ Estas medidas deveriam ser acompanhadas por uma segunda providência: a assinatura de tratados antitráfico com chefias africanas. Neste ponto, Buxton reconhecia a possibilidade de encontrar "grande oposição dos chefes da

Moloney podemos encontrar algumas citações das ideias de Buxton. As referências completas destes documentos são: SCHON, J.F.; CROWTHER, S.A. Journals of the Rev. James Frederick Schon and Mr. Samuel Crowther, who, with the sanction of Her Majesty's Government, accompanied the Expedition up the Niger, in 1841.In behalf of the Church Missionary Society. London: Hatchard and Son; Nisbet and Co.; Seeleys, 1842. p.349 e MOLONEY, Cornelius Alfred. Correspondence. Affair on the West Coast of Africa. The Journal of the Manchester Geographical Society. Vol.V, Manchester: The Manchester Geographical Sciety, 1889. p.272.

${ }_{279}$ BUXTON, Thomas F. Op. cit. 1840,p.283.

${ }^{280} \mathrm{Ibid}$, p. 283-285. 
costa". No entanto, mesmo supondo que "o poder destes chefes foi muito exagerado" por viajantes europeus que estiveram nesta parte da África, o autor sugeriu "medidas preparatórias" para a assinatura de tais tratados. ${ }^{281}$

A primeira destas medidas se referia ao "aumento da força naval empregada na supressão do comércio de escravos e concentração desta força na costa da África, formando então uma cadeia de embarcações desde a Gâmbia até Angola”. Intensificando as operações da armada britânica na costa ocidental africana, Buxton contava com a ampliação da eficácia das ações de vigilância e repressão ao tráfico. Como consequência do processo de desestruturação da principal atividade comercial de alguns portos negreiros, o autor também esperava pressionar chefias do interior a firmarem tratados pela extinção do tráfico e adoção do comércio legítimo. Neste sentido, Buxton sugeria como segunda "medida preparatória", a assinatura de

Uma cadeia de tratados com os poderes nativos no interior, obrigando-os a agirem em conformidade conosco, a suprimir o comércio de escravos em seus próprios territórios, a impedir que escravos sejam carregados por seus domínios e, ao mesmo tempo, a fornecer toda a facilidade e proteção necessárias para o transporte de mercadorias legítimas. ${ }^{282}$

Ao propor a assinatura de tratados com chefias estabelecidas mais ao interior, Buxton expandiu o foco das preocupações antitráfico para o continente. A partir desta perspectiva o parlamentar formulou uma consistente argumentação em que considerava ser tarefa da Grã-Bretanha "suscitar e elevar a mente nativa". Para isto, o comércio legítimo e a agricultura ofereceriam "fontes de riqueza mais amplas do que aquelas derivadas do comércio humano". Nesse sentido, embora considerasse os africanos, em geral, como indivíduos num estado de "profunda ignorância e superstição", sua obra culpabilizava o tráfico por esta situação. Na perspectiva de Buxton, a África "ocuparia seu lugar entre as nações civilizadas e cristãs" se missionários e comerciantes de bens lícitos atuassem na promoção dos princípios morais do

\footnotetext{
${ }^{281}$ BUXTON, Thomas F. Op. cit. 1840, p.290 e GALLAGHER, J. Op.cit, 1950, p.43.

282 Ibid, p.299.
} 
cristianismo e na disseminação da produção de bens agrícolas que seriam vendidos para Europa. ${ }^{283}$

Segundo Mann, embora as ideias apresentadas em The African Slave Trade, and its Remedy não fossem originais, a obra de Buxton teve o mérito de sintetizar as principais correntes do movimento antitráfico de sua época. Para o ex-parlamentar, as únicas formas de incentivo à supressão do tráfico atlântico estavam na promoção do comércio legítimo, no apoio à produção agrícola e na cristianização, ações a partir das quais o continente africano seria encaminhado ao progresso material e moral. Num momento em que, nas palavras de Mann, "as ideias sobre África não eram nem uniformes, nem politicamente neutras", as proposições de Buxton acerca de como extinguir o comércio humano ganharam maior visibilidade por apresentarem interesses materiais e morais como congruentes. No entanto, esta não era uma perspectiva unânime dentro do Parlamento britânico. Gallagher lembra que, na década de 1840, alguns setores do governo britânico se opunham à anexação de novas porções do território africano. Este mesmo pesquisador também adverte que desde 1824 os tratados expansionistas firmados com outros povos estavam proibidos na Inglaterra. Para os parlamentares contrários a este aspecto da proposta de Buxton "o império era grande, mas a receita não era; novas colônias significavam novas contas." 284

\subsection{O retorno de Akitoye à Lagos}

(...) a conduta de Lagos em relação aos assuntos ingleses criou motivos inquestionáveis para a guerra, e nunca houve uma guerra mais justa, ou mais consagrada pelas circunstâncias peculiares ligadas a ela. ${ }^{285}$

Aparentemente, as ideias de Thomas Buxton saíram vitoriosas deste debate e influenciaram as decisões políticas tomadas em relação à deposição

\footnotetext{
${ }^{283}$ BUXTON, Thomas F. Op. cit., p.338, 457 e 458, respectivamente.

${ }^{284}$ MANN, Kristin. Op.cit. 2007, p.89 e GALLAGHER, J. Op.cit., 1950, p.46.

285 "(...) the conduct of Lagos towards English subjects created in itself an unquestionable cause of war, and never was an act of war more just, or more hallowed by the peculiar circumstances connected with it." Excerto de The Destruction of Lagos. London: James Ridgway, 1852. p. 21.[anônimo]
} 
de Kosoko e à instalação de Akitoye como obá de Lagos. Em novembro de 1851, antes das tropas inglesas iniciarem o bombardeio sobre a ilha, Beecroft seguiu em direção à cidade com o propósito de firmar com Kosoko um tratado antitráfico. Logo que atracou numa ponta da praia, acompanhado por dez embarcações da armada britânica, o cônsul recebeu uma mensagem enviada diretamente pelo obá. Nela havia uma advertência: "se fôssemos em direção de Lagos com 10 barcos, atirariam em nós". Após argumentar sem sucesso junto aos dois interlocutores brasileiros enviados para acompanhar a comitiva inglesa - o já comentado Marcos Borges Ferras e outro negreiro conhecido apenas pelo nome de Nobre - o cônsul cedeu à condição imposta e prosseguiu acompanhado somente por duas naus. Uma vez em Lagos, Beecroft e sua escolta foram conduzidos à casa do traficante brasileiro Marcos Borges Ferras. Ali permaneceram por volta de duas horas, a espera de autorização para uma audiência com o obá. Depois disto, foram levados até Kosoko, que os recebeu "rodeado de pessoas armadas". Impondo um limite ao ingresso da marinha britânica na cidade, assim como obrigando o cônsul a aguardar até que fosse permitida sua entrada no igá e recebendo-o cercado por suas forças armadas, Kosoko colocava em ação os recursos simbólicos e concretos que estavam ao seu alcance para definir sua posição de poder e limitar um ataque surpresa à cidade. ${ }^{286}$

Em companhia dos dois interlocutores brasileiros, Beecroft sondou o obá acerca da possibilidade de Lagos firmar junto à Coroa britânica um tratado que garantiria a supressão do tráfico atlântico de escravos em seu território. Como resposta, Kosoko declarou não ser seu próprio senhor, mas um dependente do obá do Benim. Este argumento pode ser compreendido como uma referência à relação que Lagos mantinha com o Benim desde a primeira metade do século XVI. Relembro que, por volta de 1500, a ilha foi ocupada por forças do obá Orhogbua. O domínio do obá do Benim sobre o território lagosiano incorporou

\footnotetext{
${ }^{286}$ Public Record Office, Londres (PRO), Foreign Office (FO) 84/858 apud VERGER, Pierre. Op.cit., 1987, p.571. Uma descrição deste encontro entre Beecroft e Kosoko também pode ser lida em: SILVA, Alberto da Costa e.Op.cit., 2003, pp.127-128 e SMITH, Robert. Op.cit. 1978, pp.24-25.
} 
os chefes ilejos, considerados os "senhores da terra", destacados pelo uso do kerevesi, uma espécie de gorro branco. ${ }^{287}$

A manutenção da posição dos ilejos, indivíduos detentores de direitos específicos sobre a pesca e a ocupação das terras, parece ter garantido o equilíbrio necessário para que Orhogbua introduzisse mudanças na organização política de Lagos. Tais mudanças incluíam o acréscimo das chefias benins do Eletu Odibo e do Asogbon. Como vimos, uma das atribuições do Eletu Odibo era a escolha do obá que ocuparia o mando na cidade. Desta forma, quando Kosoko se apresentou a Beecroft como um obá subordinado às decisões do Benim não revelou os caminhos percorridos até a conquista da posição que ocupava naquele momento. Afinal, seu mando não havia sido indicado pelo Eletu Odibo, conforme a tradição determinava. Ao invés disto, o autonomeado obá de Lagos havia assassinado o poderoso aliado de Akitoye e tomado à força o poder da cidade. Em vista deste fato, a insistência do cônsul britânico em ir até o Benim para que o tratado fosse firmado deve ter contrariado o obá de Lagos. Desta forma, por meio de seu principal ibigá, Oshodi Tapa, Kosoko repeliu a proposta declarando "que não queria assinar nenhum tratado com os ingleses e não desejava sua amizade". ${ }^{288}$

A resposta à negativa de Kosoko apresentada pelos enviados da rainha Victória aconteceu logo depois de Beecroft consultar Frederick Forbes que, naquele momento, ocupava o posto de oficial superior da armada antitráfico estabelecida no consulado dos Golfos do Benim e de Biafra. Em uma carta enviada ao integrante da marinha britânica, o cônsul buscava se informar a respeito das forças disponíveis para uma rápida represália à Lagos. Em novembro de 1851, um despacho endereçado ao cônsul e expedido pelo Foreign Office autorizou o ingresso das tropas britânicas na cidade,

\footnotetext{
${ }^{287}$ Sobre os processos históricos que constituíram a relação entre Lagos e Benim, sugiro: ADERIBIGBE, A.B. Early History of Lagos to About 1850 in ADERIBIGBE, A.Op.cit., 1975 e MANN, Kristin. Op.cit., 2007, pp.44-50. A respeito das disputas envolvendo o mando em Lagos, indico: FALOLA, Toyin; OGUNTOMISIN, G.O.Op.cit., 2001, Cap.8 Prince Kosoko.

${ }_{288}$ Public Record Office, Londres (PRO), Foreign Office (FO) 84/858 apud VERGER, Pierre. Op.cit., 1987, p.571.
} 
acrescentando que a ação deveria ocorrer "com todas as forças que pudessem ser reunidas". 289

\section{Mapa 3: Cidade de Lagos, rede de lagoas, estuários e canais do entorno}

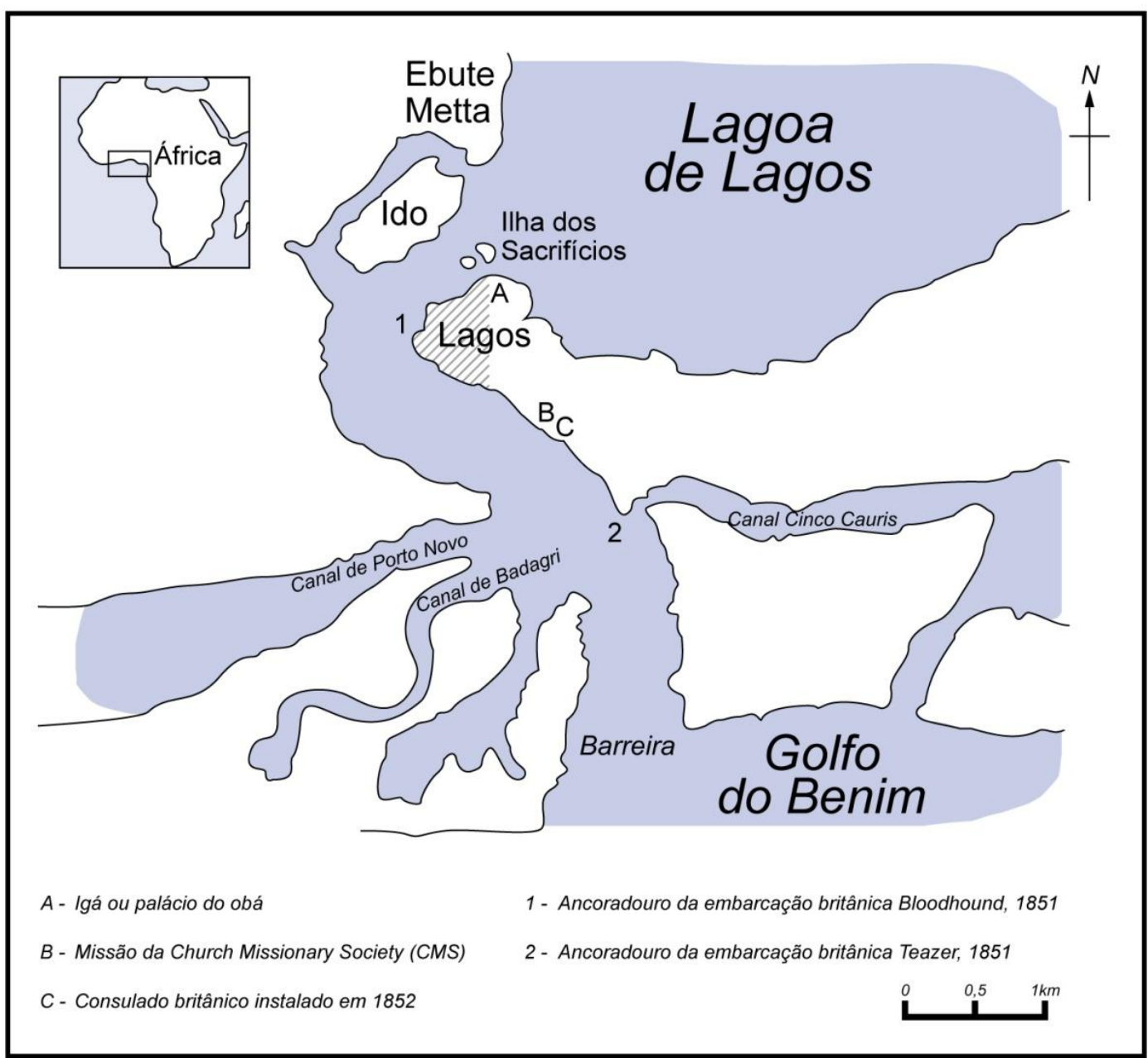

Fonte: Mapa adaptado de SMITH, Robert Sydney. The Lagos Consulate, 1851-1861. Londres: Macmillan and The University of Lagos Press, 1978, 1978, p.29.

Após a autorização direta de Lord Palmerston, aconteceram dois ataques à Lagos. O primeiro ocorreu ainda em 25 de novembro de 1851, logo depois da audiência de Beecroft com Kosoko. Nesta ofensiva inicial ficaram destruídos os barracões de três traficantes brasileiros: Marcos Borges Ferras,

\footnotetext{
${ }^{289}$ SMITH, Robert Sydney. The Lagos Consulate, 1851-1861. Londres: Macmillan and The University of Lagos Press, 1979, p.25.
} 
Nobre e Lima. ${ }^{290}$ Depois da morte de dois oficiais britânicos e de mais dez outros feridos, as tropas da Grã-Bretanha se retiraram do confronto. Entretanto, pouco menos de um mês mais tarde, um segundo assalto da armada da rainha Victória obteve maior êxito. Em 22 de dezembro, um pequeno grupo de guerreiros leais a Akitoye deixou Badagri e atacou uma localidade próxima a Lagos: Ajido. Era o anúncio de um conflito maior que estava por acontecer. Dois dias depois, na véspera de Natal, as embarcações Bloodhound, Teazer e Victoria ultrapassaram a barreira que permitia o acesso à rede de canais paralelos à costa. Como é possível visualizar no mapa 3 - Cidade de Lagos, rede de lagoas, estuários e canais do entorno - este ponto era considerado estratégico, pois limitava o ingresso aos principais canais que circundavam a cidade. Ao longo do dia 24 de dezembro, e no seguinte, a armada britânica permaneceu abrigada em suas naus, enquanto canhões atiravam contra Lagos.

Apenas no dia 26 de dezembro, as tropas inglesas atracaram na porção norte da ilha, próxima ao igá. No entanto, um rápido e eficiente contra-ataque das forças de Kosoko fez a ofensiva retornar às embarcações. No dia posterior, os três navios iniciaram, ao mesmo tempo, um intenso bombardeio que só foi suspenso quando um dos tiros alcançou o depósito de munição do obá, eliminando-o por completo. Sem condições de resistir ao ataque britânico, Kosoko e seus seguidores - dentre os quais, os traficantes brasileiros Nobre, Lima e Ferras - se retiraram para a cidade ijebu de Epe. Em seguida, no dia 28 de dezembro, Beecroft e alguns de seus oficiais desembarcaram na ilha, a fim de realizarem uma inspeção no que havia restado da cidade. Em 29 de dezembro, Akitoye foi reconduzido à morada do obá, o igá, que estava parcialmente destruído pelos bombardeios. Poucos dias mais tarde, em primeiro de janeiro de 1852, Akitoye e dois outros chefes subiram a bordo da nau Penelope para a cerimônia de assinatura do tratado que tornava Lagos protetorado da Grã-Bretanha. ${ }^{291}$

O tratado era um documento impresso e seguia o padrão de outros acordos em torno da abolição do tráfico firmados ao longo da Costa da Mina.

\footnotetext{
${ }^{290}$ Cf. SILVA, Alberto da Costa e. Op.cit., 2003,p.128.

${ }^{291}$ SMITH, Robert. Op.cit., 1979, p.30-31.
} 
Neste documento ficavam definidos os limites e obrigações a serem respeitadas pelo obá restabelecido. Composto por nove artigos, este acordo bania o tráfico atlântico de escravos, proibia que negreiros continuassem vivendo na cidade e concedia $o$ prazo de três meses para que estes mercadores convertessem seus negócios ao comércio de bens lícitos, do contrário teriam suas casas e armazéns destruídos. Neste sentido, os cinco primeiros artigos deste documento salvaguardavam a atuação britânica no combate ao tráfico nos seguintes termos:

Artigo 1‥ A exportação de escravos para países estrangeiros está abolida para sempre dos territórios do rei e chefes de Lagos. O rei e os chefes de Lagos se comprometem a elaborar e a proclamar uma lei proibindo que qualquer um de seus súditos, ou qualquer indivíduo sob sua jurisdição, venda ou auxilie a venda de algum escravo a ser transportado a um país estrangeiro. O rei e os chefes de Lagos prometem aplicar severas punições a qualquer pessoa que não cumprir esta lei.

Artigo $2^{\circ}$. Nenhum europeu ou outra pessoa que se dedique a qualquer atividade ligada ao tráfico estará autorizada a residir dentro do território do rei e dos chefes de Lagos. Nenhuma casa, ou armazém ou construção poderá ser erguida com o propósito de servir ao tráfico de escravos dentro do território do rei e dos chefes de Lagos. E, se algumas destas casas, armazéns ou construções for erguida no futuro, e nenhum rei ou chefe de Lagos se mostrar apto a destruí-las, elas serão demolidas por oficiais britânicos empregados na supressão do tráfico.

Artigo $3^{\circ}$. Se, no futuro, o tráfico de escravos voltar a ser praticado no território do rei e dos chefes de Lagos, este poderá ser destruído pela Grã-Bretanha à força. Os oficiais britânicos poderão capturar as embarcações de Lagos em qualquer lugar que estejam a negociar escravos e o rei e chefes de Lagos estarão sujeitos à severa censura da rainha da Inglaterra.

Artigo 4․ Os escravos prontos para exportação deverão ser entregues a algum oficial britânico devidamente autorizado para recebê-los. Eles serão levados para a colônia inglesa [Serra Leoa] e ali libertados. Todos os barracões e 
construções exclusivamente utilizadas no tráfico escravista deverão ser imediatamente destruídos.

Artigo $5^{\circ}$. Europeus e outras pessoas, atualmente engajados no tráfico de escravos, serão expulsos do país. Suas casas, armazéns ou construções até então empregados como fábricas de escravos, se não forem convertidos em negócios lícitos, em um período de três meses da assinatura deste acordo, serão destruídos. ${ }^{292}$

Segundo Mann, os cinco primeiros artigos levaram à saída em massa de traficantes brasileiros estabelecidos na cidade. Para a historiadora, este aspecto transformou de maneira significativa a composição da população brasileira, que se tornou, em sua maioria, constituída por africanos libertos e seus descendentes que já viviam em Lagos desde a primeira metade do século $\mathrm{XIX}^{293}$

Além dos artigos referentes ao comércio de peças cativas, o acordo também previa a supressão de sacrifícios humanos e assegurava a proteção do trabalho dos missionários. Este último item determinava o amparo dos religiosos "de qualquer nação ou país que, seguindo a vocação de disseminar o conhecimento e a doutrina do cristianismo, estendem os benefícios da civilização pelo território do rei e dos chefes de Lagos." Entendendo o proselitismo cristão e a propagação da civilização como congruentes, o Foreign Office dava sinais da importância das ações missionárias na instalação do protetorado lagosiano. E, incentivados pela possibilidade de conversão do que até então era o principal porto escravista da Costa da Mina, os primeiros missionários da CMS, liderados pelo britânico Charles Gollmer e pelo saro James White, começaram a desembarcar na cidade já no ano de 1852 . $^{294}$

\footnotetext{
292 PROL, 1862, N.1, Treaty with the King and Chiefs of Lagos, 1 de janeiro de 1852 . Este mesmo tratado foi reproduzido por Smith e pode ser lido na íntegra em: SMITH. Robert. Op.cit., 1979, Apêndice A: Treaty between Great Britain and Lagos, 1 January, 1852, pp.135-137. Pierre Verger também transcreveu trechos dos sete primeiros artigos do acordo de $1852 \mathrm{em}$ sua obra: VERGER, Pierre. Op.cit. 1987, pp.573-574.

${ }^{293}$ MANN, Kristin. Op. Cit, 2010, p.360, nota 56.

294 A biografia de Charles Gollmer foi escrita por seu filho mais velho Charles Henry Gollmer. De acordo com esta publicação, os missionários da CMS teriam desembarcado em Lagos no
} 
No entanto, o tratado firmado com Akitoye não versava apenas sobre o fim do tráfico e a instalação de missionários e comerciantes europeus em Lagos. O último artigo, de número nove, garantia a participação da França no acordo estabelecido com o obá restituído ao mando. Neste trecho do documento ficava determinado que:

Pelo presente é expressamente reservado ao Governo da França tomar parte deste Tratado, se julgar necessário, de acordo com o previsto no artigo $5^{\circ}$ da Convenção entre Sua Majestade e o Rei dos franceses pela supressão do tráfico de escravos, assinada em Londres, 22 de maio de 1845 . $^{295}$

Em meados do século XIX, a Grã-Bretanha atuava em prol da erradicação do tráfico atlântico também junto aos países europeus. Em razão disto, o tratado de 1852 convidava a França a assumir sua parte neste esforço. Mesmo em um contexto de pressão internacional pelo fim do comércio negreiro, as notícias das ações tomadas pelo esquadrão da rainha Victoria não tiveram de imediato uma recepção positiva. Além disto, as informações enviadas pelo consulado dos Golfos do Benim e de Biafra demoraram a chegar até o Foreign Office, em Londres. Quando o relatório acerca do malsucedido ataque contra Kosoko, efetuado em 25 de novembro de 1851 foi divulgado, Lord Palmerston já havia sido demitido do cargo de Foreign Secretary. Neste contexto, o novo indicado, Lord Malmesbury, desferiu duras críticas ao insucesso da primeira incursão realizada pela armada inglesa. No entanto, a descompostura que se seguiu à derrota britânica nesta investida foi logo substituída por congratulações. Meses depois, Malmesbury recebeu informações acerca da deposição de Kosoko e da assinatura do tratado que colocava Lagos na condição de protetorado britânico. Em razão deste feito,

dia 10 de janeiro de 1852. Esta data marcaria a celebração do primeiro ofício religioso realizado para cerca de duzentas pessoas. GOLLMER, Charles Henry. Charles Andrew Gollmer, His Life and Missionary Labours in West Africa. 2a ed., London: Hodder and Soughton. 1889, Chapter VI: Occupation of Lagos. Este episódio é também mencionado em: NEWBURY, C.W. The Western Salve Coast and its Rulers. European trade and administration among the Yoruba and adja-speaking peoples of South-Western Nigeria Southern Dahomey and Togo. Oxford: Clarendon Press, 1961, pp.56-57.

${ }^{295}$ PROL, 1862, N.1, Treaty with the King and Chiefs of Lagos, signed January 1, 1852. 
uma carta endereçada ao cônsul Beecroft e ao oficial naval Bruce felicitava ambos os súditos pelo feito. ${ }^{296}$

Neste mesmo ano, em 1852, foi publicado um panfleto intitulado The destruction of Lagos. Aparentemente, este impresso teve o propósito de sanar os possíveis questionamentos a respeito das ações da armada britânica tomadas neste porto. Sem autoria e com pouco mais de vinte páginas, a publicação se baseava em uma série de citações retiradas de manifestos antitráfico produzidos por oficiais britânicos e missionários cristãos. Os excertos recortados de publicações autorais parecem ter sido editados, reformulados e justapostos com o intuito de sustentar a tomada britânica da cidade. ${ }^{297}$ Neste sentido, os registros publicados em relatórios produzidos pelos religiosos Crowther e Townsend e os escritos deixados por Forbes, Beecroft e Clapperton foram fundidos de maneira a compor uma argumentação coerente e em concordância com a ocupação de Lagos. Ao apoiar o bombardeio da cidade, considerada "um ninho de pirataria e pilhagem", o documento retomava o discurso acerca da persistência do tráfico. Além deste aspecto, o folheto também fazia referência à abnegação dos religiosos que, "distantes da proteção britânica", fundaram missões em Abeokuta e Badagri, "devotando suas vidas à Providência e abrindo o coração da África”. Estes dois pontos fundamentavam a argumentação do libelo, que sustentava:

a conduta de Lagos em relação aos assuntos ingleses criou motivos inquestionáveis para a guerra, e nunca houve uma guerra mais justa, ou mais consagrada pelas circunstâncias peculiares ligadas à ela. ${ }^{298}$

Entre as "circunstâncias peculiares" referidas no folheto estavam: a destruição de propriedades e o assassinato de ingleses em Badagri, o

\footnotetext{
${ }^{296}$ De acordo com Smith, Lord Palmerston foi demitido em dezembro de 1851, depois de prematuramente apoiar o golpe de Napoleão, na França. SMITH. Robert. Op.cit., 1979, p.34.

297 A ideia de que excertos de cartas escritas por evangelistas foram reformulados, com o propósito de construir um discurso político uniforme a partir de textos cujos conteúdos guardavam entre si dissensões, está presente no artigo escrito pelo casal Comaroff. A publicação a que me refiro trata em específico das produções de missionários sul-africanos. COMAROFF, J \& COMAROFF, J. Etnografia e imaginação histórica. Tradução de Iracema Dulley e Olivia Janequine IN Proa - Revista de Antropologia e Arte (on-line). Ano 02, vol.01, n.02, nov. 2010.p.43.

${ }^{298}$ The Destruction of Lagos. London: James Ridgway, 1852. p. 21.[anônimo]
} 
tratamento conferido aos africanos libertos que deixavam Serra Leoa para retornarem à região e, por fim, os indícios frequentes de compra e venda destes libertos. ${ }^{299}$ De acordo com o panfleto, a eficiência na promoção do comércio legítimo em Abeokuta se ampliaria com a tomada de Lagos. Afinal, a ilha era considerada "a chave para o país", pois era entendida como "salubre e bem situada para o comércio". Neste sentido, o impresso defendia que a ofensiva contra a cidade teria como consequências diretas a abertura do rio Ogun e a ampliação da ação dos missionários para além de Abeokuta. Ademais, o documento fazia uso de parte dos argumentos sistematizados por Buxton, em The African slave trade and its remedy. Afinal, ao afirmar que "o comércio de escravos seria rapidamente substituído pela exportação de algodão e de vários outros produtos de valor desta parte fértil da África", o panfleto sintetizava as impressões indicadas na obra do ex-parlamentar, traduzindo o senso comum deste período. ${ }^{300}$

No mês seguinte ao estabelecimento do protetorado britânico em Lagos, Akitoye e seus chefes firmaram um acordo comercial com mercadores europeus, em sua maioria britânicos. Desta forma, em 28 de fevereiro de 1852, o recém-instalado obá anuiu ao processo de inserção em seu território de negociantes e representantes comerciais de firmas europeias interessadas no comércio de bens lícitos, principalmente no de azeite de dendê. Segundo o acordo, os produtos importados que chegassem a Lagos seriam taxados em $3 \%$ e os bens exportados em $2 \%$. As somas apuradas com estas arrecadações seriam integralmente pagas ao obá. Em troca, Akitoye protegeria comerciantes e seus bens de ataques e pilhagens de inimigos e/ou concorrentes. $O$ documento também definia a porção sul da ilha - conhecida como Canal dos Cinco Cauris (ou Five Cowry Creek) - como o espaço em que estes mercadores poderiam construir depósitos e atracadouros. ${ }^{301}$ Além disto, qualquer suspensão do comércio lícito deveria ser compensada pelo próprio

\footnotetext{
299 Smith se refere ao incêndio no armazém da companhia pertencente ao inglês Hutton e em dois componds de saros, ambos em Badagri. O fogo teria sido provocado por aliados de Kosoko e causou a morte de um britânico. SMITH, Robert. Op.cit., 1979, p. 23.

300 The Destruction of Lagos. London: James Ridgway, 1852. pp. 9, 21 e 22 (respectivamente).

${ }^{301}$ PROL, 1862, N.2, Agreement with King and Chiefs of Lagos, signed February 28, 1852.

Para uma melhor compreensão a respeito da localização da porção requisitada pelos comerciantes europeus para se instalar na ilha e de outros pontos do entorno de Lagos mencionados nesse capítulo, consulte: Mapa 3: Cidade de Lagos, rede de lagoas, estuários e canais do entorno, p.148.
} 
obá que estava obrigado a efetuar pagamentos em azeite de dendê aos mercadores europeus lesados pela interrupção de suas atividades. Era ainda responsabilidade de Akitoye impor o pagamento das dívidas contraídas por intermediários lagosianos, ficando a cargo do obá presidir um comitê, formado por lagosianos e europeus, para arbitrar disputas em torno dos negócios praticados sob seus domínios. De acordo com Mann, até o final do ano de 1852, um mercador sardenho, um alemão e três britânicos já haviam iniciado suas atividades em solo lagosiano. Dois anos depois, em 1854, a empresa francesa de Victor Régis, conhecida como Casa Régis, juntou-se às demais firmas europeias da cidade. ${ }^{302}$ Durante dois anos os itens acordados entre as partes parecem ter sido observados. Entretanto, após a morte de Akitoye, em 1853, as bases das relações comerciais entre mercadores locais e europeus tiveram de ser renegociadas com o novo obá, Docemo. ${ }^{303}$

\subsection{Lagos: Protetorado da Grã-Bretanha (1851-1861)}

Eu posso assegurar a você a partir do meu conhecimento, e do reconhecimento expresso por muitos chefes nesta parte do país, que a abolição do comércio de escravos em Lagos, que eles esperam que também aconteça em Ajudá, foi maior a libertação já feita em benefício deste país. ${ }^{304}$

Os tratados e acordos comerciais instituídos entre Akitoye, representantes do governo britânico e de firmas europeias constituíram um ponto de partida para que localidades vizinhas à Lagos cedessem às pressões da Grã-Bretanha em torno da assinatura de acordos semelhantes. No contar

\footnotetext{
${ }^{302}$ MANN, Kristin. Op.cit., 2010, p.96. Segundo Newbury, já nos primeiros meses depois de Lagos se tornar protetorado, se instalaram na cidade três prósperos agentes comerciais britânicos que atuavam em Badagri: William McCoskry (um dos envolvidos na tomada da cidade em 1861), Legreseley e J. Sandeman. Em 1853, a firma hamburguesa O'Swald \& Co. se fixou em Lagos. No ano de 1856, o sardenho Giambattista Scala, dois alemães - Meyer e Johannsen - e diversos empregados da Casa Régis também passaram a residir na cidade. NEWBURY, C.W. Op.cit, 1961, p.57.

${ }^{303}$ Cf. SMITH, Robert. Op.cit., 1979, p.36.

304 "I can assure you from personal knowledge, and from the expressed admission of many chiefs in this part of the country, that the abolition of the slave trade at Lagos, and they hoped from Whydah also, was the greatest deliverance that ever was wrought on behalf of this country" The Church Missionary Intelligencer, a monthly journal of missionary information. vol.III. New Series. London: Church Missionary House, 1872, p.125.
} 
dos meses que se seguiram à instalação do protetorado britânico em Lagos uma série de doze outros tratados antitráfico, similares ao assinado por Akitoye, foram firmados com as chefias de localidades próximas. Dentre elas podemos citar: Abeokuta, Daomé, Porto Novo, ljebu e Badagri. Segundo Ross, um primeiro tratado entre a Grã-Bretanha e o rei Guezo foi firmado em janeiro de 1852. Todavia, o soberano do Daomé se recusou a assinar o mesmo documento oferecido aos chefes de outras localidades, concordando apenas com o artigo que se referia ao abandono do tráfico. A posição de Guezo levou o Foreign Office a considerar o acordo com o rei daomeano insatisfatório. Em virtude disto, o bloqueio da marinha britânica à Costa da Mina permaneceu até julho de 1852. Quando o Daomé cedeu à pressão inglesa e aceitou as demais cláusulas do tratado proposto, o bloqueio foi suspenso. ${ }^{305}$

Como explica Smith, os oficiais Forbes e Wilmot, subordinados ao comandante Bruce, foram responsáveis por efetivar a assinatura destes tratados. Este mesmo autor teve o cuidado de relacionar as datas em que alguns destes compromissos foram firmados, todos eles no ano de 1852: Abeokuta (5 de janeiro), Porto Novo (17 de janeiro), ljebu ( 25 de fevereiro) e Badagri (18 de março). Além disso, também foi estabelecido um acordo com seis chefes ijebu. Neste documento, as chefias que haviam sido enviadas de ljebu Ode até Lagos assumiram o compromisso de expulsar Kosoko de Epe. Afinal, mesmo exilado nesta cidade o antigo obá ainda mantinha boa parte de seus negócios no comércio escravista. ${ }^{306}$

Todavia, em 1852, o tráfico não era mais tão lucrativo para os negreiros estabelecidos na Costa da Mina. No ano de 1850 a supressão do comércio de escravos em direção ao Brasil reduziu de maneira significativa o número de cativos que atravessavam o Atlântico. Neste contexto, uma parcela relevante dos negreiros brasileiros abandonou em definitivo esta atividade, passando a atuar exclusivamente no comércio lícito. Ainda assim alguns traficantes se mantiveram tanto no mercado negreiro, quanto no negócio de bens lícitos. Era o caso de Domingos José Martins, cujos negócios ligados ao comércio de azeite de dendê não o excluíam do exercício do tráfico. Como principal

\footnotetext{
${ }^{305}$ ROSS, David. A. Op.cit., 1965, p.85 (nota 37).

${ }^{306}$ SMITH, Robert. Op.cit., 1979, p.35.
} 
intermediário de Guezo e parceiro comercial de Akitoye, Domingos Martins ocupava uma posição privilegiada tanto em Ajudá, quanto em Porto Novo e Badagri, cidade em que Akitoye viveu durante seu exílio. Porém, em 1851 seu status se alterou. Em um artigo dedicado a entender a trajetória deste importante mercador de escravos, o historiador David Ross analisou as circunstâncias ligadas a esta mudança. De acordo com este pesquisador, Martins foi culpabilizado por atrair a atenção do esquadrão da rainha Victória, cujas naus cercavam o porto de Ajudá. ${ }^{307}$

Desde 8 de dezembro de 1851, a armada britânica antitráfico bloqueava os portos localizados no Golfo do Benim. A ação executada pelas embarcações que compunham o Esquadrão Africano impedia a aproximação de tumbeiros nesta porção da costa e impossibilitava a partida dos navios atracados nos portos negreiros. Neste contexto, Martins foi obrigado a deixar Ajudá para se refugiar em Porto Novo. Tal como o famoso traficante brasileiro, outros negreiros também tiveram de se adaptar à nova situação que se configurava. Diante do ostensivo bombardeio que deixou Lagos parcialmente destruída e da imposição de tratados em torno da supressão do tráfico estabelecidos entre a Coroa britânica e chefias locais, restavam poucas alternativas àqueles que insistiam em continuar a mercadejar escravos pelo Atlântico. ${ }^{308}$

Talvez a opção mais evidente fosse a transferência destes negreiros para Epe, cidade ljebu em que Kosoko havia se exilado depois de fugir de Lagos. ${ }^{309}$ Como consequência, o exílio do ex-obá em território ijebu trouxe mudanças significativas à cidade. Como é possível verificar na representação cartográfica adiante - Mapa 4: Domínios de Kosoko durante o exílio em Epe nos anos que se seguiram ao seu estabelecimento entre os ijebus, Kosoko expandiu sua atuação por territórios insulares próximos a Epe. Esperava com isto controlar as principais rotas que abasteciam Lagos com o azeite de dendê, cujos galões seriam encaminhados ao comércio atlântico, e com alimentos, que

\footnotetext{
${ }^{307}$ ROSS, David A. Op.cit., 1965, p.85.

308 Law discute a interpretação de que haveria rivalidades entre negreiros brasileiros e mercadores de dendê de Ajudá. Para o historiador, disputas comerciais certamente ocorreram sem que isto representasse, necessariamente, "conflito de interesses ou políticas diferentes". LAW, Robin.Op.cit.,2004, p.219/220.

${ }^{309}$ Kosoko primeiro se refugiou em algumas pequenas cidades localizadas no continente para, depois de conseguir a permissão do chefe de ljebu Ode, o awujale, se estabelecer na cidade ijebu de Epe. SMITH, Robert. Op.cit., 1979, p.40.
} 
seriam consumidos pela população lagosiana crescente. Além desta estratégia de cunho econômico, ataques de guerreiros leais ao obá exilado dificultavam a circulação de canoas encaminhadas a Lagos pelos canais existentes entre Epe e Ebute Metta. Ao procurar enfraquecer Lagos cortando o abastecimento de gêneros alimentícios e ocasionando a suspensão do principal produto negociado com os comerciantes europeus, o azeite de dendê, Kosoko aguardava o melhor momento para um contra-ataque que the devolveria sua posição de mando. ${ }^{310}$

\section{Mapa 4: Domínios de Kosoko durante o exílio em Epe}

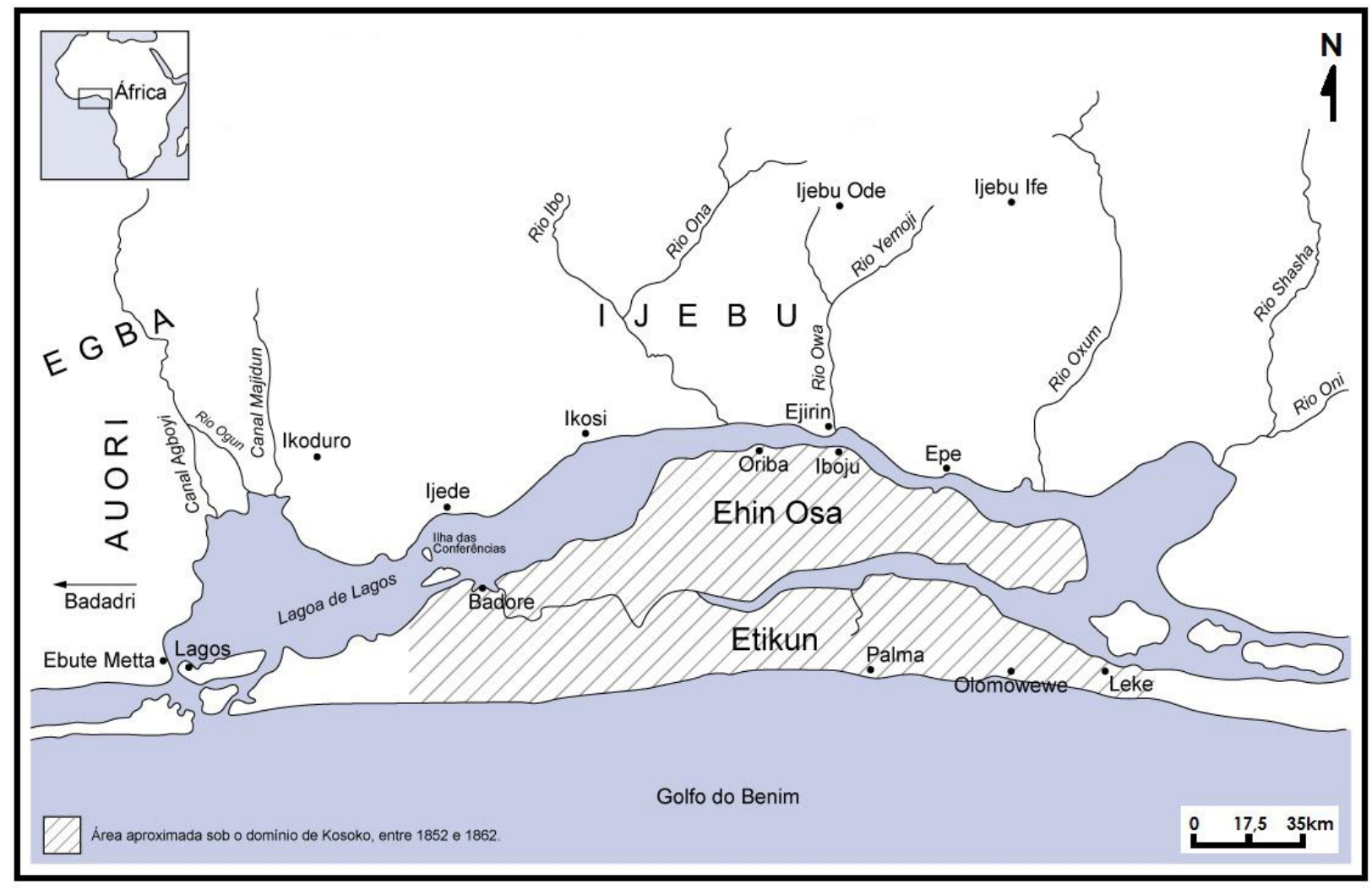

Fonte: Mapa adaptado de SMITH, Robert Sydney. The Lagos Consulate, 1851-1861. Londres: Macmillan and The University of Lagos Press, 1978, 1978, p.41.

Em agosto de 1853, Kosoko tentou invadir Lagos. No entanto, este ataque não permitiu seu retorno à cidade. De acordo com Smith, nesta ocasião os compounds de aliados que, embora vivessem em Lagos se mantiveram fiéis

\footnotetext{
${ }^{310}$ A ampliação da autoridade de Kosoko pela porção insular que separava Epe do oceano Atlântico é comentada pelas seguintes obras: FALOLA, Toyin; OGUNTOMISIN, G.O. Op.cit., 2001. pp.147/148 e SMITH, Robert. Op.cit., 1979, p.40.
} 
a Kosoko, foram completamente destruídos pelas forças de Akitoye. Em resposta à destruição promovida pelo obá, Kosoko planejou e liderou pessoalmente uma segunda ofensiva, cujos alvos eram o igá, a sede da CMS construída em Oke Faji e o compound do Ashogbon, o chefe de guerra. Esta incursão se iniciou com um ataque direto ao compound do Ashogbon. Participaram da ofensiva Oshodi Tapa, principal ibigá do obá exilado, e um traficante brasileiro conhecido como Lima. ${ }^{311}$ Todavia, o pronto revide das forças lideradas pelo chefe dos guerreiros de Akitoye levou Kosoko a ordenar a retirada de seus homens que, mais uma vez, se refugiaram em Epe. ${ }^{312}$

Diante da constatação de que, mesmo no exílio, as forças de Kosoko não deveriam ser subestimadas e da percepção de que o bloqueio às mercadorias vindas do interior poderia se estender por muito tempo, a política britânica em relação ao ex-obá começou a mostrar indícios de mudança. Adotando um tom conciliatório, Benjamin Campbell, que havia assumido o consulado de Lagos em julho de 1853, enviou para Epe uma carta em que afirmava não ser intenção britânica causar prejuízo ou perturbar Kosoko, "onde quer que ele [o obá deposto] se estabeleça e faça seu comércio pacificamente". ${ }^{313}$

A carta enviada por Campbell, em $1^{\circ}$ de setembro de 1853, foi prontamente respondida em nome de Kosoko seis dias depois. De acordo com Smith, a brevidade da réplica foi interpretada pelo cônsul como um indício da disposição do obá exilado em negociar os termos de um futuro acordo. ${ }^{314} \mathrm{~A}$ correspondência remetida a partir de Epe estava escrita em português. Neste texto Kosoko argumentava que a incursão de suas forças ao território de Lagos teve apenas o objetivo de resgatar aliados sujeitos às agressões promovidas por Akitoye. Ao encaminhar ao cônsul britânico uma missiva em português, o

\footnotetext{
${ }^{311}$ Segundo Costa e Silva, o aliado de Kosoko conhecido pelo nome de Lima foi registrado em documentos em língua inglesa como Lemon. SILVA, Alberto da Costa e. Op.cit., 2003, p.128. ${ }^{312}$ Cf. SMITH, Robert. Op.cit., 1979, p.54.

${ }^{313}$ A carta de Benjamin Campbell, endereçada a Clarendon, foi comentada por em: SMITH, Robert. Op.cit., 1979, p. 55. O primeiro cônsul de Lagos foi Louis Fraser, que anteriormente havia ocupado o posto de vice-cônsul de Ajudá, em lugar do falecido John Duncan. Fraser permaneceu no consulado de Lagos de novembro de 1852 até julho de 1853, quando foi substituído por Benjamin Campbell este, por sua vez, permaneceu no consulado de Lagos até o ano de 1859. Cf. SMITH, Robert. 1978, p.44 e CASTILLO, Lisa E. Op.cit., 2016, p.36.

${ }^{314}$ SMITH, Robert. Op.cit., 1979, p.55.
} 
obá exilado fornecia pistas acerca de quem eram os indivíduos de sua confiança. Afinal, uma vez que o domínio da escrita era em língua portuguesa, podemos perceber que traficantes brasileiros ocupavam uma posição política bastante próxima a Kosoko. A maior parte da historiografia produzida sobre este período se refere à permanência de três negreiros brasileiros ao lado do antigo obá: Marcos Borges Ferras, Nobre e Lima. Tais nomes são mencionados nas publicações que se dedicaram a compreender as disputas pelo mando em Lagos na década de $1850 .^{315}$ Nestas produções os brasileiros são considerados intermediários nas negociações realizadas entre britânicos e enviados do obá exilado. Como vimos, em novembro de 1851, Marcos Borges Ferras e Nobre receberam o cônsul Beecroft e a comitiva que o acompanhava. Enquanto os britânicos aguardavam autorização para ingressar no igá, a fim de se encontrarem com Kosoko, os enviados da rainha Victoria permaneceram na residência de Ferras. Cerca de três anos mais tarde, em 1854, também foi um brasileiro - o traficante Lima - o interlocutor que defendeu os interesses do obá exilado nas negociações estabelecidas na Ilha das Conferências ou, como foi nomeada pela historiografia escrita em inglês, na Palaver Island. ${ }^{316}$

Com o apoio destes brasileiros cujos nomes ficaram registrados em relatórios produzidos por oficiais e funcionários britânicos, Kosoko continuou a ampliar sua influência para além do território de Epe. ${ }^{317}$ Em setembro de 1853, a morte de Akitoye e a instalação de seu filho, Docemo, como o novo obá de Lagos, intensificaram ainda mais a pressão britânica pelo cumprimento dos cinco primeiros artigos do tratado lagosiano firmado em 1852. Em especial, dos pontos que se referiam à permanência de traficantes na cidade.

A atuação da armada britânica para fazer cumprir o acordo de 1852 fez crescer o número de traficantes brasileiros que se estabeleceram em Epe sob

\footnotetext{
${ }^{315}$ Refiro-me principalmente às seguintes publicações: VERGER, Pierre. Op.cit. 1987, pp.570 578; SILVA, Alberto da Costa e. Op.cit, 2003, pp.42,65 e 128; SILVA, Alberto da Costa e. Op.cit., 2004, p.119 e SMITH, Robert. Op.cit, 1979, p.38.

${ }^{316}$ A localização da llha das Conferências está assinalada no Mapa 4: Domínios de Kosoko durante o exílio em Epe.

317 A obra de Robert Smith faz uma extensa análise acerca dos registros produzidos por britânicos que se reportavam ao Foreign Office. Este autor trabalha com as seguintes coleções de documentos: Foreign Office, Colonial Office e Parliament Papers. A leitura deste conjunto de fontes tornou possível ao autor perceber a atuação dos brasileiros Ferras, Lima e Nobre em atividades ligadas ao tráfico.
} 
a proteção de Kosoko. Este, por sua vez, na impossibilidade de retomar o mando em Lagos mesmo após o falecimento de seu oponente, continuava sua estratégia de ataque e pilhagem às canoas que arriscavam cruzar a lagoa em direção ao porto lagosiano. Ao bloquear as comunicações pelo leito dos canais que ligavam Lagos a Abeokuta, provocando o desabastecimento de alimentos na cidade e afugentando comerciantes europeus, Kosoko pressionava Benjamin Campbell para que suas demandas fossem atendidas, dentre as quais, seu retorno à posição de obá. ${ }^{318}$

As ações de Kosoko para recuperar o mando na cidade eram acompanhadas de perto pelas autoridades britânicas sediadas em Londres. Ainda segundo Smith, havia rumores de que o antigo obá buscava atrair o apoio de ljebu Ode e de Abeokuta enviando presentes aos chefes de ambas as localidades. Em outubro de 1853, apenas dois meses depois da malograda incursão de Kosoko contra Lagos, forças da Grã-Bretanha retaliaram Epe. Contudo, a cidade estava circundada por uma forte barricada que servia como proteção aos soldados que se entrincheiravam nestes pontos de defesa. Este esquema de resistência permitiu que o assalto britânico sobre Epe fosse prontamente repelido. A derrota das forças inglesas colocou um ponto final na política consular de Campbell que, ora buscava uma saída negociada e pacífica para os conflitos entre Epe e Lagos, ora desferia ataques ao seu oponente, Kosoko. ${ }^{319}$

Para Smith, esta mudança representou uma transformação significativa nas ações britânicas iniciadas em 1851, com o bombardeio de Lagos, e que vigoravam até aquele momento. Ao priorizar a retomada comercial do porto lagosiano e deixar em segundo plano o combate ao tráfico atlântico de escravos, Campbell deu uma guinada política em direção aos interesses das firmas comerciais europeias instaladas na ilha. Para isto, o cônsul de Lagos suspendeu as ofensivas do esquadrão britânico contra Epe e, a partir de janeiro de 1854, iniciou uma série de encontros com representantes de Kosoko, dentre os quais estavam o ibigá Oshodi Tapa e o traficante brasileiro conhecido

\footnotetext{
${ }^{318}$ Cf. SMITH, Robert. Op.cit., 1979, pp. 40-48; FALOLA, Toyin; OGUNTOMISIN, G.O. Op.cit., 2001. pp.144-151 e MANN, Kristin. Op.cit, 2007,pp.98-99.

${ }^{319}$ SMITH, Robert. Op.cit., 1979, pp. 56-57.
} 
por Lima. O objetivo principal destes encontros era discutir os termos de um acordo que seria firmado oito meses depois. ${ }^{320}$

Em 28 de setembro de 1854, uma solenidade marcou o estabelecimento de um tratado entre os enviados da Coroa britânica e Kosoko. Fazia parte da comitiva inglesa o cônsul Campbell, o comandante Miller, três oficiais da armada da Grã-Bretanha e outros quatros comerciantes com negócios estabelecidos em Lagos. De acordo com Smith, estes últimos acompanhantes eram: o sardenho Giambattista Scala; o fante proveniente da Costa do Ouro W.R. Hansen, um saro chamado S.B. Williams, que nesta expedição também atuava como intérprete, e o brasileiro Josi Pedro da Cousta Roy (ou José Pedro da Costa Rei). Na ocasião, é possível que a presença de traficantes brasileiros fosse grande, pois os sete artigos que compunham o documento foram lidos em voz alta, primeiro em português, e depois numa língua que Campbell identificou como "awori yorubá" (ou auori iorubá). Embora a análise de Smith não deixe claro, podemos supor que talvez coubesse ao membro brasileiro da comitiva britânica - Josi Pedro da Cousta Roy - a primeira leitura do tratado. ${ }^{321}$

O episódio narrado pelo autor a partir dos relatórios escritos pelo cônsul Benjamin Campbell e endereçados ao então Foreign Secretary, Lord Clarendon, revela indícios da participação de brasileiros nas atividades políticas assumidas tanto dentro do governo consular de Lagos, quanto no governo de Kosoko em Epe. No que se refere às decisões tomadas pelo obá exilado, a atuação de brasileiros pode ter sido ainda mais relevante. Em dezembro de 1854, apenas três meses depois da assinatura do acordo com Kosoko, Campbell encaminhou uma carta a Clarendon. Na missiva endereçada ao Foreign Secretary, o cônsul de Lagos mostrava-se confiante no cumprimento do tratado firmado com o obá exilado. Apostando no incremento comercial de Lagos a partir da abertura do mercado de Epe, Campbell justificava seu entusiasmo em relação à "atual disposição pacífica" de Kosoko.

\footnotetext{
${ }^{320}$ As negociações entre Benjamin Campbell e representantes de Kosoko na llha das Conferências (ou Palaver Island) foram minuciosamente descritas por Robert Smith em: SMITH, Robert. Op.cit., 1979, cap.4 To the Palaver Islands. Também Falola e Oguntomisin dedicaram atenção a este processo de aproximação que resultou na assinatura do Tratado de Epe, em 1854. FALOLA, Toyin; OGUNTOMISIN, G.O. Op.cit., 2001. pp.152 - 156.

${ }^{321}$ SMITH, Robert. Op.cit., 1979, pp. 62-63.
} 
Segundo o cônsul britânico, o traficante brasileiro Lima havia falecido. Por esta razão, não havia motivos para se preocupar com a "influência maléfica" até então exercida por este negreiro sobre o obá exilado. ${ }^{322}$

Os diversos encontros entre as autoridades britânicas e os enviados de Kosoko, todos eles realizados na llha das Conferências, indicam que a assinatura do acordo em setembro de 1854 exigiu um longo diálogo entre as partes envolvidas. Ao contrário do tratado firmado com Akitoye três anos antes e, depois, com outras localidades vizinhas a Lagos, o acordo de Epe foi resultado de um processo de negociação que se estendeu por oito meses. Dos sete artigos estabelecidos neste documento, apenas o terceiro deles versava sobre o abandono definitivo do mercado atlântico de escravos e estabelecia o impedimento à permanência de traficantes nos domínios territoriais de Kosoko. As demais determinações fixadas neste tratado dispunham sobre os limites da influência política de Kosoko, regulavam aspectos referentes à cobrança de impostos e ao comércio lícito e determinavam o pagamento de uma pensão anual ao obá exilado. Estes aspectos foram registrados nos seguintes termos:

Artigo 1‥ Kosoko, seus cabeceiras e chefes prometem solenemente não tentar reconquistar a posse de Lagos por meio de ameaças, hostilidades ou estratégias.

Artigo $2^{\circ}$. Kosoko, seus cabeceiras e chefes reivindicam Palma como seu porto comercial. Benjamin Campbell, cônsul britânico de Sua Majestade, e Thomas Miller, comandante e oficial naval superior nos Golfos, reconhecem Palma como porto de Kosoko e de seus cabeceiras e chefes, para propósitos de comércio lícito.

Artigo 3‥ Kosoko, seus cabeceiras e chefes juram solenemente abandonar o comércio de escravos que consiste na exportação de cativos da África. Juram também não permitir que nenhum traficante resida em seu porto ou em qualquer outro lugar sob sua jurisdição e influência.

${ }^{322}$ SMITH, Robert. Op.cit., 1979, p.62. 
Artigo 4․ Kosoko, seus cabeceiras e chefes se obrigam solenemente a fornecer toda a proteção e assistência aos mercadores e comerciantes que desejarem residir entre eles com o propósito de atuarem no mercado de bens lícitos. Os mesmos também se comprometem a dar assistência ao cônsul britânico na reabertura dos mercados situados na costa de Jaboo [ljebu], em Agienu, Ecorodu [lkoduro] e Aboyee, e mantê-los em ordem e segurança.

Artigo 5ํ. Será cobrado no porto de Palma, em benefício de Kosoko, um imposto de exportação de uma cabeça de cauri para cada barril de óleo de palma de tamanho médio e vinte galões e dois cordões de cauris por cada libra de marfim exportado deste porto.

Artigo 6. Benjamin Campbell, cônsul de Sua Majestade, se compromete em nome de Sua Majestade que, para 0 cumprimento fidedigno do presente compromisso da parte de Kosoko, de seus cabeceiras e chefes deverá ser pago à Kosoko, pelo governo de Sua Majestade, uma provisão anual e vitalícia de dois mil cauris ou mil dólares, de acordo com a opção do obá exilado. ${ }^{323}$

Embora obrigações semelhantes também estivessem inscritas no acordo firmado após o bombardeio de 1851 junto à Akitoye, concessões como o reconhecimento de Palma como porto de atuação de Kosoko e o estabelecimento de um pagamento anual e vitalício de dois mil cauris - ou mil dólares, a escolha do obá deposto - colocam em evidência as especificidades deste documento. Se, por um lado, o tratado assinado com Kosoko dispunha sobre aspectos pragmáticos da abertura de rotas de abastecimento ligadas ao interior e acerca da aproximação comercial entre as partes envolvidas, por outro, o recém-instalado obá Docemo entendia o diálogo entre Kosoko e Campbell como uma ameaça à sua posição na cidade. Todavia, a dissensão de Docemo em relação ao tratado firmado entre o consulado britânico e o obá exilado em Epe não foi capaz de inviabilizar os termos deste documento. Ao

${ }^{323}$ O Tratado de Epe, firmado em 28 de setembro de 1854, entre Kosoko e o consulado britânico de Lagos, encontra-se transcrito na obra: SMITH, Robert. Op.cit., 1979, Apêncie B: The treaty of Epe, 28 September 1854. Não encontrei a localização dos portos de Agienu e Aboyee, citados no documento. 
contrário, o acordo foi colocado em prática e, tal como Campbell ansiava, os caminhos que abasteciam o mercado lagosiano com alimentos e bens exportáveis foram abertos.

Para o missionário da CMS, Samuel Ajayi Crowther, antes mesmo da assinatura do acordo entre Campbell e Kosoko, Lagos já era um porto livre do tráfico escravista. De acordo com a sua biografia, o religioso esteve na cidade pela primeira vez no ano de 1822, na condição de cativo. Seu retorno ao porto que por pouco não lhe encaminhou a uma vida de escravidão nas Américas ocorreu apenas no ano de 1852. Nesta ocasião Crowther retornava de sua terceira viagem à Grã-Bretanha. A estadia na metrópole britânica havia se estendido por cerca de quinze meses. Em março de 1851, o missionário desembarcou em Liverpool, e só voltou a pisar em solo africano em junho do ano seguinte, quando desembarcou em Lagos. Em 1852, depois de chegar ao antigo porto escravista, Crowther logo percebeu as transformações ocorridas na cidade. Segundo seu relato, parte dos barracões anteriormente empregados para armazenar escravos havia sido demolida. Nestes lugares plantações de milho e mandioca vicejavam. Os barracões ainda existentes agora armazenavam "galões de azeite de dendê e outras mercadorias, ao invés de escravos presos em correntes e ferros, em agonia e desespero". ${ }^{324}$

O missionário que abertamente defendia a associação do proselitismo cristão ao desenvolvimento agrícola e comercial - sintetizado no binômio "evangelho e arado" - percebia as mudanças ocorridas em Lagos como consequências da supressão do tráfico. ${ }^{325} \mathrm{Em}$ razão disto, apenas um ano e meio depois do bombardeio de 1851 e da instalação do protetorado britânico na cidade, Samuel Crowther afirmou que a atuação da Grã-Bretanha consistiu na "maior libertação já feita em nome deste país [Lagos]". Para ele, ao "libertar"

\footnotetext{
${ }^{324}$ Cf. PAGE, Jesse. Op.cit., 1908.p. 113.

${ }^{325} \mathrm{Em}$ janeiro de 1841, o periódico antitráfico Friend of Africa, publicou uma carta endereçada a Thomas Fowell Buxton, que demonstrava o "profundo interesse da Alemanha na causa da civilização da África". Esta correspondência continha uma declaração do príncipe Metternich, segundo o qual: "Nada além do evangelho e do arado podem civilizar a África". A afirmação atribuída ao príncipe se difundiu e o binômio "evangelho e arado" - em inglês, the gospel and the plough - passou a ser empregado entre aqueles que defendiam a conquista territorial sobre o continente africano. Cf. Friend of Africa; by The Society for the extinction of the slave trade, and for the civilization of Africa. Vol.1, London: John W. Parker, 1841, p.13. Esta publicação também é comentada no artigo: GALLAGHER, J. Fowell Buxton and the New African Policy, 1838-1842, Cambridge Historical Journal, vol.10, No. 1, 1950, p.50.
} 
Lagos do comércio negreiro as barreiras que tornavam as viagens afastadas da costa "bastante inseguras", deixaram de existir. Afinal, quando "uma tribo está aberta à outra" seus membros podem "viajar juntos pelo interior em prol do comércio mútuo e do intercurso, desta forma, muitos agricultores começam a se sentir seguros para se dedicarem às suas ocupações pacíficas". ${ }^{326}$

Publicadas em um relatório da Church Missionary Intelligencer (CMI), as considerações do missionário anglicano entendiam que a supressão do tráfico era a justificativa central à instalação do protetorado britânico em Lagos. De fato, a historiografia nos mostra que nos meses seguintes ao bombardeio de 1851, a grande maioria dos negreiros que operavam na cidade havia trasladado seus negócios, sobretudo para Ajudá, Epe e Palma. Estes dois últimos eram pontos de tráfico controlado por Kosoko. Em razão disto, o comércio de escravos na região da Costa da Mina continuou a ser praticado nos poucos embarcadouros ainda não conquistados pela armada da rainha Victoria.

Para a primeira geração de brasileiros, cuja fortuna e status político se constituíram a partir do negócio atlântico de escravos, a ação britânica sobre Lagos representou um drástico estreitamento de seu espaço político e econômico. Menos de três anos depois do bombardeio de Lagos, Kosoko acertou junto aos enviados britânicos os termos de sua rendição. A presença de brasileiros em ambos os lados das negociações que levaram à assinatura do Tratado de Epe, em setembro de 1854, constituem um indicativo da posição política ocupada por alguns destes indivíduos. Contudo, os benefícios associados ao lugar político desfrutado por aqueles brasileiros que participaram destas discussões não se sustentaram após 1854. Diante da diminuição dos poderes de Kosoko e de Docemo e da ampliação da dominação britânica que, ainda neste momento, se fazia sob a forma de protetorado, estes brasileiros experimentaram uma redução de sua influência, potencializada pela penetração de companhias europeias que reconfiguraram as relações comerciais atlânticas, a fim de atender as demandas dos mercados na Europa.

\footnotetext{
${ }^{326}$ The Church Missionary Intelligencer, a monthly journal of missionary information. vol.III. New Series. London: Church Missionary House, 1872, p.125. Um trecho menor do texto produzido por Crowther pode também ser lido em sua biografia: PAGE, Jesse. Op.cit., 1908. pp.112-113.
} 
A partir deste momento, os signos que marcariam 0 pertencimento à comunidade brasileira não se fariam mais associados ao tráfico. Embora a atividade negreira persistisse em outros portos da Costa da Mina e, eventualmente, ainda fosse motivo de queixa de alguns administradores britânicos instalados em Lagos, este já não era mais um emblema de identificação dos brasileiros que ali viviam em meados dos anos de 1850 .

Uma vez que muitos dos indivíduos estabelecidos na cidade neste momento eram libertos, a identidade brasileira foi reformulada a fim de continuar fazendo sentido para os que nela se reconheciam. Afinal, desde o início do oitocentos, mas em maior número a partir da Revolta dos malês, em 1835, uma segunda geração de brasileiros se instalou no porto lagosiano. Composta em sua maioria por africanos libertos e por seus descendentes, esta geração ocupou os espaços que surgiram depois da cidade se tornar protetorado da Grã-Bretanha. Estes novos integrantes acrescentaram outros elementos à identidade brasileira já existente. Nesta conjuntura, os emblemas de identificação antes constituídos foram associados aos aspectos de uma cultura partilhada em torno da língua, do comércio com o Brasil, da religiosidade católica, da culinária, das vestimentas e, em particular, do exercício público e coletivo da identidade em momentos de festas e celebrações. De que forma os brasileiros exerceram esta identidade múltipla e cambiante e quais são os registros que nos permitem depreender este processo contínuo de elaboração, seleção, descarte e ressignificação dos elementos identitários brasileiros são assuntos que serão trabalhados no quarto e quinto capítulos desta tese. 


\section{A colonização britânica em Lagos (de 1861 a 1900)}

Obi ficou na Inglaterra durante quase quatro anos. Às vezes achava difícil acreditar que tinha sido tão pouco tempo. [...] Foi na Inglaterra que a Nigéria se tornou para ele algo mais do que apenas um nome. ${ }^{327}$

Era julho de 1861 quando Docemo atendeu a solicitação do comerciante e, naquele momento, cônsul interino de Lagos, William McCoskry, e do comandante naval, Norman B.Bendingfield, para que subisse a bordo do navio Prometheus e que o fizesse desacompanhado de seus cabeceiras. ${ }^{328}$ Enquanto estava embarcado na nau britânica, o obá foi comunicado, por meio de um intérprete, sobre as intenções da Grã-Bretanha de tornar Lagos sua colônia. Como réplica, Docemo anunciou que se reuniria com seus cabeceiras e, no início de agosto, responderia à demanda apresentada pelas autoridades britânicas. No terceiro dia de agosto, McCoskry e Bedingfield foram ao encontro de Docemo. ${ }^{329}$ De acordo com o relatório escrito pelo comandante naval, ao longo das horas em que os enviados ingleses estiveram recolhidos no interior do igá, a nau Prometheus permaneceu atracada nas imediações da

\footnotetext{
${ }^{327}$ ACHEBE, Chinua. A paz dura pouco. São Paulo: Companhia das Letras, 2013, p.22.

${ }^{328}$ A documentação consultada fornece duas datas para este primeiro encontro de discussão do tratado de cessão. Os relatórios e cartas escritos pelo cônsul McCoskry se referem a 30 de julho de 1861. No entanto, petições ditadas por Docemo e cartas enviadas por alguns de seus chefes à rainha Victoria mencionam 29 de julho de 1861. PROL, N. 6. McCoskry to Lord J. Russel, 7 de agosto de 1861; N. 7, anexo 1.The Chiefs of Lagos to Her Majesty Queen Victoria, 8 de agosto de 1861; N.7, anexo 2. King Docemo to Her Majesty Queen Vistoria, 8 de agosto de 1861.

${ }^{329}$ PROL, N.6. McCoskry to Lord J. Russel, 7 de agosto de 1861. O episódio da cessão de Lagos em 1861 foi analisado por outros autores, entre eles: SMITH, Robert Sydney. The Lagos Consulate, 1851-1861. London: Macmillan Press/Univesity of Lagos Press, 1978,pp.120-124 e MANN, Kristin. Slavery and the Birth of an African City. Lagos, 1760 - 1900. Indiana: Indiana University Press, 2007. pp.100-102.
} 
casa do obá. ${ }^{330}$ A embarcação expunha a força bélica inglesa apontando seus canhões para o local onde os interlocutores se reuniam. Mesmo assim, ao lado de seus cabeceiras o obá se opôs aos planos de anexar Lagos à lista de colônias pertencentes à rainha Victoria. Ao se recusar a firmar o tratado de cessão de seus domínios, Docemo foi prevenido por McCoskry de que sua armada estava autorizada a "tomar posse da ilha em nome de Sua Majestade". Diante da manutenção da negativa do obá, os enviados da Grã-Bretanha retornaram a seus postos e planejaram tomar a cidade no sexto dia daquele mesmo mês. No entanto, antes do ataque da armada inglesa acontecer, uma nova conferência reuniu Docemo, McCoskry e Bedingfield. ${ }^{331}$

Em 5 de agosto de 1861, os dois representantes do Foreign Office estiveram mais uma vez com o obá de Lagos e quatro de seus cabeceiras. Os enviados britânicos chegaram até a cidade seguidos por dois barcos pequenos, equipados com canhões e acompanhados por soldados bem armados. Nos termos de uma missiva ditada pelo próprio Docemo, a comitiva parecia estar "pronta para iniciar uma batalha". ${ }^{332}$ De fato, as demonstrações do poder bélico da armada inglesa já haviam causado comoção entre a população lagosiana. Muitos habitantes desocupavam a cidade temendo um ataque semelhante ao ocorrido há cerca de dez anos, em dezembro de 1851. Naquela ocasião as forças britânicas bombardearam Lagos, depuseram Kosoko e devolveram o mando a Akitoye, pai de Docemo. ${ }^{333}$ No mês de agosto de 1861 , o documento de cessão dos domínios lagosianos foi apresentado por McCoskry e Bedingfield pela segunda vez. Sob a condição de serem feitos alguns ajustes, o tradado foi aceito. As alterações propostas pelo obá e seus apoiadores tocavam em três pontos: o primeiro se referia à continuidade do uso do título de obá por Docemo, o segundo estava ligado ao seu direito de arbitrar disputas entre os moradores locais e o terceiro dizia respeito à exigência de um selo anexado aos documentos de transferência da terra. Este selo garantiria a

\footnotetext{
${ }^{330}$ APROL, N.2, Edmonstone to B. Walker, 22 de setembro de 1861, anexo 1. Extract from Report by Commander Bedingfeld.

${ }^{331}$ PROL, N.6. McCoskry to Lord J. Russel, 7 de agosto de 1861.

${ }^{332}$ APROL, N.2, Edmonstone to B. Walker, 22 de setembro de 1861, anexo 1. Extract from Report by Commander Bedingfeld e PROL, N.7, anexo 2. King Docemo to Her Majesty Queen Vistoria, 8 de agosto de 1861. Também conforme: SMITH, Robert Sydney. Op.cit.,1978,p.124. ${ }^{333}$ PROL, N. 7, anexo 1.The Chiefs of Lagos to Her Majesty Queen Victoria, 8 de agosto de 1861.
} 
legitimidade necessária aos registros de propriedade de terras que seriam emitidos a partir daquele momento. As mudanças que se seguiram à cessão de Lagos e as formas de resistência associadas a este acontecimento são assuntos tratados neste quarto capítulo.

Em 1861, quando Lagos se tornou colônia inglesa, uma parte significativa das indústrias instaladas na Grã-Bretanha empregava o óleo de palma na composição de seus produtos. Esta matéria-prima era desembarcada principalmente em Londres, Liverpool e Manchester e abastecia as fábricas de vela, sabão, ração para o gado e glicerina. Embora fosse a principal mercadoria exportada por Lagos, o óleo e a semente de dendê não eram os únicos artigos que saíam deste porto. No correr da década de 1860, o algodão também se tornou um bem vendido pelos armazéns situados na nova colônia inglesa. Isto porque, entre 1861 e 1865, o fornecimento desta mercadoria ficou praticamente suspenso em razão da guerra de Secessão ocorrida nos Estados Unidos.

Em busca de mercados produtores alternativos que abastecessem a indústria têxtil inglesa, os agricultores de Lagos foram incentivados pelo governo colonial a ampliar o cultivo do arbusto. No entanto, os limites de Lagos não eram suficientes para alimentar a crescente demanda do comércio internacional. Em razão disto, era preciso que os campos de algodão se expandissem por territórios localizados mais ao interior do continente. Abeokuta e Ibadan eram as cidades consideradas pelos britânicos as mais adequadas à produção de algodão na região. A interiorização das lavouras algodoeiras e das plantações de dendê se iniciou na década de 1860 e continuou até o final do século XIX. As bacias dos rios Ogun, Oni e, mais ao sul, do rio Níger serviram de canal de escoamento destas matérias-primas, cuja produção se dava em porções cada vez mais afastadas do litoral. ${ }^{334}$

\footnotetext{
${ }^{334}$ Cf. M'BOKOLO, Elikia. África Negra. História e Civilizações. Tomo II - Do século XIX aos nossos dias. $2^{\text {a }}$ ed. Lisboa: Colibri, 2011.pp. 142/143. Para uma análise mais aprofundada acerca do processo de instalação das lavouras de dendê em territórios situados no interior do Golfo do Benim e a respeito da comercialização das mercadorias derivadas dos dendezeiros em Lagos, sugiro: MANN, Kristin. Op.cit., 2007, cap.4: Innocent Commerce: Boom and Bust in the Palm Produce Trade.
} 
Como Falola e Heaton indicam, o processo de colonização do território que, a final do século XIX, constituiria a Nigéria demorou mais de quarenta anos para se completar. Durante este período, a cidade de Lagos era considerada o ponto de partida à expansão colonial em direção ao território iorubá. Em 1882, tropas enviadas pelo governo colonial lagosiano interviram na Guerra de Ekitiparapo, colocando termo às disputas entre Ibadan e a aliança formada por Ekiti, ljesa, Egba, ljebu e Ife. Com o fim do conflito que já durava cerca de quinze anos, todas as chefias em disputa firmaram o compromisso de submeterem contendas futuras ao arbítrio das autoridades da Grã-Bretanha estabelecidas em Lagos. ${ }^{335}$ Dez anos mais tarde, em 1892, o então governador colonial, Gilbert Thomas Carter, tentou convencer os ijebus a aceitarem um tratado semelhante ao proposto aos envolvidos nos conflitos de Ekitiparapo. Contudo, o principal chefe entre os ijebus, o awujale, repeliu os termos do documento de submissão. Diante disto, Carter autorizou o ataque do regimento colonial britânico à cidade de ljebu Ode. A força desta ação deu mostras do poder bélico da Grã-Bretanha. Em 1893, quando Carter propôs às chefias da cidade a assinatura de um novo acordo, quase não houve resistência. Sob o comando do Colonial Office, o governador de Lagos havia conseguido "pacificar" as regiões de conflitos existentes no interior. A partir daquele momento estes territórios integravam uma área denominada pelo Foreign Office como: Colônia e Protetorado de Lagos. ${ }^{336}$

Neste contexto de escalada da violência colonizadora para além do território de Lagos, de ampliação do número de firmas britânicas no litoral e de pressão por regularidade no abastecimento das matérias-primas que seriam exportadas, como atuavam os brasileiros que viviam do comércio? Havia espaço para os comerciantes brasileiros no mercado internacional? Quais eram

\footnotetext{
${ }^{335}$ Segundo Falola e Oguntomisin, a partir da década de 1860 a maior parte do território de Ekiti foi submetida ao controle de Ibadan. Em resposta, constituiu-se uma aliança formada pela cidade de Ekiti, ljexa, Egba, ljebu e Ifé contra Ibadan. Este movimento de resistência foi liderado por Isola Fabunmi, que recebeu apoio da "Sociedade de Ekitiparapo", constituída em 1852 principalmente por indivíduos ekiti e ijexas que viviam em Lagos. Embora a análise da Guerra de Ekitiparapo fuja aos propósitos desta pesquisa considero importante destacar que a intervenção britânica que colocou termo a estes conflitos foi um marco na política "pacificadora" que passou a ser exercida pelo governo colonial britânico em território iorubá. FALOLA, Toyin; OGUNTOMISIN, G.O. Yoruba Warlords of the 19th Century. Trenton/NJ; Asmara/Eritrea: Africa World Press, 2001, pp.69-89.

${ }^{336}$ Cf. FALOLA, Toyin; HEATON, Matthew M. A History of Nigeria. Cambridge: Cambridge University Press, 2008, p.95.
} 
os bens negociados por aqueles que mantiveram seus negócios atados ao Brasil? Quem eram estes indivíduos e como o lugar social, político e econômico destes brasileiros teve de se reconfigurar em função de novas relações estabelecidas com o colonizador, são também temas deste capítulo.

\subsection{A transformação de Lagos na "Liverpool da África ocidental”}

Embora naqueles dias Lagos tenha sido o mais notório mercado de escravos da África Ocidental, agora a cidade é um dos mais importantes centros comerciais desta costa, sendo aclamada por muitos como a 'Liverpool da África ocidental'. ${ }^{337}$

Em 6 de agosto de 1861, Docemo e quatro de seus cabeceiras firmaram junto ao comandante Bedingfield e ao cônsul em exercício McCoskry o tratado de cessão de Lagos. A parte inicial deste documento foi redigida em primeira pessoa. Este era um elemento novo na redação dos acordos estabelecidos com Lagos até aquele momento. Afinal, quase uma década antes, o tratado de 1852, que garantiu o retorno de Akitoye ao mando da cidade, e o acordo comercial fixado entre o obá restituído e os mercadores com interesses no território lagosiano haviam sido escritos em terceira pessoa. ${ }^{338} \mathrm{~A}$ produção de um documento formulado pelo Foreign Office, mas composto para ser um simulacro da voz de Docemo nos fornece pistas acerca do modo como a violência da conquista foi obliterada por esta fonte em específico. Em um breve preâmbulo o obá de Lagos supostamente reconhecia ser a rainha Victoria a melhor opção para a "assistência, defesa e proteção" dos habitantes da cidade.

\footnotetext{
337 "Although Lagos was in those days the most notorious slave mart in Western Africa, it is now one of the most important centers of trade on the West Coast, being hailed by many as the 'Liverpool of West Africa"' GLOVER, Lady. Life of Sir John Hawley Glover. London: Smith, Elder and Co. 1897, p.91. Neste excerto da biografia do governador de Lagos, John Hawley Glover, sua esposa, Lady Glover, trata das dificuldades comerciais enfrentadas pelo marido em razão do fechamento das rotas de mercadorias que seriam exportadas pelo porto de Lagos.

${ }^{338}$ PROL, 1862, N.1, Treaty with the King and Chiefs of Lagos, 1 de janeiro de 1852 e PROL, 1862,N.2. Agreement with King and Chiefs of Lagos, 28 de fevereiro de 1852.
} 
Neste excerto o documento enfatizava as limitações de Docemo em fazer frente aos ataques daomeanos e às capturas de cativos em seus domínios. Em vista destes aspectos e com o consentimento de seus cabeceiras, o obá declarava

dar, transferir e, diante dos presentes, conceder e confirmar junto à rainha da Grã-Bretanha, seus herdeiros e sucessores para todo o sempre, o porto e a ilha de Lagos, com todos os direitos, rendimentos, territórios e quaisquer outras propriedades existentes, assim como seus lucros e receitas (...) e absolutos domínios e soberania sobre o referido porto, ilha e instalações $(\ldots)^{339}$

Depois de enunciar o que significava ceder Lagos ao controle colonial britânico, o tratado apresentava as justificativas que fundamentavam a suposta decisão de Docemo em anuir à tomada de seus domínios. O excerto inicial do documento expunha dois argumentos que justificariam a ação colonizadora. $O$ primeiro deles se referia à persistência do comércio escravista pelo Atlântico. Este ponto estava relacionado ao tráfico realizado em direção a Cuba. De acordo com os dados disponíveis na base de dados The Trans-Atlantic Slave Trade, entre 1841 e 1850, duas décadas antes da cessão do território lagosiano, os portos de Ajudá, Lagos, Porto Novo e Badagri exportaram para as Américas, juntos, 35.186 cativos. No entanto entre 1851 e 1860, o número de escravos que atravessaram o Atlântico caiu de maneira relevante. Para termos uma ideia acerca desta retração, no período entre 1851 e 1860 partiram de Ajudá 4.981 cativos. Neste mesmo intervalo de tempo, 1.516 cativos foram embarcados no porto de Lagos. Assim, embora seja certo afirmar que, no ano de 1861, o comércio negreiro subsistia na Costa da Mina - inclusive em Lagos, cidade que há dez anos havia sido colocada sob a tutela britânica na forma de protetorado - a atividade passava por uma significativa contração. ${ }^{340}$

\footnotetext{
${ }^{339}$ PROL, N.6. McCoskry to Lord J. Russel, 7 de agosto de 1861. anexo 1, Treaty between Norman B. Bedingfeld... Este mesmo tratado de cessão de Lagos, firmado em 6 de agosto de 1861, também pode ser lido na íntegra em: SMITH, Robert Sydney. Op.cit.,1978, Apêndice C.

${ }^{340}$ Os dados numéricos aqui apresentados foram fornecidos pela base de dados Trans-Atlantic Slave Trades, e estão disponíveis no endereço eletrônico: http://www.slavevoyages.org. A Tabela 1: Principais portos de tráfico da Costa da Mina entre 1791 e 1865, apresentada no segundo capítulo, permite um entendimento mais amplo dos anos de maior e menor volume de comércio negreiro.
} 
A diminuição no número de escravos exportados em portos localizados na Costa da Mina indicava o sucesso das ações de patrulhamento e apreensão realizadas pelo esquadrão antitráfico da rainha Victoria. Contudo, esta não era a única forma de atuação da Grã-Bretanha para colocar fim à atividade. A pressão política exercida por cônsules britânicos instalados nos principais pontos de desembarque de cativos nas Américas também rendeu frutos. Além disto, em 1850, o comércio negreiro pelo Atlântico foi proibido no Brasil depois da promulgação de uma lei que se tornou conhecida pelo nome de seu principal apoiador: o Ministro da Justiça, Eusébio de Queirós. Com o fechamento dos portos brasileiros ao tráfico, os tumbeiros experimentaram o encolhimento de seus negócios. Sem os lucros apurados no comércio com seu maior comprador de cativos, o Brasil, os traficantes continuaram atuando no mercado negreiro de Cuba até o ano de $1867 .{ }^{341}$

Embora na virada da década de 1850 para a de 1860 relatórios produzidos por cônsules que estavam alocados no posto dos Golfos do Benim e de Biafra advertissem acerca da persistência do comércio negreiro na Costa da Mina, esta parecia não ser mais uma questão prioritária para o Foreign Office. $^{342}$ Segundo Mann, a anexação de Lagos como colônia da Grã-Bretanha ocorreu em um momento em que os discursos antitráfico, elaborados por parlamentares ingleses, se tornaram parte de uma retórica que dava sustentação a interesses que nem sempre se mostravam de maneira clara. ${ }^{343}$ Um destes interesses estava relacionado à conquista efetiva de territórios mais afastados do litoral, neste caso específico, da cidade egba de Abeokuta. Este aspecto nos leva ao segundo argumento impresso no tratado firmado junto a Docemo: as constantes ameaças do Daomé à Lagos e aos territórios vizinhos.

Neste trecho o documento alegava que a colonização britânica preveniria Lagos das "guerras destrutivas" empreendidas por tropas daomeanas lançadas na captura de escravos. Na prática, a "prevenção"

\footnotetext{
${ }^{341}$ Cf. LAW, Robin. A Comunidade brasileira de Uidá e os últimos anos do tráfico atlântico de escravos, 1850-66. Revista Afro-Ásia, Nº 27, 2002, p.47.

${ }^{342}$ Refiro-me, em especial, aos documentos publicados pelo Foreign Office no compêndio intitulado: Accounts and Parliament Papers. Slave Trade. Session 6 February - 7 August 1862, vol.61, Class B. Correspondence with Foreign Powers. Africa (consular) Bight of Benin, pp.124.

${ }^{343}$ MANN, Kristin. Op.cit., 2007,p.103.
} 
oferecida pela Grã-Bretanha se estenderia até Abeokuta, cidade que apenas dois meses antes da assinatura do tratado foi visitada pelo então cônsul dos Golfos do Benim e de Biafra, Henry Grant Foote. No início de 1860, Foote foi indicado pelo Foreign Office para assumir o referido consulado. Sua permanência na região durou pouco mais de doze meses. Em agosto 1861, William McCoskry já ocupava o posto de cônsul interino. Ainda que breve, a passagem de Foote pela administração consular foi marcada por ações concebidas com o propósito de estreitar as relações da Grã-Bretanha com Abeokuta. ${ }^{344}$

Uma expedição até a cidade egba permitiu que Foote fornecesse a John Russell, na época secretário do Foreign Office, um minucioso relato acerca das possibilidades de exploração comercial e agrícola dos territórios percorridos. Acompanhado pelo reverendo Samuel Crowther, seu intérprete, o cônsul demonstrou entusiasmo ao verificar que, na medida em que se afastava de Lagos, seguindo o curso do rio Ogun, o solo deixava de ter um aspecto arenoso para se tornar "bastante produtivo". Assim, preocupando-se em identificar quais eram os recursos naturais a espera da chegada dos britânicos, Foote elaborou uma lista dos tipos de raízes comestíveis plantadas ao longo das margens do rio Ogun e das espécies de árvores e arbustos encontrados em seu caminho. De acordo com este registro, mesmo as espécies vegetais a respeito das quais o cônsul não tinha conhecimento poderiam "ser consideradas valiosas na Europa". ${ }^{345}$

Todavia, a exploração de tamanha pujança natural tinha limites. Estes limites eram determinados pelos ataques promovidos pelo Daomé. Segundo o relatório produzido por Foote, os agricultores que viviam na rota que ligava Lagos até Abeokuta sofriam constantes ameaças de sequestro pelas forças daomeanas. Como consequência, o trabalho nas lavouras era intermitente, ou seja, realizado apenas nos momentos de maior segurança. Ainda assim, mesmo sob risco de captura e escravização, os habitantes de Abeokuta e

\footnotetext{
${ }^{344}$ A biografia de Foote foi escrita por sua esposa que, em fevereiro de 1861 partiu de Londres, em companhia de sua filha, para se encontrar com Henry Foote que já estava em Lagos. FOOTE, Mrs. Henry Grant. Recolletions of Central America and the West Coast of Africa. Londres: T.Cautley Newby, 1869.

${ }^{345}$ CFP. N.9. Foote to Russell, 12 de junho de 1861.
} 
imediações caminhavam cerca de cinco ou seis milhas até chegarem às plantações. Para o cônsul britânico, este feito contrariava a reputação de que "os africanos são preguiçosos e avessos ao trabalho". A evidência concreta de que os indivíduos observados pelo cônsul se distinguiam neste aspecto estava na abundância dos campos cultivados, conforme Foote fez questão de registrar:

De fato, os campos se encontravam em um elevado estado de cultivo, o que constitui outra prova do esforço dos nativos quando consideramos as ferramentas rústicas usadas por eles. ${ }^{346}$

Como podemos perceber neste excerto, para Henry Foote, as lavouras próximas a Abeokuta vicejavam graças ao empenho de seus agricultores e a despeito das ferramentas empregadas. Em uma narrativa construída para identificar quais seriam as possibilidades de instalação de lavouras comerciais de algodão em Abeokuta, o cônsul considerava os "industriosos" e "cordiais" habitantes da cidade como mais um dos componentes favoráveis à exploração. $E$, em apoio às suas considerações, justificava sua posição. Os moradores de Abeokuta apresentavam estas características em razão da "influência dos missionários" e "do fato de muitos de seus líderes e homens de influência (...) terem sido resgatados da escravidão pelo nosso esquadrão." Neste sentido, o proselitismo cristão promovido pela Church Missionary Society e pela Wesleyan Missionary Society, instaladas na cidade desde 1842, e a ação do Esquadrão Africano responsável, em última análise, pela presença de indivíduos provenientes de Serra Leoa na localidade, foram empregados neste relatório como elementos que davam sustentação à ideia da expansão das lavouras algodoeiras em direção ao interior do continente, em específico, no sentido de Abeokuta. ${ }^{347}$

Do ponto de vista da localização geográfica, as condições para esta exploração agrícola eram favoráveis. Apenas trinta e seis horas de viagem separavam o porto lagosiano da cidade de Abeokuta. Tal proximidade

\footnotetext{
${ }^{346}$ CFP. N.9. Foote to Russell, 12 de junho de 1861.

347 CFP. N.9. Foote to Russell, 12 de junho de 1861. Sobre as primeiras missões da CMS instaladas na Costa da Mina, recomendo: ISICHEI, Elizabeth. History of Christianity in Africa from Antiquity to the Present. London: Society for Promoting Christian Knowledge, 1995,p.170.
} 
permitiria o escoamento, via rio Ogun, do dendê, do algodão, do amendoim e de alguns artigos alimentícios produzidos na região. Desta forma, Foote resumia que,

O solo e clima são os mais favoráveis, as pessoas industriosas, as terras fáceis de serem obtidas e em abundância, somados ao fácil transporte pelo rio Ogun, [Abeokuta] reúne todos os requisitos com exceção de um, a segurança. $E$ enquanto o rei do Daomé existir como governante de seu país esta insegurança continuará. ${ }^{348}$

Sob o argumento de que os ataques daomeanos à Abeokuta eram um empecilho ao abastecimento de algodão à Grã-Bretanha, Foote corroborava com a percepção de que colonização de Lagos daria maior consistência às ações britânicas contra o Daomé. Além disto, era preciso colocar termo às ameaças alardeadas pelo dadá do Daomé - Glele - contra os europeus que viviam na região da Costa da Mina. ${ }^{349}$ De acordo com este mesmo relatório, o sucessor de Guezo intimidava franceses e ingleses, anunciando que aqueles que cruzassem seu caminho seriam capturados e teriam suas cabeças raspadas. Em acréscimo, estes prisioneiros seriam submetidos à humilhação pública de carregarem pelas ruas de Ajudá "a rede de seu principal parceiro, o famoso traficante de escravos Domingos Martins." 350 Ao denunciar as ameaças proferidas por Glele, o cônsul deixava explícita a posição privilegiada de Martins junto ao poder daomeano. Afinal, prometendo subverter o lugar social ocupado por franceses e ingleses, obrigando-os a trabalharem como escravos ao traficante brasileiro, o dadá do Daomé dava mostras do quão consistente era seu vínculo com Domingos José Martins. Entretanto, as intimidações contra europeus, a persistência do tráfico e da prática de razias não eram as únicas preocupações do Foreign Office neste momento. No início da década de 1860, a atenção britânica sobre a faixa continental que se estendia de Lagos até a cidade dos egbas envolvia ainda disputas internacionais, aspecto que tornava a colonização de Lagos ainda mais complexa.

\footnotetext{
${ }^{348}$ CFP. N.9. Foote to Russell, 12 de junho de 1861. Em 1860, uma carta escrita pelo então cônsul Brand (1859-1860) defendia a ocupação de Lagos como medida para proteger propriedades e executar os débitos dos africanos com firmas europeias. PROL, Brand to Russel, 9 de abril de 1860.

${ }_{349}$ Guezo faleceu no ano de 1858 , sendo sucedido por seu filho, Gelele.

${ }^{350}$ CFP. N.9. Foote to Russell, 12 de junho de 1861.
} 
Como tratei no primeiro capítulo, no ano de 1859, Robert Campbell e Martin Delany desembarcaram em Lagos com a missão de firmar um acordo junto ao alake de Abeokuta, Okukenu. Integrando uma expedição financiada pelo Niger Valley Exploring Party, instituição formada a partir de investimentos de norte-americanos e ingleses, Campbell e Delany estavam incumbidos de conseguir uma concessão de terras para que os libertos vindos da América do Norte pudessem se estabelecer naquela cidade. ${ }^{351}$ Embora de início o alake de Abeokuta tivesse concordado com a proposta apresentada por estes dois enviados, a validade do documento foi colocada em questão quando Okukenu voltou atrás acerca dos termos do acordo que ele mesmo havia assinado. Em uma nota de repúdio à divulgação de que "o alake e seus chefes haviam assinado um tratado [de cessão de terras] a pedido" de Campbell e Delany, Okukenu procurou esclarecer o imbróglio formado em torno do assunto. Neste documento o alake explicava haver apenas concedido aos futuros lavradores que ali se estabeleceriam um lote de terras que seriam destinadas ao plantio. Ao negar a doação (ou cessão) de seus domínios, Okukenu demonstrava sua lealdade ao governo consular britânico, declarando que "não aceitaria [em seu território] nenhum homem branco que não fosse recomendado pelo cônsul inglês ou pelos missionários anglicanos e wesleyanos." 352

A discussão em torno da validade do documento chegou a Londres e ao presidente da recém-fundada African Aid Society (1860), Alfred S. Churchill. A instituição londrina se constituiu a partir de princípios humanitários, mas era mantida com os recursos apurados pela indústria e comércio de produtos têxteis. Manifestando seu apoio aos integrantes da Niger Valley Exploring

\footnotetext{
${ }^{351}$ Os detalhes desta expedição foram fornecidos pelo relato de viagem escrito por Robert Campbell e Martin Delany, respectivamente em: CAMPBELL, Robert. A Pilgrimage to my motherland, an account of a journey among the egbas and yorubas of Central Africa, in 18591860. New York: Thomas Hamilton, 1861 e DELANY, Martin. Official Report of the Niger Valley Exploring Party. New York/London: Thomas Hamilton/Webb, MMillington \& Co, 1861. A expedição patrocinada pelo Niger Valley Exploring Party é analisada pelas seguintes publicações: BLACKETT, Richard. Martin R. Delany and Robert Campbell: Black Americans in Search of an African Colony. The Journal of Negro History, vol.62, No. 1, jan. 1977 e GILROY, Paul. O Atlântico Negro, modernidade e dupla consciência. Trad. Cid Knipel Moreira. Rio de Janeiro: Editora 34/UCAM/Centro de Estudos Afro-Asiáticos, 2002, pp.65-82: Martin Delany e a instituição da pátria. Um segundo artigo também escrito por Blackett, foi dedicado a compreender a trajetória de Campbell na cidade de Lagos: BLACKETT, Richard J.M. Return to the Motherland: Robert Campbell, a Jamaican in Early Colonial Lagos. Phylon, vol.40, No.4, 1979, pp. 375-386.

${ }^{352}$ CFP, N.6, Alake of Abbeokuta to Foote, 4 de março de 1861.
} 
Party, Churchill encaminhou ao parlamentar John Wodehouse uma longa missiva em defesa da legitimidade do acordo firmado por Campbell e Delany. Em favor dos enviados provenientes dos Estados Unidos, o presidente desta nova sociedade apresentou três cartas escritas pelo filho do reverendo Samuel Crowther: Samuel Crowther Junior. Como intérprete e testemunha da assinatura do acordo com Okukenu, Crowther Junior supostamente reunia a credibilidade necessária para a avaliação da legitimidade do documento. ${ }^{353}$ Entretanto, nem mesmo o apoio público do filho primogênito do famoso reverendo da CMS foi capaz de sustentar os termos para a instalação de um estabelecimento de libertos norte-americanos no território de Abeokuta. $O$ compêndio de cartas escritas por Crowther e reunidas por Churchill foi encaminhado ao cônsul dos Golfos do Benim e de Biafra, Henry Foote. Cerca de dois meses depois dos documentos chegarem às mãos de Foote, o cônsul britânico partiu para a cidade dos egbas. Em um extenso e minucioso relatório produzido a partir das impressões recolhidas nesta viagem Foote mencionou, de passagem, ter questionado o alake e seus apoiadores sobre a validade do acordo firmado com Campbell e Delany. As respostas que recebeu de Okukenu e de seus chefes foram sempre negativas, o que parece haver tranquilizado as autoridades do Foreign Office naquele momento. ${ }^{354}$

A leitura das missivas escritas por Crowther Junior revela que Campbell e Delany seguiram todos os protocolos da época para a assinatura do acordo com Okukenu. Suas negociações foram públicas, intermediadas por um intérprete (Crowther Jr.) e contaram com a participação das chefias que apoiavam o alake. Além disto, o texto escrito passou por modificações em razão de algumas objeções de Okukenu em relação ao local em que os libertos vindos dos Estados Unidos poderiam se estabelecer. ${ }^{355}$ No entanto, nem

\footnotetext{
${ }^{353}$ CFP, N.8, Wodehouse to Foote, 22 de abril de 1861, anexo 1, A. Churchill to Wodehouse, 22 de abril de 1861; anexos 2, 3 e 4, Mr. Crowther to A. Churchill, 18 de abril de 1861.

${ }^{354}$ CFP. N.9. Foote to Russell, 12 de junho de 1861. Sobre a disputa em torno da anulação do acordo de Campbell e Delany, o papel desempenhado pela African Aid Society e os desdobramentos que resultaram na expulsão de Crowther Jr. da cidade de Abeokuta, sugiro: KOPYTOFF, Jean Herskovits. A Preface to Modern Nigeria. The "Sierra Leonians" in Yoruba, 1830-1890. Wisconsin: The University of Wisconsin Press, 1965, p. 346-347, n.15.

${ }^{355}$ CFP, N.8, Wodehouse to Foote, 22 de abril de 1861, anexo 1, A. Churchill to Wodehouse, 22 de abril de 1861; anexos 2, 3 e 4, Mr. Crowther to A. Churchill, 18 de abril de 1861. Com relação à modificação dos termos do acordo feita a pedido do alake Okukenu, Crowther explica que esta se referia à concessão do lote de terras. No documento proposto por Campbell e Delany, as terras oferecidas pelo alake poderiam se encontrar em "qualquer parte do território
} 
mesmo a observância destes procedimentos impediu que o documento fosse invalidado. Isto ocorreu, em parte, em razão da pressão exercida pelo Foreign Office no sentido de manter a exclusividade de suas ações em Abeokuta. A cidade era considerada parte da zona de influência britânica na região e, como mencionei há pouco, o relatório produzido pelo cônsul Foote expunha quais eram os recursos naturais, humanos e geográficos que traduziriam esta influência em exploração.

Entretanto, a intenção do Foreign Office em manter e ampliar sua influência sobre a cidade dos egbas não foi a única razão pela qual o acordo promovido pelos enviados do Niger Valley Exploring Party foi inviabilizado. Desde 1859 Abeokuta integrava uma aliança com as cidades de ljebu Ode e llorin, liderada por Ibadan. Esta aliança se constituiu em oposição ao grupo conduzido por ljaye e formado por Oió, ljebu Remo e o Daomé. Os conflitos decorrentes das disputas entre as duas partes foram denominados pela historiografia como a Guerra de ljaye. ${ }^{356}$ Em Abeokuta, a defesa dos ataques contra as forças de ljaye era garantida pelas armas e munições fornecidas por comerciantes estabelecidos em Lagos. Em geral, o abastecimento de Abeokuta era intermediado por mercadores saros e, em menor número, por brasileiros. Até 1861, eram eles que predominavam nas negociações de produtos provenientes da Europa descarregados no porto lagosiano. Além disto, sarôs e brasileiros controlavam o comércio varejista lagosiano, vendiam mercadorias locais, que seriam exportadas por grandes firmas europeias estabelecidas na cidade, e enviavam para as regiões mais afastadas do litoral os bens que seriam trocados, principalmente, por dendê e seus subprodutos. Embora armas, pólvora e munição chegassem até Abeokuta por meio destes intermediários, eram as grandes firmas comerciais europeias existentes em

pertencente à Abeokuta, contanto que não estivessem ocupadas". Com a mudança na redação deste excerto do documento, Okukenu se comprometia a ceder aos libertos "o direito e o privilégio de plantarem em conjunto com os egbas e construírem suas casas e viverem dentro da cidade de Abeokuta e em meio à sua população."

${ }^{356}$ Os acontecimentos que desencadearam a Guerra de ljaye fogem aos propósitos desta pesquisa. No entanto, é possível saber mais sobre esse assunto nas seguintes obras: KOPYTOFF, Jean Herskovits. A Preface to Modern Nigeria. The "Sierra Leonians" in Yoruba, 1830-1890. Wisconsin: The University of Wisconsin Press, 1965, p. 107, 137-141 e SMITH, Robert. Op.cit., 1979, p.120. 
Lagos as responsáveis, em última instância, pelo abastecimento das forças do alake.

Quando, em 1859, Okukenu aceitou firmar o acordo proposto por Campbell e Delany o conflito entre ljaye e lbadan estava apenas se esboçando. Por este motivo, é possível que Abeokuta buscasse extrair ao máximo os benefícios decorrentes das aproximações oferecidas por estrangeiros que chegavam à cidade. Naquele momento, o acordo que propunha a instalação de um estabelecimento agrícola aberto e mantido por libertos provenientes dos Estados Unidos poderia ser uma opção à carência alimentar provocada por uma guerra que prometia ser duradoura. Além deste aspecto, o acréscimo de indivíduos sob o controle do alake, mesmo que de lavradores, talvez fosse visto como uma força reserva de guerra, cujos integrantes seriam colocados em ação caso necessário. Mas, assim que Okukenu percebeu que o acordo firmado com Campbell e Delany colocaria em risco o fornecimento das armas de fogo e munição que sustentariam uma melhor posição na Guerra de ljaye, ele passou a negar os termos deste documento, inviabilizando a instalação de libertos norte-americanos em seus domínios.

Se, por um lado, o sucesso de Abeokuta nos conflitos contra a aliança formada em torno de ljaye dependia do abastecimento dos suprimentos de guerra desembarcados no porto lagosiano, por outro, a constituição de uma estrutura burocrática colonial formada a partir dos poucos recursos fornecidos pela Grã-Bretanha, exigia que a colônia recém-conquistada alcançasse viabilidade econômica por meio da pujança de suas atividades comerciais. Neste contexto, a Guerra de ljaye colocava limites à forma como os ingleses planejavam instituir a colonização em Lagos. A aposta de que Abeokuta encaminharia à exportação não apenas sua produção de dendê, mas também as safras de algodão colhidas em lavouras que seriam plantadas em seu território, não se concretizou após a cessão de Lagos, em agosto de 1861. Isto porque as disputas com os apoiadores de ljaye desorganizavam a produção agrícola, promoviam o fechamento das rotas que alimentavam o mercado lagosiano e, como consequência, diminuíam o volume de dendê e de outras mercadorias exportadas. 
A instabilidade do abastecimento causada pela interrupção do fluxo de mercadorias encaminhadas ao litoral levou um grupo de comerciantes a formar, em Lagos, a Abbeokuta Road Improving Society. Participavam desta associação saros e brasileiros que se tornaram conhecidos pela historiografia produzida sobre a Costa da Mina. Entre eles estava o já mencionado Samuel Crowther Junior, secretário desta sociedade, e o brasileiro Francisco Ribeiro, cuja proeminência social (e econômica) levou o jornal The Lagos Weekly Record a anunciar sua viagem para Liverpool, em março de 1895. 357 Intermediando o comércio tecido entre o porto de Lagos e cidades mais afastadas da costa, seus membros pleiteavam junto às autoridades locais a abertura de caminhos, negociavam o preço das mercadorias levadas até a costa e, em diversas situações, atuavam como mensageiros nos diálogos e disputas firmados entre britânicos e egbas. ${ }^{358}$ Contudo, em outubro de 1861, tal mediação promovida pela Abbeokuta Road Improving Society parecia não alcançar os resultados desejados pelo Foreign Office. Apenas dois meses após a assinatura do tratado com Docemo, o governador interino McCoskry enviou uma carta endereçada ao secretário do Foreign Office, John E. Russell. Na missiva o governador declarava não ver perspectivas para o fim dos combates que envolviam os egbas. Ao considerar "impossível convencer os habitantes de Abeokuta que nós [os britânicos] poderíamos ser seus amigos, e também os ibadans e outras tribos (...)", McCoskry recomendava a suspensão do fornecimento de munição para seus aliados envolvidos no conflito. ${ }^{359}$

A sugestão encaminhada ao Foreign Office estava fundamentada nas possibilidades de ganhos comerciais apurados a partir de uma relação duradoura e estável com o interior. Neste sentido, era necessária a suspensão dos embates que reduziam a viabilidade da cidade constituir e manter sua burocracia com os recursos provenientes da taxação dos negócios de importação e exportação. No entanto, esta não era a única questão com a qual o recém-constituído governo de Lagos tinha com que se preocupar naquele momento. Em setembro de 1861, o então reverendo da CMS, Henry Venn,

357 The Lagos Weekly Record, de 30 de março de 1895. World Newspaper Archive, African Newspapers, $1891-1906$.

${ }^{358}$ KOPYTOFF, Jean Herskovits. Op.cit., 1965, pp. 113-114.

${ }^{359}$ CFP, N.21. McCoskry to Earl Russell, 4 de outubro de 1861. 
enviou a Russell um compêndio de cartas que lhe foram entregues pelo saro J.P.Davis, o mesmo ao qual me referi no primeiro capítulo como o rico comerciante que se casou com Sarah Forbes Bonetta, a afilhada da rainha Victoria resgatada pelo oficial Frederick Forbes. Um bilhete escrito por Venn explicava que Davis estava encarregado de conduzir os diálogos entre Docemo (e seus chefes) com as autoridades britânicas. Ao todo, Henry Venn entregou cerca de sete missivas escritas com o propósito de questionar os acontecimentos que levaram ao estabelecimento do tratado de cessão de Lagos, ocorrido no mês anterior. Quatro destes documentos foram remetidos por dois aliados de Docemo: Onikoyi e Edon. ${ }^{360}$

As cartas firmadas pelos apoiadores de Docemo e aquelas remetidas pelo próprio obá guardavam semelhanças entre si. Uma delas estava no questionamento em torno da forma como a assinatura do tratado de cessão foi conduzida. Em todas elas um longo preâmbulo retomava o vínculo de lealdade e amizade entre a rainha da Grã-Bretanha e Akitoye. Este vínculo teria se constituído em razão da aliança formada em prol da destituição de Kosoko. Cerca de dois anos depois, a morte de Akitoye (em 1853) ocasionou a transferência do mando para seu filho, Docemo. Anunciando fidelidade à rainha Victoria, o novo obá teria mantido a observância dos termos acordados entre seu pai e a monarca britânica. No entanto, de acordo com as missivas encaminhadas ao Foreign Office, nem mesmo o cumprimento do acordo que previa a supressão do tráfico, a expulsão de traficantes e a destruição de seus barracões teria impedido que os súditos ingleses Bedingfeld e McCoskry tomassem a ilha. Ao apresentarem uma versão dos acontecimentos que expunha a violência das ameaças que precederam a assinatura da cessão de Lagos, Docemo e seus chefes questionavam a legitimidade do tratado firmado. Sobre este aspecto, o obá explicava a atuação dos enviados britânicos nos seguintes termos:

\footnotetext{
$360 \mathrm{O}$ bilhete escrito pelo reverendo Henry Venn e as cartas anexadas a ele podem ser lidos no seguinte compêndio de fontes: PROL, N.7, H. Venn to Earl Russel, 20 de setembro de 1861. Anexo 1. The Chiefs of Lagos to Her Majesty Queen Victoria, Anexo 2. King Docemo to Her Majesty Queen Victoria, Anexo 4. Petition from certain Natives of the Island of Lagos; : PROL, N.10. The Chiefs of Lagos to Her Majesty Queen Victoria, 28 de outubro de 1861, anexo 1. Petition from certain Natives of the Island of Lagos, Anexo 2. The Chiefs of Lagos to Her Majesty Queen Victoria; Anexo 3. King Docemo to Her Majesty Queen Victoria.
} 
Ele levou até mim um papel em que estavam escritas coisas que não eram de meu consentimento, e as quais me recusei a assinar. Mas o comandante [Bedingfeld] me impôs a assinatura e, seu eu negasse, ele estava pronto a disparar sobre a ilha de Lagos e a destruí-la em um piscar de olhos. Para prevenir esta destruição ele [Bedingfeld] me induziu a assinar este papel e com o propósito de impedir a fuga da minha gente e, ao mesmo tempo, pensando em recorrer posteriormente à Sua Majestade, a rainha, sobre o que eu havia feito [assinei o tratado]. ${ }^{361}$

Embora os argumentos que solicitavam a suspensão do tratado de cessão estivessem bem fundamentados, eles não foram suficientes para que Docemo recobrasse a autoridade e a autonomia perdidas a partir da instalação colonial. Pelo contrário, naquele mesmo ano de 1861 o obá foi informado acerca das ações do comandante Bedingfeld em relação à assinatura de um acordo com Kosoko. Este documento previa o retorno de Kosoko a Lagos. Conforme outra carta remetida por Docemo à rainha Victoria, a volta do obá destituído colocaria em risco o cumprimento da principal justificativa à tomada britânica da cidade: a supressão definitiva do tráfico. Nesta missiva Docemo relembrava as ações que haviam retirado Kosoko do mando de Lagos, obrigando-o a se exilar em Epe. Advertindo que o ex-obá "aproveitaria a primeira oportunidade de vingança" para "esquartejar crianças, afogar pessoas e mutilar príncipes e princesas do rei anterior [Akitoye]", Docemo alertava contra o que esperava serem as consequências do retorno de Kosoko à cidade. ${ }^{362}$

A advertência acerca da possibilidade de uma desforra cruel por parte do obá destituído não alterou os planos do Foreign Office de firmar um tratado que estendesse os domínios coloniais da Grã-Bretanha pelos portos de Palma, Leke, chegando até Epe. ${ }^{363}$ No final de 1862, sob protestos de Docemo e de seus aliados, Kosoko voltou a viver em Lagos. Assumindo o título de oloja de Ereko e recebendo uma pensão anual no valor de quatrocentas libras por ano -

\footnotetext{
${ }^{361}$ PROL, N.7, H. Venn to Earl Russel, 20 de setembro de 1861, anexo 2. King Docemo to Her Majesty Queen Victoria.

${ }^{362}$ PROL, N.10, H. Venn to Earl Russel, 10 de setembro de 1861, anexo 3. King Docemo to Her Majesty Queen Victoria.

${ }^{363} \mathrm{O}$ mapa 4: Domínios de Kosoko durante o exílio em Epe, apresentado no terceiro capítulo desta tese, permite uma melhor visualização da localização das cidades de Palma, Leke e Epe.
} 
seiscentas e trinta libras a menos do que Docemo recebia a título de compensação pela perda de Lagos - Kosoko cedeu aos britânicos os territórios de Palma, Leke e Epe. ${ }^{364}$ No entanto, o documento firmado com o ex-obá não foi suficiente para garantir a submissão de outras chefias estabelecidas nos territórios citados. Em fevereiro de 1863, os ingleses encontraram resistência no cumprimento do tratado firmado com o ex-obá. Conforme explica Smith, em Epe, um dos aliados de Kosoko - conhecido como Possu (ou Ipossu) - se recusou a aceitar os termos do acordo proposto pelos ingleses. Tal oposição durou poucos meses. Ao final de dois ataques promovidos pela armada da rainha Victoria, a cidade cedeu à assinatura de um documento que incluía Epe como área de influência da Grã-Bretanha. ${ }^{365}$

Iniciada em agosto de 1861, a colonização de Lagos constituiu um marco para as ações britânicas orientadas à expansão imperialista em direção aos territórios mais afastados do litoral lagosiano. Ao longo dos anos posteriores a assinatura do tratado de cessão, a cidade se tornou a base para as operações do Colonial Office na região. De Lagos partiram os enviados do governo colonial que, nas décadas de 1860 e 1870, tinham o propósito de acertar os termos para o fim da Guerra de ljaye, por exemplo. Afinal, o término deste e de outros conflitos existentes em áreas mais ao interior representava a abertura dos caminhos usados para o escoamento da produção de alimentos, de dendê e de algodão até o porto lagosiano. Com as rotas livres ao trânsito de mercadorias seria possível compor as bases para uma atividade comercial consistente e contínua.

Com um comércio sólido e pujante Lagos poderia sustentar sua estrutura burocrática por meio dos impostos recolhidos sobre as importações e exportações que circulavam em seu porto. Ao menos eram estas as intenções do Colonial Office ao restringir o orçamento da nova colônia conquistada. De acordo com Mann, os parcos recursos enviados pela Grã-Bretanha eram

\footnotetext{
${ }^{364}$ No início dos anos de 1840, Kosoko foi convidado por seu tio, o obá Akitoye, a retornar de seu exílio em Ajudá. Naquela ocasião, o obá conferiu a seu sobrinho o título de Oloja de Ereko, o que significava a posse do mercado de Ereko, com direito a constituir sua própria corte. Em 1862, quando Kosoko voltou a residir em Lagos, seu título de Oloja de Ereko foi recobrado. De acordo com o Blue Book de 1863, Docemo recebia uma pensão anual no valor de 1200 sacos de cauris ou 1030 libras. Esta mesma fonte nos informa que o Foreign Office pagava a Kosoko 400 libras anuais. Blue Books, 1863, Pensions, pp.216-217.

${ }^{365}$ SMITH, Robert Sydney. Op.cit.,1978, p.127.
} 
empregados no pagamento do salário do governador e da pensão anual destinada ao obá. Quando o primeiro governador de Lagos, Henry Stanhope Freeman, assumiu seu posto em 1861 as orientações que recebeu do então secretário do Colonial Office, o duque de Newcastle, foram bastante precisas: a colônia teria um orçamento muito restrito e, em razão disto, a burocracia que se constituiria a partir daquele momento deveria se ancorar nos impostos apurados pelas atividades econômicas efetuadas no território recémconquistado. ${ }^{366}$

\subsection{O comércio em Lagos, 1862 - 1900}

Féchouada é servida com o gari (farinha de mandioca), regada com óleo perfumado com cebola, ou com o ablo (pão de milho cozido no vapor), ou ainda com macarrão de milho ou pão. ${ }^{367}$

Grandes firmas europeias, representantes comerciais, mercadores e intermediários saros e brasileiros eram parte fundamental de uma estrutura de governo civil alimentada, quase em exclusivo, pela taxação do comércio internacional. Este aspecto demandava, por parte do Colonial Office, o controle dos valores importados e exportados através do porto lagosiano. Em 1863, apenas dois anos depois da cidade se tornar parte dos domínios coloniais britânicos, Lagos passou a elaborar e a enviar à Grã-Bretanha relatórios anuais acerca da forma como era conduzida a administração colonial. A maior parte destes documentos eram manuscritos - atualmente digitalizados - e foram compilados sob a denominação de Blue Books. Esta pesquisa trabalha com um compêndio destas fontes denominado Nigeria, 1862-1945. Este conjunto de registros trata dos mais diferentes assuntos relacionados ao governo britânico

\footnotetext{
${ }^{366}$ Cf. MANN, Kristin. Op.cit., 2010, p. 103. No último capítulo de sua obra, Robert Smith também analisa os debates ocorridos em diferentes esferas do governo britânico acerca das possibilidades em se estabelecer um equilíbrio entre os gastos para a instalação de um governo colonial em Lagos e os lucros decorrentes das atividades comerciais operadas em seu porto. SMITH, Robert Sydney. Op.cit.,1978, cap.8. A deadly gift?

367 "Féchouada se sert avec du gari (semoule de manioc) arrosé d'huile parfumée à l'oignon, ou avec de l'ablo (pain de mais cuit à la vapeur), ou encore avec des patês de mais diverses ou du pain". Trecho final da receita da Féchouada registrada por Simone de Souza. No século XIX a importação de artigos alimentícios vindos do Brasil ajudou a compor um receituário que se tornou conhecido como brasileiro. SOUZA, Simone de. La famille de Souza du Benin - Togo. Cotonu: Éditions du Benin, 1992. p. 105.
} 
operado na cidade. Anotações referentes aos prisioneiros; tabelas de gastos e despesas públicas; nomeações e mudanças de cargos no funcionalismo colonial; orçamento e número de alunos dos estabelecimentos de ensino; volume e bens importados e exportados são exemplos do conteúdo encontrado nestes relatórios. ${ }^{368}$

Os relatórios dos valores importados e exportados por Lagos constituem uma importante fonte de informações acerca das dinâmicas comerciais operadas na colônia. Estes documentos revelam a importância dos negócios estabelecidos entre o porto lagosiano e o Brasil na segunda metade do século XIX. Deste modo, a tabela a seguir mostra que, entre os anos de 1863 e 1900, as naus vindas do Brasil foram responsáveis pelo terceiro maior volume de vendas para a cidade. Superada apenas pela Grã-Bretanha e Alemanha, a somatória dos bens desembarcados por navios brasileiros corrobora a corrente historiográfica que percebe a persistência das relações comerciais e, também, culturais e humanas, entre Brasil e Lagos mesmo após a cidade se tornar colônia britânica. Segundo esta corrente historiográfica, os brasileiros que viviam em Lagos e no Brasil (em especial, na Bahia) mantiveram, ao longo de toda a segunda metade do século XIX, uma relação de troca que ia além daquelas definidas pelo comércio, se estendendo também pelo âmbito da cultura e do trânsito de pessoas pelo Atlântico. ${ }^{369}$

\footnotetext{
368 Os Blue Books podem ser consultados em: http://www.britishonlinearchives.co.uk, coleção African Blue Books, 1821-1953, série Nigeria 1862-1945. O relatório referente ao ano de 1864 não se encontra digitalizado nesta base de dados.

${ }^{369}$ Refiro-me, principalmente, às obras de Manuela Carneiro da Cunha, Alcione Amós e Alberto da Costa e Silva. Estes pesquisadores percebem que a colonização britânica em Lagos não trouxe ruptura imediata com o Brasil. As publicações que sugerem esta perspectiva são: CUNHA, Manuela Carneiro da. Negros, estrangeiros. Os escravos libertos e sua volta à África. $2^{a}$ ed. revisada e ampliada. São Paulo: Companhia das Letras, 2012, pp.138-148; AMOS, Alcione Meira. Os que voltaram: a história dos retornados afro-brasileiros na África Ocidental do século XIX. Belo Horizonte: Tradição Planalto, 2007,pp.91-125 e SILVA, Alberto da Costa e. Um rio chamado Atlântico: a África no Brasil e o Brasil na África. Rio de Janeiro: UFRJ, 2003, pp.93- 105.
} 
Tabela 3: Volume de importações para Lagos (valores em libras esterlinas) ${ }^{370}$

\begin{tabular}{ccccc}
\hline & Grã-Bretanha & Alemanha & Brasil & França \\
\hline $\mathbf{1 8 6 3}$ & 110584 & 27597 & 15500 & 9034 \\
$\mathbf{1 8 6 5}$ & 59126 & 13676 & 13762 & 3918 \\
$\mathbf{1 8 6 6}$ & 128704 & 18545 & 15283 & 13623 \\
$\mathbf{1 8 6 7}$ & 197414 & 21934 & 14580 & 25045 \\
$\mathbf{1 8 6 8}$ & 224829 & 36021 & 17853 & 6791 \\
$\mathbf{1 8 6 9}$ & 290622 & 34183 & 29526 & 25163 \\
$\mathbf{1 8 7 0}$ & 272684 & 41135 & 37026 & 13195 \\
$\mathbf{1 8 7 1}$ & 299670 & 37596 & 17134 & 6776 \\
$\mathbf{1 8 7 2}$ & 267274 & 36066 & 19249 & 11667 \\
$\mathbf{1 8 7 3}$ & 189374 & 24132 & 11901 & 7026 \\
$\mathbf{1 8 7 4}$ & 264127 & 40263 & 16763 & 6662 \\
$\mathbf{1 8 7 5}$ & 230821 & 57726 & 24627 & 24492 \\
$\mathbf{1 8 7 6}$ & 326778 & 56455 & 33964 & 32956 \\
$\mathbf{1 8 7 7}$ & 397457 & 86573 & 50727 & 58570 \\
$\mathbf{1 8 7 8}$ & 307945 & 88459 & 31436 & 21684 \\
$\mathbf{1 8 7 9}$ & 271780 & 114619 & 28745 & 49642 \\
$\mathbf{1 8 8 0}$ & 244349 & 84827 & 31580 & 14609 \\
$\mathbf{1 8 8 1}$ & 160484 & 104340 & 27177 & 18817 \\
$\mathbf{1 8 8 2}$ & 279978 & 99337 & 16810 & 7842 \\
$\mathbf{1 8 8 3}$ & 314228 & 126030 & 16718 & 10015 \\
$\mathbf{1 8 8 4}$ & 338317 & 151250 & 16978 & 6128 \\
$\mathbf{1 8 8 5}$ & 292532 & - & - & - \\
$\mathbf{1 8 8 6}$ & 222882 & 95293 & 17761 & 6176 \\
\hline $\mathbf{1 8 8 7}$ & 264275 & 107130 & 16737 & 5261 \\
$\mathbf{1 8 8 8}$ & 291562 & 124311 & 9930 & 1028 \\
$\mathbf{1 8 8 9}$ & 307045 & 126138 & 10572 & 3445 \\
$\mathbf{1 8 9 0}$ & 336714 & 130563 & 10756 & 4112 \\
$\mathbf{1 8 9 1}$ & 4353388 & 145725 & 5284 & 2188 \\
$\mathbf{1 8 9 2}$ & 323565 & 149001 & 5583 & 12392 \\
$\mathbf{1 8 9 3}$ & 525287 & 176186 & 6170 & 6550 \\
$\mathbf{1 8 9 4}$ & 486895 & 211865 & 4131 & 2339 \\
$\mathbf{1 8 9 5}$ & 605463 & 175668 & 4830 & - \\
$\mathbf{1 8 9 6}$ & 667800 & 184483 & 4502 & 75 \\
$\mathbf{1 8 9 7}$ & 574937 & 145335 & 5575 & 327 \\
$\mathbf{1 8 9 8}$ & 723650 & 123320 & 5173 & - \\
$\mathbf{1 8 9 9}$ & 788580 & 112746 & 2572 & 405 \\
$\mathbf{1 9 0 0}$ & 674855 & 103260 & 2955 & - \\
$\mathbf{1 0 T A L}$ & 16615975 & 3411788 & 599870 & 417953 \\
\hline & & & & \\
\hline & & & & \\
\hline
\end{tabular}

Fonte: Tabela elaborada a partir dos relatórios de importação/exportação constantes nos Blue Books produzidos entre os anos de 1863 e 1900.

370 O Blue Book referente ao ano de 1864 não está disponível para consulta na base de documentos digitalizados pelo National On-line Archives. 
Os dados encontrados nos relatórios anuais de importação contidos nos Blue Books eram coligidos a partir dos registros alfandegários realizados no porto lagosiano. Este aspecto exclui o desembarque de mercadorias operado em portos não oficiais, artigos desviados por meio de contrabando e possíveis equívocos nas anotações realizadas por funcionários alfandegários. Todavia, ainda que os valores apresentados sejam parciais e imprecisos, tais registros fornecem uma noção de quais eram os principais parceiros comerciais de Lagos e os montantes envolvidos nas negociações. Além disto, este conjunto de fontes também relaciona quais mercadorias eram levadas até Lagos por embarcações provenientes do Brasil. ${ }^{371}$ Desta forma, seguindo o critério da somatória dos valores importados, elaborei a Tabela 3 considerando apenas os quatro maiores importadores para Lagos. No apêndice 1, denominado Importações para Lagos, apresento uma segunda versão deste quadro incluindo os doze maiores parceiros comerciais constantes na fonte consultada.

A lista de artigos importados pela colônia britânica é extensa. ${ }^{372}$ Além do tabaco e da aguardente, bens amplamente citados por pesquisadores interessados em compreender as trocas comerciais pelo Atlântico, podemos identificar alguns outros artigos importados em menor quantidade. ${ }^{373}$ Miçangas, tamancos de madeira e utensílios de barro eram mercadorias produzidas e vendidas com exclusividade pelo Brasil. A existência deste mercado é um indicativo de como os dados relativos ao comércio podem revelar aspectos da vida cotidiana dos brasileiros de Lagos. É o caso, por exemplo, da importação da araruta, uma planta endêmica das Américas, cuja raiz possui um uso

\footnotetext{
${ }^{371}$ Ao citar C. Newbury, Cunha comenta que as cifras registradas pelos relatórios compilados como Blue Books teriam ao menos o "mérito de dar uma ideia das quantias" importadas. CUNHA, Manuela Carneiro da. Op.cit, 2012, p.143.

${ }^{372}$ No apêndice 2, intitulado Mercadorias fornecidas pelo Brasil, apresento a lista completa de artigos desembarcados em Lagos durante o período de 1863 até 1900.

${ }^{373}$ Cito aqui alguns dos estudos que, em tempos históricos diferentes, se preocuparam em desvendar as relações comerciais existentes entre o Brasil e a Costa da Mina. Selecionei em específico as pesquisas que entendem o trânsito de mercadorias pelo Atlântico como um movimento que possibilitou a circulação e troca de indivíduos e ideias pelo oceano. ALENCASTRO, Luis Felipe de. O Trato dos Viventes: Formação do Brasil no Atlântico Sul. São Paulo: Companhia das Letras, 2000; CURTO, José C., LOVEJOY, Paul E. Enslaving Connections. Changing Cultures of Africa and Brazil during the Era of Slavery, New York: Humanity Books, 2004; MATTOSO, Kátia de Queirós. Ser escravo no Brasil. 3 a ed. São Paulo: Brasiliense, 2003; SOUZA, Mônica Lima e. Entre margens: o retorno à África de libertos no Brasil, 1830-1870. tese de doutorado. UFF/RJ, 2008 e VERGER, Pierre. Fluxo e Refluxo do tráfico de escravos entre o Golfo de Benin e a Bahia de todos os Santos: dos séculos XVII a XIX. São Paulo: Corrupio, 1987.
} 
semelhante ao da mandioca e que se dizia ter efeitos terapêuticos. Embora tenha encontrado o registro de importação desta raiz apenas no ano de 1870, e em pequena quantidade, a demanda por um artigo tão específico denota as particularidades da culinária e das práticas medicinais realizadas pelos brasileiros que moravam na cidade. ${ }^{374}$

Tabela 4: Produtos importados por Lagos e fornecidos pelo Brasil em $1870^{375}$

\begin{tabular}{ll}
\hline \multicolumn{2}{c}{$\mathbf{1 8 7 0}$} \\
\hline Açúcar mascavo & Ferragens \\
Água mineral & Fiambre \\
Algodão & Guarda-chuva \\
Araruta & Licor \\
Armarinho & Manteiga \\
Armas & Mantimentos \\
Arroz & Melaço \\
Azeite & Pão \\
Banha & Papelaria \\
Café & Peixe seco \\
Calçados & Remédios \\
Carne seca & Rum \\
Cauris & Tabaco \\
Chá & Tamancos de \\
& madeira \\
Charutos & Tecidos \\
Confeitos & Utensílios de \\
& cerâmica \\
Conservas & Vestuário \\
Contas/miçangas & Vinho \\
Cutelaria & \\
Enxofre & \\
\hline
\end{tabular}

Fonte: Tabela elaborada a partir dos relatórios de importação/exportação constante no Blue Book produzido no ano de 1870.

${ }^{374}$ Blue Book, Colony of Lagos, 1870, p.266.

375 Selecionei aleatoriamente 0 ano de 1870 apenas com o propósito de exemplificar a composição das listas de importação pesquisadas. No apêndice 2 é possível consultar a lista completa referente ao período de 1863 a 1900. 
Outros itens ligados a um tipo de culinária que, com o tempo, se tornou conhecida em Lagos como brasileira também estão presentes nas relações de importação. Melaço, tapioca, toucinho, farinha de mandioca e banha constituem as mercadorias mais significativas, visto que foram incluídas em praticamente todos os anos. Esta demanda por itens que ajudaram a compor um receituário brasileiro em Lagos revela aspectos de uma identidade exercida na dimensão cotidiana e a respeito da qual existem ainda poucas análises. ${ }^{376} \mathrm{O}$ consumo de alimentos vindos do Brasil sugere que o processo de constituição da identidade dos brasileiros de Lagos assumiu diferentes formatos e se estendeu para além das esferas dos negócios e da política. Embora os registros a respeito das mercadorias importadas nos forneçam detalhes acerca da origem dos artigos, quantidades desembarcadas e preços, podemos depreender pouco acerca de quem eram os compradores no varejo, quais eram os usos destes artigos culinários e em que ocasiões os pratos brasileiros eram elaborados.

Tais limites à interpretação das informações fornecidas pela documentação são ainda mais evidentes nas listas de importações que incluem itens como livros e instrumentos musicais. Os relatórios consultados não especificam quais eram os instrumentos importados e, tampouco, informam os títulos das obras desembarcadas na colônia britânica. Ademais, a venda destes artigos não ocorria todos os anos, eles aparecem nos Blue Books referentes a $1871,1872,1874,1879$ e 1880. Estes itens eram desembarcados em Lagos em pequenas quantidades - em geral, um a cada ano - representando um volume bastante inferior quando comparado ao número de instrumentos musicais vendidos pela Grã-Bretanha. Em 1872, por exemplo, os navios britânicos desembarcaram no porto lagosiano 27 objetos classificados como

\footnotetext{
${ }^{376}$ Simone de Souza, uma francesa casada com um integrante da família de Francisco Felix de Souza, é autora de um livro sobre a trajetória do chachá de Ajudá e de seus descendentes. Embora não se refira aos brasileiros existentes em Lagos, sua obra é um dos poucos registros que apresenta as receitas elaboradas pela família Souza. SOUZA, Simone de. La famille de Souza du Benin - Togo. Cotonu: Éditions du Benin, 1992. Esse livro é parte do acervo da biblioteca da Casa das Áfricas.
} 
instrumentos musicais. Neste mesmo ano, Lagos importou da Alemanha três instrumentos e do Brasil apenas um. ${ }^{377}$

A importação de livros seguia um padrão semelhante ao encontrado no comércio de instrumentos musicais. Em 1874, as firmas comerciais britânicas descarregaram na cidade 69 livros. Uma quantidade muito superior àquela apresentada no relatório das importações provenientes do Brasil neste mesmo ano: um livro. Em que pesem o reduzido volume de importações destes itens e a ausência de informações que especifiquem quais eram os instrumentos musicais e as obras levadas do Brasil para Lagos, podemos considerar estes artigos uma das evidências materiais do longo processo de composição das várias identidades brasileiras constituídas a partir das trocas e dos contatos possibilitados pelo comércio atlântico. ${ }^{378}$

Os negócios praticados entre Brasil e Lagos obedeciam também o sentido inverso, ou seja, da colônia britânica partiam mercadorias que seriam vendidas em solo brasileiro. No entanto, as exportações de Lagos para o Brasil eram em número muito inferior aos valores importados pelo porto lagosiano. Os dados apurados na tabela 5 - Volume de exportações de Lagos - demonstram que, no período entre 1863 e 1900, o Brasil ocupou a quinta posição entre os compradores de artigos provenientes de seu território. Tal como nos relatórios de importação, os registros compilados pelos Blue Books apresentam os valores exportados por Lagos, seus respectivos destinos e quantidades de mercadorias. No caso do Brasil, o número de artigos e o valor destes itens contribuíram para que a balança comercial fosse deficitária em relação a Lagos. Além deste aspecto, quando comparamos os dados relativos às exportações que seguiam em direção à Grã-Bretanha, Alemanha, Porto Novo e França, notamos que as exportações para o Brasil não chegavam a um sexto do valor enviado para Porto Novo, o terceiro colocado na relação de exportadores.

\footnotetext{
377 Blue Book, Colony of Lagos, 1872, pp.160/161.

${ }^{378}$ Blue Book, Colony of Lagos, 1872, pp.158/159.
} 
Tabela 5: Volume de exportações de Lagos (valores em libras esterlinas) ${ }^{379}$

\begin{tabular}{lccccc}
\hline & Grã-Bretanha & Alemanha & $\begin{array}{c}\text { Porto } \\
\text { Novo }\end{array}$ & França & Brasil \\
\hline $\mathbf{1 8 6 3}$ & 92934 & 36838 & 2416 & 14612 & 8143 \\
$\mathbf{1 8 6 5}$ & 96247 & 1845 & 19682 & 9979 & 7559 \\
$\mathbf{1 8 6 6}$ & 148443 & 42457 & 9810 & 41191 & 990 \\
$\mathbf{1 8 6 7}$ & 287239 & 92310 & 11197 & 94622 & 4605 \\
$\mathbf{1 8 6 8}$ & 244396 & 114086 & 9758 & 113188 & 8120 \\
$\mathbf{1 8 6 9}$ & - & 5589 & - & - & - \\
$\mathbf{1 8 7 0}$ & 298939 & 80998 & 20823 & 12576 & 3762 \\
$\mathbf{1 8 7 1}$ & 357259 & 80942 & 23733 & 93095 & 14178 \\
$\mathbf{1 8 7 2}$ & 247981 & 77869 & 39793 & 57111 & - \\
$\mathbf{1 8 7 3}$ & 229161 & 110759 & 44258 & 31233 & 5080 \\
$\mathbf{1 8 7 4}$ & 283957 & 135927 & 37191 & 24928 & 19470 \\
$\mathbf{1 8 7 5}$ & 270975 & 189642 & 43776 & 42446 & 13725 \\
$\mathbf{1 8 7 6}$ & 265225 & - & 74365 & 59486 & 24311 \\
$\mathbf{1 8 7 7}$ & - & 112907 & - & - & - \\
$\mathbf{1 8 7 8}$ & 254989 & - & 103648 & 79157 & 13449 \\
$\mathbf{1 8 8 1}$ & 160216 & 115524 & 64070 & 77554 & 14856 \\
$\mathbf{1 8 8 2}$ & 267243 & 136264 & 65510 & 64623 & 20027 \\
$\mathbf{1 8 8 3}$ & 259057 & 176739 & 60592 & 52946 & 6083 \\
$\mathbf{1 8 8 4}$ & 249793 & 283726 & 81409 & 18020 & 13967 \\
$\mathbf{1 8 8 5}$ & 194607 & 210849 & 82689 & 87617 & 10764 \\
$\mathbf{1 8 8 6}$ & 308896 & 125915 & 37954 & 23490 & 6454 \\
$\mathbf{1 8 8 7}$ & 235621 & 168291 & 52532 & 16167 & 3929 \\
$\mathbf{1 8 8 8}$ & 167807 & 2333391 & 45829 & 38328 & 8245 \\
$\mathbf{1 8 8 9}$ & 152897 & 213924 & 51497 & 12740 & 7159 \\
$\mathbf{1 8 9 0}$ & 210141 & 248459 & 47599 & 51659 & 4851 \\
$\mathbf{1 8 9 1}$ & 285821 & 305668 & 83740 & 12291 & 4893 \\
$\mathbf{1 8 9 2}$ & 212513 & 505 & 118781 & 959 & 2 \\
$\mathbf{1 8 9 3}$ & 327612 & 358517 & 115678 & 5538 & 8120 \\
$\mathbf{1 8 9 4}$ & 302018 & 361507 & 123118 & 4908 & - \\
$\mathbf{1 8 9 5}$ & 430526 & 360193 & 108728 & 1680 & 17 \\
$\mathbf{1 8 9 6}$ & 497863 & 383540 & 54936 & - & 5160 \\
$\mathbf{1 8 9 7}$ & 400114 & 310428 & 30632 & 364 & 1344 \\
$\mathbf{1 8 9 8}$ & 403937 & 360543 & 50849 & 800 & 180 \\
$\mathbf{1 8 9 9}$ & 332336 & 445930 & 56209 & - & 1184 \\
$\mathbf{1 9 0 0}$ & 309265 & - & 47937 & 20 & 1300 \\
$\mathbf{T O T A L}$ & 8786028 & 7982082 & 1820739 & 1143328 & 241927 \\
\hline & & & & & \\
\hline & & & & & \\
\hline
\end{tabular}

Fonte: Tabela elaborada a partir dos relatórios de importação/exportação constantes nos Blue Books produzidos entre os anos de 1863 e 1900.

${ }^{379}$ Apresento apenas os cinco principais destinos das mercadorias que partiam do porto de Lagos. Uma versão mais completa, que inclui outros parceiros comerciais de Lagos, pode ser lida no apêndice 3: Exportações de Lagos. Os Blue Books não apresentam registros acerca das exportações realizadas em Lagos nos anos de 1879 e 1880. 
De maneira geral, os bens que deixavam Lagos para serem vendidos no Brasil saciavam as demandas da população africana e de seus descendentes que viviam em solo brasileiro, em especial baiano. A maioria dos itens relacionados nos documentos consultados estava ligada à culinária ou ao exercício de práticas religiosas. Em muitos casos é possível que o uso religioso e alimentar destes materiais fosse complementar. Noz de cola, sementes de egusi (um tipo de abóbora), cestos e cabaças são artigos presentes em quase todos os relatórios analisados por esta tese. Como indica Cunha, estes ingredientes e objetos de uso ritual eram valorizados em função de sua origem. Neste caso, a procedência africana destas mercadorias acrescentava um sentido metafórico aos artigos trazidos de Lagos, qualificando-os para a atividade religiosa. A existência de um comércio cujos itens eram consumidos por africanos e descendentes que viviam no Brasil expõe parte das características que definiam as trocas e os contatos engendrados pelo trânsito de mercadorias pelo Atlântico. ${ }^{380}$

$\mathrm{Na}$ cidade de Lagos as relações comerciais assumiram diferentes escalas. O comércio em pequenas proporções permeava vários setores, ocupava um número significativo de indivíduos e movimentava boa parte da economia da cidade. Uma vez que o solo arenoso da ilha impunha limites à produção agrícola, a atividade comercial se constituiu como um setor da economia local ligado aos territórios situados mais ao interior. Era principalmente das cidades de Abeokuta, Ibadan e ljebu-Ode que partiam as mercadorias que seriam consumidas em Lagos ou exportadas através de seu porto. Os bens produzidos em localidades afastadas da costa eram negociados por intermediários, dentre os quais figuravam saros e brasileiros. Embora uma parte dos artigos vindos do interior fosse destinada ao consumo lagosiano, havia também um conjunto de itens que eram negociados por firmas ou

380 Cf. CUNHA, Manuela Carneiro da. Op.cit., 2012, pp.148-152. Para uma discussão aprofundada acerca dos processos de elaboração das identidades étnicas na Bahia e a respeito do papel das religiões de origem africana nesse processo, sugiro: PARÉS, Luis Nicolau. A formação do candomblé. História e ritual da nação jeje na Bahia. Campinas: Editora Unicamp, 2006. 
agentes comerciais, cujos negócios extrapolavam as trocas locais e atavam Lagos ao mercado internacional. ${ }^{381}$

Um engenhoso sistema de crédito atrelava intermediários e produtores às firmas europeias ou aos agentes comerciais representantes destas companhias. Este sistema consistia no adiantamento das mercadorias que seriam trocadas por bens produzidos no interior, no caso das atividades exportadoras, em geral, por óleo de palma. O adiantamento destes bens importados implicava também na definição de um prazo para o pagamento da dívida. Todavia, não eram raros os casos em que, ao final do período determinado pelas partes, o devedor não conseguia saldar sua dívida. De acordo com Mann, numa situação como esta intermediários e produtores endividados recorriam a outros credores, solicitando mercadorias adicionais que seriam trocadas por bens exportáveis, a fim de quitar pendências mais antigas. Este recurso provocava um aumento da dívida e uma condição de débito permanente. Enredados por empréstimos que não conseguiam liquidar, estes indivíduos tinham seus negócios limitados a alguns poucos parceiros comerciais dispostos a adiantar bens sob a condição do pagamento de juros altíssimos. Até 1887, ano da criação do banco oficial de Lagos, estes empréstimos eram operados por comerciantes enriquecidos e não havia nenhuma regulamentação que estabelecia limites à cobrança de juros. ${ }^{382}$

$\mathrm{Na}$ segunda metade do século XIX, as grandes firmas europeias mantinham em Lagos agentes responsáveis por negociar preços, ajustar as quantidades das mercadorias comercializadas e supervisionar a qualidade dos artigos que seriam encaminhados ao mercado internacional. Neste período, firmas alemãs, francesas, italianas e, em maior número, britânicas tinham suas sedes na cidade. Além destas, algumas companhias pertencentes a negociantes brasileiros também se dedicavam ao comércio internacional

\footnotetext{
${ }^{381}$ Cf. KOPYTOFF, Jean Herskovits. A Preface to Modern Nigeria. The "Sierra Leonians" in Yoruba, 1830-1890. Wisconsin: The University of Wisconsin Press, 1865, pp.86-99.

382 Cf. MANN, Kristin. Op.cit., 2010, p.144-150. Uma menção à caixa econômica oficial de Lagos é feita por Cunha, em: CUNHA, Manuela Carneiro da. Op.cit., 2012, p.155. Embora extrapole o recorte temporal com o qual esta pesquisa trabalha (1840 a 1900), encontrei em novembro de 1901, no periódico Lagos Weekly Record, um anúncio do The Lagos Native Bank, cujos diretores eram os brasileiros Cândido da Rocha, J.B. da Silva e o saro James George. Lagos Weekly Record, 8 de novembro de 1901, World Newspaper Archive, African Newspapers, $1883-1888$.
} 
operado por meio do porto lagosiano. Firmas como a Sant'Anna \& Co, J.M.Pinto, Bernardo Rodrigues, Joaquim Branco, J.A. Lino e P.F. Gomes possuíam grandes armazéns que cumpriam a função de guardar os artigos negociados nos mercados internacional e local. Estes estabelecimentos aparecem citados em relatórios produzidos pelo Colonial Office. 0 departamento do governo britânico divulgava suas realizações e alguns dados apurados em relação a colônia, por meio de seu periódico oficial: a Government Gazette, Colony of Lagos. ${ }^{383}$

Entre os registros publicados por este jornal havia um conjunto de relatórios que informavam quais eram os comerciantes atacadistas que dispunham de armazéns na cidade, a localização dos imóveis, quem eram os fiadores destes estabelecimentos e se o espaço era utilizado por um terceiro. A leitura destes documentos revela a transformação do patrimônio de alguns brasileiros conhecidos como pertencentes às famílias mais endinheiradas da cidade. Não são raros os estudos que se referem aos indivíduos de sobrenomes Sant'Anna, Branco, Campos e Gomes como os que concentravam os maiores recursos e prestígio social na cidade de Lagos da segunda metade do século $\mathrm{XIX}^{384} \mathrm{O}$ caso da firma Sant'Anna \& Co, fundada por Manoel Joaquim de Sant'Anna e conhecida por sua ampla atuação nos mercados de Lagos e de Porto Novo, é emblemático deste processo de concentração financeira. Como é possível verificar por meio das informações apresentadas na tabela 6 - Comerciantes brasileiros que ocupavam armazéns em Lagos - no ano de 1886, a companhia mantinha seis barracões situados em uma rua bastante próxima ao porto de Lagos, a rua Kakawa. ${ }^{385}$

\footnotetext{
${ }^{383}$ Como indiquei na introdução, os exemplares das Government Gazettes são parte da seção Colonial Office e estão guardados no National Archives, em Londres.

${ }_{384}$ Refiro-me às pesquisas escritas por: Marianno Carneiro da Cunha, Manuela Carneiro da Cunha, Alcione Amós, Jean H. Kopytoff e Kritin Mann.

${ }^{385}$ A pesquisadora Jean Herskovits Kopytoff publicou, em sua obra A Preface to Modern Nigeria, um minucioso mapa acerca de como estava organizada a cidade de Lagos no século XIX. Nesta representação é possível localizar os imóveis pertencentes às grandes firmas de europeus, saros e brasileiros, assim como as residências de diversos brasileiros. Um segundo mapa, apresentado na obra escrita por Alcione Amós, permite o entendimento acerca da ocupação da cidade em 1908. No quinto capítulo apresento uma representação cartográfica adaptada do mapa elaborado por Kopytoff. Respectivamente: KOPYTOFF, Jean Herskovits. Op.cit., 1865, pp.90-93 e AMÓS, Alcione Meira. Op.cit., 2007, p.93.
} 
Tabela 6: Comerciantes brasileiros que ocupavam armazéns em Lagos

\begin{tabular}{|c|c|c|c|c|}
\hline \multicolumn{5}{|c|}{1886} \\
\hline Proprietário & Localização & $\begin{array}{l}\text { Quant. de } \\
\text { armazéns }\end{array}$ & Fiador & Usado por \\
\hline Sant Anna \& Co & Rua Kakawa & 5 & C.F. Fabre \& Co \&J.A. Colonna & - \\
\hline Sant Anna \& Co & Rua Kakawa & 1 & J.J. da Costa\& Co \&J.A. Colonna & $\begin{array}{l}\text { Madame } \\
\text { Balbina }\end{array}$ \\
\hline J.M. Pinto & Marina & 1 & - J.A. Colonna \& J.J. da Costa & - \\
\hline J.A. Colonna & Marina & 1 & Sant Anna \& Co. \& J.M. Pinto & - \\
\hline Bernardo Rodrigues & Marina & 1 & J.P.L. Davies\&M.J.Ferreira & - \\
\hline \multicolumn{5}{|c|}{1887} \\
\hline Sant Anna \& Co & Rua Kakawa & 5 & C.F. Fabre \& Co \&J.A. Colonna & - \\
\hline Sant Anna \& Co & Rua Kakawa & 1 & J.J. da Costa\& Co \&J.A. Colonna & $\begin{array}{l}\text { Madame } \\
\text { Balbina }\end{array}$ \\
\hline Sant Anna \& Co & Marina & 1 & Voigt \& Co \& Phillips Marcheli & $\begin{array}{l}\text { J. A. Colonna } \\
\text { de Lecca. }\end{array}$ \\
\hline J.M. Pinto & Marina & 1 & - J.A. Colonna \& J.J. da Costa & - \\
\hline J.A. Colonna & Marina & 1 & Sant Anna \& Co. \& J.M. Pinto & - \\
\hline Bernardo Rodrigues & Marina & 1 & J.P.L. Davies\&M.J.Ferreira & - \\
\hline Witt \& Busch & Rua Tinubu & 2 & G.L.Gaiser \& C.F. Fabre \& Co & J. da Rocha \\
\hline \multicolumn{5}{|c|}{ (a) } \\
\hline Sant Anna \& Co & Rua Kakawa & 1 & Voigt \& J.A. Fernandes & $\begin{array}{l}\text { Madame } \\
\text { Balbina }\end{array}$ \\
\hline Sant Anna \& Co & Rua Kakawa & 1 & Voigt \& J.A. Fernandes & - \\
\hline $\begin{array}{c}\text { Mante Freres \& B. de } \\
\text { R.A. }\end{array}$ & Marina & 1 & Sant Anna \& CO \& J.A. Fernandes & - \\
\hline Joaquin F. Branco & Rua Kakawa & 1 & J.A. Campos \& J.A. Augustus & - \\
\hline \multicolumn{5}{|c|}{1889} \\
\hline Sant Anna \& Co & Rua Kakawa & 1 & Voigt \& J.A. Fernandes & $\begin{array}{c}\text { Madame } \\
\text { Balbina }\end{array}$ \\
\hline Sant Anna \& Co & Rua Kakawa & 1 & Voigt \& J.A. Fernandes & - \\
\hline $\begin{array}{c}\text { Mante Freres \& B. de } \\
\text { R.A. }\end{array}$ & Marina & 1 & Sant Anna \& CO \& J.A. Fernandes & - \\
\hline Joaquin F. Branco & Rua Kakawa & 1 & J.A. Campos \& J.A. Augustus & - \\
\hline \multicolumn{5}{|c|}{1890} \\
\hline Joaquin F. Branco & Rua Kakawa & 1 & P.F.Gomes \& J.A. Campos & - \\
\hline Sant Anna \& Co & Rua Kakawa & 1 & $\begin{array}{c}\text { Campbell \& Co \& J.A. Fernandes \& } \\
\text { Co }\end{array}$ & - \\
\hline Sant Anna \& Co & Tolo & 1 & $\begin{array}{l}\text { Campbell \& Co \& J.A. Fernandes \& } \\
\text { Co }\end{array}$ & - \\
\hline \multicolumn{5}{|c|}{1891} \\
\hline Joaquin F. Branco & Rua Kakawa & 1 & P.F.Gomes \& J.A. Campos & - \\
\hline Sant Anna \& Co & Rua Kakawa & 1 & $\begin{array}{c}\text { Campbell \& Co \& J.A. Fernandes \& } \\
\text { Co }\end{array}$ & - \\
\hline Sant Anna \& Co & Tolo & 1 & $\begin{array}{c}\text { Campbell \& Co \& J.A. Fernandes \& } \\
\text { Co }\end{array}$ & - \\
\hline \multicolumn{5}{|c|}{1892} \\
\hline Joaquin F. Branco & Rua Kakawa & 1 & P.F.Gomes \& J.A. Campos & - \\
\hline Sant Anna \& Co & Rua Kakawa & 1 & $\begin{array}{c}\text { Campbell \& Co \& J.A. Fernandes \& } \\
\text { Co }\end{array}$ & - \\
\hline Sant Anna \& Co & Tolo & 1 & $\begin{array}{c}\text { Campbell \& Co \& J.A. Fernandes \& } \\
\text { Co }\end{array}$ & - \\
\hline
\end{tabular}




\begin{tabular}{|c|c|c|c|c|}
\hline Proprietário & Localização & $\begin{array}{l}\text { Quant. de } \\
\text { armazéns }\end{array}$ & Fiador & Usado por \\
\hline \multicolumn{5}{|c|}{1893} \\
\hline Joaquin F. Branco & Rua Kakawa & 1 & P.F.Gomes \& J.A. Campos & - \\
\hline \multicolumn{5}{|c|}{ 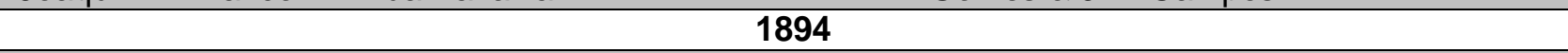 } \\
\hline Sant Anna \& Co & Rua Kakawa & 1 & Fernandes \& Co \& D. Morell & - \\
\hline Joaquin F. Branco & Rua Kakawa & 1 & J.A. Campos \& Francisco da Costa & - \\
\hline Joaquin F. Branco & Rua Kakawa & 1 & J.A. Campos \& P.F.Gomes & - \\
\hline Joaquin F. Branco & Rua Kakawa & 1 & J.A. Campos \& P.F. da Costa & - \\
\hline P.F. Gomes & $\begin{array}{c}\text { Rua } \\
\text { Bamgbose }\end{array}$ & 1 & $\begin{array}{c}\text { J.A. Campos, J.L. Williams \& E.S. } \\
\text { da Silva }\end{array}$ & - \\
\hline Sant Anna \& Co & Rua Kakawa & 1 & J.A. Campos \& J. da Rocha & - \\
\hline \multicolumn{5}{|c|}{ 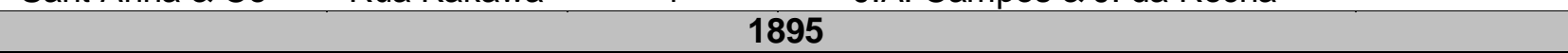 } \\
\hline Joaquin F. Branco & Rua Kakawa & 1 & J.A. Campos \& P.F. da Costa & - \\
\hline Joaquin F. Branco & Rua Kakawa & 1 & J.A. Campos \& P.F.Gomes & - \\
\hline Joaquin F. Branco & Rua Kakawa & 1 & J.A. Campos \& P.F. da Costa & - \\
\hline P.F. Gomes & $\begin{array}{c}\text { Rua } \\
\text { Bamgbose }\end{array}$ & 1 & $\begin{array}{c}\text { J.A. Campos, J.L. Williams \& E.S. } \\
\text { da Silva }\end{array}$ & - \\
\hline \multicolumn{5}{|c|}{1896} \\
\hline J.A. Lino & Rua Kakawa & 1 & $\begin{array}{c}\text { J.A. Campos, B.F. Damazio \& A.F. } \\
\text { Mondes }\end{array}$ & - \\
\hline Joaquin F. Branco & Rua Kakawa & 1 & J.A. Campos \& P.F.Gomes & - \\
\hline Joaquin F. Branco & Rua Kakawa & 1 & J.A. Campos \& P.F. da Costa & - \\
\hline Joaquin F. Branco & Marina & 1 & B.F. Damazio \& A.F. Mendes & - \\
\hline P.F. Gomes & $\begin{array}{c}\text { Rua } \\
\text { Bamgbose }\end{array}$ & 1 & $\begin{array}{l}\text { J.A. Campos, J.L. Williams \& W.P. } \\
\text { Siffre }\end{array}$ & - \\
\hline Fernandes \& Co & Rua Kakawa & 1 & J.A. Campos \& P.F.Gomes & - \\
\hline Fernandes \& Co & Rua Tinubu & 1 & W.P. Siffre \& J.A. Campos & - \\
\hline \multicolumn{5}{|c|}{1897} \\
\hline Fernandes \& Co & Rua Kakawa & 1 & J.A. Campos \& P.F.Gomes & - \\
\hline Joaquin F. Branco & Rua Kakawa & 1 & J.A. Campos \& P.F.Gomes & - \\
\hline Joaquin F. Branco & Rua Kakawa & 1 & J.A. Campos \& P.F. da Costa & - \\
\hline Joaquin F. Branco & Marina & 1 & B.F. Damazio \& A.F. Mendes & - \\
\hline P.F. Gomes & $\begin{array}{c}\text { Rua } \\
\text { Bamgbose }\end{array}$ & 1 & $\begin{array}{l}\text { J.A. Campos, J.L. Williams \& W.P. } \\
\text { Siffre }\end{array}$ & - \\
\hline \multicolumn{5}{|c|}{1898} \\
\hline Fernandes \& Co & Rua Kakawa & 1 & J.A. Campos \& P.F.Gomes & - \\
\hline Joaquin F. Branco & Rua Kakawa & 1 & J.A. Campos \& P.F.Gomes & - \\
\hline Joaquin F. Branco & Rua Kakawa & 1 & J.A. Campos \& P.F. da Costa & - \\
\hline Joaquin F. Branco & Marina & 1 & B.F. Damazio \& A.F. Mendes & - \\
\hline P.F. Gomes & $\begin{array}{c}\text { Rua } \\
\text { Bamgbose }\end{array}$ & 1 & $\begin{array}{l}\text { J.A. Campos, J.L. Williams \& W.P. } \\
\text { Siffre }\end{array}$ & - \\
\hline \multicolumn{5}{|c|}{1899} \\
\hline Joaquin F. Branco & Rua Kakawa & 1 & J.A. Campos \& P.F.Gomes & - \\
\hline Joaquin F. Branco & Rua Kakawa & 1 & Fernandez \& Co e J.A. Campos & - \\
\hline Joaquin F. Branco & Marina & 1 & Fernandez \& Co e J.A. Campos & - \\
\hline P.F. Gomes & $\begin{array}{c}\text { Rua } \\
\text { Bamgbose }\end{array}$ & 1 & $\begin{array}{l}\text { J.A. Campos, J.L. Williams \& W.P. } \\
\text { Siffre }\end{array}$ & - \\
\hline \multicolumn{5}{|c|}{1900} \\
\hline Joaquin F. Branco & Rua Kakawa & 1 & J.A. Campos \& P.F.Gomes & - \\
\hline Joaquin F. Branco & Rua Kakawa & 1 & Fernandez \& Co e J.A. Campos & - \\
\hline Joaquin F. Branco & Marina & 1 & Fernandez \& Co e J.A. Campos & - \\
\hline P.F. Gomes & $\begin{array}{c}\text { Rua } \\
\text { Bamgbose }\end{array}$ & 1 & $\begin{array}{c}\text { J.A. Campos, J.L. Williams \& W.P. } \\
\text { Siffre }\end{array}$ & - \\
\hline
\end{tabular}

Fonte: Tabela elaborada a partir dos relatórios de ocupação de armazéns de Lagos publicados pelo periódico oficial Government Gazette, Colony of Lagos, entre os anos de 1886 a 1900. 
Um destes armazéns era alugado à Madame Balbina, uma comerciante brasileira que figura nas Government Gazettes como vendedora varejista de bebidas destiladas. ${ }^{386}$ Aparentemente, os demais barracões eram utilizados pela própria companhia. Além disto, a firma pertencente à família Sant'Anna também foi listada como fiadora de outras companhias de propriedade de brasileiros estabelecidos em Lagos. Este dado, em específico, revela que ao se responsabilizar pelos negócios de terceiros, a Sant'Anna \& Co expunha aspectos de um relacionamento comercial em que os arranjos de solidariedade se combinavam a concorrência. $O$ vigor financeiro desta companhia se refletia também no negócio atacadista de destilados. Ao longo de oito anos, de 1886 até 1894, a Sant'Anna \& Co também atuou entre as empresas atacadistas de bebidas destiladas, com estabelecimentos espalhados pela cidade de Lagos. Tamanha pujança comercial permitiu à companhia estender seus negócios até Porto Novo, cidade bastante próxima de Lagos, mas que na década de 1880 estava situada numa área de influência em que predominava a França.

Em 1882, a Sant'Anna \& Co sofreu um duro golpe depois que o filho e sócio de Manoel Joaquim, Ildefonso de Sant'Anna, faleceu a bordo da escuna Africano em sua viagem de retorno do Brasil. Conforme noticiou o jornal Lagos Observer, há apenas dezoito meses Ildefonso havia deixado Lagos para se casar com uma brasileira que vivia em Aracaju. No entanto, durante a viagem de retorno, o jovem foi acometido por uma enfermidade identificada a bordo como beriberi. Sua morte, quinze dias depois dos primeiros sintomas, foi noticiada com pesar pelos periódicos lagosianos existentes na época. Dez anos depois, uma nota publicada no jornal Lagos Weekly Record convidava amigos e familiares a participarem de uma missa solene em memória do jovem integrante da família Sant'Anna. ${ }^{387}$

\footnotetext{
${ }^{386} \mathrm{O}$ nome de Madame Balbina é citado nos relatórios publicados pelo jornal Government Gazette, Colony of Lagos ao longo do período de 1886 a 1894. No apêndice 4, denominado Brasileiros com licença para comercializar bebidas destiladas em Lagos, podemos verificar que Madame Balbina é a única mulher incluída nos referidos registros.

387 The Lagos Observer, 31 de agosto de 1882, World Newspaper Archive, African Newspapers, 1883 - 1888. Segundo Verger, o episódio do falecimento de Idefonso de Sant'Anna também foi noticiado no periódico Lagos Times. VERGER, Pierre.Op Cit. 1987, p.629. O convite à ceremonia fúnebre foi publicado no Lagos Weekly Record, 27 de agosto de 1892, World Newspaper Archive, African Newspapers, 1883 - 1888.
} 
Sete meses depois do falecimento de Ildefonso de Sant'Anna, a companhia passou por um segundo revés. Em abril de 1883, a firma se envolveu em uma disputa com os agentes comerciais alemães G.L.Gaiser, Witt e Busch, em torno de uma proposta apresentada por Manoel Joaquim às chefias de Porto Novo. Um documento elaborado em conjunto com agentes de firmas francesas sugeria o estabelecimento de três medidas que dinamizariam a economia da cidade. De acordo com o próprio Manoel de Sant'Anna, tais medidas propunham a fixação do valor dos galões de óleo de palma, defendiam a suspensão da taxação sobre as exportações e o comércio local e pleiteavam a definição dos termos de um mercado regulado por pagamentos feitos em cauris, e não pela troca de mercadorias. Estas modificações foram expostas às chefias de Porto Novo e testemunhadas por intérpretes. Todavia, alegando que o esquema de taxação e de negociação seria prejudicial aos interesses mercantis de todas as companhias estabelecidas na cidade, Gaiser, Witt e Busch suspenderam suas transações com a Sant'Anna \& Co.

Sem aceitar as justificativas oferecidas pelos agentes comerciais alemães, Manuel Joaquim de Sant'Anna publicou no jornal Lagos Observer uma longa carta em que refutava os argumentos apresentados para o rompimento dos contratos firmados com Gaiser, Witt e Busch. Nesta missiva o brasileiro questionava a forma como os representantes comerciais envolvidos pressionavam a chefia de Porto Novo para reduzir o valor das principais mercadorias utilizadas na troca por óleo de palma: a aguardente (do Brasil) e o rum, proveniente principalmente da França. Ao expor aos leitores lagosianos os detalhes de uma disputa comercial ocorrida em Porto Novo, Sant'Anna lançava mão dos recursos ao seu alcance para atingir os negócios que estes representantes mantinham também em Lagos. ${ }^{388}$ Ainda assim, o comércio movimentado por estes agentes continuou bastante significativo. Segundo Olukoju, a companhia de G.L. Gaiser controlava um quarto das exportações de óleo e sementes de palma e, ainda, detinha uma grande porção do mercado importador. Além disto, nas duas últimas décadas do século XIX, a firma de

\footnotetext{
388 The Lagos Observer, 12 de abril de 1883, World Newspaper Archive, African Newspapers, 1883 - 1888. A leitura dos jornais pesquisados mostrou ser comum a publicação das correspondências dos leitores. O Lagos Observer mantinha uma seção em que estas cartas e suas réplicas eram reproduzidas. O espaço concedido à troca epistolar promovia um tipo de diálogo que, em certos casos, poderia durar meses.
} 
Witt e Busch era considerada a terceira mais importante na cidade de Lagos, precedida pela firma alemã de G.L.Gaiser e pela inglesa John Holt. ${ }^{389}$

Nem mesmo a perda do filho e sócio, Ildefonso de Sant'Anna, e a rivalidade com os agentes de companhias europeias colocaram termo aos negócios de Manoel Joaquim. Em 1885, o jornal Lagos Observer anunciou o acréscimo de um novo sócio à Sant'Anna \& Co. O parceiro somado à companhia era ninguém menos do que Manoel Bernardo de Carvalho, genro de Manoel de Sant'Anna. A associação de Manoel Bernardo à Sant'Anna \& Co coloca em evidência uma prática relativamente comum entre os brasileiros de Lagos no século XIX: a combinação das relações de negócio às de parentesco. $^{390}$

A leitura dos jornais publicados na cidade sugere diversas situações em que os casamentos estavam associados a arranjos que atendiam a interesses econômicos ou de status das famílias. Neste sentido, é possível que outras cerimônias de união tenham proporcionado benefícios para os familiares de ambas as partes. Em outubro de 1894, uma nota publicada no Lagos Weekly Record informava acerca do casamento de Eduardo da Silva e Maria Martins. De acordo com o pequeno texto, Maria Martins era irmã de Julio José Martins, conhecido comerciante brasileiro, cujo estabelecimento varejista se situava na rua Bamgbose. O periódico também informava que o casamento de Eduardo e Maria foi celebrado na igreja Holy Cross. O templo havia sido erguido com os recursos doados por brasileiros católicos da cidade e era administrado pela Société des Missions Africaines (SMA). ${ }^{391}$ Após a cerimônia os convidados se dirigiram até a residência do irmão da noiva, Julio Martins. Ainda segundo este mesmo jornal, a festa contou com mais de cem convidados, muitos deles integrantes da família do noivo, Eduardo da Silva. ${ }^{392}$

\footnotetext{
389 Cf. OLUKOJU, Ayodeji. The "Liverpool" of West Africa: dynamic and impact of maritime trade in Lagos 1900 - 1950. Trenton/N.J.: African World Press, 2004, p.13.

390 The Lagos Observer, 08 de janeiro de 1885, World Newspaper Archive, African Newspapers, $1883-1888$.

391 Cf. CUNHA, Manuela Carneiro da. Op.cit., 2012, p.193 e OTERO, Solimar. Afro-Cuban diasporas in the Atlantic world. Rochester: University of Rochester Press, 2010, p.107.

392 The Lagos Weekly Record, 6 de outubro de 1894, World Newspaper Archive, African Newspapers, $1883-1888$.
} 
Não são raros os casos de indivíduos de sobrenome Silva citados em relatórios referentes aos membros da lista anual de jurados, publicada pelo periódico oficial: a Government Gazette. No ano de 1894, por exemplo, os Silva inscritos como jurados atuavam em diferentes ramos profissionais. Alfaiate, carpinteiro, pedreiro e comerciante eram alguns deles. Entre aqueles que viviam do comércio estava S.L.B. da Silva, um negociante de Lagos cujo nome também aparece arrolado entre os registros de licença para venda de destilados na cidade. Embora seja difícil precisar como o casamento de Eduardo e Maria aproximou as famílias Martins e Silva, podemos supor que as alianças tecidas a partir de uniões como esta ajudaram a compor os vínculos que definiriam o pertencimento a uma parcela da comunidade brasileira existente em Lagos na segunda metade do século XIX. ${ }^{393}$

No ano de 1885, quando o genro de Manoel Joaquim se tornou sócio da Sant'Anna \& Co, a firma disputava sua influência sobre a chefia de Porto Novo com os agentes comerciais G.L.Gaiser, Witt e Busch. Alguns anos mais tarde, em 1893, esta não era mais uma questão para a companhia. Nos meses de agosto e setembro deste ano um anúncio publicado no jornal Lagos Weekly Record comunicava a chegada do bergantim Bento de Freitas, de propriedade de Manoel de Sant'Anna. A nota informava que a nau havia partido da Bahia e seguido direto para Lagos em um tempo surpreendente para a época: trinta dias. $\mathrm{Na}$ ocasião, trinta e oito passageiros deram entrada na cidade e 420 toneladas de mercadorias foram descarregadas no porto lagosiano. ${ }^{394}$ Outros anúncios publicados pelo mesmo periódico demonstravam que esta não foi a única viagem de travessia realizada pela embarcação da Sant'Anna \& Co. De acordo com este mesmo jornal, as travessias empreendidas pela companhia continuaram alimentando as relações comerciais entre ambas as margens do Atlântico até 1894. Em junho deste ano, uma nota avisava que o bergantim havia naufragado ao se aproximar de um banco de areia localizado na embocadura do rio Ogun. $O$ acidente contou com vítimas entre seus

\footnotetext{
393 Government Gazette, Colony of Lagos, 30 de dezembro de 1893, National Archives/UK. CO 150/5. As listas de jurados eram publicadas, via de regra, no último mês do ano anterior e valiam por todo o ano subsequente. Nestes registros eram inscritos nome completo do jurado, profissão e local de residência.

394 The Lagos Weekly Record, 19 e 26 de agosto de 1893 e 2 de setembro de 1893, World Newspaper Archive, African Newspapers, 1883 - 1888.
} 
passageiros e tripulação, além de ocasionar duras perdas à companhia que teve parte de sua carga saqueada. ${ }^{395}$

Desde o ano de 1888, a Sant'Anna \& Co já apresentava sinais de desgaste econômico. Um destes sinais se refere ao número de armazéns mantidos na cidade de Lagos pela firma. Conforme podemos perceber pelos dados apresentados na Tabela 6 - Comerciantes brasileiros que ocupavam armazéns em Lagos - em 1886, a companhia de Manoel Joaquim possuía seis barracões localizados nas proximidades do porto. Dois anos depois, em 1888, este número diminuiu para um terço, ou seja, dois estabelecimentos. A redução no volume dos negócios com o Brasil obrigou a firma a permanecer com apenas dois armazéns durante seis anos, de 1888 a 1894. Além disto, a situação da Sant'Anna \& Co se agravou em janeiro de 1895 com a morte de seu fundador, Manoel Joaquim de Sant'Anna. O falecimento de seu fundador e principal sócio levou os credores a cobrarem a imediata execução das dívidas pessoais de Manoel e as de sua empresa. Neste mesmo ano Elias Sant'Anna da Silva, um membro da família Sant'Anna e funcionário da companhia, foi acusado e condenado a dois anos de prisão por perjúrio frente ao tribunal que julgou os débitos da firma para com o governo colonial. ${ }^{396}$

Este foi o último revés enfrentado pela firma iniciada pelo brasileiro Manoel Joaquim de Sant'Anna. A partir de 1895 não há mais registros de armazéns e licenças para a comercialização de destilados publicados em nome da Sant'Anna \& Co. Este fato sugere a suspensão de suas atividades e a liquidação de bens para o pagamento de seus credores, entre os quais estava o governo colonial. Ao final do ano de 1896 uma pequena nota publicada pelo Lagos Weekly Record tecia duras críticas ao governador Gilbert Carter em razão de uma dispendiosa reforma realizada na casa onde viveu Manoel

\footnotetext{
395 The Lagos Weekly Record, 30 de junho de 1894 e 14 de julho de 1894, World Newspaper Archive, African Newspapers, 1883 - 1888. Em agosto de 1894, uma nota informava que dois pescadores haviam encontrado corpos flutuando nas proximidades dos destroços da embarcação. The Lagos Weekly Record, 18 de agosto de 1894, World Newspaper Archive, African Newspapers, $1883-1888$.

${ }^{396}$ A nota de falecimento de Manoel Joaquim de Sant'Anna foi publicada em: The Lagos Weekly Record, 12 de janeiro de 1895, World Newspaper Archive, African Newspapers, 1883 1888. As notícias que tratam da acusação e prisão de Elias Sant'Anna por perjúrio aparecem impressos em: The Lagos Weekly Record, 16 de março e 25 de maio de 1895 (respectivemente), World Newspaper Archive, African Newspapers, 1883 - 1888.
} 
Joaquim. Segundo o periódico, os cofres públicos haviam tomado o imóvel da família Sant'Anna pelo valor a duas mil libras. O montante correspondia à dívida deixada pela Sant'Anna \& Co junto ao governo colonial. No entanto, o jornal assinalava que, até aquele momento, os gastos com a reparação da casa somavam o valor da edificação de um novo imóvel. ${ }^{397}$

Embora a Sant'Anna \& Co não tenha estendido suas atividades até o final do século XIX, outras companhias pertencentes a brasileiros mantiveram seus negócios no comércio atacadista operado entre Lagos e Brasil. Estas firmas atuavam por meio de agentes comerciais instalados em território brasileiro consignando mercadorias e, em alguns casos, fretando embarcações para a realização das travessias pelo Atlântico. Este é o caso de Joaquim Francisco Branco, outro comerciante atacadista cujos negócios operados no porto lagosiano the renderam o registro de seus armazéns pelo governo colonial ao longo das décadas de 1880 e 1890 . Ao contrário do que ocorreu com a firma da família Sant'Anna, o número de barracões em nome de Joaquim Branco só aumentou neste período. Assim, como a tabela 6 demonstra, de um único estabelecimento inscrito na listagem oficial publicada pela Government Gazette no ano de 1888, a companhia de Branco passou, dez anos mais tarde, em 1898, para três imóveis.

Segundo Antonio Olinto, Joaquim Francisco Devodê Branco era um liberto de origem Mahi, nascido em 1856. Aos oito anos de idade, Branco foi levado como escravo para a Bahia, onde permaneceu por cerca de trinta anos. Esta narrativa é analisada por Castillo que sugere uma trajetória diferente ao ex-escravo. Segundo a pesquisadora, Joaquim Branco seria um caso emblemático de "um africano cuja identidade agudá foi constituída fora do Brasil". Afinal, entre 1864 e 1873, anos em que teria servido como escravo, Branco trabalhava para um traficante português que vivia na cidade de Ajudá. Em 1874, este negreiro adquiriu uma embarcação que Ihe possibilitou realizar diversas viagens até a Bahia. Neste sentido, a autora explica: "se Joaquim era

\footnotetext{
397 The Lagos Weekly Record, 5 de dezembro de 1896, World Newspaper Archive, African Newspapers, $1883-1888$.
} 
empregado neste navio, a identidade 'brasileira', adquirida primeiro em Ajudá, pode ter se consolidado durante estas visitas". ${ }^{398}$

Uma vez liberto, Joaquim Branco atuou no comércio atacadista realizado entre Lagos e Brasil, atividade que Ihe rendeu uma significativa somatória de bens. Em um testamento redigido e registrado no ano de 1919, Branco deu conta de suas propriedades, partilhou imóveis entre esposas, filhos, afilhados e outros familiares, determinou a maneira como deveriam ser administrados seus bens e fez generosas doações em libras esterlinas aos familiares de seu falecido senhor, à igreja católica de Porto Novo e às igrejas protestantes de Lagos. Sua carta testamental foi reproduzida na íntegra por Marianno Carneiro da Cunha e revela aspectos interessantes acerca da forma como Branco distribuiu uma vasta quantidade de imóveis, bens e valores entre aqueles listados como seus beneficiários. Entre os filhos, Bemvinda Venança, Elmerina Segboa, João Samuel, Clara Navajo, Patricia Sedoten e Joana Sant'Anna, o comerciante partilhou imóveis e o valor do aluguel de diversas casas, quase todas situadas no bairro brasileiro de Lagos. À esposa, conhecida pelo nome de Balodeu, Branco legou uma de suas residências localizada na rua Bamgbose. No entanto, conforme o documento deixa entrever, esta não era a única mulher que Ihe havia gerado filhos. Em Porto Novo vivia Fajiya, mãe de seu herdeiro João Samuel, cuja casa em que morava lhe foi legada neste testamento. Irmãos, sobrinhos e netos de Joaquim Branco também foram contemplados com terrenos e imóveis pertencentes ao rico mercador. ${ }^{399}$

A longa lista de beneficiários se encerrava com os legados deixados em bens móveis e em espécie. Embora Joaquim Branco já tivesse deixado aos seus dois irmãos mais novos - Atovi e Danjowu - um terreno localizado na rua Lawson, estes herdeiros receberam ainda todas as vacas de propriedade do testador. Branco legou suas cabeças de gado aos irmãos por serem estes os indivíduos responsáveis pelo cuidado dos animais. Afinal, como o próprio testamento indica, as referidas vacas já se encontravam em poder de Atovi e

\footnotetext{
${ }^{398}$ Cf. OLINTO, Antonio. Brasileiros na África. Rio de Janeiro: Editora GRD, 1964, pp.213-215 e CASTILLO, Lisa Earl. Mapping the nineteeth-century Brazilian returnee movement: Demographics, life stories and the question of slavery. Atlantic Studies, 13:1, 2016, p. 40.

399 CUNHA, Marianno Carneiro da. Da senzala ao sobrado, arquitetura brasileira na Nigéria e na República Popular do Benim. São Paulo: Nobel/Edusp, 1985, pp.183-185.
} 
Danjowu no momento em que o documento foi registrado. $O$ cuidado em informar quais eram os vínculos estabelecidos com seus herdeiros se repete em relação a outros indivíduos. Mais adiante, ao legar uma vultosa soma em dinheiro, Branco fez questão de registrar quais eram as suas ligações com seus beneficiários. Entre os beneficiários listados no documento estava Degboji, sobrinho do brasileiro e "rei de Asante, no País Mahi na Colônia Francesa de Dahomey". Além do sobrinho ilustre, Joaquim Branco incluiu na repartição dos seus valores em espécie a "irmã mais velha do referido rei", chamada Whese, e seu primo Jaketeme Ada, "rei de Panwingan no País Mahi". Ao considerar como familiares e herdeiros integrantes de chefias africanas situadas no território daomeano, Joaquim Branco colocava em evidência relações de parentesco que extrapolavam os limites da comunidade brasileira existente em Lagos. Mesmo sem especificar quais vínculos teriam conferido a Branco um sobrinho e um primo ligados ao poder no Daomé, este excerto do documento sugere que o brasileiro exercia certa mobilidade entre as esferas políticas daomeanas. A herança em espécie legada a estes indivíduos constituía um último gesto de reforço dos laços que atavam estes parentes aos seus descendentes diretos deixados em Lagos.

Os beneficiários incluídos no testamento de Joaquim Branco não se resumiam aos familiares próximos e distantes que viviam em Lagos e no Daomé. Em 1919, quando foram registradas suas últimas vontades, Branco acrescentou à sua lista de herdeiros quatro outras pessoas: Belmira da Conceição Branco, Laída da Conceição Nunes Branco, Aromara e Amélia Francisco Branco. De acordo com o documento, Belmira e Amélia eram filhas de João Francisco Branco, antigo senhor de Joaquim, nascido na cidade portuguesa de Figueira da Foz. Além delas, as irmãs Laída e Aromara eram filhas do irmão mais velho de seu senhor, o falecido capitão Manoel Francisco Branco. Ao legar generosas quantias às filhas e sobrinhas de seu ex-dono, o comerciante brasileiro expôs uma das faces de um conjunto de alianças constituídas com a função de permitir seu trânsito por diferentes esferas de poder econômico e político.

Formar uma rede de aliados comerciais e políticos poderia exigir também certa perícia social. $O$ comerciante P.F. Gomes sabia disto. $O$ 
brasileiro era proprietário de um armazém localizado na rua Bamgbose e dono de um estabelecimento varejista situado na marina de Lagos. ${ }^{400}$ Tal como Manoel J. de Sant'Anna e Joaquim Branco, o sucesso dos negócios tocados por Gomes dependia de sua articulação com os setores sociais e econômicos de seu interesse. Na Lagos da segunda metade do século XIX esta articulação poderia ser traduzida nas garantias que Gomes oferecia como fiador dos armazéns pertencentes a Branco e à firma Fernandez \& Co. Uma legislação promulgada pela administração colonial britânica, no ano de 1876, determinava que todos os atacadistas de Lagos estariam obrigados a recolher um imposto anual e a fornecer garantias de seus estabelecimentos por meio de um fiador. ${ }^{401}$ Conforme a tabela 6 apresentada neste capítulo, durante dez anos (de 1890 a 1900) Gomes cumpriu as exigências para que Joaquim Branco mantivesse seu barracão na rua Kakawa. O mesmo sucedeu com a Fernandez \& Co, outro comerciante brasileiro que, entre 1896 e 1898, teve seu estabelecimento afiançado por Gomes. ${ }^{402}$

Do mesmo modo, os dados apurados nas Government Gazettes, Colony of Lagos sugerem que P.F. Gomes recebeu garantias semelhantes em 1894, ano em que o brasileiro abriu seu próprio comércio atacadista. Segundo os relatórios publicados por este periódico, João Angelo Campos, E.S. da Silva, Walter Paul Siffre e J.L Williams afiançaram que Gomes seria capaz de pagar em dia seus fornecedores e arcar com os impostos cobrados pela administração colonial. Campos, Silva e Siffre eram comerciantes brasileiros citados pela historiografia em função de seus negócios na cidade de Lagos. ${ }^{403}$

\footnotetext{
${ }^{400} \mathrm{O}$ estabelecimento atacadista de P.F.Gomes figura nos relatórios publicados em diversas edições das Government Gazettes, Colony of Lagos (1886-1900). Além disto, o comerciante brasileiro anunciava a venda de bebidas alcoólicas e medicamentos no periódico Lagos Weekly Record. Government Gazette, Colony of Lagos, National Archives/UK. CO 150/5 a 150/9 e The Lagos Weekly Record, 16 de abril e 2 de julho de 1898, 2 de setembro de 1899, World Newspaper Archive, African Newspapers, 1883 - 1888.

${ }^{401}$ Refiro-me à Lei de número 10, seção 20, em vigor desde 1876. Conforme os exemplares da Government Gazette, Colony of Lagos consultados, o imposto anual sobre o comércio atacadista se manteve o mesmo entre os anos de 1886 e 1900: mil libras esterlinas.

${ }^{402}$ Embora esta pesquisa defina o ano de 1900 como limite, identifiquei o nome de P.F.Gomes como fiador de Branco até o ano de 1902.

403 João Angelo Campos é mencionado nas seguintes obras: AMÓS, Alcione Meira. Op.cit., 2007, p.124 e OTERO, Solimar. Afro-Cuban diasporas in the Atlantic world. Rochester: University of Rochester Press, 2010, pp.94-99. Além de citar Campos em seu trabalho, Cunha apresenta uma imagem do brasileiro, em: CUNHA, Manuela Carneiro da. Op.cit., 2012, pp. 161 e 180-1. A família Silva é tratada nas pesquisas de: CUNHA, Manuela Carneiro da. Op.cit., 2012, pp. 158, 159, 168, 191, 232 e AMÓS, Alcione Meira. Op.cit., 2007, pp.46, 47, 53, 56, 62,
} 
Todavia, estas mesmas pesquisas pouco informam a respeito de quem era o quarto fiador de P.F. Gomes: o mercador J.L. Williams. Ao se referir ao comércio internacional praticado na cidade, Koppytoff menciona a atuação da companhia Williams Brothers. A firma seria de propriedade de saros que detinham grandes armazéns situados no porto lagosiano e cujas relações comerciais atavam a companhia a Liverpool. Neste sentido, é possível que J.L. Williams fosse um dos integrantes desta firma, cujos recursos indiretamente afiançavam o estabelecimento de Gomes. ${ }^{404}$

Ao apresentar saros e brasileiros como fiadores de seu negócio, Gomes expunha a permeabilidade das fronteiras entre estes dois grupos. Os exemplares do jornal Lagos Weekly Record trazem outros registros que se referem as alianças tecidas entre saros e brasileiros em torno de um propósito comum. Os anúncios de reunião da Câmara de Comércio de Lagos são emblemáticos neste caso. Trata-se de maneira geral, de notas curtas acerca da data, pauta discutida e lista dos respectivos participantes dos encontros. A leitura destes pequenos textos permitiu conferir, com uma periodicidade quase mensal, quais eram os indivíduos presentes nestas ocasiões. Nomes de brasileiros como João Angelo Campos, P.F.Gomes, S.C.Soares, P.F. da Costa e J.A. Fernandez são recorrentes nestes registros. O comerciante Gomes, por exemplo, teve sua presença registrada de maneira intermitente entre março de 1892 e outubro de 1895. Por outro lado, João Angelo Campos compareceu com maior regularidade aos encontros promovidos pela associação, se ausentando em raras reuniões. ${ }^{405}$

Durante os anos em que a segunda Câmara de Comércio de Lagos funcionou, de 1891 a 1896, os brasileiros tomaram a palavra apenas em duas ocasiões diferentes. A primeira delas aconteceu em 9 de março de 1895, dia em que João Angelo Campos se manifestou publicamente contra a sua exclusão da entidade. $\mathrm{O}$ acalorado debate em que Campos questionou, junto

134 e 146. O comerciante Walter Paul Siffre tem seu nome citado também por: CUNHA, Manuela Carneiro da. Op.cit., 2012, pp.158 e 161 e AMÓS, Alcione Meira. Op.cit., 2007, pp.105 e 123.

${ }^{404}$ KOPYTOFF, Jean Herskovits. Op.cit., 1865, pp.97 e 170.

405 As informações apresentadas foram coligidas em pesquisa realizada no periódico The Lagos Weekly Record, entre os anos de 1891 e 1900, World Newspaper Archive, African Newspapers, $1883-1888$. 
ao presidente da Câmara, G.W. Neville, o recebimento de uma notificação cujo conteúdo informava seu desligamento, ganhou as páginas do Lagos Weekly Record. Após a descrição da discussão, o jornal informava a readmissão de Campos mediante o pagamento das parcelas em atraso referentes à sua associação. ${ }^{406} \mathrm{~A}$ segunda menção em que os brasileiros assumem uma postura mais ativa nos encontros promovidos entre os comerciantes de Lagos foi registrada por este mesmo periódico, em 12 de setembro de 1896. Esta assembleia não era, na verdade, uma reunião convocada pela Câmara de Comércio da cidade. Isto porque a organização havia sido dissolvida seis meses antes, em março daquele mesmo ano. No entanto, a maioria dos nomes listados nesta reunião de setembro de 1896 aparece nas relações anteriores referentes aos membros da Câmara comercial lagosiana, o que permite considerar este um encontro realizado pelos integrantes da associação recémextinta.

De acordo com Hopkins, em agosto de 1888, uma solenidade que contou com a presença do governador Moloney inaugurou a primeira Câmara de Comércio da cidade. A associação durou apenas dezenove meses e, em março de 1890, os jornais anunciavam o seu fechamento. A suspensão das atividades da entidade não se estendeu por muito tempo. Apenas onze meses depois, em fevereiro de 1891, os comerciantes de Lagos reabriram a segunda Câmara comercial da cidade. Sob a presidência de G.W. Neville, um agente comercial que representava companhias de vapores de Liverpool, a entidade se manteve atuante por um período mais longo: cerca de quatro anos e um mês. ${ }^{407}$ Em 7 de março de 1896, uma nota publicada no Lagos Weekly Record, divulgava o encerramento da segunda Câmara comercial lagosiana. A principal justificativa para o fechamento da associação estava no fato da Câmara se configurar como "clube de debates" e não de atuação. Sem o espaço empregado na discussão dos problemas enfrentados pelos mercadores da

406 The Lagos Weekly Record, 9 de março de 1895, World Newspaper Archive, African Newspapers, $1883-1888$.

407 HOPKINS, A.G. The Lagos Chamber of Commerce, 1888-1903. Journal of the Historical Society of Nigeria, vol.3, N.2, December/1965, pp.241-248. 
cidade, restava ainda o pleito direto com governador de Lagos e com os secretários das Câmaras de Comércio de Liverpool e de Manchester. ${ }^{408}$

Em 12 de setembro de 1896 um longo artigo impresso no Lagos Weekly Record descrevia as circunstâncias em que uma carta redigida pelos comerciantes de Lagos foi entregue ao governador em exercício, W. Bradford Griffith. ${ }^{409}$ A correspondência seria encaminhada ao governador Gilbert Carter, que naquele momento havia retornado à Grã-Bretanha, e aos secretários das Câmaras de Comércio de Liverpool e de Manchester. A cerimônia em que os signatários depositaram o documento nas mãos de Griffith contou com a presença dos brasileiros João Angelo Campos e P.F. Gomes. Na ocasião os participantes expuseram as justificativas que explicavam a contrariedade do grupo em relação ao lugar de instalação do terminal da ferrovia que ligaria a costa lagosiana à cidade de Ibadan. No projeto original a ilha de Ido constituía o ponto a partir do qual a ferrovia seguiria em direção ao interior. Este aspecto em específico desagradou a maioria dos mercadores que temiam a transferência das dinâmicas comerciais de Lagos para Ido. ${ }^{410}$ Ao final das manifestações de oposição à obra, os comerciantes encaminharam ao administrador colonial uma missiva em que apontavam oito motivos para a mudança do projeto original e para a construção do terminal ferroviário em Lagos. Esta correspondência recebeu a assinatura de trinta e três moradores da cidade, em sua maioria comerciantes. ${ }^{411}$

A oposição dos mercadores da cidade não obteve o resultado desejado. O traçado inicial da estrada de ferro foi mantido e a ilha de ldo recebeu seu terminal ferroviário. No ano de 1897 a linha férrea, cujas obras se iniciaram em dezembro de 1895, venceu as 20 milhas (ou pouco mais de 32 quilômetros)

\footnotetext{
${ }^{408}$ A suspensão das atividades executadas por esta segunda Câmara de Comércio durou até março do ano seguinte. Em 15 de março de 1897, o mesmo jornal lagosiano comemorou a retomada dos trabalhos empreendidos da terceira Câmara de Comércio da cidade. Cf. The Lagos Weekly Record, 7 de março de 1896 e 15 de março de 1897, World Newspaper Archive, African Newspapers, $1883-1888$.

${ }^{409}$ Em setembro de 1896, Griffith ocupava o posto de governador interino de Lagos. Em 1897, H.E.McCallum assumiu o governo da cidade, permanecendo à frente da administração pública até 1899.

${ }^{410}$ Para um melhor entendimento acerca da localização de Ido e Ibadan, sugiro consulta aos mapas de número 2 e 3 , apresentados no primeiro e terceiro capítulos desta tese.

411 The Lagos Weekly Record, 12 de setembro de 1896, World Newspaper Archive, African Newspapers, $1883-1888$.
} 
que separavam o terminal em Ido e a cidade de Ota. Em 1899, a estrada chegou até Abeokuta, percorrendo uma distância de 60 milhas (ou 96,56km). Dois anos mais tarde, em 1901, uma grande cerimônia marcou a conclusão da obra que levou os trens até Ibadan. A ferrovia até Ibadan tinha menos de duzentos quilômetros e demorou cerca de seis anos para ser concluída. De acordo com Oyemakinde, as comemorações que marcaram a inauguração deste percurso se estenderam por quatro dias. A festa teve início em Ido, com um almoço oferecido pelo governo de Lagos para cerca de duzentas pessoas e dez chefes locais. Depois disto, uma viagem inaugural levou o alake e seus chefes, de Abeokuta até Ido. As cerimônias se espalharam por outras cidades situadas ao longo da ferrovia, chegando até o ponto onde estava a última estação: Ibadan. Nesta cidade, uma multidão de mais de vinte mil pessoas assistiu as corridas de cavalos e experimentou os serviços da estrada de ferro que, como parte das comemorações de inauguração, transportou passageiros gratuitamente por trajetos curtos. ${ }^{412}$

Figura 2: Estação de Axo, Estrada de Ferro Lagos - Abeokuta (sem data)

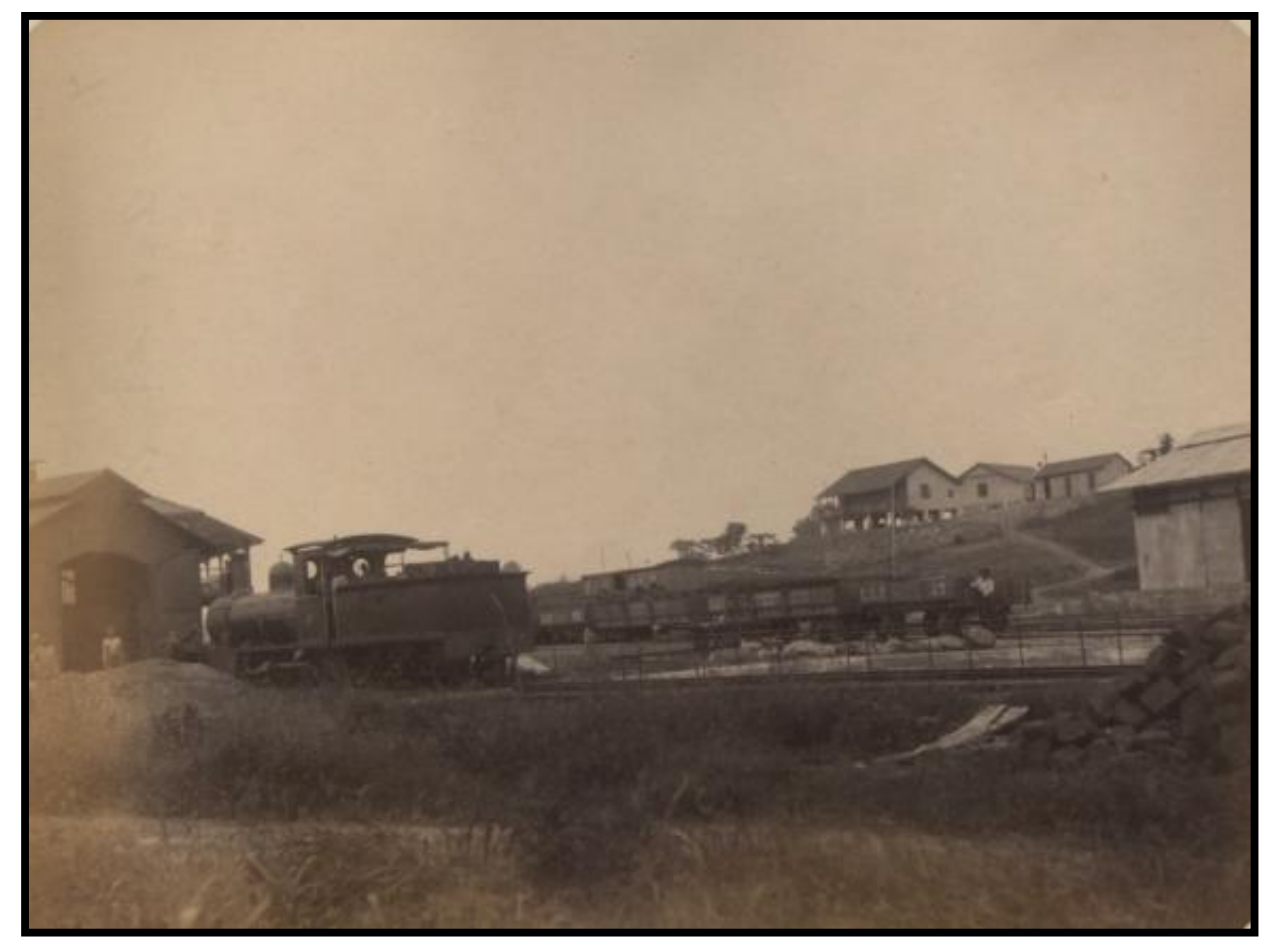

Fonte: National Archives. Nigeria, CO 1069.80.59.

412 OYEMAKINDE, Wale. Railway Construction and operation in Nigeria, 1895-1911: labour problems and socio-economic impact. Journal of the Historical Society of Nigeria, vol.VII, n.2, 1974. pp.307-308. 


\section{Mapa 4: Estradas de ferro britânicas, 1912}

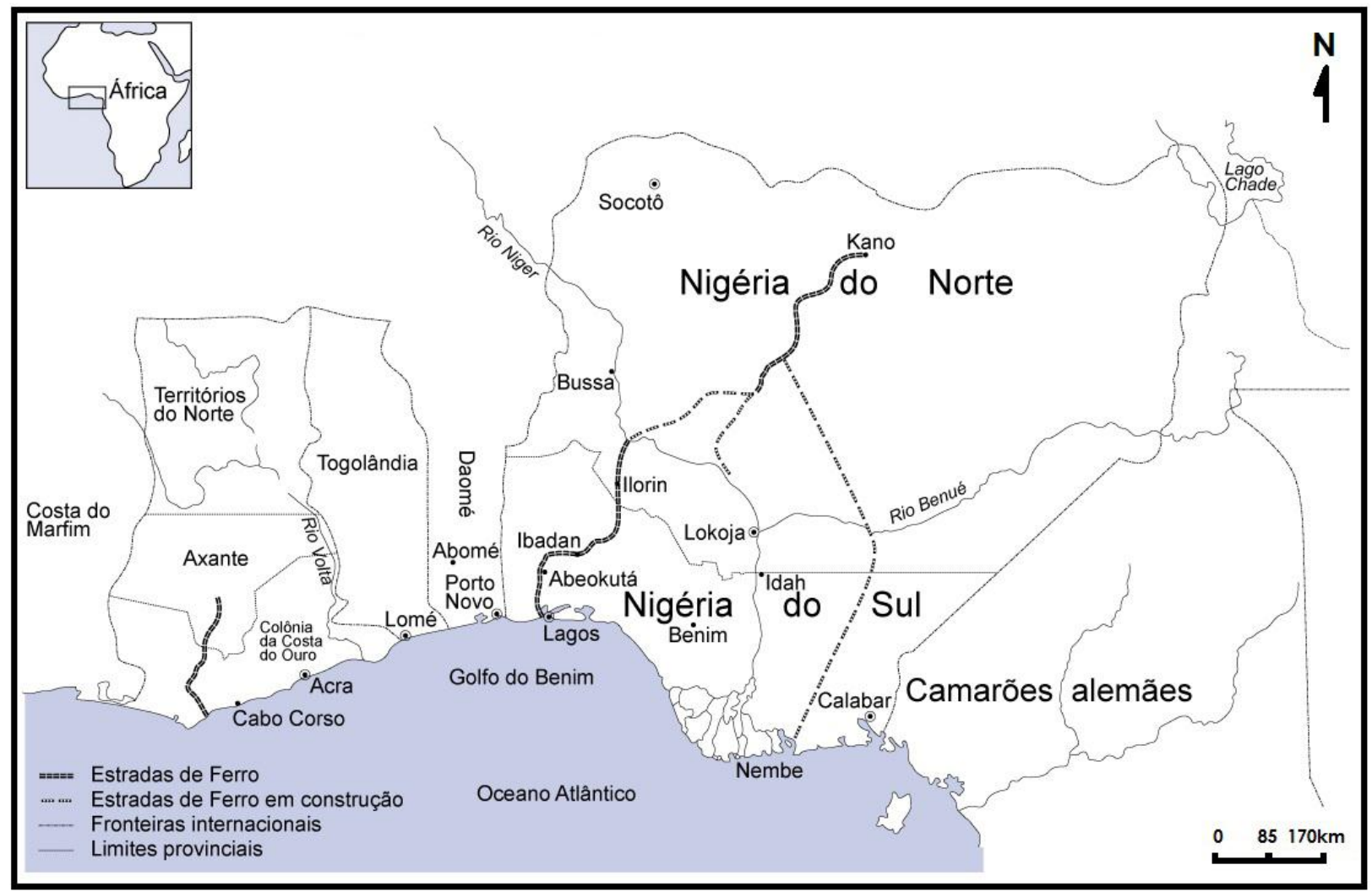

Fonte: Mapa adaptado de NEWBURY, C.W. British Policy towards West Africa. Select Documents, 1874 - 1914. London: Oxford University Press, 1971, p.102 e de FALOLA, Toyin; HEATON, Matthew M. A History of Nigeria. Cambridge: Cambridge University Press, 2008, p.120.

Ao longo dos seis anos em que a ferrovia foi construída mais de dez mil trabalhadores africanos tomaram parte do empreendimento. A maior parte destes indivíduos era utilizada como carregadores e mão de obra braçal. $\mathrm{O}$ trabalho na abertura da estrada de ferro exigia meses de afastamento da cidade natal. Vivendo em alojamentos precários, erguidos para atender 0 mínimo das condições de higiene e saúde coletivas e dispondo apenas dos parcos alimentos e salários que Ihes eram fornecidos pela administração colonial, estes trabalhadores tornaram possível as ações britânicas de penetração, controle e exploração de territórios distantes da faixa litorânea. A precariedade das relações de trabalho estabelecida desde a construção da estrada de ferro se manteve entre os funcionários responsáveis por sua operação. Em 1902, uma greve suspendeu as atividades da ferrovia por alguns dias. Dois anos mais tarde, em 1904, ocorreu uma segunda paralisação em 
protesto contra formas de contrato que discriminavam funcionários africanos e britânicos. $^{413}$

A construção da linha ferroviária que ligava a costa de Lagos a Ibadan era defendida pelo Colonial Office a partir de uma retórica fundamentada na ideia de desenvolvimento. Ao justificar a penetração colonial como parte de um conjunto de ações capazes de interiorizar a "civilização" na região, o então Secretário de Estado para as Colônias, Joseph Chamberlain, buscava mobilizar a opinião pública britânica em seu favor. Sob o argumento de que os custos da obra logo se converteriam em lucro, visto que a estrada de ferro permitiria o escoamento mais eficiente dos artigos exportáveis produzidos no interior, o Colonial Office sustentou durante os seis primeiros anos as obras da linha ferroviária. No entanto, esta não era a única razão para o estabelecimento de uma ferrovia em direção a lbadan. Subjacente ao discurso de interiorização da "civilização" havia o interesse em garantir o domínio sobre territórios recémincorporados à administração colonial sob a denominação de áreas de protetorado. Neste sentido, atendendo as determinações presentes no sexto capítulo da Conferência de Berlim, o Colonial Office garantia a manutenção de zonas afastadas da costa por meio da instalação de um conjunto de ferrovias e estradas que facilitariam a penetração direta de companhias europeias pelo interior. $^{414}$

Conforme demonstra a representação cartográfica 4 - Estradas de ferro britânicas, 1912 - a construção da linha ferroviária não parou em Ibadan. Nos anos seguintes à inauguração da estação na cidade, os trabalhadores continuaram a erguer os trilhos que levariam a ferrovia até o rio Níger, uma via

\footnotetext{
413 Segundo Oyemakinde, em agosto de 1899, os africanos empregados na construção da ferrovia chegavam a 10.426 trabalhadores. OYEMAKINDE, Wale. Op. Cit., 1974, p. 306. É possível ler mais acerca dos primeiros movimentos organizados de repúdio à exploração do trabalho, cujo principal desdobramento foi a organização de grupos sindicais, em: HOPKINS, A.G. The Lagos Strike of 1897: An Exploration in Nigeria Labour History. Past \& Present, n. 35, dez. 1966, pp.133-155.

${ }^{414}$ Os aspectos fundamentais propostos na Ata Geral da Conferência de Berlim são analisados por Leila Hernandez. Este documento foi organizado em seis capítulos. Dois deles, em especial, ajudam na compreensão das ações empreendidas pelo Colonial Office nas décadas de 1880 e 1890 . O primeiro se refere ao capítulo $2^{\circ}$, cujas disposições versavam acerca do esforço colonizador em disseminar "as vantagens da civilização" nos moldes europeus. O outro é o capítulo 6을 que propunha a ocupação territorial efetiva como pressuposto ao reconhecimento do domínio colonial. Cf. HERNANDEZ, Leila Maria Gonçalves Leite. A África na sala de aula: visita à história contemporânea. 3aㅡ ed., São Paulo: Selo Negro, 2010, p.62-64.
} 
utilizada por comerciantes europeus desde a década de 1830. Durante os anos de 1840, o delta do Níger era praticamente a única via de penetração e acesso das companhias europeias às oleaginosas - dendê, amendoim e óleo de coco - produzidas no interior. Esta posição conferiu ao estuário a denominação de "rios de óleo". ${ }^{415}$ Mas foi em 1912 que um prolongamento da estrada de ferro alcançou Kano, cidade situada na porção norte do protetorado britânico, região conhecida por sua consistente produção de amendoim. Conforme explica Olukoju, a ferrovia era uma via de escoamento alimentada por estradas construídas em áreas agrícolas. Não bastava, portanto, abrir novas rotas ou ampliar caminhos já existentes se não existissem veículos capazes de vencer grandes distâncias em pouco tempo. ${ }^{416}$

Era preciso que estes investimentos de infraestrutura fossem acompanhados pela expansão do transporte motorizado. Em 1906, o governo colonial importou o primeiro caminhão destinado a percorrer a estrada entre Ibadan e Oió para transportar as safras de algodão produzidas na região. Em apenas dois anos este número de caminhões subiu para quatro. ${ }^{417}$ Para termos uma ideia do que representou a ligação de Kano com a costa lagosiana, até o ano de 1910, o território definido como Nigéria do Norte exportava cerca de 1.179 toneladas de amendoim. Dois anos depois, o volume destas exportações apresentou uma drástica mudança. Segundo Falola e Heaton, em 1912, quando o terminal de Kano foi inaugurado, a exportação de amendoim cresceu mais de dezesseis vezes, atingindo um total de 19.288 toneladas. ${ }^{418}$ Dados como os apresentados dão suporte às análises que percebem a conquista colonial do interior e a expansão das redes comerciais das companhias europeias, em especial britânicas, como movimentos encadeados entre si. Ainda assim, sublinho que embora reconheça a prevalência das firmas britânicas na região, considero que a participação de companhias ou de

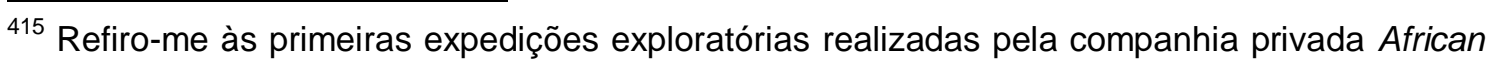
Inland Commercial Company (1832/1833) e pela firma de propriedade de Robert Jamieson, cujas embarcações foram, a partir de 1835, capitaneadas por John Beecroft. As ações destas duas companhias e de seus agentes são citadas no primeiro capítulo desta tese. Sobre a denominação do estuário do Níger como "rios de óleo", sugiro: M'BOKOLO, Elikia. Op.cit., 2011.pp.147-153.

${ }_{416}$ OLUKOJU, Ayodeji. The "Liverpool" of West Africa: dynamic and impact of maritime trade in Lagos 1900 - 1950. Trenton/N.J.: African World Press, 2004, p.18.

${ }_{417}$ OLUKOJU, Ayodeji. Op.cit., 2004, pp.17-18.

${ }^{418}$ FALOLA, Toyin; HEATON, Matthew M. Op.cit., 2008, p.120.
} 
agentes comerciais europeus, em particular franceses, alemães e italianos, se manteve até 1914, ano que marca o início da Primeira Guerra Mundial.

Ainda de acordo com Falola e Heaton, podemos considerar a intervenção britânica na Guerra de Ekitiparapo como o primeiro grande marco na escalada colonizadora em direção ao interior. $O$ conflito entre Ibadan e a aliança formada por forças Ekiti, ljesa, Egba, ljebu e Ife se arrastava por cerca de quinze anos. A longa duração da disputa havia enfraquecido ambos os lados em guerra, situação que permitiu às autoridades britânicas negociar os termos de um acordo de paz. Embora desde 1882 um cessar fogo já estivesse em vigor, a guerra só alcançou o seu termo onze anos mais tarde, em 1893. Na ocasião, um tratado firmado entre os envolvidos no conflito e o governador de Lagos, Gilbert Thomas Carter, suprimiu o controle de Ibadan sobre as cidades de Ekiti e ljesa. O documento também previa a submissão de eventuais disputas ao arbítrio do governo colonial de Lagos e determinava a abertura dos mercados e das rotas às companhias britânicas. ${ }^{419}$

Naquele mesmo ano de 1893, as autoridades britânicas apresentaram aos ijebus um tratado semelhante ao que havia sido firmado entre os envolvidos na Guerra de Ekitiparapo. Um dos pontos desta proposta se referia a suspensão dos bloqueios às rotas de escoamento de dendê, algodão e alimentos que abasteciam Lagos. No entanto, o awujale - indivíduo detentor do título mais importante entre os chefes ijebus - recusou se submeter ao que considerava uma interferência externa na regulação do fluxo de mercadorias para o litoral. Em resposta à insubordinação ijebu, Carter autorizou um violento ataque a sua principal cidade: ljebu Ode. Após quatro dias de bombardeio as forças do awujale capitularam. O tema da deposição do awujale pelo poder colonial britânico é discutido pelo historiador da Universidade de Lagos, Tunde Oduwobi. Para Oduwobi, antes da colonização da Grã-Bretanha, quando um chefe era deposto sua morte era também esperada. Embora existissem exceções, a morte do awujale colocava um fim às expectativas de seu retorno

\footnotetext{
${ }^{419}$ FALOLA, Toyin; HEATON, Matthew M. Op.cit., 2008, p.95. Um mapa apresentado nesta obra (página 94) permite uma melhor visualização dos domínios britânico, francês e alemão na região em 1899. Outro livro que faz referências à intervenção da Grã-Bretanha nos conflitos de Ekitiparapo é: FALOLA, Toyin; ADERINTO, Saheed. Nigeria, Nationalism and Writing History. New York: University of Rochester Press, 2010, pp.147-148.
} 
à antiga posição, além de encerrar um conjunto de ritos associados à sacralidade desta posição. ${ }^{420}$

Em 1893, quando o awujale foi deposto, a administração colonial classificou suas ações como medidas "pacificadoras", cuja principal realização foi colocar fim aos conflitos do interior. O término destas ofensivas era uma antiga demanda das firmas europeias com sede em Lagos. Estas companhias pressionavam o Colonial Office e o governo colonial lagosiano a empreenderem medidas capazes de garantir o fluxo permanente das mercadorias que vinham do interior. ${ }^{421}$ Um longo relatório das ações iniciadas em 1893 por Gilbert Carter ganhou as páginas do Lagos Weekly Record quatro anos mais tarde, no ano de 1897. Naquele momento Carter não ocupava mais o cargo de governador de Lagos e suas considerações acerca da "pacificação" do território ljebu foram apresentadas em uma reunião do Royal Colonial Institute, em Londres.

Um extenso preâmbulo descrevia o impasse ocasionado pela atuação dos chefes ijebu ao repelir as tentativas do governo britânico de acabar com os bloqueios às rotas de escoamento de mercadorias para Lagos. Neste trecho do documento, Carter denomina suas visitas às cidades controladas pelo awujale como "expedições pacificadoras". Embora o ex-governador fizesse questão de registrar a presença das forças haussas nestas expedições, não há neste relatório menções à violência promovida contra os ijebus. Ao selecionar as informações que julgava interessar ao seleto público do Royal Colonial Institute, Carter construiu uma refinada análise acerca dos ganhos comerciais proporcionados por suas conquistas. Fornecendo dados numéricos acerca do crescimento das importações e exportações após suas ações "pacificadoras", o ex-governador reafirmava sua posição em relação à expansão do domínio colonial em direção a áreas cada vez mais afastadas da costa. ${ }^{422}$

\footnotetext{
${ }_{420}$ Cf. FALOLA, Toyin; HEATON, Matthew M. Op.cit. 2008, p.95 e ODUWOBI, Tunde. Deposed Rulers under the Colonial Regime in Nigeria. The Careers of Akarigbo Oyebajo and Awujale Adenuga. Cahiers d'Études africaines, XLIII (3), 171, 2003, pp.553-571.

${ }^{421}$ Cf. MANN, Kristin. Op.cit., 2010, p.194.

422 The Lagos Weekly Record, 19 de junho de 1897, World Newspaper Archive, African Newspapers, $1883-1888$.
} 
A atuação das tropas colonizadoras sobre este território permitiu que as cidades vizinhas vislumbrassem o poder bélico da Grã-Bretanha. Naquele mesmo ano de 1893, quando os britânicos fizeram circular entre as demais chefias iorubás um novo termo de submissão, foram raras as resistências. Apenas os oiós repudiaram a oferta de assinatura de um novo tratado. Em razão disto, em novembro de 1894, seu território foi bombardeado e incorporado como área do protetorado britânico. Um tratado firmado entre Carter e o alafim de Oió estabelecia, em linhas gerais, que a partir daquele momento não haveria impedimento ao acesso e à instalação de súditos britânicos e religiosos cristãos em seus domínios, seus seguidores não promoveriam conflitos em regiões vizinhas a Lagos e nenhuma parte de seu território seria cedida a outra nação estrangeira sem o consentimento de sua Majestade, a rainha da Inglaterra. ${ }^{423} \mathrm{~A}$ escalada da violência colonizadora era acompanhada pela penetração comercial de companhias europeias que mantinham armazéns e escritórios em Lagos. As facilidades proporcionadas pela "pacificação" do interior, pela construção de novas estradas e expansão ferroviária permitiram a estas firmas a introdução de uma acentuada variedade de artigos importados. Parte destes bens seguia para o interior, onde seriam trocados principalmente pelo óleo de dendê, algodão, marfim e amendoim. No entanto, uma significativa parcela das mercadorias descarregadas no porto lagosiano era negociada no comércio varejista da própria cidade. ${ }^{424}$

Anúncios publicados nos periódicos Lagos Observer e Lagos Weekly Record nos fornecem uma ideia acerca das dinâmicas que envolviam a participação brasileira neste mercado. Em setembro de 1882 o comerciante S.C. Soares, citado páginas atrás em razão de sua participação na Câmara de Comércio de Lagos, pagou um pouco mais de duas libras para divulgar seus

\footnotetext{
${ }^{423}$ Government Gazette, Colony of Lagos, National Archives/UK. CO 150.4, 3 de fevereiro de 1893.

${ }^{424}$ Conforme explica Mann, todo o processo associado à elaboração do óleo de palma exigia um intenso trabalho, uma quantidade extraordinária de tempo e volumes imensos de combustível e água. Estes aspectos limitavam a produção e ocasionavam um descompasso em relação às quantidades demandadas pelas companhias exportadoras. Em função disto, firmas europeias muitas vezes optavam pela compra da mercadoria em estado bruto, ou seja, da semente do fruto da palma, a partir do qual se extraía um óleo de melhor qualidade. MANN, Kristin. Op.cit., 2010, pp.130-136.
} 
negócios no Lagos Observer. ${ }^{425}$ As breves (para a época) seis linhas de seu anúncio comunicavam a chegada em sua loja de um carregamento de batatas de primeira qualidade. O estabelecimento comercial era anexo à sua residência, localizada na rua Broad. No ano seguinte, em novembro de 1883, o mesmo jornal comunicou aos seus leitores que o vapor Kuka, pertencente a The National African Company, havia atracado no porto da cidade e que até o início de fevereiro de 1884 partiria em direção à Bahia, caso a quantidade de fretamentos fosse suficiente para cobrir os custos da viagem e garantir o lucro da companhia. A oferta do Kuka foi repetida nas edições seguintes deste mesmo periódico. O vapor parece ter preenchido seus porões dentro do prazo determinado pela companhia, pois seu último anúncio foi impresso no dia 31 de janeiro de 1884. Embora a viagem realizada pelo Kuka fosse operada por uma firma britânica - a The National African Company - ela revela aspectos importantes das ligações comerciais existentes entre Lagos e Salvador. ${ }^{426}$

Figura 3: Anúncio de venda de batatas pelo Senhor S.C. Soares

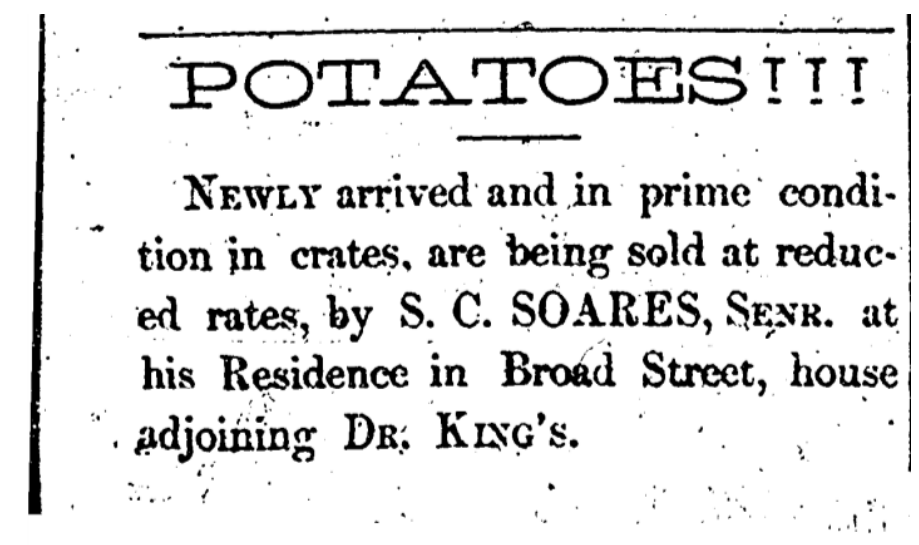

Fonte: The Lagos Observer, 14 de setembro de 1882, World Newspaper Archive, African Newspapers, 1883 - 1888.

\footnotetext{
425 O Lagos Observer participava em sua primeira página uma tabela com os respectivos valores de assinatura e tipos de propagandas. Anúncios de até doze linhas custavam 0,36 libras cada linha. Para aqueles que desejavam um espaço maior, era cobrada uma taxa de 0,04 libras por linha adicional.

${ }^{426}$ Os referidos anúncios podem ser encontrados, respectivamente, em: The Lagos Observer, 14 de setembro de 1882 e 22 de novembro de 1883 a 31 de janeiro de 1884, World Newspaper Archive, African Newspapers, 1883 - 1888.
} 
O primeiro destes aspectos se refere ao acesso de médios e pequenos comerciantes ao transporte de mercadorias pelo Atlântico. Este transporte estava condicionado à existência de embarcações dispostas a realizar a travessia de Lagos até o porto baiano, e vice-versa. Companhias maiores, como a Sant'Anna \& Co, dispunham de navio próprio para carregar seus artigos e, eventualmente, ofereciam os espaços remanescentes a outros comerciantes. Neste sentido, podemos suspeitar que importações em volume bastante reduzido atendiam a encomendas específicas ou serviam ao abastecimento de lojas de menor porte. No ano de 1884, o relatório de bens importados produzido pela administração colonial britânica relacionou 0 desembarque de diversos artigos provenientes do Brasil. Nesta lista estavam, por exemplo, uma carruagem, um pacote contendo botas e sapatos e uma imensa quantidade de tabaco, cuja somava era de 175.426 libras, aproximadamente $79.571 \mathrm{~kg}^{427}$

Em geral, as embarcações provenientes do Brasil carregavam em seus porões grandes quantidades de aguardente e tabaco, mercadorias que durante o tráfico eram parte da relação de itens para a compra de escravos. No entanto, mesmo depois do fim do tráfico para o Brasil e para Cuba, estes artigos continuaram a ter uma boa aceitação no mercado lagosiano. Ao longo de toda a segunda metade do século XIX, comerciantes baianos aviavam estes e outros itens a agentes e donos de armazéns estabelecidos em Lagos. As embarcações baianas que atracavam na cidade transportavam artigos comercializáveis e indivíduos. A maioria destes passageiros era africana ou descendente. Para estas pessoas, deixar a Bahia e atravessar o Atlântico representava a possibilidade de uma nova vida.

Este movimento de indivíduos do Brasil em direção a Lagos não passou despercebido pelas autoridades britânicas. Em 1887, o então governador colonial, Cornelius Alfred Moloney, manifestou junto aos seus superiores do Colonial Office apoio à criação de uma linha de vapores mantida por meio de um subsídio anual no valor de 1.800 libras. Para Moloney, a questão do déficit de mão de obra na lavoura poderia ser solucionada com a facilitação do

427 O Brasil ficou atrás apenas da Grã-Bretanha, que no ano de 1884 vendeu para Lagos 331.568 libras de tabaco ou cerca de 150.396 kg. Blue Book, Colony of Lagos, 1884, pp.69-81. 
ingresso de africanos libertos vindos do Brasil e dos Estados Unidos. Conforme indiquei no primeiro capítulo desta tese, o governador promoveu sua posição sobre esse assunto em congressos científicos realizados pela Manchester Geographical Society (1889) e pela Royal Geographical Society (1890). Os artigos publicados a partir da exposição de Moloney nestas duas ocasiões não surtiram o efeito esperado e a proposta de criação de uma linha de vapores ligando Salvador e Lagos foi abandonada. ${ }^{428}$

Mesmo contando apenas com os navios de carga, cujo número de travessias atendia às dinâmicas comerciais entre os dois atracadouros, os libertos vindos principalmente da capital baiana continuaram a desembarcar no porto lagosiano ao longo de todo o século XIX. Levando consigo histórias e experiências de vida diversas, a maioria destes indivíduos passou a morar no bairro brasileiro existente em Lagos: o Brazilian Quarter. Alguns deles encontraram trabalho em estabelecimentos cujos proprietários eram também brasileiros que haviam enriquecido com o comércio. Anúncios publicados nos jornais que circulavam em Lagos fornecem pistas acerca de quem eram os comerciantes varejistas brasileiros neste período. Embora reconheça que tais anúncios estavam ligados a apenas uma parcela pequena do conjunto de brasileiros que vivia na cidade e considere que os jornais eram lidos somente por indivíduos alfabetizados em língua inglesa, percebo estes registros como uma fonte importante de informações que nos permite capturar instantes da vida cotidiana destas pessoas.

Quando cotejei os relatórios compilados pelos Blue Books ao conjunto de títulos de periódicos selecionados por esta pesquisa, pude perceber que, na segunda metade do século XIX, o comércio foi a atividade econômica de maior relevância entre os brasileiros. Os negócios com o Brasil concentravam o maior volume das operações realizadas por brasileiros atacadistas e varejistas. Para além da cachaça e do fumo de corda, artigos consumidos pela população em

\footnotetext{
${ }^{428}$ Segundo Verger, em agosto de 1887 , Moloney remeteu uma carta ao Colonial Office em que reforçava sua posição acerca da criação de uma linha de vapores entre Brasil e Lagos. $O$ governador de Lagos anexou à missiva uma correspondência trocada com o agente da British African and African Steam Ship Company, M. Neville. VERGER, Pierre, Op.cit. 1987, p.622. As tentativas de oferta de uma linha regular de vapores são também citadas por Cunha em: CUNHA, Manuela Carneiro da. Op.cit. 2012, p.160. No primeiro capítulo desta tese desenvolvo uma análise mais aprofundada acerca dos artigos escritos por Alfred Moloney e apresentados nestas sociedades de pesquisa.
} 
geral, estes importadores desembarcavam no porto lagosiano bens que, de tão específicos, eram quase que exclusivamente destinados à população brasileira residente na cidade. Este aspecto merece especial atenção, pois revela um dos signos de pertencimento associados ao ser brasileiro neste momento. Este signo se refere aos negócios desempenhados pelos comerciantes que se mantiveram atados ao Brasil. Em um contexto de reconfiguração das relações atlânticas, antes ligadas ao tráfico e, a partir de 1850, ditadas pelo mercado europeu de bens lícitos como o algodão, dendê e outras oleaginosas, estes importadores brasileiros continuaram a alimentar os mercados lagosianos com produtos provenientes, em particular, da Bahia. Nem mesmo a diminuição das trocas entre os dois parceiros comerciais - percebidas de maneira mais clara partir de 1891 - extinguiu estes negócios. Para continuar existindo estas relações comerciais se reformularam em resposta à agressiva penetração das companhias europeias.

Alguns comerciantes brasileiros reduziram o número de armazéns, outros migraram seus negócios do atacado para o varejo e houve ainda aqueles que diversificaram suas mercadorias, passando a vender também produtos importados da Europa. Nestes casos, a migração das atividades do tráfico para o comércio lícito e, em uma segunda etapa, a reformulação das formas de atuação nos mercados atacadistas e varejistas, permitiu que estes indivíduos reelaborassem um dos emblemas mais destacados da identidade dos brasileiros de Lagos: o engajamento comercial. Além disto, ao garantirem o consumo de bens específicos como livros, instrumentos musicais, araruta, farinha de mandioca e tamancos de madeira, entre outros artigos, estes brasileiros-comerciantes forneciam os elementos materiais necessários ao exercício cotidiano das diversas formas de ser brasileiro na Lagos oitocentista. Adiante, no último capítulo desta tese procurei entender como, nas décadas de 1880 e 1890, estes indivíduos foram representados e se fizeram representar em anúncios, notas, registros, cartas e artigos publicados pelos jornais lagosianos impressos neste período. Nesta etapa, também proponho a análise acerca de como tais formas de representação ajudaram a compor alguns dos sentidos destas identidades brasileiras cambiantes. 


\section{Os jornais e as representações dos brasileiros}

(1886 a 1900)

Os nativos requeriam força externa para produzir ordem. Quanto mais rudes, menos desenvolvidas são suas faculdades e maior força externa é necessária para manter os indivíduos juntos e ensinar comunidades oponentes as vantagens da harmonia e da cooperação. (...) Confiança é uma planta que cresce devagar, especialmente entre as pessoas com estes antecedentes. ${ }^{429}$

Durante os cinco primeiros anos da administração colonial britânica em Lagos, entre 1861 e 1866, o governo da cidade foi mantido separado das outras colônias da Grã-Bretanha existentes na Costa da Mina. Na prática isto significava que os governadores estabelecidos na cidade possuíam certa autonomia política, administrativa e financeira em relação às duas principais colônias da África Ocidental, a saber: Serra Leoa e Costa do Ouro. ${ }^{430}$ No ano de 1866, a administração de Lagos passou por uma significativa alteração. Embora John Hawley Glover, que estava à frente do governo da cidade desde 1864 fosse mantido em sua posição, Lagos perdeu parte da independência administrativa que mantinha até aquele momento. Isto porque, entre os anos de 1866 e 1874, o governo lagosiano passou a ser tutelado pelos administradores de Freetown, capital da colônia de Serra Leoa. Em 1874,

\footnotetext{
429 "The natives required external force to produce order. The ruder a people are, the less developed in the higher faculties, the more external force is necessary to keep individuals together and to teach discordant communities the advantage of harmony and co-operation. (...) Confidence is a plant of slow growth especially among a people of such antecedents." The Lagos Weekly Record, 26 de junho de 1897, World Newspaper Archive, African Newspapers, 1883 - 1888.

${ }^{430}$ Segundo Gebara, o termo "África Ocidental" possuía, para os britânicos do século XIX, um sentido bastante específico. Longe de compreender todo o litoral atlântico do continente africano, o termo se restringia aos territórios sob controle da Grã-Bretanha ou sobre os quais os britânicos guardavam interesses econômicos. GEBARA, Alexsander. A África de Richard Francis Burton: antropologia, política e livre comércio. São Paulo: Alameda, 2010, pp.61-63.
} 
novos arranjos impostos pelo Colonial Office tornaram Lagos parte da jurisdição da Costa do Ouro. Esta situação perdurou por doze anos. Em 1886, as colônias foram separadas e a cidade recobrou sua autonomia governamental. ${ }^{431} \mathrm{Em}$ função de seu novo status administrativo, a demanda por funcionários alfabetizados voltou a crescer, atraindo saros que deixavam Freetown em busca de novas oportunidades de trabalhos urbanos. De acordo com Falola, neste momento alguns dos postos burocráticos mais altos, como 0 de secretário colonial interino, tesoureiro, coletor de impostos e de inspetor da polícia civil, passaram a ser ocupados também por africanos. ${ }^{432}$ Estes indivíduos dominavam a língua e a escrita do colonizador e, ao mesmo tempo, continuavam alimentando conexões de parentesco e culturais com sociedades mais afastadas da costa. Esta situação de permeabilidade sócio-cultural permitiu que constituíssem um grupo que foi, posteriormente, denominado pela historiografia produzida em língua inglesa como parte da "elite educada" lagosiana. Seus integrantes eram em sua maioria saros. Todavia, muitos brasileiros também passaram a integrar este conjunto de pessoas, cuja passagem pelas escolas missionárias anglicanas, metodistas e católicas havia Ihes fornecido elementos distintivos que os aproximava do colonizador. ${ }^{433}$

A partir da década de 1890, as ações colonizadoras britânicas se intensificaram sobre o território iorubá. O avanço de companhias de Londres, Manchester e Liverpool em direção às porções territoriais situadas cada vez

${ }^{431}$ Esta periodização pode ser encontrada em: MANN, Kristin. Slavery and the Birth of an African City. Lagos, 1760 - 1900. Indiana: Indiana University Press, 2007, pp.102-104. A obra de Mann também fornece informações acerca do período em que Freeman ocupou o posto de primeiro governador de Lagos, de 1862 a 1863. H.S. Freeman faleceu em 1865. Seu lugar foi depois deixado a cargo do governador John Hawley Glover, que administrou a colônia lagosiana de 1863 a 1872.

${ }_{432}$ FALOLA, Toyin. A History of Nigeria. West Port, CT: Greenwood Press, 1999, p.43. Disponível em http://site.ebrary.com/id/5005127?ppg=59.

433 De acordo com Sawada, os termos "nativo civilizado", "nativo educado" e "black englishmen", este último por vezes empregado com um sentido pejorativo e sem tradução direta, aparecem nos periódicos produzidos em Lagos entre os anos de 1880 e 1920. Embora não empregue estes termos nesta pesquisa, considero importante indicar que os jornais publicados na cidade foram os responsáveis pela propagação destas expressões. Autores como Kopytoff e Mann utilizam a expressão "elite educada" para se referir aos africanos, em sua maioria saros e brasileiros, que haviam frequentado escolas missionárias locais e, em alguns casos, completado os estudos na Europa. KOPYTOFF, Jean Herskovits. A Preface to Modern Nigeria. The "Sierra Leonians" in Yoruba, 1830-1890. Wisconsin: The University of Wisconsin Press, 1965 e MANN, Kristin. Marriage Choices among the Educated African Elite in Lagos Colony, 1880-1915. The International Journal of African Historical Studies, vol.14, n. 2, 1981, pp.201-228. 
mais ao interior tinha o propósito de solucionar o problema da regularidade no abastecimento de mercadorias que seriam comercializadas no mercado internacional. Recorrentes conflitos entre cidades iorubás ocasionavam o fechamento das rotas pelas quais eram transportados, principalmente, o óleo e a noz de palma, o amendoim e o algodão. Não por acaso, o Acordo Comercial firmado em fevereiro de 1852, entre Akitoye e negociantes europeus, obrigava o obá a pagar uma compensação caso o comércio lícito fosse suspenso. ${ }^{434}$ Além do aspecto da interrupção do fluxo de produtos para a costa, a progressiva inserção de firmas britânicas em território iorubá também visava eliminar os comerciantes locais - muitos deles, saros e brasileiros - que atuavam como intermediários nas negociações dos produtos que chegavam ao porto de Lagos. Ao substituir a atuação de mercadores independentes por agentes comerciais a serviço de seus interesses, estas companhias esperavam conseguir preços ainda menores nos lotes de algodão, nos sacos de noz de palma e nos galões de dendê comprados. Ademais, em teoria, o negócio direto com as zonas produtoras colocaria limites à dependência das firmas europeias em relação aos fornecedores responsáveis por intermediar as trocas comerciais regionais.

Se, por um lado, a partir da última década do século XIX, estas companhias ampliaram sua atuação em porções do território iorubá mais afastadas da costa, por outro, o governo colonial britânico forneceu o suporte técnico e material para que esta expansão se efetivasse. Neste contexto, foram criados os departamentos de agricultura, silvicultura e sanitário. Os objetivos destes organismos administrativos eram de incentivar a produção agrícola, aumentar a exploração dos recursos naturais endêmicos e reduzir os surtos de epidemias responsáveis pelo elevado número de óbitos na cidade. ${ }^{435}$ Neste contexto, em 1887, o então governador Cornelius Alfred Moloney inaugurou a Estação Botânica de Lagos.

\footnotetext{
${ }_{434}$ PROL, 1862, N.2, Agreement with King and Chiefs of Lagos, signed February 28, 1852. O acordo assinado por Akitoye é comentado por Smith em: SMITH, Robert. Op.cit., 1978, p.36. Detalhes do acordo firmado entre comerciantes europeus e Akitoye são tratados em detalhe no terceiro capítulo desta tese.

${ }_{435}$ DANIEL, S. Ola. Health and Social Welfare in ADERIBIGBE, A.B. (ed.) Lagos: The Development of an African City. Lagos: Longman, 1975, p.160.
} 
O estabelecimento colonial situava-se no continente, na localidade de Ebute Metta, e foi concebido como uma instalação destinada à ambientação de novas espécies e ao treinamento de trabalhadores para o cultivo, principalmente, das lavouras de café, cacau, algodão e borracha. ${ }^{436}$ Além disto, com objetivo de garantir o escoamento da produção que vinha das cidades iorubás situadas mais ao interior, a administração colonial britânica também investiu na construção de grandes obras de infraestrutura ferroviária e rodoviária. Relembro que a primeira linha férrea que ligaria Lagos a Ibadan começou a ser aberta em 1895. No ano de 1899, foram inauguradas as pontes Carter e Denton. A primeira ligava as ilhas de Lagos e de Ido e, a segunda, unia Ido a Ebute Metta, situada no continente. ${ }^{437}$

\section{Figura 4: Ponte Carter, 6 de novembro de 1929}

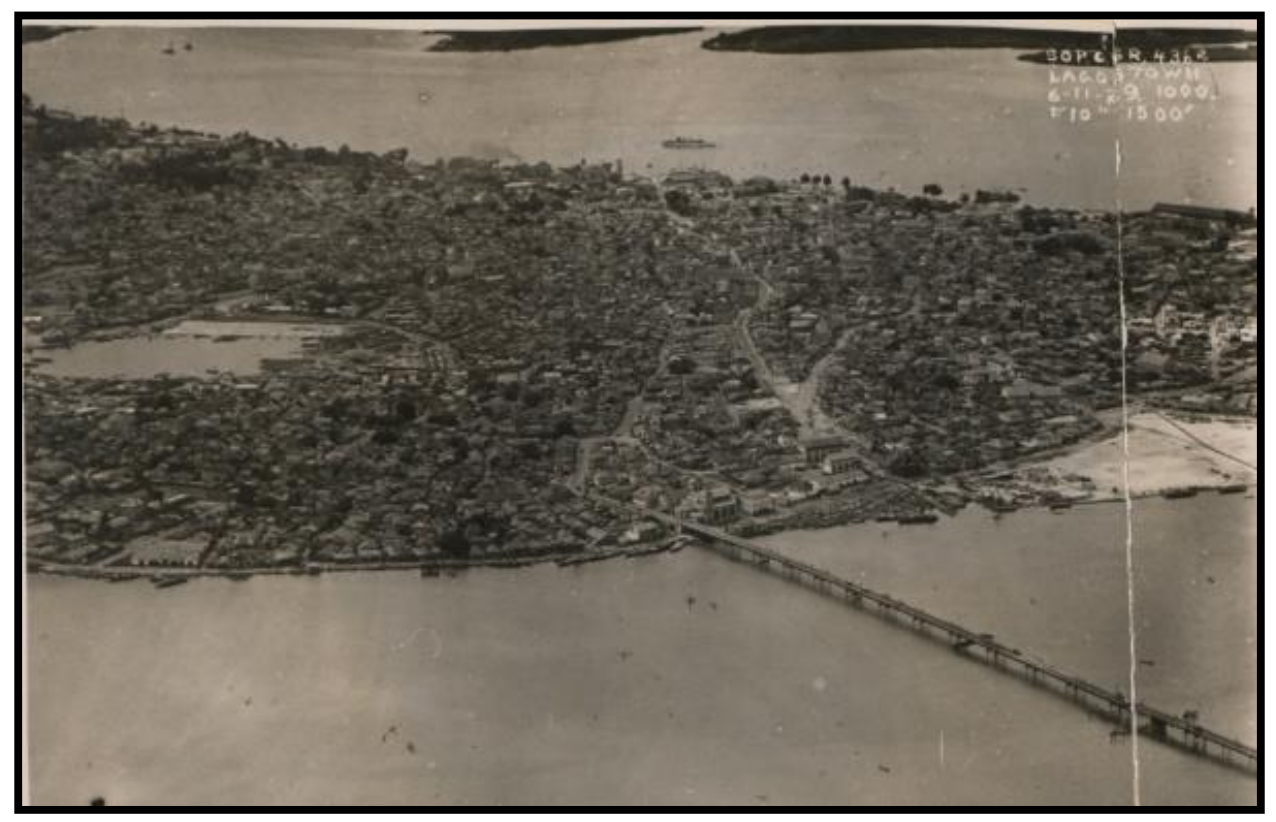

Fonte: National Archives. Nigeria, CO 1069.62.9

\footnotetext{
${ }^{436}$ No artigo apresentado à reunião da Manchester Geographical Society, Moloney expôs os propósitos da criação de uma Estação Botânica na cidade. MOLONEY, Cornelius Alfred (1889), Correspondence Affair on the West Coast of Africa. In The Journal of the Manchester Geographical Society. vol.V, Manchester: The Manchester Geographical Society, 1889. A realização de Alfred Moloney é comentada também por: CUNHA, Manuela Carneiro da. Op. cit., 2012, p.166.

${ }^{437}$ Segundo Sada e Adefolalu, tanto a ponte Carter quanto a Denton foram, posteriormente, substituídas. Uma terceira ligação foi construída apenas em 1970: a Eko Bridge. Uma representação cartográfica das principais vias de circulação existentes em Lagos e entorno, nos anos de 1970, permite uma melhor compreensão da organização urbana da cidade. SADA, P. O.; ADEFOLALU, A. A. Urbanisation and Problems of Urban Development in ADERIBIGBE, A.B. (ed.) Op.cit., 1975, pp.97 e 105.
} 
Nos anos de 1890, a ampliação da atuação comercial de empresas europeias pelo interior e as transformações infraestruturais operadas pelo governo britânico, provocaram mudanças no espaço social, econômico e político de uma parcela da população que havia frequentado escolas missionárias e alcançara uma situação sócio-econômica privilegiada na cidade. Uma década antes, em 1880, diversos títulos de periódicos começaram a circular pela cidade de Lagos. Conforme Sawada, uma parte significativa dos artigos, editoriais e correspondências publicadas pela imprensa lagosiana desta época carregava um pronunciado senso de dever em relação à totalidade da população. ${ }^{438}$

Neste capítulo trabalho com os anúncios, artigos e correspondências publicados em dois destes veículos: o Lagos Observer e o Lagos Weekly Record. As análises que se seguem procuram discutir a forma como as referências aos brasileiros impressas nestes jornais ajudaram a compor as várias faces da identidade destes indivíduos estabelecidos em Lagos nas duas últimas décadas do século XIX. Neste último capítulo busco também refletir acerca dos processos pelos quais as identidades brasileiras se reconfiguraram em resposta a um contexto de escalada das ações colonizadoras promovidas pelo Colonial Office em direção a territórios cada vez mais afastados do litoral lagosiano.

\subsection{Os anúncios de estabelecimentos e negócios brasileiros}

Manoel B. Moreira, barbeiro tradicional, cabeleireiro e dentista, informa aos fregueses sua mudança da praça Tinubu para a rua Kakawa, onde irá continuar seu negócio como de costume. Sábados das 12 às 10 da noite e em dias de semana das 6 da manhã às 6 da tarde. ${ }^{439}$

\footnotetext{
438 SAWADA, Nozomi. The educated elite and associational life in early Lagos newspapers: in search of unity for the progress of society. Tese de doutorado, Birmingham/UK: Centre of West African Studies School of History and Cultures College of Arts and Law / University of Birmingham, 2011, p.34.

439 "Manoel B. Moreira, Old Barber, Hair Dresser and Dentist, begs to inform the public that he has removed from Tinubu Square to Kakawa Street, where he will continue his business as
} 
Em 1882, um anúncio publicado no jornal Lagos Observer informava que a cachaça importada do Brasil tinha um novo concorrente: uma aguardente produzida, também a partir da cana, pela destilaria Wansbrough, situada em Apapa, porção continental da cidade de Lagos. ${ }^{440}$ Antes mesmo da propaganda da African Canna aparecer nas páginas do periódico, uma pequena nota atribuída ao comerciante italiano G. Del Grande elogiava o sabor delicado e o aspecto límpido da aguardente produzida por Wansbrough. Nesta nota, Del Grande informava que havia enviado à sua esposa um pequeno barril de cachaça, "como uma agradável surpresa e presente". Com este gesto, esperava que a opinião dela fosse a mesma que a sua: para ele a African Canna era superior à aguardente da Bahia. ${ }^{441} \mathrm{Em}$ novembro de 1882, quando as propagandas do destilado ganharam lugar no Lagos Observer, algumas das qualidades indicadas por Del Grande reapareceram em outros termos. Divulgado como o mais puro e saudável destilado do mercado, o anúncio apresentava uma relação contendo seis representantes comerciais, cujos estabelecimentos estavam autorizados a vender a mercadoria.

Entre os nomes que figuravam nesta lista estava o de João José da Costa, comerciante brasileiro arrolado pela Government Gazette como possuidor de licença para comercialização de destilados. ${ }^{442} \mathrm{O}$ nome de João Costa é citado pelo jornal oficial de Lagos, de maneira ininterrupta, até o ano de 1893. Ao final de maio deste mesmo ano, o comerciante comunicou sua saída do negócio de bebidas. Ao solicitar o comparecimento de credores e devedores ao seu estabelecimento, João da Costa dava a conhecer o encerramento de seus negócios no ramo. ${ }^{443} \mathrm{~A}$ documentação consultada fornece poucas pistas acerca dos motivos que levaram Costa a encerrar seu comércio de destilados. No entanto, podemos afirmar que comunicados como

usual Saturday from 12 noon to 10 p.m. Week day from 6 a.m. to 6 p.m." The Lagos Weekly Record, 3 de março de 1894, World Newspaper Archive, African Newspapers, 1883 - 1888.

440 The Lagos Observer, 23 de novembro de 1882 até 29 de março de 1883, World Newspaper Archive, African Newspapers, 1883 - 1888.

${ }^{441}$ The Lagos Observer, 6 de abril de 1882, World Newspaper Archive, African Newspapers, $1883-1888$.

${ }^{442}$ Sugiro consulta ao apêndice 4: Brasileiros com licença para comercializar bebidas destiladas em Lagos.

${ }_{443}$ The Lagos Weekly Record, 27 de maio; 3, 10 e 17 de junho de 1893, World Newspaper Archive, African Newspapers, $1883-1888$. 
este não eram muito comuns entre os anúncios de brasileiros publicados pelos jornais analisados nesta pesquisa.

Nem todos os brasileiros cujos negócios estavam ligados ao comércio de bebidas passaram por dificuldades nas duas últimas décadas do século XIX. Era o caso de P.F. Gomes, integrante da Câmara de Comércio de Lagos, cuja série de anúncios publicados durante o ano de 1898, no Lagos Weekly Record, informava acerca das bebidas oferecidas em sua loja e as respectivas quantidades disponíveis. A grande variedade de produtos e o número de garrafas divulgadas nestes anúncios levam a crer que Gomes atuava no mercado varejista de bebidas. Além disto, na longa relação de Gomes não há uma garrafa sequer de cachaça brasileira ou, tampouco, africana. Este aspecto em específico sugere que, nas décadas de 1880 e 1890, alguns comerciantes brasileiros redirecionaram suas atividades para a venda de produtos importados de outros países, em especial da Grã-Bretanha. Em um contexto de retração da atividade comercial entre Brasil e Lagos, uma das alternativas aos brasileiros, que antes enchiam seus empórios com artigos baianos, era negociar itens de outras origens.

Notas referentes à chegada de carregamentos provenientes do Brasil se tornaram raras a partir dos anos de 1880. Encontrei apenas três anúncios que informavam a chegada de uma embarcação vinda do Brasil. Todos eles eram referentes à nau Bento de Freitas, de propriedade de Manoel Joaquim de Sant'Anna. ${ }^{444}$ No lugar dos antigos informes de chegada de artigos brasileiros, lojas varejistas anunciavam o desembarque de produtos industrializados, fornecidos por companhias europeias. Para os brasileiros que mantinham seus negócios no varejo de importados, a opção era o acréscimo de artigos europeus ao rol das mercadorias vendidas em seus armazéns.

Em 1898, outro integrante da família Gomes, E.F. Gomes, também se utilizou desta estratégia. Ao divulgar a venda das aspirinas Teplitzer, o comerciante brasileiro comunicava aos leitores do Lagos Weekly Record que aquele era um produto confiável. Afinal, era consumido por ninguém menos do

\footnotetext{
444 Estes comunicados foram publicados no Lagos Weekly Record, nas seguintes datas: 19 e 26 de agosto de 1893 e 2 de setembro de 1893.
} 
que "os soberanos europeus e Sua Majestade a Rainha" Victoria. De acordo com o anúncio, o medicamento era "superior, tanto em qualidade quanto em sabor, a qualquer outro existente". Além disto, era recomendado no tratamento de "várias enfermidades, tais como reumatismo crônico nas articulações e nos músculos". A nota publicada durante vários meses no ano de 1898, ainda prevenia que para os "europeus residentes em climas quentes" o produto era uma necessidade. Esta última parte do anúncio de E.F. Gomes nos fornece pistas acerca de uma parcela dos consumidores de sua loja: europeus instalados em Lagos. ${ }^{445}$

Figura 5: Anúncio da aspirina Teplitzer, vendida por E.F. Gomes

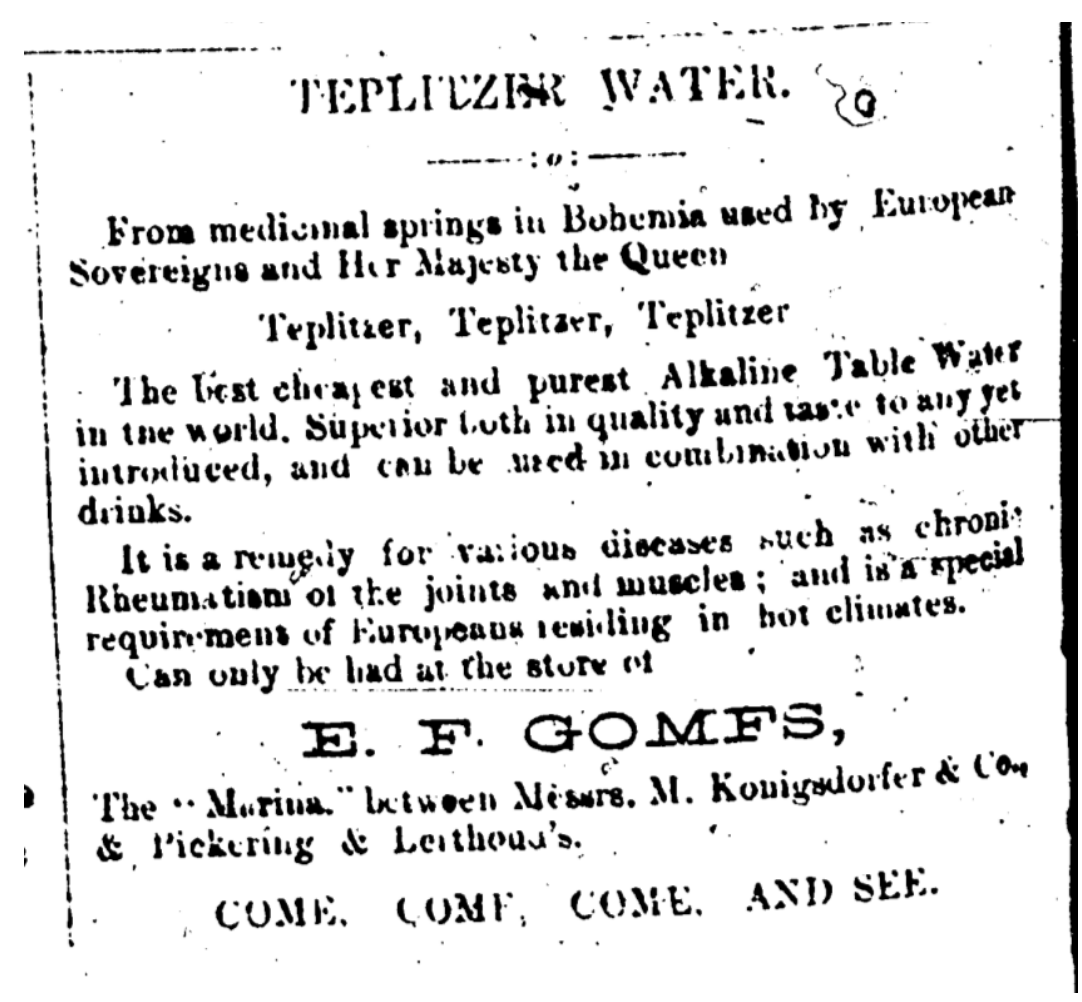

Fonte: The Lagos Weekly Record, 11 de junho de 1898, World Newspaper Archive, African Newspapers, $1883-1898$.

É difícil precisar quem eram os leitores dos periódicos onde estes anúncios aparecem. Para a pesquisadora Nozomi Sawada, o analfabetismo entre a população em geral indicaria que os jornais eram lidos por uma pequena parcela de indivíduos que dominava a língua inglesa. No entanto, os

\footnotetext{
445 The Lagos Weekly Record, 16 e 30 de abril; 7, 14, 21 e 28 de maio; 4, 11, 18 e 25 de junho; 2 e 9 de julho de 1898, World Newspaper Archive, African Newspapers, $1883-1888$.
} 
baixos índices de escolaridade não eram um limite à circulação do conteúdo impresso nas páginas destes veículos. Afinal, a mesma pesquisadora revela que, muitas vezes, as notícias publicadas nos periódicos de Lagos eram retransmitidas de boca em boca e um mesmo exemplar de jornal poderia ser compartilhado por até quatro leitores. ${ }^{446}$ Era também comum igrejas e associações promoverem reuniões em que se realizavam leituras públicas de periódicos, panfletos e excertos de livros. Segundo Nara França, nestes momentos muitos indivíduos não alfabetizados tinham acesso às questões levantadas pelas publicações que circulavam na cidade. Em sua tese acerca da vida intelectual lagosiana do final do século XIX e início do XX, França mostra que, em diversas ocasiões, discussões iniciadas em reuniões de leitura coletiva ganhavam as páginas dos jornais. Deste modo, notícias, polêmicas e questões impressas por estes veículos alcançavam um número mais amplo de indivíduos do que a quantidade de exemplares vendidos. ${ }^{447}$

Neste sentido, divulgar produtos e serviços nas páginas dos jornais poderia ser uma boa maneira de ampliar as vendas ou comunicar mudanças nos negócios. O barbeiro Manoel B. Moreira, por exemplo, publicou no Lagos Weekly Record uma série de anúncios que informavam quais eram os serviços executados em seu salão e, eventualmente, suas mudanças de endereço. Estas notas aparecem nos periódicos impressos entre fevereiro de 1894 a outubro de 1896. Nos anúncios Moreira se apresentava como um velho barbeiro, cujas habilidades Ihe permitiam atuar também como cabeleireiro e, como era comum à época, dentista. Ao pagar para ter seus anúncios impressos no jornal lagosiano, Moreira nos permite entrever o tipo de clientes que recebia em seu estabelecimento: indivíduos com recursos suficientes para dispor de um profissional considerado especializado. ${ }^{448}$

\footnotetext{
${ }^{446}$ SAWADA, Nozomi. The Educated Elite and Associational Life in Early Lagos Newspapers: in search of unity for the progress of Society. Tese de doutorado. Centre of West African Studies. University of Birmingham, 2011, p.81.

447 FRANÇA, Nara Muniz Improta. Producing Intellectuals: Lagosian Books and Pamphlets between 1874 and 1922. Tese de doutorado. Sussex/UK: University of Sussex, 2013.p.126.

${ }_{448}$ The Lagos Weekly Record, 17 e 24 de fevereiro, 3 e 10 de março de 1894; 24 e 31 de outubro de 1896, World Newspaper Archive, African Newspapers, 1883 - 1888. Lisa Earl Castilho sublinha que até a extinção do tráfico (1850) os barbeiros (escravos, libertos ou livres) eram considerados passageiros valiosos dentro dos tumbeiros que atravessavam o Atlântico. A escassez de médicos a bordo destas embarcações, valorizava o ofício dos barbeiros, capazes de realizar uma série de procedimentos cirúrgicos, como: a aplicação de sanguessugas, a
} 
Figura 6: Anúncio de mudança de endereço do barbeiro M.B. Moreira

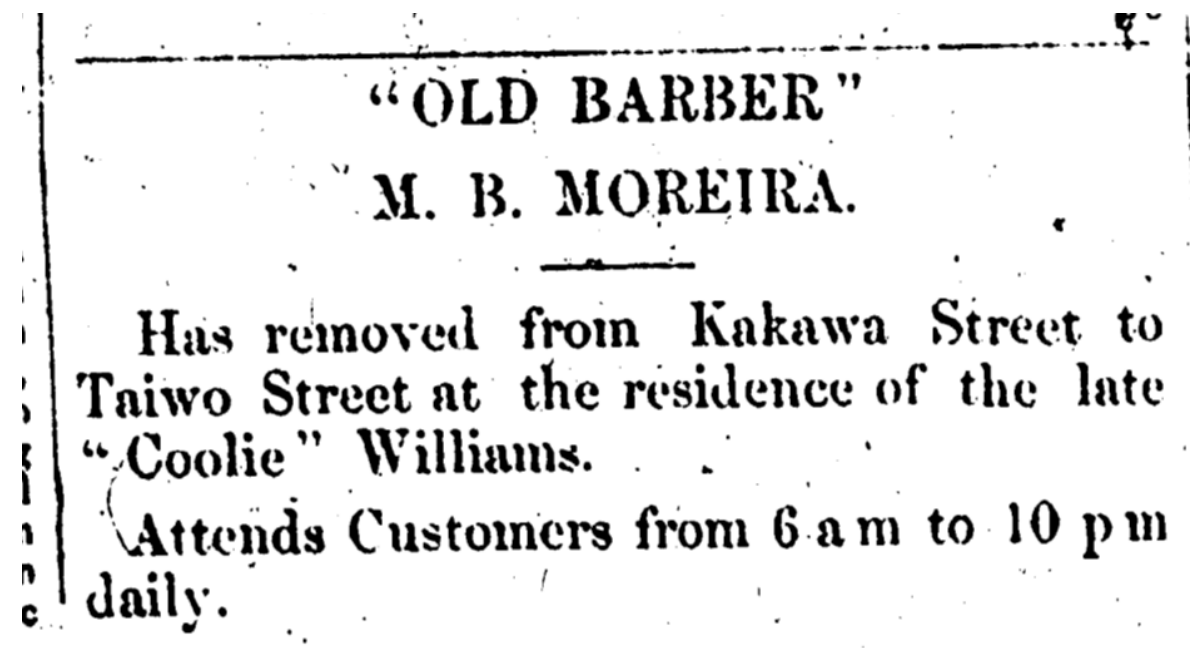

Fonte: The Lagos Weekly Record, 24 de outubro de 1896, World Newspaper Archive, African Newspapers, $1883-1898$.

Outro estabelecimento destinado a atender a um público mais abastado ganhou as páginas do Lagos Weekly Record a partir de outubro de 1897. Este lugar era o restaurante do brasileiro Cândido da Rocha. Embora a inauguração do estabelecimento tenha ocorrido apenas em novembro de 1897, desde 0 mês anterior o Restaurante Da Rocha divulgava suas futuras atividades por meio de anúncios semanais no Lagos Weekly Record. Instalado em um imóvel situado na rua Tinubu, o lugar oferecia acomodações aos viajantes e três refeições diárias a um preço fixo. Segundo estes anúncios, o valor da hospedagem, incluindo as três refeições, era de $£ 7,60$. Se 0 hóspede desejasse passar uma semana no hotel teria de desembolsar $£ 42,00$. Não hóspedes também poderiam desfrutar do serviço de alimentação. Para estes clientes, o valor do café da manhã era de £2,00, do almoço £1,60 e do jantar $£ 2,60$. Em um momento em que britânicos se dirigiam para Lagos para supervisionar a abertura de novas ruas, a expansão da rede elétrica e a construção de uma via ferroviária projetada para se estender até a cidade de

execução de sangrias, extração de dentes e o tratamento de fraturas. CASTILLO, Lisa Earl. Mapping the nineteeth-century Brazilian returnee movement: Demographics, life stories and the question of slavery. Atlantic Studies, 13:1, 2016, p. 32. 
Kano, um estabelecimento que fornecia acomodações e refeições prontas constituía uma boa opção de negócio. ${ }^{449}$

Figura 7: Anúncio do Restaurante Da Rocha

\section{TIFE "RFSTAURANT DA ROCHA."}

This New. Restaverant, situate in Tinnbo Street, in the Premises known as

IROIN IIOUSE,

a house that has always been patronized by Her Majesty's Goverument, Mferchants, 'Trivilling Agents, Doctors and Lawyers and inswering all the jumoses of a

\section{RESTACRAN'T IOTEI,}

on account of its position, and the accommodation it uffords as well as its highly rentilated rooms, will opened on Monday the 1st November.

Bosrd and Lodging including Breakfast, Lunch, and Dinner, with tea or coffee in the morning

at $7 \mathrm{~s}$ 6d. per diem.

Ditto ditto ," 42.. per. weok.

Breakfast supplied," 2s. per head

Iunch ," 18 6d," ,

Dinner , , , 28 6d 29 ,

The aloce prices do not include wines or spirits of ainy kind.

Billiards, Bagatelle, Draughts, Chess and conveniences for other amusements supplied on the premises, and every possible arrangement provided for the accomolation and convenu-!nee of visitors.

Cigars Elarte, Will's Cigarcttes, Beer, and high class Wines, and provisions supplied on the premises at reasonable rates.

For further, particulars please apply to

$$
\text { :CANDIDO. DA ROCHA, }
$$

Lagros Oct. 15, 1897. Jroprictor

Fonte: The Lagos Weekly Record, 27 de novembro de 1897, World Newspaper Archive, African Newspapers, $1883-1898$.

${ }^{449}$ As publicações que divulgavam o restaurante Da Rocha se espalharam pelos exemplares do Lagos Weekly Record, de 16 de outubro de 1897 até dezembro de 1900. O primeiro anúncio do estabelecimento do brasileiro pode ser encontrado em: The Lagos Weekly Record, 16 outubro de 1897, World Newspaper Archive, African Newspapers, 1883 - 1888. 
No entanto, não eram somente os britânicos que contribuíam para o aumento da população da cidade. De acordo com uma contagem censitária compilada pelo Blue Book do ano de 1899, 32.508 pessoas viviam em Lagos. ${ }^{450}$ Esta concentração de habitantes estava, em parte, ligada a urbanização promovida pela administração colonial. Para muitos refugiados das guerras de Ekitiparapo e de ljaye, as operações urbanas executadas em Lagos representavam uma alternativa à subsistência. A abertura de postos de trabalho iniciada ainda na década de 1880, e continuada pelo governo de Gilbert Carter (1891-1897) e seus sucessores - H.E. McCallum (1897-1899) e William MacGregor (1899-1904) -, forneceu as condições de atração necessárias para a instalação destes indivíduos na cidade. Além da ampliação da infraestrutura urbana houve também o aumento no número de firmas europeias em Lagos. A "pacificação" do interior, promovida pelo governador Carter, facilitou o estabelecimento de novas companhias de comércio no porto lagosiano. Como parte deste processo, estas firmas enviavam para Lagos representantes comerciais europeus. Tais indivíduos desembarcavam na cidade com a incumbência de conseguir um barracão para a estocagem de mercadorias; acessar as zonas agrícolas situadas no interior e administrar as relações comerciais firmadas com produtores. Tais atribuições exigiam a permanência destes representantes em território lagosiano. ${ }^{451}$

Atento ao fato de que muitos dos europeus desembarcados no porto não dispunham, de imediato, de um imóvel de aluguel para se estabelecerem, Cândido da Rocha abriu seu restaurante-hotel. Os valores das diárias e das refeições cobradas em seu estabelecimento também sugerem o tipo de clientes que o Restaurante Da Rocha buscava atrair: indivíduos com recursos disponíveis, em geral, europeus. Isto porque os salários pagos para a maioria dos africanos que integravam o funcionalismo público em 1897 - mensageiros, carteiros e ocupantes de postos classificados como de $5^{\mathrm{a}}$ e $6^{\mathrm{a}}$ classes - estava

\footnotetext{
450 Blue Book, Colony of Lagos, 1899, p.69. Os dados apresentados pelo Blue Book, 1899, diferem das estimativas expostas por Sada e Adefolalu. Para estes autores, a população de Lagos na virada do século XIX para o XX chegava a 41.847 habitantes. SADA, P.O.; ADEFOLALU, A.A. Urbanization and Problems of Urban Development in ADERIBIGBE, A.B. (ed.) Lagos: The Development of an African City. Lagos: Longman, 1975, p.79.

${ }^{451}$ Sobre 0 esforço das companhias britânicas em estabelecer negócios diretamente com 0 interior, sugiro: COLE, Patrick D. Lagos Society in the Nineteenth Century in ADERIBIGBE, A.B. (ed.) Lagos: The Development of an African City. Lagos: Longman, 1975, p.48.
} 
entre $£ 18,00$ e $£ 24,00$ ao ano. Todavia, entre os europeus que trabalhavam na administração colonial o ganho anual era muito superior. Apenas a título de comparação, no ano de 1897, o secretário de governo de Lagos teve seu salário anual registrado em $£ 1.000,00$. Embora o valor fosse considerado elevado para a época, este não era o maior salário pago a um funcionário colonial. Neste mesmo ano, o chefe de justiça da cidade recebeu um salário anual no valor de $£ 1.200,00$ e o ocupante da posição mais elevada na hierarquia colonial da cidade, o governador Gilbert Carter, teve seus vencimentos fixados em $£ 2.500,00$ ao ano. Estes e outros cargos de melhor remuneração e status eram reservados aos britânicos. Para os africanos cuja escolarização havia Ihes possibilitado alguma ascensão no funcionalismo colonial, restavam postos intermediários como, por exemplo, o de chefe de registro, ocupado por John A. Otonba Payne, com salário anual de $£ 200,00{ }^{452}$

Quando cotejamos estas informações aos valores cobrados pelo Restaurante Da Rocha podemos perceber com maior clareza quem eram os frequentadores deste estabelecimento. Além disto, podemos comparar os preços praticados por Cândido da Rocha com algumas mercadorias de consumo regular da população. Uma delas é a mandioca. Conforme um levantamento realizado por Sawada, na passagem do século XIX para o XX, cinco quilos de mandioca custavam cerca de seis pence (ou seis centavos de libra). Isto significa que, ao invés de pagar $£ 1,60$ por um almoço no estabelecimento Da Rocha - a refeição mais barata oferecida - um trabalhador poderia comprar mais de vinte e seis quilos de mandioca, ou ainda cerca de dezessete libras de carne de carneiro $(8,63 \mathrm{~kg})$. Por sua vez, ao compararmos o preço de artigos alimentícios ao da hospedagem, a diferença de valores se torna ainda mais evidente. Uma diária no estabelecimento exigia o desembolso de $£ 7,60$, o que representava cerca de 108 libras (ou 49,24 kg) de carne suína. $^{453}$

\footnotetext{
${ }^{452}$ Este relatório dos ganhos anuais do funcionalismo colonial pode ser lido em: Blue Book, Colony of Lagos, 1897, Civil Establishment, pp.40-51.

${ }_{453}$ De acordo com Sawada, na virada da década de 1880 para 1890 , o valor médio cobrado por um quilo de mandioca era de 6 pences; a carne de carneiro valia 9 pences a libra e a carne suína, 7 pences/libra. SAWADA, Nozomi. Op.cit. 2011, pp.81-82.
} 
O vigor dos negócios de Rocha durou cerca de uma década. Em 1907, uma carta assinada pelo próprio Cândido da Rocha protestava contra a desapropriação de seu imóvel pelo governo colonial. Segundo o documento, uma petição informava que seu estabelecimento atenderia aos interesses públicos e, para isto, seria transformado em residência de oficiais britânicos. Embora as fontes não forneçam dados acerca do desfecho desta situação, considero o episódio emblemático de um conjunto de mudanças iniciadas pela administração britânica em Lagos no final do século XIX e aprofundadas nos primeiros anos do $\mathrm{XX}{ }^{454}$

Nas duas últimas décadas do século XIX, os anúncios publicados em periódicos que circulavam em Lagos conferiam visibilidade às novas mercadorias e negócios. Entre os comerciantes brasileiros, o momento era de diminuição no volume de artigos vindos do Brasil e de aumento na quantidade de itens provenientes da Europa, em especial da Grã-Bretanha. Além deste aspecto, as facilidades de acesso direto aos produtores situados no interior suprimiu a necessidade da atuação de intermediários, até então responsáveis por promover o fluxo de mercadorias para a costa. Uma das saídas encontradas por alguns dos comerciantes citados neste capítulo foi a aposta no comércio varejista de bens industrializados. A oferta de serviços especializados, orientados a atender às demandas de consumidores europeus, também se constituiu como uma reação à nova configuração comercial. Em um contexto em que as relações comerciais na colônia e protetorado de Lagos se reconfiguravam em função de um processo colonizador que combinava 0 controle político com a penetração de companhias privadas, os jornais se tornaram relevantes fontes de informação. Nos periódicos analisados podemos perceber como a população brasileira fez uso destes veículos de comunicação para conferir visibilidade a determinadas formas de expressão exercidas em acontecimentos sociais.

454 The Lagos Standard, 11 de dezembro de 1907, World Newspaper Archive, African Newspapers, $1883-1888$. 


\title{
5.2. A participação dos brasileiros na vida pública de
}

Lagos

\begin{abstract}
Na quarta-feira à noite a parte brasileira da comunidade realizou uma procissão composta por homens e mulheres, as últimas vestidas de branco com uma faixa azul atravessada no ombro, e todos que carregavam lanternas seguiram até a Casa do Governo, depois de percorrer a cidade a procissão foi dissolvida. ${ }^{455}$
\end{abstract}

Nos anos de 1880 diversos títulos de periódicos começaram a circular pela cidade de Lagos. De acordo com um artigo escrito por Oso, até as primeiras décadas do século $X X$, os jornais eram administrados pelos seus proprietários que, na maioria das vezes, também escreviam textos, negociavam anúncios e, em alguns casos, até imprimiam exemplares. ${ }^{456} \mathrm{O}$ primeiro deste conjunto de jornais impressos em oficinas instaladas na cidade recebeu 0 nome de The Lagos Times and Gold Coast Colony Advertiser. Sua impressão e comercialização eram mantidas por um dos mais ricos comerciantes lagosianos da época, o saro Richard Beale Blaize. De acordo com Sawada, um editorial escrito pelo próprio Blaize anunciava que a missão de suas páginas eram "iluminar a melancólica noite gótica, que propaga as sombras da ignorância, e verter a torrente do conhecimento do mundo" sobre seus leitores. ${ }^{457}$

Embora os propósitos do The Lagos Times fossem bastante ambiciosos, o periódico teve pouco tempo para concretizá-los. Em 1883, o jornal suspendeu suas publicações. No entanto, cerca de sete anos mais tarde, em dezembro de 1890, a oficina de Blaize voltou a imprimir as páginas de seu periódico. A retomada do veículo durou menos de um ano, pois em outubro de 1891 o The Lagos Times and Gold Coast Colony Advertiser encerrou suas atividades em

\footnotetext{
455 "On Wednesday night the Brazilian section of the community inaugurated a procession composed of males and females, the latter being dressed in white with a band of blue ribbon across the shoulder, and all bearing lanterns marched to Government House the procession after marching through the town disbanded." Trecho do programa de comemorações do jubileu de diamante da rainha Victoria, denominado "The Brazilian procession". The Lagos Weekly Record, 26 de junho de 1897, World Newspaper Archive, African Newspapers, 1883 - 1888.

456 OSO, Lai. The Commercialization of the Nigerian Press: development and implications. Africa Media Review, vol.5, N.3, 1991. pp. $41-51$.

${ }^{457}$ SAWADA, Nozomi. Op.cit. 2011, p.35.
} 
definitivo. Ainda que sua circulação tenha sido limitada a alguns poucos anos, o jornal de Blaize contribuiu para a definição de um modelo de publicação que passou a ser utilizado por outros de sua época. Em linhas gerais, este modelo consistia em reservar a primeira e a última páginas para a colocação dos informes de anunciantes. ${ }^{458}$

Um dos periódicos que seguiu o padrão de organização iniciado pelo The Lagos Times and Gold Coat Colony Advertiser foi o The Lagos Observer. Fundado em 1882, por J. Balckall Benjamin, o Lagos Observer foi um dos primeiros jornais a ser produzido durante um período de tempo mais alargado e com raras interrupções. Suas edições tinham quatro páginas, periodicidade quinzenal e continuaram a ser impressas até o ano de 1890. Neste ano, o jornal foi fechado para ser reaberto em 1894. A partir daí, o The Lagos Observer adotou circulação semanal, até ser extinto três anos mais tarde, em 1897. Impresso em oficina própria, localizada na rua Bishop, o periódico publicava artigos enviados por correspondentes de Londres, Manchester e Liverpool. Além disto, mantinha outros sete correspondentes espalhados por localidades como Cidade do Cabo, Elmina, Acra, Addah, Quitta, Fernando Pó e Porto Novo. Suas páginas eram preenchidas por editoriais, cartas, artigos de correspondentes e três colunas que tratavam de aspectos cotidianos da sociedade de Lagos: By the Way, Tit Bits e Local News. A primeira era escrita sempre em primeira pessoa e consistia em um apanhado de breves notas acerca de acontecimentos ocorridos na cidade. A segunda, Tit Bits, tecia críticas a comportamentos e a indivíduos. Por esta razão, preservava um aparente sigilo ao citar apenas as iniciais ou os primeiros nomes daqueles que eram criticados. A coluna Local News trazia notas de falecimento, chegadas e partidas de embarcações e de indivíduos considerados importantes, além de anúncios de espetáculos teatrais, dentre os quais estavam os organizados pela Brazilian Dramatic Company. ${ }^{459}$

\footnotetext{
${ }^{458}$ Cf. Ibid, pp.33-36. Cito o jornal The Lagos Times and Gold Coast Colony Advertiser em razão de sua importância como o primeiro periódico a ser publicado em um momento de retomada da imprensa lagosiana na década de 1880. No entanto, a publicação de Blaize não integra a base de dados World Newspaper Archive, African Newspapers. Por este motivo este título não é parte do conjunto das fontes selecionadas para esta pesquisa.

${ }^{459}$ Cf. SAWADA, Nozomi. Op.cit., 2011, pp.38-40.
} 
Contemporâneo aos dois títulos citados, havia também o Lagos Weekly Record, fundado em janeiro de 1891, pelo pan-africanista de origem liberiana, John Payne Jackson. Este periódico circulou durante cerca de quarenta anos, de 1891 a 1930, ao longo dos quais não apenas manteve sua periodicidade semanal, como também passou a ser comercializado fora de Lagos, em função do transporte proporcionado pelas estradas de ferro construídas pelo governo colonial britânico. Impresso em oficina própria, suas páginas eram divididas em seções de artigos enviados por correspondentes da costa ocidental africana e de Londres, cartas escritas por leitores, publicidade de mercadorias e serviços, além de notícias em geral. Um número significativo de anúncios ocupava a primeira e a última páginas de cada edição. Além disto, era relativamente comum a publicação de matérias de outros jornais acerca das colônias britânicas da África ocidental. A partir da década de 1890, o veículo passou a receber um subsídio anual do governo. O aporte de recursos ocasionou uma significativa ampliação no número de páginas impressas. Afinal, em julho de 1895, o Lagos Weekly Record dobrou seu número de páginas, passando de quatro para oito. A aproximação com o governo colonial também abrandou um pouco as considerações do periódico acerca da política colonial em Lagos. No entanto, o Lagos Weekly Record manteve uma postura bastante crítica em relação à atuação política de Frederick Lugard que, por mais de uma década, atuou na cidade como comissário e governador colonial. ${ }^{460}$

Na segunda metade do século XIX, os leitores de Lagos contavam com outros periódicos para além dos tratados nesta pesquisa. Segundo Sawada, os dois primeiros jornais lagosianos foram lançados no final da década de 1850 e início dos anos de 1860. ${ }^{461} \mathrm{Em} \mathrm{1859}$, uma publicação bilíngue, produzida e mantida pela CMS, passou a circular na cidade sob o título de Iwe Irohin Fun Awon ara Egba ati Yoruba. Apenas quatro anos mais tarde, em junho 1863, foi lançado o The Anglo-African, de propriedade de Robert Campbell. ${ }^{462}$ Embora a

\footnotetext{
${ }^{460}$ Entre 1900 e 1906, Sir Frederick Lugard ocupou o cargo de Alto Comissário do Protetorado da Nigéria do Norte. Mais tarde, de 1912 a 1913, assumiu o governo das Colônias da Nigéria do Sul e do Norte e, durante o período de 1914 e 1919, atuou como Governador Geral da Colônia da Nigéria. Cf. SAWADA, Nozomi. Op.cit., 2011, p.51.

${ }^{461}$ SAWADA, Nozomi. Op.cit., 2011, pp.31-32.

462 Relembro que no primeiro capítulo desta tese trato da viagem realizada por Robert Campbell e Martin Delany. Entre os anos de 1859 e 1860, ambos integravam a expedição promovida com os recursos da organização Niger Valley Exploring Party.
} 
distribuição de ambos os veículos tenha se estendido por menos de uma década - o último exemplar do Iwe Irohin foi impresso em 1867 e o do AngloAfrican, em 1865 - estes dois jornais guardam mérito de terem sido pioneiros na imprensa lagosiana. O fechamento destes periódicos e a ausência de outros títulos que os substituíssem levaram a um lapso na produção de jornais lagosianos ao longo de toda a década de 1870. A partir dos anos de 1880, é possível perceber uma retomada da imprensa em Lagos. Neste momento, os jornais The Eagle and Lagos Critic (1883), The Lagos Standard (déc. 1890) e The Mirror (1887) foram acrescentados às publicações já existentes. ${ }^{463}$

Embora reconheça a importância destes três últimos títulos, esta pesquisa trabalha somente com os periódicos The Lagos Observer, Lagos Weekly Record e com o jornal oficial produzido pelo governo colonial britânico, a Government Gazette. Isto porque os dois primeiros títulos são os únicos que coincidem com o recorte temporal definido (1840 - 1900) e cujos exemplares estão disponíveis para consulta na base de dados World Newspaper Archive, seção African Collection. O terceiro periódico - a Government Gazette apresenta um conteúdo distinto dos demais títulos. Como veremos adiante, o jornal publicado pela administração colonial cumpria funções informativas e burocráticas. Era por meio dele que o governo colonial divulgava novas legislações, alterava cargos e salários dos quadros do funcionalismo público, anunciava concursos escolares, entre outras ações relacionadas à administração de Lagos.

Nos anos de 1880 e 1890, era relativamente comum os periódicos de Lagos participarem aspectos da vida pessoal de alguns de seus citadinos. Não raras vezes era possível encontrar anúncios de casamento, cujos noivos e convidados integravam a elite enriquecida lagosiana. A leitura dos jornais The Lagos Observer e Lagos Weekly Record mostrou que a maior parte destas notas se referiam ao casamento de saros e brasileiros, que estavam ligados ao comércio internacional, ao funcionalismo público ou às cinco instituições

\footnotetext{
${ }^{463}$ Segundo Sawada, nas primeiras décadas do século XX, os leitores da colônia e protetorado de Lagos passaram a contar com diversos outros títulos, entre os quais: The Nigerian Chronicle (1908); Nigeria Pioneer (1914); Nigerian Times (1910); Times of Nigeria (1917); Nigerian Daily Times (1926); Eko Akete (1922); Eleti-Ofe (1923); The Yoruba News (1924); Iwe Irohin Osase (1925); Eko Igbehin (1926) e Akede Eko (1928). SAWADA, Nozomi. Op.cit., 2011, pp. 49 e 62.
} 
religiosas presentes na cidade: a Church Missionary Society (CMS), a Wesleyan Methodist Society, a Société des Missions Africaines (SMA), a missão Batista e a United Native African. ${ }^{464}$ É o caso da união celebrada, em 1895, entre o reverendo James Johnson e Sabina Susanna Leigh. Conforme o Blue Book referente ao ano de 1895, Johnson atuava na igreja anglicana de Saint Paul e recebia, por ano, o salário de $£ 150$. O valor era o segundo maior pago pela CMS a um reverendo. Apenas a remuneração recebida pelo religioso F.G. Toase (£250) superava a de James Johnson. A família Leigh também aparece nos relatórios dos Blue Books. Neste mesmo ano de 1895, sete de seus membros foram relacionados como funcionários civis do governo colonial. Recebendo ordenados entre $£ 40$ e $£ 95$, os integrantes da família Leigh ocupavam cargos que variavam de aprendiz de segunda classe na tipografia oficial da colônia até zelador dos armazéns da Coroa britânica existentes na cidade. ${ }^{465}$

Estas informações revelam que o casamento de James Johnson e Sabina Leigh atou indivíduos e famílias que ocupavam espaços sociais e econômicos semelhantes. Uma longa nota publicada pelo Lagos Weekly Record descrevia os acontecimentos que marcaram as comemorações em torno dos noivos. O texto informava que cerca de duzentos convidados compareceram à festa de bodas. Entre os numerosos convivas estavam oito damas de honra, uma das quais era a brasileira Angélica de Souza. O periódico também se referia à fartura de alimentos e de bebidas experimentada pelos convidados. De acordo com o jornal, tamanha abundância alimentar foi de pronto retribuída por "numerosos e custosos" presentes oferecidos aos noivos. Os ritos e comemorações em torno do casamento, que havia se iniciado pela manhã, só alcançaram termo muito tempo depois do cair da noite. $\mathrm{E}$, como o jornal ressaltou, este foi o momento em que seis convivas brasileiros

\footnotetext{
${ }^{464}$ No ano de 1895, o relatório eclesiástico publicado pelo Blue Book citou a igreja anglicana como a instituição com o maior número de igrejas sob seu comando: oito. Em seguida estavam quatro missões metodistas, três igrejas pertencentes à United Native African, duas missões católicas e um estabelecimento batista. Blue Book, Colony of Lagos, 1895, pp.60-61.

${ }^{465}$ Blue Book, Colony of Lagos, 1895, pp.33-41.
} 
- Sr. e Sra. Campos, Sr. e Sra. Gomez e Sr. e Sra Souza - se retiraram da festa. ${ }^{466}$

A longa descrição a respeito da união de James Johnson e Sabina Leigh revela alguns aspectos acerca do papel exercido pelos jornais no reforço de posições sociais ocupadas por determinados indivíduos. $\mathrm{O}$ artigo publicado neste exemplar deixa claro que a lista de convidados não correspondia à totalidade dos indivíduos presentes na festa, mas apenas àqueles cuja "presença foi sentida" durante as comemorações. Ao relacionar os nomes de cada uma das oito madrinhas da noiva e enumerar quais eram os convidados cuja participação era digna de nota, o Lagos Weekly Record conferia visibilidade a uma parcela da população considerada parte de uma elite escolarizada e financeiramente privilegiada. ${ }^{467} \mathrm{~A}$ exposição social por meio destes veículos significava também um aumento de prestígio e um reforço dos laços de reciprocidade capazes de atar indivíduos a um mesmo grupo. Se, entre os comerciantes, esta exposição poderia se converter na ampliação no volume de negócios, entre a grande variedade de categorias existentes no funcionalismo colonial, uma menção em um periódico local poderia resultar em uma mudança de posição dentro da hierarquia burocrática lagosiana.

A leitura das notas de casamento impressas pelo Lagos Weekly Record revela que os saros não eram os únicos a terem suas cerimônias divulgadas neste periódico. Apenas cinco meses depois das bodas que uniram as famílias Johnson e Leigh, este mesmo jornal publicou um pequeno texto em que dava a conhecer alguns detalhes da união de Anna Laurencio e João Prisco. Celebrada na maior igreja católica de Lagos, a Holy Cross, a união foi classificada como uma cerimônia "radiante". Logo após o ritual religioso os convidados se reuniram na residência do pai de Anna Laurencio, localizada na rua Ajele, no bairro brasileiro existente na cidade. ${ }^{468}$ No terreiro deste imóvel uma farta refeição aguardava a chegada dos convivas que brindaram à saúde

466 The Lagos Weekly Record, 27 de abril de 1895, World Newspaper Archive, African Newspapers, $1883-1888$.

${ }^{467}$ The Lagos Weekly Record, 27 de abril de 1895, World Newspaper Archive, African Newspapers, $1883-1888$.

468 Para um melhor entendimento acerca de como estavam arranjados os diversos setores territoriais da ilha de Lagos, sugiro: KOPYTOFF, Jean Herskovits. A Preface to Modern Nigeria. The "Sierra Leonians" in Yoruba, 1830-1890. Wisconsin: The University of Wisconsin Press, 1965, p.90. 
dos recém-casados. Embora diversas saudações tenham sido feitas, o periódico mencionou apenas duas delas. A primeira foi levantada por Festus M. Silva, cuja "habitual felicidade" cativou a todos os presentes. A segunda saudação foi feita por João Angelo Campos, um dos comerciantes brasileiros mais ricos da cidade. ${ }^{469}$

Ao buscar compreender os motivos que levaram o jornal a selecionar o brinde levantado por estes dois convidados em específico, percebi que a escolha destes indivíduos talvez obedecesse a critérios capazes de diferenciálos entre si. Deste modo, enquanto João Angelo Campos aparece citado em outras edições deste mesmo jornal em razão de sua participação na Câmara de Comércio lagosiana, não encontrei nenhum registro capaz de informar quem era o convidado Festus da Silva. A nota de bodas informa pouco além do fato de Silva ser uma pessoa querida entre os convivas. Afinal, com seu "habitual" entusiasmo, o brinde de Silva foi bastante aplaudido. Este aspecto indicaria que um dos critérios utilizados pelo Lagos Weekly Record para citar a participação de alguns poucos convidados neste casamento foi o do prestígio social. No entanto, diferente de Silva, a menção à saudação proferida por Campos não decorreria apenas do reconhecimento social dirigido ao comerciante. Como membro da Câmara Comercial da cidade e fiador dos armazéns ocupados por outros mercadores brasileiros, Campos combinava seu prestígio social e um status econômico privilegiado. Considerando que a leitura destes jornais extrapolava a comunidade alfabetizada, uma vez que seu conteúdo era retransmitido oralmente e um mesmo exemplar poderia ser lido por outras pessoas, os periódicos de Lagos se configuraram como veículos de exposição das realizações, ideias e acontecimentos ligados à vida de uma parte dos cidadãos da cidade.

Dentre as realizações que costumavam ganhar as páginas dos periódicos estavam aquelas promovidas por grupos associacionistas. Nas duas últimas décadas do século XIX diversos tipos de associações floresceram em Lagos. Estas sociedades se constituíam em torno de interesses comuns e

\footnotetext{
469 The Lagos Weekly Record, 28 de setembro de 1895, World Newspaper Archive, African Newspapers, $1883-1888$.
} 
congregavam indivíduos a partir de critérios variáveis. ${ }^{470}$ Uma das formas associativas que contava com membros brasileiros eram os grupos teatrais. Em geral, os participantes se reuniam com regularidade para recitar poemas, expor canções autorais ou tocar instrumentos musicais, na sua maior parte, de origem europeia. Na maioria das vezes estes encontros eram limitados aos integrantes da sociedade. No entanto, havia momentos em que o grupo realizava apresentações públicas, quando familiares, amigos e interessados eram convidados a assistir as produções ensaiadas pelo grupo. Nestas ocasiões as associações dramáticas ganhavam as páginas dos jornais. Algumas eram veiculadas na forma de anúncios, outras como artigos, fazendo referência a eventos já realizados.

Em sete de março de 1882, o jornal Lagos Observer anunciou a performance de um grupo denominado Brazilian Dramatic Company. A exibição ocorreria em Lagos, no sofisticado Phoenix Hall. Para esta ocasião o grupo de teatro preparava a apresentação de seu repertório. A montagem foi bem recebida, pois pouco tempo depois, anúncios de novas apresentações do grupo voltaram a ser publicados no mesmo jornal. ${ }^{471} \mathrm{Em}$ maio do mesmo ano, a companhia divulgou a estreia de uma nova exibição, desta vez elaborada em homenagem ao aniversário da rainha Victoria. Segundo a nota publicada pelo Lagos Observer, o grupo planejava desempenhar pequenas apresentações de humor, drama e canções, além de audições de violino e violão. A montagem era considerada especial e, em função disto, contava com o patrocínio do cônsul alemão em Lagos, Heinrich Bey. Mesmo subsidiada pelo consulado alemão, o público deveria desembolsar o valor de duas a quatro libras para assistir a Brazilian Dramatic Company. Estes ingressos eram vendidos nos estabelecimentos de três comerciantes brasileiros: J.J. da Costa, João Angelo Campos e L.G. Barboza. Durante todo o mês de maio, os anúncios da companhia teatral brasileira se repetiram nas edições quinzenais do periódico. Em 1 de junho, um pequeno texto elogiava a montagem, ressaltava as contribuições oferecidas pelo cônsul alemão e dava notícias do sucesso da

\footnotetext{
${ }^{470}$ No terceiro capítulo de sua tese, Nozomi Sawada trata das diversas associações existentes na cidade de Lagos no século XIX. SAWADA, Nozomi. Op.cit., 2011, pp.92 - 125.

471 The Lagos Observer, 7 de março de 1882, World Newspaper Archive, African Newspapers, $1883-1888$.
} 
performance, cuja quantidade de interessados levou a uma apresentação extra. $^{472}$

Figura 8: Comunicado de montagem de apresentação, The Brazilian Dramatic Company

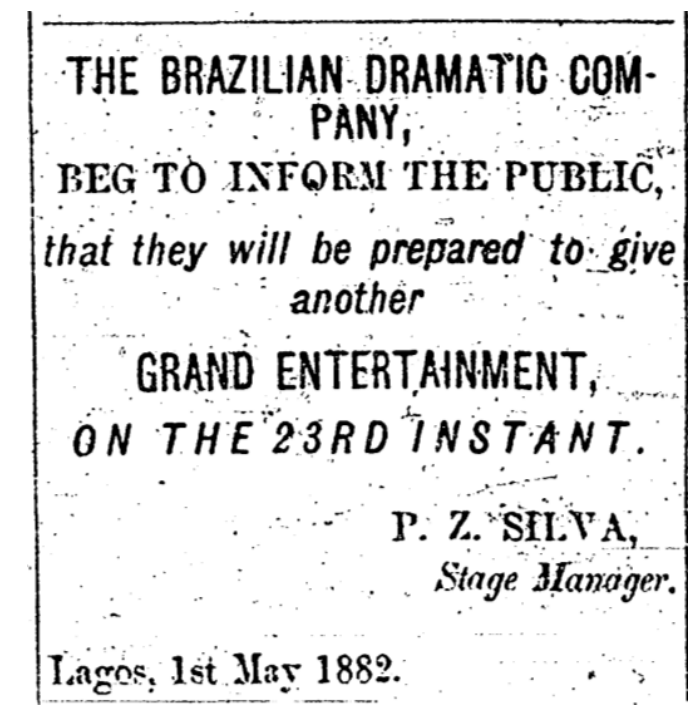

Fonte: The Lagos Observer, 4 de maio de 1882, World Newspaper Archive, African Newspapers, $1883-1898$.

Os breves registros das apresentações da Brazilian Dramatic Company nos jornais não fornecem detalhes acerca de como eram realizados os preparativos para estas exibições, quais os nomes dos brasileiros integrantes do grupo ou quem eram os expectadores destas audições públicas. ${ }^{473} \mathrm{~A}$ despeito de tais limitações, podemos considerar as montagens oferecidas pela companhia como resultado de um trabalho anterior de elaboração e/ou seleção textual, ensaio, confecção de figurino e construção de cenários. Atividades como estas exigiam horas de dedicação e encontros regulares. Eram nestes momentos que os vínculos que atavam os integrantes do grupo se reconfiguravam, recuperavam vigor ou se esgarçavam por completo. Quando o

\footnotetext{
472 The Lagos Observer, 1 e 4 de maio de 1882; 1 de junho de 1882, World Newspaper Archive, African Newspapers, $1883-1888$.

${ }^{473}$ Cunha fornece diversas informações acerca dos grupos de brasileiros existentes em Lagos no século XIX. De acordo com a autora, a Brazilian Dramatic Company se somava à associação Flor do Dia e a Aurora Relief Society. Embora cada associação apresentasse propósitos e cumprisse papéis diferentes, todas elas constituem exemplos de como seus integrantes construíram espaços para o exercício de aspectos da identidade brasileira em Lagos. CUNHA, Manuela Carneiro da. Op. cit., 2012, pp.176-182.
} 
espetáculo teatral chegava ao público eram também estas as relações que subiam ao palco. Como uma metáfora da própria comunidade brasileira de Lagos, as sociedades teatrais e literárias se configuraram como espaços de discussão de ideias, participação artística e atualização dos diferentes sentidos de ser brasileiro neste momento.

Um dos principais componentes desta identidade múltipla e cambiante era a língua portuguesa. No ano de 1882, quando a Brazilian Dramatic Company homenageou a rainha Victoria, o idioma empregado na peça não poderia ser outro senão o inglês. Entretanto, em momentos históricos diferentes, outras associações assumiram o português como um dos emblemas do grupo. Como um sistema simbólico capaz de exprimir e orientar a visão de mundo de seus falantes, os indivíduos de Lagos que dominavam a língua portuguesa expunham seu repertório de canções, versos e histórias em apresentações promovidas por associações literárias. Muitas destas sociedades estavam ligadas a escolas missionárias ou a igrejas. Era comum integrantes destes grupos frequentarem estas instituições que, via de regra, cediam seus espaços para a realização de encontros.

Era o caso da associação The Orphean Club Entertainment, constituída por saros e brasileiros, cujas reuniões aconteciam na escola da CMS situada na rua Breadfruit. Segundo o jornal Lagos Weekly Record, em outubro de 1892, os integrantes desta sociedade e alguns convidados participaram de um sarau que contou com a ilustre presença do chefe de justiça J. Smalman Smith. O encontro consistiu na apresentação de uma sequência de canções entoadas por seus membros e acompanhadas por uma pequena orquestra. Dois brasileiros integravam a exibição. Um deles era o comerciante João Angelo Campos. O segundo membro era um indivíduo conhecido pelo nome de H.J.Carro. Em sua apresentação Campos cantou uma canção em inglês, "The Sweet Voice". As páginas do jornal não oferecem nenhuma informação complementar acerca da receptividade do público à sua exibição. No entanto, pouco antes, o brasileiro Carro, sobre o qual pouco sabemos além da descrição fornecida pelo jornal, havia arrancado aplausos entusiasmados da 
plateia ao entoar a canção em língua portuguesa "Minha filha não casa bem." 474

A euforia com que a canção de Carro foi recebida pelos convidados sugere a presença de outros brasileiros entre os espectadores. Todavia, a leitura dos artigos publicados pela imprensa de Lagos revela que acontecimentos como este não eram comuns. Encontrei raras referências a exibições em língua portuguesa realizadas em situações em que havia predominância de saros ou de funcionários de altos cargos da administração colonial. De fato, em 1892, a língua portuguesa enfrentava problemas para se perpetuar entre os brasileiros. Isto porque, dez anos antes, em 1882, uma nova legislação colonial determinava que o ensino nas escolas lagosianas deveria ser em língua inglesa. A Educational Ordinance dispunha acerca de diversos aspectos do ensino escolar existente em Lagos. Seus vinte e nove artigos determinavam, além da obrigatoriedade do ensino ser realizado em inglês, que os professores fossem submetidos a exames de verificação de conhecimento promovidos pelo Conselho Educacional Local. Além disto, a administração colonial forneceria um subsídio anual para a manutenção das escolas e, em troca, regulava a educação oferecida por escolas técnicas. ${ }^{475}$ Para alguns, o domínio do idioma do colonizador ampliava as possibilidades de inserção e de posterior ascensão no funcionalismo público. Este aspecto aprofundava os limites impostos pelo governo colonial à transmissão da língua portuguesa que, embora proibida nas escolas, continuou a ser ensinada e praticada em âmbito doméstico. Neste sentido, a permanência de falantes do português ao longo do século XIX e início do XX é explicada pelo exercício cotidiano deste importante componente da identidade brasileira.

Dentro das escolas católicas havia situações em que o português era permitido. Em dezembro de 1895, para dar as boas vindas a um bispo de nome Retino e em comemoração às festividades de Natal, a Catholic Youth Men Association e a escola católica para meninas do Convento St. Mary

474 The Lagos Weekly Record, 22 de maio de 1892, World Newspaper Archive, African Newspapers, 1883 - 1888.

475 A publicação desta legislação pelo jornal The Lagos Observer foi acompanhada por um editorial que tecia críticas a alguns dos aspectos da nova lei. The Lagos Observer, 20 de julho de 1882, World Newspaper Archive, African Newspapers, 1883 - 1888. 
promoveram uma exibição que combinava audições de piano e a apresentação de canções. A maioria das canções escolhidas para a ocasião foi entoada na língua do colonizador. Contudo, uma delas arrancou aplausos da plateia a ponto de ser repetida por uma segunda vez. A canção era em língua portuguesa e se chamava "Meus Senhores e Senhoras". De acordo com o artigo publicado pelo Lagos Weekly Record, a música foi apresentada pelo cantor Paulo Valero e pelas pianistas Canuta Campos e Januária da Costa. ${ }^{476}$ Cerca de três anos mais tarde, em outubro de 1898, a Catholic Youth Men Association ganhou novamente espaço neste mesmo jornal. Desta vez a canção em língua portuguesa selecionada para compor um repertório formado quase em exclusivo por exibições em inglês, chamava-se "O que é feijouada". Segundo o periódico, a bem humorada composição provocou calorosas manifestações de apreço por parte do público. ${ }^{477}$ Embora o idioma do colonizador predominasse nestas apresentações, quando a música cantada em português tomava o salão os espectadores reagiam com entusiasmo.

O êxito das poucas canções apresentadas em português sugere que, na década de 1890, apesar do idioma do colonizador ser bastante difundido entre os membros destas sociedades literárias, a língua portuguesa persistia. Ao atuar como um sistema simbólico capaz de acionar subjetividades em torno de um pertencimento comum, este idioma encontrou formas para continuar existindo como parte da identidade dos brasileiros de Lagos. Neste sentido, o português era exercitado pública e coletivamente nas reuniões promovidas por associações que contavam com integrantes brasileiros. Estas eram ocasiões de seleção e atualização dos signos de identificação do grupo. Um dos indícios da existência de falantes e leitores do idioma neste período é fornecido pelo Lagos Weekly Record. Em 29 de outubro de 1898, uma nota redigida em língua portuguesa informava que, em 21 de abril de 1900, o Brasil comemoraria quatrocentos anos de descobrimento:

\footnotetext{
476 The Lagos Weekly Record, 14 de dezembro de 1895, World Newspaper Archive, African Newspapers, 1883 - 1888.

477 The Lagos Weekly Record, 1 de outubro de 1895, World Newspaper Archive, African Newspapers, $1883-1888$.
} 
Tendo a Brazil de solemnizar pela premeira vez o quarte centenário do seu descobrimento honra-se em manifestar dos seus filhos que entendam concorrer para o realce de tão sumptuoso acontecimento. As festas terão lugar às 21 de abril de 1900, anniversário da descoberta por Pedro Alvares Cabral. E a Bahia a primogeirita da Cabral troji a Athenaf [?] brazileira com jubilo se ergua unisona Figindo o auxilio dos seus filhos. Porto Novo, 20 de septembro de 1898. [sic] ${ }^{478}$

Apesar de publicado em um periódico lagosiano, o pequeno texto foi escrito originalmente em Porto Novo. Uma vez no The Lagos Weekly Record a nota foi impressa em uma coluna denominada Epitome of News. Esta seção apresentava textos quase telegráficos referentes a acontecimentos da vida cotidiana de Lagos e eventos ocorridos em cidades vizinhas ou em lugares mais distantes, como o Brasil. Eram comuns anúncios de noivado e de casamento, notificações de partidas e de chegadas de passageiros e embarcações, além de informativos acerca de encontros promovidos por associações recreativas. Por outro lado, eram raras as notas longas, ainda mais quando estas eram redigidas em um idioma que não o inglês. No período que compreende esta pesquisa (1840-1900) são raros os exemplos de textos escritos em outras línguas. Entre os jornais recolhidos, encontrei apenas este pequeno texto em português, uma carta escrita em francês e três notas publicados em alemão. ${ }^{479} \mathrm{~A}$ escassez de registros não exclui o mérito da nota redigida em Porto Novo. Sua existência sugere que, embora o ensino escolar do idioma do colonizador fosse obrigatório, o português continuou a ser praticado até o final do século XIX em razão de sua importância como componente identitário dos brasileiros.

Como um dos emblemas de pertencimento à comunidade brasileira existente em Lagos, a língua portuguesa se perpetuou graças à prática cotidiana de seus falantes e de seu exercício em momentos de festividade. Como vimos, algumas destas comemorações eram organizadas por

\footnotetext{
478 The Lagos Weekly Record, 29 de outubro de 1898, World Newspaper Archive, African Newspapers, 1883 - 1888.

${ }^{479}$ A carta redigida em francês pode ser lida em: The Lagos Observer, 6 de abril de 1882, World Newspaper Archive, African Newspapers, 1883 - 1888. Os anúncios publicados em alemão estão nos exemplares: The Lagos Weekly Record, 17, 24 e 31 de março de 1894, World Newspaper Archive, African Newspapers, 1883 - 1888.
} 
sociedades recreativas, dramáticas e literárias, formadas por brasileiros e, em casos específicos, por brasileiros e saros. ${ }^{480}$ Além das exibições promovidas por estes grupos, havia ainda circunstâncias específicas em que as identidades brasileiras eram colocadas em ação. Uma destas ocasiões foi o ciclo de celebrações em torno do jubileu de ouro da rainha Victoria, realizado em junho de 1887.

Nos meses anteriores às cerimônias em honra à monarca britânica, os jornais de Lagos publicaram uma série de artigos a respeito dos preparativos para a festa. Estes anúncios davam conta da participação da parcela alfabetizada e enriquecida da sociedade lagosiana. Três comissões eram responsáveis por organizar os arranjos do jubileu: o Senior Jubilee Committee, - Junior Jubilee Committee e o Women's Jubilee Society. ${ }^{481}$ Tomar parte destes grupos era também uma oportunidade de demonstrar respeitabilidade e status social privilegiado.

Um programa de festividades publicado no jornal Lagos Observer informava quais seriam os dias e horários das comemorações planejadas para a ocasião. De acordo este documento, as solenidades se iniciariam no dia 21 de junho, às seis horas da manhã, com o badalar dos sinos de todas as igrejas da cidade. ${ }^{482} \mathrm{O}$ toque dos sinos anunciaria o princípio de um conjunto de solenidades que obedeceriam a um rígido protocolo. A partir deste momento, os festejos se estenderiam por mais cinco dias. Às oito horas da manhã, igrejas anglicanas, metodistas, católicas e batistas oficiariam cerimônias pela cidade. Depois da conclusão dos ritos religiosos, uma procissão formada por coristas e escolares se reuniria na praça Tinubu, ponto inicial de um percurso planejado para passar pelas principais vias de Lagos. Portando bandeiras, estandartes, instrumentos musicais e carregando no peito uma medalha comemorativa do jubileu - a Jubilee Medal - os participantes caminhariam até a casa do governador Alfred Moloney. Em frente à residência oficial britânica, um coral entoaria o hino da Grã-Bretanha. Em seguida, a procissão partiria em direção

\footnotetext{
480 Refiro-me à Catholic Youth Men Association, constituída por saros e brasileiros economicamente privilegiados.

${ }^{481}$ Cf. SAWADA, Nozomi. Op.cit., 2011, pp.237-238.

482 O cronograma de celebrações do jubileu de ouro foi intitulado "The queen's Jubilee celebration, a programme" e se encontra publicado em: The Lagos Observer, 18 de junho de 1887, World Newspaper Archive, African Newspapers, 1883 - 1888.
} 
ao local reservado à construção do Glover Memorial Hall. Na ocasião, o governador de Lagos inauguraria a pedra fundamental, marcando o princípio das obras de construção do edifício. O projeto do Glover Memorial Hall consistia em um conjunto de salas de reuniões e um auditório planejados para abrigar conferências, palestras e espetáculos promovidos por associações políticas, literárias e dramáticas. Sua construção era uma resposta às objeções de algumas igrejas ao uso de seu espaço para a prática de atividades seculares. Batizado em homenagem ao governador de Lagos, John Hawley Glover (falecido em 1885), cujo período de atuação na administração colonial se estendeu de 1863 até 1872, a construção do Glover Memorial Hall demorou mais de dez anos para ser concluída, em 1899. ${ }^{483}$

Figura 9: Igreja Católica de Lagos, a Holy Cross (sem data)

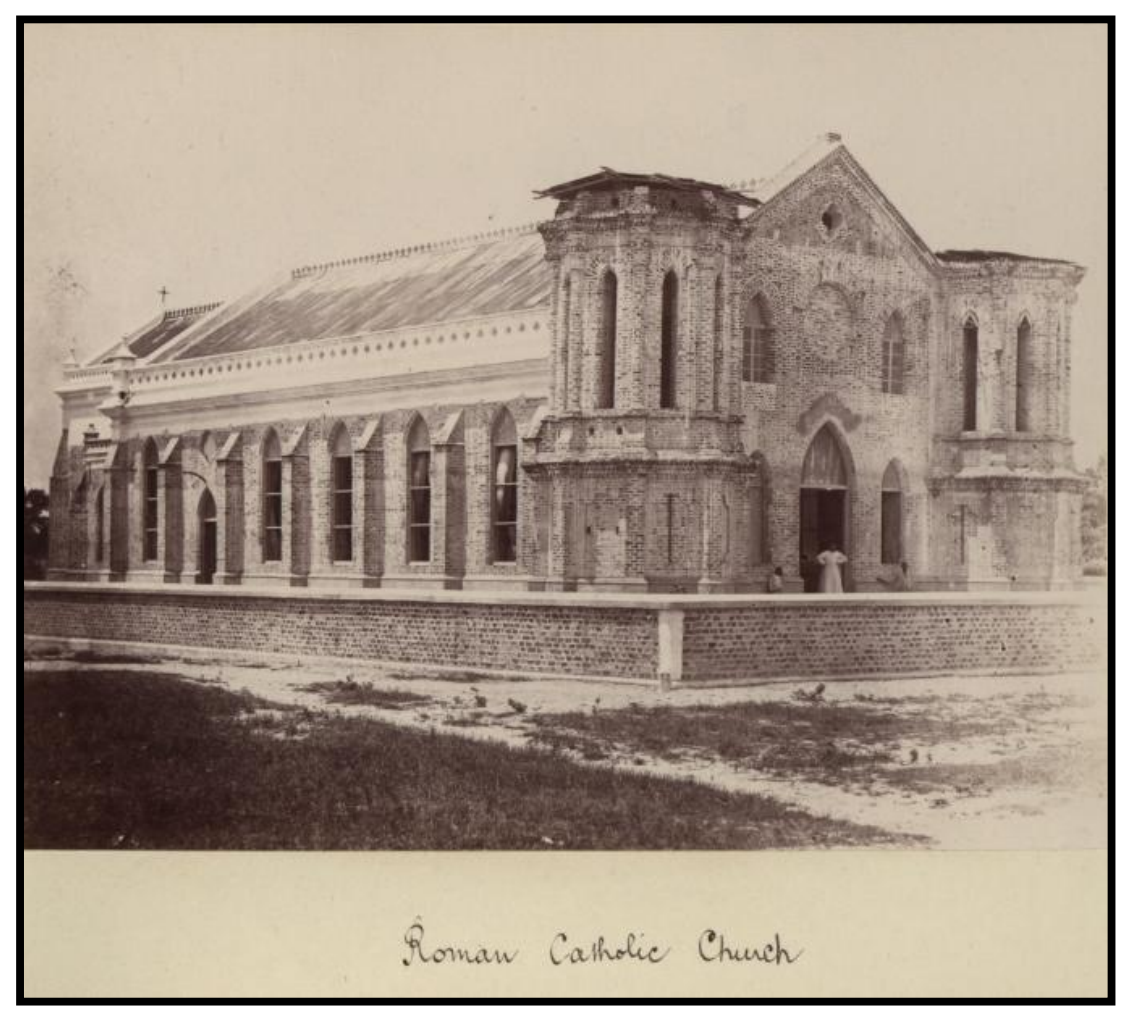

Fonte: National Archives. Nigeria, CO 1069.78.10

${ }^{483}$ Por quase dez anos, entre 1863 e 1872, Glover e Freeman se sucederam no governo de Lagos. Cf. MANN, Kristin. Op.cit., 2007, pp.106 e 116. Na década de 1960, o Glover Memorial Hall foi demolido e, em seu lugar, foi construído outro edifício que serviria aos mesmos propósitos. Cf. SAWADA, Nozomi. Op.cit., 2011, p.147. 
Em continuidade às solenidades realizadas no canteiro de obras do Memorial, os membros dos três comitês do jubileu, autoridades coloniais e chefias locais se reuniriam no Tribunal de Justiça da cidade. Todos seguiriam deste ponto até a alfândega situada na Marina. Este momento da programação era vedado à população em geral. Planejada para ser um conjunto de cerimônias a partir das quais seria possível manifestar a lealdade da sociedade lagosiana à monarca, o jubileu de ouro reafirmava lugares sociais ao delimitar quais seriam as comemorações autorizadas ao grande público. Ao ingressarem no Tribunal ostentando vestimentas solenes, os membros do comitê, integrantes da administração britânica e o então obá Oyskan e seus chefes exibiriam sua posição social na Lagos do final do século XIX. Aos populares que acompanhariam os festejos desde o início da manhã restava, ao final das comemorações do dia, uma queima de fogos planejada para acontecer às dez horas da noite.

Para o segundo dia de celebração os organizadores do jubileu programaram uma procissão, denominada pelo Lagos Observer, de "Brazilian Caretas". Na ocasião, brasileiros mascarados sairiam em desfile pelas ruas da cidade. Numa espécie de folguedo de carnaval, os participantes entoariam canções em língua portuguesa, acompanhados por tambores e instrumentos de sopro e carregando estandartes de devoções. Como um exercício simbólico do pertencimento à comunidade brasileira de Lagos, estes indivíduos ganhariam as ruas, conferindo visibilidade às "caretas" como um dos elementos de identificação do grupo. Ao final do dia, o programa publicado pelo periódico divulgava 0 oferecimento de um banquete restrito às autoridades britânicas $e$ às chefias africanas. Também nesta ocasião estava prevista uma queima de fogos nas proximidades da marina. Nos outros quatro dias, o jubileu seria comemorado com a realização de festividades nas escolas da cidade, desfiles da força policial lagosiana, um grande baile e um concerto organizado pelo comitê feminino, o Women's Jubilee Society. Tal como em outros momentos considerados solenes, os dois últimos acontecimentos do programa seriam vedados à participação popular. Ao desfrutar de uma parte das comemorações restrita à maioria da população da cidade, funcionários coloniais britânicos, 
chefias africanas, e alguns saros e brasileiros enriquecidos deixavam explícita sua posição social destacada. ${ }^{484}$

Em 1886, ano anterior às festividades em torno dos cinquenta anos de reinado da rainha Victoria, Lagos havia retomado sua autonomia administrativa, deixando de ser parte da colônia britânica da Costa do Ouro. Sob o governo de Cornelius Alfred Moloney, a cidade passou por algumas operações urbanas com o propósito de dinamizar sua economia. Uma das intervenções realizadas no primeiro ano da administração de Moloney ocorreu no campo da comunicação. No ano de 1886, foi implantada uma linha telegráfica capaz de ligar Lagos à Grã-Bretanha. Mais tarde, a mesma linha submarina se conectou a Eastern and Brazilian Companies, permitindo uma comunicação mais rápida também com o Brasil. ${ }^{485}$ Além do acréscimo de uma tecnologia responsável por encurtar o tempo do fluxo de informações, o governador de Lagos também implantou uma estrutura projetada para ambientar espécies vegetais valorizadas no mercado internacional: a Estação Botânica de Lagos. ${ }^{486}$ Estas e outras realizações do governo Moloney subsidiaram a elaboração de uma retórica de valorização do progresso material executado pela administração colonial britânica na cidade.

$\mathrm{Na}$ ocasião do jubileu de ouro, as congratulações dirigidas à rainha Victoria se somaram às manifestações de apreço às ações de modernização operadas pelo governo Moloney. Em uma declaração de lealdade à monarca, dezenove brasileiros encaminharam uma carta em que saudavam seus cinquenta anos de reinado e ressaltavam "as importantes ações de civilização e comércio e os muitos benefícios" gozados sob seu governo. Como uma forma de reconhecimento da posição de respeitabilidade alcançada por estes brasileiros, o Lagos Observer publicou cada um dos dezenove nomes dos signatários da missiva enviada ao governo colonial. Muitos dos indivíduos

\footnotetext{
${ }^{484}$ The Lagos Observer, 18 de junho de 1887, World Newspaper Archive, African Newspapers, $1883-1888$.

${ }^{485}$ CUNHA, Manuela Carneiro da. Op.cit, 2012, p.161.

${ }^{486}$ No primeiro capítulo trato do projeto do governador Alfred Moloney de fundar uma Estação Botânica em Lagos.
} 
listados pelo periódico se tornaram conhecidos pela historiografia em razão de sua proeminência econômica neste período. ${ }^{487}$

A missiva dos brasileiros foi de pronto respondida por Alfred Moloney. Em um longo texto o governador de Lagos reafirmava a ideia de que os brasileiros constituíam uma parcela da sociedade formada por indivíduos "avançados, ordeiros e industriosos", cujas ações tornavam os integrantes desta comunidade "louváveis exemplos de cidadãos". Em apoio a estas considerações, o documento ressaltava o conhecimento adquirido por exescravos durante os anos de cativeiro. Este era o elemento fundamental da argumentação de Moloney em torno da "repatriação" de libertos provenientes do Brasil. Para o governador de Lagos, "o retorno de agricultores treinados é especialmente desejável e deveria ser encorajado por todos". E, justificando sua posição, completava

A porção que erroneamente chamamos de brasileira nesta cidade, é ocupada por mercadores, negociantes, mecânicos, marinheiros, [ilegível], trabalhadores e outros, que representam, assim espero, avanço, ordem, indústria e respeito [...] e são ainda louváveis exemplos de cidadãos. ${ }^{488}$

Para Moloney, era um erro chamar de brasileira a parte em que se concentrava esta parcela da população. Ao sublinhar as especialidades profissionais destes indivíduos, o governador de Lagos deixava explícita uma argumentação que incorporava os brasileiros aos demais grupos existentes na cidade. Suprimindo as assimetrias sociais e econômicas existentes dentro do próprio grupo, Moloney recompunha uma nova forma de representação de

\footnotetext{
${ }^{487}$ De acordo com o Lagos Observer, os dezenove brasileiros eram: Prisco F. da Costa, J.J. da Costa, J.M.Assumpção, M.P. da Silva, Lasaro B. da Silva, P.M. dos Anjos, T.T. d'Sousa Marquis, E. Co's as Silica, J.D'Castro, M.F. Seigeideiro, Q.F. Gomes, Marcos A. Cardoso, H.N. Berand, P.L. da Silva, L.A. Cardoso, Salvador Lamos da Neves, João Campos, P.F. Gomes e Senhor Salvador. Ao cotejarmos alguns dos nomes listados acima aos registros de armazéns e aos anúncios de estabelecimentos comerciais, verificamos que nomes como João Campos, P.F.Gomes e J.M.Assumpção também aparecem citados em outras fontes. The Lagos Observer, 2 e 9 de julho de 1887, World Newspaper Archive, African Newspapers, 1883 1888.

${ }^{488}$ Sob o título de "Governor's replay to the brazilians of Lagos", o Lagos Observer publicou os elogios de Moloney aos brasileiros de Lagos: The Lagos Observer, 2 e 9 de de julho de 1887, World Newspaper Archive, African Newspapers, 1883 - 1888.
} 
seus integrantes, desta vez como "louváveis exemplos de cidadãos" lagosianos.

Em 1887, quando um conjunto de cerimônias e festividades marcou o jubileu de ouro da rainha Victoria, os jornais de Lagos publicaram uma série de artigos e editoriais celebrando as ações coloniais responsáveis por modificações que teriam levado a cidade a um significativo progresso material. Dez anos mais tarde, em 1897, a monarca comemorou seus sessenta anos de reinado. Nesta segunda ocasião, os periódicos lagosianos também saudaram as realizações operadas sob seu comando. Entre os meses de fevereiro e julho de 1897 encontrei, no Lagos Weekly Record, trinta e uma menções ao jubileu de diamante da rainha Victoria. Estas menções variavam entre artigos, editorias e notas. Algumas informavam os valores arrecadados pelo The Queen's Commemoration Fund. Os recursos deste fundo eram formados por doações individuais e de grupos que seriam utilizadas, na íntegra, nos festejos do jubileu. Os nomes daqueles que participavam destas cotizações e os respectivos valores doados eram impressos no periódico. Deste modo, aqueles que contribuíam com o fundo poderiam reafirmar ou atualizar, entre seus pares, seu status econômico e, por conseguinte, social.

Além destas listas de doações, os textos referentes ao jubileu de diamante se mostravam mais específicos em relação às ações da Coroa britânica do que aqueles relacionados ao jubileu anterior. Em junho de 1897, as publicações lagosianas concentravam seus elogios à "pacificação" do interior, iniciada anos antes pelo então governador Gilbert Carter. Nestes artigos, as ações promovidas por Carter em 1893 eram tomadas como resultado da atuação direta da rainha Victoria. Personificando as decisões do Colonial Office acerca dos rumos da política colonial, a monarca era representada nos jornais de Lagos como a responsável pelo término dos conflitos no interior, em outras palavras, das guerras de Ekitiparapo, ljaye e Oió. ${ }^{489}$

Um minucioso artigo publicado pelo Lagos Weekly Record sob o título "As lições do jubileu", recapitulava as ações britânicas desde o tratado de

489 The Lagos Weekly Record, 13 de fevereiro a 31 de julho de 1897, World Newspaper Archive, African Newspapers, 1883 - 1888. 
cessão firmado com Docemo, em 1861. Este longo preâmbulo a respeito da instalação colonial britânica na década de 1860 fundamentava o discurso de apoio à penetração das forças do governo lagosiano por territórios afastados da costa. Ao argumentar que a supressão dos embates existentes no interior só aconteceu em razão da intervenção da armada colonial, o artigo colocava em questão a capacidade de convivência entre as sociedades "pacificadas". Segundo o texto, a interiorização britânica não estaria completa antes que "as vantagens da harmonia e da cooperação" fossem ensinadas. Afinal,

Os nativos requeriam força externa para produzir ordem. Quanto mais rudes, menos desenvolvidas são suas faculdades e maior força externa é necessária para manter os indivíduos juntos e ensinar comunidades oponentes as vantagens da harmonia e da cooperação. (...) Confiança é uma planta que cresce devagar, especialmente entre as pessoas com estes antecedentes. ${ }^{490}$

A ideia da "dignificação da conquista" por meio de um conjunto de considerações, a partir das quais seria possível "transformar o desejo [do colonizador] por mais espaço geográfico" em uma "teoria" capaz de dar sustentação à dominação é tratada por Said. Para o autor, o processo de reificação dos indivíduos como objetos de estudo suprimiria individualidades e Ihes negaria a possibilidade de desenvolvimento sem a intervenção europeia. ${ }^{491}$ Em última instância, cabia à rainha Victoria a tarefa de interpor sua autoridade a fim de semear a confiança entre sociedades separadas por disputas alimentadas durante tantos anos. Sob este aspecto, a comemoração do jubileu de diamante se mostrava como um momento propício à disseminação da figura da monarca como uma matriarca imperial.

Foi ao redor da imagem de um reinado sólido e, ao mesmo tempo, preocupado com o bem estar de seus súditos, que os comitês organizadores do cerimonial do jubileu de diamante se reuniram. $O$ conjunto de solenidades e festejos planejados para a ocasião incluiu um desfile de brasileiros, denominado pelo Lagos Weekly Record como "the brazilian procession".

490 The Lagos Weekly Record, 26 de junho de 1897, World Newspaper Archive, African Newspapers, $1883-1888$.

491 SAID, Edward W. Orientalismo: o Oriente como invenção do Ocidente. São Paulo: Companhia das Letras, 2007, pp.281-282. 
Vestindo trajes brancos, atravessados por faixas da cor azul, um grupo de brasileiros circulou pelas ruas da cidade antes de chegar ao seu destino final: a sede do governo colonial, a Government House. Carregando lanternas que iluminavam a procissão, os participantes foram recebidos pelo então governador de Lagos, H.E. McCallum. ${ }^{492}$ Aquela era uma ocasião de exposição da respeitabilidade dos brasileiros, uma vez que o encontro com o ocupante do cargo mais elevado da administração colonial na cidade foi marcado por um protocolo de solenidades.

Figura 10: Sede do governo colonial britânico, a Government House (sem data)

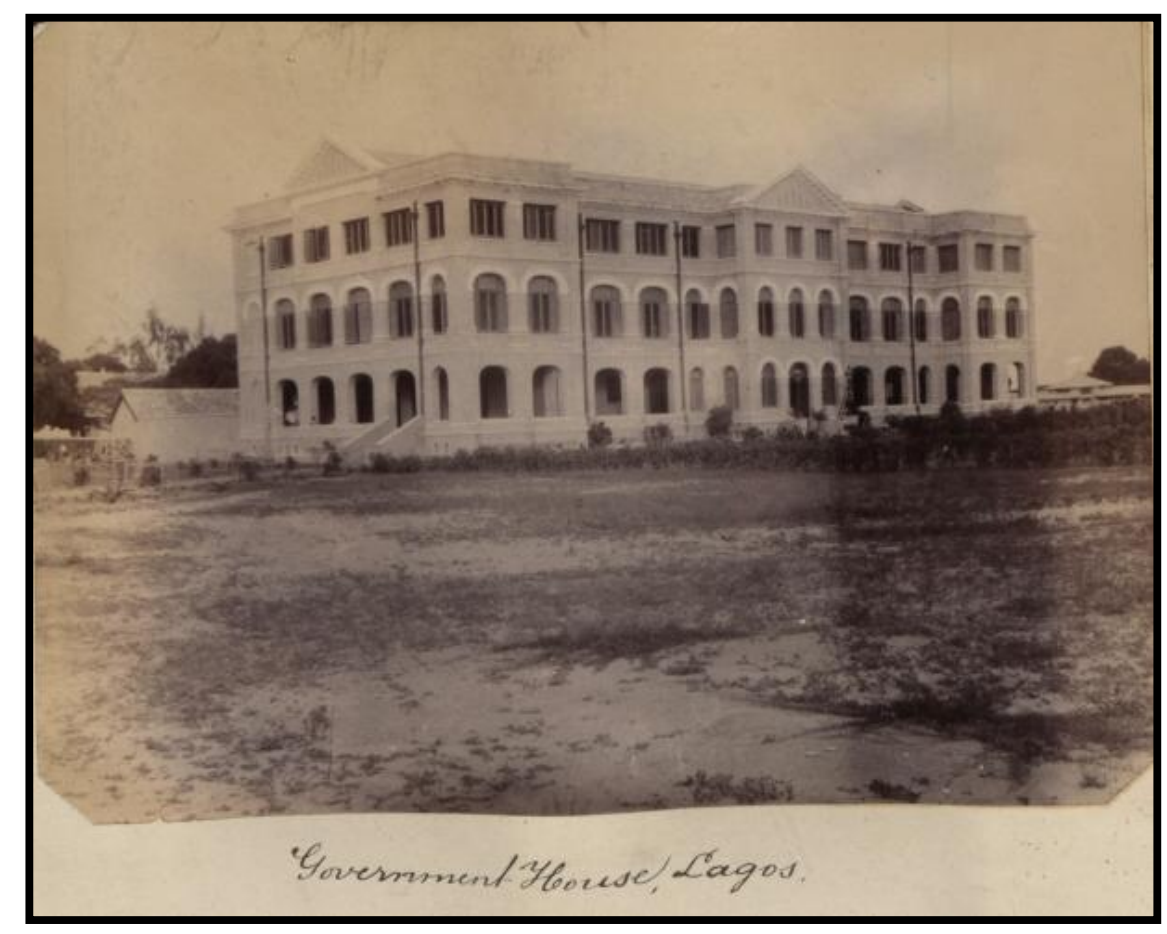

Fonte: National Archives. Nigeria, CO 1069.80.44

Quando o branco das vestes dos integrantes da procissão tomou as principais ruas da cidade, um dos sentidos de ser brasileiro ganhou forma e visibilidade. Como partícipes de um grupo social específico, definido a partir de um conjunto móvel e diversificado de signos de pertencimento - ou como chamou Manuela Carneiro da Cunha, de "sinais diacríticos" - os brasileiros

492 The Lagos Weekly Record, 26 de junho de 1897, World Newspaper Archive, African Newspapers, $1883-1888$. 
colocaram em ação uma das faces de sua identidade: a produção cultural. ${ }^{493}$ Ao selecionar os elementos que seriam expostos nos desfiles dos jubileus de ouro e de diamante, estes indivíduos formulavam e atualizavam o que significava ser, ou se tornar, ou ainda ser representado como parte da comunidade. Este processo de seleção e ressignificação dos emblemas que traduziam o pertencimento ao grupo dialogava com contextos políticos e sociais específicos.

Na última década do século XIX, os emblemas associados ao ser brasileiro eram diversificados e cambiantes. Um destes elementos da identidade do grupo estava associado à proximidade de seus indivíduos em relação ao colonizador. Neste momento, muitos brasileiros cuja educação escolar incluiu o aprendizado da língua inglesa - em escolas missionárias católicas que, desde 1882, eram obrigadas a ensinar no idioma do colonizador ou em estabelecimentos de ensino protestantes - ingressaram no funcionalismo público. Os limites impostos pelo Colonial Office aos gastos com a manutenção de sua burocracia local refletiam na redução do número de empregados britânicos em postos administrativos, cujos salários eram maiores. De acordo com Mann, além do pagamento aos ingleses ser mais elevado do que os valores gastos com os africanos, os britânicos recebiam passagens de vapor, acomodações ou subsídio para moradia, cujos valores eram somados a um abono salarial destinado aos que permanecessem por longos períodos na colônia. Estes acréscimos tornava ainda mais dispendioso o custeio destes indivíduos em cargos administrativos na cidade de Lagos. ${ }^{494}$ Neste sentido, a política de manutenção de um aparato burocrático de baixo custo e a elevada mortalidade entre oficiais e funcionários ingleses se apresentaram como fatores decisivos à incorporação de africanos ao governo de Lagos. ${ }^{495}$

\footnotetext{
${ }^{493}$ CUNHA, Manuela Carneiro da. Op. Cit., 2012, p. 242.

${ }^{494}$ MANN, Kristin. Op.cit, 2007, p.363, nota 94.

${ }^{495}$ Conforme Smith, em 1864, Freeman teria afirmado que Lagos era "um presente mortal dado pelo Foreign Office" aos cônsules e outros funcionários enviados pela Coroa britânica. Antes disto, em meados da década de 1850, Benjamin Campbell já havia comparado a residência consular pré-montada, feita em metal, a um "caixão de ferro". SMITH, Robert Sydney. Op.cit., 1978, cap.6 The Iron Coffin.
} 


\subsubsection{Os brasileiros nos quadros do funcionalismo colonial}

Os relatórios compilados pelos Blue Books informam que, desde 1863, a inserção de africanos no funcionalismo público foi significativa. Com exceção dos britânicos que desempenhavam os cargos de governador, secretário de governo, coletor de impostos, tenente-comandante do esquadrão britânico e médico-cirurgião, todos os demais postos eram ocupados por africanos. A maioria dos indivíduos que integrava a administração colonial neste período eram saros. Para termos uma ideia mais clara a respeito desta situação, em 1865, um relatório acerca dos empregados coloniais registrou um total de oitenta e oito funcionários. Apenas dois brasileiros estavam nesta lista: um indivíduo chamado Manoel, mensageiro do governo, e outro de nome Francisco, agente policial lotado em Badagri. ${ }^{496}$

Esta conjuntura, no entanto, não se repetiu até o final do século XIX. A partir da década de 1890, a interiorização da colonização britânica e a ampliação do ensino escolar em língua inglesa fez crescer o número de brasileiros incorporados aos quadros do funcionalismo público da cidade. A abertura de novos postos de trabalho estava também associada à criação de departamentos administrativos e ao desenvolvimento de obras de infraestrutura em Lagos e nas cidades situadas no interior. Neste contexto, foram criados os departamentos de agricultura, silvicultura e sanitário. O propósito era estimular a produção agrícola, a exploração dos recursos naturais regionais e reduzir os surtos epidêmicos responsáveis pelo elevado número de óbitos na cidade. ${ }^{497}$

Quando o Blue Book de 1899 registrou os nomes dos funcionários coloniais, a proporção de saros continuava maior em relação à de brasileiros. No entanto, os números gerais do funcionalismo público haviam aumentado de maneira relevante. Entre as quatrocentos e duas pessoas incluídas na lista do governo colonial, vinte e sete eram brasileiras. A maioria desempenhava

\footnotetext{
${ }^{496}$ Blue Book, Colony of Lagos, 1865, pp.82-89.

497 DANIEL, S. Ola. Health and Social Welfare in ADERIBIGBE, A.B. (ed.) Lagos: The Development of an African City. Lagos: Longman, 1975, p.160.
} 
funções rasas da hierarquia colonial. Como funcionários de quinta e sexta classes, mensageiros e almoxarifes estes brasileiros recebiam salários entre $£ 24,00$ e £42,00 ao ano. Este era o valor médio pago a todos os saros ou brasileiros que ocupavam posições iguais ou equivalentes às mencionadas. Havia ainda brasileiros que exerciam funções consideradas de médio escalão. Atuando como assistentes no departamento de obras públicas, auxiliares de inspeção das forças haussas ou funcionários de segunda classe do gabinete colonial, o salário anual destes indivíduos podia chegar até £200,00. Entre os vinte e sete funcionários brasileiros arrolados no relatório de 1899, apenas cinco deles recebiam pagamentos maiores do que cem libras ao ano. ${ }^{498}$

Um deles era S.I. Souza, escrevente de segunda classe, com salário anual de $\{132,00$, cujas atribuições estavam subordinadas à Secretaria do governo colonial. O relatório compilado pelo Blue Book de 1899 não fornece informações adicionais capazes de esclarecer que tipo de trabalho Souza executava ou quais outras funções ele teve de desempenhar até chegar a esta posição. De maneira geral, os dados reunidos pelos Blue Books seguiam um padrão de sistematização que servia para todas as colônias britânicas espalhadas pelo mundo. Este aspecto fica mais evidente nos relatórios produzidos na década de 1860 sobre a recém-conquistada colônia de Lagos. A edição referente ao ano de 1863 traz impressas uma série de tabelas que deveriam ser preenchidas manualmente pela administração colonial da cidade. Todavia naquele momento, a estrutura burocrática instalada pelo governo britânico não dispunha de recursos humanos suficientes para completar os minuciosos quadros informativos solicitados pelo Colonial Office. Em razão disto, diversas partes do relatório de 1863 retornaram para a Grã-Bretanha em branco. Dados a respeito do recolhimento de impostos, despesas públicas, anotações de entrada e saída de embarcações, lotes de terras cultivados e exploração dos recursos minerais são alguns exemplos dos itens que não constam ou estão incompletos nos registros do ano de 1863. Apesar disto, cabia ao governo colonial lagosiano coligir, anotar, resumir e organizar o maior número possível de informações sobre a colônia.

${ }^{498}$ Blue Book, Colony of Lagos, 1899, pp.44-61. 
A inscrição destes dados em grades e tabelas produzia a sistematização de um tipo de conhecimento referente aos domínios coloniais britânicos. Eram estas coleções de informações que permitiam ao Colonial Office conceber as possibilidades de exploração das possessões sob seu controle. $E$, indo mais além, de imaginar quais seriam as característica definidoras destes territórios. De acordo com Benedict Anderson, a mentalidade classificatória dos Estados colonizadores do século XIX produziu uma diversidade de registros que tornava possível ao colonizador imaginar "a natureza dos seres humanos por ele governados, a geografia de seu território e a legitimidade de seu passado". ${ }^{499}$ Ao analisar os censos, mapas e museus como instituições de poder cuja produção de saberes fornecia suporte à dominação, exploração e controle colonial, o autor discute a forma como estas instituições buscavam a representação da totalidade da população, dos territórios e dos recursos sob seu domínio.

A contagem populacional proporcionada pelos censos decenais realizados em Lagos a partir de 1863 constituiu um recurso de categorização implantado pelo governo britânico com o propósito de quantificar e classificar a paisagem humana de sua colônia. Contudo, os relatórios dos Blue Books, produzidos a partir das informações recolhidas pelos censos britânicos, expõem um processo de reformulação que coloca em evidência a reificação de identidades formuladas a partir de critérios classificatórios móveis. Isto porque, embora a historiografia mencione a contabilização de brasileiros pelos censos, estes indivíduos não aparecem nas tabulações dos Blue Books, as quais eram realizadas a partir deste instrumento de contagem. ${ }^{500}$

Os chamados "Relatórios de população, casamentos, nascimentos e mortes" tinham o propósito de inscrever em uma grade classificatória única os homens e mulheres brancos e "de cor" (coloured population), os estrangeiros residentes, os setores da economia em que a população em geral estava engajada - agricultura, comércio e manufatura - e, ao final, os casamentos,

\footnotetext{
499 ANDERSON, Benedict. Comunidades imaginadas: reflexões sobre a origem e a difusão do nacionalismo. São Paulo: Companhia das Letras, 2008, p.227.

${ }^{500} \mathrm{Em}$ relação à produção historiográfica, refiro-me à primeira edição da obra de Cunha, cujo apêndice "Brasileiros em Lagos: quantos?" menciona que um censo de 1881 teria indicado a presença de 2.723 brasileiros na cidade. CUNHA, Manuela Carneiro da. Negros, estrangeiros. Os escravos libertos e sua volta à África. 1ª edição. São Paulo: Brasiliense, 1985, p.215.
} 
nascimentos e falecimentos ocorridos no último ano. Com afirmei, estas grades classificatórias eram as mesmas para todas as colônias da Grã-Bretanha. Deste modo, não é possível traduzir a categoria "cloured population" como negra, pois esta classificação assumia diferentes significados em função da localidade onde era aplicada. Contudo, sublinho que na Lagos da segunda metade do século XIX, a população "de cor" significava a parcela negra da sociedade.

Tabela 7 - Relatório de população, casamentos, nascimentos e mortes $1866^{501}$

\begin{tabular}{ccccccc}
\hline País & \multicolumn{2}{c}{ Brancos } & \multicolumn{2}{c}{ População de cor } & \multicolumn{2}{c}{$\begin{array}{c}\text { Indivíduos } \\
\text { empregados }\end{array}$} \\
\hline Lagos & Homens & Mulheres & Homens & Mulheres & Agricultura & Comércio \\
& 42 & - & 12.457 & 12.584 & 789 & 2.540 \\
\hline
\end{tabular}

Fonte: Blue Book, 1866, Return of the population and of the marriages, births and deaths, pp.228-229.

Nestas tabelas não havia espaço para que os funcionários coloniais registrassem o que Anderson denominou de "realidades incômodas". Em outras palavras, não era possível encaixar aqueles indivíduos que apresentavam identificações múltiplas, cambiantes ou não previstas em um esquema padronizado de quantificação sistemática. Os registros do Blue Book do ano de 1866, por exemplo, informavam que vivia na cidade de Lagos uma população composta por 42 homens brancos, 12.457 homens "de cor" e 12.584 mulheres "de cor". Nenhuma mulher branca foi incluída nesta lista. A ausência de menções à presença de brasileiros, saros, egbas, ijexas e outros grupos populacionais existentes em Lagos, denota um padrão classificatório formulado para reunir a multiplicidade humana da cidade em apenas uma categoria: a de indivíduos "de cor". 502

Conforme procurei demonstrar ao longo de toda a pesquisa, mesmo antes da conquista colonial britânica sobre Lagos, os brasileiros eram uma

\footnotetext{
501 Selecionei aleatoriamente o ano de 1866 para exemplificar como eram os relatórios de população, casamentos, nascimentos e mortes publicados pelos Blue Books.

${ }^{502}$ Blue Book, Colony of Lagos, 1866, pp.228-229. ANDERSON, Benedict. Op.cit., 2008, p.234.
} 
parcela significativa da população residente na cidade. A despeito deste fato, as grades classificatórias fornecidas pelo Colonial Office, reunidas nos compêndios de documentos conhecidos como Blue Books, não refletiam a multiplicidade humana existente nesta colônia britânica. Além disto, os brasileiros não eram o único grupo da cidade cujos elementos distintivos foram subsumidos sob uma categoria fundada na percepção racializada de indivíduos "de cor". Em um contexto em que os administradores coloniais - Alfred Moloney (1886-1891), Gilbert Carter (1891-1897) e H.E.McCallum (1897-1899) - se esforçavam para suprimir os conflitos existentes no interior, reconhecer cada um dos grupos populacionais presentes na colônia lagosiana era uma tarefa arriscada, que poderia acirrar rivalidades, fortalecer privilégios ou fornecer suporte à dominação de um grupo sobre outro.

Nas duas últimas décadas do século XIX, Lagos era uma cidade constituída por uma imensa variedade populacional. As longas guerras operadas em território iorubá e as violentas incursões das forças "pacificadoras" britânicas lideradas à distância pelo governador Carter, aumentaram o número de refugiados que, na década de 1890, passaram a viver em Lagos. Estes fatores tornavam a composição da população que vivia na cidade ainda mais heterogênea e, em diversos aspectos, mais complexa.

Como um dos conjuntos humanos existentes na cidade neste período, a presença brasileira foi registrada por outros setores da administração colonial, cujas atribuições não incluíam a contagem e a categorização da população. Um dos registros capazes de fornecer informações acerca de quem eram os brasileiros que viviam em Lagos no final do oitocentos, onde viviam e quais eram seus respectivos ramos de atuação profissional são as listas de jurados publicadas pelo periódico oficial do governo britânico, a Government Gazette. Estas listas tinham validade anual e eram divulgadas no ano anterior à sua vigência, além disto, começaram a ser impressas a partir de 1887 e eram assinadas por um funcionário colonial que ocupava o cargo de "comissário distrital". Para fazer parte da relação de jurados o indivíduo precisava dominar a língua falada pelo colonizador e ser alfabetizado. Embora constituam apenas uma amostra da população existente na cidade neste período, considero as relações de convocados ao júri uma importante fonte de pesquisa capaz de 
oferecer algumas pistas acerca da composição da comunidade brasileira de Lagos.

A primeira destas pistas se refere à grande variedade de profissões urbanas declaradas às autoridades coloniais pelos jurados. Carpinteiros, alfaiates, escrivães, padeiros, pedreiros, mestres de obra, barbeiros, funileiros e comerciantes constituem as profissões mais recorrentes. Ao exercerem trabalhos diretamente ligados à vida na cidade, estes indivíduos expunham os setores profissionais em que a população brasileira se concentrava. Nas listas de jurados, aqueles que informavam viver de seu próprio comércio ou eram empregados em estabelecimentos comerciais de terceiros, em certos casos de companhias europeias, formavam a grande maioria. Este aspecto reforça a ideia de que uma parcela relevante da população brasileira tirava seu sustento da atividade comercial.

$\mathrm{Na}$ cidade de Lagos do final do século XIX, se declarar comerciante poderia significar atuar em diferentes escalas e negociando uma enorme variedade de produtos. Estavam incluídos nesta categoria pequenos negociantes que mantinham estabelecimentos retalhistas abertos à frente de suas moradias. Eram também considerados comerciantes os grandes importadores e exportadores, cujas atividades envolviam relevante volume de mercadorias e elevadas trocas financeiras. Deste segundo grupo faziam parte dois ricos mercadores brasileiros que, no ano de 1890, foram arrolados entre os integrantes do júri de Lagos: João Angelo Campos e Joaquim Francisco Branco. Reitero que estes mercadores eram reconhecidos socialmente em função da posição econômica que ocupavam na cidade. Além destes indivíduos, havia ainda aqueles jurados listados como pertencentes a um tipo específico de comerciante. Eram os agentes comerciais associados às grandes firmas importadoras e exportadoras, cujos armazéns estavam estabelecidos no porto de Lagos. Nestes casos era acrescentada uma anotação ao lado do registro da profissão do jurado: o nome da firma para a qual o indivíduo trabalhava. Foi como agente empregado na firma de Manoel Joaquim de Sant'Anna, que o brasileiro Samuel da Costa Soares integrou a lista de jurados por cinco anos ininterruptos, de 1890 a 1894. Este caso permite perceber que era comum a administração colonial da cidade repetir, durante algum tempo, os 
nomes constantes nas relações de anos anteriores. Este aspecto sugere ainda que a exigência relativa ao domínio oral e escrito da língua inglesa limitava o universo de indivíduos considerados aptos a desempenhar o papel de jurados.

Outra observação que pode ser feita a partir das listas anuais de jurados se refere à localização da população brasileira em Lagos. Como comentei, ao lado do nome completo e da profissão do jurado havia uma anotação acerca do endereço fornecido ao comissário distrital. Embora este seja um assunto bastante explorado pela historiografia e alguns mapas produzidos no final do século XIX e na primeira década do XX situem com precisão a região da cidade em que havia uma elevada concentração de brasileiros, as relações de jurados publicadas nos anos de 1898, 1899 e 1900 revelam que esta população não se manteve exclusivamente na área do chamado "bairro brasileiro" (ou Brazilian quarter). ${ }^{503}$ Ao longo dos três últimos anos do oitocentos diversos brasileiros que fizeram parte do júri lagosiano declararam como endereço imóveis situados na porção norte da ilha ou na parte continental da colônia. Em 1899, Eustashio Francisco Gomez foi arrolado como um dos moradores da cidade que atuariam naquele ano como jurado. Em virtude disto, o brasileiro ficou registrado na relação publicada pela Government Gazette como "mercador" residente na rua "Akani", situada na parte norte da ilha de Lagos, uma localidade bastante próxima à mesquita de Shitta Bey, região relativamente afastada do Brazilian quarter. ${ }^{504}$

\footnotetext{
${ }^{503}$ É possível verificar a localização exata do chamado "bairro brasileiro" a partir dos mapas elaborados por: KOPYTOFF, Jean Herskovits. Op.cit., 1965, p.90-93 e MANN, Kristin. Op.cit, 2007, p.250. Além desta publicação, há duas outras obras que reproduzem mapas de época, elaborados pela administração colonial britânica. Estas representações assinalam a área da cidade ocupada pela população brasileira. O primeiro livro apresenta a planta da cidade de Lagos no ano de 1887, trata-se da obra de CUNHA, Manuela Carneiro da. Op.cit. 2012, p.172. A segunda publicação oferece um mapa de 1908 do bairro brasileiro. Esta representação cartográfica se encontra em: AMOS, Alcione Meira. Os que voltaram: a história dos retornados afro-brasileiros na África Ocidental do século XIX. Belo Horizonte: Tradição Planalto, 2007,p.93.

${ }^{504}$ Government Gazette, Colony of Lagos, National Archives/UK. CO 150.9, 7 de janeiro de 1899.
} 


\subsubsection{Os brasileiros e o espaço urbano no final do século XIX}

Nos anos de 1897, 1898, 1899 e 1900 dois brasileiros residentes em Epetedo integraram as listas de jurados divulgadas pelo jornal oficial de Lagos, a saber: Alexandre S. Coimbra, pedreiro e Marcos A. Cardozo, carpinteiro. Nos últimos anos do oitocentos, Epetedo era uma localidade em que predominavam características rurais, uma vez que estava situada na porção continental da colônia ocupada por lavouras de alimentos, campos de cacau e palmeirais de dendê. Também entre os anos de 1897 e 1900, seis brasileiros membros do júri lagosiano declararam viver em Oke Popo, outra área localizada na parte continental da cidade. De acordo com as relações publicadas pelas edições das Government Gazette destes anos, os referidos brasileiros eram: G.S.A. da Costa, empregado da loja de livros da CMS; Alexandre Onofre Luis, pescador; Francisco Tito Nobres, pedreiro; Miguel Pacheco, carpinteiro; Julio Borges da Silva, comerciante e João M. Salvador, também carpinteiro. ${ }^{505}$

A presença de brasileiros em Epetedo e em Oke Popo, dois setores continentais de Lagos, é um indício das mudanças na organização territorial ocorrida na cidade a partir da década de 1860, mas intensificada nos anos de 1890. Conforme explica Mann, ao longo da segunda metade do século XIX, a ilha de Lagos se transformou no centro comercial e administrativo da colônia. No entanto, a composição arenosa e alagadiça de parte de seus terrenos limitava a produção de alimentos e o crescimento urbano da cidade. A partir de 1862, a ampliação do número de instalações que abrigariam uma administração colonial cada vez mais complexa e uma consistente rede de estabelecimentos missionários fez crescer as pressões sobre a ocupação territorial da ilha. No ano de 1863, uma legislação colonial britânica exigia que os residentes da porção insular de Lagos apresentassem, dentro de um ano, pedidos de reconhecimento de posse de lotes de terra. As porções do território não reclamadas seriam consideradas propriedade da Grã-Bretanha. Esta lei ficou conhecida como a lei de número nove. ${ }^{506}$

505 Government Gazette, Colony of Lagos, National Archives/UK. CO 150.8 e CO 150.9, 30 de janeiro de 1897; 24 de dezembro de 1897; 7 de janeiro de 1899 e 29 de dezembro de 1900.

${ }_{506}$ MANN, Kristin. Op.cit, 2007, cap. 7: The Changing Meaning of Land in the Urban Economy and Culture. 


\section{Mapa 6: Cidade de Lagos, c. 1886}

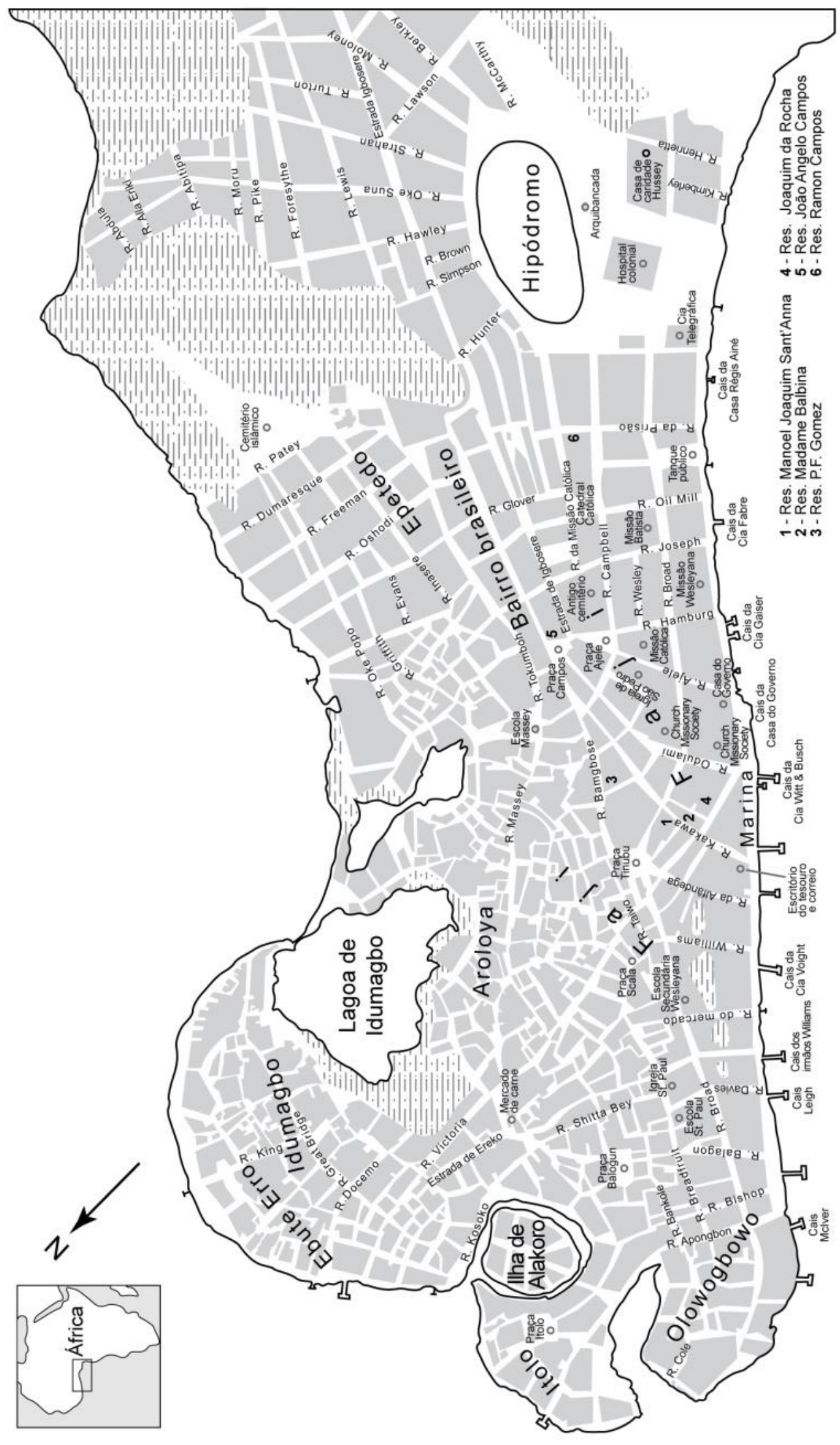

Fonte: Mapa adaptado de: KOPYTOFF, Jean Herskovits. A Preface to Modern Nigeria. The "Sierra Leonians" in Yoruba, 1830-1890. Wisconsin: The University of Wisconsin Press, 1965, pp.90-93. 
De início, o prazo para as solicitações de posse da terra foi definido para o final de 1864. Todavia, esta data foi postergada algumas vezes até se estabelecer o ano de 1869 como limite. Durante os primeiros cinco anos a valorização dos lotes insulares e das áreas continentais empregadas na lavoura alimentícia e exportadora trouxe profundas mudanças na forma de utilização do solo e dos imóveis. Como mencionei no quarto capítulo, a base do sistema comercial lagosiano era sustentada pelo crédito. Este sistema consistia no adiantamento do pagamento - em geral, em bens e não em moeda - por parte das firmas exportadoras, a fim de que intermediários locais negociassem com produtores do interior. Ao longo da segunda metade do século XIX, a terra se tornou um bem valorizado na ilha de Lagos e nas regiões produtoras de palma, cacau e alimentos. Deste modo, possuir um certificado fornecido pelo governo colonial se tornou condição de acesso ao crédito. Assim pela primeira vez, a terra adquiriu indiretamente um valor monetário. ${ }^{507}$

Quando nos últimos quatro anos do oitocentos os brasileiros Alexandre Coimbra e Marcos Cardozo integraram a lista de jurados, a ilha de Lagos passava por um intenso e acelerado processo de valorização territorial. Em função disto, muitos moradores que há décadas viviam na porção insular da cidade se mudaram para o continente. Embora as áreas agrícolas continentais também experimentassem a pressão da demanda por títulos de propriedade, esta pressão se mostrava menor do que a existente na ilha. Afinal, onde se concentravam a administração colonial e as maiores companhias comerciais o valor dos aluguéis era elevado. Estes aspectos explicariam o fato de alguns integrantes da comunidade brasileira se instalarem em setores da cidade como Epetedo e Oke Popo, distantes da concentração urbana insular.

Outro aspecto importante à compreensão desta valorização da propriedade da terra estava associado ao crescimento populacional. De acordo com Mann, diversos acontecimentos corroboraram para que a população de Lagos experimentasse um salto demográfico relevante. Um destes acontecimentos estava ligado a uma revolta ocorrida em Abeokuta, no ano de 1867. Na ocasião muitos egbas convertidos ao cristianismo deixaram a cidade

\footnotetext{
507 Ibid, cap. 7: The Changing Meaning of Land in the Urban Economy and Culture, pp. 237276.
} 
para se instalarem em Ebute Meta, porção continental da colônia lagosiana. A chegada dos egbas não foi o único acontecimento que resultou na ampliação do número de indivíduos na cidade. Além deste episódio em particular, havia questões ligadas à forma como o governo colonial britânico lidava com os escravos residentes em Lagos. Uma legislação promulgada em 1863 obrigava o registro de todos os escravos existentes na cidade. De acordo com a nova lei, todos aqueles que não obtivessem registro seriam considerados livres. Entre os escravos registrados, a legislação previa um sistema de "aprendizagem" - em inglês, apprenticeship system - que estabelecia mais alguns anos de servidão, calculados em função da idade, saúde e valor do escravo no momento da compra por seu dono. Depois de cumpridos os anos determinados pela justiça colonial, o escravo-aprendiz se tornava livre. ${ }^{508}$

A legislação de 1863 não excluía de imediato a escravidão na recémconquistada colônia britânica. Afinal, se tais disposições fossem obedecidas de maneira fiel, a lei possibilitaria a gradual manumissão da escravaria existente na cidade. $\mathrm{Na}$ prática, as novas determinações levaram a um aumento no número de escravos fugidos de territórios distantes da costa para Lagos. Uma vez estabelecidos em território lagosiano sem que nenhum senhor reclamasse sua propriedade, estes fugitivos eram reconhecidos pelo governo colonial como livres. Além deste aspecto, havia ainda casos de compra de escravos por senhores que buscavam assegurar sua posse sobre quantidades de terras muito maiores do que eram capazes de ocupar. Mais tarde, quando na década de 1890 o governo colonial passou a regular este assunto, muitos ex-escravos começaram a pleitear seus próprios certificados de terra, empunhando um direito até aquele momento vedado a esta parcela da população. Deste modo, as mudanças legislativas no sentido de permitir a incorporação de escravos ao "sistema de aprendizagem" contribuíram para o aumento da pressão populacional sobre o espaço territorial da ilha de Lagos. ${ }^{509}$

\footnotetext{
${ }^{508}$ Cf. MANN, Kristin. Op.cit, 2007, pp.160, 172 e173. Um artigo publicado pela pesquisadora Érika Delgado trata do sistema de apprenticeship aplicado aos cativos capturados pela marinha antitráfico britânica e que eram encaminhados à Freetown, Serra Leoa. DELGADO, Érika Melek. Identidades em trânsito: o caso dos africanos livres na primeira colônia britânica da África Ocidental. Revista de Ciências Humanas, Viçosa, v.14, n.2, pp.356-372, jul/dez, 2014.

${ }^{509}$ Cf. MANN, Kristin. Op.cit, 2007, p.259.
} 
Tabela 8: Lista de jurados, $1888-1900^{510}$

\begin{tabular}{llll}
\hline Ano & $\begin{array}{l}\text { Total de } \\
\text { jurados }\end{array}$ & $\begin{array}{l}\text { Total de } \\
\text { brasileiros }\end{array}$ & $\begin{array}{l}\% \text { de } \\
\text { brasileiros }\end{array}$ \\
\hline $\mathbf{1 8 8 8}$ & 489 & 33 & $6,74 \%$ \\
$\mathbf{1 8 8 9}$ & 477 & 34 & $7,12 \%$ \\
$\mathbf{1 8 9 0}$ & 539 & 55 & $10,20 \%$ \\
$\mathbf{1 8 9 1}$ & 539 & 55 & $10,20 \%$ \\
$\mathbf{1 8 9 2}$ & 578 & 80 & $13,84 \%$ \\
$\mathbf{1 8 9 3}$ & 626 & 81 & $12,93 \%$ \\
$\mathbf{1 8 9 4}$ & 649 & 89 & $13,71 \%$ \\
$\mathbf{1 8 9 5}$ & 619 & 94 & $15,18 \%$ \\
$\mathbf{1 8 9 6}$ & 662 & 87 & $13,14 \%$ \\
$\mathbf{1 8 9 7}$ & 662 & 91 & $13,74 \%$ \\
$\mathbf{1 8 9 8}$ & 704 & 95 & $13,49 \%$ \\
$\mathbf{1 8 9 9}$ & 725 & 96 & $13,24 \%$ \\
$\mathbf{1 9 0 0}$ & 715 & 94 & $13,14 \%$ \\
\hline Total & 7984 & 984 & $12,32 \%$ \\
\hline
\end{tabular}

Fonte: Tabela elaborada a partir das listas de jurados publicadas pelo jornal oficial Government Gazette, entre os anos de 1888 e 1900.

Como podemos verificar na tabela 8 - Lista de jurados, 1888-1900 - o total geral de jurados arrolados nestas relações quase dobrou ao longo dos treze anos pesquisados. A ampliação do número de integrantes do júri também se repetiu em relação à quantidade de jurados brasileiros. Em 1888, apenas $6,74 \%$ dos jurados eram brasileiros. Este percentual se alterou de maneira significativa nos anos seguintes, alcançando $15,18 \%$ sete anos mais tarde, em 1895, e mantendo uma participação superior a 13\% nos anos subsequentes. Os dados apurados sugerem um maior acesso à alfabetização da população de maneira geral e, em específico, dos brasileiros residentes na cidade. Uma vez que um dos critérios para a seleção do júri era o domínio da língua inglesa falada e da escrita, o aumento do número de jurados denota também a ampliação da quantidade de indivíduos alfabetizados.

Embora os brasileiros não fossem considerados nos relatórios dos Blue Books um grupo social específico, a forma como exerciam suas identidades tornava visíveis suas características distintivas. Em determinados momentos estas características extrapolavam os limites da comunidade e se tornavam

\footnotetext{
${ }^{510}$ Recordo que as listas de jurados ganharam as páginas do periódico oficial do governo colonial, a Government Gazette, a partir de 1887. Como estas relações eram sempre referentes ao ano subsequente, a primeira relação do júri se refere a 1888.
} 
conhecidas pela população lagosiana em geral. Os já mencionados jubileus de ouro e de diamante são exemplos de episódios de exibição pública e coletiva dos emblemas de pertencimento ao grupo. No entanto, estas não foram as únicas ocasiões em que os jornais registraram a exposição conjunta de seus membros. Em 1888, diversos artigos, editorias e cartas publicados pelo Lagos Observer saudaram o fim da escravidão no Brasil. Em uma missiva escrita apenas dois dias após a promulgação da Lei Áurea, o saro John Augustus Payne descrevia uma conferência realizada por ele no Museu Nacional do Rio de Janeiro. ${ }^{511}$

John Payne era casado com a brasileira Martha Bonifácia Lydia Payne e sua visita à corte imperial do Brasil foi coberta por quatro jornais cariocas: Rio News, Gazeta da Tarde, O Paiz e o Diário de Notícia. De acordo com os periódicos lagosianos, o discurso de Payne foi acompanhado pelo conselheiro João Alfredo, pelo visconde de Paranaguá e pelo Imperador do Brasil em pessoa. Em sua fala ele congratulou as autoridades presentes pela extinção do trabalho escravo no país. Dois meses após sua passagem pelo Rio de Janeiro, - Lagos Observer publicou uma correspondência em que Payne narrava sua experiência em terras brasileiras. Esta mesma edição do jornal trazia também uma reprodução (traduzida para o inglês) da legislação assinada pela princesa Isabel. ${ }^{512}$ Segundo Sawada, a viagem ao Brasil foi um marco em sua carreira pública. Em cartas enviadas aos jornais de Lagos e em artigos publicados por estes veículos eram frequentes as menções à conferência realizada no Rio de Janeiro. Descrito pelos periódicos lagosianos como um exemplo de sucesso da "civilização" britânica na colônia, Payne frequentemente mencionava sua experiência na Corte do Brasil como uma forma de confirmar a posição de respeitabilidade que ocupava em Lagos. ${ }^{513}$

Em quase todos os exemplares do Lagos Observer impressos nos meses de julho, agosto e outubro havia artigos e editoriais que saudavam a

\footnotetext{
511 SAWADA, Nozomi. Op.cit., 2011, pp.231-235.

512 The Lagos Observer, 14 e 21 de julho de 1888, World Newspaper Archive, African Newspapers, 1883 - 1888. Embora a carta de Payne tenha sido publicada apenas em julho, o texto informava a data e o local de sua redação: "Rio de Janeiro, 15 de maio de 1888". Neste mesmo ano de 1888, John Augustus Payne mudou seu nome para John Augustus Otonba Payne, numa referência à sua origem ijebu.

${ }^{513}$ SAWADA, Nozomi. Op.cit., 2011, pp.231-235.
} 
nova lei. Um texto escrito pelo editor e proprietário do periódico, J. Blackall Benjamin, lembrava os discursos antiescravidão proferidos por Payne durante os meses em que esteve na corte do Brasil, elogiava a abolição e terminava com uma crítica ao "incontestável despovoamento dos países do interior" provocado pelo tráfico que alimentou a escravidão do outro lado do Atlântico. Artigos como estes foram acompanhados por minuciosas descrições acerca das comemorações da abolição realizadas nas ruas, praças e igrejas de Lagos. No mês de outubro de 1888, um longo artigo tratava de um conjunto de festas e solenidades realizadas em torno da promulgação da Lei Áurea. Segundo esta edição, a festa foi paga com os recursos apurados em uma cotização feita entre os brasileiros da cidade. Os valores serviram para decorar com arcos embandeirados a praça e a rua Campos, ambas bastante próximas a principal igreja católica de Lagos: a Holy Cross. ${ }^{514}$

Uma solenidade presidida pelo senhor Antonio Miguel d'Assumpção marcou, em 28 de setembro de 1888, o início das comemorações pelo fim da escravidão realizadas por brasileiros residentes em Lagos. De acordo com o Lagos Observer, um grande número de observadores acompanhou o discurso inicial proferido pelo brasileiro. Neste momento a comunidade expôs quem eram seus membros e quais eram os sinais culturais capazes de distinguir seus integrantes. Neste mesmo dia, por volta da uma e meia da tarde, realizaram-se cerimônias religiosas em três igrejas da cidade: na católica Holy Cross, na anglicana Saint Paul e na wesleyana situada na praça Tinubu. No templo católico, o sermão escolhido para a ocasião reforçava a atuação britânica no combate ao tráfico atlântico e a consequente abolição da escravidão no Brasil. Ao final da celebração os participantes das festividades se dirigiram à sede do governo colonial, onde foram recebidos pelo governador Alfred Moloney. Nesta parte da solenidade estava presente John O. Payne. Em seu discurso acerca da promulgação da Lei Áurea, Payne ratificou o papel britânico no processo de extinção da escravidão no Brasil, ressaltou as consequências do comércio escravista para o continente africano e, ao final, elogiou as festividades

\footnotetext{
514 The Lagos Observer, 13 e 20 de outubro de 1888, World Newspaper Archive, African Newspapers, $1883-1888$.
} 
organizadas pelo comitê em honra à emancipação da escravidão em território brasileiro. ${ }^{515}$

Figura 11: Vista da marina de Lagos, com destaque para a Igreja católica Holy Cross (sem data)

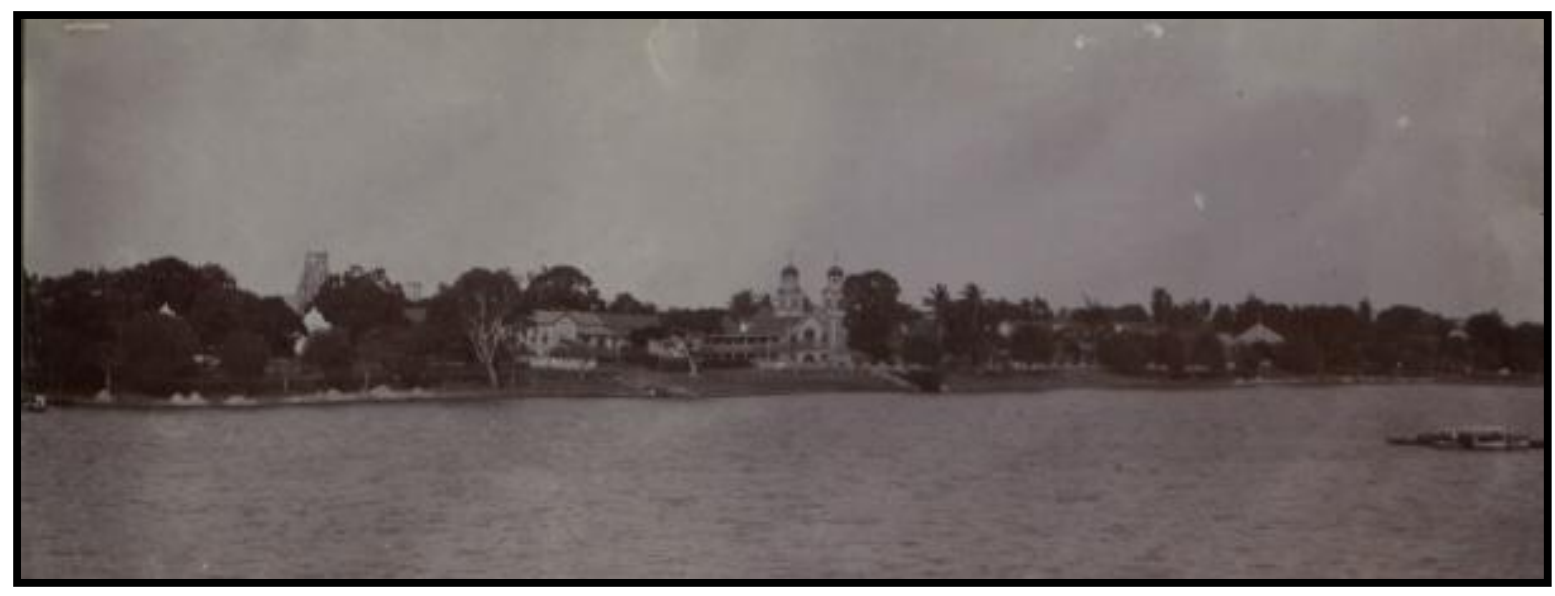

Fonte: National Archives. Nigeria, CO 1069.71.82

Ao cair da noite, integrantes do comitê cerimonial, autoridades britânicas e chefias locais se reuniram no Glover Memorial Hall em um baile restrito à maioria da população brasileira existente na cidade. Apenas os integrantes mais enriquecidos da comunidade tiveram acesso a esta parte das comemorações. Este episódio em específico se mostra interessante por tornar visíveis as clivagens sociais e econômicas existentes entre os próprios brasileiros. Dito em outros termos, a separação dos programas público e privado da festa expunha a heterogeneidade da composição econômica da comunidade brasileira que, ao final da década de 1880, vivia em Lagos. Como a maioria das grandes comemorações realizadas na cidade, as festividades se estenderam por vários dias. Nos dias seguintes o programa incluiu uma queima de fogos, uma sessão teatral organizada pela companhia formada por alunos da escola católica, apresentações musicais, um desfile de carnaval e, como

515 The Lagos Observer, 13 e 20 de outubro de 1888, World Newspaper Archive, African Newspapers, $1883-1888$. 
encerramento do ciclo de celebrações, um baile à fantasia também realizado no Glover Memorial Hall. ${ }^{516}$

\title{
5.3. Moisés da Rocha e as fissuras da dominação colonial
}

\begin{abstract}
A África tem experimentado sob o reinado da rainha [Victoria] o que eu poderia chamar de verdadeira metamorfose. Mas é ainda necessário que estas raças que não se submeteram à benigna influência das ideias ocidentais se convertam a elas de maneira pacífica. ${ }^{517}$
\end{abstract}

No ano de 1888, apenas os brasileiros mais ricos de Lagos participaram dos bailes em comemoração à abolição da escravatura no Brasil. Afinal, o ingresso às solenidades realizadas no Glover Memorial Hall era limitado aos "membros respeitáveis" da sociedade lagosiana do final do século XIX. Desta forma, quando a descrição das festividades ganhou as páginas do Lagos Observer, o jornal deixava implícito que eram estes os indivíduos que representavam a comunidade brasileira existente na cidade naquele momento. Ao conferir visibilidade ao conjunto e celebrações que tomou as ruas de Lagos, o jornal suprimia a diversidade humana dos brasileiros e selecionava os integrantes considerados como representativos do grupo. Este processo tornou-se mais evidente a partir de 1896, ano em que correspondências e artigos redigidos pelo brasileiro Moisés João da Rocha passaram a ser publicados em outro periódico existente na cidade: o Lagos Weekly Record. Segundo Amós, Moisés era filho do comerciante brasileiro, João Esan da Rocha. O patriarca da família tinha como primogênito Cândido, proprietário do hotel-restaurante Da Rocha. Embora a documentação estudada e a historiografia produzida sobre o tema não forneça dados acerca de outros filhos de João Esan, podemos supor que, a exemplo de outros ricos comerciantes

\footnotetext{
516 The Lagos Observer, 13 e 20 de outubro de 1888, World Newspaper Archive, African Newspapers, $1883-1888$.

517 "Africa has during the Queen's reign undergone what may be truly called a metamorphose. But still it is necessary that such races as have not been under the benign influence of Western ideas should be converted to these by pacific means". The Lagos Weekly Record, 09 de outubro de 1897, World Newspaper Archive, African Newspapers, 1883 - 1888.
} 
existentes na cidade neste período, o patriarca da família Rocha constituiu sua extensa prole a partir de mais de uma união. Nascido no ano de 1875, Moisés seria um de seus filhos mais jovens. ${ }^{518}$

Depois de estudar nas quatro principais escolas missionárias de Lagos a Wesleyan Tinubu School, ligada à Wesleyan Missionary Society; a Faji School, pertencente à CMS; a St. Xavier Catholic School, mantida pela SMA e a St. Gregory's Grammar School, também da CMS - Moisés partiu para a Inglaterra. Uma nota publicada em agosto de 1896 anunciava a saída do vapor Axim, cuja lista de passageiros contava com o filho do então falecido "Senhor João da Rocha". O breve texto impresso nas páginas do Lagos Weekly Record desejava que, uma vez estabelecido em seu destino final, Moisés expusesse sua "considerável habilidade intelectual" e provasse "capacidade na profissão que escolhera seguir". No entanto, depois de iniciar o curso de medicina em Edimburgo, na Escócia, o herdeiro de João da Rocha passou a dedicar grande parte de seu tempo a atividades não relacionadas à sua futura carreira na medicina. $^{519}$

$\mathrm{Na}$ virada do século XIX para o XX a discussão acerca das ações imperialistas britânicas havia chegado até os estudantes negros que residiam na Grã-Bretanha. A maioria deles era proveniente de colônias inglesas existentes na África e no Caribe. Como parte de uma "elite" formalmente educada em língua inglesa, e com recursos financeiros suficientes para completar seus estudos em instituições de ensino britânicas, estes alunos ingressaram nos debates políticos acerca da promoção da unidade entre africanos e seus descendentes diasporizados pelo tráfico. Segundo o abolicionista norte-americano William Wells Brown, no ano de 1851, quando visitou a escola de medicina de Edimburgo, estudavam na instituição três rapazes "de cor". Seu longo relato acerca das experiências vividas na Irlanda, Escócia, Inglaterra e França é permeado por comparações entre o lugar ocupado pelos negros que viviam na Europa e nos Estados Unidos. Entusiasmado com o fato de haver encontrado estudantes de medicina negros

\footnotetext{
${ }^{518}$ AMÓS, Alcione Meira. Op.cit., 2007, pp.112-113.

519 The Lagos Weekly Record, 22 de agosto de 1896, World Newspaper Archive, African Newspapers, $1883-1888$.
} 
tratados com "companheirismo e respeito" por seus colegas brancos, Brown ainda acrescentou ter observado nas ruas da cidade universitária de Edimburgo "homens de cor caminhando de braços dados com brancos". 520

Mais de quatro décadas depois da narrativa de viagem de William Brown ser publicada, Moisés da Rocha ingressou nesta mesma escola de medicina. Naquele momento é provável que o número de alunos matriculados neste curso fosse bastante superior aos três alunos registrados pelo visitante norteamericano. Em 1897, apenas um ano após iniciar seus estudos na instituição, Moisés se tornou secretário da African Association. No ano de 1900, a associação - que tinha entre seus membros o então estudante de direito nascido na ilha de Trinidad, Henry Sylvester Williams - organizou a primeira Conferência Pan-africana realizada em Londres. ${ }^{521} \mathrm{O}$ interesse do estudante brasileiro pela discussão política em torno das questões raciais se aprofundou e ganhou visibilidade quando suas ideias chegaram aos jornais. Já a partir de 1897, cartas e artigos redigidos por Moisés da Rocha foram publicados em periódicos em Edimburgo, Londres, Liverpool, Washington, África do Sul e Lagos. $^{522}$ Entre os jornais impressos em Lagos, no período de 1897 a 1900, encontrei seis textos assinados pelo brasileiro que vivia em Edimburgo, todos eles publicados pelo Lagos Weekly Record. Embora estes escritos tratassem de assuntos que se diferenciavam entre si, é possível perceber três características predominantes na maioria dos textos de Moisés.

A primeira delas está relacionada à exposição da erudição do autor. Ao construir um conjunto de argumentos em favor de uma posição política

\footnotetext{
${ }^{520}$ BROWN, William Wells. The American Fugitive in Europe: Sketches of Places and people abroad. With a memoir of the author. Boston/New York: John P. Jewett and Company/ Sheldon, Lamport \& Blackeman, 1855, pp.265-266. Com base nos registros de Brown a respeito de sua visita à Edimburgo, Paul Gilroy compara as experiências do então aluno de medicina, matriculado na universidade norte-americana de Harvard, Martin Robison Delany. Segundo o autor, Delany enfrentou situações muito mais desfavoráveis do que os estudantes da escola de medicina escocesa. GILROY, Paul. O Atlântico negro: modernidade e dupla consciência. São Paulo/ Rio de Janeiro: Ed. 34/ Universidade Candido Mendes, Centro de Estudos AfroAsiáticos, 2001, p.70, n. 57.

${ }^{521}$ Cf. AMÓS, Alcione Meira. Op.cit., 2007, pp.112-113. De a biografia de Sherwood, Henry Sylvester Williams estudou direito na Inglaterra, tornando-se o primeiro negro a exercer esta profissão na Cidade do Cabo, África do Sul, e um dos dois primeiros negros eleitos para integrar o conselho colonial de Westminster, Londres. SHERWOOD, Marika. Origins of PanAfricanism: Henry Sylvester Williams, Africa, and the African Diaspora. New York/London: Routledge, 2011.

${ }^{522}$ Cf. AMÓS, Alcione Meira. Op.cit., 2007, p.114.
} 
específica, Moisés da Rocha citava trechos bíblicos, comparava entre si acontecimentos semelhantes ocorridos em outras partes do mundo e fundamentava suas considerações a partir de exemplos encontrados na história. Em agosto de 1897, o primeiro artigo assinado pelo brasileiro chegou às páginas do Lagos Weekly Record. Neste texto Rocha discutia a questão racial norte-americana. Suas críticas aos linchamentos praticados contra negros residentes nos estados de Ohio e do Alabama foram acompanhadas por considerações acerca de formas discriminatórias experimentadas por outras populações residentes na Rússia, na Armênia e na Bulgária. Ao citar os trabalhos de autores dedicados ao combate da violência contra judeus, armênios e búlgaros, o brasileiro dava mostra de uma formação intelectual que extrapolava o âmbito da medicina. Expondo um amplo conhecimento acerca dos autores de seu tempo, Moisés construiu uma argumentação intertextual sobre a qual apoiava um conjunto de críticas à forma como eram tratados pela justiça norte-americana os episódios de violência contra negros residentes nos Estado Unidos. Como membro do movimento pan-africano e secretário da African Association, Moisés da Rocha parecia entender a questão racial norteamericana como uma das faces de um processo discriminatório que atingia a população negra de maneira geral, ou seja, capaz de abarcar os negros da diáspora e os do próprio continente africano, o que incluía os brasileiros. Neste sentido, uma parcela de suas considerações estava também fundamentada em sua experiência como estudante de medicina da universidade de Edimburgo. ${ }^{523}$

Em outro texto publicado seis meses após a estreia de seu primeiro artigo no periódico lagosiano, Moisés da Rocha demonstrava uma erudição que combinava um saber generalista acerca da história, literatura e política mundiais, com seu conhecimento psíquico, aprendido no curso de ciências médicas. Com o título "Caráter, um fenômeno psíquico", Moisés construiu um conjunto de contra-argumentos que colocavam em questão a etnologia racista de sua época. Assumindo um tom de denúncia contra as "atrocidades cometidas no Congo, no árido e arenoso Sudão, na Matabeleland e em Mashonaland [as duas últimas situada no atual Zimbábue] em nome da

523 The Lagos Weekly Record, 21 de agosto de 1897, World Newspaper Archive, African Newspapers, $1883-1888$. 
civilização", o brasileiro criticava a atuação de exploradores europeus que deixavam de observar "os mandamentos ditados a Moisés no Monte Sinai", para se tornarem "incultos e pagãos". Nestes casos, apesar de tais exploradores anunciarem serem portadores das "mais nobres motivações" em relação às populações residentes nos territórios percorridos, uma vez em viagem pelo continente africano, eles logo se tornavam "cruéis e valentões nas regiões em que 'costumes bárbaros' prevaleciam". 524

Ao equiparar o comportamento de exploradores europeus aos das populações africanas classificadas como "bárbaras", Rocha procurava desconstruir o discurso que validava o uso da violência como recurso civilizatório. No entanto, como é possível notar a partir dos textos deixados pelo brasileiro, a atuação de exploradores britânicos é representada como descolada dos direcionamentos fornecidos pelo Foreign Office. Em outras palavras, para Moisés da Rocha, a forma como estes britânicos operavam suas incursões pelo rio Níger era resultado de ações individuais e não de uma orientação proveniente de instâncias superiores do governo da Grã-Bretanha. Esta perspectiva permitia ao brasileiro tecer agudas críticas à violência promovida por exploradores sem, porém, se dirigir diretamente ao Foreign Office ou ao Colonial Office. Este aspecto remete à segunda característica presente nos escritos de Moisés da Rocha: o apoio a algumas das ações "civilizatórias" britânicas promovidas em suas colônias. ${ }^{525}$

No artigo em que Rocha tece comentários ao fato dos "linchamentos terem se tornado comuns na América" é evidente o apoio do brasileiro à atuação do governo colonial britânico no continente africano. Para ele, os linchamentos ocorridos nos Estados Unidos demonstrariam que os norteamericanos não eram uma "nação progressista", tal como anunciavam suas lideranças políticas. Conforme o autor, a resposta à situação de exacerbação da violência contra a população negra estava do outro lado do Atlântico, na Inglaterra. Afinal, embora a antiga metrópole dos Estados Unidos fosse

\footnotetext{
${ }^{524}$ No original os exploradores europeus são adjetivados como "cut-throats", traduzido livremente por mim como "cruéis". Este termo, no entanto, pode assumir outros significados, sendo um deles o de "degolador".

525 The Lagos Weekly Record, 5 de fevereiro de 1898, World Newspaper Archive, African Newspapers, 1883 - 1888.
} 
responsável pela introdução da escravidão em suas colônias, foi também a Grã-Bretanha quem iniciou os movimentos humanitários que colocaram termo ao tráfico atlântico de escravos. De acordo com Moisés, esta ruptura em relação ao comércio escravista havia provocado uma guinada "moral" entre os britânicos e, em razão disto, o brasileiro recomendava à população branca norte-americana maior "atenção ao mundo civilizado". ${ }^{526}$ Ao sugerir que as agressões contra negros colocavam os Estados Unidos entre as nações não civilizadas, o brasileiro fazia uso de um suporte discursivo elaborado no interior do universo branco e colonizador.

De certo modo Moisés da Rocha personificava o sucesso das ações "civilizatórias" empreendidas pela Grã-Bretanha. Durante os anos em que viveu em Lagos ele passou pelas quatro principais instituições de educação formal da cidade: a Wesleyan Tinubu School, a Faji School, a St. Xavier Catholic School e a St. Gregory's Grammar School. Conforme informa Amós, no ensino secundário se tornou editor do jornal estudantil The Grammarian e, no ano de 1893, concluiu o curso secundário como primeiro aluno da turma. ${ }^{527}$ A brilhante trajetória escolar iniciada quando ainda vivia na colônia britânica, certamente contribuiu para seu ingresso na faculdade de medicina em Edimburgo. Era desta cidade escocesa que Rocha escrevia e enviava os textos que seriam publicados em diversos periódicos, dentre os quais no Lagos Weekly Record. Nestas cartas e artigos o brasileiro expressava abertamente seu posicionamento político em relação às transformações operadas pelos britânicos em suas colônias.

Em um longo artigo acerca do "covarde e indefensável [...] massacre da expedição do cônsul Phillips" - em referência, ao vice-cônsul britânico James Robert Phillips - promovido por forças benins, Moisés da Rocha expunha sua opinião em relação ao que considerava uma "verdadeira metamorfose" realizada nas áreas dominadas pelos ingleses. Embora reconhecesse que a conquista da cidade do Benim faria desaparecer o "último estado independente da África ocidental", o brasileiro considerava ser uma espécie de "consolo" os

\footnotetext{
526 The Lagos Weekly Record, 21 de agosto de 1897, World Newspaper Archive, African Newspapers, 1883 - 1888.

${ }^{527}$ AMÓS, Alcione Meira. Op.cit., 2007, p.113.
} 
"benefícios" que acompanhariam a colonização promovida pelos britânicos. Neste sentido, a incursão das forças da Grã-Bretanha por territórios ainda não tocados "pela benigna influência das ideias ocidentais" deveria acontecer de maneira "pacífica". Em razão disto, o texto de Rocha questionava a política adotada pelo Colonial Office de "limpar o campo antes de semear". Dito em outros termos, de exilar chefias africanas oponentes após a conquista imperial de seus territórios. Este excerto do artigo expunha os limites do apoio conferido por Moisés da Rocha à atuação colonizadora britânica na região do Protetorado da Costa do Níger, o qual havia se estabelecido há apenas quatro anos, em 1893. Definindo seu texto como "a expressão da opinião de um nativo", o brasileiro expôs o terceiro, e último, elemento caracterizador de suas produções impressas nos jornais lagosianos: a auto-representação como africano nativo. ${ }^{528}$

Embora este seja o único artigo encontrado em que Moisés da Rocha declara abertamente sua posição de "nativo", é possível entrever formas de representação semelhantes em outros textos publicados pelo autor. Em julho de 1899, Rocha enviou ao Lagos Weekly Record uma carta em que anunciava sua participação em uma comissão internacional denominada como Bureau International Permanent de la Paix, cuja sede se localizava em Turim, na Itália. De acordo com esta correspondência, o grupo tinha a função de discutir os "massacres cometidos por tropas europeias" contra "hordas mal armadas e [contra] as chamadas raças inferiores". Neste sentido, o brasileiro expunha a razão pela qual foi chamado a integrar a referida comissão. Rocha era um africano e, como tal, seu discurso possuía, de antemão, a legitimidade necessária às análises que seriam produzidas pelo grupo. Além deste aspecto, Moisés apresentava uma formação acadêmica que o habilitava a compreender e a dialogar com as representações europeias elaboradas sobre o continente africano. Estes dois elementos permitiriam ao brasileiro analisar as "políticas coloniais" promovidas na África a partir de uma perspectiva bastante

\footnotetext{
528 The Lagos Weekly Record, 09 de outubro de 1897, World Newspaper Archive, African
} Newspapers, 1883 - 1888. 
específica: a de "nativo" africano que representa a si mesmo a partir da gramática do colonizador. ${ }^{529}$

Ao se comprometer com os termos do colonizador, Moisés da Rocha escreveu um conjunto de textos que constitui a expressão do que Mary Louise Pratt denomina "auto-etnografia". Em sua análise acerca das narrativas elaboradas por indivíduos que, no século XVIII, pertenciam às colônias espanholas nas Américas, Pratt propõe o uso do termo "auto-etnografia" para definir as produções que, embora escritas por indivíduos nascidos em territórios colonizados, construíram suas reflexões a partir da "apropriação do léxico do conquistador". Como registros produzidos a partir do contato com o colonizador - ou para empregar a expressão da autora, elaborados nas "zonas de contato" entre colonizador e colonizado - os textos auto-etnográficos eram, muitas vezes, formulados em "diálogo com as representações metropolitanas". ${ }^{530}$ Desta forma, apesar do lócus de produção destes documentos ser o universo colonial, é possível notar os limites existentes nas representações comprometidas com uma gramática colonial. Este é um dos motivos que explicaria porque Rocha elabora duras críticas à violência adotada pelas investidas das forças britânicas na conquista da cidade do Benim e, ao mesmo tempo, considera a instalação do estado colonial como capaz de operar uma "verdadeira metamorfose" nos territórios sob seu comando. Ou porque ao denunciar os linchamentos promovidos contra negros nos Estados Unidos, o brasileiro se reporte à atuação britânica no combate ao tráfico. Ao retomar as ações pregressas dos movimentos humanitários britânicos como uma evidência de que, na Inglaterra, a questão racial já estava resolvida, Moisés da Rocha formulava uma argumentação que selecionava quais seriam os alvos de suas críticas. Ao se expor como um africano nativo Rocha deixava em segundo plano sua identidade brasileira. Afinal neste momento, ser brasileiro não the permitiria um posicionamento político tão contundente quanto ser africano. Este episódio se mostra emblemático desta identidade brasileira cambiante, cujos sentidos de pertencimento eram acrescentados ou, como neste caso

529 The Lagos Weekly Record, 01 de julho de 1899, World Newspaper Archive, African Newspapers, 1883 - 1888.

530 PRATT, Mary Louise. Os olhos do império: relatos de viagem e transculturação. Trad. Jézio Hernani Bonfim Gutierre, Bauru: EDUSC, 1999.p.33. 
específico, sobrepostos a outras identidades associadas a um universo de pertencimento múltiplo. ${ }^{531}$

No final do século XIX, Rocha não era o único africano nascido em Lagos cujos escritos revelavam um posicionamento atrelado a alguns pressupostos formulados pelo colonizador. Segundo Nara França, neste período e nas duas primeiras décadas do século $X X$, debates impressos em livros, panfletos e jornais produzidos em Lagos adotavam discursos que ajudaram a compor uma produção intelectual lagosiana bastante heterogênea. Para a historiadora, embora o termo "intelectual" não fosse comum entre os escritores, aqueles considerados como pertencentes a este grupo eram parte de uma rede de indivíduos ligada aos processos de publicação, como: editores, gráficos e vendedores de livros. Muitos dos autores de livros e dos escritores de artigos para jornais atuavam também como proprietários e editores de periódicos, empregados em estabelecimentos de impressão ou livreiros. ${ }^{532}$ Para outra pesquisadora dedicada a entender o papel desempenhado pelos jornais na segunda metade do século XIX, Nzomi Sawada, tais veículos de comunicação teriam contribuído para a construção de narrativas históricas formuladas pelos próprios lagosianos. ${ }^{533}$

Embora estas produções fossem elaboradas a partir das representações constituídas pelo colonizador, é possível reconhecer que artigos escritos por Moisés da Rocha desferiam duras críticas a determinados aspectos do colonialismo britânico. Ao deixar à mostra algumas das fissuras da estrutura de dominação colonial, Rocha expunha os meandros da complexa relação entre colonos lagosianos e colonizadores britânicos. Além deste aspecto, os textos impressos na forma de livros ou como artigos para jornais não disseminavam apenas a narrativa constituída pela parcela alfabetizada da população de Lagos. A circulação destes escritos também tornava públicas as pessoas que assinavam seus textos. Isto explica as notas relativas à vida pessoal de Moisés da Rocha impressas pelo Lagos Weekly Record durante o período em que vivia

\footnotetext{
${ }^{531}$ Refiro-me aos artigos do The Lagos Weekly Record assinados por Moisés da Rocha nas seguintes datas, respectivamente: 09 de outubro de 1897 e 21 de agosto de 1897.

${ }^{532}$ FRANÇA, Nara Muniz Improta. Producing Intellectuals: Lagosian Books and Pamphlets between 1874 and 1922. Tese de doutorado. Sussex/UK: University of Sussex, 2013.pp.3-4.

${ }^{533}$ SAWADA, Nozomi. Op.cit., 2011, pp.9-17.
} 
em Edimburgo. Como um indivíduo cujas ideias eram públicas em função da divulgação proporcionada pela imprensa lagosiana, Rocha se tornou uma figura emblemática da comunidade brasileira instalada na cidade. Ao considerar que ele personificava um dos posicionamentos políticos possíveis entre a população brasileira, procurei na última parte desta tese retomar a ideia inicial de que os sentidos de ser brasileiro em Lagos passaram por amplos e profundos processos de redefinição ao longo do século XIX. Como vimos, as identidades dos brasileiros de Lagos se reformularam a partir de contextos históricos específicos e, em razão disto, em resposta a processos dialógicos e de disputas que a caracterizaram como identidades cambiantes.

Enfatizo que embora grupos de leitura e de discussão permitissem o acesso de brasileiros não alfabetizados em língua inglesa ao conteúdo dos jornais, percebo que a maioria dos textos impressos nestes periódicos se referia a acontecimentos e ideias associadas à elite econômica brasileira existente na cidade. Em outras palavras, eram raros os artigos publicados que assinalavam a participação de populares na sociedade lagosiana da segunda metade do século XIX. Os programas de comemoração em torno dos jubileus de ouro (1887) e de diamantes (1897) da rainha Victoria - publicados pelo Lagos Observer e pelo Lagos Weekly Record, respectivamente - são os dois principais registros que marcam a presença maciça de brasileiros, inclusive dos mais pobres.

Este aspecto se apresenta de maneira mais evidente nas referências à parte pública das celebrações. Nestas ocasiões brasileiros pobres e ricos desfilaram pelas ruas centrais da cidade. Ao portarem bandeiras de devoções católicas e entoarem canções em língua portuguesa, estes indivíduos ativavam pública e coletivamente alguns dos componentes de uma identidade plural e cambiante. Todavia, no programa de festejos em honra à rainha Victoria havia limites à participação popular e os periódicos analisados não deixaram escapar este aspecto. Banquetes e algumas solenidades específicas eram reservados apenas aos convidados, ou seja, aos britânicos que integravam a administração colonial, às chefias locais e aos saros e brasileiros mais ricos. Neste sentido, ao conferirem visibilidade à parcela escolarizada e economicamente privilegiada dos brasileiros, os jornais de Lagos ajudaram a 
compor um conjunto de representações que, com o tempo, se tornaram associadas à totalidade dos indivíduos existentes na cidade. Silenciando as assimetrias sociais, políticas e econômicas presentes, os jornais contribuíram para a elaboração da ideia de que o tecido conjuntivo responsável por atar os brasileiros uns aos outros era uma identidade comum. Contudo, as identidades brasileiras foram múltiplas e variáveis. Construídas em resposta a conjunturas históricas específicas, estas identidades se tornaram ainda mais complexas quando, nas décadas de 1880 e 1890, a política colonial britânica promoveu um conjunto de ações que redefiniram o lugar de seus indivíduos na sociedade lagosiana. 
Toda identidade humana é construída e histórica $(. . .)^{534}$

A ideia de que os brasileiros estabelecidos em Lagos elaboraram identidades cambiantes que se reformularam em resposta aos contextos apresentados ao longo do período de 1840 a 1900, se tornou o ponto a partir do qual esta tese se desenvolveu. Este pressuposto estava vinculado à proposta central de compreender quais foram os contextos em que os brasileiros de Lagos tiveram de ressignificar e atualizar os signos responsáveis por conferir identificação aos integrantes de seu grupo.

Narrativas de viagem, relatórios produzidos por oficiais e funcionários britânicos e artigos publicados em periódicos mantidos por associações científicas inglesas se mostraram fontes relevantes ao entendimento de que as formas de representação dos brasileiros nestes documentos estavam diretamente associadas aos interesses colonialistas britânicos na Costa da Mina. Na segunda metade da década de 1840, os relatos escritos por John Duncan e Frederick Forbes se referem, quase em exclusivo, aos negreiros existentes na região. De certa maneira, a generalização dos brasileiros como traficantes conferiu sustentação aos discursos de combate ao comércio atlântico de escravizados que se mostravam favoráveis às intervenções armadas nos pontos de tráfico conhecidos.

Quase duas décadas mais tarde, em 1864, Richard Francis Burton também registrou a presença de brasileiros-traficantes em portos situados na Costa da Mina. No entanto, as descrições deixadas pelo então cônsul dos Golfos do Benim e de Biafra davam conta do sucesso das operações executadas pelo Esquadrão Africano na região. Afinal, na primeira metade da década de 1860 os negreiros ainda existentes naquela porção da costa estavam empobrecidos ou haviam transferido seus negócios ao comércio lícito

\footnotetext{
${ }_{534}$ APPIAH, Kwame Anthony. Na casa de meu pai: a África na filosofia da cultura. Tradução Vera Ribeiro. Rio de Janeiro: Contraponto, 1997, p.243.
} 
de dendê. Num contexto em que representantes das firmas comerciais de Manchester, Liverpool e Londres pressionavam o Parlamento britânico pelo acesso regular e direto às safras exportáveis de dendê e de algodão, que eram produzidas em áreas afastadas da costa, a narrativa de Burton forneceu apoio ao discurso de que o próximo passo à dominação colonialista deveria se dirigir ao interior.

Os argumentos em defesa da expansão da atuação britânica para áreas cada vez mais distantes da cidade de Lagos estavam também ligados à preocupação do Colonial Office em relação às disputas por estes territórios com outros países europeus. Apenas três anos antes de Burton publicar sua obra acerca da expedição em que foi ao encontro com Gelele, no Daomé, o afro-jamaicano Robert Campbell havia firmado junto ao alake de Abeokuta, Okukenu, um tratado para o estabelecimento de libertos norte-americanos em seus domínios. Este acordo foi visto com apreensão pelo governo britânico e, embora tenha sido desfeito, serviu como um sinal de alerta ao Foreign Office, cujo secretário à época era John Russell.

Ainda que Robert Campbell não tenha concretizado seu intento, suas experiências ficaram registradas em um relato de viagem publicado no ano de 1861. Neste documento os brasileiros não foram representados como traficantes. Na narrativa de Campbell os brasileiros eram "industriosos" e "empreendedores", donos de habilidades que haviam contribuído para a realização de um "trabalho gigantesco" na cidade de Lagos. Enquanto, por um lado, Robert Campbell colocava os brasileiros numa posição de inferioridade quando comparava suas habilidades de trabalho às dos libertos provenientes dos Estados Unidos - pois, para o afro-jamaicano, estes últimos seriam mais aptos a dar continuidade ao trabalho já iniciado pelos indivíduos vindos do Brasil - por outro, seus escritos constituem uma das primeiras referências que descolaram a representação dos brasileiros do comércio escravista. ${ }^{535}$

A ideia de que os brasileiros dominavam técnicas agrícolas e detinham certas habilidades de trabalho em razão de sua passagem pela escravidão,

\footnotetext{
${ }^{535}$ CAMPBELL, Robert. A Pilgrimage to my motherland, an account of a journey among the egbas and yorubas of Central Africa, in 1859-1860. New York: Thomas Hamilton, 1861, p.73.
} 
aparece em muitas das narrativas consultadas. No entanto, havia nuanças nas formas de representação desta percepção. Como vimos, para o governador de Lagos, Cornelius Alfred Moloney, a mão de obra procedente do Brasil seria a resposta ao problema do déficit de lavradores necessários às plantações de algodão e às atividades de extração do óleo de dendê. No final da década de 1880, a demanda das firmas europeias por estas mercadorias era crescente e a produção não acompanhava a ampliação do consumo. Além disto, desde 1886 Lagos havia recobrado sua autonomia administrativa, deixando de fazer parte da jurisdição da Costa do Ouro. Este contexto se mostrava favorável à aposta de Moloney na transferência de "repatriados do Brasil" para as lavouras da colônia e protetorado de Lagos.

Representados como um ponto de partida ao desenvolvimento de regiões mais afastadas de Lagos, os brasileiros se tornaram um elemento importante do discurso colonialista em defesa da interiorização da "civilização". Na segunda metade dos anos de 1880, o governo britânico de Lagos buscava ampliar a atividade comercial exportadora, a fim de obter ganhos suficientes à manutenção do novo aparelho burocrático constituído à parte da jurisdição de outras colônias da Grã-Bretanha na Costa da Mina. Além deste aspecto, havia ainda a pressão de companhias europeias instaladas no porto lagosiano pelo aumento na produção de mercadorias que seriam comercializadas no mercado internacional. Neste sentido, ao adotar uma retórica que desqualificava a mão de obra existente nas cidades produtoras de óleo de dendê, algodão, amendoim e borracha, Moloney incorporava "o esforço, inteligência e caráter" dos "emancipados do Brasil" como parte dos argumentos em favor da expansão da colônia de Lagos por áreas, até aquele momento, consideradas apenas parte do protetorado britânico.

Esta associação à "civilização" é uma das várias versões da identidade brasileira em Lagos. Como procurei demonstrar ao longo desta tese, o aspecto plural desta identidade derivou de um processo duradouro em que os sentidos de ser brasileiro se redefiniram em função de trocas e disputas estabelecidas em contextos específicos. Neste sentido, as reflexões aqui desenvolvidas tiveram o intuito de demonstrar como as diferentes formas de expressão destas identidades se vincularam ao lugar político, social e econômico ocupado por 
seus indivíduos ao longo do período estudado. Como vimos, até meados da década de 1850 , os brasileiros-traficantes desfrutavam de certa proximidade em relação ao poder político lagosiano. A pequena cidade insular, utilizada como ponto de apoio ao tráfico até meados do século XVIII, viu seu papel no comércio escravista se alterar a partir de 1760, quando Akinsemoyin se tornou obá. Uma vez no poder, Akinsemoyin permitiu que João de Oliveira e outros negreiros brasileiros ali estabelecessem suas atividades. Nas décadas seguintes Lagos experimentou um progressivo aumento destas atividades ligadas ao mercado atlântico de escravizados. Em 1821, seu porto já era o principal embarcadouro de escravos da Costa da Mina. Sem dúvida, a presença dos brasileiros foi essencial ao alcance desta posição. $O$ comércio escravista movimentava a economia da cidade e, como uma de suas consequências, ajudava a sustentar os obás que se sucediam no mando.

As fontes analisadas por esta pesquisa sugerem que 0 apoio de negreiros como Domingos José Martins e Marcos Borges Ferras se tornou um componente relevante em meio às disputas iniciadas em 1834 pela posição de obá. Os conflitos entre Akitoye e Kosoko em torno do mando de Lagos tiveram como desdobramento duas grandes mudanças na forma como estava organizado o poder político exercido pelos grandes negreiros existentes na cidade. A primeira delas se refere ao bombardeio executado pela armada da rainha Victoria sobre Lagos, a deposição de Kosoko, seu exílio na cidade de Epe e a retomada do mando por Akitoye. Com o auxílio das forças da GrãBretanha, o antigo obá - Akitoye - recobrou seu lugar em Lagos. No entanto, não tardou para que os aliados britânicos cobrassem por este feito. Logo após retornar ao igá, o recém-instalado obá firmou um acordo em que se comprometia a expulsar todos os traficantes que haviam permanecido na cidade. Embora seja certo que a maior parte dos negreiros que viviam sob a proteção de Kosoko havia seguido o obá destituído até Epe, correspondências de governadores britânicos estabelecidos no porto lagosiano dão conta da permanência de alguns comerciantes de escravos na cidade.

A tomada de Lagos constituiu um importante marco no processo de afastamento dos brasileiros-traficantes do poder político da cidade. Em um momento em que o comércio atlântico de escravizados era inviabilizado pela 
vigilância do Esquadrão Africano, pela tomada de Lagos e pela assinatura de tratados antitráfico com as cidades de Porto Novo, Badagri, Abeokuta e ljebu Ode, restava a estes brasileiros a transferência de seus negócios para o comércio de bens lícitos. Esta situação estava relacionada à segunda grande mudança operada neste contexto: a inserção dos brasileiros como intermediários nas negociações entre cidades produtoras situadas no interior e companhias europeias instaladas em Lagos. $O$ decréscimo e posterior extinção das atividades ligadas ao tráfico atlântico ampliaram o número de brasileiros que negociavam alimentos, dendê, algodão, marfim e, com o tempo, também amendoim e borracha, que eram produzidas em localidades afastadas do litoral. Estas mercadorias chegavam até a costa por meio de intermediários, em sua maioria saros e brasileiros, que tinham acesso às rotas que ligavam Lagos às principais cidades fornecedoras destes artigos: Abeokuta, Ibadan, Oió e ljebu Ode.

De maneira geral, durante dez anos (de 1851 a 1861), os brasileiros que concentraram suas atividades no comércio atlântico de bens lícitos, e aqueles que se dedicaram à intermediação comercial entre produtores e firmas exportadoras, desfrutaram do vigor de seus negócios. Neste sentido, embora afastados do poder político em razão do estabelecimento do protetorado de Lagos, os brasileiros comerciantes ainda mantinham uma posição econômica proeminente. Esta situação se modificou a partir de 1861, quando um tratado assinado por Docemo transformou Lagos em mais uma colônia da GrãBretanha. A forma como o documento de cessão dos domínios de Docemo foi apresentado constituiu um dos marcos na escalada da violência sobre a região.

Como se viu, a tomada de Lagos pela armada da Grã-Bretanha em 1861 iniciou um processo de penetração colonizadora que adquiriu maior intensidade a partir da década de 1880. Este momento foi caracterizado por ações de "pacificação" dos conflitos existentes na região. Com o argumento de que os embates entre as cidades do interior se estendiam por anos e que tais contendas desorganizavam a produção, fechavam as rotas de abastecimento e prejudicavam o comércio exportador, o então governador de Lagos, Gilbert Carter, promoveu uma série de ataques às cidades envolvidas nas guerras de Ekitiparapo e de ljaye. A "pacificação" conquistada por meio da violência das 
tropas haussás, treinadas e lideradas por oficiais britânicos, permitiu que em 1895 se iniciassem as obras de construção de uma linha ferroviária até a cidade de Kano. Sob a retórica de interiorização da "civilização" Carter favorecia as grandes companhias exportadoras, cujos interesses estavam no acesso direto às regiões produtoras e na consequente eliminação dos intermediários.

A penetração das firmas europeias, em sua maioria britânicas, contribuiu para um drástico estreitamento do espaço econômico ocupado pelos brasileiros que atuavam como intermediários e como atacadistas no porto lagosiano. Sem o capital necessário para poder fazer frente a estas companhias, muitos brasileiros migraram seus negócios para o comércio varejista. Para termos uma ideia acerca do que estas mudanças representaram ao comércio atacadista praticado pelos brasileiros de Lagos, até o ano de 1890 a soma dos artigos importados vindos do Brasil era sempre superior a dez mil libras. Em 1890, por exemplo, a cidade recebeu 10.756 libras em mercadorias importadas do Brasil. No sentido inverso, embora fosse em menor volume, Lagos também mantinha um ativo comércio exportador com o Brasil. Neste mesmo ano de 1890, a cidade enviou aos portos brasileiros uma quantidade de mercadorias equivalente a 4.851 libras.

Entretanto, a pujança comercial entre estes dois parceiros não se manteve nos anos seguintes. Considero 1891 o ano da viragem das relações comerciais entre Lagos e Brasil. Como as tabelas apresentadas no quarto capítulo desta tese mostraram, a partir deste momento o volume de libras movimentado em função das importações e das exportações se retraiu para menos da metade. Em 1891, a soma das importações do Brasil para Lagos atingiu apenas 5.284 libras. Embora o volume de exportações tenha se mantido equilibrado em 1891, alcançando 4.893 libras, esta situação não se repetiu nos anos seguintes. Em 1892, a soma dos bens exportados para o Brasil chegou a inacreditáveis duas libras e em 1894 a movimentação exportadora em direção aos portos brasileiros sequer foi registrada nos relatórios alfandegários britânicos. 
Mesmo com o decréscimo no volume de comércio operado entre Lagos e o Brasil, muitos brasileiros com negócios na cidade continuaram suas atividades neste setor. De modo geral, o comércio constituía um dos principais ramos profissionais associados ao pertencimento à comunidade brasileira instalada na cidade. Afastados do mercado atacadista atlântico, alguns brasileiros migraram seus negócios para o varejo. Como procurei demonstrar no quarto e quinto capítulos, alguns destes indivíduos abriram estabelecimentos e/ou ofereceram serviços orientados ao consumo dos europeus instalados na cidade. Porém, nem todos os brasileiros de Lagos tiravam seu sustento deste tipo comércio. A partir da década de 1890, as ações de interiorização da colonização britânica fizeram crescer o número de membros do funcionalismo local e, como consequência, de funcionários públicos brasileiros. Incorporados aos quadros da administração colonial, em sua maioria em postos de quinta e sexta classes, os nomes destes brasileiros foram relacionados nos relatórios anuais compilados pelos Blue Books.

Ainda que a presença de brasileiros fosse anotada nas listas do funcionalismo colonial lagosiano, os censos apresentados neste mesmo conjunto de documentos não registraram a existência desta parcela da população. Inscritos sob a denominação genérica de "coulored population" os brasileiros - e também outros grupos existentes na Lagos da segunda metade do século XIX - desapareceram em meio às grades classificatórias fornecidas pelo Colonial Office. Deste modo, como procurei sugerir, a comunidade brasileira de Lagos encontrou outras formas para se fazer presente na cidade. Nos anos de 1880 e 1890, algumas das maneiras de ser (ou se tornar) brasileiro eram colocadas em ação em cerimônias, festas e apresentações públicas. É o caso das performances realizadas por grupos de dramaturgia existentes na cidade, dos saraus em que eram entoadas canções em língua portuguesa e das cerimônias em torno dos jubileus de ouro e de diamante da rainha Victoria. Nestas ocasiões os componentes da identidade brasileira eram pública e coletivamente ativados.

Em geral, os textos impressos nos jornais de Lagos não se referiam aos momentos anteriores a estas exibições públicas. Pouco se sabe acerca dos ensaios, encontros e discussões que preparavam as apresentações teatrais 
elaboradas pela Brazilian Dramatic Company. Pode se dizer o mesmo dos arranjos que antecediam as performances realizadas pela Catholic Youth Men Association ou pelo The Orphean Club Entertainment. A despeito das limitações impostas pelas fontes, é possível inferir que era nestes momentos de preparação que os sentidos de ser brasileiro se refaziam e ganhavam diferentes significados. Dito em outros termos, era nas ocasiões que antecediam ao espetáculo, quando os integrantes do grupo se encontravam para compartilhar seu fazer artístico, que as ideias eram postas em discussão e a língua portuguesa, por exemplo, era exercitada. Nestas situações, os signos de pertencimento que atavam os indivíduos em torno de um pertencimento comum se reelaboravam.

Também nas duas últimas décadas do século XIX existiram maneiras mais individualizadas de exposição dos sentidos de ser brasileiro em Lagos. Em razão disto, selecionei um conjunto de artigos e correspondências assinadas pelo estudante de medicina, da universidade de Edimburgo: Moisés da Rocha. Os textos escritos por Rocha foram publicadas pelo jornal Lagos Weekly Record e o tornaram uma figura de destaque entre os brasileiros. Mostrando um amplo conhecimento acerca dos autores e das discussões de seu tempo, Moisés personificou alguns dos posicionamentos políticos possíveis dentro da comunidade brasileira de Lagos. Como se viu, certos artigos publicados por Moisés da Rocha atacavam determinados aspectos do colonialismo promovido pela Grã-Bretanha. Neste sentido, este brasileiro em específico expunha as fissuras da estrutura de dominação colonial, colocando em evidência as complexidades do relacionamento entre colonizadores britânicos e seus colonos.

Ao tentar entender em que contextos as identidades brasileiras tiveram de se reformular e atualizar seus signos de pertencimento, a fim de continuar conferindo significado aos indivíduos que nela se reconheciam, percebi que os anos de 1880 e 1890 foram fundamentais no processo de redefinição dos sentidos de ser brasileiro. Em 1887 e em 1897, quando grupos de brasileiros com suas vestes brancas, atravessadas por faixas azuis e douradas, tomaram as ruas centrais de Lagos em comemoração aos jubileus de ouro e de diamante da rainha Victoria, alguns dos emblemas culturais desta identidade 
comum ganharam visibilidade. Contudo, o programa de festividades dos jubileus delimitava os momentos restritos à população lagosiana em geral. Jantares e solenidades específicas estavam restritos ao alto escalão do governo colonial, ao obá e alguns de seus apoiadores e, ainda, aos saros e brasileiros enriquecidos. Como um episódio emblemático da heterogeneidade econômica e social dos brasileiros de Lagos, os jubileus de 1887 e 1897 constituem uma resposta simbólica à questão acerca do lugar destes indivíduos em meio à escalada colonizadora britânica na região. Este aspecto ressalta que as formas de pertencimento à comunidade brasileira em Lagos não foram uniformes e tampouco permanentes. Isto porque, as identidades brasileiras se constituíram a partir de diálogos, negociações e dissensos estabelecidos com o universo societário do qual eram parte e, em função disto, assumiram o aspecto de identidades cambiantes.

Como as identidades humanas são historicamente construídas, os signos de pertencimento capazes de traduzir os sentidos que envolviam ser brasileiro em Lagos na segunda metade do século XIX eram reais e revelavam uma complexa rede de disputas em torno do lugar social e político de seus indivíduos. Contrapondo-se, entre outros, aos saros, egbas, ijexas e também aos europeus, a comunidade imaginada de brasileiros em Lagos fazia parte de um fazer e refazer do pertencimento coletivo em que estavam intrinsecamente ligados ocupação, status, poder e manifestações culturais, homogeneizando uma população diversa, o que escamoteava a fragmentação e as assimetrias entre "os estabelecidos" (as elites) e os "outsiders" (a maioria da população). ${ }^{536}$

Vale lembrar que eram raros os textos dos jornais lagosianos que conferiam alguma visibilidade aos brasileiros comuns. Com o tempo, a repetição dos signos de pertencimento associados às elites brasileiras escamoteou as assimetrias sociais, políticas e econômicas existentes entre estes indivíduos. No esforço por compreender as variações dos sentidos de ser brasileiro, para além das representações evidenciadas nas narrativas e jornais analisados, percebi que as identidades "florescem [...] a despeito de terem suas raízes em mitos e mentiras". Em outras palavras, embora nem todas as

\footnotetext{
${ }^{536}$ ELIAS, Norbert \& SCOTSON, John. Os estabelecidos e os outsiders. Rio de Janeiro: Jorge
} Zahar, 2000. 
famílias brasileiras contassem com traficantes em suas origens, o envolvimento com o comércio atlântico de escravos se tornou um dos emblemas assumidos como parte das identidades. Processos semelhantes ocorreram em relação ao engajamento no comércio, à religiosidade católica, à língua portuguesa e a algumas das manifestações culturais. Longe de se tornarem rótulos limitadores - ou, no sentido proposto por Appiah, "rótulos incapacitantes" - do que significava ser brasileiro, o estudo das conjunturas em que um signo de pertencimento prevaleceu sobre outro, constituiu o caminho que encontrei para expor a variabilidade dos sentidos de pertencimento associados às identidades brasileiras cambiáveis em Lagos entre 1840 e 1900. Parafraseando Chinua Achebe, ser brasileiro tem rótulos e cada um deles "um sentido, um preço e uma responsabilidade". ${ }^{537}$

${ }^{537}$ APPIAH, Kwame Anthony. Op.cit., 1997, pp.243, 248 e 245, respectivamente. ACHEBE, Chinua. Entrevista citada por Appiah in Ibid, p.241. 


\section{APÊNDICES}


Apêndice 1: Importações para Lagos (valores em libras esterlinas) ${ }^{1}$

\begin{tabular}{|c|c|c|c|c|c|c|c|c|c|c|c|c|}
\hline & $\begin{array}{c}\text { Grã } \\
\text { Bretanha }\end{array}$ & Alemanha & Brasil & França & Zanzibar & $\begin{array}{l}\text { Porto } \\
\text { Novo }\end{array}$ & Moçambique & $\begin{array}{l}\text { Serra } \\
\text { Leoa }\end{array}$ & $\begin{array}{c}\text { Windward } \\
\text { Coast }\end{array}$ & $\begin{array}{c}\text { Estados } \\
\text { Unidos/NY } \\
\text { Chicago }\end{array}$ & $\begin{array}{c}\text { Leeward } \\
\text { Coast }\end{array}$ & Madeira \\
\hline 1863 & 110584 & 27597 & 15500 & 9034 & 2883 & 656 & - & 1457 & 1287 & - & - & 97 \\
\hline 1865 & 59126 & 13676 & 13762 & 3918 & 7606 & 3332 & 5304 & 2011 & 1861 & - & 742 & 17 \\
\hline 1866 & 128704 & 18545 & 15283 & 13623 & 5823 & 4312 & 14759 & 1445 & 3123 & 499 & 1220 & 400 \\
\hline 1867 & 197414 & 21934 & 14580 & 25045 & 23959 & 9429 & 14806 & 2665 & 4845 & 1455 & 3139 & 4 \\
\hline 1868 & 224829 & 36021 & 17853 & 6791 & 30801 & 7872 & 7819 & 2854 & 1021 & 1135 & 1352 & 66 \\
\hline 1869 & 290622 & 34183 & 29526 & 25163 & 21624 & 3748 & 5047 & 2523 & 832 & 18 & 3147 & 169 \\
\hline 1870 & 272684 & 41135 & 37026 & 13195 & 9365 & 3636 & 1741 & 3985 & 853 & - & 533 & 121 \\
\hline 1871 & 299670 & 37596 & 17134 & 6776 & 17412 & 3931 & 4938 & 2023 & 104 & - & 970 & 286 \\
\hline 1872 & 267274 & 36066 & 19249 & 11667 & 15088 & 7050 & 5917 & 1425 & 249 & - & 458 & 271 \\
\hline 1873 & 189374 & 24132 & 11901 & 7026 & 9668 & 3005 & 3852 & 1509 & 1795 & 4321 & 794 & 213 \\
\hline 1874 & 264127 & 40263 & 16763 & 6662 & 9866 & 2496 & 405 & 1514 & 1211 & 1185 & 431 & 29 \\
\hline 1875 & 230821 & 57726 & 24627 & 24492 & 8902 & 2983 & 1536 & 1610 & 3710 & - & 3026 & 284 \\
\hline 1876 & 326778 & 56455 & 33964 & 32956 & 8875 & 775 & 5409 & 1805 & 9280 & - & 418 & 89 \\
\hline 1877 & 397457 & 86573 & 50727 & 58570 & 21611 & 1245 & 9571 & 282 & 5348 & - & 1875 & 149 \\
\hline 1878 & 307945 & 88459 & 31436 & 21684 & 15195 & 1689 & 4290 & 2744 & 4228 & - & 970 & 190 \\
\hline 1879 & 271780 & 114619 & 28745 & 49642 & 26486 & 2904 & 6173 & 2222 & 3696 & 2779 & 4493 & 413 \\
\hline 1880 & 244349 & 84827 & 31580 & 14609 & 9842 & 1378 & 6054 & 2041 & 3780 & 6674 & 698 & 1170 \\
\hline 1881 & 160484 & 104340 & 27177 & 18817 & 2714 & 672 & 1972 & 1454 & 3978 & 8140 & 1308 & 1110 \\
\hline 1882 & 279978 & 99337 & 16810 & 7842 & 3600 & 1165 & - & 2194 & 7816 & 6167 & 944 & 280 \\
\hline 1883 & 314228 & 126030 & 16718 & 10015 & 3919 & 1432 & 4332 & 1023 & 5683 & 5422 & 2294 & 217 \\
\hline 1884 & 338317 & 151250 & 16978 & 6128 & 4807 & 987 & 1838 & 494 & 3950 & 5862 & 4655 & 346 \\
\hline 1885 & 292532 & - & - & - & 3997 & 1813 & 26 & 1063 & - & 1993 & - & 523 \\
\hline 1886 & 222882 & 95293 & 17761 & 6176 & 1536 & 1779 & - & 1450 & - & 2256 & - & 665 \\
\hline 1887 & 264275 & 107130 & 16737 & 5261 & - & 1440 & 950 & 1612 & - & 1541 & - & 595 \\
\hline 1888 & 291562 & 124311 & 9930 & 1028 & - & 2177 & - & 900 & - & 1314 & - & 397 \\
\hline 1889 & 307045 & 126138 & 10572 & 3445 & - & 7106 & 554 & 823 & - & - & - & 427 \\
\hline
\end{tabular}

${ }^{1}$ Os relatórios anuais publicados pelos Blue Books apontam a existência de um número maior de parceiros comerciais na Europa, Américas e na África. Selecionei aqui apenas os doze parceiros com os quais Lagos movimentava as maiores somas de libras esterlinas. 
Apêndice 1: Importações para Lagos (valores em libras esterlinas - continuação)

\begin{tabular}{|c|c|c|c|c|c|c|c|c|c|c|c|c|}
\hline & $\begin{array}{l}\text { Grã } \\
\text { Bretanha }\end{array}$ & Alemanha & Brasil & França & Zanzibar & $\begin{array}{l}\text { Porto } \\
\text { Novo }\end{array}$ & Moçambique & $\begin{array}{l}\text { Serra } \\
\text { Leoa }\end{array}$ & $\begin{array}{l}\text { Windward } \\
\text { Coast }\end{array}$ & $\begin{array}{l}\text { Estados } \\
\text { Unidos/NY } \\
\text { Chicago }\end{array}$ & $\begin{array}{l}\text { Leeward } \\
\text { Coast }\end{array}$ & Madeira \\
\hline 1890 & 336714 & 130563 & 10756 & 4112 & - & 7874 & - & 811 & - & - & - & 277 \\
\hline 1891 & 4353388 & 145725 & 5284 & 2188 & - & 5999 & 1202 & 1863 & - & - & - & 316 \\
\hline 1892 & 323565 & 149001 & 5583 & 12392 & - & 11632 & - & 2137 & - & 794 & - & 256 \\
\hline 1893 & 525287 & 176186 & 6170 & 6550 & - & 3903 & - & 3004 & - & 1350 & - & 483 \\
\hline 1894 & 486895 & 211865 & 4131 & 2339 & - & 5321 & - & 1716 & - & - & - & 264 \\
\hline 1895 & 605463 & 175668 & 4830 & - & - & 2081 & - & 2593 & - & 14 & - & 29 \\
\hline 1896 & 667800 & 184483 & 4502 & 75 & - & 4797 & - & 1933 & - & - & - & 46 \\
\hline 1897 & 574937 & 145335 & 5575 & 327 & - & 5181 & - & 3192 & - & - & - & 92 \\
\hline 1898 & 723650 & 123320 & 5173 & - & - & 2358 & - & 5712 & - & 16 & - & - \\
\hline 1899 & 788580 & 112746 & 2572 & 405 & - & 898 & - & 1164 & - & 6591 & - & 71 \\
\hline 1900 & 674855 & 103260 & 2955 & - & - & 1076 & - & 1257 & - & 5288 & - & 36 \\
\hline TOTAL & 16615975 & 3411788 & 599870 & 417953 & 265579 & 130132 & 108495 & 70510 & 68650 & 64814 & 33467 & 10398 \\
\hline
\end{tabular}

Fonte: Tabela elaborada a partir dos relatórios de importação constantes nos Blue Books produzidos entre os anos de 1863 e 1900. 


\section{Apêndice 2: Mercadorias fornecidas pelo Brasil}

\begin{tabular}{|c|c|c|c|c|c|c|c|c|c|}
\hline 1863 & 1865 & 1866 & 1867 & 1668 & 1869 & 1870 & 1871 & 1872 & 1873 \\
\hline Algodão & $\begin{array}{l}\text { Açúcar } \\
\text { (refinado) }\end{array}$ & Azeite & Absinto & $\begin{array}{l}\text { Açúcar } \\
\text { (refinado) }\end{array}$ & $\begin{array}{l}\text { Açúcar } \\
\text { mascavo }\end{array}$ & $\begin{array}{l}\text { Açúcar } \\
\text { mascavo }\end{array}$ & $\begin{array}{l}\text { Açúcar } \\
\text { mascavo }\end{array}$ & $\begin{array}{l}\text { Açúcar } \\
\text { mascavo }\end{array}$ & $\begin{array}{l}\text { Açúcar } \\
\text { mascavo }\end{array}$ \\
\hline Armarinho & Algodão & $\begin{array}{l}\text { Açúcar } \\
\text { mascavo }\end{array}$ & $\begin{array}{l}\text { Açúcar } \\
\text { mascavo }\end{array}$ & $\begin{array}{l}\text { Açúcar } \\
\text { mascavo }\end{array}$ & $\begin{array}{l}\text { Açúcar } \\
\text { (refinado) }\end{array}$ & $\begin{array}{l}\text { Água } \\
\text { mineral }\end{array}$ & $\begin{array}{l}\text { Açúcar } \\
\text { (refinado) }\end{array}$ & Água mineral & Algodão \\
\hline Armas & Armarinho & Algodão & Azeite & $\begin{array}{l}\text { Algodão } \\
\text { bruto }\end{array}$ & Algodão & Algodão & $\begin{array}{l}\text { Açúcar } \\
\text { triturado }\end{array}$ & Algodão & Alho \\
\hline Café & Armas & Armarinho & Algodão & Armarinho & Armarinho & Araruta $^{2}$ & Algodão & Alho & Armarinho \\
\hline Carne & Arroz & Arroz & $\begin{array}{l}\text { Algodão } \\
\text { bruto }\end{array}$ & Armas & Arroz & Armarinho & Armarinho & Armarinho & Azeite \\
\hline $\begin{array}{l}\text { Chapéus e } \\
\text { gorros }\end{array}$ & Azeite & Bacalhau & Armarinho & Arroz & Calçados & Armas & Arroz & Arroz & Banha \\
\hline Charutos & Bacalhau & Brotos & Bacalhau & $\begin{array}{l}\text { Artigos em } \\
\text { lã }\end{array}$ & Carne & Arroz & Azeite & Azeite & Batatas \\
\hline $\begin{array}{l}\text { Contas/ } \\
\text { miçangas }\end{array}$ & Brotos & Café & Brotos & Azeite & Chá & Azeite & Café & Batatas & Café \\
\hline Ferragens & Café & Carne & Calçados & Bacalhau & $\begin{array}{l}\text { Chapéus e } \\
\text { gorros }\end{array}$ & Banha & Calçados & Café & Cal \\
\hline Genebra $^{3}$ & Carne & Chá & Carne & Banha & Confeitos & Café & Carne & Calçados & Calçados \\
\hline Joias & Chá & Charutos & Chá & Broto & Conservas & Calçados & $\begin{array}{l}\text { Cerveja } \\
\text { preta }^{4}\end{array}$ & Carne & Carne \\
\hline Louça & Charutos & $\begin{array}{l}\text { Chapéus e } \\
\text { gorros }\end{array}$ & Charutos & Café & $\begin{array}{l}\text { Contas/ } \\
\text { miçangas }\end{array}$ & Carne & $\begin{array}{l}\text { Chapéus e } \\
\text { gorros }\end{array}$ & Cauris & $\begin{array}{l}\text { Chapéus e } \\
\text { gorros }\end{array}$ \\
\hline Macarrão & Confeitos & Conservas & Confeitos & Calçados & Cutelaria & Cauris & Charutos & $\begin{array}{l}\text { Chapéus e } \\
\text { gorros }\end{array}$ & Charutos \\
\hline $\begin{array}{l}\text { Panelas de } \\
\text { ferro }\end{array}$ & $\begin{array}{l}\text { Chapéus e } \\
\text { gorros }\end{array}$ & $\begin{array}{l}\text { Contas/miçan } \\
\text { gas }\end{array}$ & $\begin{array}{l}\text { Contas/ } \\
\text { miçangas }\end{array}$ & Carne & Enxofre & Chá & Conservas & Charutos & Cigarros \\
\hline Pão & $\begin{array}{l}\text { Contas/ } \\
\text { miçangas }\end{array}$ & Couro & Macarrão & Chá & Farinha & Charutos & $\begin{array}{l}\text { Contas/ } \\
\text { miçangas }\end{array}$ & Confeitos & Confeitos \\
\hline
\end{tabular}

${ }^{2}$ A araruta é uma planta endêmica da América do Sul. Sua raiz se assemelha à da mandioca.

${ }^{3}$ Genebra é um tipo de bebida alcoólica feita a partir do zimbro, esta planta serve também como base para elaboração do gim.

${ }^{4}$ No relatório de importações este tipo de cerveja aparece como "Porter's Ale". 
Apêndice 2: Mercadorias fornecidas pelo Brasil (continuação)

\begin{tabular}{|c|c|c|c|c|c|c|c|c|c|}
\hline 1863 & 1865 & 1866 & 1867 & 1668 & 1869 & 1870 & 1871 & 1872 & 1873 \\
\hline Pregos & Conservas & Cutelaria & Melaço & & & Confeitos & Farinha & Conservas & Conservas \\
\hline Remédios & Cutelaria & Ferragens & Pão & $\begin{array}{l}\text { Chapéus e } \\
\text { gorros }\end{array}$ & $\begin{array}{l}\text { Guarda- } \\
\text { chuva }\end{array}$ & Conservas & Feijão & $\begin{array}{l}\text { Contas/ } \\
\text { miçangas }\end{array}$ & $\begin{array}{l}\text { Contas/ } \\
\text { miçangas }\end{array}$ \\
\hline $\begin{array}{l}\text { Tamancos } \\
\text { de madeira }\end{array}$ & Ferragens & Frutas & Papelaria & Charutos & Genebra & $\begin{array}{l}\text { Contas/ } \\
\text { miçangas }\end{array}$ & Ferragens & Ferragens & $\begin{array}{l}\text { Farinha de } \\
\text { mandioca }\end{array}$ \\
\hline Vestuário & Frutas & Genebra & Piaçava & Confeitos & Joias & Cutelaria & Fósforos & Genebra & Feijão \\
\hline Vidraria & Genebra & $\begin{array}{l}\text { Guarda- } \\
\text { chuva }\end{array}$ & Pistolas & Conservas & Manteiga & Enxofre & Frutas & $\begin{array}{l}\text { Instrumentos } \\
\text { musicais }\end{array}$ & Ferragens \\
\hline \multirow[t]{11}{*}{ Vinho } & Manteiga & Louça & Rum & Coral & Melaço & Fiambre & $\begin{array}{l}\text { Guarda- } \\
\text { chuva }\end{array}$ & Madeira & Genebra \\
\hline & Melaço & Macarrão & $\begin{array}{l}\text { Tamancos } \\
\text { de madeira }\end{array}$ & Cutelaria & Pão & $\begin{array}{l}\text { Guarda- } \\
\text { chuva }\end{array}$ & $\begin{array}{l}\text { Instrumento } \\
\text { s musicais }\end{array}$ & Móveis & Pão \\
\hline & Móveis & Pão & Tapioca & $\begin{array}{l}\text { Farinha de } \\
\text { mandioca }\end{array}$ & Peixe & Licor & Lâmpadas & Papelaria & Peixe \\
\hline & Queijo & Papelaria & Temperos & $\begin{array}{l}\text { Frutas } \\
\text { secas }\end{array}$ & Pistolas & Manteiga & $\begin{array}{l}\text { Lâmpada a } \\
\text { óleo }\end{array}$ & Peixe & Linguiça \\
\hline & Pão & Sardinhas & & Genebra & Relógios & Melaço & Móveis & Remédios & Móveis \\
\hline & $\begin{array}{l}\text { Picles e } \\
\text { molhos }\end{array}$ & Tabaco & & $\begin{array}{l}\text { Guarda- } \\
\text { chuva }\end{array}$ & Remédios & Pão & Pão & Rum & Papelaria \\
\hline & Pistolas & $\begin{array}{l}\text { Tamancos } \\
\text { de madeira }\end{array}$ & & $\begin{array}{l}\text { Lâmpada a } \\
\text { óleo }\end{array}$ & Rum & Papelaria & Papelaria & Sabão & Pregos \\
\hline & Pólvora & Temperos & & Macarrão & & Peixe & Peixe & Tabaco & Velas \\
\hline & Pregos & Velas & & Manteiga & Vestuário & Remédios & Perfumaria & $\begin{array}{l}\text { Tábuas e } \\
\text { arruelas para } \\
\text { barril }\end{array}$ & Vestuário \\
\hline & Remédios & Vidraria & & Maquinaria & $\begin{array}{l}\text { Utensílios } \\
\text { de } \\
\text { cerâmica }\end{array}$ & Rum & Pistolas & Toucinho & Relógios \\
\hline & Rum & Vinagre & & Móveis & Sabão & Tabaco & Relógios & Velas & Remédios \\
\hline
\end{tabular}




\begin{tabular}{|c|c|c|c|c|c|c|c|c|c|}
\hline \multirow[t]{10}{*}{1863} & 1865 & 1866 & 1867 & 1668 & 1869 & 1870 & 1871 & 1872 & 1873 \\
\hline & Sementes & Vinho & & Pão & Tabaco & $\begin{array}{l}\text { Tamancos } \\
\text { de madeira }\end{array}$ & Remédios & Vestuário & Rum \\
\hline & Tabaco & & & Papelaria & $\begin{array}{l}\text { Tamancos } \\
\text { de madeira }\end{array}$ & Tecidos & Rum & Vidraria & Selaria \\
\hline & $\begin{array}{l}\text { Tamancos } \\
\text { de madeira }\end{array}$ & & & Peixe seco & Temperos & & Tabaco & Vinagre & Sementes \\
\hline & & & & & Vidraria & $\begin{array}{l}\text { Utensílios } \\
\text { de } \\
\text { cerâmica }\end{array}$ & & Vinho & Tabaco \\
\hline & & & & & & & & & $\begin{array}{l}\text { Utensílios } \\
\text { de } \\
\text { cerâmica }\end{array}$ \\
\hline & & & & & & & & & Verniz \\
\hline & & & & & & & & & Vidraria \\
\hline & & & & & & & & & Vinagre \\
\hline & & & & & & & & & Vinho \\
\hline
\end{tabular}

Fonte: Tabela elaborada a partir dos relatórios de importação constantes nos Blue Books produzidos entre os anos de 1863 e 1873. 
Apêndice 2: Mercadorias fornecidas pelo Brasil (continuação)

\begin{tabular}{|c|c|c|c|c|c|c|c|c|c|}
\hline 1874 & 1875 & 1876 & 1877 & 1878 & 1879 & 1880 & 1881 & 1882 & 1883 \\
\hline $\begin{array}{l}\text { Contas/ } \\
\text { miçangas }\end{array}$ & Charutos & $\begin{array}{l}\text { Açúcar } \\
\text { mascavo }\end{array}$ & $\begin{array}{l}\text { Açúcar } \\
\text { mascavo }\end{array}$ & $\begin{array}{l}\text { Açúcar } \\
\text { mascavo }\end{array}$ & $\begin{array}{l}\text { Açúcar } \\
\text { mascavo }\end{array}$ & $\begin{array}{l}\text { Açúcar } \\
\text { mascavo }\end{array}$ & $\begin{array}{l}\text { Açúcar } \\
\text { mascavo }\end{array}$ & $\begin{array}{l}\text { Açúcar } \\
\text { mascavo }\end{array}$ & $\begin{array}{l}\text { Açúcar } \\
\text { mascavo }\end{array}$ \\
\hline $\begin{array}{l}\text { Farinha de } \\
\text { mandioca }\end{array}$ & $\begin{array}{l}\text { Contas/ } \\
\text { miçangas }\end{array}$ & Algodão & Aguardente & Álcool & Algodão & Aguardente & Algodão & $\begin{array}{l}\text { Açúcar } \\
\text { refinado }\end{array}$ & Absinto \\
\hline $\begin{array}{l}\text { Farinha } \\
\text { (de trigo) }\end{array}$ & Cimento & Algodão bruto & Algodão & Algodão & Alho & Algodão & $\begin{array}{l}\text { Argolas de } \\
\text { ferro }\end{array}$ & Armarinho & Algodão \\
\hline Ferragens & Confeitos & Armarinho & $\begin{array}{l}\text { Argolas de } \\
\text { ferro }\end{array}$ & Aniagem $^{5}$ & Aniagem & $\begin{array}{l}\text { Argolas de } \\
\text { ferro }\end{array}$ & Armarinho & Armas & $\begin{array}{l}\text { Argolas de } \\
\text { ferro }\end{array}$ \\
\hline Frutas & Embarcações & Armas & Armarinho & $\begin{array}{l}\text { Argolas de } \\
\text { ferro }\end{array}$ & $\begin{array}{l}\text { Argolas } \\
\text { de ferro }\end{array}$ & Armarinho & Armas & Artigos em lã & Armarinho \\
\hline $\begin{array}{l}\text { Guarda- } \\
\text { chuva }\end{array}$ & $\begin{array}{l}\text { Farinha de } \\
\text { mandioca }\end{array}$ & Arroz & Arroz & Armarinho & Armarinho & Armas & Artigos em lã & Azeite & Azeite \\
\hline $\begin{array}{l}\text { Lâmpada a } \\
\text { óleo }\end{array}$ & $\begin{array}{l}\text { Farinha (de } \\
\text { trigo) }\end{array}$ & Café & Azeite & Armas & Armas & $\begin{array}{l}\text { Artigos em } \\
\text { lã }\end{array}$ & Azeite & Carne & Botas \\
\hline Livros & Feijão & Calçados & Café & Arroz & Artigos em lã & Azeite & Banha & $\begin{array}{l}\text { Chapéus e } \\
\text { gorros }\end{array}$ & Café \\
\hline Mel & Ferragens & Carne & Calçados & $\begin{array}{l}\text { Artigos } \\
\text { em lã }\end{array}$ & Azeite & Azulejos & Café & Charutos & Calçados \\
\hline Melaço & Frutas & Chá & Carne & Azeite & Azulejos & Charutos & Carne & Cigarros & Carne \\
\hline Móveis & Guarda-chuva & $\begin{array}{l}\text { Chapéus e } \\
\text { gorros }\end{array}$ & Cebola & Calçados & Banha & Cigarros & $\begin{array}{l}\text { Carroças e } \\
\text { carruagens }\end{array}$ & $\begin{array}{l}\text { Contas/ } \\
\text { miçangas }\end{array}$ & $\begin{array}{l}\text { Carroças e } \\
\text { carruagens }\end{array}$ \\
\hline Pão & Máquinas & Charutos & Cerveja preta & Carne & Café & Café & $\begin{array}{l}\text { Chapéus e } \\
\text { gorros }\end{array}$ & Ferragens & Charutos \\
\hline Peixe & Melaço & Confeitos & $\begin{array}{l}\text { Chapéus e } \\
\text { gorros }\end{array}$ & Chá & Calçados & Conservas & Charutos & Madeira & Cigarros \\
\hline Remédio & Móveis & $\begin{array}{l}\text { Contas/ } \\
\text { miçangas }\end{array}$ & Charutos & $\begin{array}{l}\text { Chapéus e } \\
\text { gorros }\end{array}$ & Carne & Calçados & Cigarros & Melaço & Cortiça \\
\hline Rum & Pão & Couro & Confeitos & Charutos & $\begin{array}{l}\text { Carroças e } \\
\text { carruagens }\end{array}$ & Carne & Conservas & $\begin{array}{l}\text { Peixe } \\
\text { salgado }\end{array}$ & Conservas \\
\hline
\end{tabular}

\footnotetext{
${ }^{5}$ Canvas era um tipo de tecido utilizado para velas de navio.
} 
Apêndice 2: Mercadorias fornecidas pelo Brasil (continuação)

\begin{tabular}{|c|c|c|c|c|c|c|c|c|c|}
\hline 1874 & 1875 & 1876 & 1877 & 1878 & 1879 & 1880 & 1881 & 1882 & 1883 \\
\hline Tabaco & Papelaria & Embarcações & $\begin{array}{l}\text { Contas/ } \\
\text { miçangas }\end{array}$ & Cigarros & Cerveja preta & $\begin{array}{l}\text { Cascos de } \\
\text { navios, } \\
\text { mastros e } \\
\text { navios } \\
\text { condenado } \\
\text { s }\end{array}$ & $\begin{array}{l}\text { Contas/ } \\
\text { miçangas }\end{array}$ & Potássio & $\begin{array}{l}\text { Contas/ } \\
\text { miçangas }\end{array}$ \\
\hline $\begin{array}{l}\text { Utensílios de } \\
\text { cerâmica }\end{array}$ & Peixe & $\begin{array}{l}\text { Embarcações } \\
\text { condenadas }\end{array}$ & $\begin{array}{l}\text { Farinha de } \\
\text { mandioca }\end{array}$ & Conservas & Chá & $\begin{array}{l}\text { Chapéus e } \\
\text { gorros }\end{array}$ & Ferragens & Relógios & Cutelaria \\
\hline Vestuário & Perfumaria & $\begin{array}{l}\text { Farinha de } \\
\text { mandioca }\end{array}$ & $\begin{array}{l}\text { Farinha (de } \\
\text { trigo) }\end{array}$ & $\begin{array}{l}\text { Contas/miça } \\
\text { ngas }\end{array}$ & $\begin{array}{l}\text { Chapéus e } \\
\text { gorros }\end{array}$ & $\begin{array}{l}\text { Contas/miç } \\
\text { angas }\end{array}$ & Joias & Rum & Ferragens \\
\hline Vidraria & Pistolas & $\begin{array}{l}\text { Farinha } \\
\text { (de trigo) }\end{array}$ & Feijão & $\begin{array}{l}\text { Farinha de } \\
\text { mandioca }\end{array}$ & Charutos & Enlatados & Máquinas & Sabão & $\begin{array}{l}\text { Guarda- } \\
\text { chuva }\end{array}$ \\
\hline Vinagre & Queijo & Feijão & Ferragens & $\begin{array}{l}\text { Farinha (de } \\
\text { trigo) }\end{array}$ & Cigarros & Ferragens & Melaço & Seda & $\begin{array}{l}\text { Instrumentos } \\
\text { musicais }\end{array}$ \\
\hline \multirow[t]{9}{*}{ Vinho } & Relógios & Ferragens & $\begin{array}{l}\text { Guarda- } \\
\text { chuva }\end{array}$ & Ferragens & Conservas & $\begin{array}{l}\text { Materiais } \\
\text { para } \\
\text { construção }\end{array}$ & Papelaria & $\begin{array}{l}\text { Substâncias } \\
\text { químicas e } \\
\text { drogas }\end{array}$ & Melaço \\
\hline & Remédios & Guarda-chuva & $\begin{array}{l}\text { Lâmpadas a } \\
\text { óleo }\end{array}$ & $\begin{array}{l}\text { Guarda- } \\
\text { chuva }\end{array}$ & $\begin{array}{l}\text { Contas/ } \\
\text { miçangas }\end{array}$ & $\begin{array}{l}\text { Guarda- } \\
\text { chuva }\end{array}$ & Rum & Tabaco & Móveis \\
\hline & Rum & Joias & $\begin{array}{l}\text { Macarrão e } \\
\text { aletria }\end{array}$ & Mantimentos & Cordame & $\begin{array}{l}\text { Lâmpada a } \\
\text { óleo }\end{array}$ & Tabaco & $\begin{array}{l}\text { Tapeçaria } \\
\text { estofamento }\end{array}$ & Munição \\
\hline & Sabão & $\begin{array}{l}\text { Macarrão e } \\
\text { aletria }\end{array}$ & & Máquinas & Cortiça & Livros & $\begin{array}{l}\text { Tapeçaria / } \\
\text { estofamento }\end{array}$ & $\begin{array}{l}\text { Utensílios de } \\
\text { cerâmica }\end{array}$ & Pistolas \\
\hline & Sardinha & Mantimentos & $\begin{array}{l}\text { Utensílios de } \\
\text { cerâmica }\end{array}$ & Melaço & Cutelaria & Mastros & $\begin{array}{l}\text { Utensílios de } \\
\text { cerâmica }\end{array}$ & & Potássio \\
\hline & Seda & Móveis & Mantimentos & Móveis & $\begin{array}{l}\text { Embarcaçõe } \\
\text { s e canoas }\end{array}$ & Melaço & Verniz & & Relógios \\
\hline & Tabaco & Melaço & Máquinas & Papelaria & $\begin{array}{l}\text { Farinha de } \\
\text { mandioca }\end{array}$ & $\begin{array}{l}\text { Peixe } \\
\text { salgado }\end{array}$ & Vestuário & & Rum \\
\hline & Tinta & Papelaria & Melaço & Pão & Feijão & Relógios & Vinagre & & Sabão \\
\hline & $\begin{array}{l}\text { Utensílios de } \\
\text { cerâmica }\end{array}$ & Pão & Móveis & Rebites & Ferragens & Rum & Vinho & & Seda \\
\hline
\end{tabular}


Apêndice 2: Mercadorias fornecidas pelo Brasil (continuação)

\begin{tabular}{|c|c|c|c|c|c|c|c|c|}
\hline 1874 & 1875 & 1876 & 1877 & 1878 & 1879 & 1881 & 1882 & 1883 \\
\hline & Velas & Peixe seco & Pão & Remédios & Fósforos & Sabão & & $\begin{array}{l}\text { Substâncias } \\
\text { químicas e } \\
\text { drogas }\end{array}$ \\
\hline & Vestuário & Pistolas & Peixe seco & Rum & $\begin{array}{l}\text { Guarda- } \\
\text { chuva }\end{array}$ & Sal & & Tabaco \\
\hline & Vidraria & Remédios & Pistolas & Sabão & $\begin{array}{l}\text { Lâmpadas a } \\
\text { óleo }\end{array}$ & Seda & & $\begin{array}{l}\text { Tamancos } \\
\text { de madeira }\end{array}$ \\
\hline & Vinagre & Rum & Queijo & Tabaco & Lápides & $\begin{array}{l}\text { Substância } \\
\text { s químicas } \\
\text { e drogas }\end{array}$ & & Temperos \\
\hline & Vinho & Sal & Rebites & $\begin{array}{l}\text { Tamancos } \\
\text { de madeira }\end{array}$ & Limão & Tabaco & & $\begin{array}{l}\text { Utensílios de } \\
\text { cerâmica }\end{array}$ \\
\hline & & Tabaco & & $\begin{array}{l}\text { Tapeçaria } \\
\text { /estofamento }\end{array}$ & Livros & Temperos & & Vestuário \\
\hline & & $\begin{array}{l}\text { Utensílios de } \\
\text { cerâmica }\end{array}$ & Remédios & Temperos & Máquinas & $\begin{array}{l}\text { Utensílios } \\
\text { de } \\
\text { cerâmica }\end{array}$ & & Vinagre \\
\hline & & Vestuário & Rum & $\begin{array}{l}\text { Utensílios de } \\
\text { cerâmica }\end{array}$ & Mastros & & & Vinho \\
\hline & & Vinagre & Sabão & Velas & Melaço & Vestuário & & \\
\hline & & Vinho & Sal & Vestuário & Móveis & Vinagre & & \\
\hline & & & Seda & Vinagre & Munição & Vinho & & \\
\hline & & & Tabaco & Vinho & Pão & & & \\
\hline & & & Vestuário & & Papelaria & & & \\
\hline & & & Vinagre & & $\begin{array}{l}\text { Peixe } \\
\text { salgado }\end{array}$ & & & \\
\hline & & & Vinho & & Perfumaria & & & \\
\hline & & & & & Pistolas & & & \\
\hline & & & & & Potássio & & & \\
\hline & & & & & Queijo & & & \\
\hline & & & & & Relógios & & & \\
\hline & & & & & Remédios & & & \\
\hline & & & & & Rum & & & \\
\hline
\end{tabular}


Apêndice 2: Mercadorias fornecidas pelo Brasil (continuação)

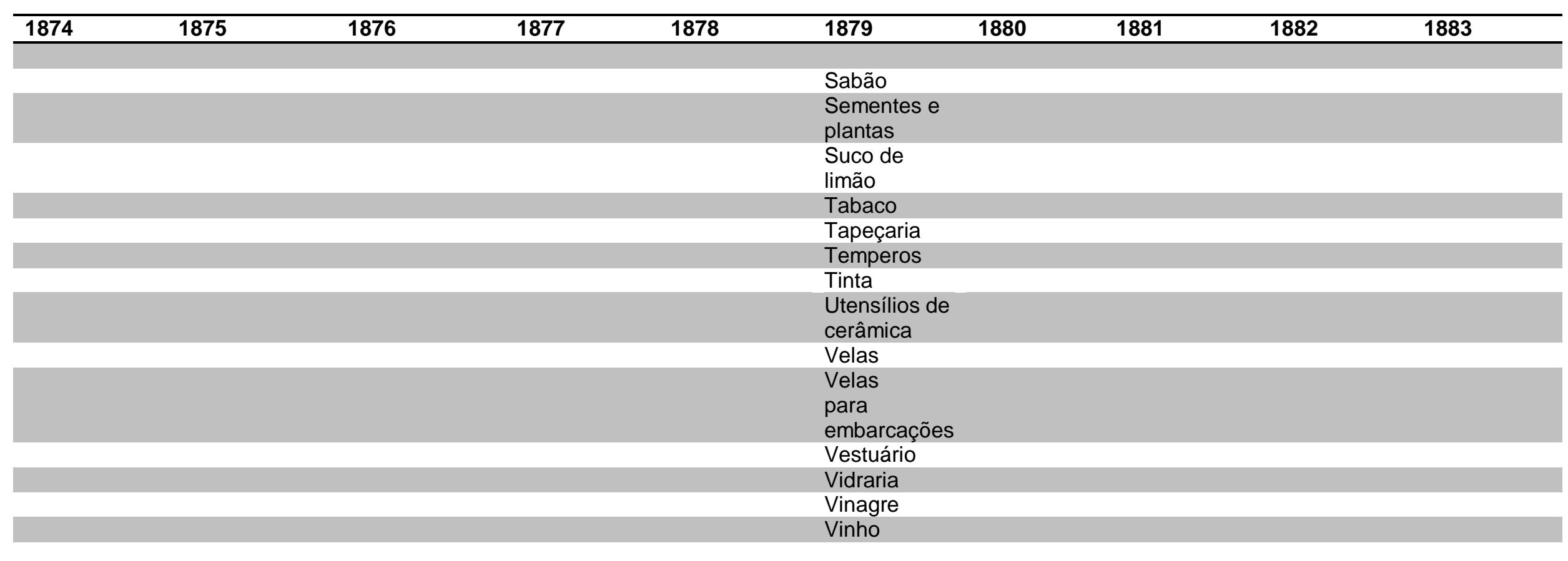

Fonte: Tabela elaborada a partir dos relatórios de importação constantes nos Blue Books produzidos entre os anos de 1874 e 1883. 
Apêndice 2: Mercadorias fornecidas pelo Brasil (continuação)

\begin{tabular}{|c|c|c|c|c|c|c|c|c|c|}
\hline 1884 & 1885 & 1886 & 1887 & 1888 & 1889 & 1890 & 1891 & 1892 & 1893 \\
\hline Absinto & Algodão & $\begin{array}{l}\text { Açúcar } \\
\text { mascavo }\end{array}$ & $\begin{array}{l}\text { Açúcar } \\
\text { mascavo }\end{array}$ & $\begin{array}{l}\text { Açúcar } \\
\text { mascavo }\end{array}$ & $\begin{array}{l}\text { Açúcar } \\
\text { mascavo }\end{array}$ & $\begin{array}{l}\text { Açúcar } \\
\text { mascavo }\end{array}$ & $\begin{array}{l}\text { Açúcar } \\
\text { mascavo }\end{array}$ & $\begin{array}{l}\text { Açúcar } \\
\text { refinado }\end{array}$ & $\begin{array}{l}\text { Açúcar } \\
\text { mascavo }\end{array}$ \\
\hline $\begin{array}{l}\text { Açúcar } \\
\text { mascavo }\end{array}$ & Armarinho & $\begin{array}{l}\text { Água } \\
\text { gaseificada } \\
\text { para o } \\
\text { governo } \\
\text { colonial }\end{array}$ & Armarinho & Algodão & Aguardente & $\begin{array}{l}\text { Água } \\
\text { gaseificada }\end{array}$ & Algodão & Algodão & Armarinho \\
\hline Algodão & Café & Algodão & Blocos & Armarinho & Algodão & Algodão & Armarinho & Armarinho & Aves \\
\hline Armarinho & Carne & Armas & Café & Armas & Armarinho & Armarinho & Armas & Armas & Azeite \\
\hline Azulejos & $\begin{array}{l}\text { Contas/ } \\
\text { miçangas }\end{array}$ & Armarinho & Carne & Azeite & Armas & Azeite & Azeite & $\begin{array}{l}\text { Batata e } \\
\text { cebola }\end{array}$ & Blocos \\
\hline Carne & Cachimbos & $\begin{array}{l}\text { Artigos em } \\
\text { lã }\end{array}$ & $\begin{array}{l}\text { Chapéus e } \\
\text { gorros }\end{array}$ & Brinquedos & $\begin{array}{l}\text { Batata e } \\
\text { cebola }\end{array}$ & Café & Café & Blocos & Café \\
\hline $\begin{array}{l}\text { Carroças e } \\
\text { carruagens }\end{array}$ & $\begin{array}{l}\text { Chapéus e } \\
\text { gorros }\end{array}$ & Azeite & Charutos & Café & Café & Carne & Carne & Café & $\begin{array}{l}\text { Carne bovina } \\
\text { e carne de } \\
\text { porco }\end{array}$ \\
\hline $\begin{array}{l}\text { Contas/ } \\
\text { miçangas }\end{array}$ & Cutelaria & Azulejos & $\begin{array}{l}\text { Contas/ } \\
\text { miçangas }\end{array}$ & Carne & Carne & Cestaria & Charutos & $\begin{array}{l}\text { Carne bovina } \\
\text { e carne de } \\
\text { porco }\end{array}$ & Cerveja preta \\
\hline Cutelaria & Ferragens & $\begin{array}{l}\text { Batata e } \\
\text { cebola }\end{array}$ & $\begin{array}{l}\text { Farinha (de } \\
\text { trigo) }\end{array}$ & Cerveja preta & Confeitos & Chá & Fósforos & Charutos & $\begin{array}{l}\text { Chapéus e } \\
\text { gorros }\end{array}$ \\
\hline Esteiras & $\begin{array}{l}\text { Ferragens } \\
\text { reimportação }\end{array}$ & Blocos & Ferragens & $\begin{array}{l}\text { Chapéus e } \\
\text { gorros }\end{array}$ & Charutos & Charutos & $\begin{array}{l}\text { Lâmpada a } \\
\text { óleo }\end{array}$ & Couro & Charutos \\
\hline Ferragens & $\begin{array}{l}\text { Guarda- } \\
\text { chuvas }\end{array}$ & Brinquedos & $\begin{array}{l}\text { Guarda- } \\
\text { chuva }\end{array}$ & Charutos & $\begin{array}{l}\text { Equipament } \\
\text { os para } \\
\text { tanoeiros }\end{array}$ & Confeitos & Mantimentos & $\begin{array}{l}\text { Farinha (de } \\
\text { trigo) }\end{array}$ & Conchas \\
\hline
\end{tabular}


Apêndice 2: Mercadorias fornecidas pelo Brasil (continuação)

\begin{tabular}{|c|c|c|c|c|c|c|c|c|c|}
\hline 1884 & 1885 & 1886 & 1887 & 1888 & 1889 & 1890 & 1891 & 1892 & 1893 \\
\hline Melaço & Mantimentos & Café & $\begin{array}{l}\text { Lâmpada a } \\
\text { óleo }\end{array}$ & $\begin{array}{l}\text { Contas/ } \\
\text { miçangas }\end{array}$ & Estopa & $\begin{array}{l}\text { Contas/ } \\
\text { miçangas }\end{array}$ & $\begin{array}{l}\text { Materiais de } \\
\text { construção }\end{array}$ & Ferragens & $\begin{array}{l}\text { Contas/ } \\
\text { miçangas }\end{array}$ \\
\hline Potássio & Munição & Cauris & Mantimentos & Cutelaria & Ferragens & Couro & Melaço & Licores & Cordame \\
\hline Rum & Rum & $\begin{array}{l}\text { Cerveja } \\
\text { preta }\end{array}$ & $\begin{array}{l}\text { Materiais de } \\
\text { construção }\end{array}$ & Esteiras & Licor & Enlatados & Móveis & Máquinas & Curiosidades \\
\hline Tabaco & Tabaco & $\begin{array}{l}\text { Chapéus e } \\
\text { gorros }\end{array}$ & Melaço & Ferragens & Máquinas & $\begin{array}{l}\text { Espécies de } \\
\text { madeira }\end{array}$ & $\begin{array}{l}\text { Pão e } \\
\text { biscoitos }\end{array}$ & Mantimentos & Esteiras \\
\hline \multirow[t]{7}{*}{ Vestuário } & Vestuário & Charutos & Móveis & $\begin{array}{l}\text { Guarda- } \\
\text { chuvas }\end{array}$ & $\begin{array}{l}\text { Materiais } \\
\text { de } \\
\text { construção }\end{array}$ & $\begin{array}{l}\text { Farinha (de } \\
\text { trigo) }\end{array}$ & Potássio & $\begin{array}{l}\text { Materiais de } \\
\text { construção }\end{array}$ & Ferragens \\
\hline & Vinagre & Cimento & $\begin{array}{l}\text { Óleo de } \\
\text { colza }\end{array}$ & $\begin{array}{l}\text { Instrumentos } \\
\text { musicais }\end{array}$ & Melaço & Ferragens & Relógios & $\begin{array}{l}\text { Pão e } \\
\text { biscoitos }\end{array}$ & $\begin{array}{l}\text { Guarda- } \\
\text { chuvas }\end{array}$ \\
\hline & Vinho & Confeitos & $\begin{array}{l}\text { Pão e } \\
\text { biscoitos }\end{array}$ & Licores & $\begin{array}{l}\text { Peixe } \\
\text { salgado }\end{array}$ & Genebra & Retratos & $\begin{array}{l}\text { Peixe } \\
\text { salgado }\end{array}$ & Genebra \\
\hline & & $\begin{array}{l}\text { Contas/ } \\
\text { miçangas }\end{array}$ & $\begin{array}{l}\text { Peixe } \\
\text { salgado }\end{array}$ & Máquinas & Potássio & Joias & Rum & Potássio & $\begin{array}{l}\text { Lona/ } \\
\text { encerado }\end{array}$ \\
\hline & & Esteiras & Potássio & $\begin{array}{l}\text { Materiais de } \\
\text { construção }\end{array}$ & Relógios & Licores & Sabão & Relógios & Máquinas \\
\hline & & & Relógios & Melaço & Rum & Lona/encerado & $\begin{array}{l}\text { Sapatos e } \\
\text { botas }\end{array}$ & Retratos & Mantimentos \\
\hline & & & & & & & $\begin{array}{l}\text { Substâncias } \\
\text { químicas e } \\
\text { drogas }\end{array}$ & & \\
\hline
\end{tabular}

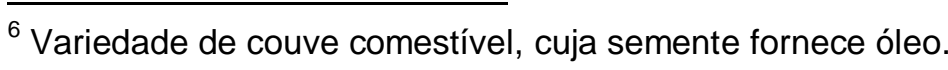


Apêndice 2: Mercadorias fornecidas pelo Brasil (continuação)

\begin{tabular}{|c|c|c|c|c|c|c|c|c|c|}
\hline 1884 & 1885 & 1886 & 1887 & 1888 & 1889 & 1890 & 1891 & 1892 & 1893 \\
\hline & & Ferragens & Rum & Móveis & $\begin{array}{l}\text { Sapatos e } \\
\text { botas }\end{array}$ & $\begin{array}{l}\text { Materiais de } \\
\text { construção }\end{array}$ & Tabaco & Rum & $\begin{array}{l}\text { Materiais de } \\
\text { construção }\end{array}$ \\
\hline & & $\begin{array}{l}\text { Folha de } \\
\text { flandres }\end{array}$ & $\begin{array}{l}\text { Sapatos e } \\
\text { botas }\end{array}$ & $\begin{array}{l}\text { Pão e } \\
\text { biscoitos }\end{array}$ & $\begin{array}{l}\text { Substâncias } \\
\text { químicas e } \\
\text { drogas }\end{array}$ & Máquinas & $\begin{array}{l}\text { Utensílios de } \\
\text { cerâmica }\end{array}$ & $\begin{array}{l}\text { Sapatos e } \\
\text { botas }\end{array}$ & Melaço \\
\hline & & $\begin{array}{l}\text { Lâmpada a } \\
\text { óleo }\end{array}$ & $\begin{array}{l}\text { Substâncias } \\
\text { químicas e } \\
\text { drogas }\end{array}$ & Papelaria & Tabaco & Mantimentos & Vestuário & $\begin{array}{l}\text { Substâncias } \\
\text { químicas e } \\
\text { drogas }\end{array}$ & Móveis \\
\hline & & Máquinas & Tabaco & Perfumaria & $\begin{array}{l}\text { Utensílios } \\
\text { de cerâmica }\end{array}$ & Melaço & Vinagre & Tabaco & $\begin{array}{l}\text { Pão e } \\
\text { biscoitos }\end{array}$ \\
\hline & & Mantimentos & $\begin{array}{l}\text { Tapeçaria/ } \\
\text { estofamento }\end{array}$ & $\begin{array}{l}\text { Peixe } \\
\text { salgado }\end{array}$ & Vidraria & Móveis & Vinho & $\begin{array}{l}\text { Tapeçaria/ } \\
\text { estofamento }\end{array}$ & Peixe salgado \\
\hline & & $\begin{array}{l}\text { Materiais de } \\
\text { construção }\end{array}$ & $\begin{array}{l}\text { Utensílios de } \\
\text { cerâmica }\end{array}$ & Potássio & Vinho & $\begin{array}{l}\text { Pão e } \\
\text { biscoitos }\end{array}$ & & Vestuário & Potássio \\
\hline & & Melaço & Vestuário & Relógios & & Parafuso & & Vinagre & Rebolo $^{7}$ \\
\hline & & Móveis & Vinagre & Retratos & & $\begin{array}{l}\text { Peixe } \\
\text { salgado }\end{array}$ & & Vinho & Relógios \\
\hline & & Pão & Vinho & Rum & & Perfumaria & & & Sabão \\
\hline & & $\begin{array}{l}\text { Peixe } \\
\text { salgado }\end{array}$ & & $\begin{array}{l}\text { Sapatos e } \\
\text { botas }\end{array}$ & & Potássio & & & $\begin{array}{l}\text { Sapatos e } \\
\text { botas }\end{array}$ \\
\hline & & Perfumaria & & $\begin{array}{l}\text { Substâncias } \\
\text { químicas e } \\
\text { drogas }\end{array}$ & & Relógios & & & $\begin{array}{l}\text { Substâncias } \\
\text { químicas e } \\
\text { drogas }\end{array}$ \\
\hline & & Pistolas & & Tabaco & & Rum & & & Tabaco \\
\hline
\end{tabular}

${ }^{7}$ Em linhas gerais, a palavra rebolo possui dois sentidos. O primeiro se refere a uma peça de arenito que, quando colocada sobre um eixo giratório, tem a função de afiar objetos cortantes. O segundo sentido estaria associado a uma parte da cana de açúcar utilizada ao plantio. Acredito que o artigo levado até Lagos a partir do Brasil estava associado a este significado. 
Apêndice 2: Mercadorias fornecidas pelo Brasil (continuação)

\begin{tabular}{|c|c|c|c|c|c|c|}
\hline 1884 & 1885 & 1887 & $1888 \quad 1889$ & 1891 & 1892 & 1893 \\
\hline & & Potássio & $\begin{array}{l}\text { Tapeçaria } \\
\text { estofamento }\end{array}$ & Sabão & & $\begin{array}{r}\text { Tapeçaria/ } \\
\text { estofamento }\end{array}$ \\
\hline & & Relógios & $\begin{array}{l}\text { Utensílios de } \\
\text { cerâmica }\end{array}$ & $\begin{array}{l}\text { Sapatos e } \\
\text { botas }\end{array}$ & & $\begin{array}{l}\text { Utensílios de } \\
\text { cerâmica }\end{array}$ \\
\hline & & Rum & Vestuário & $\begin{array}{l}\text { Selas (de } \\
\text { montaria) }\end{array}$ & & Vestuário \\
\hline & & $\begin{array}{l}\text { Sabão } \\
\text { Temperos }\end{array}$ & Vinagre & $\begin{array}{l}\text { Substâncias } \\
\text { químicas e } \\
\text { drogas }\end{array}$ & & Vidraria \\
\hline & & $\begin{array}{l}\text { Sapatos e } \\
\text { botas }\end{array}$ & Vinho & Tabaco & & Vinagre \\
\hline & & Seda & & $\begin{array}{l}\text { Tapeçaria/ } \\
\text { estofamento }\end{array}$ & & Vinho \\
\hline & & $\begin{array}{l}\text { Substâncias } \\
\text { químicas e } \\
\text { drogas }\end{array}$ & & $\begin{array}{l}\text { Utensílios de } \\
\text { cerâmica }\end{array}$ & & \\
\hline & & Tabaco & & Vestuário & & \\
\hline & & Tijolos & & Vinagre & & \\
\hline & & $\begin{array}{l}\text { Tábuas e } \\
\text { aduelas para } \\
\text { barril }\end{array}$ & & Vinho & & \\
\hline & & $\begin{array}{l}\text { Utensílios de } \\
\text { cerâmica }\end{array}$ & & & & \\
\hline & & Vidraria & & & & \\
\hline & & Vinagre & & & & \\
\hline & & Vinho & & & & \\
\hline
\end{tabular}

Fonte: Tabela elaborada a partir dos relatórios de importação constantes nos Blue Books produzidos entre os anos de 1884 e 1893. 
Apêndice 2: Mercadorias fornecidas pelo Brasil (continuação)

\begin{tabular}{|c|c|c|c|c|c|c|}
\hline 1894 & 1895 & 1896 & 1897 & 1898 & 1899 & 1900 \\
\hline Açúcar refinado & Armarinho & Armarinho & Açúcar refinado & Açúcar refinado & Melaço & $\begin{array}{l}\text { Carne bovina e } \\
\text { carne de porco }\end{array}$ \\
\hline Algodão & Café & Café & Armarinho & Armarinho & Rum & Melaço \\
\hline Blocos & $\begin{array}{l}\text { Carne bovina e } \\
\text { carne de porco }\end{array}$ & $\begin{array}{l}\text { Carne bovina e } \\
\text { carne de porco }\end{array}$ & Blocos & Blocos & Tabaco & Papelaria \\
\hline $\begin{array}{l}\text { Carne bovina e carne } \\
\text { de porco }\end{array}$ & Charutos & Ferragens & Café & Café & & Rum \\
\hline Chá & $\begin{array}{l}\text { Mantimentos } \\
\text { produzidos na } \\
\text { África }\end{array}$ & Mantimentos & $\begin{array}{l}\text { Carne bovina e } \\
\text { carne de porco }\end{array}$ & $\begin{array}{l}\text { Carne bovina e } \\
\text { carne de porco }\end{array}$ & & $\begin{array}{l}\text { Substâncias } \\
\text { químicas e } \\
\text { drogas }\end{array}$ \\
\hline Charuto & Máquinas & Melaço & Charutos & Charutos & & $\begin{array}{l}\text { Tabaco não } \\
\text { manufaturado }\end{array}$ \\
\hline Confeitaria & Melaço & Potássio & Contas/miçangas & Contas/ miçangas & & \\
\hline Cordame & Móveis & Rebanho $^{8}$ & Ferragens & Ferragens & & \\
\hline Espécies de madeira & Relógios & Relógios & Máquinas & Máquinas & & \\
\hline Ferragens & Rum & Rum & Mantimentos & Mantimentos & & \\
\hline $\begin{array}{l}\text { Instrumentos científico } \\
\text { matemáticos e } \\
\text { instrumentos } \\
\text { cirúrgicos }\end{array}$ & $\begin{array}{l}\text { Substâncias } \\
\text { químicas e drogas }\end{array}$ & Sabão & Melaço & Melaço & & \\
\hline Instrumentos musicais & Tabaco & $\begin{array}{l}\text { Substâncias } \\
\text { químicas e drogas }\end{array}$ & Peixe salgado & Peixe salgado & & \\
\hline Lâmpada/lamparina & $\begin{array}{l}\text { Utensílios de } \\
\text { cerâmica }\end{array}$ & Tabaco & Potássio & Potássio & & \\
\hline Livros & & Vinagre & Relógios & Relógios & & \\
\hline Máquinas & & & Rum & Rum & & \\
\hline Mantimentos & & & $\begin{array}{l}\text { Substâncias } \\
\text { químicas e drogas }\end{array}$ & $\begin{array}{l}\text { Substâncias } \\
\text { químicas e drogas }\end{array}$ & & \\
\hline Móveis & & & Tabaco & Tabaco & & \\
\hline
\end{tabular}

${ }^{8} \mathrm{O}$ registro não especifica que tipo de rebanho chegava em Lagos à bordo de embarcações vindas do Brasil. 
Apêndice 2: Mercadorias fornecidas pelo Brasil (continuação)

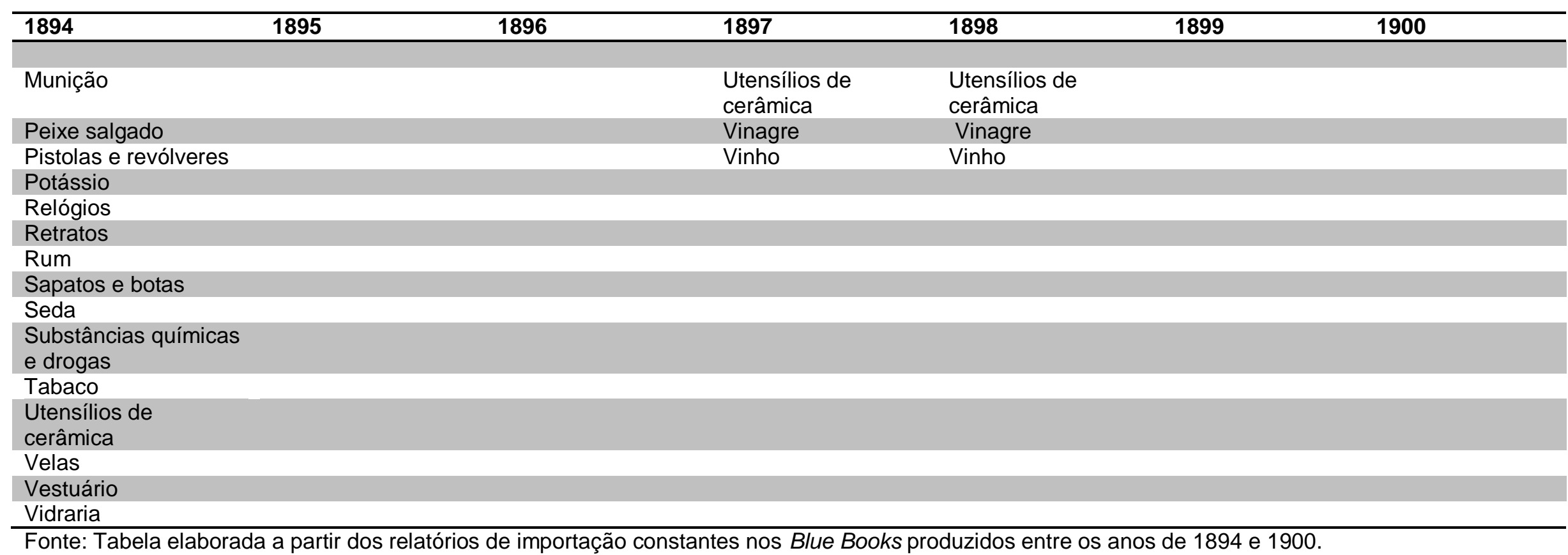

Fonte: Tabela elaborada a partir dos relatórios de importação constantes nos Blue Books produzidos entre os anos de 1894 e 1900. 
Apêndice 3: Exportações de Lagos (valores em libras esterlinas) ${ }^{9}$

\begin{tabular}{|c|c|c|c|c|c|c|c|c|c|c|c|c|}
\hline & $\begin{array}{l}\text { Grã } \\
\text { Bretanha }\end{array}$ & Alemanha & $\begin{array}{l}\text { Porto } \\
\text { Novo }\end{array}$ & França & Brasil & $\begin{array}{l}\text { Costa } \\
\text { do } \\
\text { Cabo }\end{array}$ & $\begin{array}{l}\text { Leeward } \\
\text { Coast }^{10}\end{array}$ & $\begin{array}{l}\text { Costa } \\
\text { do } \\
\text { Ouro } \\
\end{array}$ & $\begin{array}{l}\text { Serra } \\
\text { Leoa }\end{array}$ & Acra & $\begin{array}{l}\text { Windward } \\
\text { Coast }^{11}\end{array}$ & $\begin{array}{l}\text { Estados } \\
\text { Unidos/NY } \\
\text { Chicago }\end{array}$ \\
\hline 1863 & 92934 & 36838 & 2416 & 14612 & 8143 & - & 60 & - & 1180 & - & 2155 & - \\
\hline 1865 & 96247 & 1845 & 19682 & 9979 & 7559 & - & 7966 & - & - & - & 1023 & - \\
\hline 1866 & 148443 & 42457 & 9810 & 41191 & 990 & - & - & - & 2219 & - & 6081 & 2735 \\
\hline 1867 & 287239 & 92310 & 11197 & 94622 & 4605 & - & 601 & - & 3109 & - & 12272 & - \\
\hline 1868 & 244396 & 114086 & 9758 & 113188 & 8120 & - & 8024 & - & 1313 & - & 8764 & - \\
\hline 1869 & - & 5589 & - & - & - & - & - & - & 1313 & - & - & - \\
\hline 1870 & 298939 & 80998 & 20823 & 12576 & 3762 & - & 389 & - & 420 & - & 108 & - \\
\hline 1871 & 357259 & 80942 & 23733 & 93095 & 14178 & - & 9613 & - & 334 & - & 3280 & - \\
\hline 1872 & 247981 & 77869 & 39793 & 57111 & - & - & 12057 & - & 343 & - & 6975 & - \\
\hline 1873 & 229161 & 110759 & 44258 & 31233 & 5080 & - & 7309 & - & 545 & - & 5275 & - \\
\hline 1874 & 283957 & 135927 & 37191 & 24928 & 19470 & - & 7437 & - & 221 & - & 1211 & - \\
\hline 1875 & 270975 & 189642 & 43776 & 42446 & 13725 & - & 2687 & - & 668 & - & 6494 & - \\
\hline 1876 & 265225 & - & 74365 & 59486 & 24311 & - & 1592 & - & 531 & - & 4101 & - \\
\hline 1877 & - & 112907 & - & - & - & - & - & - & - & - & - & - \\
\hline 1878 & 254989 & - & 103648 & 79157 & 13449 & - & 99 & - & - & - & 13084 & - \\
\hline 1879 & - & - & - & - & - & - & - & - & - & - & - & - \\
\hline 1880 & - & - & - & - & - & - & - & - & - & - & - & - \\
\hline 1881 & 160216 & 115524 & 64070 & 77554 & 14856 & - & - & 3795 & 576 & - & - & 16946 \\
\hline 1882 & 267243 & 136264 & 65510 & 64623 & 20027 & - & 9321 & 2394 & 517 & - & - & 14790 \\
\hline 1883 & 259057 & 176739 & 60592 & 52946 & 6083 & - & 26309 & 5922 & 924 & - & - & 3254 \\
\hline 1884 & 249793 & 283726 & 81409 & 18020 & 13967 & - & 12836 & 5021 & 1614 & - & - & 3323 \\
\hline 1885 & 194607 & 210849 & 82689 & 87617 & 10764 & 1650 & - & - & 2486 & 4599 & - & 3783 \\
\hline
\end{tabular}

9 Para compor a relação dos países importadores de mercadorias embarcadas no porto lagosiano adotei o critério do volume de libras movimentado nas relações comerciais. Este critério restringiu a lista a apenas doze países, embora os relatórios dos Blue Books indiquem um número muito maior de parceiros comerciais.

${ }^{10} \mathrm{O}$ território chamado Leeward Coast estaria situado a leste do Cabo Palmas. Mantive a grafia original em inglês por considerar ser esta a mais comum entre a produção historiográfica.

${ }^{11}$ A região denominada Windward Coast corresponde ao litoral ocidental que compreende parte das atuais Libéria e Costa do Marfim. Também neste caso optei por manter a ortografia em inglês. 


\begin{tabular}{|c|c|c|c|c|c|c|c|c|c|c|c|c|}
\hline & $\begin{array}{l}\text { Grã } \\
\text { Bretanha }\end{array}$ & Alemanha & $\begin{array}{l}\text { Porto } \\
\text { Novo }\end{array}$ & França & Brasil & $\begin{array}{l}\text { Costa } \\
\text { do } \\
\text { Cabo }\end{array}$ & $\begin{array}{l}\text { Leeward } \\
\text { Coast }\end{array}$ & $\begin{array}{l}\text { Costa } \\
\text { do } \\
\text { Ouro }\end{array}$ & $\begin{array}{l}\text { Serra } \\
\text { Leoa }\end{array}$ & Acra & $\begin{array}{l}\text { Windward } \\
\text { Coast }\end{array}$ & $\begin{array}{l}\text { Estados } \\
\text { Unidos/NY } \\
\text { Chicago }\end{array}$ \\
\hline 1886 & 308896 & 125915 & 37954 & 23490 & 6454 & 1398 & - & - & 1448 & 2558 & - & 692 \\
\hline 1887 & 235621 & 168291 & 52532 & 16167 & 3929 & 1579 & - & 76356 & 2179 & 1509 & - & - \\
\hline 1888 & 167807 & 2333391 & 45829 & 38328 & 8245 & 1852 & 1843 & - & 2195 & - & - & 47 \\
\hline 1889 & 152897 & 213924 & 51497 & 12740 & 7159 & & & & 3291 & - & - & - \\
\hline 1890 & 210141 & 248459 & 47599 & 51659 & 4851 & 1852 & - & - & 4065 & 2937 & - & - \\
\hline 1891 & 285821 & 305668 & 83740 & 12291 & 4893 & 5982 & - & - & 4385 & 3897 & - & - \\
\hline 1893 & 327612 & 358517 & 115678 & 5538 & 8120 & 3524 & - & - & 5309 & 3395 & - & - \\
\hline 1894 & 302018 & 361507 & 123118 & 4908 & - & 5403 & - & - & 4830 & 3047 & - & - \\
\hline 1895 & 430526 & 360193 & 108728 & 1680 & 17 & 2497 & - & - & 1703 & 1518 & - & - \\
\hline 1896 & 497863 & 383540 & 54936 & & 5160 & 41434 & - & - & 4554 & 25274 & - & - \\
\hline 1897 & 400114 & 310428 & 30632 & 364 & 1344 & 19045 & - & - & 2705 & 5633 & - & - \\
\hline 1898 & 403937 & 360543 & 50849 & 800 & 180 & 24503 & - & - & 6870 & 12632 & - & - \\
\hline 1899 & 332336 & 445930 & 56209 & - & 1184 & 43270 & - & - & 6560 & 4757 & - & - \\
\hline 1900 & 309265 & - & 47937 & 20 & 1300 & 43993 & - & - & 6760 & 799 & - & 43 \\
\hline TOTAL & 8786028 & 7982082 & 1820739 & 1143328 & 241927 & 201363 & 108143 & 93488 & 80894 & 77155 & 70823 & 45613 \\
\hline
\end{tabular}

Fonte: Tabela elaborada a partir dos relatórios de importação constantes nos Blue Books produzidos entre os anos de 1863 e 1900. 
Apêndice 4: Brasileiros com licença para comercializar bebidas destiladas em Lagos

\begin{tabular}{llll}
\hline Varejo & Localização & Atacado & Localização \\
\hline 1886 & & & \\
\hline J.J. d'Costa & Rua Bamgbose & Sant Anna \& Co. & Rua Kakawa \\
M. Balbina & Rua Kakawa & & \\
J.A.Fernandez & Praça Tinubu & & \\
E.A. de Souza & Ebute Meta & & \\
H. Joaquim & Rua Campbell & & Rua Kakawa \\
S.L.B. da Silva & Rua Osodi & & Rua Broad \\
1887 & & Sant Anna \& Co. & Offin \\
\hline J.J. d'Costa & Rua Bamgbose & Sant Anna \& Co. & \\
M. Balbina & Rua Kakawa & Sant Anna \& Co. & \\
J.A.Fernandez & Praça Tinubu & Sant Anna \& Co. & \\
E.A. de Souza & Ebute Meta & & Rua Kakawa \\
H. Joaquim & Rua Campbell & & Offin \\
S.L.B. da Silva & Rua Osodi & Ebute Ero \\
1888 & & Sant Anna \& Co. & \\
\hline M. Balbina & Rua Kakawa & Sant Anna \& Co. & \\
J.J. d'Costa & Rua Bamgbose & Sant Anna \& Co. & \\
S.L.B. da Silva & Rua Osodi & & Rua Kakawa \\
H. Joaquim & Rua Campbell & & \\
J.A.Fernandez & Praça Tinubu & & \\
1889 & & & \\
\hline M. Balbina & Rua Kakawa & Sant Anna \& Co. & \\
J.J. d'Costa & Rua Bamgbose & & \\
S.L.B. da Silva & Rua Osodi & & \\
H. Joaquim & Rua Campbell & & \\
J.A.Fernandez & Praça Tinubu & & \\
Louisa Antonia & Praça Tinubu & & \\
\hline & & & \\
\hline
\end{tabular}




\begin{tabular}{llll}
\hline Varejo & Localização & Atacado & Localização \\
\hline $\mathbf{1 8 9 0}$ & & & \\
\hline J.A.Fernandez & Praça Tinubu & Sant Anna \& Co. & Rua Kakawa \\
J.J. d'Costa & Rua Bamgbose & Sant Anna \& Co. & Tolo \\
M. Balbina & Rua Kakawa & & \\
Louisa Antonia & Praça Tinubu & & \\
S.L.B. da Silva & Rua Tokunboh & & \\
$\mathbf{1 8 9 1}$ & & Sant Anna \& Co. & Rua Kakawa \\
\hline Maria Antonia & Lagos & Sant Anna \& Co. & Tolo \\
J.J. d'Costa & Rua Bamgbose & Irmãos Medeiros & Elegbata \\
M. Balbina & Rua Kakawa & Lagos \\
S.L.B. da Silva & Rua Tokunboh & Irmãos Medeiros & \\
J.A.Fernandez & Praça Tinubu & & \\
Louisa Antonia & Praça Tinubu & & \\
$\mathbf{1 8 9 2}$ & & & Rua Kakawa \\
\hline J.A. Fernandez \& & Praça Tinubu & Sant Anna \& Co. & \\
Co. & & Tolo \\
Louisa Antonia & Praça Tinubu & Sant Anna \& Co. & Elegbata \\
S.L.B. da Silva & Rua Tokunboh & Irmãos Medeiros & \\
J.J. d'Costa & Rua Balogun & & \\
Maria Antonia & Rua Campbell & & \\
Maria Balbina & Rua Kakawa & & \\
\hline $\mathbf{1 8 9 3}$ & & & \\
\hline Louisa Antonia & Praça Tinubu & Sant Anna \& Co. & Rua Kakawa \\
\hline Maria Balbina & Rua Kakawa & Sant Anna \& Co. & Tolo \\
S.L.B. da Silva & Rua Tokunboh & & \\
Maria Antonia & Rua Campbell & & \\
Maria F. Ramos & Rua Bamgbose & & \\
& & & \\
\hline
\end{tabular}




\begin{tabular}{llll} 
Varejo & Localização & Atacado & Localização \\
\hline $\mathbf{1 8 9 4}$ & & & \\
\hline Louisa Antonia & Praça Tinubu & Sant Anna \& Co. & Rua Kakawa \\
Maria Balbina & Rua Kakawa & Sant Anna \& Co. & Tolo \\
S.L.B. da Silva & Rua Tokunboh & & \\
$\mathbf{1 8 9 5}$ & & & \\
\hline Maria F. Ramos & Rua Bamgbose & & \\
Louisa Antonia & Praça Tinubu & & Rua Kakawa \\
S.L.B. da Silva & Rua Tokunboh & & \\
$\mathbf{1 8 9 6}$ & & & \\
\hline Maria F. Ramos & Rua Bamgbose & J.A.Lino & \\
Louisa Antonia & Praça Tinubu & & \\
S.L.B. da Silva & Rua Tokunboh & & \\
Fernandez \& Co & Rua Aroloya & & \\
Fernandez \& Co & Praça Tinubu & & \\
$\mathbf{1 8 9 7}$ & & & \\
\hline Fernandez \& Co. & Rua Aroloya & \\
Fernandez \& Co. & Praça Tinubu & & \\
Fernandez \& Co. & Rua Igboshere & & \\
S.L.B. da Silva & Rua Tokunboh & & \\
A. Loureiro & Rua Tokunboh & & \\
& & & \\
\hline
\end{tabular}

Fonte: Tabela elaborada a partir dos relatórios de licenças para comercialização de destilados em Lagos publicados pelo periódico oficial Government Gazette, Colony of Lagos, entre os anos de 1886 a 1997. A partir de 1898, estes relatórios deixaram de ser publicados. 


\section{FONTES}

\section{Jornais e relatórios}

The National Archives / Londres

Coleção: Colonial Office (CO), Government Gazettes

CO 150/1 - 1881 a 1886

CO 150/2 - 1887 a 1888

CO $150 / 3$ - 1889 a 1890

CO 150/4 - 1891 a 1892

CO 150/5 - 1893 a 1894

CO 150/6 - 1895 a 1896

CO 150/7 - Index of Government Gazettes, 1886 a 1896

CO 150/8 - 1897 a 1898

CO $150 / 9$ - 1899 a 1900

Coleção: Colonial Office (CO), Photographs

https://www.flickr.com/photos/nationalarchives/albums/72157625850393609

CO 1969/62.9

CO 1069/71.82

CO 1069/71.138

CO 1069/78.10

CO 1069/80.44

CO 1069/80.59

World Newspaper Archive

Coleção: African Collection

Lagos Observer - 1882 a 1888

Lagos Weekly Record-1891 a 1906 
Coleção African Blue Books, 1821-1953, série Nigeria 1862-1945.

Blue Book/1863

Blue Book/1865 até Blue Book/1899

\section{Fontes publicadas}

Additional Papers Relating to the Occupation of Lagos (APROL), Presented to both House of Parliament by Command of Her Majesty, London: Harrison and Son, 1862.

BORGHERO, Francisco; MANDIROLA, Renzo; MOREL, Yves (eds.) Journal de Francesco Borghero, preimier missionaire du Dahomey, 1861-1865. Paris: Éditions Karthala, 1997.

BOWEN, John. (sister) Memorials of John Bowen. Late Bishop of Sierra Leone. Compiled from his Letters and Journals by his sister. London: James Nisbet \& Co, 1869.

BROWN, William Wells. The American Fugitive in Europe: Sketches of Places and people abroad. With a memoir of the author. Boston/New York: John P. Jewett and Company/ Sheldon, Lamport \& Blackeman, 1855.

BURTON, Richard Francis. Wanderings in West Africa: from Liverpool to Fernando Pó. vol.I, London: Tinsley Brothers, 1863A.

BURTON, Richard Francis. Abeokuta and the Camaroons Mountains: an exploration. vol.I, London: Tinsley Brothers, 1863B.

BURTON, R.F. A mission to Gelele, king of Dahome. $2^{\mathrm{a}}$ ed. vol.I e II London: Tinsley Brothers, 1864.

BUXTON, Thomas Fowell. The African slave trade, and its remedy. London: John Murray, 1840. 
BUXTON, Charles. Memoirs of Sir Thomas Fowell Buxton. 3a ed. London: John Murray, 1849.

CAMPBELL, Robert. A Pilgrimage to my motherland, an account of a journey among the egbas and yorubas of Central Africa, in 1859-1860. New York: Thomas Hamilton, 1861.

CMI, A Monthly Journal of Missionary Information. Vol.VIII. London: Church Missionary House, 1872.

Correspondence with Foreign Powers (CFP) with British Ministers and Agents in Foreign Countries, and with Foreign Ministers in England relating to the Slave trade, from January 1 to December 31, London: Harrison and Son, 1862.

CROWTHER, Samuel Adjai. A Charge Delivered on the Banks of the River Niger in West Africa. London: Seeley, Jackson \& Halliday, 1866.

DELANY, Martin. Search for a Place: Black Separatism and Africa, 1860. Ann Arbor: University of Michigan Press, 1969.

DUNCAN, John. Notice of a Journey from Whydah on the West Coast of Africa to Adofoodiah in the Interior, Journal of the Royal Geographical Society, 16, 1846, pp.154-162.

DUNCAN, John. Travels in Western Africa, in 1845 \& 1846. A journey from Whydah, through the kingdom of Dahomey, to Adofoodia, in the interior, vol. I e II. London: Richard Bentley, 1847.

The Destruction of Lagos. London: James Ridgway, 1852. [panfleto anônimo]

FOOTE, Mrs. Henry Grant. Recolletions of Central America and the West Coast of Africa. Londres: T.Cautley Newby, 1869. 
FORBES, Frederick. Five Years in China from 1842 to 1847. With na account of the occupation of the islands of Labuan and Borneo by Her Majesty's Forces. London: Richard Bentley, 1848.

FORBES, Frederick. Six Month's Service in the African Blockade from April to October, 1848, in command of H.M.S. Bonetta. London: Richard Bentley, 1849.

FORBES, Frederick E. Dahomey and the dahomans: the journals of two missions to the king of Dahomey, and residence at this capital, in the years 1849 and 1850. vol.I e II, London: Longman, 1851.

FREEMAN, Thomas Birch. Journal of Various Visits to the Kingdoms of Ashanti, Aku and Dahomi in Western Africa. Cambridge: Cambridge University Press, 2010. (Primeira edição foi publicada em 1844, a $2^{\mathrm{a}}$ edição, em 1968.)

Friend of Africa; by The Society for the extinction of the slave trade, and for the civilization of Africa. Vol.1, London: John W. Parker, 1841.

GLOVER, Lady. Life of Sir John Hawley Glover. London: Smith, Elder and Co. 1897.

GOLLMER, Charles Henry. Charles Andrew Gollmer, His Life and Missionary Labours in West Africa. 2a ed., London: Hodder and Soughton, 1889.

MILUM, John. Thomas Birch Freeman: Missionary Pioneer to Ashanti, Dahomey, and Egba. New York: Fleming H. Revell Company, 1893.

MOLONEY, Cornelius Alfred (1889), Correspondence Affair on the West Coast of Africa. In The Journal of the Manchester Geographical Society. vol.V, Manchester: The Manchester Geographical Society, 1889, pp.256 - 276.

MOLONEY, Alfred. Notes on Yoruba and the Colony and Protectorate of Lagos, West Africa. Proceedings of the Royal Geographical Society and Monthly Record of Geography, vol.12, No. 10, October, 1890, pp. 596-614. 
PAGE, Jesse. The black bishop, Samuel A. Crowther. London: Hodder and Stoughton, 1908.

Papers Relating to the Occupation of Lagos (PROL). Presented to the House of Commons by Command of Her Majesty, in pursuance of their Address dated May 2, 1862. London: Harrison and Son, 1862.

READE, William Winwood. The African Sketch-Book. vol. I, London: Smith, Elder \& Co, 1873.

RUSSEL, George W.E. Lady Victoria Buxton, a memoir with some account of her husband. London: Longmans, Green and Co., 1919.

SCHON, J.F; CROWTHER, S.A. Journals of the Ver. James Frederick Schon and Mr. Samuel Crowther, who with the sanction of her Majesty's Government, accompanied the Expedition up the Niger, in 1841. In behalf of the CMS with appendices and map. London: Hatchard and Son, 1842.

SPEED, Edwin Arney. Ordinances and orders and rules thereunder in force in the Colony of Lagos. On April $30^{\text {th }}, 1901$ with an appendix containing the letters patent constituting the colony, and the instructions accompanying them; various acts of Parliament; orders of the Queen in Council; treaties, and proclamation. Vol. II, London: Stevens and Sons, 1902.

WILBERFORCE, Robert Isaac; WILBERFORCE, Samuel. The life of William Wilberforce. Philadelphia: Perkins \& Marvin, 1839.

\section{REFERÊNCIAS BIBLIOGRÁFICAS}

ACHEBE, Chinua. A educação de uma Criança sob o Protetorado Britânico: ensaios. São Paulo: Companhia das Letras, 2012. 
A paz dura pouco. São Paulo: Companhia das Letras, 2013.

ADERIBIGBE, A.B.; AJAYI, J.F.A. (eds.) Lagos: The Development of an African City. Lagos: Longman, 1975.

ALENCASTRO, Luis Felipe de. O Trato dos Viventes: Formação do Brasil no Atlântico Sul. São Paulo: Companhia das Letras, 2000.

AMÓS, Alcione Meira. Os que voltaram: a história dos retornados afrobrasileiros na África Ocidental no século XIX. Belo Horizonte: Tradição Planalto, 2007.

AMSELLE, Jean-Loup; M'BOKOLO, Elikia (coord.) Pelos meandros da etnia. Etnias, tribalismo e estado em África. Luanda/Ramada: Edições Mulemba/Edições Pedago, 2014.

ANDERSON, Benedict. Comunidades imaginadas: reflexões sobre a origem e a difusão do nacionalismo. São Paulo: Companhia das Letras, 2008.

ANIBABA, Musliu Olaiya. A Lagosian of the 20th Century. Lagos: Tisons Limited, 2003.

APPIAH, Kwame Anthony. Na casa de meu pai: a África na filosofia da cultura. Tradução Vera Ribeiro. Rio de Janeiro: Contraponto, 1997.

BAKER, J.N.L. Sir Richard Burton and the Nile Sources. The English Historical Review, vol.59, n.233, jan.1944, pp.48-61.

BARNES, Sandra T. Ritual, Power, and outside Knowledge. Journal of Religion in Africa, vol.20, Fasc.3, Out./1990, pp.248- 261. 
BARNETT, Clive. Impure and Worldly Geography: the Africanist Discourse of the Royal Geographical Society, 1831 - 1873. Transactions of the Institute of British Geographers, vol.23, n.2, 1998, pp.239-251.

BASSETT, Thomas J; PORTER, Phillip W. "From the Best Authorities": The Mountains of Kong in the Cartography of West Africa. The Journal of Africa History, vol.32, n.3, 1991, pp.367-413.

BETHELL, Leslie. A abolição do tráfico de escravos no Brasil: a Grã-Bretanha, o Brasil e a questão do tráfico de escravos, 1807 - 1869. São Paulo: Edusp. 1976.

BLACKETT, Richard. Martin R. Delany and Robert Campbell: Black Americans in Search of an African Colony. The Journal of Negro History, vol.62, No. 1, jan. 1977, pp.1-25.

. Return to the Motherland: Robert Campbell, a Jamaican in Early Colonial Lagos. Phylon, vol.40, No.4, 1979, pp. 375-386.

BRITO, Luciana da Cruz. Sob o Rigor da Lei: Africanos e a Legislação Baiana no Século XIX. Sankofa. Revista de História da África e de Estudos da Diáspora Africana. n. 2, dez.2008, pp.38-57.

. Sob o Rigor da Lei: africanos e africanas na legislação baiana (18301841). Campinas: Dissertação de mestrado. IFCH/UNICAMP, 2009.

A legalidade como estratégia: africanos que questionaram a repressão das leis baianas na primeira metade do século XIX. Revista dos Pósgraduandos em História Social da Unicamp, n.16, 2009, pp.15-28.

CASTILLO, Lisa Earl. Mapping the nineteeth-century Brazilian returnee movement: Demographics, life stories and the question of slavery. Atlantic Studies, 13:1, 2016, pp.25-52. 
CHILDE, A.F. Good out of evil, or The history of Adjai. London: Wertheim and Maclntosh, 1852.

CLIFFORD, Nicholas J.; HOLLOWAY, Sarah L.; RICE, Stephen P.; VALENTINE, Gill (eds.) Key concepts in Geography. 2a ed, London: Sage, 2009.

COMAROFF, J \& COMARROF, J. Etnografia e imaginação histórica. Tradução de Iracema Dulley e Olivia Janequine In Proa - Revista de Antropologia e Arte (on-line). Ano 02, vol.01, n.02, nov. 2010. Disponível em: http://www.ifch.unicamp.br/proa/Traducoesll/comaroff.html.

CORDELIER, Serge (coord.). Nações e nacionalismos. Lisboa: Dom Quixote, 1998.

CUNHA, Manuela Carneiro da. Negros, estrangeiros. Os escravos libertos e sua volta à África. $2^{2}$ ed. revisada e ampliada. São Paulo: Companhia das Letras, 2012.

CUNHA, Marianno Carneiro da. Da senzala ao sobrado, arquitetura brasileira na Nigéria e na República Popular do Benim. São Paulo: Nobel/Edusp, 1985.

CURTIN, Philip D. The Image of Africa. British Ideas and Action, 1780 - 1850. Vol.2, Wisconsin: University of Wisconsin Press, 1973.

CURTO, José C., LOVEJOY, Paul E. Enslaving Connections. Changing Cultures of Africa and Brazil during the Era of Slavery, New York: Humanity Books, 2004.

DELGADO, Érika Melek. Identidades em trânsito: o caso dos africanos livres na primeira colônia britânica da África Ocidental. Revista de Ciências Humanas, Viçosa, v.14, n.2, jul./dez., 2014, pp.356-372. 
DIKE, K.O. John Beecroft, 1790 - 1854. Her Brittanic Majesty's Consul to the Bights of Benin and Biafra, 1849 - 1854. Journal of the Historical Society of Nigeria, vol. 1, n. 1, December, 1956, pp.5-14.

DRIVER, Felix. The World and Africa: Rediscovering African Geographies. Royal Holloway/ University of London, Royal Geographical Society with IBG, 2011.pp.1-8.

FALOLA, Toyin. A History of Nigeria. West Port, CT: Greenwood Press, 1999. Disponível em http://site.ebrary.com/id/5005127?ppg=59.

; OGUNTOMISIN, G.O. Yoruba Warlords of the 19th Century. Trenton/NJ; Asmara/Eritrea: Africa World Press, 2001.

; CHILDS, Matt D. (ed.) The Yoruba Diaspora in the Atlantic World. Bloomington/Indianapolis: Indiana University Press, 2004.

; HEATON, Matthew M. A History of Nigeria. Cambridge: Cambridge University Press, 2008.

; ADERINTO, Saheed. Nigeria, Nationalism and Writing History. New York: University of Rochester Press, 2010.

FRANÇA, Nara Muniz Improta. Producing Intellectuals: Lagosian Books and Pamphlets between 1874 and 1922. Tese de doutorado. Sussex/UK: University of Sussex, 2013.

GALLAGHER, J. Fowell Buxton and the New African Policy, 1838-1842, Cambridge Historical Journal, vol.10, No. 1, 1950. pp.36-58.

GEBARA, Alexsander. Uma análise dos textos de Frederick Forbes nas décadas de 1840-1850. O esquadrão africano e o final do tráfico escravo na África ocidental. História, Histórias. Brasília, vol.1, n.1, 2013. pp.195-211. 
A África de Richard Francis Burton: antropologia, política e livre comércio. São Paulo: Alameda, 2010.

GEERTZ, Clifford. A interpretação das culturas. $13^{\mathrm{a}}$ reimpressão. Rio de Janeiro: LTC, 2008.

GILROY, Paul. O Atlântico Negro, modernidade e dupla consciência. Trad. Cid Knipel Moreira. Rio de Janeiro: Editora 34/UCAM/Centro de Estudos AfroAsiáticos, 2002.

GONÇALVEZ, Ana Maria. Um defeito de cor. $4^{a}$ ed. Rio de Janeiro: Record, 2008.

HERNANDEZ, Leila Maria Gonçalves Leite. A África na sala de aula: visita à história contemporânea. 3ํㅡㄹ. ed., São Paulo: Selo Negro, 2010.

HOPKINS, A.G. The Lagos Chamber of Commerce, 1888-1903. Journal of the Historical Society of Nigeria, vol.3, N.2, December/1965, pp.241-248.

. The Lagos Strike of 1897: An Exploration in Nigeria Labour History. Past \& Present, n. 35, dez. 1966, pp.133-155.

ISICHEI, Elizabeth. A History of Nigeria. Essex: Longman, 1984.

. History of Christianity in Africa from Antiquity to the Present. London: Society for Promoting Christian Knowledge, 1995.

JANCSÓ, István; KANTOR, Iris (orgs.) Festa: Cultura \& Sociabilidade na América Portuguesa. Vol.I, São Paulo: Hucitec/Editora da Universidade de São Paulo/FAPESP/Imprensa Oficial, 2001.

JOHNSTON, Ron; WILLIAM, Michael. A century of British Geography. London: Oxford University Press, 2003. 
KOPYTOFF, Igor.(org.) The African Frontier. The reproduction of Traditional African Societies. Bloomington: Indianapolis: Indiana University Press, 1989.

KOPYTOFF, Jean Herskovits. A Preface to Modern Nigeria. The "Sierra Leonians" in Yoruba, 1830-1890. Wisconsin: The University of Wisconsin Press, 1965.

LAW, Robin. Trade and Politics behind the Slave Coast: The Lagoon Traffic and the Rise of Lagos, 1500 - 1800. The Journal of African History, vol.24, n.3, 1983. pp.321-348.

; MANN, Kristin. West Africa in the Atlantic Community: the case of the Slave Coast. In Willian and Mary Quarterly, 56, 2, 1999, pp.307-334.

. Further Light on John Duncan's Account of the 'Fellatah Country', History in Africa, vol.28, 2001, pp.129-138.

A Comunidade brasileira de Uidá e os últimos anos do tráfico atlântico de escravos, 1850-66. Revista Afro-Ásia, 27, 2002, pp. 41 - 77.

. Ouidah: The Social History of a West African slaving 'port', 1727-1892. Ohio: Ohio University Press/ Oxford: James Currey, 2004.

LOCKHART, Jamie Bruce; LOVEJOY, Paul E. (ed.). Hugh Clapperton into the Interior of Africa. Records of the Second Expedition 1825 - 1927. Leiden: Brill, 2005.

LOVEJOY, Paul E. A escravidão na África: uma história de suas transformações. Tradução Regina Bhering e Luiz Guilherme Chaves, Rio de Janeiro: Civilização Brasileira, 2002. 
LUHNING, Angela (org.). Verger - Bastide: dimensões de uma amizade. Rio de Janeiro: Bertrand Brasil, 2002.

MACKENZIE, P.R. Inter-religious Encounters in Nigeria. S.A. Crowhter's Attitude to African Traditional Religion and Islam. Leicester: Leicester University Press, 1976.

MANN, Kristin. Marriage Choices among the Educated African Elite in Lagos Colony, 1880-1915. The International Journal of African Historical Studies, Vol.14, No. 2, 1981, pp.201-228.

. Women, Landed Property, and the Accumulation of Wealth in Early Colonial Lagos. Signs, vol.16, No. 4, 1991, pp.682-706.

; BAY, Edna (eds.) Rethinking the African Diaspora: the making of a Black Atlantic World in the Bight of Benin and Brazil. Portland: Frank Cass Publishers, 2001.

. Slavery and the Birth of an African City: Lagos, 1760 - 1900. Indiana: Indiana University Press, 2007.

MATTOSO, Kátia de Queirós. Ser escravo no Brasil. $3^{\text {a }}$ ed. São Paulo: Brasiliense, 2003.

M'BOKOLO, Elikia. África Negra. História e Civilizações. Tomo II. Do século XIX aos nossos dias. $2^{\mathrm{a}}$ edição. Lisboa: Colibri, 2011.

MEILLASSOUX, Claude. Antropologia da escravidão. Rio de Janeiro: Jorge Zahar Editor, 1995.

MUDIMBE, V.Y. A Invenção da África. Gnose, Filosofia e a Ordem do Conhecimento. Ramada/Luanda: Edições Pedago/Edições Mulemba, 2013. 
ODUWOBI, Tunde. Deposed Rulers under the Colonial Regime in Nigeria. The Careers of Akarigbo Oyebajo and Awujale Adenuga. Cahiers d'Études africaines, XLIII (3), 171, 2003, pp.553-571.

OJO, Olatunji. The Organization of the Atlantic Slave Trade in Yorubaland, ca. 1777 to ca. 1856. The International Journal of African Historical Studies, vol.41, n.1, 2008, pp.77-100.

OLINTO, Antonio. Brasileiros na África. Rio de Janeiro: Editora GRD, 1964

OLUKOJU, Ayodeji. The "Liverpool" of West Africa: dynamic and impact of maritime trade in Lagos 1900 - 1950. Trenton/N.J.: African World Press, 2004.

OSO, Lai. The Commercialization of the Nigerian Press: development and implications. Africa Media Review, vol.5, N.3, 1991. pp. 41 - 51.

OTERO, Solimar. Afro-Cuban diasporas in the Atlantic world. Rochester: University of Rochester Press, 2010.

OYEMAKINDE, Wale. Railway Construction and operation in Nigeria, 18951911: labour problems and socio-economic impact. Journal of the Historical Society of Nigeria, vol.VII, n.2, 1974. pp.307-308.

PARÉS, Luis Nicolau.A formação do candomblé. História e ritual da nação jeje na Bahia. Campinas: Editora Unicamp, 2006.

PARIS, Melanie. Repatriated Africans from Cuba and Brazil in nineteenth century Lagos. Ohio: thesis of master of arts/The Ohio State University, 1998.

PRADO, J.F. de Almeida. A Bahia e suas relações com o Daomé in O Brasil e o colonialismo europeu. São Paulo: Companhia Editora Nacional, 1956.

PRATT, Mary Louise. Os olhos do império: relatos de viagem e transculturação. Trad. Jézio Hernani Bonfim Gutierre, Bauru: EDUSC, 1999. 
QUINTÃO, Antonia Aparecida. Lá vem meu parente: as irmandades de pretos e pardos no Rio de Janeiro e em Pernambuco (Século XVIII). São Paulo: Annablume/Fapesp, 2002.

REIS, João José. Rebelião escrava no Brasil, a história do levante dos malês (1835), edição revista e ampliada, São Paulo: Brasiliense, 2003.

RODRIGUES, Jaime. O infame comércio. Propostas e experiências no final do tráfico de africanos para o Brasil (1800-1850). Campinas: Ed. da Unicamp, 2000.

ROSS, David A. The Career of Domingo Martinez in the Bight of Benin, 183364. The Journal of African History, Vol. 6, №. 1, 1965, pp.79-90.

SAID, Edward W. Orientalismo: o Oriente como invenção do Ocidente. São Paulo: Companhia das Letras, 2007.

SANTOS, Maria Emília Madeira (dir.) A África e a Instalação do Sistema Colonial (c.1885 - c.1930). III Reunião Internacional de História de África. Lisboa: Centro de Estudos de História e Cartografia Antiga, 2000.

SARRACINO, Rodolfo. Los que volvieron a África. Havana: Editorial de Ciencias Sociales, 1988.

. Cuba-Brasil: os que voltaram à África. Estudos Afro-Asiáticos, n.20, junho, 1991, pp.85-100.

SAWADA, Nozomi. The educated elite and associational life in early Lagos newspapers: in search of unity for the progress of society. Tese de doutorado, Birmingham/UK: Centre of West African Studies School of History and Cultures College of Arts and Law / University of Birmingham, 2011. 
SHERWOOD, Marika. Origins of Pan-Africanism: Henry Sylvester Williams, Africa, and the African Diaspora. New York/London: Routledge, 2011.

SILVA, Alberto da Costa e. A manilha e o libambo: a África e a escravidão, de 1500 a 1700. Rio de Janeiro: Nova Fronteira, 2002.

. Um rio chamado Atlântico: a África no Brasil e o Brasil na África. Rio de Janeiro: Nova Fronteira/EdUERJ, 2003.

- Francisco Félix de Souza, mercador de escravos. Rio de Janeiro: Nova Fronteira/ed. UERJ, 2004.

- Imagens da África: da Antiguidade ao Século XIX. São Paulo: Penguin, 2012.

SILVA, Angela Fileno da. "Amanhã é dia santo": circularidades atlânticas e a comunidade brasileira na Costa da Mina. São Paulo: Alameda/ Fapesp, 2014.

SMITH, Robert Sydney. The Lagos Consulate, 1851-1861. London: Macmillan Press/Univesity of Lagos Press, 1978.

SOARES, Laurent Azevedo Marques de. A primeira abolição francesa da escravidão (4 de fevereiro de 1794) e o problema dos regimes de trabalho. Saeculum. Revista de História, 29: João Pessoa, jul/dez.2013, pp. 125-143.

SOARES, Mariza de Carvalho. Devotos da Cor. Identidade étnica, religiosidade e escravidão no Rio de Janeiro, século XVIII. Rio de Janeiro: Civilização Brasileira, 2000.

SOUMONNI, Elisée. Daomé e o mundo atlântico. Centro de Estudos AfroAsiáticos/Universidade Cândido Mendes, 2001.

SOUZA, Marina de Mello e. Reis Negros no Brasil escravista: história da festa de coroação do Rei Congo. Belo Horinzo: Ed. UFMG, 2002. 
SOUZA, Mônica Lima e. Entre margens: o retorno à África de libertos no Brasil, 1830-1870. tese de doutorado. UFF/RJ, 2008.

SOUZA, Simone de. La famille de Souza du Benin - Togo. Cotonu: Éditions du Benin, 1992.

VERGER, Pierre. Influence du Brésil au Golfe du Benin, in Mémoire de l'IFAN, n.27, Dakar, 1957. . Fluxo e Refluxo do tráfico de escravos entre o Golfo de Benin e a Bahia de todos os Santos: dos séculos XVII a XIX. São Paulo: Corrupio, 1987.

VERGER, Pierre. Os Libertos: sete caminhos na liberdade de escravos da Bahia no século XIX. São Paulo: Corrupio, 1992.

VIANNA FILHO, Luiz. O negro na Bahia. $2^{\underline{a}}$ ed. São Paulo: Martins, 1976.

WALLS, Andrew F. The Legacy of Samuel Ajayi Crowther. International Bulletin of Missionary Research, vol.16, n.4, jan.1992.

WEST, Shearer. Black Victorians: Black People in British Arte, 1800 - 1900. Victorian Literature and Culture, Cambridge University Press, vol.35, March 2007, pp.329 - 334. 